\title{
An Historical Account of the Black Empire of Hayti
}

\section{MARCUS RAINSFORD}

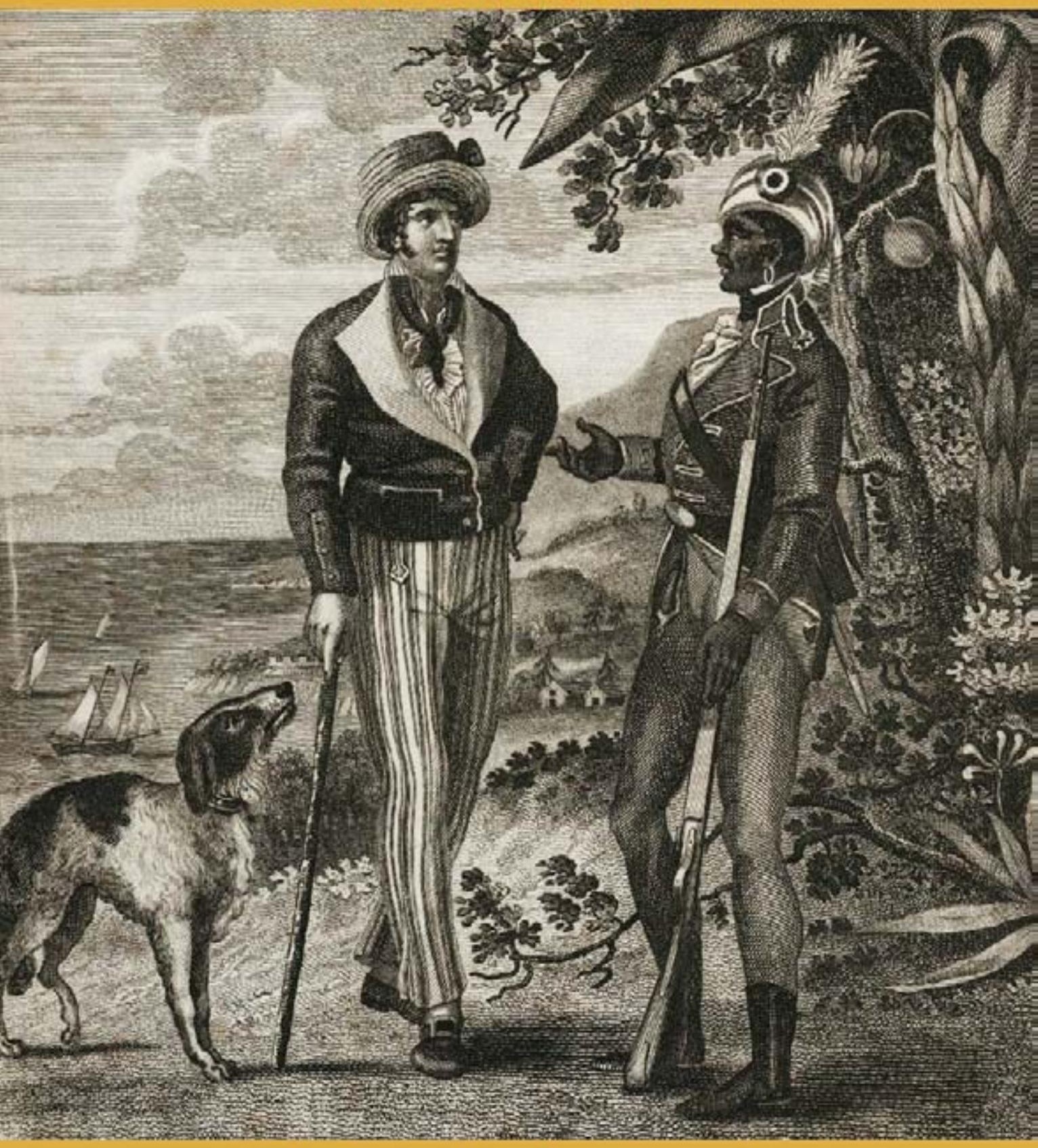

Edited and with an Introduction by 
AN

Historical Account

OF THE

BLACK EMPIRE OF HAYTI 


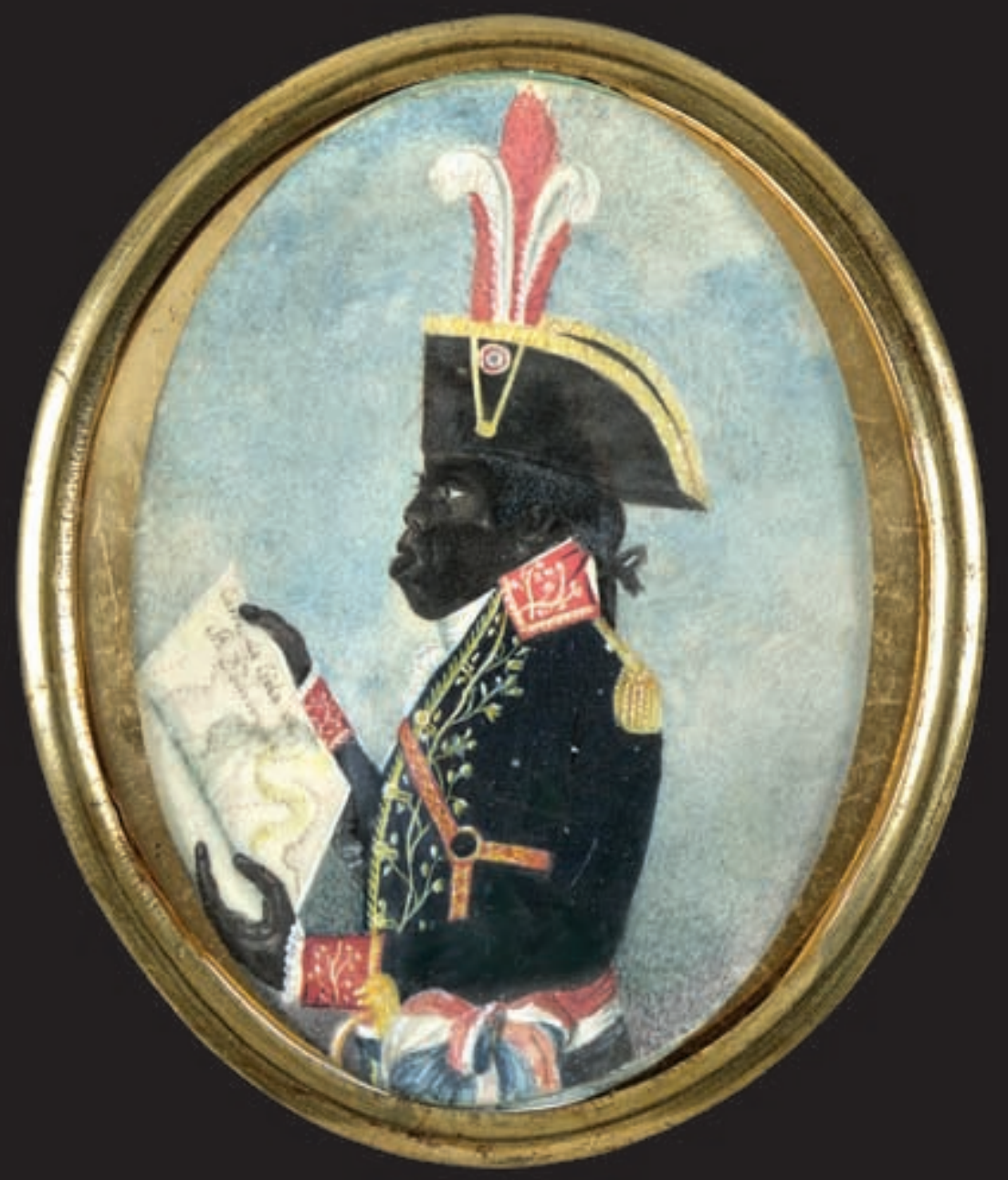




\title{
AN
}

\section{Historical Account}

\author{
OF THE
}

\section{BLACK EMPIRE OF HAYTI}

\author{
MARCUS RAINSFORD
}

Edited and with an Introduction by

PAUL YOUNGQUIST AND GRÉGORY PIERROT

Duke University Press Durham and London 2013 
This Edition, Introduction, Notes, and Bibliography

(C) 2013 Duke University Press

Frontispiece: Portrait of Toussaint Louverture. Collection of the

New-York Historical Society, accession number 1956.123.

All rights reserved

Printed in the United States of America

on acid-free paper @

Designed by Cherie Westmoreland

Typeset in Whitman

by Tseng Information Systems, Inc.

Library of Congress Cataloging-in-Publication Data

Rainsford, Marcus, fl. 1805 .

An historical account of the black empire of Hayti / Marcus Rainsford ; edited and with an introduction by Paul Youngquist and Grégory Pierrot.

p. $\mathrm{cm}$.

Includes bibliographical references and index.

IS BN 978-o-8223-5278-5 (cloth : alk. paper)

IS BN 978-o-8223-5288-4 (pbk. : alk. paper)

1. Haiti-History-To 1791. 2. Haiti-History-Revolution, 1791-1804.

I. Youngquist, Paul. II. Pierrot, Grégory. III. Title.

F1923.R15 2013

$972.94^{\prime} \mathrm{O} 3-\mathrm{dc} 23$

2012044752

PAUl YoungQuist is a professor of English at the University of Colorado, Boulder. He is the author of Cyberfiction: After the Future (2010), Monstrosities: Bodies and British Romanticism (2003), and Madness and Blake's Myth (1989).

GrÉgory PieRrot is a visiting assistant professor of English at Bucknell University. 
FOR CAITLIN AND CHLOË 



\section{CONTENTS}

Acknowledgments ix

Chronology xi

Introduction xvii

A Note on the Text lvii

An Historical Account of the Black Empire of Hayti 1

Editorial Notes 277

Bibliography 321

Index 331 



\section{ACKNOWLEDGMENTS}

This edition of Marcus Rainsford's An Historical Account of the Black Empire of Hayti is the work of a crew of formidable sleuths and scholars. Grégory Pierrot has been a close friend and collaborator throughout. Without his spirited conversation and relentless curiosity, Rainsford's book may have remained entombed in the mausoleum of history. Annotations by him and Scott Hagle helped resurrect it. Preparing and correcting the typescript required the labor of a spirited team: Dana Van Kooy, John C. Leffel, Krystal McMillen, and Michele Speitz. I received generous support from the Center for Humanities and the Arts at the University of Colorado for travel to collections in Kingston, Jamaica, and London. In both places I benefited from the immense cunning of many archivists, researchers, and activists, among them James Robertson, Julia Gaffield, Kesia Weise, Jillian Pazereckas, Jack and Maren Youngquist, Charles Campbell, Colonel Frank Lumsden, and Evan Williams. Timely historical help came from Roger Norman Buckley, David Patrick Geggus, Carolyn E. Fick, and Laurent Dubois. Sara Arnold of the Gibbes Museum conjured Toussaint Louverture's miniature image from oblivion. Carol Aiken made it permanently visible. Ken Wissoker and Leigh Barnwell at Duke University Press gave this book its lease on life. The press's anonymous reader brought it strength and beauty. Finally, nothing would ever get done without the love and support of a few wondrous people: Jeffrey N. Cox, Frances Botkin, Sajay Samuel, Samar Farage, Erika Polson, Joanne Youngquist, and Caitlin Rose. - PAUL YOUNGQUIST

An Historical Account of the Black Empire of Hayti was the topic of countless conversations with Paul Youngquist before he had the idea to propose this edition. For this and the journey that followed I am very grateful to him. Thanks to Aldon Nielsen for his continual and crucial question, "Why is Haiti always being rediscovered?" Alain Bernheim, Gerard Besson, and Jacques de Cauna provided invaluable information regarding the intriguing life of Philippe-Rose Roume and his descendants, who deserve more attention than we could give them here. Thanks to Marie-Lucie Vendryes for her help in locating the Toussaint Louverture miniature attributed to Rainsford. Sara Marzioli's translation helped us follow Rainsford throughout European news. In my work for this edition I have been supported by several institutions at 
the Pennsylvania State University: I received a research grant from the Africana Research Center; a travel grant from the Center for American Literary Studies, and a George and Barbara Kelly Fellowship from the English Department. This book would not have seen the light of day without the help of the librarians of the Rare Books and Manuscripts, Special Collections Library, Pennsylvania State University Libraries, with a special mention to Sandy Stelts, and to Curt Krebs at the Digital Preservation Department. Thanks also to James Capobianco at the Houghton Library, Harvard University, for his assistance and diligence. Le meilleur pour la fin: many thanks to Kate and Chloë Pierrot for putting up with this project and supporting me throughout; to Germaine and François Pierrot for indulging for so many years my obsessive and often obnoxious interest in Napoleonic history; and a special dedication to the late André Guillemin, for teaching me a most crucial lesson in history, a long time ago. - GRÉGORY PIERROT 


\section{CHRONOLOGY}

1492 Christopher Columbus lands on the island called Xaymaca by its Taíno and Arawak inhabitants. The Spaniards build the fort La Navidad. Columbus returns a year later to find the fort destroyed and all Spanish occupants dead.

1502-9 The Spanish governor Nicolás de Ovando arrives on the island with hundreds of troops and introduces the cultivation of sugar cane from the Canary Islands. A year later under pretense of a friendly meeting he massacres many Taíno.

1513 Enslaved Africans are first imported to Jamaica.

1625 French and English buccaneers settle on the island of Tortuga off the northern coast of Hispaniola, present-day Haiti.

1665 Louis XIV establishes the French colony of Saint-Domingue (St. Domingo), which includes Tortuga and the western half of Hispaniola.

1676 The Maroon leader Padrejean incites St. Domingo's first slave rebellion near Port de Paix. He is caught and killed by buccaneers.

1697 Spain recognizes French possession of western Hispaniola with the Treaty of Ryswick.

1743 François Dominique Toussaint de Bréda is born.

$175^{8}$ Marcus Rainsford is born in Salins, County Kildare, Ireland.

1763 The Treaty of Paris settles the Seven Years War. Great Britain gains control of French possessions in North America.

1770 The first edition of Guillaume-Thomas Raynal's Philosophical and Political History of the Settlements and Trade of the Europeans in the East and West Indies is published.

1773 Rainsford graduates with a Master's degree from Trinity University, Dublin.

1775 The American Revolution begins.

1776 The Second Continental Congress approves the Declaration of Independence.

1779 Rainsford joins Lord Francis Rawdon's Volunteers of Ireland to fight in the American War for Independence.

1781 Rainsford is shipped to Jamaica in Lord Montagu's Duke of Cumberland Regiment, also known as the South Carolina Rangers. The unit is disbanded two years later, and Rainsford is released on half-pay. 
October 1781 The British surrender at Yorktown, Virginia.

1782 William Hayley publishes An Essay on Epic Poetry, calling for the revival of epic poetry in Britain.

1783 The Treaty of Paris ends the American War for Independence, and Great Britain recognizes the United States of America.

1789 Representatives of the clergy and the Third Estate in France meet in assembly and swear not to disband without a constitution.

July 14, 1789 The people of Paris storm the Bastille.

1790 The mulatto planter Vincent Ogé leads a failed revolt in St. Domingo. He is caught, tried by colonial authorities, and executed at Cape François.

1791 The first canto of Marcus Rainsford's The Revolution; Or, Britain Delivered is published anonymously in Edinburgh and London.

May 1791 The Constituent Assembly in France gives full political rights to mulattos and free blacks.

August 14, 1791 A voodoo ceremony at Bois Caïman in St. Domingo, led by Jamaican-born Boukman Dutty, sparks revolution, which ignites in full on August 21. Cape François burns.

October 1791 Port-au-Prince is burned during the fighting between whites and mulattos. Toussaint Louverture joins the rebellion, siding initially with the Spanish.

1792 The French Legislative Assembly grants citizenship to all free men of color. The commissioners Léger-Félicité Sonthonax, Étienne Polverel, and Jean-Antoine Ailhaud arrive in St. Domingo with six thousand troops.

January 1793 Louis XVI and Marie Antoinette are executed in Paris. Spain joins the coalition against France.

February 1793 France declares war on Great Britain. Toussaint and his troops side with Spain against the French.

August 1793 Sonthonax abolishes slavery in the northern province. Abolition is extended to the western and southern provinces by year's end.

September 1793 British troops land at Jérémie in St. Domingo.

1794 Toussaint and the Spanish gain control over the north of St. Domingo except Cape François.

February 1794 Slavery is officially abolished by the French National Assembly.

May 1794 Toussaint changes sides and joins France, becoming a general in the French Army.

June 1794 British troops take Port-au-Prince.

June 1794 Sonthonax is recalled to France to face trial for treason. 
October 1794 General Étienne Laveaux is appointed the interim governorgeneral of St. Domingo. Marcus Rainsford joins the Duke of York's expedition in the Netherlands with the Royal York Fusiliers.

1795 French troops led by Toussaint and André Rigaud fight the British in the western and southern provinces of St. Domingo.

1795 Spain cedes eastern Hispaniola to France.

1796 Rainsford arrives in Jamaica with the Third West India Regiment as a recruiting officer. Lieutenant Governor Lord Balcarres detains him and other troops meant for St. Domingo to fight rebellious Maroons.

March 1796 Governor Laveaux is arrested and temporarily jailed in a failed coup attempt.

April 1796 Laveaux names Toussaint the lieutenant governor of St. Domingo.

May 1796 The commissioners Sonthonax, Phillipe-Rose Roume, and Julien Raimond arrive in St. Domingo.

October 1796 Laveaux returns to France to serve as the representative for St. Domingo.

January 1797 Rainsford returns to England from St. Domingo to recover from an arm injury and possibly yellow fever.

May 1797 Sonthonax appoints Toussaint the commander in chief of French colonial forces.

August 1797 Toussaint forces Sonthonax to return to France.

October 1797 Rainsford lands in St. Domingo at Mole St. Nicholas.

1798 Rainsford visits Cape François disguised as an American sailor. Later he is arrested as a spy, tried, and condemned to death. His sentence is commuted by Toussaint.

May 1798 The English General Thomas Maitland and Toussaint sign an armistice. British troops begin evacuating, remaining at Mole St. Nicholas until October.

April 1799 Rainsford rejoins the Third West India Regiment in Martinique.

May 1799 The War of Knives begins between Toussaint and Rigaud.

June 1799 Toussaint negotiates a secret convention with Great Britain and the United States.

November 1799 Napoleon Bonaparte overthrows the Republican government in the Eighteenth Brumaire coup d'état.

March 1800 Rainsford is released from military service on half-pay. He returns to England and sells his commission.

July 1800 Toussaint defeats Rigaud, who flees to Guadeloupe. 
1801 The second edition of Rainsford's The Revolution: Or; Britain Delivered is published in London.

January 1801 Toussaint seizes Spanish Hispaniola and abolishes slavery there.

July 1801 Toussaint creates a constitution for St. Domingo that proclaims himself governor general for life.

October 1801 The Treaty of Amiens suspends hostilities between Great Britain and France. Napoleon appoints his brother-inlaw Charles Victor Emmanuel Leclerc the chief of an expeditionary force for regaining control of St. Domingo and restoring slavery.

January 1802 Rainsford's Memoir of Transactions That Took Place in St. Domingo is published in London.

February 1802 Leclerc's troops land in St. Domingo near Cape François. Toussaint leads the resistance.

March-April 1802 The Battle of Crête à Pierrot.

May 1802 The generals Jean-Jacques Dessalines and Henry Christophe surrender to Leclerc. Toussaint capitulates and retires to his plantation in Ennery.

June 1802 Leclerc arrests Toussaint under false pretense and deports him with his family to France. Two months later Toussaint is jailed in the Fort de Joux in the Jura Mountains.

August 1802 Rainsford's St. Domingo; Or, an Historical, Political and Military Sketch of the Black Republic is published in London, a second edition of his memoir. A third, containing a portrait of Toussaint, appears before the end of the year.

October 1802 As the revolution's final leader, Dessalines renews the fight against the French.

November 1802 Leclerc dies of yellow fever and is succeeded by General Rochambeau.

February 1803 William Wordsworth's “To Toussaint Louverture” is published in London's Morning Post.

April 1803 Toussaint dies in his cell in Fort de Joux.

November 1803 Dessalines and Alexandre Pétion defeat French troops at the Battle of Vertières. Rochambeau capitulates.

January 1, 1804 Dessalines proclaims independence from France and himself the governor general of the nation of Haiti.

March-April 1804 Dessalines massacres the white colonists remaining in Haiti.

July 1804 Rainsford writes An Hymeneal on the Marriage of the Right Hon. Francis, Earl of Moira, etc., to the Right Hon. Flora, Countess of Loudon; on the 12th Day of July, 1804. 
October 1804 Dessalines proclaims himself emperor of Haiti.

December 1804 Napoleon declares himself emperor of France.

1805 Rainsford's An Historical Account of the Black Empire of Hayti is published in London.

October 1806 Dessalines is assassinated. Christophe is appointed president.

1807 Haiti is divided into the Northern State of Haiti under Christophe and the Southern Republic of Haiti under Pétion.

1807 The British Parliament passes the Slave Trade Act abolishing the slave trade in the British Empire.

1809 Spain regains Santo Domingo from Haiti with help from Britain.

1810 Rainsford joins the First Royal Veteran Battalion.

1811 Christophe declares himself King Henry I of the Northern Kingdom of Haiti.

1813 Rainsford is imprisoned for debt.

April 1814 Napoleon abdicates and is exiled to the island of Elba. Louis XVIII becomes king of France.

November 1814 The Congress of Vienna authorizes France to resume the slave trade for five years. Rainsford participates in a popular campaign of opposition.

1815 Rainsford acts as an agent in London on behalf of King Henry I.

February 1815 Napoleon escapes Elba and regains control of France.

March 1815 Great Britain, Prussia, Russia, and Austria form the Seventh Coalition against Napoleon at the Congress of Vienna.

June 1815 Napoleon is defeated at Waterloo.

1816 Pétion provides Simon Bolivar haven and support in his expedition against Spanish colonial authorities in Venezuela.

1816 Rainsford's Translation of an Official Communication from the Government of Hayti is published in London.

November 4, 1817 Rainsford is buried at Saint Giles in the Fields, Middlesex. 


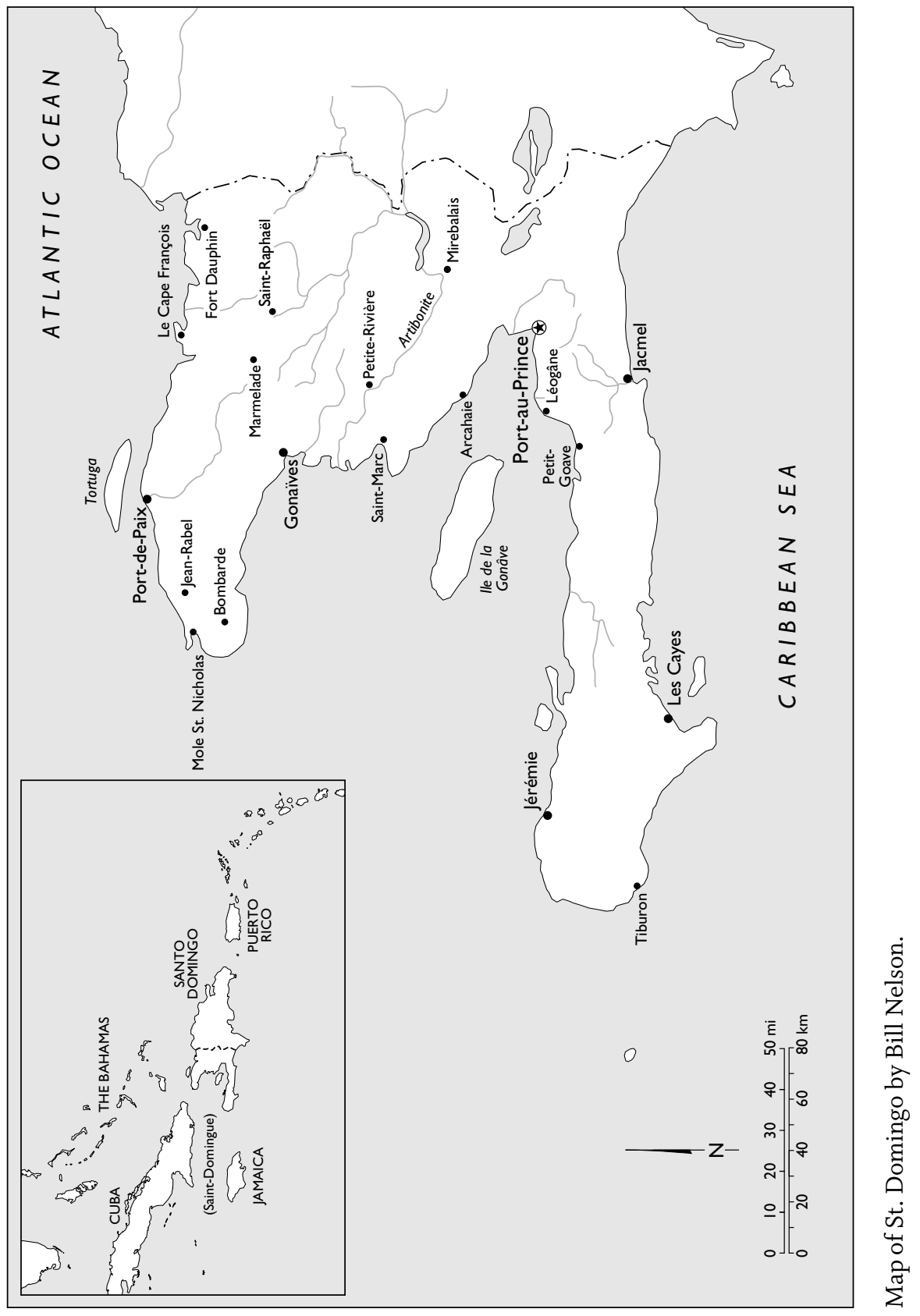




\title{
INTRODUCTION
}

\author{
Paul Youngquist and Grégory Pierrot
}

On October 24, 1797, an aging captain of the Third West India Regiment stepped ashore from HMs Hannibal at Mole St. Nicholas, the "Gibraltar of the Antilles" and bastion of the British occupation of St. Domingo. ${ }^{1}$ A sojourn of several months would change his life and inspire An Historical Account of the Black Empire of Hayti (1805), the first complete account in English of the Haitian Revolution. Captain Marcus Rainsford had been in St. Domingo before, in 1796. Then he was mustering black troops for the British army, there to prop up and grab the colony. Rainsford returned at a difficult time. The occupation had proven a magnificent waste of soldiers' lives and British pounds Sterling, and life at the Mole was turning precarious. The "brigands," as the British called revolutionary blacks, were pounding at the door. "So closely were we surrounded by the Brigands, at all points," wrote Rainsford, "that it was not possible to move half a mile from the town, without extreme danger while all within was wretchedness of every description!"2 A hard destiny came calling. In 1798 those black freedom fighters would evict the British and with them slavery from the French colony of St. Domingo. Five years later they would proclaim to the world the free and independent nation of Haiti.

\section{Occupational Hazards}

Rainsford's account of the Haitian Revolution is the creature of a convulsive period of Atlantic history. ${ }^{3}$ As the eighteenth century drew to a close Britain was waging war with Republican France to defend its vaunted liberties and to buttress its sagging empire. The loss of its thirteen North American colonies in 1783 had delivered England an economic and moral blow. With the eruption in 1789 of revolution in France, which scattered sparks of insurrection throughout the Atlantic world, the 1790 s would become a time of opportunity for both the empire and its enemies. The West Indies would witness a struggle between the forces of slavery and freedom. Europe's great colonial powers - England, Spain, and France - jockeyed for advantage and superiority. The focus of their rivalry: the sumptuous French colony of St. Domingo on the island of Hispaniola. The insurrection that blazed up there in August 
1791 ignited dreams not just of freedom but of colonial dominion, too. During the thirteen years of fighting that followed, England, Spain, and France would all make military bids to possess the richest colony in the Caribbean. ${ }^{4}$

The British bid was driven by economic opportunism. By the late eighteenth century Great Britain seemed to many Britons an island of freedom in a sea of slavery. The Somerset decision of 1772 had declared it a crime to return Africans to slavery in the Caribbean colonies against their will. An insurgent abolitionist movement was gaining popularity, driven by doubts about empire that came with American independence. ${ }^{5}$ In the colonies of the West Indies, however, slavery was still a way of life. In 1791, for instance, one quarter of a million enslaved Africans inhabited Jamaica. Throughout the 1790 s their ratio to whites remained just under ten to one. ${ }^{6}$ Sugar production required those numbers. It was labor intensive and uniquely specialized, a harbinger of a coming industrialization. Along with other exotic commodities (coffee, indigo, and cotton), sugar was an engine of Britain's imperial and cultural expansion. ${ }^{7}$ Revolutionary unrest in St. Domingo, only 257 nautical miles east of Jamaica, made the richest sugar colony in the Caribbean seem ripe for the picking. With Republican France's declaration of war in 1793, Britain had the excuse it needed to add this prize to its colonial possessions.

"Rule Britannia! rule the waves: / Britons never will be slaves": the famous lines from the de facto anthem of the British empire proclaim its complicated relationship to African slavery. Britons may never have been slaves, but many a British merchant bought and sold them, trafficking in Africans across the Atlantic with the indifference that comes with habit and huge profits. The years 1793 to 1798 mark a curious interlude in the mythology of British liberty. While abolitionists at home fought to outlaw the slave trade and deal slavery a deathblow, British soldiers in St. Domingo fought even more fiercely to perpetuate them. Such was the Janus face of slavery. However questionable, the slave system appeared too profitable to stop. So when in January of 1793 French planters from St. Domingo, their fields smoldering and their future dim, appealed for relief to William Pitt's government, an opportunity arose that was too promising to resist. Intervene in St. Domingo. Hoist the Union Jack over the charred and stubbled cane fields. Enter its ports to tame a brigand horde bent on destroying property and achieving freedom. Rescue a desolate plantocracy and replace the rule of France.

A prize beyond imagining: French St. Domingo, jewel of the Antilles, by far the most opulent colony of the West Indies. There were of course other motives for intervention: the menace of rebellion in nearby Jamaica, Britain's most profitable slave colony, and the necessity of victory in the war with France. St. Domingo was a chance Pitt and his secretary of state for war 
Henry Dundas had to take. When a hundred more French planters joined the call for aid the British government signed a set of propositions authorizing the occupation of St. Domingo. By September 1793 redcoats were disembarking at Jérémie, welcomed ashore by inspiring strains of "Long live the English!"8 Britain's most determined defense of slavery had begun.

At first things went well. Within eight months of landing, the British occupied one-third of the island, securing not only Mole St. Nicholas in the north, but also the port towns of Saint Marc, Port-au-Prince, Léogane, and Tiburon. The French colony of St. Domingo wore a fringe of British invaders. Their hold over this territory was, however, tenuous. In the estimation of J. W. Fortescue, the invasion force itself "never numbered more than nine hundred effective soldiers." 9 Lacking the numbers needed to secure the colony, the occupiers played a military shell game, sending troops here and there in groups of varying size to shore up shaky defenses. The arrival of reinforcements swelled the ranks in Port-au-Prince to 3,500, with 1,800 more soldiers, mostly cavalry, distributed up and down the coast. But a promise of 2,00o more troops from England failed to materialize until 1796, bad planning and worse weather hampering their departure. ${ }^{10}$ Although the redcoats could boast impressive early success, they remained outnumbered and hemmed in throughout St. Domingo by a patchwork of determined enemies: French revolutionaries, Spanish auxiliaries, and those so-called brigands, formidable black insurgents fighting for a freedom the British had come to deny them.

Events contemporary with the occupation ensured that slavery would be its raison d'être. Just weeks before the British arrived, the Jacobin commissioner at Cape François, Léger-Félicité Sonthonax, issued a decree abolishing slavery throughout St. Domingo. In February 1794 the National Convention in Paris followed suit, declaring that "all men, without distinction of color, domiciled in the colonies, are French citizens, and enjoy all the rights assured under the Constitution." 11 Blacks were no longer brigands savagely torching their masters' property. They were free people fighting for their rights as French citizens. Armed with musket, bayonet, and cannon, the British stood between them and liberty, a fortified line dividing slavery from freedom, black slaves from white masters. That the British government was comfortable defending the white side of that line appears most clearly in the notorious fourth clause of the Capitulation that was required signing for all French who committed themselves to the arms of their protectors: "Men of color will have all the privileges this class enjoys in English colonies"- - which is to say no privileges at all. ${ }^{12}$ If that could be said of racially mixed people of color, then blacks obviously stood beyond the pale of British citizenship. To defend slavery on St. Domingo was to live or die for white privilege. 
The British thus faced a formidably motivated adversary, and it wasn't long before military momentum shifted toward the French revolutionaries with their newly emancipated black troops. Marcus Rainsford played a small but revealing part in this dubious military drama. The book that came out of it, An Historical Account of the Black Empire of Hayti, is remarkable for acknowledging the intelligence and effectiveness of those black soldiers. A career officer who had been stationed in Jamaica between actions in the American War for Independence and the horrific winter campaign of 1793-94 against France in the Netherlands, Rainsford was appointed captain in June 1795 to the Third West India Regiment, one of six new units destined for action in the West Indies. ${ }^{13}$ A British - which is to say white-officer, he would recruit black rank and file. The fierce resistance of mulatto and black fighters in St. Domingo convinced military leadership to fight fire with fire, blacks with blacks. Rainsford would muster them to the British cause. The scheme was not without precedent. African loyalists fought during the Revolutionary War, drawn to serve by the promise of freedom. Blacks were used in Jamaica as military pioneers, laborers, and artificers attached to white companies. But what the historian Roger Norman Buckley calls "the Africanization of the British military" began in earnest during the occupation of St. Domingo. ${ }^{14}$

There were other motives too for mustering black troops: the belief that Africans were better suited than Europeans to the demands of warfare in tropical climes, not to mention the simple need to maximize numbers where the British army was outgunned. Rainsford would help build the black West India Regiments, which military leaders believed would carry the day against seasoned rebels throughout the West Indies. These regiments would be nearly 9,00o strong, trained and equipped like Europeans. ${ }^{15}$ They would not of course be paid like Europeans. They would serve according to terms Britain traditionally granted their kind: room, board, and a decent burial. The war secretary Dundas opposed granting blacks freedom for military service. The Africanization of the British military followed, at least initially, plantation logic: the West India Regiments would be mobilized plantations of soldier-slaves, free only to serve and die. Black recruits in St. Domingo, however, so frequently deserted to the freedom-granting French that Dundas was forced grudgingly to offer them freedom for five years of service. His attachment to the plantation model persisted nevertheless. In 1798 he supported a simpler method of mustering than recruitment: "Negroes should be procured at the expense of the Government." ${ }^{16}$ To advance British interests in the West Indies, Dundas was ready to purchase an army of enslaved Africans.

The Third West India Regiment, also known as Keppel's, was destined for St. Domingo. As captain and recruiter, Rainsford would be in regular, direct 
contact with black troops. ${ }^{17} \mathrm{He}$ would also witness the withering of Britain's dream to possess the colony. For every soldier who arrived by ship in St. Domingo, it seemed, another departed - in a coffin. Battle casualties were a secondary cause. Yellow fever stalked unseasoned European recruits implacably, striking quick and fell. Although quiescent during the early months of the occupation, it woke with fury as redcoats took up positions in the miasmic flats around Port-au-Prince. With the disembarkation in early June 1794 of infected troops from Martinique, an epidemic was in the making. Over 2,ooo soldiers died that year in St. Domingo, the majority from disease; in 1795, more than 3,ooo. Numbers climbed steadily, until by the end of the occupation in 1798, of over 20,500 men sent to St. Domingo, 12,500 were dead, some from bullets and grapeshot, some from fatigue, but over half from yellow fever. ${ }^{18}$

It was a nasty death. Thomas Phipps Howard, a lieutenant in the York Hussars stationed in St. Domingo from 1796 to 1798, gives a grisly description in his journal. To redcoats in the vicinity of the port of Saint Marc, death became grimly familiar:

The Dead Carts were constantly employed, \& scarcely was one empty, tho' they held from 8 to 12 each, but another was full. Men were taken ill at dinner, who had been in the most apparent Health during the Morn:, \& were carried to their long Homes at Night. In short, the putridity of the Disorder at last arose to such an $\mathrm{h}[\mathrm{e}]$ ight that hundreds, almost, were absolutely drowned in their own Blood, bursting from them at every Pore. Some died raving Mad, others forming Plans for attacking, the others desponding; in fact, Death presented itself under every form an unlimited Imagination could invent. To sum up this Picture of Horror, by a Return made from the $3^{\text {th }}[\mathrm{sic}]$ to the 13th, our Regiment alone had lost eight Officers, three Quartermasters, thirteen Serjeants and Corporals, and one hundred \& fifty Hussards. ${ }^{19}$

The York Hussars numbered 693 men at the beginning of that return, 465 by its bleak finish in July $1796 .{ }^{20}$ After another year in St. Domingo only 234 Hussars would be alive. Some fell honorably in the field. But like too many of their brothers in arms, many died miserably from disease. Edmund Burke's mordant quip rang true: "it was not an enemy we had to vanquish but a cemetery to conquer." ${ }^{21}$ Yellow fever struck a big blow, but strangely, on behalf of freedom.

It would be wrong, however, to conclude that disease beat the British out of St. Domingo. ${ }^{22}$ There were other strong reasons to leave. If the British were bleeding men, they were hemorrhaging money. The first eight months of the occupation drained $£ 120$, ooo pounds from Pitt’s coffers. ${ }^{23}$ Costs soared 
after that. French planters did their best to profit from the presence of their saviors. British hopes of handing them the bill faded fast. They dodged taxes and pocketed the price of outfitting colonial militias. Many of the municipal officials charged with collecting poll and slave taxes did the same. The local economy was a wreck. Exports were scarce, and duties negligible. By 1795 it was becoming clear that planters in St. Domingo might capitulate to British rule, but they weren't about to pay for it.

They were not alone in making colonial adventurism expensive. The occupiers bore responsibility too. Most of the blame fell on Sir Adam Williamson, the governor of St. Domingo from October 1794 to March 1796. He was a generous man with a penchant for fine living. Every war has its refugees. This one drove them into occupied cities in large numbers. Williamson treated them with exorbitant kindness, adding cash to their free rations. ${ }^{24} \mathrm{His}$ delight in good company inspired frequent visits from many guests: five, ten, sometimes twenty at a time for an evening of wine and banter. He lavished similar luxuries on his troops, quartering them in style whenever possible. He created new corps at the drop of a captain's hat. Costs for officer pay, costume, and equipment spiked. In the words of David Patrick Geggus, "Williamson was incapable of saying no to anyone." ${ }^{25}$ Nor was he alone guilty of such magnanimity. The agent-general for St. Domingo took a whopping 5 percent commission on all expenditures. It made him a rich man, earning him $£ 86$,ooo in just two and a half years. When Williamson was replaced in 1796 it was reported in the House of Commons that the costs of occupation had reached $£ 4,300,000$. It fell to his successors to reduce expenditures to a mere $£ 25$, Ooo per month. ${ }^{26}$ That never happened. St. Domingo continued to suck money from the British treasury: $£ 5,765$, ooo all told, not including military pay to rank and file. ${ }^{27}$ By 1798 evacuation was beginning to make as much economic as military sense.

The redcoats were faring badly. Pitt and Dundas tried desperately to salvage the occupation during 1795-96 with the largest naval expedition hitherto mounted - a projected 30,000 men and an astonishing 100,000 tons of shipping-but bad winds scattered the flotilla and forced a scale-back in the operation..$^{28}$ Even had the expedition landed in St. Domingo, however, its success remains doubtful. Over the course of the occupation a storm of another kind had been gathering. Blacks were honing their military skills in armies of the French Republic or the Spanish king. Mulattoes were doing the same, sometimes forming armies of their own. British troops provided opportunity for those tenacious soldiers to prove their mettle and improve their tactics. Scattered attacks all across St. Domingo - in Mole St. Nicholas, Saint Marc, Léogane, Tiburon - turned the formerly enslaved into freedom fighters. It is 
one of history's happier ironies that an occupier come to preserve slavery advanced its undoing.

Armies of free blacks, not disease or expense, drove the British from St. Domingo. In this the name of Toussaint Louverture serves as a memorial, symbolizing thousands inspired by freedom to take up arms against slavery. "I am Toussaint Louverture. My name is perhaps known to you. I have undertaken vengeance. I want Liberty and Equality to reign in Saint-Domingue. I work to bring them into existence. Unite yourselves to us, brothers, and fight with us for the same cause." 29 Toussaint made this declaration on the very day Sonthonax proclaimed slavery abolished in August 1793 and just a month before the British landed. It does not simply announce the emergence of a great leader. It testifies to the readiness of a multitude of men and womenfrom different plantations and for diverse ends - to fight for freedom. An early measure of their success was the expulsion of one eighteenth-century superpower - Great Britain - from the colony it came to master. AnotherFrance - would follow after five more years and some desperate fighting. The British were equal neither to Toussaint nor the multitude that, in a variety of ways, heeded his call to arms. Buckley's observation remains astute: "The British army's ventures into the once rich heartland of the ravaged colony, against an alert, tough, and at times elusive foe, were little more than puny and indecisive operations which were destined to fail." ${ }^{30}$ Such are the wages of mastery. The British came to enslave. They left beaten by the free.

Marcus Rainsford had the strange fortune to witness and play a small part in these events. He mustered black troops in St. Domingo and came to admire their prowess. He later met Toussaint and experienced his magnanimity firsthand. Behind An Historical Account of the Black Empire of Hayti hangs the tattered backdrop of the British occupation. At first Rainsford himself preferred not to notice it. In an earlier pamphlet on St. Domingo, he writes, "Enough has been professionally told of this disastrous enterprize by those so much more adequate to the task than myself, that I shall presume to add nothing more on the subject." 31 Three years later, however, he unfurled a full history of the Haitian Revolution - including the occupation - from the vantage of a career soldier who witnesses not just the weakness of the power he serves but the strength of its inspired adversaries. This white captain learns to respect the black troops on both sides of the revolutionary struggle. His initial dismissal of the British occupation registers its importance in the annals of embarrassed imperialism. St. Domingo was for a time in the 1790 os the desideratum of three colonial powers. That none came to possess the colony proves the indomitable force of the free blacks who would after thirteen years of struggle declare Haiti an independent state on January 1, 1804. Their vic- 
tory, the great legacy of the Haitian Revolution, makes Rainsford's history a complex contemporary commentary on the high cost of colonial slavery.

\section{An Officer's Life}

Marcus Rainsford, son of Edward Rainsford, was born in 1758 in County Kildare, Ireland. ${ }^{32}$ The Rainsford family had moved from England to Ireland in the seventeenth century, rising socially when Oliver Cromwell rewarded William Rainsford handsomely for his political allegiance by granting him considerable tracts of land. ${ }^{33}$ The family's fortunes did not end with Cromwell: William's son, Sir Mark Rainsford, was made High Sheriff of Dublin in 1690 and Lord Mayor of Dublin in 1700. Among the Rainsford properties was a brewery at St James's Gate in the Irish capital. Its lackluster success led the Rainsfords to lease it in 1759 to a young brewer named Arthur Guinness - at $£ 45$ per annum for 9,00o years. The Guinness brewery sits today at the corner of St James's Gate and Rainsford Street.

Marcus was the third of three children, preceded by his sister Frances and his brother Edward. He attended Trinity University in Dublin, receiving a master's degree in $1773 .{ }^{34}$ The following year, Frances married an officer in the British army, Welbore Ellis Doyle. Edward grew up to be a Dublin barrister who, in his brother's phrase, came to "enjoy the liberal fortune of our ancestors." ${ }^{35}$ This comment was more than slightly sardonic. As second son, Marcus expected the smaller share of his father's inheritance, but Edward Jr. apparently kept for himself everything bequeathed his siblings. ${ }^{36}$ Doyle would prove a better brother to Rainsford than Edward, always ready if need be with a place to stay or a few pounds. In the late 1770s, Rainsford followed him to fight against the North American colonies in the American War for Independence.

When Rainsford arrived, his brother-in-law had been serving for several years as an officer in the Fifty-fifth Regiment of Foot, bringing Frances with him to the colonies. Irishmen were heavily represented on both sides of the battlefield, and the British commander in chief, General Henry Clinton, soon thought of creating a regiment out of Irish deserters from American units. He put Francis Hastings, Lord Rawdon, in charge of forming the Volunteers of Ireland in New York and Philadelphia in the winter of 1778. Rawdon was a young Anglo-Irish aristocrat whose courage in battle propelled him swiftly up the military hierarchy. As the colonel of this regiment he chose exclusively officers born in Ireland, appointing Welbore Ellis Doyle as lieutenant-colonel. Marcus Rainsford likely purchased his commission as ensign in the regiment 
in 1778 , although his name first appears on a muster in $1779 .{ }^{37}$ His brother-inlaw probably recommended him, a pattern that would become recurrent.

Rainsford was present at the siege of Charleston in April 178o. He also participated in the battle of Camden in August 1780 before joining Lord Charles Montagu's Duke of Cumberland's Regiment, a unit raised in the American colonies but authorized by Governor Dalling of Jamaica for eventual service there. In November 1780 Montagu began forming his regiment-also known as the South Carolina Rangers - mostly from rebel prisoners taken at Charleston and Camden, but also from enslaved Africans. Blacks in the army hitherto performed mostly menial work because the British remained reluctant to arm them. Now they were needed to defend cities, and were promised freedom for their service. Black soldiers were engaged in several of the actions in which Rainsford was involved. By the end of the war they were a small but permanent part of his regiment. ${ }^{38}$

The South Carolina Rangers were transferred to Jamaica in August 1781, and Rainsford was promoted to captain there the following year. ${ }^{39} \mathrm{His}$ company was based at Fort Augusta near Kingston from December 1782 to August 1783, at which point the regiment was disbanded, and he was released from duty on half-pay. ${ }^{40}$ Many white officers from colonial corps sent to Jamaica at the end of the American War of Independence settled on the island. Nothing indicates that Rainsford was among them. Black loyalist troops transferred to the island were not free to settle, however. Jamaican planters were wary of the example free black soldiers might set for the enslaved. Black soldiers from the South Carolina Rangers would later form the backbone of the First West India Regiment, mustered to defend Jamaica against the contagion of rebellion in St. Domingo. ${ }^{41}$

Rainsford returned to England, where his whereabouts grow murky. The year 1791 was an eventful one. The Morning Chronicle notes his appearance in Portsmouth at a fashionable dinner for fellow officers in January. Other newspapers from the same year report a feud provoking Rainsford's indictment on charges of offering a challenge. ${ }^{42}$ Soon thereafter he made his way to London, possibly for trial. There he took steps to achieve what must have been a longtime dream: celebrity as a poet. He published - anonymously but with a distinguished press - the first canto of an epic, The Revolution; Or, Britain Delivered. Written in heroic couplets, the poem when finished (as its table of contents promised) would comprise twelve cantos on the potent historical subject of the Glorious Revolution. ${ }^{43}$ As a bid for literary distinction, however, The Revolution proved disappointing. Reviewers universally ignored it.

Rainsford's active military service would resume as the shock of revolution in France and St. Domingo rattled British shores. The Duke of Cumberland's 
Regiment had been disbanded nearly a decade, and Rainsford was eager to obtain a new commission. Although his sister and brother-in-law appear to have supported him financially during this period, he felt the pinch of his circumstances, having had the ill luck at one point to fall afoul of highway robbers. ${ }^{44}$ Sometime in 1793 he wrote a letter to Prime Minister Pitt begging him in the name of "Officers on half pay of his Majesty [sic] American Forces" for "any engagement his Majesty is pleased to allow." ${ }^{45}$ It is unclear whether Pitt replied, but Rainsford soon got his wish. As usual his military fortunes followed his brother-in-law's.

Rainsford participated in the Duke of York's ill-fated expedition against France in the Netherlands in 1794. He was assigned to Colonel Thomas Hardy's Royal York Fusiliers, a corps made of German mercenaries commanded by British officers. His brother-in-law was again involved in the expedition. Doyle managed to find glory in an otherwise disastrous campaign, winning battles in its early stages and later with the Earl of Moira's expeditionary force. ${ }^{46}$ Rainsford's corps was raised in Germany, and it did not arrive in the Netherlands until late in the year, when the bitter winter was approaching that would bring the expedition to a horrific close. Rainsford's military feats there hardly bear comparison to his brother-in-law's, but he took heroic care of his men, risking his life to see them decently clothed in the deadly cold and securing safe haven for his sick and wounded during the ensuing retreat in January $1795 \cdot{ }^{47}$

Doyle's heroics brought him more than fame. When he returned to England in February 1795 he was made brigadier-general and governor of Southampton. ${ }^{48}$ Rainsford followed him to England, freed from his commission in the York Fusiliers through Doyle's rising influence. He probably stayed with his sister and Doyle while awaiting reassignment, sending a memorial to the Duke of York, perhaps in thanks for a new commission. ${ }^{49}$ Indeed, through his "inestimable brother-in-law," Rainsford was appointed captain and recruiter in one of the newly minted West India regiments in July $1795 .^{50}$ His experience in America and Jamaica doubtless also played a part in convincing military authorities of his value as a recruiter for a corps to be raised from among the enslaved in the West Indies.

A year earlier, General John Vaughan first floated the idea for such a corps as a way to offset the terrible toll that guerilla warfare, climate, and sickness were already taking on British troops. ${ }^{51}$ Recruiters were initially instructed to muster soldiers primarily in St. Domingo, but a lack of enthusiasm among free blacks for the British cause led authorities to authorize requisitioning slaves in Jamaica as well. ${ }^{52}$ Rainsford landed there at Port Royal early in 1796 destined for St. Domingo. ${ }^{53}$ A sudden armed uprising by the Trelawney Ma- 
roons caused Lord Balcarres, then governor of Jamaica, to order many of the troops passing through to stay and fight what became known as the Second Maroon War. ${ }^{54}$ Rainsford participated in the conflict in some fashion. He certainly observed it. The British deployment of bloodhounds against the Maroons made a vivid and lasting impression, which he later recorded in his Historical Account of the Black Empire of Hayti. The war was over by March 1796, thanks in no small part to the bloodhounds, but Lord Balcarres was still reluctant to allow British troops to proceed to their original destinations.

The exact date of Rainsford's arrival in St. Domingo remains unclear, as are the particulars of his movements, but he was probably on the island by mid-1796. Recruiting was a difficult assignment, and it allowed unusual mobility. Muster rolls for the Third West India Regiment list Rainsford "absent by leave" from its inception and throughout his time in St. Domingo. ${ }^{55}$ Black volunteers there were scarce. Even planters supporting the British occupation hesitated to turn their slaves into soldiers. The British quickly imposed a mandatory levy in the occupied zone of one in fifteen enslaved Africans. ${ }^{56}$ They would in time resort to buying blacks from Jamaican planters - and from Africa on the sly. ${ }^{57}$ Despite Rainsford's efforts, the Third West India Regiment never fully materialized in St. Domingo. It remained mostly a corps of officers, some of whom were garrisoned at Stony Hill in St. Andrews Parish, Jamaica, in 1796. The regiment was eventually ordered to Martinique, where its commander, Lieutenant-Colonel Keppel, had been appointed civil and military governor. ${ }^{58}$

Rainsford returned to England early in 1797, apparently to recover from an injury to his left arm. ${ }^{59}$ His name appears on the musters of HMs Sampson, which docked at Plymouth on January $8 .^{60}$ By February he was in London seeking payment from the War Office for his stint in the West Indies. In a written reply the undersecretary $M$. Lewis rejected Rainsford's request for "Bat and Forage money stated to be due [. . . ] for service in the island of Jamaica" on the grounds that such pay could only be issued by a regimental agent in the field.$^{61}$ Strapped for cash as usual Rainsford could no longer rely on the generosity of his brother-in-law. In April 1796 Doyle had sailed to Ceylon to take up the duties of commander in chief and acting governor. ${ }^{62}$ The Duke of York's crackdown on nonchalant behavior among British officers provided yet another incentive for Rainsford to return to the field. ${ }^{63}$ Sometime in mid-1797 he again sailed for the West Indies, that soldier's cemetery, to rejoin his regiment and collect his pay.

His first challenge was to find his unit. During his absence, the Third West India Regiment had been transferred out of St. Domingo, but it wasn't clear where. Martinique seemed the likely destination, since Lieutenant-Colonel 
Keppel, the unit's commanding officer, was now military governor there. But when Rainsford arrived, the governor informed him that, no, the regiment was in Jamaica. ${ }^{64}$ Rainsford boarded a transport and made his way to Port Royal, only to find that his unit had already left Jamaica - for Martinique. He had no alternative but to return windward. It was well past time to rejoin his regiment. The good soldier would do his duty, or so Rainsford claims in his writings. Musters of the Third West India Regiment contain traces of a more complicated story, however. They list him "absent by leave" until July 1798 , when he finally reappears in Martinique. Rainsford would not catch up with the Third West India Regiment for over a year after he had set out to find it. ${ }^{65}$

In the meantime he had adventures. Making his way from Jamaica to Martinique, he boarded the Hannibal on October 8, 1797, at the invitation of his friend Admiral Edward Tyrell Smith and sailed to occupied St. Domingo. On October 24 he disembarked at Mole St. Nicholas. ${ }^{66}$ Exactly how long Rainsford stayed on the island remains a mystery. On December 8 he at last secured his pay, receiving $£ 45.15$. o for services rendered from August 25 to December 24, $1797 .{ }^{67}$ Tempting as it might have been to remain in a war zone, he was wanted in Martinique. Early in 1798 Rainsford arranged passage on the schooner Maria, flying a Danish flag but piloted by a British captain named James Frazer. The ship had the bad luck to run into a hurricane and was forced ashore at Cape François, the Republican capital of the colonyenemy territory, since the British would not evacuate until autumn. As several French vessels sailed to intercept the Maria, Rainsford made a snap decision. He would pretend to be an American to avoid arrest and detention as a prisoner of war.

The trick worked. Rainsford passed as an American sailor and on landing encountered a lively if war-weary town. Trade with American merchants remained brisk (hence the disguise). Cape François still had fine hotels and an active theater, which Rainsford found time to attend. ${ }^{68}$ He seems to have enjoyed the high life, such as it was, and it wasn't long before he met the famed general in chief of the Republican Army, Toussaint Louverture. Rainsford conversed with him on several occasions and even tested his skill at billiards. Always the soldier, Rainsford made the military most of his unintended stay among the enemy. He drew sketches of the town and its surrounding fortifications, intending to present them to the Duke of York. His observations of black troops confirmed what he and the British army had learned from experience. Their skill at guerrilla warfare was impressive. Their military discipline was, too. They could march and maneuver with the best, as Rainsford noted when he witnessed a review of several thousand troops. ${ }^{69}$

But Captain Rainsford had a regiment to find, so after repairs the schooner 
embarked again for Martinique. Only forty miles down the coast, however, the boat sprung a leak, or so Frazer and Rainsford told local authorities when they landed at the heavily defended port of Fort Liberté. This time Rainsford fooled no one. A sentry immediately arrested him under suspicion of being a British spy. Luckily he was detained on board the Maria long enough for him to toss the bag containing his notes, sketches, and military papers overboard. His captors soon transferred him to a jail on shore to await trial. A dashing Republican officer named Moïse, Toussaint's adopted nephew, commanded Fort Liberté. He served as a member of the military tribunal hearing Rainsford's case, over which General Henry Christophe presided. ${ }^{70}$ It was a who's who of revolutionary leaders, and they were in no mood for mercy. Frazer's protests were to no avail: Rainsford was judged a spy, condemned to death, and returned to prison to await Toussaint's endorsement of the verdict.

Rainsford remained there for two weeks before Toussaint's answer finally came. To Rainsford's surprise and lasting gratitude, the general ordered his immediate release and departure. Toussaint informed the British officer that he should never return to the island without proper identification, a mischievous quip that convinced Rainsford the general in chief had no more been fooled by the American disguise than had his tribunal. Rainsford left St. Domingo grateful to be alive. The Maria suffered no further misadventure and eventually reached Martinique safely. The commander there, General Cornelius Cuyler, welcomed the truant recruiter back to his regiment and authorized compensation for the abandoned bag containing his sketches and papers. But Rainsford did not stay long in Martinique. The promise of compensation drew him to London, superseding, apparently, the demands of his commission. ${ }^{71}$

Rainsford settled for a few months at 27 James Street near Covent Garden and as usual chased his pay. He repeatedly wrote the War Office, only to get the same rejections he received a year earlier from the same M. Lewis. ${ }^{72}$ Rainsford may have tried to sell his West Indian commission or exchange it for one in a better climate. ${ }^{73}$ But once again, he was forced to return to the West Indies, if only to collect his salary. He arrived in Martinique once and for all on April 18, 1799, serving dutifully until March 19, 1800, when he retired, "ordered by his Excellency the Commander in Chief [General Thomas Trigg] to do no more duty for the Regiment but to receive pay for the present."74 Rainsford must have sailed with the first available transport to England, for he sold his commission on June $17,1800 .{ }^{75}$ His military life was over, at least for the moment.

He still harbored his old dream, however, of achieving distinction as a man of letters. In June 1800 R. B. Scott published a new six-canto edition of Rains- 
ford's 1791 epic. This time the poem found an audience, albeit few and not so fit. It received very harsh notice in several literary journals. ${ }^{76}$ This reaction may have dampened Rainsford's poetic ambitions, but not (according to the press) his social life. Rainsford regaled London high society with tales of his adventures in St. Domingo, finding an audience for another kind of writing. ${ }^{77}$ Although his poetry never caught on, his military memoirs would. In 1802 Scott published Rainsford's first pamphlet, A Memoir of Transactions That Took Place in St. Domingo in the Spring of 1799. The public was hungry for news about revolution in the French colony. In the wake of the British evacuation, information was sketchy. Newspapers spread the notoriety of Toussaint Louverture as the British government sought to drive a wedge between him and the French Republic in order to secure favorable commercial relations in the event of independence in St. Domingo. At the same time fear of an independent black state there was growing among British planters in Jamaica, their political allies at home, and increasingly the general public. These issues gained currency as peace with France gained plausibility. The pacific interlude that opened with the Treaty of Amiens (March 1802) saw the publication of several pamphlets debating the fate of St. Domingo. ${ }^{78}$ As Napoleon organized an invasion force and as Britain discretely observed neutrality, commentators including Rainsford deliberated the outcome.

The military apologist Colonel Charles Chalmers judged the occupation to have been "a most important and splendid enterprise," whose disappointing outcome was an effect, not of black military prowess, but of white administrative incompetence - and yellow fever. ${ }^{79}$ James Stephen offered more caustic commentary. With abolitionist intensity, he denounced England's "cart-whip empire" and dismissed the occupation as "a long blockade." ${ }^{80}$ Stephen perceived French intentions with baleful clarity: "a counter-revolution in the state of the enfranchised negroes, is the main object of France in her West India expedition." ${ }^{81}$ Would England stand by and watch as Napoleon, in the name of the Republic, re-impose slavery on people freed in the name of the Republic? ${ }^{82}$

Rainsford's first published accounts of his experience in St. Domingo participate in this debate. He wrote his 1802 Memoir of Transactions That Took Place in St. Domingo, as its opening pages claim, both to deny that Toussaint was untrustworthy and to prove that an independent black state in St. Domingo posed no threat to British West Indian possessions. These were provocative and original arguments, at odds with prevailing prejudices. ${ }^{83}$ The pamphlet attracted some critical attention in England, and was reviewed, lauded, and excerpted in foreign journals. ${ }^{84}$ Rainsford's eyewitness insights were appreciated abroad, among other reasons, for providing a counterpoint to French reports. Reception was favorable enough for Scott to publish a sec- 
ond edition of the memoir later in 1802 under the title St. Domingo; Or, an Historical, Political and Military Sketch of the Black Republic. ${ }^{85}$ This edition was thirty pages longer than the first and included a new a section devoted to the island's geographical and historical background, as well as a freshly engraved map. Scott published yet a third edition near the end of the year, this one containing one of the earliest extant portraits of Toussaint. ${ }^{86}$ British readers responded positively to a firsthand account revolution in St. Domingo.

Napoleon's invasion force, 25, ooo strong, landed at Cape François in February 1802. Military momentum soon swung against the revolutionaries. Under the command of Napoleon's brother-in-law, Charles Leclerc, the French achieved quick victories, defeating some black troops outright and absorbing others with their leaders into the French Army. Toussaint resisted magnificently but, with the arrival of 5,500 seasoned French veterans, he saw victory slipping away. Reluctantly, he negotiated surrender. His troops became soldiers of France, while he retired from the field of battle to private life on his plantation at Ennery. News of Toussaint's surrender reached Britain later in 1802, yet Rainsford remained steadfast in his favorable opinion of the black revolutionaries: "French policy has been successfully exerted, but St. Domingo is not subdued." ${ }^{7}$ The horror and hard victory still to come on the island would prove Rainsford right. In the meantime he enjoyed a small celebrity, hoisting cups with his former comrades and commanders of the campaigns in America and the Netherlands, all of whom had risen up the military ranks. Prominent among them was the Earl of Moira, whose nuptials in 1804 provided Rainsford with another opportunity to test his muse. He was not as close to Moira as had been his brother-in-law Doyle, but he nevertheless wrote a wedding poem in his honor: An Hymeneal on the Marriage of the Right Hon. Francis, Earl of Moira. ${ }^{88}$ His sonnet on the death of Erasmus Darwin had appeared earlier in the Gentleman's Magazine. ${ }^{89}$ The old soldier was having some success with his new vocation.

St. Domingo was more than ever in the news. The devious capture and arrest of Toussaint, spirited to France to languish and die in prison at Fort de Joux, did little to assuage British wartime prejudices. Accounts of atrocities on both sides circulated widely. With the renewal of hostilities in May 1803 Britain established a naval blockade around St. Domingo. Better an independent black state than a recovered French colony. Black revolutionaries rallied around Toussaint's successor, General Jean-Jacques Dessalines, who fought tenaciously and achieved final victory in November 1803 at the Battle of Vertières near Cape François. Dessalines's army drove the French from the island for good, inflicting heavy damage on their colonial empire and shaping the course of world history. ${ }^{90}$ Napoleon had met his match. Dessalines pro- 
claimed an independent Haiti on January 1, 1804, and himself emperor the following September.

Rainsford's predictions were vindicated. The astonishing rise of this black empire convinced Rainsford that readers would welcome a longer, fully documented version of his historical account. He further researched the natural and political history of the island. He read all available documents, then sought out more. ${ }^{91} \mathrm{~A}$ lavish, comprehensive, and expensive book appeared a year later in 1805, and it made a splash. It was widely reviewed in England and on the continent and was translated twice within the year. ${ }^{92}$ The ultimate impact of An Historical Account of the Black Empire of Hayti may be debatable, but its immediate impact is not. It attracted wide interest and reigned for a time as the standard British account of Haitian independence. Rainsford, who had failed as a poet, flourished as a historian.

Even so, his later years saw accomplishment mixed with obscurity. However successful, the publication of his book did not solve Rainsford's money problems. In May 1810 he enlisted as an ensign with the First Royal Veteran Battalion, a unit made up of wounded, infirm, and aging soldiers fit mostly for garrison duties. He served until it was disbanded four years later. In December 1811 Rainsford began to receive a military pension of $£ 100$ a year for "injury sustained while a prisoner of war" in St. Domingo. ${ }^{93}$ Steady income seems not to have brought him the financial security he perennially chased. His fortunes took a hard turn when in 1813 he was again imprisoned, this time for debt. According to a notice in the London Gazette, he owed money to a crowd of creditors: army outfitters, winesellers, tailors, bankers, coal merchants, all the muses of a desperate affluence. He was living beyond his means. ${ }^{94}$

The old soldier was not quite done with the limelight, however, nor was he done with the West Indies. With Dessalines's assassination in 1806 Haiti split into separate states in the north and south. The rise to power of General Henry Christophe in the north boded well for diplomatic and commercial relations between Great Britain and Haiti. A native English speaker born in St. Kitts, Christophe held the British in high regard. After being proclaimed king in 1811, he viewed the United Kingdom as a political, economic, and cultural ally. King Henry I of Haiti, as he was known, favored British fashion and British governance, partly as a matter of survival. ${ }^{95}$ The Treaty of Paris of 1814 allowed France to resume the slave trade and effectively recognized its title to St. Domingo. The restored French monarch, Louis XVIII, plotted to reconquer Haiti. ${ }^{96}$ Both King Henry and President Alexandre Pétion of the southern republic prepared for a French invasion. The French threat was suddenly once again palpable. 
Henry's foreign minister, Count Limonade, and his secretary to the king, Baron de Vastey, wrote pamphlet after pamphlet denouncing France's plans, distributing them throughout Europe to awaken sympathy for Haiti's cause. ${ }^{97}$ King Henry himself corresponded directly with the famed abolitionists Thomas Clarkson and William Wilberforce, who in turn organized demonstrations against French slavery in England. Britons reacted strongly to this shameful aspect of the Treaty of Paris. Meetings occurred in pubs and taverns calling for universal abolition of the slave trade. Rainsford himself attended at least one event that was noted all the way across the Atlantic in Haiti. On November 24, 1814, the Times of London published a letter sent by Count Limonade to Marcus Rainsford thanking him on King Henry's behalf for a stirring speech delivered at a public meeting at the Horns tavern, Kennington, a few months earlier. ${ }^{98}$ Rainsford's staunch support for a free Haiti impressed the Haitian court. ${ }^{99}$

That support appears also to have inspired Haitian gratitude. If the evidence can be trusted, Rainsford was subsequently appointed lieutenant general in the Haitian army. It was obviously an honorary appointment, and its duties (if there were any) remain a mystery. Perhaps he acted in a diplomatic capacity. But according to the Morning Chronicle of February 25, 1815, he attended one of the prince regent's levees as an officer of the Haitian army, for he presented the Duke of York with "A Plan of Defence of the kingdom of Hayti." 100 Whether officially or not, Rainsford served the cause of an independent Haiti until the end. In June 1816 he translated and published several texts by Baron de Vastey under the title Translation of an Official Communication from the Government of Hayti, which he signed "Lieutenant-General Sir Marcus Rainsford, of the Haytean Army." 101 These texts served as a salvo in the war of words waged by the publicists of King Henry and President Pétion. Rainsford, as any lieutenant general would have, stood with his commander and the northern kingdom.

In spite of this apparently crowning appointment, Rainsford never returned to the island that had so intimately touched his life. He died in London and was buried on November 4, 1817, in the parish of St Giles in the Fields, survived by no one, his books achieving only an ambiguous immortality. ${ }^{102}$ Even after death his fate remained tied to the black empire whose rise from slavery he was the first to chronicle fully in English. In his will he mentions "money [.. . ] due to me in Saint Domingo in the West Indies or coming therefrom," which he bequeathed to a woman named Ellen Houghton, "in consideration of her faithful attendance on me for the last Eleven years." ${ }^{103}$ What her relationship was to Rainsford remains a mystery, as does so much else about this career soldier, sometime author, and permanent friend of Haiti. 
Such was the life of Marcus Rainsford reconstructed from documentary evidence. Perhaps it comes as no surprise that his own account should differ in a few minor but decisive details. Chief among them is the date he gives for his adventures in St. Domingo, emblazoned in the title of his earliest pamphlet: A Memoir of Transactions That Took Place in St. Domingo in 1799. That date is incorrect. Rainsford landed at Mole St. Nicholas on October 24, 1797, as the musters of Hмs Hannibal attest. He received payment there in December as captain of the Third West India Regiment, and he remained in St. Domingo for part of the following year. But by November 1798 he was back in London, writing letters to the War Office appealing for pay and compensation. Why this discrepancy? Maybe Rainsford simply got the date wrong-in edition after edition of his historical memoir. The more likely answer is less flattering: he willfully misrepresented the facts. Shifting that date forward one year, from 1798 to 1799, puts Rainsford in St. Domingo after the British evacuation. That little adjustment extenuates the question of what exactly a British officer was doing so far behind enemy lines. Beyond his frequent and emphatic denials, no hard evidence exists that Rainsford was in fact a spy. His lost sketches of enemy fortifications and troop deployments attest to little more than the fact gathering of any blue-blooded officer of His Majesty's army.

The motivation for Rainsford's time-slip is cultural rather than military: by transporting his adventures ahead one year, he directs attention away from the disaster of the British occupation and toward the glory of the Haitian Revolution. Rainsford's historical writing serves a double ideological agenda. As it chronicles the inspiring victory of black freedom fighters in their battle against re-enslavement by the French, it also downplays Britain's recent attempt to defend slavery by military means. Although he devotes forty pages to the British occupation in his history, that "disastrous enterprize" gets subsumed by his personal adventures, which quite conveniently occur a year after the evacuation of 1798. However quietly, Rainsford participates in a cultural cover-up that subordinates the impetus of revolution - chattel slavery-to happier outcomes, in this case a commuted death sentence and an independent Haiti. The problem of Britain's larger role in thirteen years of slaughter in St. Domingo remains understated.

This is artful dodging, certainly. At least one early reviewer had trouble completely accepting the authenticity of Rainsford's history, although he pointed out only a few factual errors. ${ }^{104}$ The rhetorical cunning of An Historical Account of the Black Empire of Hayti is not only the effect of a few factual liberties, however. Rainsford was a literary author, or wanted to be one. 
His historical account of the Haitian Revolution aims for epic scope, as the book's opening lines attest: "It has frequently been the fate of striking events, and particularly those which have altered the condition of mankind, to be denied that consideration by their contemporaries, which they obtain from the veneration of posterity." 105 This rousing overture turns out to be a barely modified version of the first sentence of the dedication to The Revolution: Or, Britain Delivered: "It has been the distinguishing fate of these great events, which have changed the state of a Government, to receive always but part of the praise to which they are entitled." ${ }^{106}$

Rainsford finds his true epic subject in St. Domingo: an unsung martial contest, complete with warring nations, fallen heroes, and victory against incalculable odds. He sings the birth of a new nation from the womb of slavery. What to many seemed a historical fluke-successful slave rebellionbecomes in his hands a heroic revolution. The peculiar form of An Historical Account of the Black Empire of Hayti (part history, part personal narrative, part news roundup) obfuscates its indebtedness to Rainsford's poetic writings. But the ambition to compose an epic drives Rainsford's work from the start. If Rainsford did not openly court the epic muse, Calliope, until 1791, they had met before. Having attended Trinity College, Rainsford, like most students at the time, would have dabbled in composing poetry. He certainly studied it extensively, along with history, Greek, and Latin. Throughout his career as an officer in His Majesty's army, Rainsford would keep poetry close to his heart.

In 1782 the poet and critic William Hayley published An Essay on Epic Poetry, a spirited call for the revival of epic form in Britain. John Milton, a master of the form in English, who had written the definitive Christian epic a century earlier, commanded Hayley's respect. ${ }^{107}$ Yet Milton's Paradise Lost, with its Heavenly Muse and diabolical rebellion, its pallid Adam and greedy Eve, too clearly showed the touch of religious faction to suit the liberal nation Britain had since become. Hayley urged poets to return to a more classical epic form, one celebratory of the nation, its martial history and moral prowess: "I wish to kindle in our Poets a warmer sense of national honour, with ambition to excel in the noblest province of poesy." ${ }^{108}$ Not Heaven and Hell but Britain and her native-born heroes provide the true stuff of epic: "Th' Heroic Muse, in earthly virtue strong / May drive the host of Angels from her Song." 109 This new, secular epic, faithful to classical progenitors, might resuscitate the reputation of England as much as its poetry:

That Poesy's sublime, neglected field May still new laurels to Ambition yield;

Her Epic trumpet, in a modern hand, Still make the spirit glow, the heart expand: 
Be such our doctrine! Our enlivening aim

The Muse's honor, and our Country's fame! ${ }^{110}$

Hayley's new epic would be historical and human, alive with "scenes that glitter with no heavenly blaze, / Where human agents human feelings raise." ${ }^{111}$ And these human agents would be British. Every nation has its heroes. Why should England's go unnoticed? "By some strange fate, which rul'd each Poet's tongue, / Her dearest Worthies yet remain unsung." 112 The solution was an epic grounded in British history and devoted to British virtue:

To sing, with equal fire, of nobler themes,

To gild Historic Truth with Fancy's beams!

To Patriot Chiefs unsung thy Lyre devote,

And swell to Liberty the lofty note! ${ }^{113}$

Hayley challenges the next great English poet to produce a poem worthy of the English nation, a celebration of "Patriot Chiefs unsung."

English poets heeded Hayley's call for a "new national epic," Rainsford among them. ${ }^{114}$ In his introduction to the first edition of The Revolution: Or, Britain Delivered, Rainsford restates Hayley's lament, noting how decisive historical events "receive but part of the praise to which they are entitled." ${ }^{115}$ With this assertion, Rainsford makes clear that his narrative will not be merely historical: indeed, the Glorious Revolution of 1688 was already a topic for "serious" histories. ${ }^{116}$ But neither would it be merely poetic. He intended to produce a new, hybrid form, an epic poem that could stand as history; inspiration supported by incontrovertible evidence:

By the subsequent view, it will appear that the Author does not mean a simple panegyric on the Revolution, a work of imagination only. He wishes to aim at something higher; the connection of History and Poetry; and, though obliged, from the recent date of the facts, (which do not admit such embellishment), to exclude from the former every aid of the marvellous, (a license allowable with a remote period), he is persuaded that the interesting nature of the subject itself will sufficiently compensate for this defect [...]. Hence it may be considered, perhaps, as a work sui generis, that aims, like the Epic Poem, at celebrating a great event, but, from the nature of its subject, is more strictly confined to truth in its detail; while, depending on the greatness of the subject itself for its resources, it applies less to the imagination than to the head and heart. ${ }^{117}$

A year earlier James Ogden had made a similar claim of historical worth for his epic poem The Revolution. ${ }^{118}$ Where Ogden was content with a "foundation in historical facts," however, Rainsford painstakingly introduced into the first edition of his poem modes of documentation borrowed from historical 
writing. Almost every page is laden with footnotes providing short biographical sketches for major characters or explanations of historical events. The Revolution; Or, England Delivered is an odd text, reading like an annotated edition of itself. Mixing poetry and history may not have been unprecedented, but Rainsford felt it was necessary to give the Glorious Revolution its due.

The Revolution landed with a thud, provoking no critical response in 1791. That only one of the first volume's promised seven cantos was published suggests it was no crowd pleaser. But Rainsford soldiered on. R. B. Scott published his considerably revised six canto edition of The Revolution in 1800. The poem's dedication, barely modified, now lauds the king. Its pages still carry footnotes, but they are fewer in number and shorter in length. Rainsford similarly streamlines his original preface, paring down his disquisition on historical writing. He again defends his originality, asserting that "however the present work in the eye of criticism may appear to be executed, this merit it can at least boldly claim, that the Principles of the Revolution are held out by it, in a point of view the most engaging that has yet been offered." 119

Critics did not think so. Rainsford's poem was savaged in several journals. The Monthly Review pilloried its "rugged" versification and its "remarkably incorrect" rhymes." ${ }^{120}$ Rainsford may have hoped he would be recognized for inventing an original epic form, but critics ignored that aspect of the poem, preferring to attack its style. The Critical Review noted that "the author may be intimately acquainted with the history of the times of which he treats, but, decidedly, he is no poet" - rough judgment for anyone responsible for two hundred and fifty pages of verse. ${ }^{121}$ The Monthly Review, however, concluded that "a perusal of this work affords more entertainment than many other compositions of the same kind, which possess superior poetical merit." 122 To read beyond the bad poetry (Rainsford's clunking heroic couplets) is to discover an epic of exactly the kind Hayley calls for; however, one that describes recent historical events and celebrates superior national virtues. Admittedly, the Tonnage and Poundage Act and the Exclusion Bill lack the thrill of Troy's windy plains (not to mention Heaven's starry spheres), but Rainsford's turn to the Glorious Revolution for the stuff of epic is nevertheless bold in its way. It advances the era of epic glory from the distant to a more recent past, claiming for contemporary England a living legacy of national superiority.

Hardly a popular argument today, nor even, apparently, then. But for Rainsford, the Glorious Revolution was, historically and politically, a revolution. It transformed British society from autocracy into a liberal polity. ${ }^{123}$ Rainsford writes a Whig history in couplets that narrate the historical fall of tyranny (of both crown and faction) and the triumph of law, guarantor of freedom: "True 
Freedom's reign, on Law's just sway depends, / Where public weal, the private int'rest blends." ${ }^{24}$ His epic muse is "fair Freedom," whose descent he calls upon to inspire his rhymes. His epic heroes are famous (Protestant) Britons, whose devotion to law in the face of power proves their enduring virtue: the First Earl of Bedford, who narrates the poem; his martyred son Russell; James Scott, First Duke of Monmouth; and Algernon Sydney, eventually beheaded in the cause of freedom:

Accept ye Patriot Band! Your Country's praise, To you did Freedom owe here spreading blaze;

'Twas your fair toil, first wak'd the nation's zeal, Against their Rights each inroad to repell, That trac'd the bound where regal sway should end, And gave to trampl'd law her just command. ${ }^{125}$

To sing the triumph of law over power and privilege may not achieve the sublime. But for Rainsford as for Hayley freedom is the true subject of the contemporary epic. National heroes consolidate a (Protestant) nation in the name of freedom: "Immortal chiefs! to whom Britannia owes / Fair Freedom's gem that now adorns her brows!" 126

Rainsford seldom acknowledged publicly his poetic ambitions. They remained mostly anonymous, something only friends, family, and acquaintances deserved to know. His attempt at historical epic, however, was instrumental in leading him to try writing history with an epic scope. In the rebellion in St. Domingo Rainsford found material for a new national epic, in its own way glorious: a revolution transforming a slave colony into an independent nation. He approached the project with premeditation, publishing two synoptic pamphlets before attempting a complete account of the revolution. An Historical Account of the Black Empire of Hayti shares with the classical epic its encyclopedic reach and martial content. Moving from minute details of daily life among free blacks to the military exploits of their great hero Toussaint Louverture, it incorporates epic convention into the body of historical narrative. More importantly it continues the project begun in The Revolution; Or, Britain Delivered of celebrating law and liberty as the foundation of national virtue - only this time the "Patriot Band" comprises once enslaved insurgents and their "Country's praise" exalts a newborn nation, Hayti.

Rainsford faced a peculiar historical conundrum, however, one he experienced firsthand as part of the British force of occupation. The Glorious Revolution in England led historically to counter-revolutionary intervention in St. Domingo. His sometime epic muse ("Freedom") stood baffled by contemporary events. Enter the historian, Captain Marcus Rainsford, Esq., a career 
soldier writing as a simple observer of events in St. Domingo. Chief among Rainsford's literary achievements may be this authorial persona: Captain Rainsford, twenty-four years in His Majesty's service, a devoted if obscure officer who witnessed revolution in the making. This Rainsford is a mere chronicler of looming historical events, history's pawn rather than its producer. He contrasts with the anonymous author of The Revolution; Or, Britain Delivered in lacking the moral assurance that Britain is another word for liberty. His participation in the events he narrates complicates their value - for himself as much as for his readers, a point he makes in his earliest published account of St. Domingo: "Very little will be expected in the following pages when coming from the pen of a Soldier but that little will be found to be his own." 127

This emphasis on personal involvement in the narrative of history allies Rainsford's Historical Account of the Black Empire of Hayti with contemporary literary innovation. British Romantic writers who invoke the epic muse do so as themselves. William Wordsworth is the obvious example. The Prelude (1798-1805) implodes the classical epic, turning everyday life into material for heroic song and placing the poet at its center. Rainsford's personal turn is less complete but similarly heuristic. Including himself in his narrative, if even provisionally, allows him to observe a new nation being born: Hayti, true heir to a British freedom that for the moment even Britain has forsaken, but that this British bard does his best to sing. It's a neat trick, this Britishization of the Black Empire. It anticipates at the level of historical narrative the neo-colonial agenda of British foreign policy toward an independent Haiti. Rainsford's history recapitulates his poetry's ambition to establish national preeminence, with this difference: Haiti now wears "fair Freedom's gem" by proxy. The Revolution; Or, St. Domingo Delivered, Rainsford's epic history, assimilates the Haitian Revolution to its Glorious precursor, making Haiti the heir of British liberty and Britain the executor of Haitian freedom.

Rainsford reached for epic scope by cobbling together extant accounts of St. Domingo's history. He references early records of travel in the West Indies, quotes French sources on the settlement of Hispaniola, and cites contemporary classics about St. Domingo. On the Haitian Revolution itself, Rainsford refers to and comments on a variety of French and British sources. ${ }^{128} \mathrm{His}$ book shows the influence of other genres too. From travel narrative Rainsford takes an ethnographic attentiveness to his surroundings, describing mundane details of domestic and social relations among free blacks at Cape François. Romance adds a touch of sentiment to his story when a woman of color, an "angelic representation of mercy," visits him in jail at Fort Liberté while he awaits execution. ${ }^{129}$ An Historical Account of the Black Empire of Hayti mixes a 
variety of popular and belletristic genres to produce a narrative that Rainsford hoped would appeal to a wide audience.

Reviews were generally positive if not unanimously kind. The book's composition came under particularly harsh scrutiny in the Edinburgh Review, which skewered Rainsford for leaning too heavily on the Abbé Raynal, William Robertson, and Bryan Edwards, without bothering to comment on their mistakes. It dismissed the book's heft as demonstrating "the true way to expand a narrative of thirty or forty pages, into several pounds weight of letter-press." ${ }^{130}$ Other reviews were much more favorable. Rainsford's general description of life in St. Domingo, his portrayal of Toussaint Louverture, and his vignette about the benevolent woman of color were all excerpted at length. ${ }^{131}$ Rainsford's enthusiasm for the newborn Haitian state, however, frequently met with condescension. In an otherwise generous response the Anti-Jacobin Review concluded that Rainsford "forgets himself, by making the negro see with the eyes of an European." ${ }^{132}$ The Monthly Review, while noting his admiration for "the Negroe race," confessed that its editors could not "entirely adopt his sanguine views." ${ }^{133}$ The views of this simple soldier were ahead of their time.

An Historical Account of the Black Empire of Hayti fared even better abroad than in Britain. The philosopher and editor Wilhelm Von Archenholz published extensive selections in his journal Minerva, a source for German intellectuals of information about the revolution in St. Domingo. Among them was Georg Wilhelm Friedrich Hegel, an avid student as much of current events as of contemporary philosophy. Hegel was even then refining his dialectical conception of history as the concretization of spirit. He published The Phenomenology of Spirit in 1807, the very year of the abolition of the slave trade in Britain. Given the centrality to his views of the restive relation between Master and Slave ("Herrschaft und Knectschaft") there is every reason to believe that the Haitian Revolution helped inspire Hegel's dialectic. ${ }^{134}$ Through his influential account of black rebellion, then, Rainsford plays an oblique part in the development, of not only dialectical philosophy, but also its later, more insurgent interpretations.

He plays a direct part in creating a lasting historical awareness of the Haitian Revolution as a progressive event. Other contemporary accounts, most notably Bryan Edwards's An Historical Survey of the French Colony in the Island of St. Domingo, looked with trepidation on the prospect of an independent black state in the Caribbean. Edwards first published his history in 1797, then republished it in 1801 as the third volume of The History, Civil and Commercial, of the British Colonies in the West Indies. He personally witnessed the immediate aftermath of the uprising around Cape François in August 1791, and 
what he saw was "the triumph of savage anarchy over all order and government." ${ }^{135}$ As proof he offered a litany of atrocities. His authority was formidable, having lived most of his life in Jamaica and amassed great wealth as a planter. Edwards interpreted the rebellion in St. Domingo as a Republican contagion that menaced nearby Jamaica, and he wrote in hope that "fellowcolonists, in lamenting its catastrophe, might at the same time profit by so terrible an example." ${ }^{136}$ Profit they did, as government policy veered toward securing the safety of Britain's richest colony. Edwards viewed the occupation of St. Domingo as a noble endeavor "to restore peace, subordination, and good government on this theater of bloodshed." 137

Rainsford served this military endeavor, but his history abdicates Edwards's agenda of restoring "peace, subordination, and good government." Instead, it accounts politically for the unprecedented phenomenon its title announces: the Black Empire of Hayti. In doing so Rainsford helps orchestrate a chorus of dissent that includes abolitionists, poets, and pamphleteers. The celebrated abolitionist Thomas Clarkson provided financial backing for armed rebellion in St. Domingo. ${ }^{138}$ As early as 1792 the anonymous An Inquiry into the Causes of the Insurrection of the Negroes in the Island of St. Domingo lays blame for the unrest squarely at the feet of French planters: "Resistance is always justifiable where force is the substitute of right." ${ }^{139}$ William Blake wove the revolutionary events in St. Domingo into the mythology of his contemporaneously written long poem Vala: Or, the Four Zoas. ${ }^{140}$ Rainsford would hardly endorse the radicalism of some of these activists. His history nevertheless offers an important corrective to writers and politicians who saw only savagery in the prospect of black independence. An Historical Account of the Black Empire of Hayti endorses the Haitian Revolution as an instance of human progress. The history of an independent Haiti, far from falling into eclipse as a potent tradition of commentary would have it, continually challenges conventional beliefs and disturbs colonialist behaviors. Haiti found in Rainsford's historical account a source of persistent historical memory. ${ }^{141}$

\section{The Revolution, Illustrated}

That memory persists most vividly through the engraved images that accompany Rainsford's text: twelve in all, including a newly drawn map of St. Domingo and a plan of the city of Cape François. With the exception of the latter, Rainsford is credited with creating the original drawings on which the engravings are based. He clearly possessed some talent with the pencil as well as the quill. He also produced at least one political cartoon, a satire 


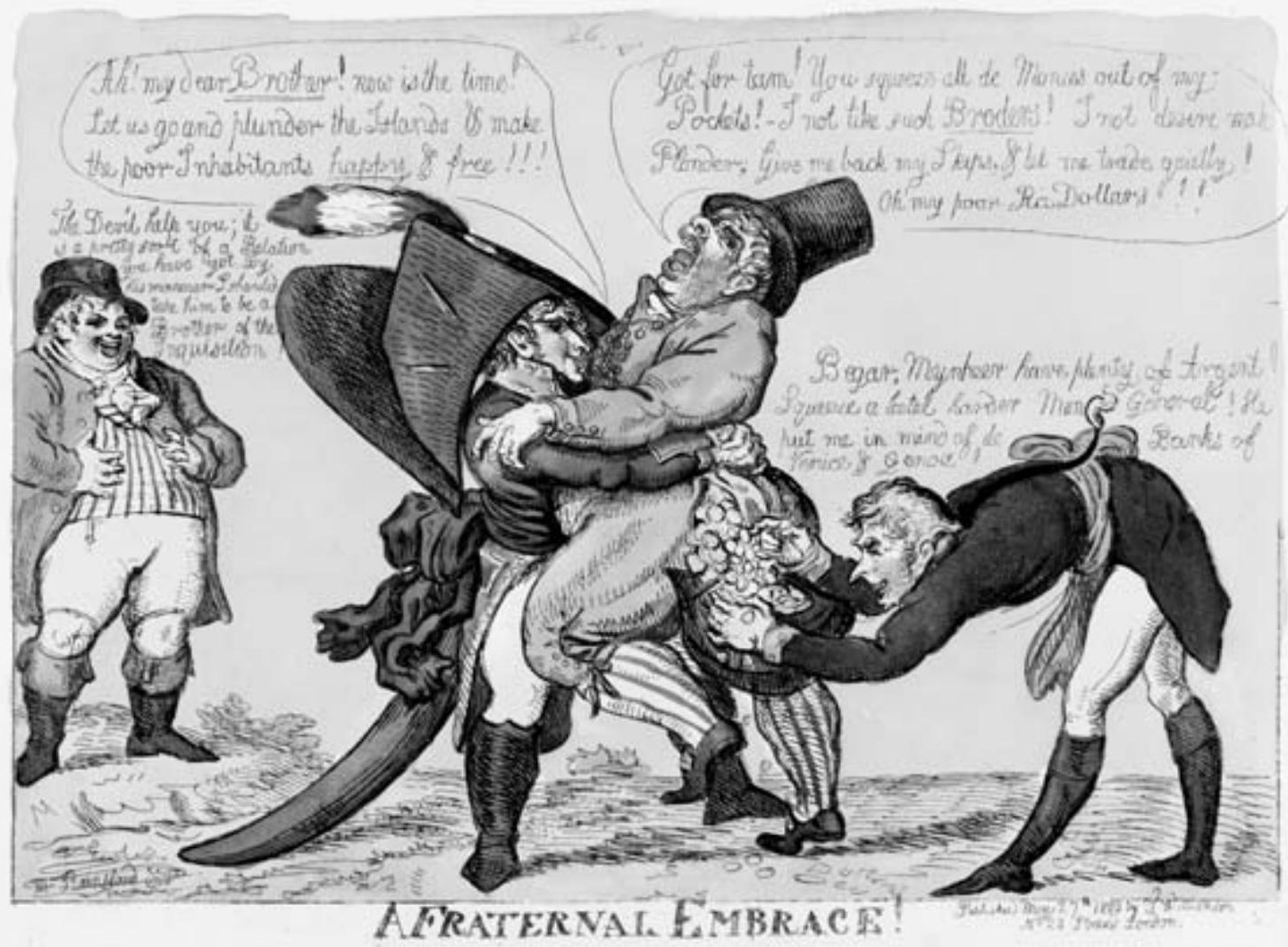

A Fraternal Embrace! pF в 8.N1627.z805n (no.21), Houghton Library, Harvard University.

published on May 27, 1803 (just two weeks after the collapse of the Peace of Amiens), titled "A Fraternal Embrace!" This arch image pillories Napoleon's grip on Holland and his belligerence against blacks. ${ }^{142}$ Rainsford added images to his pamphlets on St. Domingo, increasing their number as his publications grew longer. ${ }^{143}$ The stark engravings in An Historical Account of the Black Empire of Hayti remain to this day the best known contemporary representations of the Haitian Revolution. They were executed by Inigo Barlow, an engraver working in London known for meticulous renderings of natural scenes and specimens. Barlow contributed illustrations to a variety of noteworthy books, including Abraham Rees's Cyclopaedia (1788-91), Thomas Maurice's Indian Antiquities (180o), and John Gabriel Stedman's Narrative of 
a Five Years Expedition against the Revolted Negroes in Surinam (1796), a commission he shared with, among others, William Blake. The engravings Barlow made for Rainsford's book range from the tender to the horrific and include a full-length portrait of Toussaint Louverture. Together they tell an unprecedented visual story of events in St. Domingo.

That story falls into two acts: the first illustrating Rainsford's personal adventures and the second depicting the horrors that followed Leclerc's invasion. This simple visual narrative personalizes Haiti's complicated history. Both Rainsford and his reader become privileged witnesses at the birth of the black empire. Rainsford's physical presence in the first four images establishes the ruling perspective of his visual and verbal narratives: that of a British officer in foreign territory. Both come slanted by and for British eyes, communicating not the history of Haiti so much as this particular Englishman's historical account. Rainsford emphasizes the uniqueness of this perspective in the book's frontispiece. Surrounded by St. Domingo's lush vegetation and wearing his American disguise, he engages (as the caption states) "in Conversation with a Private Soldier of the Black Army." Rainsford comes not to conquer but to converse. His regard for black revolutionaries is serious; his gaze direct and respectful. His history will follow suit: this foreign observer sees the revolution in terms favoring British interests.

The next image shows a diminutive Rainsford walking up the steps of a small temple to French liberty - curious homage for an Englishman to pay. The appearance of this temple evolves over the course of Rainsford's publications on St. Domingo. ${ }^{144}$ Here it sits in a forest clearing by a brook, guarded by two disproportionally tall sentinels. Although the engraving depicts an edifice of classical symmetry, Rainsford's text speaks of "a canopy, or dome, of which the architecture was not perfectly regular." ${ }^{145}$ Prominent in the middle of the structure is an altar on which sit two tablets of stone marked with Roman numerals in imitation of the French Declaration of the Rights of Man and of the Citizen, surmounted by a liberty cap on a stake. Rainsford describes "two seats, and above them an inscription" from a speech by the French commissioners Sonthonax and Etienne Polverel, men "execrated for their conduct" yet held in an esteem "favorable to their talents and to their spirit." ${ }^{146}$ With Rainsford, British readers shrink in the presence of this declaration of freedom, which far from being a "gift" from the French Republic, arose out of the exigencies of revolution. ${ }^{147}$

The two images that follow narrate the episode of Rainsford's trial and conviction as a spy. In the first the accused stands, handcuffed and flanked by guards, to the right of a table fronting the tribunal judging him. The image restages da Vinci's The Last Supper, with General Henry Christophe, Toussaint's 
second in command and future ruler of the Kingdom of Haiti, in the place of honor. All eyes are on Rainsford as Christophe delivers the verdict. Still in disguise, this white officer receives a death sentence from a black military tribunal. Nothing in the image suggests a miscarriage of justice. On the contrary the faces of these judges are reasonable and humane. ${ }^{148}$ However final their judgment, the authority they serve maintains order and implements truth. Such is the rule of law among these blacks. The last image featuring Rainsford shows him sitting chained and jailed behind an iron grid in a cell beside a deep romantic chasm. "A benevolent Female of Colour" stands at the grid, giving the anxious prisoner a mango with one hand and holding in the other a basket containing a bottle. Clad in flowing white, a cross prominent on her bosom, this angel of mercy comes to comfort the condemned man. His hard fate takes a romantic turn when love appears to soften death's blow. A grateful Rainsford receives this unexpected kindness with one hand on his heart. The unsolicited devotion of this woman of color complements the austere but lawful verdict of those black military men. In both Rainsford finds cause to respect, even admire, the sincerity of the people of St. Domingo. The reader last sees him looking up, into the eyes of his nameless benefactress.

The images illustrating Rainsford's personal story present a highly sympathetic account of St. Domingo's revolutionaries, at whose head stands the figure of Toussaint Louverture. Few portraits of the indomitable general circulated in England when Rainsford was writing his history. ${ }^{149}$ Louis Dubroca's Life of Toussaint Louverture (1802), a malicious biography immediately translated into English, included a handsome portrait of Toussaint by François Bonneville advertised as "taken from Life." 150 Verbal descriptions tended to be less flattering. In testimony later compiled by Victor Schoelcher, for instance, Toussaint appears as "a small man, with bright, piercing eyes, a repulsive ugliness and poor build [... ] with a disagreeable face on which, nevertheless, a certain air of goodness could be discerned." ${ }^{151}$ General Caffarelli, the officer in charge of interrogating Toussaint in France at Fort de Joux, would describe him as having "big eyes, prominent cheekbones, a flat but rather long nose, a large mouth, no upper teeth, a prominent lower jaw with long salient teeth, sunken cheeks, an elongated face." This description chimes with Toussaint's known loss of teeth in battle..$^{152}$

Rainsford produced at least two - possibly three - portraits of Toussaint. His first appears in the third edition of his pamphlet on St. Domingo. It shows a peculiarly youthful, round-cheeked black officer, whose jovial girth and eagerness seems wildly at odds with contemporary verbal descriptions, even Rainsford's own. ${ }^{153}$ In An Historical Account of the Black Empire of Hayti, Rainsford testifies that "Toussaint was of a manly form, above the middle stature, 
with a countenance bold and striking, yet full of the most prepossessing suavity - terrible to an enemy, but inviting to the objects of friendship or his love," 154 a conveniently vague description that leaves more than a little room for artistic license. The visual image he unveils for his readers embodies an independent St. Domingo. Toussaint stands alone, holding a plan of fortifications in one hand, cradling in the other the hilt of a large sheathed sword. His soldiers reconnoiter behind him in the distance. High above him flies a tiny French flag. Toussaint comes between them, harbinger of a new order. In the larger sequence of Rainsford's images, this one marks the transition from personal adventure to public struggle. It conjures a vision of possibility that momentarily triumphs over wartime atrocities yet to come.

This image lived on to become one of the most familiar representations of Toussaint. He is tall, handsome, and generic: a white man in blackface. A long tradition stands behind this heroic fantasy of blackness. ${ }^{155}$ Rainsford lavishes much more detail on the general's military dress than his physical features. In the accompanying verbal description, Toussaint wears a red cape covering a "kind of blue jacket, with [... ] red cuffs, with eight rows of lace on the arms, [...] a pair of large gold epaulettes [...], scarlet waistcoat and pantaloons, with half boots; round hat, with a red feather, and a national cockade." ${ }^{156}$ This outfit seems more a colorful military patchwork than a general's uniform. It evokes the guerilla commander Toussaint had formerly been rather than the French general he had become when Rainsford met him. In the engraving Toussaint wears a conspicuous plumed round hat, an item borrowed directly from the British military uniforms of West Indian Regiments such as Rainsford's own. ${ }^{157}$ It later entered French military fashion in the West Indies, proving more comfortable in the heat than the traditional bicorn. The downward pointing chevrons on Toussaint's sleeve similarly reveal a British bias. In the French army they would point upward. ${ }^{158}$ With shirt wide open and coat casually sashed, Rainsford's Toussaint cuts a romantic figure. He seems a far remove, however, from the man his son Isaac describes, who "always wore a general's undress uniform and a general's hat." ${ }^{159}$ Rainsford's portrait severs Toussaint from French allegiances, anglicizing this agent of liberty. He more closely resembles a British colonial auxiliary officer than a French general. ${ }^{160}$ The robust leader staring straight at the reader is an anti-French fantasy. His uniform quietly declares independence in the British style. With France dwindling from the picture, Toussaint might just turn blacks into Britons, even as he leads the struggle to transform St. Domingo.

The French return with a vengeance in the latter half of Rainsford's visual narrative. These engravings depict the brutalities that followed their invasion, rendered with a visceral intensity that far exceeds Rainsford's verbal descrip- 
tions. The title of the next image speaks volumes: "The Mode of exterminating the Black Army practiced by the French." The image itself simply screams: a placid and mustachioed French officer readies his fist to send a black soldier, arms bound and ankles shackled, reeling into a sea turbulent with black bodies and swimming hounds. The hint here of genocide is hardly accidental. It helps explain the coming engraving, "Revenge taken by the Black Army for the Cruelties practiced on them by the French." Three black troops hoist high a French officer, rope around his neck, against a landscape dotted with busy gallows. This massacre at least has the legitimacy of revenge. French cruelty requires it. Rainsford's obvious sympathy with the blacks dissipates when this plate gets reprinted independently - with much greater frequency than its companion piece - reinforcing the very stereotypes the sequence means to dispel.

It would be hard to minimize the savagery of the final two plates, however. These depict the deployment of bloodhounds against black soldiers and civilians. In an appendix devoted to the subject Rainsford describes the lethal force of these weaponized dogs, trained by the Spanish to seek and destroy runaway slaves: "they proceeded to the neighbouring woods, and surprizing an harmless family of laborers at their simple meal, tore the babe from the breast of its mother, or involved the whole party, and returned with their horrid jaws drenched in [. . . ] gore." With a mixture of horror and indignation he cuts himself off in mid-sentence: "the picture becomes too dreadful for description even for the best of purposes." 161 The verbal picture, perhaps, but not the visual one. Rainsford illustrates his description with a gruesome scene of five bloodhounds harrying and holding that harmless black family. Two dogs clamp soldiers in their jaws while a third in the background lunges for the father's throat. Wife and child, as usual, become collateral damage.

Although news that the French unleashed bloodhounds traveled fast, no published accounts existed when Rainsford was writing his history. ${ }^{162} \mathrm{He}$ relied for his descriptions on his earlier experience in Jamaica, where he witnessed the military deployment of Spanish bloodhounds against rebellious Maroons. From a friend who accompanied the mission to Cuba that procured the dogs and their handlers, Rainsford learned the brutal manner of their training, which he depicts in his final sketch. ${ }^{163}$ The dogs acquired a taste for flesh by being exposed to a wicker figure filled with gobbets of meat. A French commander presents a cage of snarling bloodhounds with this macabre manikin, painted black to synchronize sight with scent. The vicious effects of this grisly practice appear in the distance as dogs gore a group of laborers. Such is Rainsford's final visual comment on the revolution in St. Domingo. True savagery belongs to the French, who spared no atrocity in their efforts to defeat the black revolution. 
For their emotional and ideological impact, Rainsford's images remain the most influential aspect of An Historical Account of the Black Empire of Hayti. ${ }^{164}$ Reproduced countless times in numerous studies, they still provide a visual backdrop for the Haitian Revolution, at least in English. When contemporary reviewers bothered to comment on the engravings, however, they were hardly enthusiastic. The British Critic considered them "ill chosen as to the subjects, and of worse execution. They seem added as an excuse for increasing the price of the book." 165 The Edinburgh Review was even harsher: "We cannot give them any great recommendation for taste or skill; and we are certain that, in some particulars, they have no claim to accuracy. There is not, for example, a single negro represented with any of the features peculiar to his race. Every one has the high skull, and nose, and thin lips, and general expression of the European; so that the negroes of Mr Rainsford's pencil, are exactly whites with their faces blackened." 166 However bigoted that observation, it shows Rainsford turning black revolutionaries into Britons. His images may not have been to the liking of British reviewers, but they circulated widely. Toussaint's portrait in particular became an icon of the British and U.S. abolitionist movements. ${ }^{167}$ Such is the ideological force of Rainsford's graphic representations of revolution in St. Domingo: they pervade the visual rhetoric of black insurgency throughout Atlantic culture.

Rainsford's influence may extend even further. Among the most familiar images of Toussaint Louverture is one attributed to French artists Nicolas Eustache Maurin and François-Séraphin Delpech that appeared sometime between 1825 and $1838 .{ }^{168}$ It depicts the black general in profile, wearing a dress uniform and a plumed bicorn hat. On the strength of an apocryphal story published in the Haitian historian Joseph Saint-Rémy's Vie de Toussaint Louverture (1850), this portrait is traditionally deemed a copy of an older one painted from life and allegedly given by the general himself to the French agent Philippe-Rose Roume de Saint-Laurent. ${ }^{169}$ Many different artists have reproduced many different versions of this profile over the years, but the Maurin/Delpech version has always been deemed the earliest. ${ }^{170}$

Until now. The unheralded existence of a miniature portrait of Toussaint Louverture troubles this story - a miniature attributed to Rainsford. Painted meticulously in watercolor on a large ivory wafer ( $23 / 4 \times 3 \frac{3}{4}$ inches $)$, the miniature resided for many years in the collection of a prominent South Carolinian family, the Rutledges, who claimed to have obtained it from Rainsford himself. ${ }^{171}$ It appeared as part of an exhibition of miniatures at the Gibbes $\mathrm{Mu}$ seum in Charleston, South Carolina, in 1936. The exhibition catalog credits Marcus Rainsford, "Captain in the zrd West India Regiment," with painting a renowned image of the renowned general. Heirs sold it twenty years later to the New-York Historical Society, where the miniature now resides. ${ }^{172}$ It's 


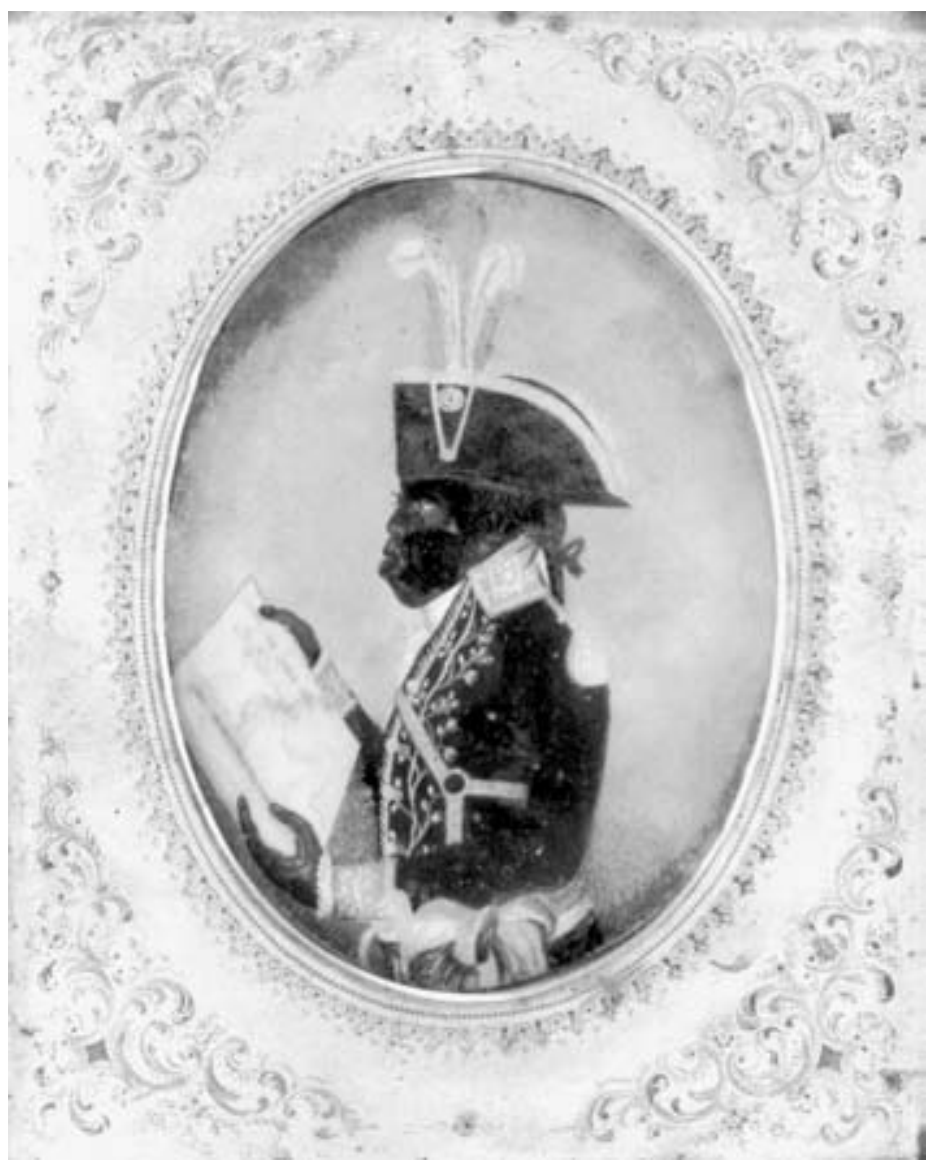

Miniature portrait of Toussaint Louverture, attributed to Marcus Rainsford. Image courtesy of the Gibbes Museum of Art / Carolina Art Association.

a startling image, not only for Toussaint's stark expression and steady gaze. If Rainsford indeed had a hand in creating it, the image disrupts the whole visual tradition of representing Toussaint. It shows Toussaint Louverture in the profile made famous by Maurin and Delpech. It differs from known versions by picturing him in full bust, holding a map that bears the dim words "Carte de l'isle de St Domingue." Details of the uniform match those of other images, from the plumed hat to the leafy collar and the belt across Toussaint's chest. Its style of execution and display, however, indicates that this miniature predates the Maurin and Delpech engraving. ${ }^{173}$ The canonical history of Louverture's likenesses requires revision. The mysterious original possessed 
by the Roume family must contend for prominence of place with this early miniature, possibly painted by a hand that shook Toussaint's. Perhaps the miniature also copies that lost original. Perhaps it copies other copies. But perhaps, however preposterous, Rainsford's miniature is that original, the famous image of Toussaint from which later versions descend.

Rainsford attests that his sketches for An Historical Account of the Black Empire of Hayti, including that of Toussaint, were inspired by his experience. That both the miniature and the full-length portraits show the general holding a military document do not establish proof of a shared origin, but it is tempting to see significance in this detail. At the very least the miniature raises the possibility that Rainsford, the man responsible for creating the two most popular portraits of Toussaint in the English world, also influenced Toussaint's most infamous "French" portrait-infamous, because accusations of racial stereotyping have long accompanied its scholarly analysis. Although many commentators accept its likeness, some take it to express French racism and scorn, arguing that it commits petty vengeance on the charismatic leader by exaggerating his least attractive features. ${ }^{174}$ Painted by the hand of a known admirer, however, this small portrait becomes an act of homage. By far the least anglicized of Rainsford's images, it represents not just Toussaint Louverture, but also the vexed effort of a British officer to see him truly. It may not be Toussaint's best likeness. But it could well be the most influential. Whether Rainsford created or merely copied it, he would have inserted himself permanently into the enduring legacy of Toussaint's portraits. The sharp profile and military dress continue to inspire a stirring iconography of black resistance.

\section{Common Causes}

"The close of the eighteenth century, a period marked by the grandest operations and the most gigantic projects, presented to the world, a new and organised empire, where it was not only supposed to be impossible to exist, but, where even its existence was denied, although it was known by those connected with that quarter of the globe to have taken place, and under the most flourishing auspices." ${ }^{175}$ Rainsford writes of the Haitian Revolution as a global event, one among many gigantic projects, but unique for being both stunningly successful and largely ignored. An Historical Account of the Black Empire of Hayti was published just one year after Dessalines's declaration of an independent Haiti. No European power had yet extended diplomatic recognition - or would for nearly thirty years. ${ }^{176}$ Rainsford wrote in part to remind 
his readers that Haiti was a legitimate state. ${ }^{177}$ The aim of his narrative is thus double: not merely to provide an authoritative full account, the first in English, of the thirteen years of war in St. Domingo that ended in independence, but also to urge prevailing powers to acknowledge this astonishing victory and the once enslaved people who won it. What a curious irony, then, that his book has never seen republication since its original appearance!

Rainsford's history has nevertheless achieved a prominent if ambiguous position amidst the historical literature of the Haitian Revolution. An Historical Account of the Black Empire of Hayti provides an important early perspective on an event whose legacy continues to shape the world. C. L. R. James's magisterial portrait of Toussaint Louverture and the revolution he served, The Black Jacobins, didn't help Rainsford's reputation by dismissing his and similar histories as "little more than propaganda pamphlets." ${ }^{178}$ While Rainsford clearly delivers his account from a British point of view, it is one surprisingly critical of the policies it was his duty as a soldier in His Majesty's army to serve. It may be impossible to mistake him for an abolitionist or a Republican, but he wrote with an unusual sympathy for the blacks he fought both with and against, particularly for an officer mustering troops in St. Domingo in order to defend slavery.

Perhaps the personal story at the center of his history obscures its ideological agenda. Rainsford pitched his book partly as private adventure. The exhaustive title of his first pamphlet promises "A Memoir of Transactions that took place in St. Domingo," including a sketch of "The Real Character of its Black Governor, Toussaint L'Ouverture" and a narrative of "the Rescue of a British Officer under Sentence of Death." Racy stuff-and according to Rainsford, true. His adventure as accidental spy in Cape François - captured and sentenced to death at Fort Liberté, jailed but comforted by a beautiful Creole maid-adds an element of romance to an already monumental history. So too his personal encounter with the legendary Toussaint. Who alive in England could boast playing billiards with St. Domingo's architect of freedom? Who alive in England owed Toussaint his life? Rainsford's story gives his history a romantic aura that, unintentionally perhaps, blunts its ideological edge.

Looking past the personal, however, reveals a portrait of Toussaint that deserves comparison with James's. James helped create the Toussaint familiar to recent students of the Haitian Revolution: bold, ubiquitous, enlightened, relentless, and flawed. James's Toussaint is a tragic figure, a skilled and intelligent Creole inspired and ultimately beaten by the ideals of the French Revolution. He dies for liberty and equality, partly out of his undying devotion to France. That contradiction - between Enlightenment ideals and their politi- 
cal deployment-constitutes Toussaint's tragic flaw: his decision, however vexed, to abandon the revolutionary black masses. Toussaint simply can't believe that Napoleon intends to re-enslave or exterminate them. He chooses France - and falls to Enlightenment ideals and French perfidy. Behind this Toussaint stands a long legacy of tragic figures, most potently Shakespeare's Hamlet. ${ }^{179}$ By placing Toussaint so adroitly in this European tragic tradition, James not only reveals the limits of Enlightenment ideals, their hankering after blood but he also charts a path beyond Toussaint and tragedy that only a true avenger can follow: a swift sword called Dessalines.

Rainsford's Toussaint is peculiarly free from the inner torment of the tragic hero. He is a paragon of virtue, an intelligent leader, a tender husband and father: a man whose "powers of invention in the art of war, and domestic government," are "the wonder of those who surrounded, or opposed him." ${ }^{180}$ On the battlefield he is a force of nature, riding indefatigably from engagement to engagement, rallying troops and harrying enemies. In the camp he is a wise counselor, preferring mercy to vengeance, life to justifiable punishment. To the oppressor he is a scourge; to the oppressed a staff of comfort. So uncomplicated and true is his character that it ranks with the best that civilization has achieved:

Had a sanguinary revenge occupied his mind, he would not so often have offered those pathetic appeals to the understanding, which were the sport of his colleagues, on crimes which the governors of nations long civilized would have sentenced to torture! His principles, when becoming an actor in the revolution of his country, were as pure and legitimate, as those which actuated the great founders of liberty in any former age or clime. ${ }^{181}$

This Toussaint is as purposeful as he is uncomplicated: a man with no inner contradictions to compromise his devotion to liberty and his people. He is a match for any leader in any age, equal to the best of Europe's political reformers and immune to the contradictions that plague its tragic heroes. This Toussaint is an epic hero. He is a warrior, gifted in understanding but unburdened by interiority. He is lettered, cultured, and controlled. ${ }^{182}$

Above all he is not French. Where James stresses Toussaint's devotion to France and the ideals of the revolution, even to the point of downfall, Rainsford paints a less nationalist portrait. Toussaint serves the cause not of French liberty but liberty pure and simple, a concept capacious enough to include the British. This Toussaint, looming larger than mere "propaganda," becomes a character British readers can admire - precisely because his fate exceeds his ability to choose it. He is less a tragic hero than a victim of history, and the force that destroys him, implacably, is France. Rainsford completely down- 
plays Toussaint's allegiance to the Republic, to the point that St. Domingo under his governance is for all practical purposes already independent-a vision meant to anticipate the coming Black Empire of Hayti. That the British after Napoleon's invasion would prefer an independent state to a French colony was both clear and commercially imperative. Toussaint falls only to French guile: "Great as he had always been, he was now surprized for the first time, by a band of authorised assassins, whom armies had never been able to perplex." ${ }^{183}$ Great warriors deserve better than sneaking assassins. Rainsford's Toussaint dies a strangely British death, martyred by the French less to Enlightenment ideals than an even higher sense of martial valor and his people's freedom.

An Historical Account of the Black Empire of Hayti does not pretend to political objectivity. But neither is France Rainsford's only object of criticism, as the following reflection on Toussaint's incarceration shows so clearly: "France forgot awhile the habits of a civilized nation, to entomb one she should have graced with a public triumph; and England, instead of making a common cause to annihilate a nation of heroes, and depress the human intellect when rising to its level, should have guarded from violation the rights of humanity in its person." ${ }^{184}$ Rainsford proves no toady of Pitt, Dundas, and the Duke of York. His indictment of British policy is clear: it shares with that of France a vicious antagonism (genocidal in spirit) toward the blacks of St. Domingo, that "nation of heroes." It is here, in his attitude regarding those black freedom fighters, that Rainsford reveals the complexity of his ideological aims, their irreducibility to simple propaganda. His book both narrates the rise of an independent Haiti and describes - with extraordinary sympathy - the exemplary lives of its black inhabitants.

Abolitionist he was not. Rainsford's position on slavery is more complicated than that of either its foes or advocates. By the time An Historical Account of the Black Empire of Hayti was published in 1805, the abolition of the slave trade was all but a foregone conclusion. It had been a long time coming. The Somerset decision of 1772 gave the movement a legal precedent of sorts. The Quakers were first to mount a moral campaign against the slave trade, but as Christopher Leslie Brown shows in Moral Capital: Foundations of British Abolitionism, that campaign gained public approval only after Britain's loss of the North America colonies raised the question of slavery in a climate of anxiety about empire. Granville Sharpe, Thomas Clarkson, and even the pious Clapham Sect made slavery a litmus test of legitimate empire, turning the slave trade into its guilty conscience. These were hard claims to sustain during Britain's military bid for St. Domingo, but increasingly persuasive after evacuation in $1798 .{ }^{185}$ As an officer stationed twice in the West Indies, 
Rainsford had ample opportunity to reflect on the relationship between empire and slave labor. He never advocated an end to slavery. And yet he acquired vastly more experience of both imperial adventurism and its indebtedness to enslaved Africans than most avid abolitionists.

Probably as a result of mustering black recruits for much of his career, Rainsford gained an enormous respect for the way they served on the field and lived at home. That in no way meant he advocated their freedom. His position was that of a father confronted with children suddenly seeking to live their own lives: a paternalism that mixed skepticism and confusion with grudging respect. That the chaos of revolution could have been avoided in St. Domingo he had no doubt. The fault lay with masters, to whom Rainsford always attributes a civilized superiority. "If happily discerning the signs of the times, the planters of this delightful and flourishing colony" had "conciliated the affections of those to whose labours, under the present regimen, every thing productive of wealth or prosperity must depend," revolution may never have erupted. "If they had then contemplated some more legitimate means of prosecuting the labours of their colony, they might, however immediately unavailing, have laid a foundation for their posterity more lasting than the bequest of inordinate wealth, and have claimed the approbation of society." 186 But no, the planters only exploited the enslaved. Buried here is the suggestion, not a pretty one, that a conciliated slavery might at least have maintained the subordination of blacks. Rainsford's paternalism leads him to conclude that he knows what's best for both the planters and enslaved Africans.

But it also forces him to acknowledge the legitimate claim of the enslaved to liberty. It's a problem of dialectical proportions, and Rainsford can find no way around it, although he wants to. On the penultimate page of his history, he offers hard advice to those who still profit from the shackles: "to the Proprietors of the British colonies in particular it is recommended, to think of an inducement to some degree of devotion among their slaves an object of importance, with a careful diffusion of morality." ${ }^{187}$ Why this plea for inspiring devotion and diffusing morality? Here's why: such concessions are "more certain than all the inflictions, that coercive measures can devise to prevent a spirit of deliberation (the first revolutionary system) among slaves." ${ }^{188}$ Rainsford tips his hand. The practitioners of slavery must inhibit deliberation among the enslaved, or else. Once reflection sets in, so does revolution, and there's not much anyone, British or French, can do about it.

Here then is the upside of Rainsford's paternalism. It acknowledges the alliance of deliberation with freedom: not a radical politics, perhaps, but enough to legitimate the violent overthrow of French planters in St. Domingo. Wit- 
ness the uprising of the black freedom fighters. Witness the military paragon Toussaint. Witness Dessalines's proclamation of April 28, 1804. In Rainsford's view, "a specimen of this kind of composition [.. .] is a positive refutation of those who, in opposition to reason and notoriety, describe the inhabitants of Hayti as being in a 'savage state.' It burns with all the fire of martial oratory, while breathing that bewitching eloquence which entwines and captivates the heart." ${ }^{189}$ Rainsford may not advocate freedom for the enslaved. But faced with the obvious greatness of their achievements as soldiers, workers, and politicians, liberalism overwhelms bigotry and leads him to acknowledge "this singular, and important part of the human species." 190

Perhaps Rainsford's personal adventures, then, are not what remain most valuable about An Historical Account of the Black Empire of Hayti. Perhaps its most lasting contribution is less to the knowledge of the Haitian Revolution (piles of books written since have told a fuller story) than to an appreciation - from an unabashedly British perspective - of the free blacks who even in the shadow of foreign occupation were reinventing St. Domingo. Rainsford's vivid description of their everyday lives offers a brief, exhilarating glimpse of the freedoms they were fighting to achieve and sustain. It presents a strangely attractive picture of a living commons, a kind of counter-memory to not only European colonialism but also its civil stepchild, liberal democracy. Equality in this commons is a collective, not an individuated attribute. Living black is being together. "The usual subordinations of society were entirely disregarded," Rainsford writes, witnessing "for the first time, a real system of equality." 191 His universal antipathy to things French and Republican makes such an observation all the more compelling. Among the blacks of Cape François he experienced as never before a disconcerting equality that redrew the boundaries between "mine" and "yours," for instance at meal time: "Here were officers and privates, the colonel and the drummer, at the same table indiscriminately; and the writer had been scarcely seated at a repast in the first room to which he was conducted, when a fat negro, to initiate him in the general system, helped himself frequently from his dish, and took occasion to season his character by large draughts of the wine, accompanied with the address of 'Mon Americain."' 192 Rainsford's American disguise lowered his British profile at a time when his presence at Cape François would have been that of an enemy combatant. Miming the foreigner, he encounters a deeper foreignness: a life in common in which differences between mine and yours, American and French, black and white cease for a time to matter. He lives a conviviality grounded not in wit but simple eating. However briefly, Rainsford sweeps the curtain away from rank and British posture and shares with common strangers a meal, a laugh, and life. 
It's as a record of this life in common that An Historical Account of the Black Empire of Hayti still has much to communicate about the aims and ends of the Haitian Revolution. Sometimes its observations are exhilarating: "Negroes, recollected in the lowest state of slavery, including Africans, filled situations of trust and responsibility; they were, likewise, in many instances, occupied by those who had been in superior circumstances under the old regimen, free negroes, and mulattoes." ${ }^{193}$ Perhaps in spite of himself-and only intermittently-Rainsford produces an ethnography of a people on the verge of birth, whether ever fully delivered is for history to decide. Basic human practices are different among these free blacks, not uncivilized in Rainsford's view so much as incommensurable with European customs.

Such is his experience of family in Cape François. Welcomed into the home of "a brigand of peculiar intelligence" (the phase sums up Rainsford's nonplussed perceptions), he finds "the whole so compact, and clean, with such an air of properté [sic] throughout as was absolutely attractive." ${ }^{194}$ Homemade furniture abounds, as do books, including "a mutilated volume of Volney's Travels." ${ }^{195}$ As do wives and children: two wives and thirteen children, to be exact. They don't all live under this particular roof, but those who do share a "singular bedstead" that could be rearranged according to the needs of the moment. Rainsford adds in an aside that "it might have been adapted to the European cottage with many advantages," an offhand remark that traffics in the possibility not only of creolized domestic comforts but of cultural exchange between blacks and whites. While he observes stereotypically that "continence is not a virtue of the blacks," he openly admires the way they regulate a domestic economy far more complicated and fluid than its European counterpart. ${ }^{196}$ Family among the black revolutionaries presents a challenge that Rainsford seems open to imagining.

He proves a genuine admirer, too, of their economy: "the productive system of the earth seemed to be founded on original principles." ${ }^{197}$ Formerly enslaved cultivators now work the field in a coordinated way that benefits all in common. Notice the relation Rainsford observes between the one and the many: "Every individual employed a portion of his time in labor, and received an allotted part of the produce for his reward, while all took the field, from a sense of duty to themselves." ${ }^{198}$ Utopian? Perhaps. But historical, too. Rainsford witnesses the emergence of a new order that never fully emerges, a collectivity that labors together to sustain life in common. Labor as here lived owes something to African habits and something to European principles, but it remains appropriate to the people performing it, a function of their struggles, aspirations, and victories. Missing is the martial husbandry of Toussaint the agrarian, who ordered free blacks back to their former plan- 
tations to work for wages and a share under threat of military punishment. Compared to familiar Western prejudices, too, such work in common has much to recommend it: "Labor was so much abridged, that no want of leisure was felt; it would be a great gratification to the feeling heart, to see the peasant in other countries with a regulated toil similar to that of the laborer in St. Domingo." ${ }^{199}$ What is good for the peasant could be good for the career officer, and Rainsford senses it. The blacks of Cape François practice a common economics that directs the labor of one to the care of the many: a prospect that remains to this day revolutionary.

An Historical Account of the Black Empire of Hayti reads in retrospect like both the celebration of a world to come and an elegy for a world that never arrived. However unevenly, it acknowledges the overwhelming strength of black resistance to white domination in St. Domingo and holds the door open to the forms of life that might arise in the aftermath of revolution. Rainsford's little part in the doomed British occupation of the colony taught him something about the arrogance and the limits of imperial power: "Such was the end of this disastrous enterprize, which had for five years fed the hopes and vanity of the British empire, to which had been latterly sacrificed many valuable lives, and an extravagant portion of the public money. That it was undertaken with too little consideration, must be always acknowledged. [. . .] It is, however, probable, that no force which could have been furnished, would have been sufficient to cope with the power of the revolted negroes." ${ }^{200}$ Rainsford writes as a friend to those revolutionary blacks and a fellow soldier on the field of freedom. His history of their revolution concedes their indomitable force. In spite of his prejudices, he came to admire these freedom fighters and their fierce devotion to the bloody project of transforming a slave colony into an independent state.

Rainsford was himself no revolutionary. He had no fear of a black planet. The Black Empire in Haiti was perfectly compatible with a British Empire of global reach. An Historical Account of the Black Empire of Hayti manages to celebrate the virtues of both. To imperial adventurism in the name of national interest and influence, Rainsford replies with a cautionary account of insurrection in the name of liberty, "a Revolution, which ranks among the most remarkable and important transactions of the day" - his and ours. ${ }^{201}$ The Haitian Revolution continues to inspire dreams of independence because, partly thanks to Rainsford, this remarkable transaction remains indomitably alive in the annals of history. 


\section{A NOTE ON THE TEXT}

An Historical Account of the Black Empire of Hayti was first published in 1805 and never republished, except in German and Dutch translations. The only English edition contains a list of errata. We correct sentences as indicated. We silently correct other typographical errors.

Rainsford's spelling can be confusing, at times because it follows conventions that have since become obsolete, at other times because it is inconsistent. We stay as close to the original text as possible, so we retain Rainsford's unorthodox spellings when they are consistent throughout. When he gives alternate spellings for the same word ("independent" with an "e" or an "a," for instance) we stick to the more common spelling. We also systematically use British instead of American spelling in his text, for obvious reasons. Our editorial endnotes, though, follow American spelling conventions.

Rainsford's spelling often strays from accepted spellings of proper nouns. We retain misspelled names when routinely misspelled in documents of the time, except in cases when the same name is spelled different ways throughout. Then we use the spelling closest to the accepted and keep to it. Thus Rainsford writes St. Mark in some instances and St. Marc in others. We use the second consistently. Because he spells Jean Rabell consistently, we retain it, even though the accepted spelling is Jean Rabel. In our notes we use contemporary accepted spellings.

When Rainsford misspelled otherwise accurate quotations (usually in French), we correct them. We retain Rainsford's inaccurate quotations in English (often from poems) and French (for instance the Marseillaise) and indicate mistakes and departures from originals in endnotes. We did not modify Rainsford's misspellings of non-English words.

Rainsford uses English aristocratic titles for French people, but keeps the French particle (Count de Noé, count d'Artois). We retain this convention in both his text and our own notes.

We retain Rainsford's original notes throughout his text. Marked by symbols, they appear as footnotes. Our comments on those notes appear beneath them between brackets. Our notes to Rainsford's text are numbered and appear as endnotes. Grégory Pierrot translated sections II, III, and V of the appendix from the original French. 
lviii A NOTE ON THE TEXT

Finally, we follow Rainsford's usage in our introduction and endnotes: St. Domingo indicates the French part of the island of Hispaniola and Santo Domingo the Spanish part. 


\section{AN \\ 吕igtototical Account \\ OP THE \\ BLACK EMPIRE OF HAYTI: \\ commanixdise $A$ virw or}

THE PRINCIPAL TRANSACTIONS IN THE REVOLUTION

or

SAINT DOMINGO;

wirn

ITS ANTIENT AND MODERN STATE.

DY

MARCUS RAINSFORD, EsQ.

LATE CAPTAIN THIRD WEST-IXDIA REGIMENT,

f.c. \&c.

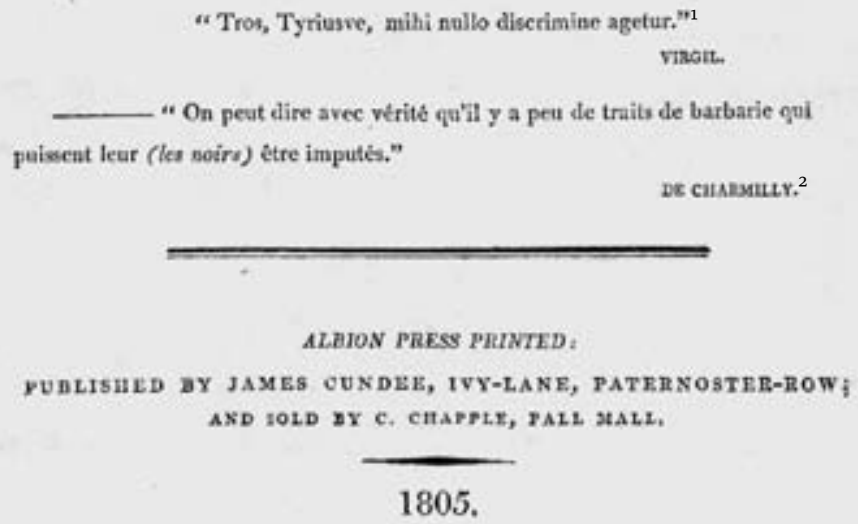




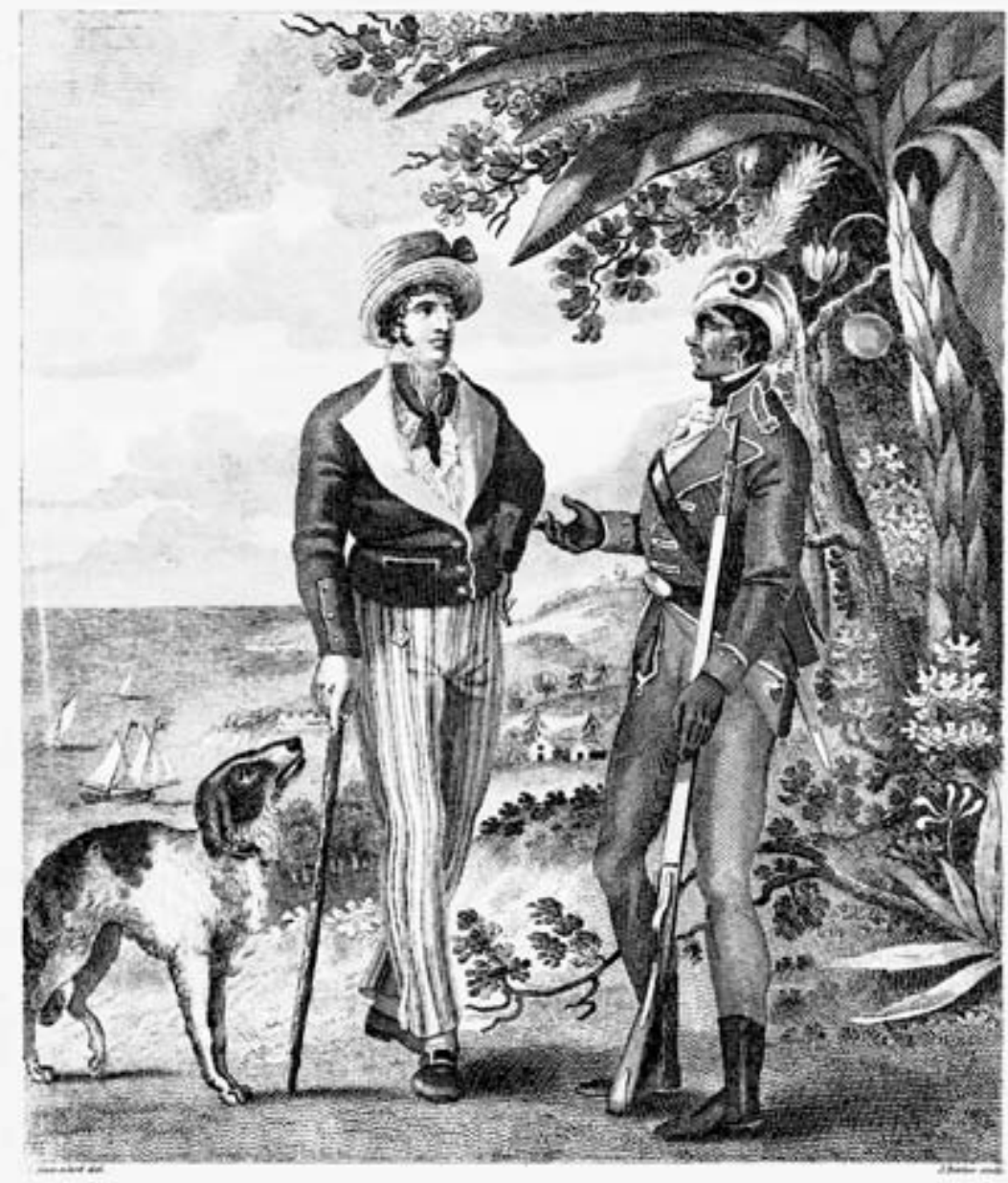

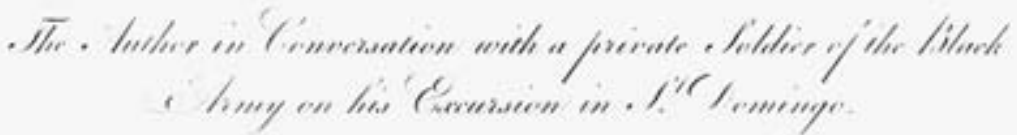

The Author in Conversation with a private Soldier of the Black Army on his Excursion in St. Domingo. Reproduced with the permission of Rare Books and Manuscripts, Special Collections Library, the Pennsylvania State University Libraries.

Overleaf: Title page of the 1805 edition. Reproduced with the permission of Rare Books and Manuscripts, Special Collections Library, the Pennsylvania State University Libraries. The superscript note numbers were added editorially for this publication. 


\section{ADVERTISEMENT.}

As all that is necessary to preface the following work will be found in the Introduction, nothing more is intended in this place than to advertise the reader of some circumstances which could not be so well communicated under any other head.

The sedentary attention so necessary to the production of a literary work, but ill comports with the character of a soldier; this, with other temporary inconveniences, and frequent migrations during their composition, will, it is feared, give occasion for apology in regard to some parts of the following sheets, where an inequality of style and occasional confusion of persons are perceptible, which must be attributed to the want of that tranquillity, the desire of the enlightened in all ages, so necessary to a correct view of men and things, and which polishes, while it imparts the utmost reach of intellect. A deficiency may, perhaps, be found in the part confessedly compilation: but it may, at the same time, be said, that to make a book nothing unnecessary is obtruded: and the writer may truly assert, that "he sat down to write, what he thought, (and saw) not to think what he should write." ${ }^{3}$

It is pleasing to contemplate the kind attentions of those who disinterestedly communicate what information they possess. Of these, the writer would wish to have mentioned many, who, with a delicacy equal to their intelligence, refused to be thanked in public: yet he resolves, without permission, to acknowledge his obligations to Admiral sмIтн, ${ }^{4}$ whose local information, had it not been for the distance between them, might have conferred much more interest upon his work; - to JOHN CAMPBELL, Esq. ${ }^{5}$ of his Majesty's navy, whose name will be found hereafter, and whose absence at sea he has never ceased to regret; - to wILLIAM CURTIS, Esq. ${ }^{6}$ of Cavendish-square, for the liberal communication of his plans, of which he is anxious to avail himself further, in future; - to an AMERICAN resident, at St. Domingo, of whose assistance he was proud in that island: and to another FRIEND to whom he is indebted for the highest literary obligations.

The work is now committed to the indulgence of the public "with all its imperfections on its head;" " if truth be at all elucidated - if virtue derive one more friend from its aid, - or policy, quitting the frail basis of expedience, be further grounded on justice and humanity, the writer will not have recorded, in the first empire of the world, the simple annals of Hayti, in vain. 



\section{INTRODUCTION.}

It has frequently been the fate of striking events, and particularly those which have altered the condition of mankind, to be denied that consideration by their contemporaries, which they obtain from the veneration of posterity. In their vortex, attention is distracted by the effects; and distant society recedes from the contemplation of objects that threaten a violation of their system, or wound a favourite prejudice. It is thus that history, with all the advantages of calm discussion, is imperfect; and philosophy enquires in vain for the unrecorded causes of astonishing transactions.

To remedy the evil in this enlightened æra, the disquisitions of the observer, and the relations of the traveller occur; but these are perused with the rapidity, with which they are necessarily made, and, although they teach us what regards our own nature, impress no other sense of the period described, than as relates to the fleeting objects of immediate import-furnishing, therefore, little more (if so much may always be expected) than frail documents for the judgment of the future historian.

Such is precisely the case with the subject of the following pages. The rise of the Haytian empire is an event which may powerfully affect the condition of the human race; yet it is viewed as an ordinary succession of triumphs and defeats, interrupted only by the horrors of new and terrible inflictions, the fury of the contending elements, and destructive disease, more tremendous than all.

It will scarcely be credited in another age, that philosophers heard unmoved, of the ascertainment of a brilliant fact, hitherto unknown, or confined to the vague knowledge of those whose experience is not admitted within the pale of historical truth. It will not be believed, that enlightened Europe calmly witnessed its contrasted brilliancy with actions which, like the opaque view of night, for a sullen hour obscured the dazzling splendour.

It is on ancient record, ${ }^{*}$ that negroes were capable of repelling their ene-

\footnotetext{
* LeO AFRICANus says, that the negroes between Senegal and Gambia, in Africa, (the parts from whence slaves are, at present, supplied,) lived in the utmost innocence and simplicity, till the armed Moors came among, and subjected them, teaching them after wards their religion, and the arts of life. About the fourteenth century, however, Heli Ischia, a native-negro, at the head of his countrymen, turning their own arts against them,
} 
mies, with vigour, in their own country; and a writer of modern date* has assured us of the talents and virtues of these people; but it remained for the close of the eighteenth century to realize the scene, from a state of abject degeneracy: - to exhibit, a horde of negroes emancipating themselves from the vilest slavery, and at once filling the relations of society, enacting laws, and commanding armies, in the colonies of Europe.

The same period has witnessed a great and polished nation, ${ }^{8}$ not merely returning to the barbarism of the earliest periods, but descending to the characters of assassins and executioners; and, removing the boundaries which civilization had prescribed even to war, rendering it a wild conflict of brutes and a midnight massacre.

To attract a serious attention to circumstances, which constitute an æra in the history of human nature and of martial affairs, is the purpose of the present disquisition; which, it is hoped, will tend to furnish an awful, yet practical lesson, as well as to excite and gratify a laudable curiosity.

To this subject, the attention of the writer was peculiarly led, from a long acquaintance with the West Indies, and opportunities of considerable observation of the colonies in that Archipelago. To the French colony of St. Domingo, his notice was early and particularly attracted; several of his military friends were afterward employed on its shores, and ultimately an accident caused a personal visit; the information resulting from which, on account of its subsequent effects, could not fail to be deeply impressed on his memory.

Of Hispaniola, or St. Domingo, ${ }^{9}$ there is no particular history, in any language, similar to those of the British colonies, so ably executed by Sir HANS SLOANE $^{10}$ and others. The earliest accounts are incorporated with the voyage of the great discoverer, his Spanish coadjutors, and the legends of the missionaries. Of these the description of COLUMBUs, ${ }^{11}$ and that of PETER MARTYR, ${ }^{12}$ are the most intelligent, while the account of LAS CASAS ${ }^{13}$ is particularly interesting, and the History of HERRERA ${ }^{14}$ acute and correct. That of VESPUCCI ${ }^{15}$ ought scarcely to be named, in retribution for his injury to Columbus. After the establishment of the French colony, ${ }^{16}$ when priests from the mother-country settled upon the island, they furnished accounts of the

bravely expelled their Moorish conquerors; This negro continued in power, and acted as king, leading them to several foreign wars, and establishing them in power over a great extent of Country. [Joannes Leo Africanus (c. 1494-c. 1554) was a Moorish diplomat, traveler, and author of Descrittione dell'Africa (1550).]

*Adanson, Voyage à l'Afrique, 1749-53. [Actually entitled Histoire naturelle du Sénégal (1757). Michel Adanson (1727-1806) was a French naturalist who spent several years in Senegal.] 
establishment, and of the manners of its inhabitants, generally interesting and correct; the most celebrated of these are by the Fathers DU PERS, CHARLEVOIX, DU TERTE, and LABAT. ${ }^{17}$ Neither are the accounts of the Buccaniers (the first founders of the French colony), ${ }^{18}$ by themselves - nor the observations of an anonymous writer in the Histoire Générale des Voïages, ${ }^{*}$ without merit. From these sources, with the assistance of the able compilation of the ABВÉ RAYNAL, ${ }^{19}$ and occasional reference to the most polished of modern historians, Dr. ROвERTSON,${ }^{20}$ the facts with which the present work commences, are drawn. - For the different light in which some incidents will appear, from their authorities, as well as the opinions or sentiments which are occasionally interspersed, the writer alone is answerable.

When the circumstances which ultimately led to the independence of the island commenced, the first English work, exclusively, on St. Domingo made its appearance; ${ }^{\dagger}$ and, though in the form of a pamphlet, contained a correct account of facts, with no other fault than an inflammatory style, easily imparted by such a subject at the period it was written. Not long after, Mr. BRYAN EDWARDS, ${ }^{21}$ who had been successful in a General History of the British Colonies in the West Indies, and who had intended to write a similar one of the French colonies, $\stackrel{\ddagger}{\ddagger}$ published a quarto volume on the subject, comprising all the information he could collect. This work, however, although it contained documents of the most authentic kind, did not increase Mr. Edwards's fame as an accurate writer; being, in point of fact, as well as topographically, incorrect; it provoked a volume of equal size in answer, from a gentleman, who, for many reasons, was well acquainted with his subject; M. de CHARMILLY, $\$$ the commissioner empowered by a number of the colo-

*Paris, 1759. [Abbé Prévost (1697-1763) initiated the fifteen-volume Histoire Générale des Voyages (1746-1759), though the work was continued by other writers.]

${ }^{\dagger}$ An Inquiry into the Causes of the Insurrection in St. Domingo, 1792. [Jean-Philippe Garran-Coulon, An Inquiry into the Causes of the Insurrection of the Negroes in the Island of St. Domingo (1792). De Coulon (1749-1816) was a leading member of the Paris Commune, the government of Paris during the French Revolution.]

$\ddagger$ Hist. Survey. Preface. [Bryan Edwards, An Historical Survey of the French Colony in the Island of St. Domingo (1797).]

§ To Mr. Edwards he says, (in his "Lettre en Refutation de son Ouvrage sur St. Domingue") "You should have acknowledged, that all your information was derived from others, during a stay of a few weeks only, in a time of general disorder, shut up in the town of the Cape; while the inhabitants of the colony, and even the city, were divided into different parties; and that you could not speak the French language, or very badly."

“'II fallait dire-' Pendant un séjour de quelques semaines seulement que j’ai demeuré enfermé dans la ville du Cap, aussitot après la révolte des nègres en 1791, j’ai rassemblé dans un tems de désordre et de troubles, les importans matériaux qui m’ont servi:- 'que vous aviez rien vu par vous-même,"” \&c. 
nists to offer a capitulation of St. Domingo to Great Britain. Though replete with errors arising from personal interest, and local prejudices, some facts are furnished by both these writers which could not be obtained by any other means. About the same time, there appeared at Paris, a work in two small volumes, in the form of Letters, under the name of the "Baron de WIMPFFEN;" 22 which, from external evidence, appear to be a collection of facts, arranged in an agreeable manner, on a subject occupying the attention of the French public, at the time. Whether it were or not a real voyage, among a variety of observations calculated to suit a temporary purpose, there are some that deserve a much better character. To these were added in France, a short time after, a work containing some authentic facts in a memoir of Toussaint, and a life of that great man, distorted for the purposes of party, by a popular writer, DU BRoCAs. ${ }^{23}$ The Remarks of Colonel CHALmers, ${ }^{24}$ in England, succeeded; from whose experience and local opportunities much was to be expected.* Of these, with a variety of private documents obtained from an extensive and intelligent correspondence, the writer has availed himself, in his third and fifth chapters, in a way, he trusts, neither injurious to their authors, nor unacceptable to the public.

Two other works have arisen out of the subject more recent than the foregoing, which deserve to be mentioned: that of M. d'ARCHENHOLTZ ${ }^{25}$ on the Buccaniers, published in Germany; and Mr. DALlas's ${ }^{26}$ English History of the Maroons, ${ }^{27}$ furnished from the materials of their superintendant, Mr. Quarrell, ${ }^{28}$ of Jamaica. On the former, while it furnishes illustrations of human nature, little dependence is to be placed in point of historical fact; for it follows the Spanish accounts of the people of whom it treats, and conveys an obvious

M. de Charmilly, at the same time, views the conquest of St. Domingo by the English as very easy - ridicules the idea of the blacks ever attaining any force, and hangs the fate of the whole of the Antilles on the prosecution of his favorite project.

*It is amusing to see the confidence with which the subjugation of St. Domingo constantly inspired its advocates. Col. Chalmers, in other respects, a well-informed soldier and gentleman, is incautious enough to have the following assertion in his preface:- "The late events in St. Domingo have been much misunderstood, or highly exaggerated: he trusts that he has clearly proved that the temporary misfortunes sustained by France were occasioned by her impolicy, cruelty, or other causes, totally independent of the power of her black enemies, whose strength, as stated, is utterly inadequate to render them independent of that empire, or of any other much less formidable power. If so, it is humiliating to hear senators gravely pronounce that France has lost St. Domingo." The colonel adds, from Homer, -

"To few, and wonderous few, has Heaven assign'd

"A wise, extensive, all-considering mind!!!" [Pope’s Illiad, bk. 13. Rainsford substitutes "Heaven" for "Jove."] 
calumny on their most respectable members. ${ }^{*}$ From the latter, some inferences are to be drawn, applicable to the subject of this volume, though the source, enveloped in interest, and the prejudice inseparable from a favourite project, is not so pure as could be wished on such an important occasion.

To the abstracts of these works may be added a variety of temporary productions (including the foreign and English public journals), to which proper reference has been had, with the caution necessary for consulting such an heterogeneous mass of materials. Thus, no correct or comprehensive account, has been given in our language, of this interesting country; even those who have enlightened the public mind on other great occasions, falling in with the general apathy, have forborne on this wonderful revolution. ${ }^{\dagger}$

To supply this omission, in a small degree, the writer, on a former occasion, ${ }^{\ddagger}$ submitted to the public his ideas in a crude and imperfect state; and the attention they received from some intelligent minds, afforded sufficient proof, that the public only required to be roused to entertain the considerations they suggested; while the adoption of his humble narrative in the journals of those countries ${ }^{\S}$ that might be supposed to possess the priority of information, evinces the necessity of such a communication as the present.ll

In it will be found a succinct, and he trusts candid, view of the early history of the Spanish colony, in which the impolicy of cruelty, and the errors of injustice, are exposed, in preference to any national prejudice, or habit. The same ideas are continued, regarding the French establishment; and a reference to human nature is preferred, when considering the character of those, whose actions of terrific splendour could be tried by no other test. In regard to the height of the French colonial prosperity, he has not dilated the account by so minute a view of their domestic life as by some might be wished; but, in what is necessary to give a correct idea of manners and conduct, it is hoped no deficiency will appear. In any case where the question of slavery interferes, con-

*Of the intrepid, generous, and intelligent Morgan (among others), M. d'Archenholtz asserts, "The horrors he committed are more dreadful than those of any of his colleagues. This monster filled the highest posts in the (British) state, and enjoyed with perfect security that enormous wealth which had cost the tears and blood of so many victims to his avarice, without suffering the smallest remorse to approach his hardened heart!" [Sir Henry Morgan (c.1635-1688) was a famously fearsome privateer.]

†From this censure, however, must be excepted Mr. Cobbett, (the author of the Political Register) who has in more than this instance deserved the character he has obtained of an enlightened politician. [William Cobbett (1763-1835), famous pamphleteer and advocate for Parliamentary Reform.]

$¥$ In the winter of 1801-2.

\$See "The Merchant," a respectable paper published in Rotterdam in the beginning of 1802 , \&c. \&c.

IISee also "The Monthly," and other Reviews of this period. 
sidering the subject on a broad basis, without regard to party, he has shewn its general inexpediency, rather than scrutinized its measures. And in tracing the revolutionary spirit to its source, he has endeavoured to point out moral delinquency without any other expression of rigidity than that which arose from the subject itself. In contemporary history, that hazardous, and perhaps invidious enterprize, he has rather adopted those facts, wherever such could be found, which have already received the common consent, than obtruded his own, in their place; and where the latter are of necessity introduced, they have been scrupulously examined and confirmed. His own sojourn at Cape François and Fort Dauphin is the unaffected tale of a way-worn soldier, experienced in the cross-roads of life, equally happy in the hospitality of an Indian cottage, or that of a magnificent empire - yet not regardless of each exclusive excellence, nor appropriating that of the one, to the other, or denying either. With regard to the transactions of the Black Republic (the appellation first given to the black government by the author), great care has been used to obtain the medium of truth between a variety of conflicting accounts; and, for the better comprehending their direct intent and views, much attention has been paid to give in the translation of their public papers, their original spirit.

Of one prominent subject of the present volume, it is painful to speak - yet an application to the general reader is necessary, as well as an apology to the sensibility of that sex, which the author would be much afflicted to foregofor the representations of cruelty, which will, he trusts, prevent such another violation of the human character. He is also desirous to avoid the appearance of enlarging on a subject which regards a country against whom his own is in hostilities. It must, therefore, be recollected, that it was during the peace ${ }^{29}$ which afforded an opportunity for the commission of crimes against human nature, of which he complains, that he first attacked the expedition against St. Domingo, and the immediate recourse to the assistance of the ferocious animals, which were surpassed by the cruelty of those, by whom they were employed. Mere description conveys not with so much force as when accompanied by graphic illustration, those horrors which are wished to be impressed upon the public mind. The existence of blood-hounds in the Spanish settlements in America, though disgraceful to the nation by which it is permitted, may yet continue, without any effect more extensive than with regard to the colonists, or their visitants; but the practice of, and terrible reference to, the savage custom of a barbarous age (only employed exclusively against

\footnotetext{
*The writer, at the time of his first publication, had been twenty-four years an officer in his Majesty's service.
} 
the worst criminals) in a European army, is a subject of the most alarming kind. That every public exhibition of even the forms of cruelty is productive of dangerous effects on the human mind, cannot be denied, and should be avoided; what then must be the callous insensibility produced on a soldier by circumstances such as are here delineated? It is reducing the heroism of war to a base contrivance of death. This cautionary memorial records the first step; it is for the public only, by marking it with a general sentiment of detestation, to preclude another and more dreadful, because more extensive, employment of the means. Such measures increase upon those who adopt them by insensible gradations, and once admitted, may extend even beyond their own intentions. The modern art of war is already removed to a sufficient distance from the magnanimity of ancient combat. Let not the breach be rendered wider by adoptions such as these. 



\section{CONTENTS.}

CHAP. I.

A SUCCINCT historical View of the Colonies of Hispaniola and St. Domingo, from the Discovery of Hayti, by Columbus, to the Height of their Prosperity in $1789 \quad 15^{-69}$

CHAP. II.

Origin of the Revolutionary Spirit of this Period in

St. Domingo 69-77

CHAP. III.

Account of the Progress and Accomplishment of the Independence of St. Domingo $77-132$

CHAP. IV.

State of Manners on the Independence of the Blacks in St. Domingo, with a Memoir of the Circumstances of the Author's Visit to the Island in $1799 \quad 132-148$

CHAP. V.

View of the Black Army, and of the War between the French Republic and the independent Blacks of St. Domingo 148-216

CHAP. VI.

On the Establishment of a Black Empire, and the probable Effects of the Colonial Revolution 216-218 


\section{APPENDIX.}

NO. I. Letter of the Abbé Grégoire to the Citizens of Colour in the French West Indies 221

II. Principles of the First General Assembly of St. Domingo 226

III. Dying Testimony of Ogé against the Insurgents 229

IV. Terms of Capitulation proposed by the Inhabitants of Grand Anse, \&c. to Major-General Williamson 232

v. Honorable Dispatch of Chevalier De Sevré to Colonel Whitlock 234

vi. Account of M. de Charmilly 235

vir. Documents illustrative of the Character and Manners of Toussaint L'Ouverture 238

viII. Extract from the Author's former Work 243

IX. First Colonial Regulation of the Captain-General Le Clerc 247

$\mathrm{x}$. An account of the Nature and History of the Blood-hounds used in the American Colonies 251

XI. First colonial Regulation issued during the Government of Rochambeau 256

XII. Documents respecting the Evacuation of St. Domingo by the French Army under Rochambeau 256

XIII. Declaration of the Independence of the Blacks of

St. Domingo 260

XIv. Proclamation for a solemn Abjuration of the French Nation 262

xv. Communication of the Intentions of the Black Government on the Appointment of a Governor-General for Life 264

Xvi. Caution to the Spaniards 267

XVII. Programa issued on the Coronation of the first Emperor of Hayti 268

XViıi. Statement of the Black Force at the Revolution 270

XIX. Additional Remarks 271 


\title{
A SUCCINCT HISTORICAL VIEW OF ST. DOMINGO.
}

\author{
CHAP. I. \\ From the Period of its Discovery, by Columbus, to its highest \\ State of Prosperity in 1789.
}

HAYт , Hispaniola, or St. Domingo, the largest and most valuable of the West India Islands, is situated in the Atlantic ocean, between the island of Puerto Rico on the east, and Jamaica and Cuba on the west; a small part of the rocks and shelves which form the Bahama islands lie at no great distance to the north; and it is bounded on the south by the Caribbean sea, and ultimately by the continent of South America. It lies in the latitude of $18 \mathrm{deg}$. 20 min. north, and in 68 deg. 40 min. west longitude from Greenwich. ${ }^{30}$ It is in length, according to the best accounts, more than 450 miles from east to west, and 150 in breadth. ${ }^{31}$

This beautiful island was the sixth discovered by the enterprising and unfortunate Columbus in his progress towards the discovery of a new world, of the honor of which, in the appropriation of a name, he was to be deprived by the caprice of his contemporaries, in favor of an obscure adventurer, of no other merit in the discovery, than that of having trodden in his steps. ${ }^{*}$ It was the first on which he formed a settlement, or made any stay in his first voyage, and appears to have afterwards received the principal marks of his consideration. To it he was directed by the natives of Cuba, where he had previously landed, as more rich in its mines of that fertile ore with which it was necessary to bribe the avarice of the Spaniards, to prolong that ardour of discovery which it had cost him so much labour to excite.

Columbus first arrived at Hayti, for so this country was called by its natives, on the 6th day of December, 1492. He landed at a small bay, which he called St. Nicholas, and then named the island Espagnola, in honor of the country

\footnotetext{
*When the prosecution of discoveries in Spain had fallen into the hands of private adventurers, Alonzo de Ojeda, who had accompanied Columbus in his second voyage, was among the first to propose an expedition under his own command. With this active and gallant officer sailed Amerigo Vespucci, a Florentine gentleman, apparently of no ostensible character whatever; but having framed a fraudulent narrative of his voyage with some elegance, which formed the first description of any part of the new world, he obtained from its circulation the honor of giving name to America.
} 


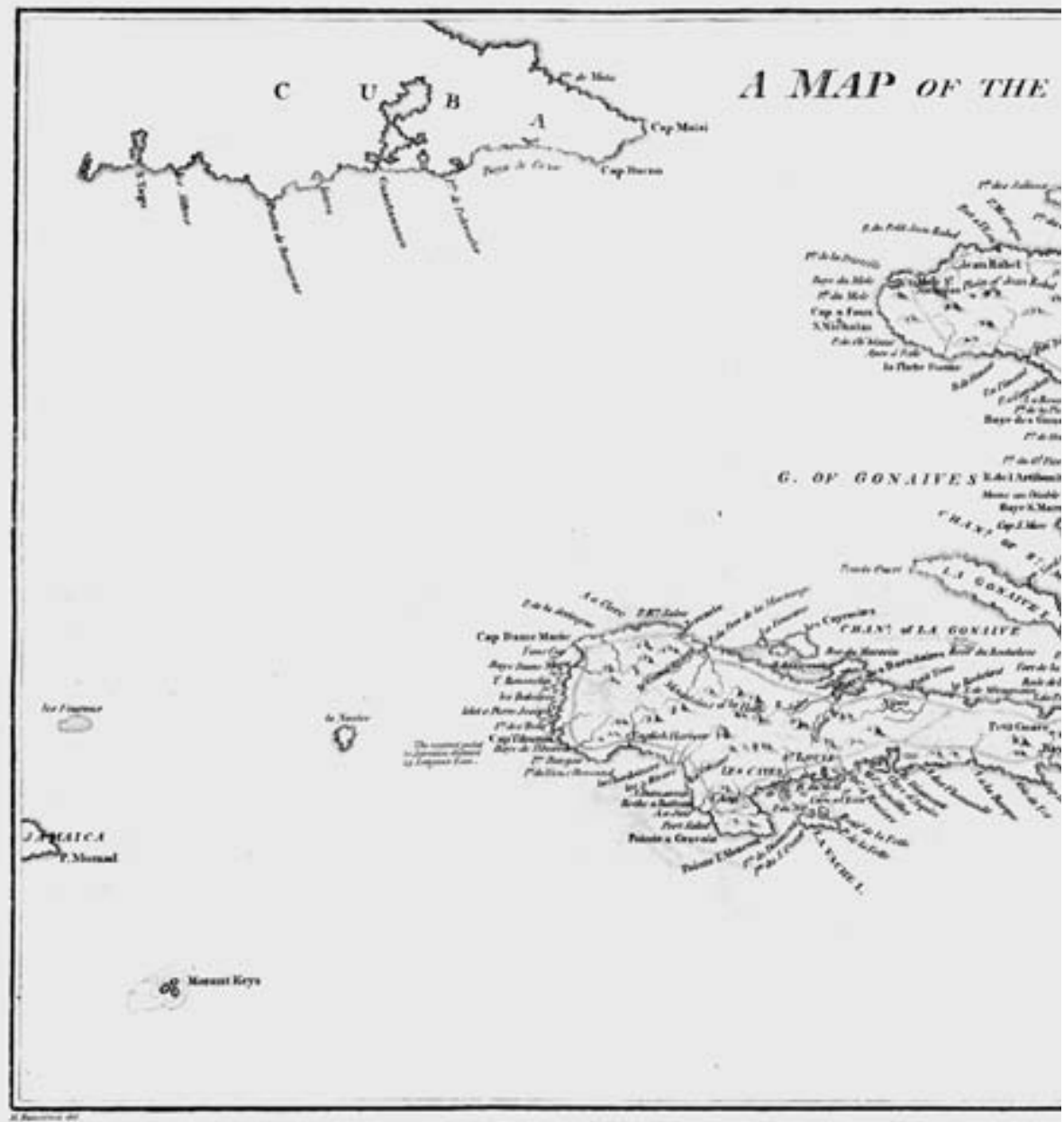

Map of St. Domingo. Reproduced with the permission of Rare Books and Manuscripts, Special Collections Library, the Pennsylvania State University Libraries. 


\section{ISLAND OF ST DOMUNGO.}

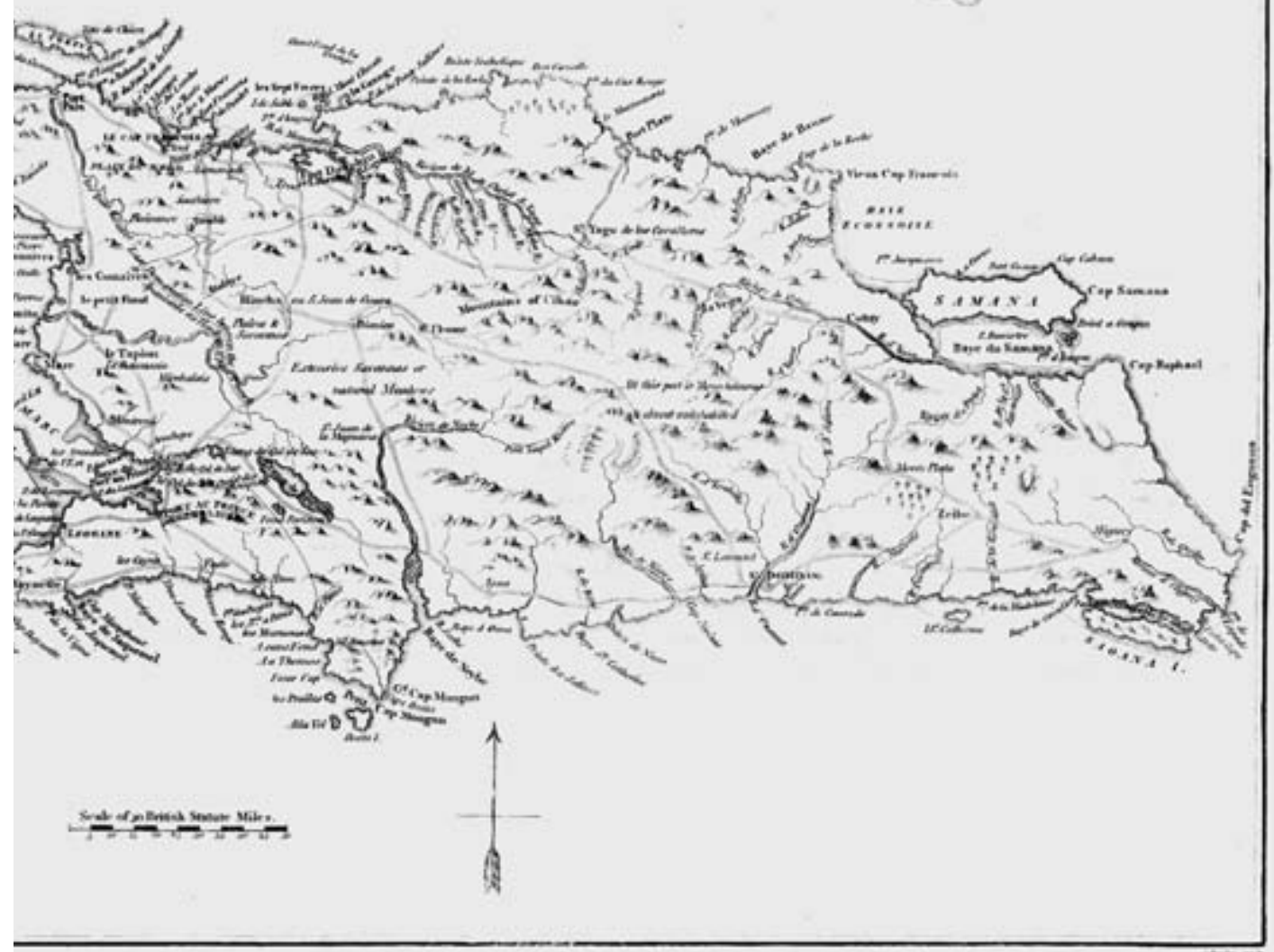


by whose king he was employed: from thence he sailed along the northern coast till he found a more convenient harbour, which he named Conception, and where he first had access to the inhabitants, through the means of a female whom his people overtook, and prepossessed in their favor, by the usual means of trifling presents and gentle behaviour.

It is our wish to pursue in this place a sober narrative of fact, rather than to give loose to the fascinations of romantic description, or else the early Spanish writers have handed down such accounts of the aborigines of Cuba, Hispaniola, and Jamaica, as would warrant the most extravagant eulogy on their personal appearance, manners, and ingenuity. It may, however, naturally be supposed possessing the necessaries of life without labour, on a soil the most fertile, and in a benignant climate, in a state of the utmost simplicity, and consequently free from the general enemies to beauty, they would have personal advantages not to be expected in their descendants under the combined evils of slavery in a voluptuous state. Even the rigidity of history has been softened into the most pleasing descriptions of them: "They appeared," says Robertson, "in the simple innocence of nature, entirely naked, their black hair, long and uncurled, floated upon their shoulders, or was bound in tresses around their heads. - They had no beards, and every part of their bodies was perfectly smooth. Their complexion was of a dusky copper colour; their features singular, rather than disagreeable; their aspect gentle and timid; though not tall, they were well shaped and active." "The industry and ingenuity of this race," says another elegant writer, "must have exceeded the measure of their wants. Placed in a medium between savage life, properly so called, and the refinement of polished society, they were perhaps equally exempt from the bodily distresses and sanguinary passions of the former conditions, and from the artificial necessities and solicitudes of the latter." They were unquestionably the most unoffending, gentle, and benevolent of the human race. ${ }^{\dagger}$

That there were some grounds for a belief in the ingenuity ascribed to them by Peter Martyr $\ddagger$ and others, as far as it related to their simple agriculture, and some progress in the arts of ornament as well as utility, may, perhaps, be proved by a fact of another nature which tends to illustrate the character of this people, while it may afford a lesson to our own times; - would that we could not say to our own country.

When, among the numerous disasters of Columbus, he was wrecked on the eastern coast of the island, and if he had before impressed the natives with admiration of the superior nature of their visitors, was now placed in a situa-

\footnotetext{
*Hist. of America, vol. i. 1. 2.

†Hist. Jamaica, Dallas's Hist. vol. i. 23.

$\ddagger$ De Rebus Oceanis, \&c.
} 
tion the best calculated to prove their natural equality, and even to tempt by an unlucky opportunity any inclination to their injury, instead of the smallest hostility. Guacanahari, the cazique, or king of this division of their island, of which it appeared to be governed by seven, having been informed of his misfortune, expressed great grief for his loss, and immediately sent aboard all the people in the place in many large canoes; they soon unloaded the ship of every thing that was upon deck, as the king gave them great assistance: "He himself," says Columbus, who records it, "with his brothers and relations, took all possible care that every thing should be properly done both aboard and on shore; and from time to time he sent some of his relations weeping, to beg of me not to be dejected, for he would give me all that he had. I can assure your Highnesses," he adds, "that so much care would not have been taken of securing our effects in any part of Spain; as all our property was put together in one place near his palace, until the houses which he wanted to prepare for the custody of it were emptied; he immediately placed a guard of armed men, who watched during the whole night, and those on shore lamented as much as if they had been interested in our loss. migrated originally from the neighbouring continent, and are ascribed by Sir Walter Raleigh to the Arrowauk ${ }^{32}$ tribe of Guiana. ${ }^{\dagger}$

Thus far we have preserved the necessary sobriety in collecting a description of the first inhabitants of St. Domingo; but when we come to speak of the territory itself, this caution ceases, for, no description that we have yet seen is adequate to the appearance, even at the present day, of a country which requires all the aid of romance to imagine, much less to describe. - Of fertility, which it requires but the fostering hand of man to guide to all the purposes of life, and of a climate the most salubrious among the Antilles, and in which longevity is general. - "In these delightful countries too," observes Robertson, "Nature seemed to assume another form; every tree and plant, and animal, was different from those of the ancient hemisphere;" 33 - Columbus boasted of having discovered the original seat of Paradise. - "In these delightful vales," exclaims the Abbé Raynal, $¥$ "all the sweets of spring are enjoyed, without either winter or summer. There are but two seasons in the year, and they are

\footnotetext{
*Letter of Columbus to Ferdinand and Isabella of Spain. See his Life in Churchill's Voyages, as written by his younger son Ferdinand, an ecclesiastic, and founder of the Columbine Library at Seville; also Herrera's General History. [Awnsham Churchill (1658-1728) was a leading London publisher. His most famous work was A Collection of Voyages (1704).]

${ }^{\dagger}$ Raleigh's Voyages. [Sir Walter Raleigh (c.1552-1618) was an aristocrat, poet, and explorer who twice attempted to establish a colony at Roanoke, Virginia. He later turned his attention to Venezuela and Guyana in search of the legendary El Dorado and recorded his voyage in The Discovery of Guiana (1596), the book Rainsford seems to be referring to here.]

$\ddagger$ East and West Indies, vol.iv. 231 [Raynal, A Philosophical and Political History].
} 
equally fine. The ground always laden with fruit, and covered with flowers, realizes the delights and riches of poetical descriptions. Wherever we turn our eyes, we are enchanted with a variety of objects, coloured and reflected by the clearest light. The air is temperate in the day time, and the nights are constantly cool." - "In a country of such magnitude," says Edwards, " diversified with plains of vast extent, and mountains of prodigious height, is probably to be found every species of soil which nature has assigned to all the tropical parts of the earth. In general it is fertile in the highest degree, every where well watered, and producing almost every variety of vegetable nature and beauty for use, for food, and luxury, which the lavish hand of a bountiful providence has bestowed on the richest portion of the globe." "The possessions of France in this noble island," he continues, "were considered as the garden of the West Indies, and for beautiful scenery, richness of soil, salubrity, and variety of climate, might justly be deemed the paradise of the new world." - "What you have said," replies De Charmilly, ${ }^{\dagger}$ animadverting on the preceding passage, "is nothing when it is known that the extent of the French part is but one half of that of the Spanish division, and that this is yet more fertile than the French part, requiring only cultivators, \&c." Of even such an account, when contemplating the various parts of St. Domingo in which we have been, with an eye well accustomed to tropical scenery, and satiated with the luxury natural to its soil, we could be almost inclined to say too, this is nothing.

It is not to be wondered at, that the inhabitants should consider the Spaniards, on their first interview, as preternatural beings, a circumstance, however, very favorable to their intercourse, and which might have been turned to more advantage in a better purpose than that to which it was applied. They possessed gold, which they found in the beds of the rivers, or washed by the heavy rains from the mountains, and which they gladly exchanged for bells, beads, or pins. A prince, or cazique of the country, who visited Columbus, was carried in a sort of seat upon men's shoulders, and derived great respect from his attendants. He was extremely courteous, and presented the admiral with many articles of curious workmanship, and received with complacency some trifles in return.

They had no idea of the imaginary value attributed by their visitors to gold, and readily pointed out the mountains, which yet retain their original name of Cibao, ${ }^{34}$ as the great repository of the ore they so much desired.

It was at this period that Columbus lost one of his ships through the care-

\footnotetext{
*Historical Survey, chap. 19.

†Lettre à M. Edwards, p. 70 .
} 
lessness of a pilot, and experienced the tenderness which has been already mentioned. Of another of his vessels out of three, he had procured no intelligence since his arrival, and suspected some treachery in the captain who commanded it. The third was of course insufficient to receive the whole of his crew, and he was desirous to return to Spain. The simplicity of the natives, and their terror from the incursions of the people who inhabited several islands to the south east, whom they called Caribbeans, ${ }^{*}$ and who were of a very opposite character to themselves, being fierce and warlike, and devouring the flesh of their prisoners, gave confidence to Columbus, in the proposition of leaving a part of his crew behind, which would embrace the two advantages of forming a settlement on the island, and enable him to return to Spain immediately. They agreed without a murmur, and even assisted in the erection of a fort which was to be afterwards used as a means of their own subjection.

Thirty-eight Spaniards were appointed to remain on the island, under the command of Diego de Arado, ${ }^{35}$ a gentleman of Cordova, to whom Columbus communicated his own powers, and every thing requisite for their establishment; having first endeavoured very successfully to impress the natives in their behalf, by acts of beneficence and exhibitions of power. He promised to revisit them soon, and in the interim to make respectable mention of them to their country. Columbus left the little colony on the 4th of January 1493, and arrived in Spain in the month of March following.

The departure of Columbus had not long taken place, when, as too often happens, the garrison he had left behind grew impatient of restraint, and threw off the command of their newly appointed governor. Regardless of the prudent instructions which had been given them, the men who composed it became insolently independent, and gratified their avaricious and licentious desires at the expence of the natives, making a wasteful prey of their gold, their women, and their provisions; thus, instead of supporting the estimation in which they were held; exhibiting themselves as the most depraved of human beings. At length the cazique of Cibao, ${ }^{36}$ whose country the Spaniards chiefly infested, cut off a part of the colonists, surrounded the remainder, and destroyed their fort.

Columbus having employed himself for six months at the court of Spain in

${ }^{*} \mathrm{M}$. de Charmilly constantly confounds the character of the inoffensive aborigines of St. Domingo, with that of the Charaibs, or Cannibals, and of the African negroes in their present state of slavery, and thence draws deductions, which must consequently fall to the ground. [Many early European explorers viewed the Caribs as cannibals. The English term "cannibal" in fact derives from the native word "caribe," signifying "brave or daring" (OED ). There is no evidence that the Caribs ate humans.] 
receiving the rewards of his distresses, and in interesting it in behalf of the splendid enterprize of which he was the author, no sooner accomplished his aim, and procured a sufficient fleet, under the papal sanction, on the part of the king of Spain, than he became impatient to revisit his colony. He accordingly departed on his second voyage, and after touching at several other islands towards the north west of his route, arrived at Hispaniola on the $22 \mathrm{~d}$ of November following.

His surprize may easily be conceived to find that his colony no longer existed; and while the Spaniards in dismay were weeping over the fate of their countrymen, a brother of the friendly cazique Guacanahari arrived, and related to him the account of their fate.

Instead of wasting his time by a retaliation of injuries, Columbus set about the erection of a town, of which he traced the site in a large plain, near a spacious bay. He obliged every person in his suite, of whatever quality, to assist in a work so necessary to the common safety. This City, the first which obtained that appellation in the new world, was named Isabella, ${ }^{37}$ in honor of his patroness the queen of Castile.

Columbus experienced all the difficulties attendant on an infant colony, and a timely excursion in great pomp to the mountains of Cibao, which they found to answer the description of the Indians, in the possession of gold in considerable quantities, perhaps only saved the establishment from final ruin. As soon as concord was restored by the prospect of the mines, Columbus again purposed to leave his colony for the prosecution of new discoveries. He appointed his brother Diego, ${ }^{38}$ with a council of officers, to govern in his absence; and a body of soldiers, under the command of Don Pedro Margarita, ${ }^{39}$ were sent to visit the different parts of the island, and to establish the authority of the Spaniards. He then set sail on the 24th of April, but after an absence of five months, during which time he had not been distant many leagues, and had experienced the most disastrous circumstances, he returned almost dead to the colony, where he found a brother Bartholomew, ${ }^{40}$ whom he had not seen for thirteen years, who had arrived in his absence, and whose unexpected appearance, after sustaining distresses scarcely inferior to his own, so much revived his spirits as to produce a speedy convalescence.*

\footnotetext{
*Bartholomew Columbus had been dispatched by the great navigator to England, to negociate with Henry VII. his project of discoveries, in case he should be disappointed in Spain, as he had been in Portugal. On his voyage, the negociator fell into the hands of pirates, who stripped him, and retained him several years a prisoner. At length, having escaped, he arrived in London, but in such poverty, that he was incapable of appearing at court on his mission, till, by drawing maps for sale, in the execution of which he was very ingenious, he procured decent clothing, and a moderate subsistence.
} 
During the absence of Columbus, the soldiery under Margarita had repeated the conduct of the first colony, while the necessities even of abstemious Spaniards rendered them unwelcome neighbours to a race who, requiring very little food to support a life of indolence and innocence, made but proportional provisions when any care was necessary. Maize, with a few vegetables, and very little, if any animal food, formed their only necessary stock, and on this a body of men fortifying themselves in towns, must have made a formidable inroad. Famine, and the success of their former revolt, with long repeated grievance, at length provoked other attempts to rid themselves of the burthen, and Columbus was compelled to have recourse to arms, which he had hitherto with much solicitude avoided. The Indians were defeated by their precipitance: instead of the mode natural to them, of drawing the enemy into their fortresses, they rushed into an open plain, the Vega Real, and numbers being thrown into consternation by the first appearance of European warfare, the impetuosity of cavalry, (which they conceived, like the Thessalonians, to be Centaurs, ) and the fierce onset of the dogs, ${ }^{*}$ they yielded to Columbus an easy victory; and those who were not taken prisoners, and reduced to servitude, resigned themselves entirely to despair. Such was the disparity of power, that though near an hundred thousand Indians took the field with missile weapons of their rude fashion, the victory was obtained by two hundred foot, twenty horse, and twenty large dogs, which formed the whole disposable force of the Spaniards.

Columbus employed several months in passing through the island to complete its subjection, and impose a tribute on all the natives above the age of fourteen, which was one of the first effects of a policy adopted against his own inclination to gratify the avarice of the Spanish court, at which he was attempted to be undermined, and which proved afterwards, however moderately used by himself, a means of tyranny and cruelty in the hands of others. This taxation was an insurmountable infringement on the habits of the Indians, to whom restraint on labour was an intolerable evil. It induced an attempt at another kind of hostility, that of starving the appetites of the Spaniards, on the gratification of whose voracity they conceived so much to depend. They pulled up the roots, and suspended all their simple agricultural operations, and retiring to inaccessible mountains, they produced in themselves the effects they vainly hoped to produce in their usurpers. Few as were their wants, they were soon totally unsupplied, and more than a third part became victims to their self-created famine.

\footnotetext{
* Of the mode of introducing these combatants into Spanish tactics, some account will be found in a future chapter. [See section X of the appendix.]
} 
It was at this time that divisions began to be created in the island through the intrigues of the enemies of Columbus in Spain; they procured one Aguado, ${ }^{41}$ a groom of the bed-chamber, to be sent as commissioner to Hispaniola, who displayed all the insolence of mean minds disordered by sudden elevation. To relieve himself, and obtain an explanation with his enemies before his monarch, Columbus returned to Spain, leaving his brother Bartholomew as adelantado, or lieutenant-governor, and through a misplaced trust, appointing Francis Roldan, a gentleman of rank and character, chief justice.

Though as usual experiencing difficulties in his passage, he so far gained over Ferdinand and Isabella, as to obtain further provisions for his colony, in a digested plan, and on a more permanent and extensive scale. Women, artificers, and husbandmen, were joined to the new expedition, but, as all his acquisitions received some alloy, to these were unadvisedly added the criminals from the jails, that fatal resource for population which has so often miscarried. It was almost two years, however, before Columbus set out on his third voyage, and several months after before he returned to Hispaniola, having in the interim discovered the continent of America, ${ }^{42}$ the crown of all his enterprizes, and of all his sorrows. He returned weary and sick, but he found the colony in a state that admitted of no repose.

Don Diego Columbus had, at the desire of his brother, during his absence, removed the colony to a more eligible station on the opposite side of the island, where he had founded a city, which he dedicated to St. Domingo, or Dominica, in honor of the name of his father, and which remained so long the seat of Spanish dominion in the new world. ${ }^{43}$

Restless spirits will sometimes be found, however inconsistently, in the highest stations, and political troubles arise from very unexpected sources; such was the case with Roldan, whose appointment was to have preserved peace and order; and, when Diego had reduced to subjection what remained of the island unsubdued by his brother, this man excited rebellion among his countrymen, and even the Indians, with such artifices, as caused the most alarming effects, and was only quelled by the temperate, conciliatory, and expedient policy of Columbus. Of the bad consequences of this restoration of tranquillity, however, was the re-establishment of Roldan, and a concession to the avarice of the Spaniards, which was the first step in reducing the Indians to actual slavery. Lands being allotted to the mutineers in different parts of the island, the Indians of the district were appointed, in lieu of their tribute, to cultivate a certain portion of ground for the use of their new masters, from the characters of many of whom may be easily derived the origin of numberless calamities to that unhappy people.

Of the mutiny, the effects were by no means terminated in appearances, 
the progress of discovery was stopped, and such false representations were made by his opponents, that a knight of Calatravia, called Francis de Bovadillo, ${ }^{44}$ was sent to supersede Columbus, and by means known only to courts, to send him immediately a criminal in chains to Spain. Thus closed the fifteenth century in St. Domingo, a period which, while it saw the founder of an empire disgraced and wretched, afforded a better prospect to the colony than had hitherto appeared. Such provisions had been made for working the mines, and cultivating the country, as assured not only its existence, but a considerable revenue to the monarch, who suffered Columbus to be circumvented and abused.

Bovadillo proceeded, as might be expected, to render himself popular, by gratifying the entire inclinations of his countrymen. He numbered all the remaining Indians, and dividing them into classes, distributed them as property among the Spaniards, who, disregarding the only true means of obtaining wealth by agriculture, sent them to the mines, and imposed on them such a disproportioned labour as threatened their utter and speedy extinction.

To prevent this dreadful event, and preserve the shew of decency to the world, on the arrival of Columbus in Spain, and his appeal to the justice of Ferdinand, another knight of the military order of Alcantara, Nicholas de Ovando, ${ }^{45}$ was sent to replace Bovadillo. Regulations were adopted to prevent the licentious spirit which had arisen in the colony under his government; and, to check the inordinate progress of wealth, the gold was ordered to be all brought to a smelting-house, where one half should become the property of the crown. Columbus remained in Spain many months soliciting attention in vain, till his proposition of an attempt at discoveries to the east was accepted; and he sat out on his fourth voyage in May, 1502.

Ovando brought to St. Domingo the most respectable armament hitherto seen in the new world, consisting of thirty-two ships, with two thousand five hundred settlers. ${ }^{46}$ On his arrival, Bovadillo, with Roldan and his accomplices, were ordered to return to Spain.

Columbus having experienced some inconvenience from one of his vessels, altered the course in which he steered, and bore away for St. Domingo, with a hope of exchanging it for some ship of Ovando's fleet; eighteen of which, however, he found laden, and preparing to depart for Spain. He requested permission to enter the harbour, (first acquainting Ovando with his destination,) that he might negotiate an exchange, and avoid a violent hurricane that he saw approaching, and which he advised the departing fleet also to avoid. To neither of these objects did he obtain an acquiescence. He, however, took precautions against the tempest, and saved himself, while nearly the whole of the eighteen ships of his enemies were lost. In them perished Bovadillo, Roldan, 
and the greater part of those who had persecuted Columbus and the Indians, with the whole of their ill-gotten wealth, amounting in worth to upwards of fifty thousand pounds sterling; a sum at that time equal to many multiplications of its value at present.

Columbus did not long remain on the inhospitable shore of a country to which he was refused access, by those who owed to him entirely its possession, but prosecuted his voyage in the fruitless hope of discovering the Indian ocean.

In the mean time Ovando, who had received a commission more favorable to humanity than his predecessors, relieved the Indians from compulsory toil, and the colony, though retarded by deficiency of labourers, began to advance in its approaches to a regular society; but, alas! in no instance is the constant variance between justice and expedience in what is called the social state to be more regretted than in the present. The Spaniards became incapable, without the assistance of the inhabitants, (which no inducement could procure) to cultivate the soil, or to work the mines, and many of the new settlers died of disorders incident to the climate, not yet understood, while others quitted the island when deprived of their slaves. These circumstances demanded some attention, and the consequence once more returned to the unoffending Indians.

Columbus, persevering through misfortune, this year again paid a visit to his favorite isle, after having been not only unsuccessful in his attempt at farther discoveries, but a sufferer by complete shipwreck, and detained near twelve months in the island of Jamaica, which he had discovered nine years before, but of which no farther notice had been taken. ${ }^{47}$ Ovando appears to have been cautious of admitting into the country, under his government, a man of such vast powers, and to whom belonged, by the most determinate of all rules, the dominion of a world he had found: he at length, however, furnished the means for his escape, and received him with every public honor on his arrival at St. Domingo.

He remained only a month upon the island; with his usual ill-fortune, encountering violent storms, sailed seven hundred leagues with jury-masts on his way to Spain, where, exhausted by his sufferings, and disgusted with the dissimulation and injustice of a monarch whose reign he had immortalized, he died fifteen months after, ${ }^{*}$ aged fifty-nine years. It is useless to lament in this place the melancholy end of a man whose memory is eternized. The recollection of it rather communicates a balm to the sorrows of inferior multitudes; and the details of history will apply the event with advantage to the instruction of future ages.

\footnotetext{
* On the 2oth of May, 1506.
} 
A few months before Columbus, died his patroness Isabella; so that a powerful influence was withdrawn from the interests of humanity, as they regarded the new world; and as Ovando began to experience the ill effects of a liberal conduct, he began also to relax in the execution of the royal edicts. He made a new distribution of the Indians among the Spaniards, with the difference only, that they were to be paid for their labour, reduced the royal share of the gold to one third, and afterwards to a fifth part; for which he obtained, (with better success than Columbus,) the sanction of the court.

Notwithstanding the apparent mildness of the present governor, it was at this period that the rage for cruelties commenced which have stained the page of history with more horrors than can be conceived by those possessing even an ordinary love for the species. No treachery was too gross, no violation of sex or dignity too painful for this unhappy people in the hands of the Spaniards; all regulations tending to mitigate the rigour of their servitude were forgotten, while their labour was increased. Ferdinand conferred grants of them as rewards to his courtiers, who farmed them out, being no longer treated or considered but as animals of an inferior species, of no other use than as instruments of wealth, and I could almost say, subjects of oppression. At their expence, however, the colony increased in riches and in consequence; for with such rapidity and success were the mines explored, that for several years the gold brought into the royal smelting-house, amounted in value to more than half a million sterling, (according to the present standard of money). Sudden fortunes arose among private persons, which tempted others to embrace the opportunity of enriching themselves both at the expence of health and reason; and the effect was for a time highly advantageous to the colonists, and to the government of the mother country. Like the progress of a conflagration, however, the blaze was short in proportion to its extent. The same exertions which exhausted the unhappy Indians enriched the Spaniards, both as related to the nature of the operations, and to the government of Ovando, who is described to have introduced much wisdom and justice into his jurisdiction over his countrymen, but a proportionate rigour towards the original inhabitants of the country.

Ovando first gave a permanence to the laws he had established by executing them impartially, the only means of procuring regard for any establishment. He seems also to have attended to every object of advantage to the colony, and, among others, endeavoured to turn the attention of some of the Spaniards to the more laudable pursuits of agriculture. Having obtained from the Canary Islands some slips of the sugar-cane, which throve exceedingly, he tempted them to form plantations, and to erect sugar-works, which fortunately became an important support when the bowels of the earth were exhausted. ${ }^{48}$ The conduct and success of Ovando soon apprized Ferdinand of 
the value of those discoveries, he had hitherto appeared to depreciate, and on the author of which he had conferred only disgrace and misery; he accordingly set about forming commercial and ecclesiastical regulations, and at length established a system of policy the most profound, and every way calculated to secure to Spain the entire advantages of her colonies.

While these provisions were taking place for its government, some circumstances began to make their appearance, for which, however to be dreaded, no remedy could be found; and therefore, notwithstanding all other advantages, immediately threatened the dissolution of the colony. The consumption of the natives, which was the natural consequence of the inconsiderate oppression of the Spaniards, (and in whom rested the source of all their prosperity,) became so evident, as to afford serious cause for alarm. Fatigue, to which they were unequal; diseases, the result of an inattention to their change of habit; famine, the effect of preferring so long the search of wealth in the mines to agriculture; and self-violence, the consequence of despair, conspired so forcibly, as to reduce their number upwards of 40,000 in the space of fifteen years, there remaining but about 60,000 out of more than a million, to which the original population amounted.*

This diminution continued with such rapidity, as to occasion a stagnation not only of the colonial improvements, but of the common operations of life, which demanded immediate relief, and Ovando in consequence adopted an expedient which was again the source of enormities that seemed to increase in proportion to the progress of their society. The description will afford a

*M. Charmilly, (Lettre à M. Edwards,) has a long, and, in some respects, sufficiently accurate calculation, to prove the original diminutive population of St. Domingo, in opposition to Mr. Edwards's general description of the massacre of a million of inhabitants. He falls, however, as is usual with those influenced by a spirit of party, into self-contradictions and inconsistency: for he alludes to a perfect knowledge of the topographical antiquities of the country, the existence of which he has proved to be impossible; and he supposes his author to have believed in the instantaneous sacrifice of a million of persons in the four chief mines of the country. General assertions are certainly distracting, and Mr. Edwards is too frequently superficial; but in this instance he is perfectly right. It is from Herrera, the most correct and intelligent of the Spanish historians, whom Dr. Robertson has also adopted, that the fact in the present text is derived, and not Oviedo, to whose amplifications M. de Charmilly ascribes the supposed error. Benzoni states the original population at two millions. [Gonzalo Fernández de Oviedo y Valdés (1478-1557) lived in Hispaniola and was named historiographer of the Indies in 1523 . He wrote La historia general y natural de las Indias and Las Quinquagenas de la nobleza de España (1526-35). Girolamo Benzoni (c.1509-?) wrote Historia del Mondo Nuovo (1565). His exaggerated estimate is perhaps due to the work's fiercely anti-Spanish slant and his attempt to paint the Spaniards as particularly barbarous masters. Estimates of the size of the native population when the Spaniards arrived at Hispaniola in 1492 range from 100,000 to 2,000,00o. A census taken in 1507 revealed that their numbers had fallen to 60,000 .] 
mild example of the temper and conduct experienced by the simple, and benevolent beings of whom, Columbus, with an ingenuousness natural to great minds, had spoken in such exalted terms to the Spanish court. He proposed to seduce the inhabitants of the Lucay Islands, ${ }^{*}$ which had been previously discovered, to Hispaniola, "under the pretence that they might be civilized with more facility, and instructed to greater advantage in the Christian religion, if they were united to the Spanish colony, and placed under the immediate inspection of the missionaries settled there." Ferdinand, deceived by this artifice, or willing to connive at an act of violence which policy represented as necessary, gave his assent to the proposal. Several vessels were fitted out for the Lucayos, ${ }^{49}$ the commanders of which informed the natives, with whose language they were now well acquainted, that they came from a delicious country, in which the departed ancestors of the Indians resided, by whom they were sent to invite their descendants to resort thither to partake of the bliss enjoyed there by happy spirits. That simple people listened with wonder and credulity; and fond of visiting their relations and friends in that happy region, followed the Spaniards with eagerness. By this artifice above forty thousand were decoyed into Hispaniola to share in the sufferings which were the lot of the inhabitants of that island, and to mingle their groans and tears with those of that wretched race of men. ${ }^{\dagger}$

The ardour for discovery, which had languished during the anxiety for the wealth of the mines, began to be renewed by an expedition under Juan Ponce de Leon, ${ }^{50}$ (who commanded under Ovando in the eastern district,) to the island of Puerto Rico, which in a few years was subjected to the fate of Hispaniola. Ovando also commissioned an officer, named Sebastian de Ocampo, ${ }^{51}$ to ascertain the insular situation of Cuba, which Columbus had supposed to be a part of the neighbouring continent.

But though late and unexpected, by a perseverance the most constant, a degree of justice was at length to be accorded to Columbus in the person of his son Diego. ${ }^{52}$ Almost wearied out in the courtly delay which had exhausted his father, he determined upon the bold alternative of an appeal against his monarch to a council for Indian affairs, which he had himself established. Unequal as the parties were, and recent as was its own existence, the court honourably sustained its integrity, and determined on the side of justice, even against the king: with this decision, and the support of powerful connections,

*The same with the Bahamas.

†Hist. of Amer. vol. i. p. 263. I have quoted this from Dr. Robertson, as the best and most moderate description. His authorities are, Herrera, Dec. J. lib. 7. c. 3.; Oviedo, lib. 3. c. 6.; Gomara Hist. c. 41. [Francisco López de Gómara (c. 1511-66?) wrote La Historia General de las Indias (1552).] 
subsequently acquired by marriage, he soon obtained (though but a partial concession of his rights) the government of St. Domingo, and such privileges as enabled him to arrive in the island with more splendour and magnificence than had hitherto been witnessed: Ovando was of course recalled. That splendour, and the numerous retinue with which it was supported, while it added lustre to the settlement, effected no other change to the unhappy aborigines, than the seal of a more determinate slavery, by a numerical division of them among the Spaniards, according to the rank of the latter.

The destruction of the labourers proportionally decreasing the produce of wealth to their masters, naturally excited an impatience in those who had been glutted with wealth, and satiated with dissipation. They had already begun to contemplate other countries, whose inhabitants were yet unexhausted; they had established a pearl-fishery at the small island of Cubagua, ${ }^{53}$ and lodged a small colony on the continent, at the gulf of Darien, ${ }^{54}$ under the brave and enterprising, though as usual, unfortunate, Vasco Núgñez de Balboa, ${ }^{55}$ when Diego Columbus made a proposition to which they readily acceded. This was the establishment of a colony in the neighbouring island of Cuba, to which an armament immediately embarked under the command of Diego Velasquez, ${ }^{56}$ one of the companions of the great discoverer on his second voyage. The only circumstance concerning this expedition, as it regards the island which is more immediately under our consideration, besides its relief from a number of discontented members, was the opposition of Hatuey, ${ }^{57}$ a cazique, or prince, who having fled thither from St. Domingo, indignant at the destruction of his innocent subjects, might naturally be expected to oppose the intrusion of their destroyers into the place of his refuge. His feeble party (for they were of the same inhostile nature with his former subjects) were soon dispersed, himself taken prisoner, and condemned to the flames under the barbarous maxim, which considered him only as a slave, who had taken arms against his master. "When Hatuey," says Dr. Robertson, * "was fastened to the stake, a Franciscan Friar, labouring to convert him, promised him immediate admittance into the joys of Heaven, if he would embrace the Christian faith." - "Are there any Spaniards," says he, (after some pause), "in that region of bliss which you describe ?" "Yes," replied the monk, "but only such as are worthy and good." "The best of them," rejoined the indignant cazique, "have neither worth nor goodness; I will not go to a place, where I may meet with one of that accursed race!"

Another expedition soon took place from St. Domingo, to assist in the discovery of the South Sea, by the justly celebrated Balboa, from whose incur-

\footnotetext{
${ }^{*}$ Hist. of America, vol. i. p. 277. edit. 1800.
} 
sions in the continent on which he was established, he had sent home such quantities of gold, as tempted a number by no means contemptible to join him. It comes not into my promise to shed fruitless tears on the perverted fortunes of this truly great man; ${ }^{58}$ his name, consigned to unfading memorials, has, I trust, its use with those who possess a fertile mind without the power to sustain its operations. - Though the passage to the Indian ocean was not obtained, as was expected, they reached the South Sea, and prepared the way for more important discoveries.

In 1514, died more peaceably than he had lived, Bartholomus, the uncle of the present Governor; a man of very respectable powers, and an unsullied character; who had occasionally filled offices of high importance in the island, and who, it would appear, was more closely connected with its history than his contemporaries have enabled us to state.

The government of Diego Columbus was neither inefficient nor violent; neither did he want inclination or ability to render the colony both prosperous and happy: but that justice which had been unwillingly accorded him, on the part of the deceased Monarch, was, as much as possible, impeded by every political artifice that could be employed. The meaner officers of the government were encouraged to thwart the authority of the governor, in a variety of measures, and at length the power of distributing the Repartimientos ${ }^{59}$ was created into an office, and conferred upon Roderigo Albuquerque, the relation of a confidential minister called Zapata. On the loss of this necessary advantage, in addition to the embarrassment he had already experienced, Diego resolved on returning to Spain for the purpose of remonstrance: leaving behind him the best administration in his power, reached his destination in safety, but he soon found with very small hopes of redress in the object of his voyage.

In his new capacity Albuquerque discovered no other care than to repair his own indigent circumstances, for which purpose he first ordered a renumeration of the Indians, (now reduced to 14,ooo,) and then put them up to sale in different lots. This was the only stroke wanting to complete the extinction of this unhappy race, by a consequent separation from the habitations to which they had been accustomed, and the imposition of additional labour for the indemnification of their purchasers. ${ }^{60}$

As is too frequently the case when political injuries become irreparable, those measures which, earlier adopted, would have preserved a sacrificed people; now served, only to excite useless controversy and public disturbance; the Monks, who, since the ecclesiastical establishment of Ferdinand, had arisen to considerable power, began to oppose their eloquence publicly to the system on which the natives were reduced to absolute slavery, or rather, 
consigned to perish in progressive misery. They could not be insensible to the impolicy of the measure; and, no doubt, impressed with the inutility of a mission to a people who were rapidly ceasing to exist, they had early remonstrated, but appear to have been easily silenced, till the present period. Even now, but a part of the mission, the Dominicans, ${ }^{61}$ stood forth to represent the mild precepts of religion; the Franciscans ${ }^{62}$ attached themselves to the more popular cause; and while they could not unblushingly defend the Repartimientos, palliated the principle on the ground of expedience, so often improperly assumed in society.

The consequence was, an application to the king by both parties, of which the only circumstance of importance, was the interference of Las Casas, a man of romantic disposition, and benevolent mind; whose exertions, though unsuccessful, were neither wanting in genius or perseverance; whose character cannot be omitted even in the compression of abridgment. It may be previously observed, that the appeal was terminated on the side of the Franciscans, a few regulations of their labour only being for decency promulgated; Albuquerque pursuing his violence and rapacity with impunity.

Bartholomew de las Casas, (a Clergyman,) who came hither on the second voyage of Columbus, and who had early exerted himself in the cause of the Indians, was not to be diverted from his purpose; finding the rapacious governor deaf to all expostulation that militated against his immediate interest, he embarked for Spain, to make a personal appeal to the Emperor, and to exert that eloquence, of which he was so eminently possessed, in their behalf. Aided by fortuitous circumstances, he was particularly successful with the Emperor, then on the point of death, and with Cardinal Ximenes, ${ }^{63}$ who became Regent. The effect of this success was the appointment of three Superintendants of the colonies, to whom were added a lawyer of probity named Zuazo, ${ }^{64}$ with judicial power, and Las Casas, with the title of Protector of the Indians. These soon arrived in St. Domingo, and began their career by the auspicious act of liberating all the natives who had been granted to the Spanish courtiers, or to any person not residing in America. To avoid the influence of party spirit, neither of those orders, who had contended the subject were suffered to have a member among these Superintendants; they were composed of three Monks of the order of St. Jerome, ${ }^{65}$ who appear to have exercised not only ability, but a knowledge of the world, which is seldom to be obtained in a cloister. The result of this mission was, as might be expected, only negatively advantageous to the Indians, without whose labour, reduced as it was, the colony could not be hoped to exist; the best regulations that could be formed were adopted for the prevention of excessive rigour and of cruelty towards them, while, without coercion, they ceased to work, and were obstinate in proportion to their power. 
Las Casas still dissatisfied with any thing less than, the entire freedom of the Aborigines, and finding no countenance in the island, with undiminished perseverance, again returned to Spain and found Ximenes, as he had before found Ferdinand, on the point of death. With the Emperor, (Charles V) ${ }^{66}$ who immediately arrived from the Low Countries, and with his Flemish minister, he prevailed so far, as to induce the recall of the superintendant and his colleague Zuazo; and Roderigo de Figuerra was appointed Chief Justice of the Island, with directions to moderate the sufferings of the Indians, and to prevent their threatened extinction. Finding that this, was all that could be accomplished, in the hurry of imagination which always marks such characters, (not more eminently successful on some occasions, than dangerous on others, ) Las Casas now proposed, in support of his favourite scheme, to substitute, in the place of those he wished to liberate from slavery in their own country, the inhabitants of a distant one, whom he appeared to consider more capable of labour, and more patient under sorrow. ${ }^{67}$

The earliest advantage of the Portuguese in Africa had arisen from a trade in slaves, ${ }^{*}$ but it had been abolished, and was considered ineffectual. About fourteen years before, the importation of a few slaves had been permitted by Ferdinand, but not as a public concern, and in 1511 the number was increased, without producing any effect on the population. ${ }^{68}$ This plan, which had been peremptorily refused by Ximenes, was adopted by Charles, who granted a patent to one of his Flemish favorites for an importation of the limited number of four thousand; this privilege being sold to some Genoese merchants, proved the first formation of a regular trade for supplying the island, which has continued to increase through the whole Archipelago.

Even the farther introduction of other Slaves produced so small a change in the Colony, that the invention of Las Casas was directed to other substitutes; and with a more plausible view, it occurred to him, that if Labourers could be induced to emigrate from the Mother Country, their habits of life would enable them to bear the effects of the climate under agricultural operations; and that they might, by soon becoming opulent citizens, introduce habits of industry, and a promotion of virtue: - but, though countenanced by the ministry, his laudable plan was defeated by an ecclesiastic, who had long opposed him, the Bishop of Burgos. ${ }^{69}$ Thus deprived, of all his hopes with regard to his favourite Island, this extraordinary man turned his attention to the Continent, and his schemes to the prevention of similar abuses in that part of the new world, which was yet but little explored. After many unsuccessful applications in behalf of this colony of labourers, he at length obtained permission

\footnotetext{
*For the origin of this traffic the reader is referred to a future chapter, to which it is more closely connected.
} 
to form one in Cumana; but with such opposition, that the number of colonists whom he could persuade to accompany him did not exceed two hundred. It is not within our plan to follow this unfortunate party through their various distresses, occasioned by the bewildered cruelty of their countrymen:- prevented from arriving at their destined country by the detestation which was every where excited against the Spanish name, and unpopular with Spaniards as the followers of Las Casas, they became the innocent victims of both parties; while their leader, driven from every asylum, shut out from all resource, abandoned, and houseless, took refuge in the Dominican convent in the city of St. Domingo; where he soon after assumed the habit of the order, and, as it may be readily supposed, did not long survive the death of all his happiness.

The occasion of that violence which had every way met the party of Las Casas, originated more particularly in the predacious excursions of the Spaniards, who would seem in these piracies to have left no means of cruelty or depredation unattempted. When, by the extinction of the Natives, every exertion of industry began to stagnate in St. Domingo, and even Slaves, were sold at a price beyond the reach of many, they fitted out a sort of Privateers, ${ }^{70}$ which, cruizing along the coast of the continent, under the pretence of trading with the unsuspecting natives; whenever they found an opportunity, seized upon and sold them as slaves on their return: this conduct, however, combined all the Indians to revenge it, and in consequence, among others, two Dominican Missionaries were killed. This was the signal for more extensive hostilities, and Diego Ocampo, with five ships, and three hundred men, were dispatched to lay waste the country of Cumana, and to transport all the inhabitants that could be procured as slaves to St. Domingo.

About this time, to add to the embarrassments of the colony, it suffered considerably from those extraordinary swarms of ants which sometimes used to infest the Archipelago, and injure the vegetation. After ineffectual many endeavours to destroy them, the Spaniards (according to Herrera) determined on appealing to the saints; but some time elapsed before they could fix upon one for so singular a business; at last, however, being relieved from the disastrous effects of the insects, and happening to invoke St. Saturninus ${ }^{71}$ at the same time, that saint acquired the merit of a miracle.

The return of Diego Columbus to Spain appears to have been attended with some circumstances which are yet unknown, for he shewed no inclination to return to the new world, till we find him in 1523 called to Jamaica to suppress a revolt of the Indians, in the absence of Francis de Garay, ${ }^{72}$ its governor, who had embarked in an expedition against Panuco, ${ }^{73}$ which had, without his knowledge, already submitted to the government. Among the political ar- 
rangements of Ferdinand, was that which separated from the power of Diego the island of Jamaica, attaching it to that division of the continent, not subject to his dominion: he, however, acted with a spirit no less creditable to his character than on former occasions, and regained the island; which afterwards descended to his heirs, and, yielded the title of Marquis, among other honors, which descended to his family. Diego Columbus died in 1525 .

To return to the domestic situation of Hispaniola, that quick decline, which we have already described, continued to be accelerated, by the cruelty and impolicy of those, to whom no means were exceptionable in the search of wealth. In external appearances, however, this decline was not perceptible, and the capital of St. Domingo, as is the case with all falling states, still presented an august reverse to the internal poverty of its inhabitants. In 1528, the city is described by some Spanish historians, and particularly Oviedo, who was there at that time, as "not inferior to any in Spain, the houses mostly built of stone like those of Barcelona, but the streets much better, being large and plain, crossing each other at right angles. With the sea on the right, and the river Ozamo on the left, health and beauty were united more than in any other part of the world. Ships heavy laden discharged their cargoes in a manner under the house windows. The citadel, which stood exactly in the centre, also gave security to an extensive command. The houses were fit to receive any nobleman of Spain with his suite, and the grandeur of Don Diego's palace as viceroy was beyond conception, and every way fitting to receive the king his master. The cathedral was of exquisite workmanship, and well endowed; the dignity of its bishop and canons well supported. There were three monasteries, dedicated to St. Dominic, St. Francis, and St. Mary de Mercedes, and an hospital founded by Michael Passamont, the treasurer-general."74

How much were it to have been wished, that such public splendour had argued equal prosperity; that it did not, however, is certain, from every account; and Benzoni asserts, that towards the middle of the sixteenth century, scarce one hundred and fifty of the native Indians remained alive.*

The dealers in slaves, however, beginning to lessen their demands, as time and competition affected their trade, the colony might have once more recovered itself by an attention to agriculture; but that cruelty which appeared to be inherent in the breasts of these early colonists, (increased by disappointment and pecuniary difficulties, ) excited in their new servants a spirit of insurrection that soon broke into open revolt, and which, though unsuccessful, compelled their masters to a relaxation of their severity and inordinate avarice.

\footnotetext{
*Benzoni, Nov. Orb. Hist.
} 
The consequences produced by the smallest degree of moderation, became soon perceivable in the increased cultivation, and sugar, tobacco, cocoa, ginger, cotton, peltry, ${ }^{75}$ \&c. were shipped for Spain in such quantities, as induced the best hopes of their increase continuing; but these flattering hopes were not to be realized, the Spaniards remaining inactive, weak, unprotected, and useless.

In 1586, Sir Francis Drake ${ }^{76}$ came before the island, and pillaged the capital with a degree of barbarity, surprizing in the present refinement of European warfare. The invaders held possession of St. Domingo for a month, during the latter part of which they employed every means from day-break, till the heat became intense in the forenoon, to destroy the beautiful edifices that surrounded the town, but on which, from being composed of stone, fire made no great progress, and ordinary means became too laborious; after two hundred sailors, with as many soldiers to protect them, had been employed for several days only to destroy one third part of the town, and were completely wearied with the task, they condescended to accept of about 7,0oo l. sterling as a ransom for the rest.

Among the severities which were practised, the following will afford an example, which, notwithstanding its cruelty, some will think from the circumstances of the times, not badly imagined: a negro boy having been sent on a message to the Spanish governor with a flag of truce, was run through the body by some straggling Spanish officers, and only lived to complain to the English general; he immediately ordered two friars, who were his prisoners, to be taken to the same spot, and hanged, commissioning another at the same time to acquaint the Spaniards, that until the party, who had thus murdered the general's messenger, should be delivered into his hands, there should no day pass without the execution of two prisoners; on the following day the offender was produced, and his countrymen compelled to be his executioners. ${ }^{*}$

The decline of the mother country could not fail to weaken the situation of her colonists, who had suffered neglect, even from the importance of her acquisitions at home. Those who remained, rather from a want of power to quit the island, than any other cause, sunk into a kind of debility and sloth that resigned them to every evil. Gradually degenerating from the spirit and manners of their ancestors, they became little anxious about any thing beyond an indulgence, as degrading as fatal. Associating in common with their female slaves, they propagated a people of almost every grade of colour, and

\footnotetext{
*See the account of this expedition in Hackluit's Voyages. - Sir Anthony Shirley pursued a similar conduct in Jamaica in 1596. [Richard Hakluyt (c. 1552-1616), British writer and advocate of American colonization, author of Diverse Voyages Touching the Discoverie of America (1582).]
} 
became entirely a mixed colony, of which, Spaniards formed in fact a very small part. Their mines were deserted, agriculture was neglected, and their cattle ran wild in the plains. They employed themselves, as may be expected from such an irregular establishment, not only in an illicit foreign trade, but in piracies against the property of their own country, of which the practice of fitting out ships clandestinely, for the purpose of procuring slaves, (as has been already observed,) afforded them the best opportunities, and a secret understanding with the ships of war, guaranteed their safety and success. Instead of an attempt to remedy this evil, of which there were many means, ${ }^{*}$ the short-sighted policy of the Spanish court chose rather to complete the dejection of the islanders, by demolishing the sea-ports which had been illicitly employed, and compelling the inhabitants to retire to the interior of the country. History is silent, during a considerable period of the existence of this miserable people, whose actions could indeed admit but of little variety; who are described as "demi-savages, plunged in the extremes of sloth, living upon fruits and roots, in cottages without furniture, and most of them, without clothes." + “Their slaves had little more to do," says Raynal, "than to swing them in their hammocks;" nor can a more striking proof be given of the wretched situation of that country which had supplied empires with gold, than the necessity to which it was reduced, of adopting pieces of leather as a circulating medium among its inhabitants. $\ddagger$

While the government of Spain, however, was so remiss in regard to the colony, which might be considered as the centre of their possessions in the new world, they were as much the reverse, with respect to the admission of any other power into a participation of its produce, or its territory:their caution extended even to absurdity; and all ships were stopped who were met beyond the tropics. Notwithstanding this care, during a war with Spain, the English and French, had become acquainted with the Windward Islands, ${ }^{77}$ (whose warlike and sullen inhabitants, the Charibs, generally repelled the Spaniards, ) equipped a small fleet to interrupt the Spanish vessels in those seas, whose piracies were not interrupted by peace; in consequence of the jealous policy already described. A part of these under an enterprizing Englishman named Warner, ${ }^{78}$ and the captain of a French privateer called Desnambuc, ${ }^{79}$ took possession of the island of St. Christopher ${ }^{80}$ on the same

\footnotetext{
*Among others, even the Flemish were refused the permission they requested to clear the lands of this fertile country, and revive its splendour by the more solid pursuits of agriculture.

†The Abbé Raynal, - History of the Trade and Settlements in the East and West Indies, vol. iv. p.18.

$\ddagger$ Edwards’s History of the British West Indies, b. ii.
} 
day, ${ }^{*}$ and divided it into two equal shares; the fierce inhabitants, who had been more favorable to the enemies of the Spaniards than to themselves, retiring from the parts on which they were fixed, telling them nevertheless, with usual Indian acuteness, that "land must be very bad, or very scarce with them, since they had traversed such a distance with so much difficulty, to seek for it among savages."

The court of Madrid immediately alarmed, at the vicinity of these members of two active and industrious nations, ordered Frederic of Toledo, ${ }^{81}$ on his way against the Dutch in Brazil, to attack these newly established powers while they were yet weak in their new establishment; they were soon defeated, and those who were not either killed or taken prisoners, fled for refuge to the neighbouring islands. The greater part, however, returned to their possessions as soon as the danger was over, except a small number who remained on the little barren isle of Tortuga ${ }^{82}$ lying off the north-west coast of Hispaniola, and within a few leagues of Port Paix. ${ }^{83}$ These, inconsiderable as they were in their outset, were the founders of a race which giving rise to the French colony that is soon to become an important part of this history, and being hitherto but imperfectly described, demands particular attention.

Previously, however, it is but justice to the Spanish colony to say, that after the first surprize at seeing a large English fleet commanded by Admiral Penn, ${ }^{84}$ with nine thousand land forces under Colonel Venables, ${ }^{85}$ (the same which afterwards conquered Jamaica,) who had been dispatched by Oliver Cromwell ${ }^{86}$ to obtain for England a portion of the new world, they compelled the enemy to re-embark with disgrace. A want of unanimity was the apology made on the part of the English, who ill brooking such a reception, determined on no alternative between victory and death on their next and more successful attempt.

By the middle of the seventeenth century these incursers had received some accessions from the French colonies, which had by that time been established, and assumed an appearance as formidable as it was singular. They had gradually obtained notice under the appellation of Buccaniers from their mode of curing animal food, which was derived from the savages, being slowly dried, or rather smoked, over fires of green wood, in places from thence called by the Spanish term, Buccans, ${ }^{87}$ a custom yet retained by the Spaniards. ${ }^{88}$ As they were for a time destitute of wives and children, they associated pairs, (as recorded by former historians); property was common, and survivor inherited the residence; theft was unknown amongst them, though

*Some writers state that Mr. Warner had obtained possession two years before, and had suffered the loss of his plantations by an hurricane. [This hurricane occurred in September 1624.] 
no precaution was used against it, a virtue they borrowed from the savages. They seldom disputed, but if any were obstinate, they decided with arms; and if any foul appearance occurred in the combat, as a back or side wound, the assassin was put to death. Every member of the fraternity assumed a warlike name on admission into the body, which descended to their several successors. Their dress consisted of a shirt died with the blood of the animals they killed in hunting; an apron, or trowsers, yet dirtier; a leathern girdle, containing a short sabre, and other knives; a sort of military cap, and shoes, without stockings. A Buccanier was satisfied if he could supply himself with a small gun, and a pack of dogs, to the number of twenty or thirty. Their employment consisted chiefly in hunting the bulls, with which the Spaniards had furnished the neighbouring island; which they killed chiefly for the skins, regaling, perhaps, on a small part of the flesh, preparing it sometimes with a seasoning of pimento, and the juice of orange.

The remainder of the indolent colonists could not, however, bear with the idea of more active neighbours; which gave rise to several unavailing conflicts, that ended in a determination to destroy all the bulls by a general chase, a scheme which had the effect of turning the attention of the Buccaniers to the more permanent pursuits of agriculture. - Tobacco soon became a profitable culture, which, with the produce of several excursions made by the most intrepid in their cruisers, amply repaid their difficulties. However, another Spanish armament was commissioned for their extirpation, which inspirited them to deeds that will live to future ages - pregnant with bravery and horror.

Possessed of an island eight leagues long and two broad, in a fine air, and with capability of improvement, unshackled by the prescriptions of ancient society, with a vast territory open to their predatory incursions, and numerous channels accessible to their maritime courage, the success of the Buccaniers may be easily supposed to have spread. To this lawless, yet far from unsalutary dominion, those who sought a refuge from the tyranny of creditors, or of want, as well as enterprizing spirits without opportunity for action, in their mother-country, (particularly from Normandy,) had a resource, which formed a considerable acquisition to its power. Envious of the establishment, the court of Spain made an attempt to dislodge them, which is worthy of notice, only from its wonted cruelty; the general of the galloons exerted his commission while the greater part were at sea, or hunting on the large island; he put all he found to death, leaving Tortuga as desolate as possible.

The effects of these cruelties, and the sentiments of revenge they inspired, produced a closer combination of the Buccaniers; for which purpose they agreed to sacrifice personal independence, to social safety, and accordingly 
appointed a leader, much in the same way, as the origin of all monarchies; as they were yet composed of English and French united, an Englishman, distinguished for his prudence and valour, named willes, was the first appointed, who appears to have excited jealousy, by an invitation of his countrymen to the settlement, and the use too frequently made of power, when its origin becomes forgotten in its advantages. A governor-general had, therefore, no sooner been appointed over the French windward islands, ${ }^{*}$ than finding the opportunities probably agreeable, and being, perhaps, privately solicited, he sent a small force from St. Vincent, who, joined by the Frenchmen on the island, suddenly ordered all the English to withdraw from it; when supposing an order of such audacity supported by a much greater force, they immediately agreed to evacuate the island, and never returned. They still pursued the bold career in which they had embarked, and afterwards obtained regular commissions from the English government to act against the common enemy, though the settlements and navigations of the Spaniards continued the prominent objects of their hostility. One of them afterwards arrived at situations of honour and emolument, having received the dignity of knighthood, and being advanced to the high office of lieutenant-governor of Jamaica! His character, however, will be given more regularly among those of the other Buccaniers, to whom, as original founders of the French colony in St. Domingo, this history is more particularly directed.

Alternately losing and gaining the little island of Tortuga from the Spaniards, the French, under a captain of their own choice and nation, at length retained it, and obtained a firm footing on St. Domingo, which rendered it, at the same time, of less importance. Of the consequence to which they arrived (a consequence which, to this day, furnishes the West Indies with legendary tales of their valour and honour), an idea will be best obtained by a description of their mode of life and warfare, and of those characters to whom they were indebted, for many of the exploits which have rendered them conspicuous to the admiration, if not the approbation, of the present and of future ages.

\footnotetext{
*This Governor, who was named De Poincy, appears to have held his appointment on the same tenor as Willes, receiving it when the increased followers of Warner and Desnambuc had, in 166o, joined in a treaty independent of their respective governments, which had regarded them with indifference. By this treaty it is pleasing to see the native Charibs considered, Dominica and St. Vincent's being appropriated to their reception. According to their respective rights of conquest, France obtained Guadaloupe, Martinico, Grenada, and some less considerable acquisitions; and England was confirmed in the possession of Barbadoes, Nevis, Antigua, Montserrat, and several other islands of little value. St. Christopher's still belonged to both nations. - See Raynal's History, Vol. III. p. 284. \&c. [Phillippe de Longvilliers de Poincy (1583-1660) enlisted the buccaneers to remove the English from Tortuga in 1640.]
} 
They formed themselves into small companies, from fifty to three times that number, of whom, some appear to have preferred agricultural pursuits. As the authority they had conferred on their captain did not extend to their domestic economy, they were at perfect liberty as to their manners, or a preference of rest or pleasure in their intervals of peace. Their armaments were formed of boats, without any difference, but in size, in which, they were exposed to all the inclemencies of the weather; as through their careless dispositions, on shore they were subject to the severest extremities of hunger and thirst. After the various cruelties exercised by the Spaniards in the attempt to extirpate them, the sight of a ship is said to have transported them to frenzy; - no superiority of power affected them, they boarded as soon as possible, and the skill they had in the management of their small vessels, screened them from the fire of their enemies, while their fusleers, ${ }^{89}$ who presented themselves at the fore-part of their vessels by an excellent aim at the port-holes opposed to them, confounded the most experienced gunners. They seemed to have a religious notion of humility and gratitude, for they implored the aid of heaven to their success in any onset, and returned thanks to the deity for every victory obtained; such was their uninterrupted bravery, that the Spaniards, at length, trembled at their very approach, and surrendered immediately to those whom they designated as devils, as much as if they had been in reality preternatural beings. Among those whose names have come down to us, as having particularly distinguished themselves, were Montbar, ${ }^{90}$ a Frenchman; a Welshman (already mentioned) named Morgan; and a Dutchman, called Van Horn. ${ }^{91}$ In the conduct of these men, may be seen the general character of the Buccaniers, the proportion of this sketch not admitting of a more enlarged insertion, which might otherwise be easily selected.

Montbar was born a gentleman of Languedoc, ${ }^{92}$ and his connection with the freebooters appears to have arisen neither from necessity nor chance, but an early spirit of romance - such as has determined the most heroic characters. Indeed, to those who have seen unqualified descriptions of the Spaniards in the New World, without an acquaintance with human life sufficient to discriminate, such a Quixotic idea will not excite surprize. It is said, that while at college having seen these accounts, their enormities had so strongly impressed him, that, acting in a private play the part of a Frenchman, who quarrelled with a Spaniard, it was with difficulty the performer of the latter character escaped from him with life. His imagination continuing to be heated by day-dreams, in which he beheld the expiring victims of a rage, more cruel than that of religious fanaticism, he viewed them, as calling on him for vengeance; although but imperfectly acquainted with the history of the Buccaniers, he determined to join them, and accordingly procured a 
ship for the expedition. On the passage they met with a Spanish vessel, which they immediately boarded, when Montbar was the first, sabre in hand, to fall upon the enemy; he broke through them, and hurrying twice from one end of the ship to the other, levelled every thing that opposed him. When the enemy surrendered, leaving to his companions the care of the booty, he desired only to contemplate, with horrid pleasure, the dead bodies of the Spaniards, which lay in heaps upon the decks, and seemed strengthened in the cause, in which he had so romantically embarked. Arriving on the coast of St. Domingo, the Buccaniers, who applied to barter provisions for brandy, pleaded, as an apology for their quality, that the Spaniards had recently taken advantage of their absence to destroy them: "And do you not seek revenge?" exclaimed Montbar. He soon found they were no more tardy in destruction than himself, and offered his services as a leader: was accepted, and astonished the boldest by his bravery. He continued with them during his life; and their sufferings (from his courage and success) procured for him, among the Spaniards, the appellation of The Exterminator.

Van Horn was a native of Ostend, ${ }^{93}$ whose intrepidity in the discipline of his crew, is the only peculiar trait handed down to us. He commanded a frigate, which was his own property. In the heat of an engagement, he was constantly seen in every part of the ship; and where he observed any one shrink at the sudden report of the cannon, he instantly killed him. He became the idol of the brave, and liberally shared with his successful companions, the riches so dreadfully acquired.

It is pleasing to turn from characters terminating with the same violence with which they set out, to one who, after having blazed in the full strength of a meridian-sun of power, is seen retiring to the mild evening of domestic life.

MORGAN, ${ }^{*}$ the Welshman, only remains to be mentioned, descended from respectable parents in Glamorganshire, ${ }^{94}$ whom he early quitted (as it was then termed) in search of his fortune. His adventurous spirit leading him accidentally to Bristol, ${ }^{95}$ he found an opportunity of embarking for the West Indies, in the way of many others, by indenting himself for four years to serve

*I wish to be acquitted of any local preference in the description of these men, or partiality of delineations in their characters. But notwithstanding the representation given of Morgan (in extension of the calumnious old history of the Buccaniers) by the Abbé Raynal, he is constrained to confess, that in the midst of hostility he fell in love with a beautiful Spaniard; and that he did not sacrifice her to his wishes, though she attempted his life. A breast capable of admitting a passion of this nature, under such circumstances, could not surely be considered as the most barbarous; and of the respectability of his subsequent character, we have certainly the best account. 
a planter. When released from a service executed with fidelity, he joined the Buccaniers, and adding ability to courage, soon shared their success and their riches. One of the exploits which first rendered him famous was the capture of Porto Bello ${ }^{96}$ (which Admiral Vernon ${ }^{97}$ afterwards destroyed with difficulty); for which, the plan of operations was so well contrived, that he took it without opposition. In attacking the fort, to spare the effusion of blood, he compelled the women and the priests, whom he had made prisoners, to set the scaling-ladders to the walls, from an idea, that the Spaniards would not fire at the objects of their love and reverence. Their omnipotent power, however, was wealth, in preference to religion or beauty; and the humane expedient miscarried, to the great injury of the besieged. The conquest of Panama $^{98}$ seems to have been attended with prodigious difficulty, both by sea and land; but even here, he did not forget a merciful expedient - buying the fortified island of St. Catharine, ${ }^{99}$ which was necessary to his progress. At Panama they found immense treasures: among the dreadful sacrifices that were made, some circumstances less severe are recorded: vanity received a singular punishment; and it was here that Morgan became captivated by a captive. The first of these circumstances occurred in a beggar, who, entering a castle deserted by its owners, found some rich apparel, which, in preference to every thing else, he adopted; the besiegers entered, and pressed the grotesque noble for his wealth, when, pointing to the rags he had just quitted, he received the effects of his folly and pride in a death scarcely unmerited.

Morgan, appears to have addressed the lady by whom he was smitten, with respect and forbearance, sentiments not always to be found, in more refined invaders, and they met with a contrary return. "My fortune and my liberty, which depended on others," said the indignant fair, "you have already, but my honour is my own care;" upon which, she drew a poignard from beneath her dress, and attempted to plunge it into his breast; fortunately he avoided the blow. - Agonized with passion, yet incapable of violation, with more philosophy than is often called forth under such circumstances, it is probable that he wisely and nobly tore himself from the scene of his attraction, as he suddenly quitted the spot; even before his companions could accompany him. On the peace, which a few years after took place, between England and Spain, he retired to Jamaica, and having purchased a plantation, betook himself with much industry to its cultivation. He succeeded in these tranquil pursuits, and, in time, grew into equal repute in a pacific life to that which he had experienced in war; he was called to bear a part in the government of the island in which he had become a proprietor; and, finally, to the command of Lieutenant-Governor of Jamaica, and to the dignity of knighthood. ${ }^{100}$ He executed the duties of every situation in which he was placed with probity and 
honour; and a writer of the present day, ${ }^{*}$ who saw some of his letters in the possession of a friend on the island, describes them as manifesting a spirit of humanity, justice, liberality, and piety.

It is painful to relate, that Sir Henry Morgan, three years before the close of his chequered and useful life, was committed to the Tower ${ }^{101}$ by King James II. at the instance of the Spanish Emperor, where he remained till his death without trial, and of course without conviction of any crime. ${ }^{102}$ Though a sacrifice to the same monarch, with his great predecessor Raleigh, his life was not, however, included, and he died in peace.

To return to the community of Buccaniers, although separated from each other, the English and French still continued to act in concert; the latter retiring, after the conflict, to St. Domingo, to share the spoil, and the former to Jamaica. When any were maimed, the first steps, were those taken for their provision in the most honourable way; no one secreted any share of the booty under pain of expulsion; nor had favour any influence in its division, which was with much judgment. Dissipation of every kind succeeded their advantages, and he who was rich one day, resigned himself to poverty the next. They continued to increase in force, and to proportionally depress the Spaniards, who, at length, retired into a sullen inactivity, which passively continued, till all other communication with their mother-country ceased, than that which could be maintained by a single ship of no great burthen.

Nor did the Buccaniers themselves continue to prevail as they had been accustomed. After the settlements of the French and English in the New World became established, many were killed and lost, and some adopted agriculture; till, at length, France, who had not been altogether ignorant of its progress, became attracted by the infant colony then formed in St. Domingo, if it could yet be so called.

The number of planters to whom only could be really accorded the character of colonists did not exceed four hundred; the first care of the government then was to multiply this number, and to form them into a more regular society; for this purpose it commissioned a gentleman named Bertrand D'Ogeron, ${ }^{103}$ who had emigrated from Anjou ${ }^{104}$ about nine years before, but who had evinced too much virtue and sensibility to hope for commercial success, without a better fortune. With the best contrived plans he had failed; but the ability and fortitude, he had shewn in adversity, had won him the general esteem and attachment so much, that he was considered as the most proper person to direct, or rather to settle the colony.

\footnotetext{
*Bryan Edwards, Esq. M.P. F.R.S. \&c. [History, Civil and Commercial, of the British Colonies in the West Indies (1793).]
} 
Of the difficulty of such an enterprize, none could doubt but himself, depending much on his own powers, who knew no other wish, than the good of human kind; he began by reconciling the idle to labour, and those who had traded with all the world, to the monopoly of a privileged company, which had the year before, been established for all the French settlements. ${ }^{105}$ He held out allurements for new inhabitants in a country which had suffered every species of calumny: when the maritime determined to go in search of greater advantages, he seduced them to stay, even by relinquishing the revenues of his post, and procuring them commissions from Portugal to attack the Spaniards, when they had made peace with France; to the huntsmen he advanced money without interest to erect habitations: and to the planters he united every encouragement. Nor did he long suffer them to remain in a cheerless celibacy, which denied an increase of population by the best and most natural of all means, and left them without the most powerful attraction to a fixed residence - that of mild, unassuming beings, who create comforts unknown by any other means; conferring interest and felicity, while they are as ministering angels to alleviate the sorrows, and soften the asperities of man. D'Ogeron sent for women, and obtained an hundred from France-such as should be the female inhabitants of an infant colony, young, healthy, amiable, and enterprising. To prevent the effect of the most impetuous of passions, he contrived, that while choice was not entirely suppressed, those should first become husbands whose industry had rendered them equal to the payment of an adequate sum; and the others (who respected social justice) waited anxiously to be so blessed in their turn: but they were disappointed, and the colony injured, as is too often the case, by expedients of which their insufficiency is the most favorable objection. The females, who afterwards made their appearance from the mother country, as if all regard for the constitutions of society, had been lost, were those for whom delicacy would wish to find a better name than the refuse of cities; selected without discrimination, they were bound as to masters for three years; of such a connexion, we need not attempt the description. The only circumstance worthy of record respecting it, is the declaration of the Buccaniers, who chiefly adopted them, on their simple marriage. "I ask you no questions," said he, "respecting your former life, but you are now mine; and if you prove false, this," putting his hand to the muzzle of his gun, "will revenge me." The effects of the profligacy introduced at this time were long, very long felt. In the course of four years, however, D'Ogeron found means to increase the number of planters in proportion to the population, so that, in $1699,{ }^{106}$ they amounted to more than 1,500 .

In the following year the benign exertions of this good man, received a check from the elation of the India Company, which is the too frequent con- 
sequence of successful monopolies. Conceiving themselves secure in a new and extensive trade, and not satisfied with a moderate profit, they ventured to raise the prices of their goods in a proportion of two thirds; the colonists, who had not yet changed their natural inclinations to violence, had immediate recourse to arms, and the price of tranquillity was a free trade to France, except an allowance of five per cent, to the company, to be paid by all ships on their arrival and departure. Even this disaster afforded D'Ogeron an opportunity for exertions of beneficence, of which only himself was capable. He procured two ships seemingly intended for his own produce, but, in fact, for the use of the colony. Every one shipped his commodities on board these vessels at a moderate freight, and, on their return, the cargo brought from the mother country was exposed to public sale at prime cost. A general credit was given without interest, and even without security, this generous governor hoping to inspire them with probity and noble sentiments by such a confidence: thus, under a jurisdiction so exquisite, every public disaster served but to consolidate the colony; and could not fail also to excite a regret the most poignant, on an occasion which happened much too early; for the patriotic and benevolent D'Ogeron was cut off in the midst of his parental offices in $1673,{ }^{107}$ an example of every humane and social virtue.

It was three years before the much lamented death of D'Ogeron, that the town of Cape François had been founded. It is to be regretted as a consequence of religious intolerance to drive from their country its most useful members. Gobin, a calvinist, ${ }^{108}$ flew from persecution to the mild state of St. Domingo, and built the first habitation on the cape, to which he invited others, who immediately flocked thither as the ground became cleared.

The place held by D'Ogeron was supplied with tolerable success by his nephew, M. Ponancey, ${ }^{109}$ who, although described as of a less amiable disposition than his uncle, seems to have followed him in his laudable plan of government. He had the honor of completing what his great predecessor had so ably begun, the establishment of a colony upon a regular and firm basis, without the promulgation of laws, or the coercion of military force. More virtue than could be expected, from a variety of governors, was, however, required to sustain such a government; as licentiousness, naturally increased with population, aided by the unfortunate introduction of females, of the character already mentioned, it became of course necessary to submit to ordinary forms. Two administrators were therefore commissioned from Martinico, ${ }^{110}$ who established courts of judicature for the several districts, accountable to a superior council at Petit Goäve. ${ }^{111}$ These innovations were gained by a little finesse without much disagreement, and, but for the interference of private interest, which will ever obtrude upon infant establishments, the colony might have immediately opened a mine of wealth upon its shores. 
It may not be improper to remark here, as a glaring instance of the want of power, or capacity in the Spanish colony, that in $1685^{112}$ it suffered the Duke of Albemarle, ${ }^{113}$ then governor of Jamaica, and Sir William Phipps, ${ }^{114}$ to obtain considerable wealth, by raising the wreck of a Spanish plate ship which had been stranded off the north-east coast of their own territory twenty-four years before, on a shoal between the north and south riff, almost in sight of Old Cape François.

Skins and tobacco, were hitherto, the principal articles of commerce from the French colony; for the latter, in consequence of the restrictions, they substituted indigo and cocoa; for similar reasons the profitable culture of cotton, which had been added, was soon abandoned. Hitherto the labours of the colony had been prosecuted chiefly by the poorest of the inhabitants, and a few negroes, which had been obtained by successful expeditions against the Spaniards; but in the war of 1688, several slaves being taken from the English, they began to contemplate the culture of the sugar-cane, as an additional source of wealth, and one of the greatest importance. With this view they continued to increase their stock of negroes, by every means in their power, though but slowly, till the year 1694, when, taking advantage of a combination of misfortunes which had reduced Jamaica, the governor (a spirited man, who had before desired permission to chase the Spaniards from his own colony,) landed in that island with a force, which shewed the anterior progress of St. Domingo to power, and increased it more than any other event, that had hitherto occurred. Whatever were the other motives that induced this expedition, Du Casse ${ }^{115}$ seems to have had an eye to the principal necessities of his colony, by including in his booty a considerable number of negroes, perhaps not less than two thousand. ${ }^{116}$ The other captured property, added to the private wealth of some of the remaining Buccaniers, (if those embarked in privateering, could be still so called,) enabled them to employ these slaves, and furnish buildings and articles for the production of sugar. The year following, however, the English returned the compliment of M. Du Casse, by attacking the now flourishing settlement of Cape François, in conjunction with the forces of Spain, which they took, plundered, and reduced to ashes. It was soon, however, rebuilt on the same site; and from this period no difficulty or misfortune to the colony, was sufficient to impede its gradual progress to that eminence, which obtained for it, in another century the appellation of the Garden of the West Indies.

The peace of Ryswick ${ }^{117}$ afforded the first regular cession of the western part of the island to the French; for the preceding treaties of Aix la Chapelle ${ }^{118}$ and Nimeguen ${ }^{119}$ in 1668 and 1678 did not, by any means, conciliate the national antipathies in St. Domingo; and even by it there were no other boundaries established to the possessions thus ceded, than a custom, constantly sub- 
mitted to change from a variety of circumstances. By this cession the French appear to have obtained all the territory excluded, without an oblique line reaching from the then Cape François on the north-east coast, to Cape Rosa on the west, intercepting the towns of Isabella and Jago at the one point, and those of Petit Goäve and Port Louis at the other.* Still, therefore, the scene of constant feuds between the more ancient colonists and their neighbour, a large part of the colony towards the south, continued unoccupied, except by a few straggling inhabitants in miserable huts, and it remained a desirable object with the government to procure its settlement, in some way, at once both permanent and effectual. To accomplish this end, another company was privileged in France, which adopted the title of St. Louis, ${ }^{120}$ to whom this fine and extensive country was granted as a property for thirty years; on conditionthat it should open a contraband trade with the Spanish continent, and clear the ground. The company immediately granted lands to all who chose, with certain allowances, providing them also with slaves and other necessaries, and every thing began to wear a promising aspect. The colony continued to increase with so much vigour, that, at the beginning of the next century a superior jurisdiction became necessary in Cape François, and it was accordingly established in 1702. The town of the Cape was, in every other respect, the capital of the colony, though, except in time of war, when it was removed hither, Port-au-Prince was the seat of the government.

In proportion as the French colony rose in splendor, the Spanish inhabitants decreased in comfort, apparently shrinking from the effects of an industry they could not reach; yet, the former was not without difficulties to counterbalance its advantages: for in the year 1715, the death of nearly all the cocoa trees on the colony, deprived it of a very lucrative revenue; and shortly after, it experienced, in common with more important states, a shock that threatened its total subversion. This flourishing colony had arrived at a pitch of prosperity and refinement, sufficient to enable many of its proprietors to return with ample fortunes to France, or retire under easy circumstances when age required it; but when LAw's fatal scheme of finance exploded, those whose property had been paid for in the notes, or securities of the Mississippi company, ${ }^{121}$ or others, allied to them, were left destitute, without any hopes of retribution; many returned poor to the island, from which they had departed rich, and were compelled to serve those, who had formerly been their servants, for bread. The presence of these unfortunate victims, seemed to prolong a sensation with respect to that delusive stroke of policy, which

\footnotetext{
*From the demarcation on the map of Herman Moll executed in less than twenty years after.
} 
nothing else could have occasioned; it, however, recovered the shock; and, in its worst moments, surrounded by the pleasing effects of successful industry, might look with pity upon the opposite situation of its neighbours; if such sentiments could be expected to prevail under a disparity of circumstances.

In 1717, the Spanish colony, (which had in the time of Herrera, according to his history, included 14,00o pure Castilians ${ }^{122}$ among its inhabitants, with a proportional population in every class,) had only 18,410 souls of every description; and, but for the ecclesiastical and juridical importance of its dilapidating capital, perhaps scarcely even a vestige would have remained. Without affecting, in allusion to these times, either the bigotry, which must be occasionally allowed in Edwards, or the inveteracy of Raynal, in favor of peculiar opinions, we may clearly view, in this decline, the fatal consequences of intolerance and cruelty, while we can happily contemplate with redoubled pleasure the agreeable contrast, which a mild regimen affords through every class of created beings.

In 1720 , the produce of the French colony amounted, according to Raynal, ${ }^{*}$ to $1,200,000$ pounds weight of indigo, 1,400,000 pounds of white sugar, and 21,000,000 pounds of raw sugar, and its increase was as rapid, as it was successful: never satisfied, however, with ordinary advantages, it is the very nature of monopoly to grasp at every opportunity of increasing its exclusive rights, without any regard to those which are the objects of its privileges. In consequence of a degree of insolence, with which, the introduction of a measure intended to confine the trade of slaves to themselves was conducted, a violent commotion took place in 1722, which was not quelled entirely for two years, during which period the buildings and ships of the company were destroyed, and their commissioners disgraced. It will naturally be supposed that a commotion which extended with the most inconceivable firmness through every part of the island, affected the progress of cultivation and commerce for some time after the re-establishment of peace; yet, in 1734, we find a considerable increase of plantations, in which the growth of cotton, and coffee, had been added to a great extent. This increase of opulence, occasioned, naturally, an augmentation of the respectability of the government, for in 1750 we find a new establishment at Port-au-Prince, the capital, which now became the residence of a commander in chief, a superior council, and an intendant. $^{123}$

In the year 1754, the amount of the various commodities of the colony was equal to $1,261,469$ l., but such was its increasing prosperity, that the inhabitants received from the mother country, imports to the amount of $1,777,509 l$.

\footnotetext{
*Settlements and Trades in the East and West Indies, vol. iv. p. 235.
} 
The population of pure whites amounted to upwards of 14,000; free mulattoes nearly 4,000; and upwards of 172,000 negroes of different descriptions. There were 599 sugar plantations, and 3,379 of indigo. The cocoa trees amounted to 98,946 ; the cotton plants to $6,300,367$; and there were near $22,000,000$ of cassia trees. The provisions consisted of near $6,000,000$ of banana trees; upwards of 1,000,000 plots of potatoes; 226,000 plots of yams; and near 3,000,000 trenches of manioc. The cattle did not exceed 63,000 horses and mules, and 93,000 head of horned cattle.*

In short, the remaining events of St. Domingo, up to the period of the French revolution, consists of a series of successes the most brilliant, and a display of industry and opulence the most creditable to the French character. Even the government of Madrid seems to have been excited, to some degree of emulation about the year 1757 , as a company was formed at Barcelona, ${ }^{124}$ with exclusive privileges, to attempt a re-establishment in the eastern part of the island. The most, however, that appears to have been accomplished, was the equipment of two small vessels annually, by which they received in return, a few thousand hides, and some other trifling articles; but in 1765 , when Charles III. ${ }^{125}$ opened a free trade to all the Windward Islands, they suddenly assumed quite an altered appearance; and Hispaniola, so long depressed by the false policy of the mother country, seem determined to attempt a renewal of her former activity. During the five years preceding 1774, the custom-house duties were more than doubled. It extended, however, comparatively to little more than a dying struggle. The French still continued to increase rapidly; in 1764, they had a force of 8,786 white men, capable of bearing arms, with whom 1,414 mulattoes were enrolled, and their slaves had increased to $206,000 .{ }^{126}$ In 1767 , they laded 347 ships for France, besides a considerable overplus, not less than one fifth of that number, distributed in various ways.

As if it were to temper the success of this splendid colony, a dreadful earthquake happened on the third day of June, 1770, which levelled the capital, Port-au-Prince, with the ground. It has been, however, rebuilt with additional convenience, and enlarged with much labour, several streets having been raised upon the shore by means of causeways, though it does not possess, by any means, the elegance of Cape François; many of the buildings being composed of wood.

In 1776 , a determinate cessation took place of the dreadful feuds which had constantly occurred between the Spanish and French inhabitants of the colony, by the formation of a new line of demarcation, ${ }^{127}$ to separate the dif-

\footnotetext{
*Raynal, vol. iv. p. 236.
} 
ferent partitions of the island. This settlement, though from a strange avarice in the Spaniards of territory, which they knew not how to occupy, appears to encroach considerably on the former possessions of France, was a most desirable concession to the latter. Nor were the consequences of this agreement less favorable to the Spaniards in other respects: for they afterwards opened a more liberal commerce with their neighbouring colonists; whom they supplied with every description of cattle, receiving in return through their means all the productions of Europe, and expending with them the monies received from Spain for the purposes of the government.

After the conflict between Great Britain and her American colonies ${ }^{128}$ the Spanish government began to pay more regard to its territories in that quarter, and it accordingly became furnished with a more respectable garrison. Since that time, the number of Europeans added to it, tended also to improve its respectability as a colony.

From this period, to the commencement of revolutionary activity in 1789 , when those principles ${ }^{129}$ which had long been concealed in a smouldering flame, were about to have vent through the world, the French establishment in St. Domingo reached a height superior, not only to all other colonial possessions, but to the conception of the philosopher and politician; its private luxury, and its public grandeur, astonished the traveller; its accumulation of wealth surprized the mother country; and it was beheld with rapture by the neighbouring inhabitants of the islands of the Antilles. Like a rich beauty, surrounded with every delight, the politicians of Europe, sighed for her possession; but they sighed in vain; she was reserved for the foundation of a republic as extraordinary as it is terrible, ${ }^{130}$ whether it ultimately tend only, to the ascertainment of abstract opinions, or unfold a new and august empire to the world, where it has heretofore been deemed impossible to exist.

It remains only to the present division of the work, to add a brief account of the general appearance of the island, as it existed at this date of its history; which, will then subdivide itself into the different heads, under which it is proposed to consider the causes, progress, and consequences of its revolution, and present establishment.

Notwithstanding, the reduced state of that part of the island which still continued in the possession of Spain, what has been collected of its topography, or, natural history, shall, in justice to the ancient proprietors, commence the brief detail which concludes the present chapter.

The Spanish division of St. Domingo is understood to have comprehended, at that period, the whole territory within the diversified line of demarcation, fixed upon a few years before, which confined the French to apparently an insignificant part of the island. Commencing with the river Du Massacre on 
the north, it stretched in an irregular curve towards the west, crossing all the great roads from Fort Dauphin and the Cape, passing the hills at about thirty miles distant from the coast, and intersecting the conflux of the streams of La Trouble and Plaisance; when, turning shortly round the hills at Atalaye, it assumes its southern direction, and crossing the stream of La Petite Rivière at its mouth, stretches through a delightful plain watered by the great river Artibonite: crossing this, and the river Du Fer, and winding round a single hill, it then proceeds through the little lake of Cul de Sac; returning to its eastward direction, it falls in with the river à Pitres at a point nearly opposite to that of its departure, having formed an ellipsis of not less than 170 miles, the nearest point approaching within a very short distance of the town of Gonaives, situated in the bay of that name, upon the western coast.

It will be perceived, what a large proportion of this delightful territory, remained in the possession of Spain; which, whatever the degraded character we have been obliged to attribute to its possessors, must have produced a very ample return for the cultivation they bestowed upon it. With an extent of coast of between five and six hundred miles, in which are not less than seven capacious bays, (with innumerable inlets,) into which twenty large rivers, besides many nameless streams, discharge themselves; while the interior, consisting of large fertile plains, well watered, and protected, rather than interrupted, by the different chains of mountains with which they are variegated; producing the most delightful and salubrious vallies: nothing was wanting but the moderate labour of the cultivator, and a liberal policy, to render it the most desirable country in the world. In wanting these, however, it sunk into a beautiful wilderness, and its sullen shores repelled the eye which had been attracted by distant fertility. On sites that would have received and encouraged the population of cities, were placed the solitary huts of fishermen; whose miserable toils, perhaps, a melancholy monk was embittering by a thousand painful restrictions of his poverty-stricken career on earth, and dreadful views of eternity; the result of morbid intellects, nursed by the wild scene around him.

The principal towns, after the ancient city of St. Domingo, were, Monte Christi, La Vega, St. Jago, formerly that of the Conception, Zeibo, St. Thomé, Azua, and Isabella, if the latter could deserve the appellation. The other places were merely villages of the most wretched appearance, which, instead of alluring society from the distant provinces, seemed rather to mark with desolation those natural meadows with which they abounded. The most important

\footnotetext{
*This line is believed to be accurately delineated in the corrected map of the island prefixed to the present work.
} 
of these were St. Laurent, a few miles north of the capital, in which were a few villas, very inviting, from the beauty of the plain in which it was situated; Higuey, whose advantageous situation on the river of that name, might have procured for it much more importance; Baya, Bayaguana, and Monte Plata, surrounded by the finest land in the known world, and in the vicinity of forests, whose riches and utility were unappreciated; Cotuy, near the union of the rivers Yuna and Cotuy, about eight leagues from the centre of the bay of Samana; St. Juan de Maguana, delightfully placed on the banks of the Neybe, and separated by a small mountainous district from the lake of Riquille; St. Jean de Goava and Banica, served often as points of the commerce between the two colonies, as well as Atalaye, which stretched towards the extremity of the angle reaching into the French division opposite the bay of Gonaives; St. Miguel, Dejabon, Venta de Cana, Sala, Jarbon, Espani, and Amina, distributed in the course of a few leagues from the northern coasts, though inhabited by a kind of wealthy graziers, form a powerful contrast to the wild beauty of the surrounding country.

St. Domingo, the capital, and seat of the ecclesiastical government of the colonies, and at one time of the whole of the Spanish dominion in the new world, still continued an archiepiscopal see, to which the bishops of the other islands were suffragans. ${ }^{131}$ It is situated, as hath been before described, near the mouth of the river Ozama, on the southern coast of the island, and on the border of a fertile and delightful level of near ninety miles in length, and thirty in breadth, significantly called Los Llanos. The cathedral, and other public buildings, yet retained no mean degree of importance; and, notwithstanding their dilapidating antiquity, wore an elegance of appearance that was not to have been expected. The remains of many other superb buildings of antiquity were yet to be seen, and those of a modern date of brick, stone, and wood, were not unworthy the capital of such a territory. It yet contained several religious establishments, and what is of more importance, the extent and safety of its harbour, containing an ample depth of water, and, protected by a bar, over which the largest vessels rode with safety, could not fail to render it of great commercial interest. The streets were principally broad, and towards the middle of the town retained their original rectangular neatness; they were also clean, and enlightened by three handsome squares. It yet contained an appearance of great strength towards the sea, and even on the side of the land it was guarded by a sufficient wall. Some remains yet exist of the ancient citadel, and also of the palace of the First Viceroy.

The town of Monte Christi still retained a busy appearance, and some degree of importance, from its continued traffic with the neighbouring continent of North America, and the vicinity of some of the most flourishing plan- 
tations of the French colony. During the wars between England and France, while Spain was disengaged from the troubles, the Spaniards traded much to this part, as did also the English smugglers.

La Vega, neither pleasing nor convenient, situated in the extensive plain of the Vega Real, which is, in length, nearly that of half the island, though seldom exceeding thirty miles in breadth, derived its chief consequence from the surrounding pasturage, and some excellent sugar-walks in its vicinity.

St. Jago retained a considerable air of antiquity, but no other recommendation; for all the former grandeur which it would appear to have possessed is now in ruins, and it affords but an additional monument of desolation; yet it contained a miserable monastery of Franciscans, to whom were attached some of the finest lands in the neighbourhood; but whose chief power seemed to be employed in the rule of the slaves in the adjacent plantations, in the care of whose religious duties they frequently forgot their temporal avocations.

Zeibo was a place of some business, from being the only town towards the eastern coast, as St. Thomas is, again, from being situated in the very centre of the island, among the mountains of Cibao. Agua was also of little other importance than from being placed in the middle of a very fine bay on the southern coast. The first and the last of these towns, besides their desolatory state, bordering on extensive swamps, were therefore unhealthy; while St. Thomé, receiving the invigorating winds, as they sweep from the mountains on one side, and the salubrious breeze from the plains on the other, was a situation desirable for the farmer, or the valetudinarian, and capable of much improvement. On the site of the first city erected in the new world, in honour of Isabella, remain a few houses and ruins, while here and there a solitary cross peeping from amidst the luxuriant grass, served just to tell us - "such things were." One little stream watered its vicinity, and a rugged road marked its few occasions to direct an inquisitive traveller to its haunts.

Of the ecclesiastical government of the island, little shall here suffice. Notwithstanding that conduct on the part of the clergy which had compelled certain regulations of their conduct, and the liberality of sentiment which began to gain ground in Spain, the American church still retained an inordinate power over every class of the community, and an undue interference with every object of the colony. Independent of the papal jurisdiction, ${ }^{*}$ and originally endowed with immense revenues from the wealth, and afterwards the devotion of the people, they still continued in extraordinary numbers,

*The Emperor Ferdinand having obtained from the Popes Alexander VI. and Julius II. such an exemption on the first discovery of the New World, to favour its extension. [Ferdinand VI (1713-59) was the king of Spain from 1746 until his death in 1759. His reign was characterized by numerous reforms aimed at modernizing Spain.] 
fattening on the very desolation of the country, to whose benefit their order had not, in the least, contributed.* Many of the benefices were, however, now filled by the secular clergy, according to the effort of Ferdinand VI. to remedy the vicious and abominable abuses of the regulars. It has been already stated to have been honoured with the seat of the archiepiscopal see; it had also all the minor dignities, while the Curas, or parish-priests, were to be found in all the sacerdotal dignity throughout the country. The inquisition ${ }^{132}$ was also established in this as well as all the other American islands.

The constitution of Hispaniola is not easily defined. The different towns were under the immediate direction of a sort of local municipality; but their power was very weak, and much infringed by the privileges of different bodies of the clergy. They confined themselves chiefly, therefore, to the minor commercial regulations of their own district, and even these were under the control of a governor of the colony. The more important ends of general justice were administered by six more respectable judges, severally appointed, for civil and criminal jurisdiction, who formed one of the eleven Courts of Audience distributed among the colonies, and which are a model of the Spanish Chancery. The decisions of these courts were subject to appeal to the Council of the Indies in Spain, except in civil cases, where the object of litigation did not amount, in value, to a sum near fifteen hundred pounds. The vice-roy of New Spain represents the head of the government. The council over-ruled every department, civil and ecclesiastical, military and commercial, and has always preserved its dignity; with it originates every ordinance relative to the government of the colonies, which must be passed by the majority of a third of its members. At the head of this council the king is always understood to preside. There is also a commercial assembly for the purposes of an immediate attention to all its objects which could not be affected by any other means. The local officers immediately below the whole of these, consist of the different commandants, and a variety of inferior officers of almost every description; many of whose situations were sinecures, as valuable as the proprietors of the island were depreciated.

Of the military force of the colony little can be said; for, except the garrison of St. Domingo, and a few posts established towards the line of demarcation, the regular soldiery distributed throughout the island were inconsiderable;

\footnotetext{
*"Though, by the ample provision which has been made for the American church, many of its members enjoy the ease and independence which are favourable to the cultivation of science, the body of secular clergy has hardly, during two centuries and a half, produced one author whose works contain such useful information, or possess such a degree of merit as to be ranked among those which attract the attention of enlightened nations." Robertson's Hist. Vol. IV. p. 50.
} 
nor could the militia, in which all capable of bearing arms were included, be said to produce an addition very effective. The principal ports along the line were those of Verettes, St. Michael, and St. Raphael.

The different inhabitants of the Spanish colony were designated as follows:-The pure Spaniards, who visited America for the purpose of employment, and who always enjoyed every situation of power, were called Chapetones. They looked down with disdain upon every other order of men.

The second class of subjects were the Creoles, or descendants of Europeans settled in America. Though frequently deriving their pedigree from the noblest families in Spain, and possessing ample fortunes, yet the abjectness of political debasement - the enervation of indulgence in a warm climate, had subdued their minds, and subjected them to the vilest sloth. While the Chapetone amassed immense wealth, the Creole remained satisfied with his unimpaired patrimony; a determined hatred reigning between them.

The third was the offspring of an European with an Indian, or a negro: the former, called Mulattoes, the latter Mestizos. ${ }^{133}$ Of these, there was a considerable number in this, as in all the other Spanish settlements. In proportion as the number exceeded the colonies of other nations, from the early policy of encouraging an intermixture of the Spaniards with the natives, and from a greater indulgence of licentious intercourse. Among these there were a variety of different shades of colour, from the jet black of Africa, and the copper, or brown hue of America, to that of the European complexion. Those of the first and second generations, were considered not sufficiently removed, for distinction, from their parent race; in the third, the colour sensibly declined; and, in the fifth they embraced the characteristics and privileges of Europeans. ${ }^{134}$ The mechanic arts and active offices of society were left, by the proud and indolent Spaniards, to this robust and hardy race; who were lively, well-tempered, and frequently accomplished.

The Negroes compose the fourth rank; of this singular, and important part of the human species, more will be found in another department of this work. In Hispaniola, as well as several other of the Spanish colonies, the Negroes were much used in domestic service, and for purposes of luxury. They were splendidly dressed, and, in many respects, rendered so subservient to vanity, that they became themselves, more silly, vain, and imperious, than their masters.*

However, the distinctions between Europeans and the people of colour were, by no means, kept up in the Spanish colonies as in those of other nations, except with regard to ecclesiastical establishments, to which they were not generally admitted.

\footnotetext{
*The Indians in those of the Spanish colonies where they yet remain, form a fifth, and the most depressed class of inhabitants.
} 
The Spanish coast is, in many parts, of a bold and rocky appearance, presenting high cliffs and extended promontories, and, in others, for many leagues, beautiful in the extreme, delighting the eye with an agreeable variety of hills, vallies, woods, and rivers. The generally luxurious face of the country continues the same throughout, with very little appearance of sterility even on the deserted north-east coast. The richest glades, with a most delightful foliage appear in the very bosoms of the mountains; and nothing can exceed the fertility of the cultivated lands, in every direction. The vast plain of Los Llanos, stretching along the south-east part of the island, is adapted to the growth of every tropical production, and, (abounding with rivers,) always capable of irrigation, as well as the Vega Real, which lies more towards the north, and through which flows the Yuna and the Cotuy, over a space of from fifty to an hundred miles; till meeting at a short distance from the coast, they discharge their united streams into the bay of Samana. On the northern coast, (by which Columbus first approached the island,) is also a large tract of land which, though consigned to vast herds of wild cattle of various descriptions, exhibited its fertility, in the support of this object of commerce, as well as in several grass-farms, which lay to the northward line of demarcation. The present produce is sugar, ginger, cocoa, tobacco, cotton, indigo, maize, and the Cassava root, ${ }^{135}$ of which, what they could spare (with wood for dying,) was received by the mother-country. But their principal article of exportation was the hides of the horned-cattle, which ran wild in the plains, with no other guards than the names, or the marks of their owners: at length, they regarded the carcasses also, which being gladly received by their neighbours, they were found to be a valuable resource. Not confining themselves to horned-cattle, they furnished also great numbers of horses and mules, which required less trouble in their rearing, and were very acceptable to the French colony.

The population, though an exact account may be deemed impossible, may, probably, approach to the statement of M. de Charmilly, at 6o,ooo; the number of whites was certainly greater than 2,00o, and that of the negroes less than half the total number; the free race of mixed blood of different grades, composing the remainder. ${ }^{136}$

The Spanish division of Hispaniola, affords every species of tropical herb, and beast; as, in this respect, it is similar to the western part of the island, they will be considered together.

The French colony of St. Domingo, comprehended the whole of the territory westward of the line of demarcation, before described: with fewer natural advantages, it presented such a contrast to the inactivity of the neighbouring country, as procured for it a character almost equal to that which has been so generally given to the whole of the island at its discovery. This colony, of which we are able to give a more regular account, was divided, as indeed 
nature appears to have directed, into the northern, western, and southern provinces. The first of these extended about forty leagues along the northern coast, from the river Massacre to Cape St. Nicholas, and contained (including the island of Tortuga) twenty-six parishes. The principal towns and harbours were, Cape François, Fort Dauphin, Port Paix, and Cape St. Nicholas.

The western province commenced at Cape St. Nicholas, and occupying the whole line of roadsted forming the Bight, or vast and general bay of Leogane, terminated at Cape Tiburon. It contained fourteen parishes, in which the chief towns were, Port-au-Prince, St. Marc, Leogane, Petit Goäve, and Jeremie; with the considerable villages of Gonaives, and Arcahaye. The best harbours are those of Port-au-Prince and Gonaives, the others are open and dangerous.

The southern province occupied the remaining coast from Cape Tiburon to L'Anse à Pitre, (or rather the river of that name): of the ten parishes, there were but two chief towns, those of the Cayes ${ }^{137}$ and Jacmel. Its roads and harbours are dangerous; and the shipping off Aux Cayes are frequently obliged to take refuge in the bay des Flamands.

The town of Cape François, in effect the capital of the colony, stands on a small plain, as it were, hollowed out of the Morne du Cap, a mountain which rises on both sides from the bay. The Morne, which allows only a narrow passage to the plain, is joined by the northern mountains, extending to Fort Picolet, which is placed on the edge of the rock, and defends the entrance to the roads; though built, in some respects, disadvantageously (except as regarded its commodious bay, and sometimes experiencing an inconvenient closeness from the situation,) it had risen to a degree of elegance concordant to the importance of the island, and which might cope with many European cities of the first order and opulence. It was composed of upwards of thirty well-formed streets, which crossed each other at right angles, and were many of them elegant. The houses built of stone and brick, were frequently handsome and commodious. It contained also two magnificent squares, those of Notre Dame and Clugny, ornamented with fountains; besides public shops, and long ranges of warehouses, suited to the commercial purposes to which this scene is dedicated. The principal public buildings after the church, which had not been erected many years, were the government-house, formerly a convent of Jesuits, ${ }^{*}$ the barracks, arsenal, playhouse, and prison. There were

\footnotetext{
*His Royal Highness, the Duke of Clarence, was entertained in this building at the conclusion of peace in 1783. [The Duke of Clarence (1765-1837) became King William IV after the death of George IV in 1830. He served in New York during the American Revolutionary War. The Jesuits, or the Society of Jesus, are a religious order of the Catholic Church founded in 1534 by St. Ignatius of Loyola. They were very present in South America until
} 
also, I believe, two hospitals of a similar nature to our own, and two of the establishments which Raynal calls houses of Providence. ${ }^{138}$ Whether the Hôpital de la Charité (an alms or work-house), in the road to L'Haut du Cap, at a small distance from the town, was of this kind, I am not certain, though I believe it; they were, however, as Raynal observed, "truly pious and divine institutions;" being for the benefit of such Europeans as might remain in the colony destitute of resources, or who, before they had acquired by industry, an opportunity to procure subsistence, became subject to disorders often fatal. Males and females were separately taken care of, and nourished till they were disposed of in some employment in which they could help themselves. The theatre was supplied by a respectable company of comedians, who performed, with short intervals, all the year round, besides other exhibitions and entertainments.

Fort Dauphin, about thirty miles from the cape, from whence there is an excellent road at a small distance from the shore, supplies the place of an ancient town called Bayaha, which was situated at a greater distance from the coast: it was the last town on the eastern frontier of the French, and stands in the farthest recess of a spacious harbour, which has only one narrow outlet. It has a small river flowing by the village of Trou to the west, and the shore of Manchenillo bay to the east. The fort stands on a little peninsula to the north, and it is bounded on the south by the same luxurious and extensive plain which enhanced the riches of the town that has been just described. It was well fortified, and could have held out against a considerable force for some time. It had also a theatre well supplied, assemblies, and concerts. Though the greater part of the produce of the plain was carried to Cape François, Fort Dauphin had more than its share of contraband trade, with several advantages, derived from proximity to the forlorn part of the Spanish dominion.

Port Paix stands on a worse situation than either of the preceding towns, from the former of which it is distant about forty miles. It was the first establishment of the Buccaniers on the island, when, quitting the habits of freebooters, they began to form themselves into a more peaceable society. Port Paix is healthy, though a considerable swamp is not far distant, to the northeast; and every exertion of Agrarian industry has been exercised to its advantage, even to the erection of several well-planned aqueducts. Its retirement well adapting it to the purposes of contraband trade, to the great emolument

they suffered a backlash for their political influence in all the principal Catholic countries of Europe. They were expelled from Portuguese, French, and Spanish colonies between 1758 and 1770.] 


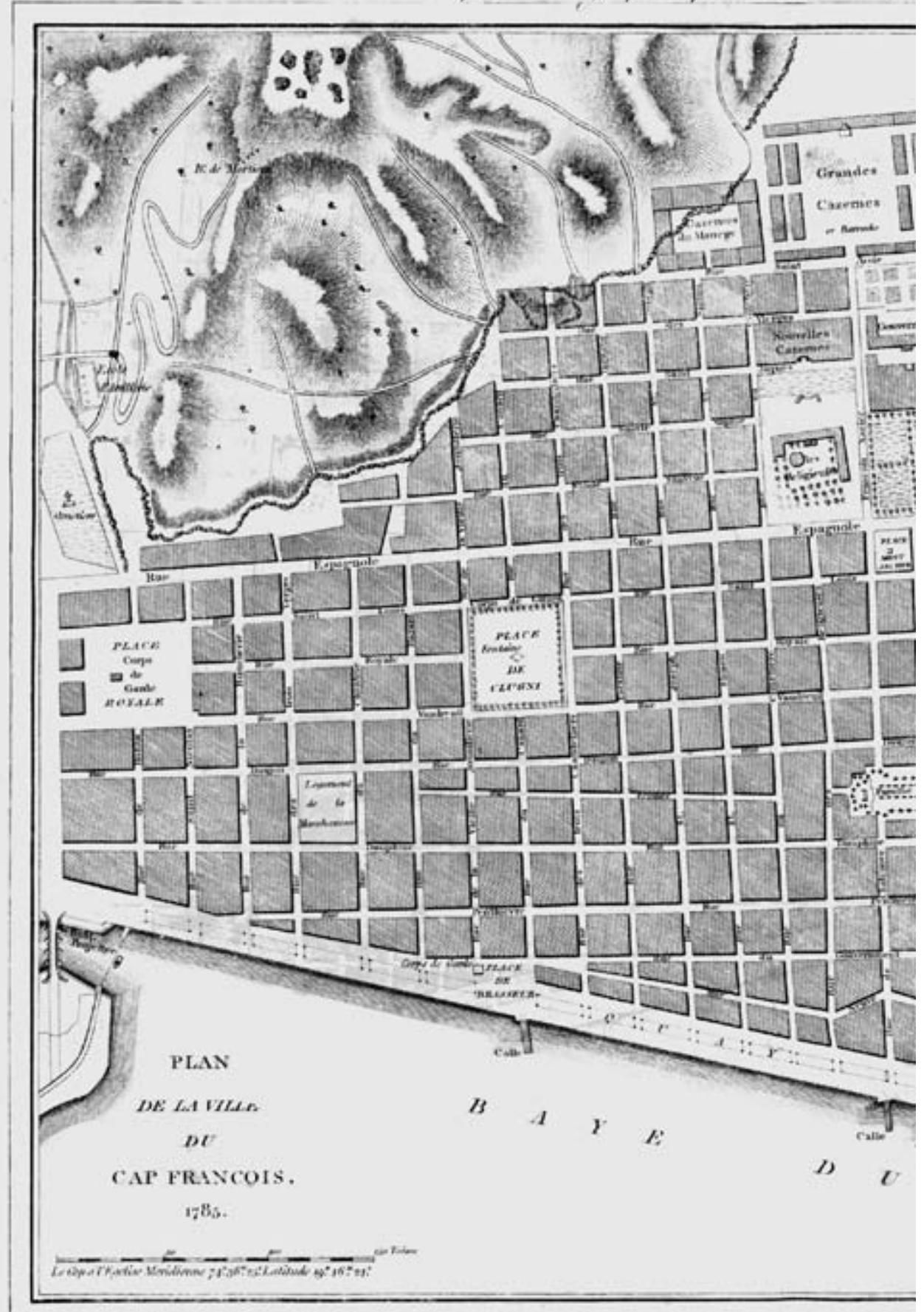

Plan of Cape François. Reproduced with the permission of Rare Books and Manuscripts, Special Collections Library, the Pennsylvania State University Libraries. 


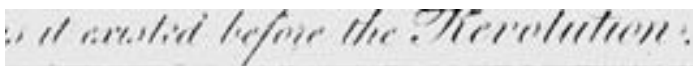

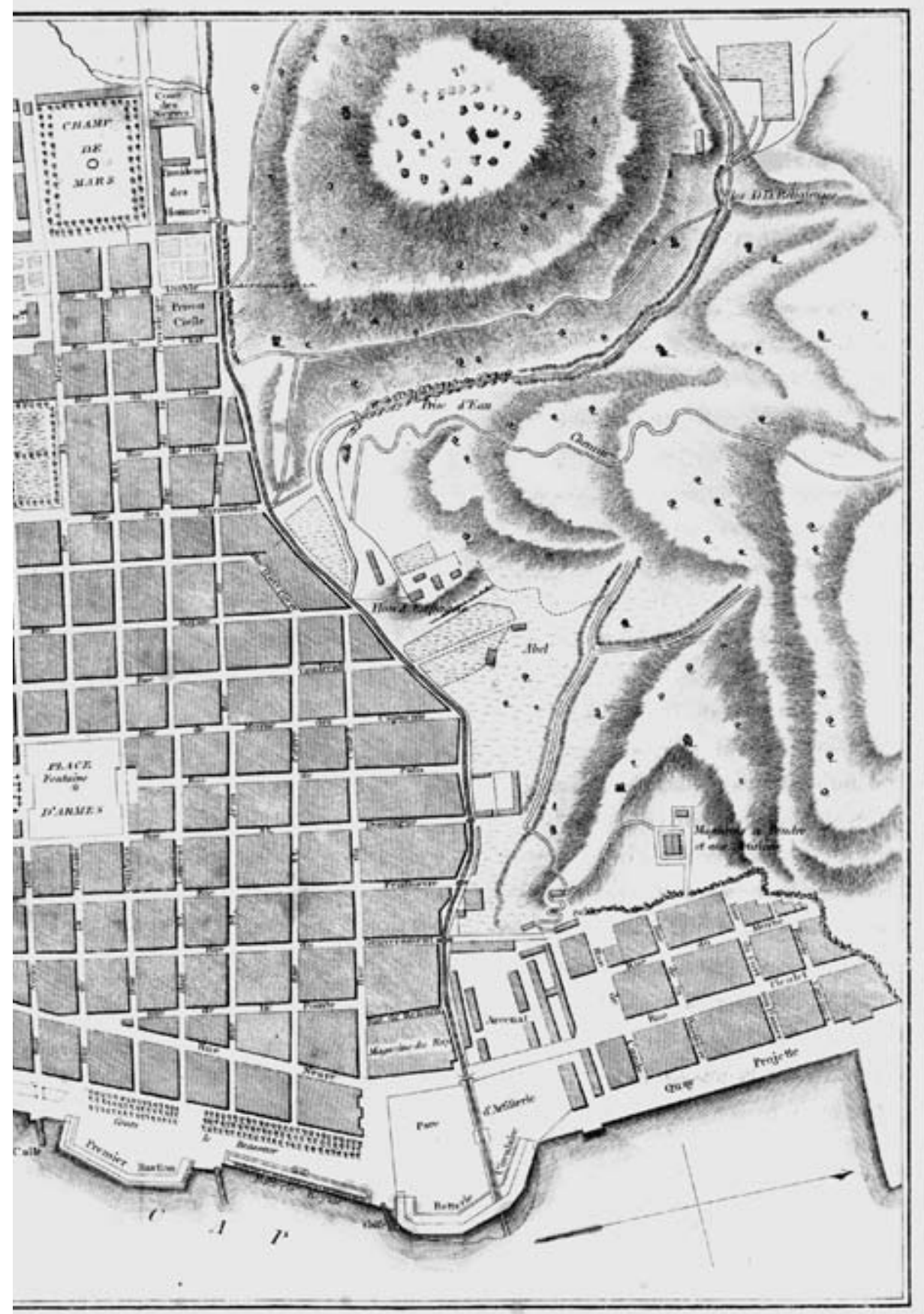


of the Americans, who frequented this port as well as the next, which forms the boundary of the northern province.

The town of Cape St. Nicholas is situated on the sterile spot from which it derives its name, and which is considered the key to the windward passage, being directly opposite to the port of Maisi in Cuba. Its chief excellence is its harbour, which is capacious, and rendered perfectly secure by the mole, or peninsula, on the north-west, which, with the mountains on the north-east, form a bay nearly six miles long, sheltered from every wind. Behind, rise the mountains of the cape, which, altogether, renders it a place of a formidable appearance. It was rendered a free port ${ }^{139}$ by the French in consequence of its unproductive quality, (as before mentioned,) and to allure residents, to whom the French ministry allied a colony of Acadians ${ }^{140}$ and Germans.

Port-au-Prince was the ostensible metropolis of the French colony, and the seat of its government; except in time of war, when it was removed to Cape François. It must have been one of the unaccountable caprices that sometimes direct the settlements of towns, that could have obtained for this place, indefensible at all points, the distinction it received. It was neither healthy nor inviting, though opulent, and well built, with every attention to convenience, but chiefly of wood. The water is of a brackish and otherwise disagreeable taste. It enjoyed, in common with the principal towns of the other provinces, the vicinity of a rich plain, the $\mathrm{Cul} \mathrm{de} \mathrm{Sac,} \mathrm{which} \mathrm{contained} \mathrm{no}$ less than 150 sugar plantations, with every convenience for their advantage; while the mountains behind it, clothed with plantations of coffee, reached quite to the Spanish settlements at Riquille. The dreadful earthquake which happened in 1770, occasioned the town to be much enlarged and improved. There were many long and populous streets, but not handsome. A few public edifices ornamented situations, not the best calculated to receive them; among these, the residence of the intendant, and the theatre, were most conspicuous. There are two harbours formed by some islets, open to any attack. The town extending along the sea-shore, in the centre of the western coast, is damp, and cheerless, except from the hurry of business. It is accessible at every point, from the land. A road, about 40 miles in length, reaches from hence to the village of Sale Trou, situated between two small rivers, near L'Anse à Pitre, on the southern coast.

The town of St. Marc, stretching along the sea-shore at the bottom of the bay of that name, was rather handsomely built, of freestone from the hills, which form a crescent behind it; the only instance of that kind of building in the colony. It was not large, possessed a good trade, and received all the crops from the intervening country, to Cape St. Nicholas. It is within ten miles of the mouth of the great river Artibonite, which winds its serpentine 
course through the plain to which it gives name, flowing behind it at the village of Tapion, about four leagues in the interior. Being the only river on the plain, an artificial use of water, by irrigation to a great extent, was necessary for its cultivation, which was an impediment to its opulence in contrast to those plains, which, (as was generally the case,) were watered by numerous streams or rivulets.

Leogane stands about a mile and a half from the shore opposite the island, or peninsula, of Gonave, between the channel of Gonave and the bay of St. Marc; it is a spacious, handsome town, surrounded with fertility, and in the neighbourhood of many streams of excellent water. It is a situation capable of defence, and in many respects preferable to Port-au-Prince. It was here the seat of government was transferred from Goäve, previous to its settlement at the late capital.

Petit Goäve, the original seat of government of the whole French colony, was long in a very decayed state, notwithstanding its importance in the first settlement of the Buccaniers, and the excellence of its harbour, still extremely good, and to which may be attributed any advantage it yet retains.

L'Anse de Jeremie, or, La Grand Anse, is a thriving town, well situated, healthy, and neat. Its trade was forming in a manner that left no doubt of increasing opulence, and to it, the privateers generally brought the prizes they made, in its neighbourhood.

The village of Gonaives is situated on the south side of the bay of that name, immediately opposite the projecting point of the line of demarcation, so that the French colony in this part, (nearly the centre of their territory,) contained in breadth little more than twenty miles. The soil is the most productive, and the most grateful to man, of any spot in the whole of the Antilles. Its harbour was excellent in point of safety, being formed by a little island, which crossing the bay, left a narrow channel, but with sufficient depth of water.

Aux Cayes is completely sunk in marshy ground, without a harbour, or salubrity to recommend it; yet such is the fertility which every where surrounds this town, as to have tempted the choice of every new settler to its swampy shores, and stagnant ponds. Its population was, therefore, much greater than could have been supposed. It has also in its vicinity a variety of bays and villages, which all tend to its prosperity. - Many ships have been lost here, from the insecure and dangerous anchorage; yet, as the Abbé Raynal has observed, "even the caprices of industry are to be indulged by the government;" and "trade like a plant that only flourishes in a soil of its own choosing, disdains every kind of restraint." ${ }^{141}$ Vache Island, which lies off this coast, was a celebrated resort of the freebooters in their molestation of the Spaniards, and is yet the successful haunt of the privateers of an enemy. 
To this island, as to that of Tortuga on the opposite coast, the colony was indebted for the foundation of a town, which, though small, is of some importance. Jacmel, at the best of times, did not contain one hundred houses, and derives no support from its soil, which is not fruitful, and comparatively hid among the neighbouring hills. As Port-au-Prince is to L'Anse à Pitre, so is Jacmel to Le Petit Goäve, being situated on the opposite side of the south projection of the Bight, sometimes called the Bight of Leogane. It is therefore a kind of store-house, or magazine, to the colony, receiving safely during war, (which can be done at no other place,) assistance of every kind, which is easily communicated to the western side, by a road of only twenty miles, leading to Leogane, and from thence to Port-au-Prince.

Besides the towns, and the villages of Gonaives and Arcahaye already mentioned, there are numerous others to which either commerce, agriculture, beauty, or strength of situation, attached important advantages; among these may be ranked St. Louis, which, though poor, and containing a small number of houses, without even water to drink, till some Jews, in return for their safety, proposed to erect, at their own expence, an aqueduct; by being occupied in some of the purposes of government, receiving the men of war which appeared there, and thus protecting the trade and wealth of Aux Cayes, it assumed the characteristic of a defence of the island. Baynette, about fifteen miles from Jacmel, and Acul, at a less distance from Aux Cayes, derive a similar adventitious importance, as well as Nipes and Miragoane, on the opposite coast; while Cul de Sac, Petit Fond, and Plaisance, in the interior, are of a different character. To these many more might be added upon the northern coast, but enough hath been said to shew the different appearance of the French colony from that of Spain: suffice it to add, that every part teemed with population, and smiled with industry.

The cultivated land in the colony amounted to 2,289,480 English acres, which was divided into 793 plantations of sugar, 3,117 of coffee, 789 of cotton, 3,16o of indigo, 54 of cocoa or chocolate, and 623 smaller settlements for raising grain, yams, and other vegetable food. ${ }^{\dagger}$

Of the differences which agitated the two colonies, happily religion did not form an object; for, though exempt from the interference of Rome, on one part, by express concession, and, on the other, by a light administration of ecclesiastical government, they both acknowledged the forms of her church, and entertained all the appendages of her hierarchy. The order of Jesuits was

\footnotetext{
* Or 763,923 carreaux of French measurement. [The carreau was a unit of surface measure specific to the West Indies in the ancien régime. It equals about 3.18 acres.]

†This last statement, which has every mark of authenticity, is taken from Mr. Edwards, Hist. Surv. p. 136.
} 
obtained here; that able, though insidious body, which, separated from secular projects and political intrigues, might have become benefactors to the human race. More need not be said of the local establishments of religion in a colony, whose inhabitants counted really but little upon it, and whose writers have told us still less. ${ }^{*}$ The edifices of public worship did not, in elegance of building, detract any other, and that there were many excellent benefices, might be collected from the manner in which many of the ecclesiastics have been known to live.

The government of the French colony was composed of two principal officers, a governor-general, and an intendant, or general administrator, whose office lasted three years. They were appointed through the marine minister, and their power was unbounded; for they, in effect, enacted laws, filled all vacant offices, and presided ultimately over all councils, or courts of justice. The governor had the whole naval and military force under his command, and had the power of personal liberty throughout the colony. He had also the power, by certain impediments, to prevent arrest by any other authority, and in part to stop the course of justice. The intendant regulated and superintended every department relative to the public revenue: to this he had the occasional assistance of a court ridiculously enough called the Colonial Assembly, in which every superior public officer bore a part. A subordinate court of justice was placed at Port-au-Prince, for the provinces. The principal officers presided in it, with a president, twelve counsellors, and four assistant judges. In this court, which was formerly divided between that town and Cape François, were registered all the royal edicts, and those of the colonial government. Much, very much of the happiness of the colony, depended on the governor, who was generally a person of distinction, and most frequently selected from the army or navy. An appeal from every decision lay to the king, in which justice was insured; whatever impediments to its course might have been found in St. Domingo.

The chief force of the island, though certainly inadequate to its defence, consisted of the militia, of which each parish raised from one to three companies of whites, one of mulattoes, and one of free blacks, none of which received pay; and the king's troops upon the colonial establishment generally comprised from two to three thousand men.

The inhabitants were composed, as usual, of pure whites; people of colour, ${ }^{142}$ and blacks of free condition; and negroes in a state of slavery. The whole of the intermediate grades were called generally mulattoes.

\footnotetext{
*Except the tales of some fanatics among the French missionaries, with whom many of the slaves are described as "spiritual," though it is sufficiently known that these people, in a state of slavery, neither comprehend, nor retain, even the forms of Christian worship.
} 
The character of the European planter in St. Domingo was imperious, and voluptuous to a higher degree than in the other islands: this character also shewed itself on every occasion; he was impatient of even the constraint of the laws, avaricious of wealth and honor, and a devotee to all the arts of indulgence. Hospitality was unbounded among them, and charity, at the same time, very extensively bestowed. "'Tis the inheritance," says Father le Pers," "which they have preserved the most entire from their ancestors; and it would seem that this excellent virtue was conferred with the very air of St. Domingo."

Many circumstances combined to render the situation of the mulattoes much more eligible than in any other island, though in some respects worse. They were also more numerous. ${ }^{143}$ The free man of colour had the command of his own property, without any restriction, both in life and death; he could bear testimony even against the whites; he could marry as he pleased, and transmit freedom to his children; and he might embrace a liberal profession; but prejudice frequently damped his efforts, and precipitated him below what an hostile law could have done. The meanness of birth was never forgotten in his own land. They were also compelled to serve in one of the brigades of horse, furnished in all the parishes, under the appellation of the Marshalsea. ${ }^{144}$ The numbers of this class were to be accounted for, by several circumstances, amongst which were the superior comforts of the lower order of whites, ${ }^{145}$ employed in the superintendence of the plantations, and the engaging manners of the women of colour, who are often elegant, if not sometimes really beautiful.

The next class, the enslaved negro, appears to have been comparatively happy, rather than otherwise; not condemned to an unreasonable duration of labor, they were sufficiently provided, without any anxiety for their future existence. They had gardens which produced the necessaries of life; pigs, poultry, and even horses; and were sufficiently clothed, agreeably to the climate; but they were considered and treated, as much beneath, the ordinary class of human beings: yet, M. de Charmilly, whose judgment in this particular need not to be doubted, says, "that this race of men is naturally good; that if nature has denied them attention, reflexion, observation, perseverance, and all the advantages which render the whites superior to them, she has done every thing for them necessary to the climate in which they exist, not only in physical advantages, but also in those of the heart; for she has given that sensibility for the sex which makes them forget so many sorrows, and the

\footnotetext{
*“L'héritage qu'ils ont conservé le plus entier de leurs pères, c'est l'hospitalité; il semble qu'on respire cette belle vertu avec l'air de S. Domingue." Charlevoix Hist. de S. Domingue.
} 
most lively affection for their children, which renders every thing supportable to them."*

The appearance which we have already ascribed to the Spanish coast, may be naturally supposed to extend itself to that French division, with the difference which must be created by a continual range of cultivation, either glistening in a tropical sun, or winding in an umbrageous alley towards dwellings which might be easily conceived a second paradise. The Mole of Cape St. Nicholas, which is justly considered as a key to the windward passage, presents an appearance such as it should to the ocean, sterile and commanding. The south peninsula resounded with the language of trade, and the northern coast with arms and with agriculture. - Unlike their neighbours, the French colonists caused their land to be cultivated up to the very mountain tops, from which the cane-grounds appeared as so many thickets; while every invention that could be adopted to their purpose was readily encouraged. Their roads were in general excellent, being made and kept in repair, by the contributions of every planter, who sent a proportionate number of his slaves to work upon them, (a burthen entitled the Corvées.) ${ }^{146}$ Sometimes they overflowed in the morning, and were dusty again in the evening; although generally shaded on both sides by lime trees; and the different grounds were separated by hedges of citron trees. The approach to the residence of a planter, was through an avenue of both these, and the pimento and palm graced its extended prospect.

Their principal rivers are the Artibonite, which flows from its source in the centre of the island, through the plain of that name, till it empties itself in the gulf of Gonaves; that called the Three Rivers, whose mouth is at Port Paix; and the Great River, or La Grande Rivière, which reaches the sea near Jeremie.

To describe the productions of the French colony of St. Domingo, would be enumerating those of the whole of the Antilles. Their principal were, however, as have been before described, sugar, coffee, cotton, indigo, and cocoa, or chocolate. To these may be added a little tobacco.

In return for the useful droves of cattle for slaughter and labour, smoked beef, bacon, skins, and the greatest part of the money received from Spain, they supplied their neighbours with wearing apparel, hardware, and guns.

* - "Que cette race d'hommes est naturellement bonne; que si la nature lui a refusé l'attention, la réflexion, l'observation, la persévérance, \& tous les avantages qui rendent les blancs supérieurs à eux, elle a tout fait pour eux du côté du climat, des avantages physiques \& même du coeur; car elle leur a donné cette sensibilité pour les femmes qui fait oublier tant de malheurs! et le plus vif amour pour leurs enfans, qui leur rend tout supportable!"-Venault de Charmilly, Lettre à M. Bryan Edwards, \&c. p.41. 
The population was considered at about 40,000 whites, 500,000 negro slaves, and 24,000 free people of colour; and the average exports, as stated by M. Marbois, ${ }^{147}$ the intendant of the colony, amounted to $4,765,129$ l. sterling. ${ }^{148}$

It is not intended in this place, to satisfy the scientific views of the naturalist in regard to St. Domingo, notwithstanding that, with an inclination to that study, the writer had some opportunities for its indulgence, which were not entirely lost, but reserved for some future opportunity. The amateur of this elegant research will, no doubt, have recourse to the valuable histories which have been long furnished of a neighbouring island, ${ }^{149}$ in these respects so similar, as to admit of very little variation in the subject to which I allude.

The food of the early inhabitants of St. Domingo, appears to have comprised a similar description of vegetables to that of the negroes at this day:plantains, Indian wheat, ${ }^{150}$ millet, the cassavi root, potatoes, and Caribbee cabbage. ${ }^{151}$ Their quadrupeds included the smaller species of a lizard, yet, the delicacy of a West India table; the Agouti Rat, of which a description are yet found in some of the islands; and the Alco, a small short-tailed dog, which did not bark, with others whose names have not come down to us. Their fishery was more abundant, every bay and creek furnishing an ample supply, as many of them do to the present time. The European quadrupeds now supply the necessary food of European colonists, with only such local additions as are objects of delicacy, or introduced by custom; among these, may be named the land crab, the ortolan, ${ }^{152}$ and a variety of wild fowl of delicious taste and flavor. The indigenous vegetables yet remain, including plantains, yams, a species of spinach, potatoes, cassava, Indian wheat, and cabbage; to these are added the European roots, herbs, and pulse; ${ }^{153}$ and no want is found of cabbage, turnips, carrots, parsnips, peas, beans, artichokes, \&c. A variety of fruits ornament the luxury of the table, among which, the melon and pineapple, peaches and strawberries, oranges and lemons, the cashew, apples, pears, plums, and nuts, are plenteously combined with a variety of productions introduced from different countries.

To describe the nature, properties, and mode of cultivation of those productions, which form the different objects of commerce, would uselessly extend the present chapter, and the accounts are to be found in different works peculiarly appropriated to these subjects. ${ }^{*}$ Sufficient is now already men-

\footnotetext{
*Sugar, coffee, and cotton, are rendered familiar to almost every reader. I shall, however, briefly add here a slight description of the two other staple commodities of St. Domingo - cocoa and indigo.

The cocoa-tree presents less beauty than utility to its cultivator, for its branches form so many trunks separating from each other to a distance immediately above the parent one,
} 
tioned to acquaint the reader with the country, from whose rich prospects, and cloudless sky, he is to turn to scenes of conflagration, and the horrors of massacre.

CHAP. II.

Origin of the Revolutionary Spirit of this Period in St. Domingo.

THE origin of principles is not always to be traced to the approximating causes of an event; for, as in nature, so in morality, the seeds of many productions lie dormant through varying seasons, till the moment when an unseen influence calls them into obvious existence: hence, to be capable of discerning the signs of the times, is a power that hath always been duly appreciated,

and these bend with their separate branches immediately down to the earth. It seldom, therefore, rises high. Its leaves are long, terminating in a point, and emitting an agreeable smell. In the pistil of a flower blooming from every part, is contained an husk, in the form of a melon, which grows ordinarily to the length of six inches, and the breadth of four or five, composed of several small inclosures, in which the fruit, comprising a number of small nuts, of the shape of almonds, is found. It is propagated from the seed; is green in the early part of its growth, and becomes yellow at maturity. When it assumes a deep hue, it must be immediately gathered and dried; two crops of equal value are annually formed. It requires shade and moisture, and loves the protection of large trees at a sufficient distance, which must be also regarded with respect to its own plants. It requires rather due care, and a few necessary precautions, than a culture either laborious or expensive, and its returns are of the most profitable kind. Its nutritious, and other advantageous qualities, are too sufficiently known to require a recital, and its commercial value will be better known from other parts of the present account.

Indigo, an article of such general domestic service, as to be used as a beautifier of the finest part of our dress, and an important object of commerce, flourishes nowhere so well as at St. Domingo. It is a shrub with a thick, spreading root, about two feet high, of a faint, but not disagreeable smell. The stem is of a dry appearance, and different shades of colour. The leaves are of an oval form, and connected by a short pedicle. The pistil of its small and scentless flowers changes into a pod, and discloses its seeds, of the appearance of gunpowder. The blue is found adhering to the leaves, which, when gathered on the branches, are thrown into a tub filled with water, and fermented: it is then made to run into another, when it is discovered among the water, in the form of a subtile earth. The water is then agitated by various means, and with the utmost circumspection, to combine the coloured particles, which, when effected, are left to precipitate to the bottom. The liquid, become of a thicker consistence, is drawn off into another vessel to settle, and thence drained through sacks, from which it is removed into chests, where it becomes dry, and fit for sale. It is divided into two sorts, whimsically designated the true and the bastard. The first is finer, but the latter heavier and more profitable, and therefore more generally cultivated. 
and an attention to which hath frequently changed the fate of a country, if not of mankind. Yet, it is not often that man can be hoped to distinguish with precision, the approaching evil from the good, particularly in circumstances that affect, perhaps, not only his interest, but his immediate happiness; it is thus, therefore, that surprize is so frequently excited, at the apparent blindness to the future with which principles and practices are so frequently urged in society, diametrically opposite to the dictates of nature and philosophy, and repugnant to the common experience of ages. Collateral circumstances form the general argument in their favor; and it may endure with them a little while; but truth is eternal.

If accuracy of discrimination is not always to be found in philosophers, it is not to be expected in any large mixed body; and still less so, in those who form the population of colonies, particularly of the extent of that which is the subject of the present observations. Though the greatest empires have arisen from the overflow of cities into colonies, it cannot be contended that no feculence ${ }^{154}$ mixed with the flood.

To attribute to the general number of colonists any specific character, (where, collected fortuitously, they must necessarily admit of the strongest marks of variety), would be ridiculous; it is, however, certain, that among those, devoted to pursue fortune in distant dependencies upon their native country, may be ranked many who have no peculiar capacity, nor opportunity for employment at home; many of the higher classes without prospects, and of the lower without character; who cannot fail to consider their destination, as intended to supply every want; and to consider those means the best, which have the most facility. To those may, no doubt, be added many of the germs of genius, to whom, it is to be feared, the warmth of a tropical sun does not always prove more genial, than the wintry rays of their own; and, probably, some with qualities fitted for any sphere of life, to whom a spirit of enter-

They are both liable to frequent accidents, among which the most destructive is the effect of the caterpillar, which devours the leaves, and their produce, in a few mornings. It is quickly ripe, and generally cut at intervals of six weeks. At the end of two years it becomes degenerated, and fresh plants are necessary. Moisture and shade are required considerably for this plant, and the principal care is to deprive it of the weeds, which would otherwise immediately choke it. It exhausts the soil considerably, and potatoes, and other similar plants, are cultivated in its place occasionally, for the purpose of burning the leaves as manure.

Those who would enjoy an acute and curious dissertation on sugar, may consult the interesting account of Dr. Moseley, in his volume of Medical Miscellanies, \&c. [Benjamin Moseley (1742-1819) worked as a surgeon-apothecary in Kingston, Jamaica, beginning in 1768 and later held the post of surgeon-general there. Among other works, he wrote A Treatise on Sugar (1800).] 
prize alone might dictate the migration. To the self-interested, the term of his own probation will always bound his considerations, and it is not the bulk of mankind who can be, nor who incline to be, legislators, much less moralists. The officers of government may be able and good, but their dominion is too short to conciliate any local affection, and an expedient temporization will and must always supersede even ordinary virtue.

Of the West India colonists from France, the modern writers of that nation have afforded us no reason to think with increased tenderness, since Raynal has imputed to them a viciousness of conduct, beyond the apparent bounds of human actions; and De Charmilly (one of themselves) has described those, of whom the best conduct was to be expected, receiving appointments under the government of the colony, as the rewards of an intriguing court to its meanest dependants, and vilest accessaries! Their character, as displayed on prominent occasions, during that period which is the intent of these sheets to describe, unhappily was not often such as to controvert the assertions made from such good authority.

The man who first contemplated the purchase of laborers by thousands, ${ }^{*}$ to be conveyed in close vessels, without the power of rest or exercise, or nourishment proper for any situation, much less for a dreary voyage to a foreign land; and, who knew these men, although little removed from a state of nature, to be susceptible of those impressions which mock the utmost refinements of civilization, to the attainment of some of which, morality often strives in vain; must have been bold to conceive that they would continue always patient of their wrongs, and resigned to compulsory labour, even though it should be in a state of comparative advantage, particularly in the constant converse of annual acquisitions of their countrymen, whose remembrances were not

\footnotetext{
*The commencement of the African slave-trade, like many other objects of importance, seems to have taken place from a very trifling accident. In 1440, Anthony Gonsales, one of the Portuguese navigators, in the prosecution of his discoveries, seized, and carried off some Moors near Cape Bojador, whom prince Henry afterwards ordered him to restore. When again exploring the coast of Africa about two years after, he executed this order, landing them at Rio del Oro, and received from the Moors, in exchange, ten blacks, and a quantity of gold dust. His success in this transaction tempted his countrymen to a repetition, till at length they fitted out ships for the purpose, and afterwards formed settlements for the trade in black slaves. Ultimately patents were granted, and the dealers in human flesh were sanctified by a bull from the holy see. [Antão Gonçalves was the first European to buy Africans as slaves. Rainsford's account is rather fanciful. Gonçalves bought an Azengue Berber chieftain and 11 other slaves from black slave traders on the West African coast. He returned a few years later (there is no indication that Prince Henry the Navigator ordered him to return) and traded the chieftain for more slaves, gold dust, and ostrich eggs. In 1452 Pope Nicholas V issued the papal bull Dum Diversas, which granted Afonso V of Portugal the right to conquer and enslave Saracens and pagans.]
} 
obliterated; yet no objection would appear to have occurred to him, and his plan proceeded till the employers of it, with a physical proportion of twelve to one against them, imagined themselves capable of coercing five hundred thousand of these men, exclusive of the descendants of others, without any determined exertion of virtue, or consideration on their own part.

Let it not be conceived that it is here intended to arraign the conduct of the planters in general, or to view with complacency the revolt of servants of any description, much less to plead their apology; I am but to state facts which are necessary to the argument intended to be produced.

The African negro is described as "frivolous, inconstant, vain, timid, jealous, and superstitious; yet good and generous, without foresight, always guided by the impression of the moment; and adding to these characteristics, the vices of slaves, indolence, gluttony, dishonesty, and falsehood; vindictive also, like all weak beings, injustice driving them to despair."* I take the whole of this character for granted, from the experience of the writer, and the different opportunities which have been confided to him of judging with truth. That the dependance of colonies, then, could have been originally placed upon such beings, was a strange perversion of human judgment; but that it could be expected to continue through ages, without a superior portion of human wisdom and virtue, (instead of a very small exercise of either,) is only attributable to the blindness I have just described. The result has proved the position; for, from the first moment at which African slaves were imported, the effects of all the bad qualities ascribed to them have been frequent, in revolt, treachery, murder, and suicide; nor, at the same time, have the instances been few, of actions arising from the superior impulses, or unconquerable affection, gratitude, inviolable fidelity, or bravery, have been experienced from them by their masters and connections; and circumstances are still recited that might cope with the history of the ancient republics. No more is described than is necessary to the present purpose; for it is not the wish of the writer to discuss the question of the slave-trade, ${ }^{155}$ already too much agitated in this country, but to trace the origin of the revolutionary spirit which has ended so fatally to the colonies of France.

Regardless of the frequent exercise of several minor qualities also which must tend to render men impatient of slavery, the labour of the islands continued to be performed by their means; without any other foresight, than related to expedients which might procrastinate the evil for each successive

* - "légers, inconstans, vains, timides, peureux, jaloux, bons, généreux, sans prévoyance, superstitieux, toujours conduits par l'impression du moment: ils joignent à cela les vices des esclaves: paresseux, gourmands, voleurs, menteurs, vindicatifs, commes tous les êtres, faibles, l'injustice les désespère." De Charmilly, Lettre, p. 41. 
proprietor. Hence they have been successively punished by domestic means, chased as wild-beasts, combated like a foreign enemy, and treated with as independent powers! Yet, so prone are men to consider that what they wish the case, that scarcely a doubt was entertained of those who had not deserted, or marooned, ${ }^{156}$ nor were any other than coercive principles contemplated for those who remained; the same routine of purchase to supply deficiencies, and of regulations to secure their value, prevailed. The planter, instead of exhibitions of virtue and power that should impress respect and awe, appeared a feeble voluptuary, forgetting, in idle dalliance with the female labourers of his field, the utility of moral principles, and the decencies of life. The effects of such examples are incontestable, as regards private morality, without any allusion to the offices of religion; and it requires not to be depressed into a community of the most abject description of slaves to discover, that the effects of vice in undermining public virtue is the certain basis of revolt.

Thus an ignorance, in the first instance, of human nature, a blindness to actual circumstances, and a want of individual virtue in the colonists, gave birth to the revolutionary spirit in St. Domingo; which, instead of being created, was only fanned into flame by the occurrences which took place in the relations of the colony, with the mother-country, on the change of its government.

The support of colonies by means of such a disproportion of African slaves, to the other population as are necessary, continually and progressively acquired, is radically impossible, from the nature of the people themselves, and the manner of obtaining them; but if it were not, the want of powers required for their management - of a policy sufficiently subtle and yet enlightened, for their government, would render it, permanently, impracticable; even with both these probabilities in their favour, that, in such a depraved state as that of the French colony in St. Domingo, every other advantage would be annihilated. ${ }^{157}$

It is, perhaps, necessary here to anticipate an observation not unlikely to be made; therefore, be it understood, that the impossibility of the continued existence of slavery is not by any means asserted. ${ }^{*}$ It is not forgotten that there was a period when, from the happy state under which this subject is now considered, unrestricted by the check of civil or ecclesiastical tyranny, parents sold their children as slaves to a foreign country, and inherited others themselves, who were their captives, or who had been acquired by other means;

\footnotetext{
*See an account of slavery in Europe in Robertson's Charles V. vol. I. p. 272.-Also an assemblage of the different laws on this subject, in Huntingford's Laws of Master and Servant Considered, chap. I. p. 36.
} 
but these, notwithstanding they may have been treated as inferior classes of society (as the productive power is too generally to this day), bore no mark, by which they should be considered, as distinguished by nature to be scarcely belonging to the human species, as is the case with that of complexion.

Nor, is the writer at present opposing the practice of the slave-trade. $\mathrm{He}$ is an enemy to it, only, as he is to every employment which offers an undue power to many, not the most unlikely to abuse it; and as a principle hostile to humanity and inefficient in its purposes. He is aware, that the situation of colonial-slaves at present is, in many respects, superior to that of the labourers or the artizans of Britain. The first have not, indeed, the command of secession, neither have the two latter the power; for if they cease from labour, they cease from its advantages. When it is considered that the artizan must wander in search of employment, and submit to the optional reward of those who may chuse to employ him, after encountering distress in consequence of repeated refusals; the slave will appear more happy, though sometimes enduring corporeal punishment too severe, whose food and residence is provided without anxiety; and who is certain of employment, or of the same provision.

Nor, would the writer be supposed to sanction the means which have been used to procure an abolition of the trade, which he disapproves; much less, the emancipation of those slaves already in the colonies. Of the latter step, the humanity would be equally problematical, with that which would dictate the liberation of the poor bird long nursed in domestic comfort, to flutter a little while in solitary freedom, a stranger to his own kind, and to the winds of heaven.

What has been said, has arisen from a conviction that, but for the circumstances described, a revolutionary spirit would not have so soon been spread throughout St. Domingo; and to point out the beacon to the colonies of the British nation in the same sea, ${ }^{158}$ with that which has produced an illustration of these positions, and a picture so full of terror, on this more will be said, and with greater propriety, at the end of this work.

Flushed with opulence and dissipation, the majority of planters in St.

\footnotetext{
*It is recorded, but where I cannot, at present, refer, that St. Gregory observing some beautiful English children in the slave-market at Rome, exclaimed in a Latin pun, if I may be allowed the expression, that they were not English, but Angels, if they had but been Christians. - "Non Angli, sed Angeli," \&c. This practice will, however, appear to have been continued after they had the benefit of the Christian Religion. See Anderson's History of Commerce, vol. I. p. 99. [According to the Venerable Bede, Pope Gregory I responded to this sight by sending St. Augustine of Canterbury to convert the English. Adam Anderson, An historical and chronological deduction of the origin of commerce (1764).]
} 
Domingo had arrived at a state of sentiment the most vitiated, and manners equally depraved; while, injured by an example so contagious, the slaves had become more dissolute, than those of any British island. If the master was proud, voluptuous, and crafty, the slave was equally vicious, and often riotous; the punishment of one was but the consequence of his own excesses; but that of the other, was often cruel and unnatural. The proprietor could bear no rival in his parish; and would not bend even to the ordinances of justice. The creole-slaves looked upon the newly-imported Africans with scorn, and sustained, in their turn, that of the mulattoes, whose complexion was browner; while all were kept at a distance from the intercourse of the whites. Nor did the boundaries of sex, it is painful to observe, keep their wonted distinction, from the stern impulses that affect men. The European ladies too often participated in the austerity and arrogance of their male kindred; while the jetblack beauty, among slaves, though scarcely a native of the island, refused all commerce with those who could not boast the same distinction with herself.

Such was the situation of the inhabitants of St. Domingo in the beginning of the year 1789, prompt to any movement that should create an effervescence among them, or afford the one party an opportunity of opposing the other; yet, while private feuds were eager for an opportunity to burst into public clamour, the situation of the country was such as hath been described, like the verdant bosom of a volcano, unconscious of the flame about to burst; the people were cheerful, the markets plentifully stocked, the lands loaded with production, and the colony, if "overwhelmed with debt,"* it may be admitted to be so said, flourishing every where.

In the mean time, the great kingdom, under whose care it had expanded to its present growth, and to whose government it yet looked for parental care, disordered by embarrassment, and agitated by conflicting interests, began to approach to that period which had been considered as inevitable, by philosophers, for more than half a century. Notwithstanding the absolute tyranny which had prevailed in other respects, France, under the feeble reign of the unhappy Louis, ${ }^{159}$ had been the nurse of morality and philosophy; and she drew nigh, not unwittingly, to that political mortality to which it would appear all states are subject; for it had been sung by her poets under the walls of her own capital, and repeated in auguries which did not err. ${ }^{160}$

Of the different expedients that had been resorted to, the colonies did not want information; nor did it fail in the effect which might be expected upon

* - "la colonie qui, ayant encore beaucoup de dettes, n'avait pas besoin de payer celles de la France." Lettre à Edwards, p. 48. ["the colony which, yet being overwhelmed with debt, did not need to have to pay France's."] 
every class of their inhabitants. In a new regimen the proprietors looked to some aggrandizement either in property or consequence; the free people of colour anticipated a favourable change in their condition; and even the slaves viewed, through the political alterations that began to occupy the attention of those above them, something to excite their curiosity, and a vigilance to gratify it. Each motion of the French court became canvassed by every class throughout the island. When a spirit of deliberation upon subjects usually considered above the capacities of the vulgar begins to spread, it seldom ends precisely as it begun; whatever may be the event, it does not fail to call into notice circumstances and opinions not easily repressed, and characters in their support who might otherwise have preserved through life "the noiseless tenor of their way." ${ }^{161}$ It had its full effect in St. Domingo, already so ripe to receive it; and when the news arrived that the States-General of France ${ }^{162}$ were to be summoned (the last convulsive effort of expiring monarchy), all parties resolved on making their own interests a part of the general concern.

In opposition to the wishes of a judicious few (among whom was the intelligent De Charmilly) and even to the prohibitions of the government, the impetuous proprietors summoned provincial and parochial meetings, for the purpose of electing themselves to legislative functions; heated resolutions were passed; and eighteen deputies were elected, to represent the island in the meeting of the States-General, without any other authority than the noise of demagogues, and their own inclinations. Twelve were never recognized in France, and the other six were received with difficulty. ${ }^{163}$ The mulattoes, who could have no share in this self-created body, thought it naturally time to show an attention to themselves; and, accordingly, not only communicated with numbers of their brethren then resident in the mother country, but augmented those powerful advocates in their behalf, with much more effect than was produced by the self-created body of colonial deputies. ${ }^{164}$ The negroes, however, more successful than all, without either deputies or intercessors, obtained, unsolicited, the interest of such a powerful body in their behalf, as to drown the recollection of every other object. A society, in which were enrolled the names of several great and good men, under the title of "The Friends of the Blacks" (Amis de Noirs), ${ }^{165}$ circulated its protests and appeals with such vigour, that, before the negroes themselves, although eager and alert in their enquiries, were acquainted with the importance which they had obtained in the deliberations of the mother country, they were the prominent subjects of conversation and regret in half the towns of Europe. They were not, however, tardy in acquiring this information; and though it would be difficult to contemplate any thing in human nature so bad, as to suppose that the highest and best of motives did not actuate so respectable a body as that 
which composed this society, or the similar establishment which had before obtained in London; ${ }^{166}$ yet the unhappy eloquence with which the miseries of slavery were depicted by them, and the forcible points of view in which all the errors of their opponents were placed, as well as the enthusiasm which always accompanies the exertions of ardent minds, were certainly the cause of bringing into action, on a broad basis, that spirit of revolt which only sleeps in the enslaved African, or his descendant, and which has produced on their side, and on that of the white inhabitants of the colonies, such horrors as "make ev'n the angels weep." 167

Thus concludes this account of the origin of the revolution of St. Domingo, with observing how much better it would have been for themselves, and perhaps for humanity, if happily discerning the signs of the times, the planters of this delightful and flourishing colony (a character which none have attempted to deny it), by resigning an overweening fondness for dominion, and an undue avarice of gain, had rather calmed than provoked the dissentions of those whose interest should have bid them to agree; and by softening the evils of a state which is so bad in its best form, have conciliated the affections of those to whose labours, under the present regimen, every thing productive of wealth or prosperity must depend. A partial concession to those who, by complexion itself, claim half a right to political existence, would have been sufficient: with a little regard for the morals of a people who require them the most, and a revolution in their own minds, as far as human nature will admit. These would have preserved to them, now lingering in a melancholy exile, if not the sudden victims of their impolicy, an island the boast of the new world, and a powerful support of the old. If they had then contemplated some more legitimate means of prosecuting the labours of their colony, they might, however immediately unavailing, have laid a foundation for their posterity more lasting than the bequest of inordinate wealth, and have claimed the approbation of society.

CHAP. III.

Account of the Progress and Accomplishment of the Independence of St. Domingo.

AT the commencement of these changes in the government of the mother country, and consequently of others in that of the colonies, the governor of French St. Domingo was M. Duchilleau, ${ }^{168}$ a man of no moderate powers, 
but who, from conciliating the temper of the new council of France, was continued in his office. It soon however became, in power or consequence, but nugatory; for, upon the first meeting of the assemblies before described, his proclamations were disregarded, and his government insulted, if not despised.

The States-General, at which two deputies appeared from each of the provinces, declared themselves the National Assembly in May, 1789, and on the 2oth of August they made their Declaration of Rights. ${ }^{169}$ Between these two periods, the public mind had been heated against the white colonists by such a variety of means, as to threaten their total annihilation.

The publication of the Declaration of Rights did not tend to remedy this unfavorable impression of the people against one of their own communities; for the article that, "All men are born, and continue, free and equal as to their rights," ${ }^{170}$ implied an entire subversion of their establishments, and created a complete ferment among the whole of the French proprietors. They conceived, and the French government appear afterwards to have done the same, that the effect of this declaration was to rouse the negroes to an assertion of those rights it was supposed to give them. Apprehensive of disorders arising in the colony, the governor soon received orders from his new constituents, the National Assembly, ${ }^{171}$ to call together the inhabitants for the purpose of interior regulation. The measure had been anticipated by the ready disposition of the self-constituted legislators, and a provincial assembly for the northern district had already met at Cape François; an example which was soon followed by the western and southern provinces, the former of which met at Port-au-Prince, and the latter at Aux Cayes. For more immediate communication between the people, and to accommodate every description, parochial committees were also established. These committees were of the disposition which might be expected, and, by dividing among themselves upon every occasion, they served only to inform the negroes of their frivolity, and to excite them to take advantage of their want of unanimity and power; and the principal determination in their proceedings was that, of the necessity of a full and speedy colonial representation. The order of the king, however, which was received in January 1790, tended to supersede their deliberations, by convoking a general Colonial Assembly, which was appointed to meet in the central town of Leogane. The mode which it directed of electing the members did not satisfy the provincial assemblies, and they substituted a plan of their own, changing the town of Leogane to that of St. Marc, and fixing on the 25th of March, and afterwards on the 16th of April, for the time of meeting.

The mulattoes, not willing to be left behind in exertion, when they perceived the opposition of the whites to every movement of the government, 
determined to proceed a step still further, and accordingly arming themselves, they proceeded to claim by force the benefit of equal privileges with the whites. Their combination was premature, and they were soon overpowered. Different parties were secured at Jacmel and Artibonite, to whom, on their submission, notwithstanding the exasperation of the whites in general against them, an unconditional pardon was given. ${ }^{172}$ In the division of parties, too, inconsistent as it may appear, some of the whites, among whom were included persons of high respectability, adopted the cause of the people of colour, and even seconded their inclination to revolt. Among these, an old magistrate named Ferrand de Beaudierre, ${ }^{173}$ was the first to become conspicuous, for the purpose of removing the disgrace which had attached to him in consequence of having offered marriage to a woman of colour. He drew up a memorial in their behalf, which had not time to be presented to the parochial committee, before he was seized by an enraged mob, and put to death. The deputy procureur-general, M. Dubois, ${ }^{174}$ also, whose duty demanded a different course, became so infatuated, as to declaim against the slavery of the negroes in their presence; but he enjoyed a milder fate; he was only arrested by the people, and dismissed from the colony by the governor, who soon after followed.

Such was the confused state of the colony, and every one seemed to be so bent upon harassing the metropolitan government, that it was, with great reason, apprehended in France, that the island was about to declare itself independent, or to submit to some foreign power. The alarm became general throughout those places which had any concern with St. Domingo, and the National Assembly on being earnestly implored to consider of the best means of saving so valuable a dependency resolved, after a serious discussion of the subject, "That it was not the intention of the Assembly to interfere with the interior government of the colonies, or to subject them to laws incompatible with their local establishments; they therefore authorized the inhabitants of each colony to signify their own plan of legislation and commercial arrangement, preserving only a conformity with the principles of the mother country, and a regard for the reciprocal interests of both." ${ }^{175}$ It superadded, that no innovation was intended in any system of commerce in which the colonies were already concerned. It will easily be conceived that this conciliating resolution, so necessary, as regarded the discontented white colonists, would be very differently received by the people of colour. It excited among them a general clamour, which extended to every part where their cause (diffused by the means used on those occasions) was known, or even heard of.

The period having arrived to which the General Assembly of St. Domingo had been prorogued, it met to the number of two hundred and thirteen members, at the town of St. Marc. These consisted of two representatives from 
each parish, twenty-four from the city of Cape François, sixteen from that of Port-au-Prince, and eight from Aux Cayes. The provincial assemblies continued in their self-appointments notwithstanding, and even formed committees, to act in the intervals of meeting. The new assembly commenced its functions by reviewing the objects of abuse in the old colonial government, and in proposing means for their remedy, of which the political incapacities of the mulattoes, and a revisal of the slave laws, bore a promising part. They put the mulattoes, in point of military duty, on the same footing with the whites, restricting the king's officers commanding in the towns, from those oppressive acts towards them which they had sometimes experienced; they examined into those abuses in the courts of judicature which claimed immediate redress; and set about preparing a new colonial constitution.

To extend the divisions, which were increasing, rather than otherwise, among the proprietors and their representatives, the new governor-general ${ }^{176}$ was a man privately devoted to the old system, who immediately combined those who had any interest in the ancient despotism, to oppose the colonial revolution, which would be likely to deprive them of their corrupt sources of profit. As these included all the officers under the fiscal administration, tax-gatherers, appendages to the courts of civil and criminal jurisdiction, and most of those who held military commissions under the king's authority, they formed a power, by no means contemptible, and possessed an advantage in being all sincere in their attachment to one cause, while a diversity of opinions swayed the newly established party. To this association was added one, (from many of whom their country has since suffered much,) who, with considerable talents, and an enterprising genius, was bent upon counter-projects against every act of the General Assembly; this was the Colonel and Chevalier Mauduit, ${ }^{177}$ who commanded, and was beloved by the regiment of Portau-Prince. He had returned from France, by way of Italy, and had last parted with the Count D'Artois, ${ }^{178}$ to whose fortunes he was much devoted. Thus, impressed with more than common warmth in the cause, in which he now took such an active part, he did not fail to strike a blow to the interests of the colony; by insinuating himself between the Assembly and those in whose favor they were exerting themselves, he divided them against each other, and to this effort Peynier, who was weak and uninformed, resigned all his power, or influence, into his hands.

As if to meet the insidious policy of Mauduit, the divisions of the new legislative bodies burst into open convulsion, by the conduct of the provincial assembly of the north, who endeavoured to the utmost of their power, to counteract the provisions of the General Assembly.

The decree which was the result of its deliberations being May completed, the plan for a new constitution was published; which, as if every thing was to 
coincide with the untoward disposition of affairs, was so framed as to please scarce any party, and formed the ostensible motive for the commencement of hostilities in the party of $\mathrm{M}$. Peynier. The principal articles of this constitution (of which there were ten,) consisted in

I. Vesting in the "General Assembly of the French part of St. Domingo," the entire management of the internal concerns of the colony.

II. Preventing any act of the legislative body relative to the internal concerns of the colony, from becoming a law, until definitively sanctioned by the Representatives of the People, and confirmed by the king.

III. IV. and V. Enabling the Assembly to enact provisional laws for their own government. Nevertheless, to keep as a separate question the execution of those laws; and in case of the governor-general (to whom such decrees shall be notified for the purpose of being enforced) sending any observations on them to the Assembly, causing them to be entered on the Journals, ordering a consequent revision, and ultimately deciding on its confirmation, or rejection, by a majority of two thirds.

VI. Establishing a communication on all common, and commercial concerns, with the National Assembly, without which, nor until they are confirmed by the Colonial Assembly, its decrees shall not be valid.

VII. Allowing the importation of necessary articles upon pressing occasions, under the cognizance of the governor-general.

VIII. Submitting every provisional act of the Assembly to be transmitted for the royal sanction, and suspended upon its refusal.

IX. Creating a new General Assembly biennially.

$\mathrm{X}$. Communicating to the king, the National Assembly, the Colonial Governor, and the different districts and parishes, the present decree. ${ }^{179}$

To repeat that much difference of opinion existed with respect to this decree, is what was to be expected from every circumstance; and the power retained by the Assembly, was evidently beyond what had ever been contemplated in the colonies. The leading opinions were, however, (among those the most capable of judging,) that it was intended to declare the island an independent state, or, that it was already sold by a party to the English. That both these reports were not entirely without foundation, subsequent events will appear to have proved, for it is confessed by M. de Charmilly, one of the members of this very assembly, that the former proposition "was a subject of consideration among a few of the inhabitants, the opulence and prosperity of the colony having dazzled some sanguine characters,"* and, it was not three

\footnotetext{
*“Je conviens qu'il a été question d'indépendance parmi un petit nombre d'habitans, mais la richesse de la colonie, sa prospérité, avaient trompé quelques caractères ardens, \&c."-Lettre, p. 52.
} 
years after, before that gentleman induced the British government to accept the submission of a part of the proprietors of the island..$^{180}$

The inhabitants of the Cape, and of some of the western parishes, did not wait for these confirmations of their opinions; for, immediately on the publication of the new plan of government, they renounced all obedience to the Assembly, and presented a memorial to the governor, requesting its dissolution. This step could not but be agreeable to Peynier, if it was not the effect of the exertions of his party; and, another circumstance which happened, gave him the opportunity he evidently desired, of coming to an open rupture. In consequence of an espousal of the conduct of the governor and his party by M. Galisonierre ${ }^{181}$ the commander of a ship of the line, called the Leopard, then in the harbour of Port-au-Prince, the crew thought proper to withdraw their obedience from him, and to oblige him to quit the ship; they then gave the command to the first lieutenant, and declared themselves waiting the orders of the General Assembly. The Assembly, by no means disinclined to such an offer, transmitted them in return a vote of thanks, and directed them, in the name of the law and the king, to detain the ship in the road, there to wait till further orders. To retain this acquisition, they permitted some of their partizans to take possession of the powder magazine at Leogane. It has been disputed whether the crew of M. Galisonierre's ship had been corrupted by the party supporting the Assembly, or actuated by the caprice which so often influences seamen; but as it appears that their future movements were without the knowledge of the Assembly, it is reasonable to believe, that neither the one nor the other was the cause, but that they acted entirely by themselves, among whom might be probably some characters of more importance, than is conceived by those who view them merely in their ordinary employment.

Such are the fortuitous incidents which lead to events that decide the fate of countries.

M. Peynier now conceived himself provided with the means of criminating the party, whose power so much curtailed his own. He immediately proclaimed the dissolution of the Assembly, charging it with projects of independency, and with having traitorously possessed itself of one of the king's ships by corrupting the crew; pronouncing the whole, with their adherents, traitors to the colony, the French nation, and the king; he declared his intention of bringing them to condign punishment, and to commence hostile operations against them. He had no sooner threatened, than he attempted to put his menaces into execution. He prepared for the restoration of the ancient system, and he even applied to the neighbouring island of Cuba for the aid of foreign troops; and he commissioned Mauduit to arrest the committee of the western provincial Assembly, who had become obnoxious to him from their 
inclination to the measures of his opponents, at their midnight meeting in Port-au-Prince. Mauduit, however, found them protected by four hundred of the national guards, (formerly the colonial militia,) and having himself but one hundred men, he was compelled, after a short skirmish, to retire, without effecting any thing more than the seizure of the national colours, which he must have obtained by some undue means, and bore off in triumph.

The General Assembly in return summoned the people from every part of the colony, to arm for the protection of their representatives, and the summons seemed to be generally obeyed with alacrity. The western and the southern provinces were unqualified in their approbation, and immediately dispatched a force of two thousand men on their way to Port-au-Prince. The Provincial Assembly of the north, however, joined the party of the governor, and detached a part of the regular troops in that quarter, with a body of two hundred mulattoes. Thus the flames of civil war were immediately about to be lighted, and a dreadful conflict was expected on every side, when a circumstance occurred which for the present prevented it, and gave a more favourable turn to the public affairs than that which they had hitherto taken.

The crew of the Leopard having determined upon returning to France, they brought the ship into the entrance of St. Marc's bay, to apprize the Assembly of her departure, and to wait under sail for their dispatches to the king and the National Assembly. The General Assembly was reduced by this time, in consequence of sickness and secession, to less than one hundred members, and was diminishing every day: they had found themselves at first not sufficiently competent to the art of legislation, and their task was becoming every day more arduous. The majority of them were fathers of families; and could not but perceive that a storm was gathering, in which some, if not all of them, might be involved. Whatever was the motive, or whether or not it had a portion of the eccentricity which has been ascribed to it, eighty-five members of the General Assembly came to the immediate, and unexpected resolution, of availing themselves of this opportunity to proceed to Europe, for the purpose of deriving assistance in their future conduct, and justifying themselves as to what had already passed, preventing the effusion of human blood. They took their departure, therefore, on board the Leopard, and such was the good fortune which attended this step in the outset, that it excited for them, for the first time, a very general admiration; crowds followed them to the shore with tears and blessings, and prayers were every where preferred for the success which their forbearance was considered to deserve. The armaments were mutually suspended. The heads of the government party viewed the circumstance with mixed emotions of surprize and terror, and M. Peynier tremblingly resumed his seat.

Thus, it were to be hoped that peace would have continued during the 
passage of the members to France, and until the result of their journey were known; particularly as the remaining part were occupied in arrangements, and in prepossessing the French government against the General Assembly on their arrival; but, no sooner was one cause of commotion removed, than another supplied its place, of a more hostile complexion, and with less occasion - the rebellion of James Ogé, ${ }^{182}$ a mulatto; whose mother had a coffeeplantation about thirty miles from Cape François. During his residence at Paris, for the purpose of education, he had imbibed, in addition to the natural feelings of his class, all the prejudices entertained at this period against the white planters in the mother country. Having become connected with the society of Amis des Noirs, and inflated with an idea of his own capacity, he was easily persuaded by Robespierre, ${ }^{183}$ and other violent members, to attach himself to a conspiracy, supposed to be already ripe in St. Domingo, and requiring only the talents of an active leader to produce the effects desired, in behalf of the people of colour. Armed indirectly by their means, and charged with all the inveteracy of the party, Ogé arrived in St. Domingo about two months after the Assembly had left it, and immediately prepared to assume an imaginary command, for which he had no foundation. He found means to convey a quantity of arms and ammunition to a place called Grande Rivière, about fifteen miles from the Cape, where his brother had been prepared to receive it, and, having collected about two hundred followers, exerted himself every where in spreading disaffection; he wrote imperiously to M. Peynier, stating the inattention which had been paid to the execution of the Code Noir, ${ }^{*}$ demanding its enforcement, and also an extension of the privileges enjoyed by the whites to all persons without distinction. He took upon himself the character of Protector of the Mulattoes, and declared his intention, if necessary, of arming in their behalf. He established his camp where he had deposited his stores, and appointed his two brothers, and another mulatto, of a ferocious character, named Mark Chavane, ${ }^{184}$ his lieutenants. These men commenced their unruly operations by the murder of two white men, whom they met accidentally, and by punishing with extreme cruelty those of their own complexion not disposed to revolt; one who excused himself on account of a wife and six children, they murdered, with the whole of his family. Fortunately their reign was not long, for a body of regular troops, and the Cape militia, were dispatched to invest their camp, when, with a weak resistance, they were totally routed; many were killed, sixty were taken prisoners, and the chiefs escaped into the Spanish part of the island.

This rebellion, though so easily crushed, excited a considerable animosity

\footnotetext{
*The laws for the protection of the Blacks, instituted by Louis XIV.
} 
against the people of colour, who, in their turn, as if fearing a retaliation of cruelty, took to arms, and formed camps in different parts of the island, each of them of much greater importance than that of Ogé. The white inhabitants collected themselves in force to oppose them. But Colonel Mauduit, (by means not publicly communicated,) in a conference, had, singly and unattended, with the mulatto leaders, at their chief camp at Verettes, induced them to an immediate dispersion. Various doubts existed as to the nature of the means, which were supposed not to be highly honourable to M. Mauduit: certain it is, however, the mulattoes were not perfectly satisfied; for their leader at Aux Cayes, Rigaud, ${ }^{185}$ declared that "it was a transient and deceitful calm, and, that no peace would be permanent until one class of people had exterminated the other."*

The insurrection of the mulattoes was no sooner suppressed a second time, than a fresh object of disturbance arose, more fatal than either, and least expected. This was the arrival of a decree of the National Assembly, censuring, with great asperity, the conduct of the General Assembly of St. Domingo, charging it with disaffection to France, and insubordination; annulling all its acts, incapacitating its members from ever serving again; approving the conduct of the governor's party, particularly the Northern Provincial Assembly and Colonel Mauduit; directing a new Colonial Assembly to be formed on the principle of the decree of March 8, and the instructions of March 28, and ordering under arrest, during its pleasure, the members who had quitted the island, and who were still at Paris. It also recommended an additional force, both naval and military, to be sent to the colony for the better support of the authority of the government. ${ }^{186}$

On the arrival of the eighty-five members of the Colonial Assembly at Brest (on the 13th of September), they had been received with the utmost respect and attention by all ranks of people; and the most liberal provision made for them in every way; but, such had been the activity of M. Peynier, that deputies had arrived before them from the provincial assembly of the north, who, with their agents, had so prejudiced the mind of $\mathrm{M}$. Barnave ${ }^{187}$ the minister for this department, that they met at Paris with indignities of every kind; were dismissed from the bar of the National Assembly with contempt, and refused even permission to confront their enemies as they requested. On the 16th of October the report of the committee for the colonies on the subject was presented by M. Barnave, their president, and the members placed under arrest.

A very general manifestation of surprize and indignation took place on

*Edwards's St. Domingo, p. 46. 
the arrival of this decree, and a very different sentiment pervaded the public mind from that intended to be produced by the National Assembly; in every particular Mauduit and his regiment became objects of the warmest resentment. Many of the parishes would send no other deputies to form the new Colonial Assembly, because they considered those in France as their legal representatives, the annulling of whose decrees, they attributed to the revival of the ancient system of despotism.

Whether it was from intimidation at these succeeding disorders, or from the wish of the National Assembly, does not appear; M. Peynier, however, to the great satisfaction of the majority of the planters, at this time resigned his office to the gentleman next in command, General Blanchelande, ${ }^{188}$ a fieldofficer in the French service, who entered upon the government with peculiar vigour.

The first exercise of his power, and one rather unexpected, was to demand of the Spaniards the fugitives from the rebellion of Ogé, who were accordingly delivered up, and placed in the jail of Cape François, till a commission should be issued to bring them to trial. It was soon commenced, but lasted for a considerable time, during which they were strictly examined, and, of course, condemned.

Ogé and his lieutenant, Chavane, were sentenced to be broken alive upon the wheel, and left to perish. His followers, including one of his brothers (the other not being found), to the number of twenty, were condemned to be hanged. Ogé was not a man calculated for a leader of rebellion. His mother having been enabled to support him in France as a gentleman, he had cherished a delicacy of sentiment very incompatible with the ferocity of revolt; but it would appear also that he wanted personal courage, and that fidelity to his colleagues which alone inspires respect in his circumstances. When he heard the judgment of the court, he wept bitterly, and implored mercy in the most abject manner; proposing to purchase life by exposing the secrets of numerous conspiracies, which he described as impending over the colony: he, however, extended it only by a reprieve for twenty-four hours, just time enough to make a brief deposition of facts of the highest importance, if they had been immediately attended to; and was then hurried to execution with a celerity rather barbarous, and an impolicy which afterwards met with its consequences. Chavane preserved the appearance of courage to the last, and resigned himself to his fate without a groan.

The persons before whom the deposition of Ogé was taken, (Ruotte and Vertierres ${ }^{189}$ members of the Northern Provincial Assembly,) had been appointed to examine the revolters; and were devotees to the ancient system; from what motive, perhaps, may be seen afterwards, whether by the desire of 
the principal officer in the colonial administration, or of the Northern Provincial Assembly, is not minutely ascertained; but these men suppressed entirely the information communicated by Ogé, and reported that he had said nothing of importance, burying his secret, if he had any, with himself. That this was not the case will appear hereafter.

The decisive spirit of the new governor did not prevent the people from viewing the detention of their representatives in France with a general dissatisfaction, and those to whom they attributed the original cause of it, with additional dislike. Mauduit continued to be the object of their censure in a particular degree; they avowedly disapproved of that conduct at St. Marc's, which the National Assembly had made a subject of particular approbation; one act of which they availed themselves with reason; this was, taking from a detachment of the national guards, as before-mentioned, their colours, which had never been returned. This deprivation the whole of the national guards regarded as an insult to their body, which they would have immediately revenged, but that the veteran regiment of Port-au-Prince was remarkable for its superior discipline, and attachment to the commanding officer, whose bounty was always open to them. They had long given him a particular token of their regard, in supplanting the national cockade, ${ }^{190}$ by a white feather, the avowed insigne of royalty. The regiment therefore, as well as its colonel, became obnoxious to the whole of the army, who were attached to the new constitution. At this time, a reinforcement of troops from France, comprising two battalions of the regiments of Artois and Normandy, arrived in the frigates Le Fougueux and Le Borée, who, having communicated in some way with the crew of the Leopard (the vessel which carried the Colonial Assembly to France), no sooner landed at Port-au-Prince, than they discovered the same animosity against the regiment of Mauduit, as was manifested by the national guards. They treated them as traitors, which, no doubt, the peculiarity of the white feather confirmed, and refused all kind of intercourse with them. The conduct of the national guards had hitherto passed unheeded, but when two other regiments, and those arrived from the mother-country, became leagued against them, it occasioned a visible effect upon the minds of the officers and the men. They began to view each other with distrust, and to consider the regard which they had hitherto born to their idolized commander, as almost criminal. A sullen discontent appeared on every face, and their actions, amongst which was a contemptuous dismissal of the white feather, augured no good intentions towards him who, but a few weeks before, might have led them over the world. Mauduit was not insensible of the change, or of the probability of danger; and he prepared for some arrangement to induce a return of the good opinion of his troops; before he made the 
experiment, however, he bravely insisted on the governor removing himself and his family to Cape François, that he might not have a chance of sharing in his own ruin if it was unavoidable, to which M. Blanchelande (rather pitifully) consented.

Colonel Mauduit prepared, as the first effort of conciliation, for a restitution of the colours to the national guards, the unfortunate cause of the alienation of his own troops; and proposed, if they would support him, to carry them with his own hands, at their head to the church, in which they should be deposited. He harangued his grenadiers to that purpose, and they promised to support him with their lives. On the succeeding day he put his proposed plan in execution, before the whole community of Port-au-Prince. A considerable murmur took place, but means were taken by the citizens (among whom it is said were some he had most injured) to prevent any accident.* He had replaced the colours, and was turning, no doubt, to meet the gratulations of his troops, which had so often cheered him, when one of them commanded him aloud, to ask pardon of the national guards, on his knees! He started with indignation at the proposition, and intending to offer them his life, rather than his honour, exposed to them his naked bosom. In an instant, an hundred bayonets seemed to vie with each other which should wound the deepest, and he fell, gored all over; while scarce an arm of the number he had so often made happy, was raised to save him, or a voice among those so often exerted in his praise, to bid his spirit rest. ${ }^{\dagger}$ The spectators, however unfriendly they might have been to the deceased, were petrified with astonishment and disgust. Not contented with the extinction of life, this unmanly and treacherous number, whose conduct is, it is hoped, unparalleled, not content with destroying his house, and every thing belonging to him, gratified themselves with mutilating the dead body of their once-loved commander; and, by a thousand diabolical contrivances, rendering disgusting in death a form which, through life, had been always beloved and honoured, and sometimes respected and admired. This wretched regiment met the proper fate of all such dastardly perpetrators. They were despised even by the soldiery whom they meant to oblige, compelled to lay down their arms, and sent prisoners to France, where, in some shape or other, punishment failed not to await them.

\footnotetext{
*The exertions on this occasion of the brave Beausobre were too striking to be passed in silence. He had been struck with a shot, when protecting the Colonial Committee, in the affair for which Mauduit was now attempting an extenuation; yet, with a generosity not often equalled, he was among the foremost to step forward on the present occasion, and was wounded by a sabre in defending the life of Mauduit.

${ }^{\dagger}$ Two officers named Galefeau and Germain, to their honour, did not desert their colonel till the last moment, but their exertions were of no avail; and the indignation of the soldiers being at its height, there was no time for preparation.
} 
During these dreadful transactions, as if eager to provide fresh fuel to light up in this unhappy island, the society of Amis des Noirs continued to devise new projects that thoroughly effected that purpose. There was great reason to suppose, at this time, that the general body of mulattoes were not averse to conciliation, while there was as much cause to desire it on the part of the whites. The president of the colonial committee in France, (M. Barnave,) had also, after the most strenuous opposition to the planters, avowed his conviction, that all interference of the mother-country with their internal regulations should cease. But the principal members of this society, among whom were Grégoire, La Fayette, and Brissot, ${ }^{191}$ determined otherwise, and the foundation of their plan was in making the National Assembly the medium, in obedience to the chapter of instructions for its proceedings, which had followed the decree of March 8. These instructions, which consisted of eighteen articles, directed "that every person of the age of twenty-five and upwards, possessing property, or, having resided two years in the colony, and paid taxes, should be enabled to vote in the formation of the Colonial Assembly." ${ }^{192}$ This direction, repugnant to the very decree it was to accompany, was asserted by those who procured it, to regard only the privilege of voting in the Parochial Assemblies; as under the old government it was known that they were constituted solely of white persons, the mulattoes had expressed no inclination to intrude themselves. To induce them to do so, they were apprised that not being excepted, they were virtually included, and after much entreaty, were persuaded to send deputies to France, to procure an explanation from the National Assembly. This was the chief point required, for it produced a public debate on the subject, in which was also introduced the claim of the mulattoes to all the privileges of whites. The fascinating eloquence of the Abbé Grégoire was exerted on the subject with its usual vigour, and, to give additional aid, the death of Ogé became known at the same time, which afforded a popular subject for the theatres. Every mode was exerted to render the proprietors of the colonies detestable; and with such success, that they could not, at length, appear in public with safety. "Perish the colonies," exclaimed Robespierre, "rather than sacrifice our principles!"193 - Grégoire, Condorcet, ${ }^{194}$ La Fayette, and Brissot, names which often excited admiration, all joined in the cry. The National Assembly forgetting, at once, its former acts, and the principles it had acknowledged, decreed to the people of colour "an equal right with the white proprietors, in the choice of representatives and to seats in the colonial government." ${ }^{195}$ The colonial committee at Paris, which had formerly opposed the General Assembly, immediately declared itself useless; and the deputies of the colonies declined further attendance. These decisive steps had no other effect, however, than that of hastening the departure of three commissioners, ${ }^{196}$ (who had been appointed some time 
previous) to St. Domingo, for the better regulation of its affairs. The proceedings of the colonial officers in the mother-country, afforded but a faint presentiment of those which took place in St. Domingo on the arrival of the first information of this last decree in that island. There then existed a variety of opposite opinions, and parties inveterate against each other, but it immediately consolidated them all. They heard it with doubt, which was soon succeeded by the frenzy of despair. All the divisions of party united themselves against the mother-country; every violence was projected and commenced; the preparations making for the federation of the 14th of July were suspended; they determined to reject the civic oath; an embargo was laid on all vessels in the harbour; and even a motion was made in the Northern Provincial Assembly, to erect the British standard in the place of the national colours; all subordination was done away, and it is said, "the people of colour being threatened to be fired upon in the streets, fled from the city, retiring to the woods and other retreats for safety."* At length it was determined to elect a new general Colonial Assembly, which had its first meeting, to the number of one hundred and seventy-six members, at Leogane, from whence they adjourned to Cape François, proposing to open their session at the expiration of a fortnight.

During the whole of these transactions the governor-general, M. Blanchelande, remained a political cypher, without any other power, than to give a formal assent to proceedings which he could neither impede nor amend. He wrote to the king's ministers an account of the disturbances, and expressed his fears that the decree would prove "the death-warrant of many thousands of the inhabitants;" 197 he sent a copy of his letter to the Provincial Assembly, with a solemn assurance, that he would suspend the execution of the decree whenever it should come to him.

Alarmed at the various symptoms of hostility manifested towards them, the mulattoes collected in armed bodies in different places, and fears were entertained of fresh conflicts between them and the whites; but the latter were too much occupied in the hopes entertained from the meeting of the Colonial Assembly to notice them, and, in fact, a complete removal of grievances was fully expected.

As little cessation had been experienced, from the occurrence of one disaster to another, on the expectation of pacific measures (from the auspicious sentiments of the new assembly, ) another misfortune arose, which, however it might have been long expected, was still more unlooked-for than any other. Witnesses of the general commotion of the colony, and perceiving that, not-

\footnotetext{
*“Inquiry into the Causes of the Insurrection in St. Domingo," \&c. 1792.
} 
withstanding the attention which had been paid by the mother-country to the people of colour, (except interweaving their sufferings with the subject, for the purposes of oratory,) nothing was proposed with regard to them; the negroes began to consider of some melioration for themselves among the new arrangements then taking place. As they had unfortunately perceived that the first step in all the disputes of their masters had consisted of outrage, so they determined to follow those means which promised such certain success, and at the same time, afforded objects the most grateful to people in a state of slavery. It cannot be denied, that they may have felt no great pleasure in contemplating an acquisition of power by the mulattoes, who, from being, according to their own account, more conversant with their habits, and better acquainted with their dispositions, had always been considered by the negroes as their severest masters; it is very probable, that they exercised the same, or greater rigor, over the negroes, than they received themselves from the whites. Be this as it may, while a perfect calm seemed to pervade every contending interest, one morning before day-break a sudden and confused alarm spread throughout the town of the Cape, that the negro slaves in the neighbouring parishes had revolted, were murdering the whites, and setting fire to the plantations. The governor immediately assembled all the military officers, but nothing certain could be collected till dawn, when the reports were too sadly confirmed by the arrival of numbers, just escaped with life, who, begging for protection in the town, communicated the particulars.

From them they found, that the negroes in a plantation called Noé, in the parish of Acul, were the ringleaders, fourteen of whom, after having murdered the principal managers of the plantation, followed by the remainder, hastened to the adjoining one, and repeated the same enormities. The slaves of this estate immediately joined them. Their determination seemed, that it was necessary none should escape, for they shewed not the same discrimination they afterwards used. M. Clements, the owner of the latter plantation received his death from one he had regarded with much tenderness, and promoted (for so it was considered) to be his postilion. The same occurred at the largest plantation on the plain of the Cape, that of M. Galifet, whose negroes, the whole of whom joined the insurrection, were proverbial for receiving good treatment. ${ }^{198}$ Similar circumstances took place at the very time, on the estate of M. Flaville, a few miles distant, from whence they carried off the wife, and three daughters, of the Procureur, after murdering him before their faces. Day-light convinced the astonished inhabitants that the revolt was concerted, for some parties of observation sent from the town, soon perceived that the rising was general throughout the province, and the flames quickly burst from all quarters. The terror of the whole community now be- 
came excessive, and the shrieks of women and children as the appearances of horror spread, wildly running from door to door, inquiring their fate of each other, produced a most distressing effect. The men armed themselves, and the General Assembly invested the governor with the command of the National Guards. As soon as any plan could be matured, it was determined, to send the white women and children on board the ships in the harbour; and the ablest of the domestic negroes in the town were also sent, under a guard, lest they should be concerned in any treacherous connection.

The next transaction which took place was relative to a considerable body of mulattoes in the town, who, although they had not joined the previous disputes, were immediately marked as objects of vengeance by the lower classes of white people, and it became necessary for the Assembly to afford them protection. This circumstance became the medium of an agreeable conciliation; for, in return, all the able men among them, proposed themselves to march against the rebels, leaving their wives and children as hostages for their fidelity. They were, therefore, enrolled in the militia, and a mutual confidence, to a certain degree, established itself between them.

As many seamen as could be spared from the ships were joined to the inhabitants, and the whole formed into a military order, when M. de Touzard, ${ }^{199}$ an officer who had distinguished himself in North America, took the command of a detachment of militia and troops of the line, and marched to attack the most powerful body of the revolters in the neighbourhood. They were posted at the plantation of $\mathrm{M}$. Latour, to the number of 4 , ooo negroes, a large portion of whom were destroyed, but their places were supplied by such increased numbers, that $M$. de Touzard was compelled to retreat. The weakness of the town obliged the governor to stand on the defensive, till he could contrive means to strengthen the only position he could command; if the negroes had proceeded to Cape François at that time, they might have easily taken the town, and effected every enormity they chose.

On the river which intersected the main road from the plain at the east end of the town, over which there was a ferry, a battery of cannon was raised on boats, protected by two small camps at a short distance; at the other principal road lying over the Haut du Cap, a considerable body of troops, with artillery, was stationed, while a strong palisade and chevaux-de-frize, ${ }^{200}$ surrounded the town on the land side; an embargo was laid on the shipping, for the purpose of retreat, and retaining the assistance of the sailors. The whole of the inhabitants, without distinction, laboured at the fortifications.

Every method was used to communicate the information of the insurrection, when it could be conveyed with safety, and several camps were formed, which seemed to arrest the progress of the rebellion; nevertheless, those at 
Grande Rivière and Dondon were attacked by the negroes, joined by mulattoes, and after a sharp contest, forced with great slaughter. The surviving whites from Dondon took refuge in the Spanish territory.

The whole of the plain, of the Cape, and the district of Grande Rivière, now in the possession of the insurgents, and abandoned to their ravages, as were the miserable inhabitants, to whom no assistance could be given, who, therefore, suffered every injury, that bewildered licentiousness could devise, before a death, in this instance merciful, but of more than common torments, closed for them the scene.

It serves few of the purposes of history to describe the various modes of torture which occurred to the savage insurgents, or to relate accounts of the grossest violations of virgins and pregnant women, in the presence of their dying husbands, or parents; much it is to be regretted, that civilized states should ever find it necessary to render torture of any kind familiar to vulgar minds, for they are exhibitions that live in the memory, and steel the heart against those affections which form the grandest boundary of our nature. There is reason to fear that the perpetrators of those horrid deeds, had been witnesses to the ridicule of misery in others who should have evinced themselves superior to such conduct, by the godlike attributes of mercy and benevolence; the licentiousness of their intercourse with the female slaves, could leave no impression to prevent a retaliation on the occasion, with objects, too, of such superior attraction, alas! unhappily for themselves.

It is pleasing, however, to alleviate these horrors by the recital of an instance of fidelity, and affectionate solicitude, in one of the revolted negroes, which has been already narrated, but which cannot be too much impressed upon the minds of the people in every relation of society. Mr. Edwards's account is here quoted as the most authentic, as I know of no more authentic source to which I can refer.

"Monsieur and Madam Baillen, their daughter and son-in-law, and two white servants, residing on a mountain plantation about thirty miles from Cape François, were apprized of the revolt by one of their own slaves, who was himself in the conspiracy, but promised, if possible, to save the lives of his master and his family. Having no immediate means of providing for their escape, he conducted them into an adjacent wood; after which he went and joined the revolters. The following night he found an opportunity of bringing them provisions from the rebel camp. The second night he returned again with a further supply of provisions, but declared it would be out of his power to give them any further assistance. After this they saw nothing of the negro for three days; but at the end of that time he came again, and directed the family how to make their way to a river which led to Port Margot, assur- 
ing them they would find a canoe on a part of the river which he described. They followed his directions; found the canoe, and got safely into it, but were overset by the rapidity of the current, and after a narrow escape, thought it best to return to their retreat in the mountains. The negro, anxious for their safety, again found them out, and directed them to a broader part of the river, where he assured them he had provided a boat; but said it was the last effort he could make to save them. They went accordingly, but not finding the boat, gave themselves up for lost, when the faithful negro again appeared, like their guardian angel. He brought with him pigeons, poultry, and bread; and conducted the family, by slow marches in the night, along the banks of the river, until they were within sight of the wharf at Port Margot; when, telling them they were entirely out of danger, he took his leave for ever, and went to join the rebels. The family were in the woods nineteen nights."*

The town of the Cape being somewhat strengthened, the governor, with the advice of the Colonial Assembly, came to the resolution of re-commencing offensive operations against the rebels; accordingly, a small force, under the command of M. Rouvray, ${ }^{201}$ encamped at a place called Roucooa, in the eastern part of the plain. A division of the negroes at the same time took possession of the principal buildings on the estate of the amiable M. Galifet, and mounted on the walls several pieces of heavy artillery, which they had procured from the different harbours on the coast. In this intrenchment, they began to shew somewhat of regular manoeuvres; though they seldom stood more than a single volley in their skirmishes, yet they were repeated with alacrity, and with such success, that they harassed the whites by perpetual alarms, and desolated the country. After their first stock of ammunition was exhausted, it was discovered they had been supplied from the king's arsenal, by some negroes in Cape François; in a short time the small American vessels opened a brisk trade with them in this article, for the sugar and rum of their masters.

In two months of the rebellion, upwards of two thousand white persons had fallen, of all conditions and ages; it appeared, one thousand two hundred families were "reduced from opulence to such a state of misery, as to depend altogether for their clothing and sustenance on public and private charity;"202 one hundred and eighty plantations of sugar, about nine hundred of coffee, cotton, and indigo, had been destroyed, and the buildings consumed by fire. On the side of the rebels it was computed, that upwards of ten thousand had perished in the different accidents attendant on their horrid warfare, besides several hundreds by the execution of the law. It is to be lamented, that a re- 
taliation of cruelty took place upon all rebel prisoners who were taken, which could produce no advantage to those who had already suffered, and might cause additional miseries to the unfortunate objects who afterwards fell in the way of the enemy. One description of punishment at the Cape, has been often quoted from the gentleman who witnessed it. I cannot perfectly coincide with him in the oblique censure conveyed against the unfortunate persons who expressed a degree of satisfaction at the death of their enemies, for it is a difficult sentiment to repress on such an occasion; nor, while I lament, can I deny the necessity of such executions, ON SUCH OCCASIONs; they are not intended as a feast for the philosopher, but they are a gratification to those whose services, whatever their feelings and their sentiments, demand and obtain from all enlightened politicians on all occasions respect.

"Two of these unhappy men," says Mr. Edwards, "suffered in this manner under the window of the author's lodgings, and in his presence, at Cape François, on Thursday the 28th of September, 1791. They were broken on two pieces of timber placed crosswise. One of them expired on receiving the third stroke on his stomach, each of his legs and arms having been first broken in two places; the three first blows he bore without a groan. The other had a harder fate. When the executioner, after breaking his legs and arms, lifted up the instrument to give the finishing stroke upon the breast, and which, (by putting the criminal out of his pain, ) is called le coup de grace, the mob, with the ferociousness of cannibals, called out arretez, (stop,) and compelled him to leave his work unfinished. In that condition, the miserable wretch, with his broken limbs doubled up, was put on a cart-wheel, which was placed horizontally, one end of the axle-tree being driven into the earth. He seemed perfectly sensible, but uttered not a groan. At the end of forty minutes, some English seamen, who were spectators of the tragedy, strangled him in mercy. As to all the French spectators, (many of them persons of fashion, who beheld the scene from the windows of their upper apartments,) it grieves me to say, that they looked on with the most perfect composure and sang-froid. Some of the ladies, as I was told, even ridiculed, with a great deal of unseemly mirth, the sympathy manifested by the English* at the sufferings of the wretched criminals."*

*Will the present writer merit censure if he ventures to observe in this place, for the honor of a sex, of whom he feels a difficulty in recording a slander, that there was not, perhaps, one of these unhappy fair spectators who had not lost, through the means of the victims before them, a father, a mother, brother, or sister, or some of the tenderest connexions in human existence; and that despair, mingled with revenge, assumed the place of a sensibility too exquisite for their loss. This place need not be occupied with instances in the memory of every one, of the change effected in the best dispositions under such cir- 
Having mentioned the residence of Mr. Edwards at the Cape, it may not be amiss to repeat in this place the account he gives of the appearance of the island, to a stranger, at that time. He had returned from Jamaica with the commissioners, who had been sent thither, and to the different neighbouring powers, to request the assistance of troops, arms, ammunition, and provisions; when Admiral Affleck ${ }^{203}$ ordered the Blonde and the Daphne frigates to repair to that place to overawe the insurgents.

"We arrived," says he, "in the harbour of Cape François, in the evening of the 26th of September, and the first object which arrested our attention, as we approached, was a dreadful scene of devastation by fire. The noble plain adjoining the Cape was covered with ashes; and the surrounding hills, as far as the eye could reach, every where presented to us ruins still smoking, and houses and plantations at that moment in flames. It was a sight more terrible than the mind of any man, unaccustomed to such a scene, can easily conceive. - The inhabitants of the town, being assembled on the beach, directed all their attention towards us, and we landed amidst a crowd of spectators, who, with uplifted hands and streaming eyes, gave welcome to their deliverers, (for such they considered us, and acclamations of vivent les Anglois resounded from every quarter).

"The governor of St. Domingo, at that time, was the unfortunate Blanchelande, a marechal de camp in the French service, who has since perished on the scaffold. He did us the honor to receive us on the quay. A committee of the Colonial Assembly, accompanied by the governor's only son, an amiable and accomplished youth, had before attended us on board the Blonde, and we were immediately conducted to the place of their meeting. The scene was striking and solemn. The hall was splendidly illuminated, and all the members appeared in mourning. Chairs were placed for us within the bar, and the governor having taken his seat on the right hand of the president, the latter addressed us in an elegant and affecting oration, of which the following is as literal a translation as the idiom of the two languages will admit:

"We were not mistaken, Gentlemen, when we placed our confidence in your generosity; but we could hardly entertain a hope, that, besides sending us succours, you would come in person to give us consolation. You have quitted, without reluctance, the peaceful enjoyments of happiness at home,

cumstances as these; and, while he eagerly joins his tribute of praise to the sympathy of his brave countrymen in this instance, he cannot forget that the inhabitants of St. Domingo, may not always have seen them in a light equally amiable; so that the contrast, added to the accompanying circumstances, may have excited a risibility, perhaps, convulsive. It is accessory to view all sides of a question which affects the character of a nation.

${ }^{*}$ Edwards's Hist. ch. vi. p. 78. 
to come and participate in the misfortunes of strangers, and blend your tears with ours. Scenes of misery (the contemplation of which, to those who are unaccustomed to misfortune, is commonly disgusting) have not suppressed your feelings. You have been willing to ascertain the full extent of our distresses, and to pour into our wounds the salutary balm of your sensibility and compassion.

"The picture which has been drawn of our calamities, you will find has fallen short of the reality. That verdure with which our fields were lately arrayed, is no longer visible; discoloured by the flames, and laid waste by the devastations of war, our coasts exhibit no prospect but that of desolation. The emblems which we wear on our persons, are the tokens of our grief for the loss of our brethren, who were surprized, and cruelly assassinated by the revolters.

"It is by the glare of the conflagrations that every way surround us, that we now deliberate; we are compelled to sit armed and watchful through the night, to keep the enemy from our sanctuary. For a long time past our bosoms have been depressed by sorrow; they experience this day, for the first time, the sweet emotions of pleasure, in beholding you amongst us.

"Generous islanders! humanity has operated powerfully on your hearts; you have yielded to the first emotion of your generosity, in the hopes of snatching us from death; for it is already too late to save us from misery. What a contrast between your conduct, and that of other nations! We will avail ourselves of your benevolence; but the days you preserve to us, will not be sufficient to manifest our gratitude; our children shall keep it in remembrance.

"Regenerated France, unapprized that such calamities might befall us, has taken no measures to protect us against their effects; with what admiration will she learn, that, without your assistance, we should no longer exist as a dependency to any nation.

"The commissioners deputed by us to the island of Jamaica, have informed us of your exertions to serve us. - Receive the assurance of our attachment and sensibility.

"The governor-general of this island, whose sentiments perfectly accord with our own, participates equally in the joy we receive at your presence, and in our gratitude for the assistance you have brought us.

"At this juncture, the French colonists in St. Domingo, however they might have been divided in political sentiments on former occasions, seemed to be softened into perfect unanimity. All descriptions of persons joined in one general cry against the National Assembly, to whose proceedings were imputed all their disasters. This opinion was indeed so widely disseminated, and 
so deeply rooted, as to create a very strong disposition, in all classes of the whites, to renounce their allegiance to the mother country. The black cockade was universally substituted in place of the tri-colored one, and very earnest wishes were avowed in all companies, without scruple or restraint, that the British administration would send an armament to conquer the island, or rather to receive its voluntary surrender from the inhabitants. What they wished might happen, they persuaded themselves to believe was actually in contemplation.

"The ravages of the rebellion during the time that I remained at Cape François, extended in all directions. The whole of the plain of the Cape, with the exception of one plantation which adjoined the town, was in ruins; as were likewise the parish of Limonade, and most of the settlements in the mountains adjacent. The parish of Limbé was every where on fire; and, before my departure, the rebels had obtained possession of the bay and forts at L'Acul, as well as the districts of Fort Dauphin, Dondon, and La Grande Rivière.

"Destruction every where marked their progress, and resistance seemed to be considered by the whites, not only as unavailing in the present conjuncture, but as hopeless in the future. To fill up the measure of their calamities, their Spanish neighbours in the same island, with a spirit of bigotry and hatred which is, I believe, without an example in the world, refused to lend any assistance towards suppressing a revolt, in the issue of which, common reason should have informed them, that their own preservation was implicated equally with that of the French. They were even accused, not only of supplying the rebels with arms and provisions, but also of delivering up to them to be murdered, many unhappy French planters who had fled for refuge to the Spanish territories, and receiving money from the rebels as the price of their blood.

"The merchants and importers of European manufactures, apprehending every hour the destruction of the town, as much from incendiaries within, as from the rebels without, offered their goods, for ready money, at half the usual prices; and applications were made to Captain Affleck, by persons of all descriptions, for permission to embark in the Blonde for Jamaica. The interposition of the Colonial Government obliged him to reject their solicitations; but means were contrived to send on board consignments of money to a great amount; and I know that other conveyances were found, by which effects to a considerable value were exported both to Jamaica, and the states of North America."*

\footnotetext{
*Edward's St. Domingo, Preface, p. v.
} 
From the northern province the rebellion, rapidly spread to the west; in which quarter it assumed a new appearance; for the revolters being chiefly men of colour, to whom about six hundred negroes had attached themselves, it tended to confirm the opinion and the prejudices of those who conceived the men of colour to have been the original cause of the rebellion. A detachment sent against them from Port-au-Prince was repulsed, and the enemy advanced to set fire to the city; when, happily, some of the mulatto chiefs obtained its redemption, and began to express sentiments of amity, which was attributed, with some reason, to the tardiness of the negroes, at their headquarters, in joining them. Anxious to embrace any opportunity of quelling the disturbance, a planter of eminence, $\mathrm{M}$. de Jumecourt, ${ }^{204}$ undertook to mediate between the two parties, and immediately obtained attention. The effect of this interference was a treaty, called the Concordat, ${ }^{205}$ which was determined upon the 12th of September, between the insurgents of the neighbourhood, and the white inhabitants of Port-au-Prince. The principal provisions were, an amnesty for the past, and an engagement by the whites to admit the full force of the decree of the 15th May. The honourable conduct of the mulattoes in Cape François, precluded any objection in the General Assembly to the ratification of this agreement; from the most rational policy, they extended their care to those who had been born of enslaved parents; military companies of mulattoes were formed, in which men of colour, under certain regulations, were permitted to hold commissions.

Thus circumstances, as far as respected the mulattoes, began to wear a promising appearance, when with that eagerness with which we supplant the remembrance of evil, by the prospect of good, the return of general quiet was contemplated. But a fresh and most tremendous blow was about to fall on this devoted colony, when least intended, by the mother country; whose regard, in this instance, similar to that of some animals, was not less fatal than its vengeance. This was the information, which at this time arrived in the colony, of the repeal of the decree of the 15th of May, which had been the original cause of the present disturbance, and which the white inhabitants had just agreed to allow.

On the accounts arriving in France the beginning of September of the dreadful consequences attendant on this fatal decree, it excited general consternation throughout the trading districts; the loss of the colonial commerce by a civil war between the whites and the mulattoes, was an event to be dreaded from the probable issue; still they never apprehended any interference of the negroes; so blind are we to the approach of political danger. The idea of immense losses, and all the accompanying considerations, produced such an effect upon the merchants principally concerned, that they, with 
their connections, did not fail to press the National Assembly by every mode of appeal and remonstrance, for the immediate relief of the planters from the restrictions then operating so destructively upon the interests of the mother country. There is in every thing a certain satiety, resulting from attainment or enjoyment, which produces relaxation; in the present instance it appears to have had a remarkable effect; for, of all the violent members of the society, "Amis des Noirs," but few appear to have exerted themselves on the present occasion, and that few to have been as little attended to. ${ }^{206}$ In fact, the popular opinion seemed changed to another direction, and the Constituent Assembly being on the point of dissolution, the obnoxious decree was annulled by the sanction of a large majority, at the moment in which it was becoming the medium of peace in the colony.

When it became known in the colony none would believe, (nor indeed was it reasonable they should,) that it had not been brought about at the instance of the planters, and that in consequence they were unsafe with such deceptive negotiators. They had already required repeated ratifications of the Concordat, but now every idea of amity vanished. The people of colour charged the whites with horrid duplicity, and came to the determination that one party or the other must be exterminated; accordingly, throughout the western and southern provinces, they immediately had recourse to arms, and became masters of Port St. Louis, but from Port-au-Prince having been lately reinforced, they could effect nothing more than a dreadful conflagration, which destroyed, at least, one third of the buildings. They established themselves at La Croix des Bouquets in considerable force. The contest here, assumed a more furious character; the negroes in several places joined the mulattoes, and in every action a dreadful slaughter ensued. At Cul de Sac two thousand negroes were left dead on the field, from being placed, as was frequently the case, in the front of the mulattoes. If there remained any invention in cruelty unexerted on former occasions it was now practised, with reiterated vigor, and each party strove how they could convince the other of the fertility of their cruelty, rather than of superiority of power.

At length, about the middle of December, the three commissioners, who had been long before appointed at Paris, for the civil affairs of the colony, arrived, and every one began to hope from them a cessation of the accumulated horrors which everywhere made their appearance. They were named, Mirbeck, Roume, and St. Leger, ${ }^{207}$ the former two had been advocates in the parliament of Paris, and the latter (a native of Ireland) a surgeon by profession. They were neither of them in a situation of life which warranted the appointment, but had arisen through accident, in the confusion of the revolution. They were received with every degree of submission, on the part of the 
governor and inhabitants, by military honors, and a procession to the cathedral.

No sooner were these men in full possession of their offices, than, after announcing the new French constitution, ${ }^{208}$ and the decree of the $22 \mathrm{~d}$ September, (as if every step was to be marked by some additional misfortune,) they proclaimed a general amnesty and pardon to every description of revolters who should lay down their arms, come in within a prescribed time and take the oaths. This measure lost the desired effect with the mulattoes, from being accompanied by the repeal of the decree in their favour; in the opinion of the whites, it justified their enormities; and, tempted the negroes who yet remained faithful, to join those who experienced such an indemnification. The commissioners could not expect to obtain the confidence of the inhabitants, as Mirbeck resigned himself to every kind of low debauchery, while St. Leger employed himself in levying contributions wherever he found an opportunity. The third exerted himself with honesty to the duties prescribed to him, but wanting ability, and acting with colleagues of the character already described, could accomplish very little. The effect of these circumstances, which rendered them contemptible (and being without means to enforce authority), was their return to France, separately, after a residence of three months only.

It was, however, during the stay of the commissioners, or immediately before their arrival, that, in consequence of a resolution of the General Colonial Assembly, copies of the deposition of Ogé, given during the twenty-four hours he was respited, were obtained from the Register of the Council of the Cape; but not till they had been imperiously demanded. By these it was found, that, if instead of being suppressed, as beforementioned, the evidence had been promptly and decisively acted upon, all the horrors which had blackened the colony for the last nine months might have been to a great degree, if not entirely prevented. He asserts upon oath as follows:

"That in the commencement of the month of February preceding, if the rivers had not overflowed their banks, there would have been a rising of the people of colour, who were to have fallen upon the town of the Cape in considerable numbers; that they were then re-united to the number of 11,000 men, from Mirebalais, Artibonite, Limbé, Ouanaminthe, Grande Rivière, and other parts of the colony: that, at the same time, one hundred men of colour left the Cape for the purpose of joining this band: that he was certain that the authors of this revolt were the Declains, free negroes of Grande Rivière, now under accusation; Dumas and Yvon, free negroes; Bitozin, a free Spanish mulatto; Peter Godard, and John Baptiste, his brother, free negroes; Legrand, and Toussaint Mazeau, free negroes; Peter Mauzi, Ginga Lapaire, Charles 
Lamadieu, the Sabourins, John Peter Goudy, Joseph Lucas, free mulattoes; and Maurice, a free negro, all under accusation.

"That the grand movers of rebellion down the coast were, Daguin, under accusation, rebel, of Mirebalais; Pinchinat and Labastille, under accusation: that the most violent partizans of the revolt, who had moved in large parties, were those who had shone in the environs of St. Marc, and who were endeavouring to excite it again: that there were at that moment many people of colour in different quarters, who were very resolute to maintain their projects, notwithstanding the number of those who had lost their lives by engaging timidly in the cause: that he remembered at present the name of one only, the son of La Place, a free quadroon, whose sister he had seen in the prisons, and quitting Limbé to go and raise recruits in the quarter of Ouanaminthe; that these recruits, and risings of people of colour, were continued there under the countenance of Fleury and Hirondelle Viard, deputies of the people of colour to the National Assembly, the one residing at Mirebalais, and the other in the quarter of Grande Rivière.

"That assemblies were yet held in the subterraneous passages near La Crête à Mareau, and the district of Giromen, in the parish of Grande Rivière; and that if he could be conducted to these places, he would strive hard to take the chiefs of the rebellion: that the agitation in which he found himself under his present circumstances, did not permit him to enter into more circumstantial details: that he would acquaint us with the remainder when he became a little more tranquil: that it occurred to him at the moment, that Castaing, a free mulatto of this dependency, is not concerned in any manner in the present affair, but that if his brother Ogé had followed the persuasion of Castaing, he would have been brought into much greater extremities."

The commissioners for taking the deposition then stated, that Ogé having heard the above read on the day after it was made, and being again sworn, he confirmed it in every respect, adding, "That the two Didiers, brothers, free mulattoes, whom he had seen but that time, and that John Peter Gerard and-Caton, free mulattoes of the Cape, were employed to gain a party of the Grande Rivière; that they kept together by the day, and dispersed at night."

They mention, that on being confronted with James Lucas, who had accused him, of threatening to hang him, he said, "it was necessary to tell them why Lucas had not insisted upon his explaining the reason of that threat, lest it should cost him his life: that the said Lucas had been always foremost in every perpetration of horror, the most active seducer of the blacks, and promoter of massacre, and had of necessity been restrained by him several times, on occasions which he repeated.

“That Fleury, Perisse, and L'Hirondelle Viard, arriving in, the colony, the 
two former were landed at Aquin, and left at the house of Dupont, but that L'Hirondelle Viard proceeded to the Cape.

"That La Place, whose father was then in prison for raising recruits at Ouanaminthe, was of the number of those who marched from Limbé against the Cape; that to avoid suspicion, he went to Port Margot, where he lay concealed for several days; that the senior La Place had told him that he knew his neighbour, who was a white man, would not inform against him, though he knew all his proceedings; that he was sure Girardeau, then in prison, would declare nothing, because he was too much his friend to betray him; and that, if he were denounced, he should be forced to denounce many others, both in Limbé and other quarters.

"That he had omitted to mention, on the subject of Lucas seducing the slaves, that Peter Maury had brought thirty slaves to Lucas, whom Ogé and his brother sent away again, the people of colour saying that it was a future supply; that he had on the same occasion a dispute with the tallest of the Didiers, whom he wished to fight with pistols, on account of his treasons; that he had seen a short note written by Peter Maury to John Francis Tessiers, by which he signified, that he continued to collect together, and that the negro Coquin and the widow Castaing, armed with pistols mounted with silver, and a short sword which Maury had furnished, watched every thing that passed, and gave an account every night to Maury; which was all that the accused could declare at present, conjuring the commissioners to be persuaded, that if it were possible to obtain mercy, he would willingly expose himself to every danger, to arrest the chiefs of the rebellion, and that in all circumstances he should prove his zeal and respect for the whites."*

He was, however, as before stated, immediately at the close of the confession, hurried to execution, and the whole suppressed, without any proceeding upon it whatever.

The matter of the deposition has been particularly given, for this reason, it exhibits the manner of the rebellion, and the quality of its leaders, who appear to have been well acquainted with its various manoeuvres; and if the principal persons mentioned, particularly Pinchinat, Castaing, and Viard, had been arrested at that time, they would have been prevented forming their attack of the 25th August. - Thus does party, which, as before described, in dividing the colony of St. Domingo, unconsciously act against itself, and a want of political foresight ruin the best intentions.

*See the original paper in the Appendix. [This French transcription entitled "Testament De Mort D’Ogé" can also be found in the additional notes section of Edwards's Historical Survey.] 
To add to the effects of the disclosure of this extraordinary error, the talents of the black leaders began to appear in an instance in the conduct of one, Jean François, whose followers having destroyed all the provision grounds, and devoured all the cattle on the plain, he compelled them to plant in the mountainous districts provisions for their future subsistence; thus judiciously preparing for an indeterminate prolongation of the war.

In the mother country fresh changes continuing to take place, new horrors were prepared for this unhappy colony from that quarter. The jacobin party, and the society of Amis des Noirs, were, at this period, resuming a powerful ascendancy, and on the 29th of February, Garan de Coulon proposed an abrogation of the last decree, (of September 24,) and a general amnesty throughout the French colonies; the formation of new colonial assemblies, whose opinions were to be submitted to them, and who should particularly aid in the abolition of negro slavery. This inconsistent plan fell immediately to the ground; but it gave birth to another, about two months after, which was considered little more beneficial to the miserable inhabitants of the colony.

The decree of the $4^{\text {th }}$ of April consisted, as related to St. Domingo, of the following items; after an acknowledgment of the political equality of the free negroes and people of colour with the whites:

I. A re-election of colonial and parochial assemblies, after the mode of the decree of the 8th March 1790, and the subsequent instructions.

II. The eligibility of free negroes and people of colour to votes and seats in the legislature, upon certain qualifications mentioned in the fourth article of these instructions. ${ }^{209}$

III. IV. V. VI. VII. Three civil commissioners to be named, to enforce the decree, to dissolve the present colonial assemblies; to take every measure for convoking the others, and establishing peace and order; to determine provisionally upon all questions relating thereto, conditionally reserving an appeal to the National Assembly; to procure correct information of the authors of the troubles; to send the guilty to France for accusation, transmitting constantly minutes of their proceedings, and of the evidence they collect; to call forth the public force to their protection, or the execution of orders.

VIII. A sufficient force of National Guards to be sent to the colonies for the various purposes.

IX. X. The Colonial Assembly to transmit their sentiments on all subjects to the mother country; and to send delegates with them proportional to the population.

XI. All former decrees, not hostile to the present, to continue in force.

To perform its functions, three commissioners, named Sonthonax, Polverel, and Ailhaud, ${ }^{210}$ were appointed, (who were of the most violent of the jacobin party,) and with them a force of eight thousand men, under officers 
whose principles were well known. M. Blanchelande was superseded by M. D'Esparbes ${ }^{211}$ under the title of commander in chief. The commissioners arrived at Cape François on the 13th of September. They found the governor and the Colonial Assembly involved in disputes, and therefore sent him prisoner to France, and prepared for the first article of their decree to be carried into effect.

The arrival of these men, (from the unfavourable impressions produced by their predecessors, ) instead of causing peace in the colony, which appears to be the first intention of the new decree, produced an effect entirely opposite. Amidst such a contrariety of enactions as had agitated them from the mother country the result of men coolly sitting down to provide remedies for the worst of circumstances, at so great a distance from the scene of action, and unaffected by its immediate difficulties, the people were in doubt what was intended by the new commission, they sent delegates from all quarters to inquire their intentions; some had concluded that they were merely come to exact money, but all had an indifferent opinion of their projected operations. The commissioners answered generally, and certainly with dissimulation, that their views went no farther than to enforce the decree of the $4^{\text {th }}$ of April, in favor of the people of colour, and to settle the future state of the colony, so as to ensure its permanence.

Notwithstanding this declaration, the inhabitants were not perfectly satisfied of their probity, and, when they found that the commissioners corresponded with the mulatto chiefs in all parts of the colony, they did not conceal their mistrust. In consequence the commissioners immediately avowed their intentions, and, strengthened by the co-operation of the people of colour, declared themselves the protectors of the negroes, and mulattoes, and seized the persons and effects of those who were most eager to oppose their measures. Many were sent to France, among whom were the superior officers of the regiment of the Cape.

When the white inhabitants denied the election of the new Colonial Assembly, they instituted an intermediate commission (commission intermediaire) as a legislative council, formed of twelve persons, six of whom had been members of the last assembly, and six mulattoes. To these they delegated a part of their power, chiefly for financial purposes. With that promptitude for which the reign of the jacobins in France was distinguished, when the governor D'Esparbes claimed a share of dominion, he was arrested, and conveyed to France as a state-prisoner: when four of the white members of the intermediate commission objected to a financial measure of $M$. Sonthonax, he commended their frankness, invited them to supper; and, when they came, they were surrounded by a detachment of military, and conveyed on board of ship as state-prisoners. One of them was taken prisoner in the ship in 
which he was confined, and brought to England, where Mr. Edwards saw and rendered him service. ${ }^{212}$ Another of the triumvirate ${ }^{213}$ dissenting from the union, more timely seceded from his situation, and returned voluntarily to the mother-country.

The affairs of France, now drawing towards an apparent crisis, occupied the Executive Government so fully, as to leave the two commissioners, Sonthonax and Polverel, absolute masters of the colony. They eagerly embraced every advantage of such enormous power, which was increased by the attachment of the military, and a considerable portion of the revolters, whom they had found means to secure to their interest. The same scenes which occupied the whole of France at this period, were acted again in St. Domingo. The inhabitants complained in the bitterest manner of their wrongs, but it produced no other amendment, than the appointment, as governor, of M. Galbaud, ${ }^{214} \mathrm{a}$ respectable officer of artillery, and a proprietor in the colony, whom they dispatched (on the declaration of war against Great Britain and Holland), with directions to put the colony in a proper state of defence against a foreign enemy.

Again were the arrangements of the French government respecting this unhappy colony, the cause of commotion and bloodshed. When M. Galbaud arrived with his suite at the Cape, they were received with transport by the municipality and the inhabitants, immediately took the oaths, and entered on his government; but when the commissioners, who (at the time of his landing) were quelling an insurrection in the western province, found he was invested with powers independent of their authority, they immediately set about disrobing him; and the readiest way being, by an existing decree, which prohibited any proprietor of an estate in the colony from holding the government, they attacked and defeated his claims on that score. They ordered him to depart on board the sloop La Normande, for the purpose of returning to France, and invited M. de la Salle, ${ }^{215}$ whom they had previously made commandant at Port-au-Prince, to receive the command of the colony in the name of the French republic.

The indignity thus offered to Galbaud was not tacitly received by his brother, who collected from the inhabitants, the Cape militia, and the seamen in the harbour, a strong party to support his authority. At the expiration of seven days the two brothers landed, at the head of a powerful party, and proceeded in array towards the government house, where the commissioners were prepared, with a greater force, to receive them; being defended by the people of colour, a body of regulars, and a piece of cannon. A bloody contest ensued; but, in consequence of the seamen getting possession of a wine-cellar, the governor's party were compelled to retire and take refuge in the royal arsenal, where they remained the whole of the night. In the ensu- 
ing morning the governor issued a proclamation, inviting all good citizens to join him, and several skirmishes took place between the two parties, but without any remarkable occurrence, till Galbaud's brother being taken prisoner by the commissioners, and the son of Polverel by the party of Galbaud, it was proposed by the governor to exchange the one for the other. "My son," replied Polverel, "knows his duty, and is prepared to die in the service of the republic!"216

The fatal stroke still remained to be put to the fate of St. Domingo, as a colony of France. The white inhabitants had, from the time of the arrival of the commissioners, anticipated the measure; yet with that want of discernment which had led them into their difficulties; thereby creating a degree of stupor amongst them, inasmuch that they had not been able to attempt any method to divert the blow.* This was the emancipation of all the slaves in the colony. When the intentions of Galbaud became known to the commissioners, and that he was supported by so large a body of seamen, they immediately dispatched agents to call to their assistance the revolted negroes, with the offer of a free pardon for the past, the plunder of the city at present, and perfect freedom in future. The first to whom they applied among the leaders, and those of the most conspicuous eminence amidst the blacks, refused the invitation; but another, named Macaya, ${ }^{217}$ formerly a negro slave, accepted it, and on the 21st, about noon, entered the town with upwards of three thousand slaves, and begun an indiscriminate slaughter. M. Galbaud and his adherents had, despairing of success, on the same morning, retired to the ships, to which the whole of the whites endeavoured to follow, when their retreat being interrupted by the mulattoes, all that could not escape were immediately murdered. This confusion and slaughter continued through the whole of the two succeeding days, at the end of which they set fire to the principal buildings, and more than half of the city was consumed. The commissioners themselves, astonished at the devastation they had occasioned, and intimidated by the conduct of the allies they had chosen, sought protection under the cover of a ship of the line.

Nor, were the mulattoes less amazed and vexed, when they found that the exertions against the whites, which they supposed confined to their interest

\footnotetext{
*“J'avais écrit dans la colonie, dès 1792, que c'était le plan confié aux commissaires. On pouvait employer des mesures vigoureuses pour l'empêcher, elles étaient indiquées, \&c, Mais l'esprit de vertige qui a accompagné tout ce qui s'est fait pour empêcher les maux de la révolution eut lieu dans cette circonstance, \&c." Charmilly, Let. p. 65. [I had written, while still living in the colony, as soon as 1792 , that this was the plan given to the commissioners to execute. Vigorous methods could be employed to forestall it; such methods were even necessary, etc. But the stupor that accompanied everything done to prevent the ills of the revolution occurred in this circumstance, etc."]
} 
only, extended to the liberation of their own slaves, on whose labour their fortunes depended; they now perceived that they had been made the tools of the Amis des Noirs, in obtaining their darling object, the emancipation of the whole body of negroes. There is an enthusiasm and a fanaticism in politics, as well as religion, equally dangerous in both, which, with an unaccountable bigotry to their projects, must have led the society to urge, such excesses; they could not have originally desired the effusion of human blood only, as hath been asserted, however strongly they might afterwards have imbibed a spirit of revenge against their opponents. - Such is the spirit of Jacobinism, endless, and undirected by any social principle.

The effect of the declaration of freedom to the slaves themselves, was such as might be naturally expected from a people of their character and condition. A considerable part remained in their former situation with their masters, in preference to a change; a greater number joined the party of the commissioners, who manumitted them; and, perhaps, the greatest number, fearful their liberty would not be permanent, RETIRED IN SAVAGE BODIES TO THE MOUNTAINS.

During the four years, in which divisions and tumult had reigned in St. Domingo, many emigrations took place to the continent of North America, and to the several neighbouring islands. These, of course, increased as security grew less, and more particularly since the first revolt of the slaves in the northern province. To them were now added Galbaud and his party, who met, as the others had done, an asylum wherever they fled. The principal planters, however, still remained behind, attached to the colony, either lingering with hopes of returning tranquillity, or planning schemes for the independence of the island. Among them were some, conversant with the economy of politics, more active and able than those who had hitherto been distinguished; who looked forward from the year 1791, to some arrangement with the crown of Great Britain, that should place the island, and its proprietors of their description, under the government, and protection of that puissant nation; and there were a few others desirous of attaching the colony to Spain. They all saw, in the last desperate proceeding of the commissioners, nothing left to hope for from the judgment of the mother country. The latter, therefore, employed a party to apply to the government of Spanish St. Domingo, who were unsuccessful. The former, with more judgment, determined upon making a formal application to Great Britain on the same subject: for this purpose they commissioned their colleague, M. de Charmilly, a man of strong mental powers, and of great activity, to communicate with the British ministry, and to bring their plans, so long in agitation, to an issue.

This gentleman, it will have appeared from the preceding part of this chapter, possessed a considerable interest in the island, and an extensive knowl- 
edge of its concerns, which had given him a share in several of its legislative bodies, where he appears to have long communicated his inclination towards the measure now confided to him.

The British ministry, hitherto deaf to any proposition of attempting the capture of St. Domingo, became rather more inclined from the occurrence of a war, which was commenced against the new government of France. More than a negative consent it could scarcely be called, for the arrangement was left to the option of the government of Jamaica, and, in fact, whether any thing should be ventured its attainment. An intercourse of the most honorable nature to the British character, had already taken place between the unhappy colonists of St. Domingo and those of Jamaica, who raised considerable subscriptions for their aid, and applied them in the way best calculated for their benefit, under the friendly auspices of General Williamson, ${ }^{218}$ the governor; and when allured by the professions of the governor of Spanish St. Domingo, ${ }^{219}$ they thought they could succeed better there, they were forwarded according to their wishes, Captain Rowley ${ }^{220}$ undertaking their safe convoy. Mr. Henry Shirley, ${ }^{221}$ of the House of Representatives, appears to have exerted himself in a manner which deserves the highest eulogy. When the Spanish government refused to afford them an asylum in their island, M. de Charmilly lost no time in setting off for Jamaica, and by his representation of the state of St. Domingo, of the disposition of the planters towards the British nation, and the facility of obtaining some ground with a very small force, he prevailed upon General Williamson to grant him the aid he required; a force certainly inadequate to the invasion of such an island under any circumstances.

The French commissioners, Sonthonax and Polverel, who still retained a disputable power in St. Domingo, were quickly acquainted with the intended invasion, and began to prepare for it accordingly. Their force consisted of the remnant of the troops they brought with them from France, a body of whites who continued attached to their cause, and the slaves which had joined them, of which power little could be judged, being dispersed throughout the provinces. To render themselves in a better state to repel the invaders, they had recourse to a still more determinate step, that of procuring the aid of the whole of the negro slaves. They, ${ }^{*}$ therefore, declared by proclamation, "That every kind of slavery was abolished, and that the negroes were thenceforward to consider themselves, and to be considered as free citizens." $†$

\footnotetext{
*It was signed only by Polverel, who was alone at Port-au-Prince, from whence it was issued. Sonthonax was in the northern province.

†It has been asserted that they were still to exercise the same labour, but in the condition of annual servants. Those acquainted with the proclamation, recollect no such excep-
} 
The inhabitants of St. Domingo, at this period, might be considered under the following classes:-

1. The principal, and most intelligent of the planters, who desiring tranquillity, and the renovation of their property, (which they could not expect from the distracted state of France,) looked to the protection of a powerful nation, and perhaps most to that of England.

2dly. The remainder of the white planters, who had become republicans, and chose rather to support the commissioners as the representatives of the republic, probably from principle, than to adopt any other country, and to sacrifice their immediate interest to their allegiance: - the impartiality of history demands that this class should not receive any harsher description.

3dly. A number of those persons, to be found in all countries, particularly when under embarrassed circumstances, who, having nothing to lose, and frequently without principle, are ripe for enterprize; many of whom, by stratagem, or other means, had obtained the property of absent planters, availing themselves of the state of the colony, to their own aggrandizement. The mulattoes I consider as partaking of each of these characters: and,

4thly. The emancipated slaves, the most important body of the whole, in whom were comprised almost every description of character. Some of them had already exhibited talents of a superior nature, both in civil and military government, among the revolters; others had proved themselves equal to many of the higher purposes of life, and they were possessed at least of eminent physical power.

If we might pause for a moment, to consider the propriety, or impropriety of the accession of the British government to the proposition of M. de Charmilly, we might lavish censure on those who could, with such small hopes of success, enter into a plan of such extent, with so little information on its nature, and such small means for its execution; but we will leave it for the partizan, with every local or supposed advantage of judging, to condemn those without; and who, in the complex dominion of a country with many dependencies, and with as many jarring interests to reconcile, must be sometimes hurried into arrangements which may not prove ultimately successful, notwithstanding their discrimination. Sometimes, too, ambition may be sup-

tions, which would, in fact, have rendered the abolition a nullity. [Of the "Decree abolishing slavery in the North of Saint-Domingue" (1793), Edwards writes that the Proclamation "expatiates upon the necessity of labour, and tells the negroes that they must engage to work as usual, from year to year; but that they are at liberty to make choice of their respective masters," 143n.] 
posed to intrude; nor will the brave and intelligent De Charmilly complain of having also attributed to him, in no slight degree,

“The glorious fault of angels and of gods!" 222

That those who had determined on adopting the British government, were prepared to sustain their engagements, there is no doubt, but they formed one class only of the numerous remains of a vast population; while the remainder had the strongest motives for opposition - interest, party, and relief from slavery. If, even the two former ideas could have been overcome, every colonist, or other individuals acquainted with colonial affairs might have known, from the example of the black Charribes of St. Vincent, or the Maroons in Jamaica, that the last was not to be easily subdued.* Retaining all the advantages they had derived, in many instances, from the partiality of favorable masters, and particularly in the experience of the different controversies, and conflicts that had taken place, they had become, what is impossible, without an intercourse with them to conceive; an unique people.

It was hoped, however, that interest might assimilate the whole of the whites; that the hostility of the people of colour might be nearly exhausted; and that the negroes were not so far alienated from their duty, as never to be expected to return; still much was left, with great reason, to the bravery and ability of those who were to conduct the enterprize.

Under such circumstances, an armament was formed at Jamaica, composed of the 13th regiment of foot, seven companies of the 49th regiment, and a detachment of artillery, under Captain Smith, furnishing about 870 rank and file. With the first division of these, consisting of about 679 rank and file, Lieutenant-Colonel Whitlocke ${ }^{\dagger}$ arrived at Jeremie on the 19th of September, and took possession of the town and harbour on the following morning. Agents from M. de Charmilly had already arranged every point, the troops therefore disembarked without the smallest opposition. British colours were hoisted on the forts, with royal salutes, and the inhabitants immediately swore allegiance to the king of Great Britain. Commodore Ford ${ }^{223}$ having at that time the command on the Jamaica station, accompanied in the Europa man-of-war, the transport of the troops, and assisted in the necessary formalities of receiving the submission of the place. The Mole of Cape St. Nicholas, (the Gibraltar, or key of the Antilles,) immediately followed. To it,

\footnotetext{
*See Dallas's History of the Maroons, also Edwards's British West Indies.

†Now Major-General Whitlocke. [John Whitelocke (1757-1833) led an expedition to the Western coast of St. Domingo. After an initial setback at Tiburon, he received reinforcements and went on to conquer nearly the entire western coast of the French colony.]
} 
on the next day, according to the pre-arrangement, the commodore directed his course, and, on the 22nd, landing the marines only, took possession of the fortress and harbour. This port was soon after supplied by the grenadier company of the 13th regiment, to which was added the second division of the armament, comprising five companies, of forty men each. The town of St. Nicholas, however, did not capitulate, for its inhabitants were hostile to the British, and immediately joined the republican army.

The great extent of important coast thus coming into the possession of the English, excited the most sanguine prospects, and determined all parties in the prosecution of an enterprize which promised such brilliant success. We shall quit the exertions of the commissioners, who were at present employed in defensive operations about the capital, while their new allies, the slaves, were forming a separate interest in the interior, to follow the new possessors of the south-east and north-west districts of the colony in their united movements with the brave colonists, by whom they appear to have been cordially and respectably joined.

The neighbouring port to Jeremie, first attracted the attention of Colonel Whitlocke, who was instructed, that it would be of importance to the security of La Grand Anse. He therefore sailed for Tiburon with his whole force, and arrived in the bay on the 4 th day of October; a planter, named Morin Duval, ${ }^{224}$ was to proceed by land with five hundred colonial troops, ${ }^{225}$ and to form a junction at an appointed spot; but, unfortunately, a piece of cannon compelled Colonel Whitlocke to disembark three miles distant, and the wind intercepted the signal of Duval, who in consequence wandered about the whole of the day, in imminent danger, with a faithful and intelligent negro called John Vina, ${ }^{226}$ whose men formed a part of the five hundred. At the same time, a reinforcement of cavalry from Aux Cayes joining the enemy, Colonel Whitlocke was obliged to return, with a loss of twenty men, without effecting his purpose.

A small check is sufficient to turn the tide of joy when it is full set in, consequently this defeat was magnified in the opinion of those, who had before only to step into possession of wealthy towns, and with well-filled magazines. It had the effect of disheartening the troops; to whom General Williamson sent as encouragement, till reinforcements, which were expected from England, should arrive, the remaining part of the 49th regiment, the 2oth regiment, and the 1st battalion of the Royals. This addition not only served to cheer the drooping spirits of the soldiery, but to increase the confidence in the planters, as to the intention of Great Britain following up the enterprize; accordingly, the parishes of Jean Rabell, St. Marc, Arcahaye, and Boucassin, became attached to the territory of Great Britain. From this period until the 
middle of January, no farther advance was made; when the colonists, who had established a port at Irois, a few miles distant from Tiburon, in order to overawe that place, having, for security, erected a fort in the centre of a marsh, which considerably affected their health; they became impatient to re-attempt that port, and the Privy Council of La Grand Anse eagerly solicited Colonel Whitlocke for the purpose. On the 21st of January, therefore, the commodore received the troops on board at Jeremie; and on the $2 \mathrm{~d}$ of February, in the evening, they arrived off Cape Tiburon. The commodore stood out to sea, and Capt. Rowley, a brave and sensible officer, had the management of the attack; while Lieutenant-Colonel Spencer, ${ }^{*}$ no way inferior in any quality, commanded the troops, which consisted partly of colonists, and a detachment of the British army. The enemy appeared in considerable force, but the fire of the ships cleared the beach; they came forward again, and directed their musquetry at the boats; when the troops landing, and forming instantly, with the gallant Colonel Spencer at their head, entirely dispirited the defenders. Their line was routed with considerable slaughter, and one hundred and fifty surrendered prisoners of war. In this, as in the former instance, they found the magazine well stored with ammunition. The loss, on the part of the victors, was extremely small.

By this victory the whole of the bay, or bight of Leogane, became under the command of the British squadron; and nothing was wanting but an additional armament, which was constantly expected, to secure Port-au-Prince, the capital of the colony, to which every one looked with an anxious eye.

In the interim, however, it was conceived expedient to obtain the possession of the ancient town of Port-Paix, an important post on the northern side of the island; and Colonel Whitlocke was induced to attempt procuring its surrender by the offer of a sum of money to the general who commanded in it. This was M. Laveaux, ${ }^{227}$ a man of broken fortune, though of a good family, who had been long in the service, and had a troop of dragoons before the revolution. Whether Colonel Whitlocke formed his calculation alone upon this circumstance, or, as hath been mentioned, his orders were improperly executed, cannot, at present, be determined; but, it is certain, that General Laveaux possessed considerable confidence from the republican army, and that he did not abuse it. The offer was made in a letter sent with a flag, and $5000 \mathrm{l}$. the sum stipulated. He silently read the letter, and asked the officer, upon his honour, if he knew its contents; upon being answered in the nega-

\footnotetext{
*Now Major-General Spencer. [Sir Brent Spencer (176o-1828) would later distinguish himself fighting against the French in Egypt and Spain. Prior to the British evacuation of St. Domingo, he commanded British and colonial troops against Toussaint.]
} 
tive, he told him, that, if he had known them, he should have immediately been hung on a gibbet. He then read the letter aloud to those around him, and returned the following answer:-

"You have endeavoured to dishonour me in the eyes of my troops, by supposing me so vile, flagitious, and base, as to be capable of betraying my trust for a bribe: this is an affront, for which you owe me personal satisfaction, and I demand it, in the name of honour. Wherefore, previous to any general action, I offer you single combat until one of us fall; leaving to you the choice of arms, either on foot, or horseback. Your situation as my enemy, on the part of your country, did not give you a right to offer me a personal insult; and, as a private person, I ask satisfaction for an injury done me by an individual."*

Of the character of Gen. Laveaux, a midst the conflicts of party, in which he was situated, it is difficult to judge. But he certainly possessed talents; and, if there were no other cause for this proposition than his circumstances, the misfortunes of a brave man should be respected. The situation and character of Col. Whitlocke, however, demanded an attention to every expedient object. ${ }^{\dagger}$

The fortress of L'Acul, in the vicinity of Leogane, was next invested, and carried on the 19th of February, but with the loss of two valuable officers. At four in the morning, the flank-companies, a detachment of the royal artillery, and of the 13th regiment, with some colonial troops, two five half-inch howitzers, and two four-pounders, marched from Leogane, under the command of Colonel Whitlocke; while two hundred colonial troops, and a few British artillery, under the orders of the Baron de Montalembert, ${ }^{228}$ which were previously embarked, were to land and attack the fort from the sea at an hour appointed. Colonel Whitlocke moved forward on the great road, and took post just without cannon-shot; while Capt. Vincent, with the light infantry of the 49th, and about 80 colonial troops, were dispatched by a higher road to combine their effects with those of Montalembert, in favour of the main body. But, unfortunately, from the intoxication of the captain of one of the transports, notwithstanding the ability and propriety of the other, the King, Montalembert could not be landed, and all the service they could perform, was

*This answer is copied from Edwards, who is not contradicted by De Charmilly, though its terms differ from another copy in the possession of the author. [See Edwards, Historical Survey, 152-53.]

†Though the impartiality we wish to preserve on all occasions demands that the preceding facts should be fairly stated, we wish to offer a sincere tribute of respect to the conduct of Major-General Whitlocke, as an officer of undoubted bravery, honour, and talents of the highest order. [Edwards notes, "Colonel Whitelocke, I suppose, rejected the challenge," Edwards, Historical Survey, 153.] 
that of diverting the attention of 200 negroes and mulattoes, who were kept on the beach to receive them. The enemy cannonaded from seven till eleven, when Colonel Whitlocke ordered Captain Smith, with the howitzers and cannon, to advance, and fire upon the fort, supported by the light-infantry of the royal, and 13th regiments, under the command of Lieutenant-Colonel Spencer. On the discovery of a failure on the sea-side, it was determined to storm the fort, and Colonel Spencer, with the grenadiers of the 49th, and light-infantry of the 13th, proceeded to join Captain Vincent on the MountainRoad. Between four and five the two columns proceeded, and the main-body immediately received a heavy fire of cannon and musquetry. It was ordered to advance and gain the fort, which it executed with the utmost rapidity, and with more effect than could have been expected, by so small a party. After obtaining possession of the fort, considerable damage was sustained from the explosion of one of the buildings, which had been filled with combustibles by the commander, on finding he could no longer defend it. It was fired by a negro recently from the coast of Africa, who is supposed not to have known what he did, or, the use of powder; he set fire to an artillery-waggon on the spot, and perished, with thirteen privates of the besiegers and two officers, Capt. Morshead, of the 2oth grenadiers, who had been previously wounded in the body, and Lieutenant Caulfield, of the $62 \mathrm{~d}$. They were buried with military honours, attended by the British garrison. Lieutenant $\mathrm{M}^{\mathrm{c}}$ Kerras, ${ }^{229}$ of the engineers, and Captain Hutchinson, of the royals, though both wounded in the attack, continued on duty till the fort was carried. Lieutenant Tilnin, of the 2 oth grenadiers, was wounded, but recovered.

Thus the first sharp action that was fought, ended successfully; but the same was not the case with the second, which occurred immediately after, though of less importance. This expedition was intended to punish the treachery of the German inhabitants of Bombarde, before described. It was composed chiefly of marines from the different ships, who were performing the garrison-duty of the Mole with the regular troops, under the orders of Lieutenant-Colonel Spencer, and Lieutenant-Colonel Markham; ${ }^{230}$ two Frenchmen accompanied them, M. Deneux, ${ }^{231}$ the major of artillery, and Lieutenant-Colonel Charmilly, who was necessary every where, not only on account of the great responsibility under which he lay to all parties, but from the general want of knowledge, in the language of the country by the commanders.

The detachment set off at nine o'clock at night, and arrived at the redoubt $^{232}$ about three in the morning, having marched fifteen miles in the woods and mountains. It was defended by 150 German soldiers, intrenched, with three pieces of cannon. They were relieving guard at the moment, when 
the troops were discovered, and the alarm-gun fired. Colonel Markham, with half the detachment, attacked the redoubt in flank, while the remainder approached the gate. The enemy suffered them to arrive within half-gun shot, when having challenged three times, calling - "Qui vive?" Colonel Spencer answered, "England!" and immediately the assailants received a fire, perfectly well directed, and kept up with so much order and briskness, that the enterprize was obliged to be immediately abandoned. Several of the officers advanced as far as the ditch, supported by some grenadiers, but not being sufficiently numerous; all retired in confusion. M. De Charmilly (who recounts the affair) was at the side of the ditch, ten feet from the entrenchments, which served as a rampart, and was wounded by several musquet-shot: one ball struck the plate of his belt, and another the barrel of a brass-pistol in his pocket, either of which must have killed him. There were sixteen men killed, and twenty-six taken prisoners; the remainder retreated without any further misfortune than the hardships experienced by a small party, which I shall describe from the authority of the officer just mentioned; ${ }^{*}$ the retreat being very precipitate, there was no signal to indicate it, so that many of the people strayed from the main body.

A young and brave officer, Lieutenant Garstin, of the first regiment of royal English infantry, who was with his detachment, found, at day-break, that he had strayed from the road with eight men belonging to his company. All his endeavours to find it led him farther from it; when, towards the middle of the day, he fell in with a German patrole, consisting of six men, who desired him to surrender. He answered by threatening to fire upon them if they attacked him. Seeing him so determined, they contented themselves with following, while he continued to stray still farther from his intended point. They acquainted him with it, and again pressed his surrender, which was as constantly refused. The Germans, fatigued with following him over the dry and sandy plains, on the approach of night retired; they continued to wander, fainting with hunger, thirst, and fatigue; at the end of two days and a night, during which time two of the number died of want and weariness, having found nothing but the fruit of Indian fig-trees and aloes, they arrived, by a fortunate chance, at the landing place of the Platform, a republican port, which had been destroyed three weeks before by Captain Rowley. Here they found an old abandoned fishing-boat, in which they embarked without provisions,

\footnotetext{
*M. De Charmilly, though extremely and often justly severe with Mr. Edwards in the errors which crept into his Historical Survey, is, occasionally, rather incorrect himself in his descriptions: an instance of which, it is apprehended, occurs in the affair of Lieut. Garstin, as it also did in a transport which he calls the King Grey.
} 
fresh water, or a sail, with very bad oars. They arrived on the morning of the third day at the entrance of the bay of the Mole St. Nicholas, from whence the fishermen brought them into the town.

During this retreat from the enemy in one quarter, they were giving a repulse in another of considerable importance. One of the lieutenants of Rigaud, with 1500 men of different colours, had prepared to attack the important post of L'Acul de Leogane; on the day preceding the intended attack, they were intercepted by 400 men, (only 150 of whom were of the British legion, and the remainder of the militia of Leogane,) under the command of the Baron de Montalembert, who completely routed them, and took a piece of cannon. They charged with fixed bayonets, and upwards of 300 of the enemy lay dead upon the field.

The same success occurred in the attack which was made by the mulatto officer Rigaud, of Aux Cayes, on the fort of Tiburon, the possession of which had cost so dear. His force consisted of 2000 men, chiefly revolted negroes, with two pieces of cannon, four-pounders. They surrounded the fort about three in the morning, and it was defended with much spirit till a quarter before nine, notwithstanding the great battery being entirely dismounted, and a number of men killed and wounded by the explosion of a quantity of gunpowder, when the besieged (a party of whom, under the command of Jean Kina,${ }^{233}$ had before made a sortie on one side,) quitting the fort, routed the assailants with great slaughter, 170 of their number being left dead on the field. The pleasure of the victory, was damped, when it was found that out of the small number of British that were in the fort, 28 had fallen, besides 100 of the colonial troops. This affair, notwithstanding, was one which conferred equal honor on all the forces, and the Chevalier de Sevré, ${ }^{234}$ in his dispatch on the occasion to Colonel Whitlocke, pays a tribute to the small garrison, which so distinguished itself on the occasion.

Still, during these occasional successes, the general spirit of the colony began to droop, on perceiving, that during a period of eight months, not the smallest re-inforcement had arrived from Great Britain, nor was it only in fears, that this despondency and diffidence began to shew themselves, for a parish which, a few months before, had voluntarily adopted the protection of England, (that of Jean Rabell,) ${ }^{235}$ compelled the officers of the garrison to deliver up their post to Laveaux; and it was much feared, that many others would follow their example. This defection was less felt, as between four and five thousand persons had returned to the plantations from their different asylums.

At this moment, so temporarily inauspicious, when the British interests seemed devoted to contempt, on the 19th of May, the Belliqueux, the Irre- 
sistible, and the Fly sloop, cast anchor in the harbour of Cape St. Nicholas, with the $22 \mathrm{~d}, 23 \mathrm{~d}$, and $41 \mathrm{st}$ regiments of infantry, under the command of Brigadier-General Whyte. ${ }^{236}$ All spirits were now resumed, the despondency which overwhelmed the colony disappeared, and all seemed, as from a general impulse, to expect the reduction of the capital of Port-au-Prince, and a considerable share of wealth from the capture.

These troops were detached by General Sir Charles Grey ${ }^{237}$ from Guadaloupe, after the reduction of the French Windward Islands, where they had experienced a severe campaign, and where their services were yet wanted. Great evils were ascribed to the circumstance of withdrawing them - the loss of the island they left, and the occasion of the largest and most expensive armament that ever sailed from England to the West Indies, with other misfortunes.*

Commodore Ford had, for a considerable time, blockaded the harbour of Port-au-Prince, to the great discouragement of the commissioners; on the arrival of this re-inforcement, although inferior to what had been hoped, it was considered best that the expectation of the inhabitants should not be disappointed. General Whyte, therefore, having landed his sick at St. Nicholas, received in their place 160 of the garrison, and proceeded to the rendezvous, in the road of Arcahaye, on the 23d of May, to concert the enterprize with the Commodore, and receive such of the colonial troops as were to cooperate. On the zoth they sailed again, and arrived off Port-au-Prince in the evening. Notwithstanding the operations, in a warlike view, may not be of the first importance, it should be mentioned that the squadron comprized four ships of the line, the Europa, the Belliqueux, the Irresistible, and the Sceptre, three frigates, and four or five smaller vessels, the whole under the command of Commodore Ford. The British land-forces, under the orders of General Whyte, consisted of 1,465 rank and file, fit for duty, to whom were added 2,00o colonial troops. It is proper to remark, that at this period the French inhabitants composing the latter corps, likewise chiefly supplied the Mole, St. Marc, Leogane, Jeremie, the camps Des Rivaux and Du Centre, and Tiburon, (on which place an attack was projected, by the mulatto chief Rigaud, from Aux Cayes.)

The necessary preparations being made, the next morning a flag was sent, demanding the surrender of the town, which, not being admitted, it was determined to cannonade the fortress of Bizotton, which defended the great carriage road leading from Leogane to Port-au-Prince, which protected one part of the Bay, and in which were 500 men, eight pieces of heavy artillery,

\footnotetext{
${ }^{*}$ Colonel Chalmers's Remarks on the late War in St. Domingo, p. 21.
} 
and two mortars. The fort was dismantled on the side next the sea in the course of the day, (May 31,) by two line of battle ships and a frigate, but on the land side remaining perfect, an assault became necessary. Colonel Spencer, with 300 British, and 500 colonial troops, were accordingly landed in the evening, within a mile of the fort, and night soon approached, accompanied by the horrors of a most tremendous thunder-storm, and deluge of rain. A council of war was held, consisting of the Commander, the Baron de Montalembert, Colonel de Charmilly, and the brave Captain $\mathrm{M}^{\mathrm{c}}$ Kerras of the engineers; when it was suggested by Colonel de Charmilly, who was best acquainted with the nature of the country, to attack with fixed bayonets, as the torrents from the elements would render the cannon and musquetry in the fort useless, and drown the sound of the approaching assailants. Captain Daniel, of the 41st regiment, led the advanced guard, of only sixty men, and executed the plan with such vigor and judgment, that entering a breach, and bearing down all before them, (except those who begged and obtained mercy,) the fort was carried directly, to the astonishment even of the brave Colonel Spencer. Captain Daniel was severely wounded, and his second in command, Captain Wallace, died on the glacis, ${ }^{238}$ as he had lived, full of bravery and honor.

It is a subject of deep regret to the writer, from the nature of this work, not to be able to adorn his pages with the account of numerous actions which, could he have transmitted to posterity, would immortalize many whose names and heroism the various chances of war frequently consign to oblivion. It is sometimes necessary that the historian should select his characters with a view to dramatic effect, yet a place on the roll of fame should not be denied to any; as that is often considered the noblest reward for a life of perseverance and sorrow; and the most honorable incentive to future services of danger and national glory.

The capture of Bizotton determined the fate of Port-au-Prince. The party remained in the fort till joined by the main body of the army from L'Arcahaye, which, one part by land, and the other by sea, made its approach on the side next the rich plain of $\mathrm{Cul}$ de Sac. On the 4 th of June they arrived within three miles of the town, and, at ten in the morning, the detachment of Colonel Spencer marched to occupy a post on the heights behind the capital. When they had advanced about half way they were met by a mulatto woman, who acquainted them, to their surprize, with its evacuation. Colonel de Charmilly, with fifty of the colonial cavalry, were dispatched to ascertain the fact, which they found as she had stated; and they immediately took possession of the fort of the Gate of Leogane. About half an hour after, a cry was heard from a cellar in a very concealed situation, and upon the door being broke open, 
a negro was discovered, surrounded by barrels of gunpowder. The unhappy wretch had been placed there, according to the opinion of M. de Charmilly, the preceding night, to blow them up at a certain time, but his match being extinguished, his own life, as well as that of those who surrounded him, were thus spared by mere accident.

The fort De L'Hôpital was the next to be taken possession of, which was accomplished in the same manner, but with the appearances of imminent danger they escaped with their lives; for here the commissioners had planned their principal blow to destroy the new masters of the place, which had been defeated by the rain just mentioned. A train of powder was found reaching from the magazine, (where several of the barrels had their bottoms knocked out, and the powder strewed about the floor,) to the thickets behind the fort; the whole, fortunately, was wet, and by precaution every accident was prevented.

Fort Robin, in which were between two and three hundred men, who had refused to fly with the commissioners, readily surrendered to M. de Charmilly. The Baron de Montalembert was sent to take possession of Fort St. Joseph, which commanded the gate of the town leading to the Cul de Sac, and a detachment of troops from Leogane went to the Fort de St. Claire. Thus, in a few hours, the English were in full possession of Port-au-Prince. The commodore, who had entered the road, took possession of Fort de l'Islet, and sent in a British flag, which De Charmilly hoisted at Port Robin, with sensations that are easier to be felt than described. "I considered," says he, "this happy event as a recompense accorded me by Fate for all my labours, and all my troubles in the salvation of St. Domingo." ${ }^{239}$ At six o'clock General Whyte arrived.

Such was the capture of this important capital, whose character and wealth had tempted every person employed in the intended conquest of the island. Within the compass of its lines were one hundred and thirty one pieces of cannon regularly mounted in batteries. In the harbour were twenty-two vessels laden with sugar, indigo, and coffee, of which thirteen were from three to five hundred tons burthen, besides seven thousand tons of shipping in ballast, in value amounting to $400,000 \mathrm{l}$. A booty much more considerable was conveyed away by the commissioners, who loaded two hundred mules with their riches, and carried away near two thousand persons in their train. Having previously arranged their affairs, and finding the people of colour, (of whose aid, they had only intended to avail themselves temporarily,) possessed of the whole natural strength of the island, under the mulatto Rigaud, and a negro named Toussaint L'Ouverture,${ }^{240}$ they soon after quitted the colony, consigning immense wealth both to America and France, leaving General Laveaux in the character of commander in chief; and returned to France, where they 
received from the government presiding at that time a sanction of their proceedings. Polverel soon after died, the victim of a life of dissipation, but Sonthonax lived to pay the colony a triumphal visit.

Much controversy has existed on the idea of some private arrangement having taken place between them and the commodore, with whom several flags of truce passed during the three days in which the detachment from the army was kept inactive. How this was, has never been explained, but from the situation of the road from Port-au-Prince to Jacmel, it is clear, that their retreat might have been interrupted, and, according to some, the fate of the colony determined. Immediately after Port-au-Prince came into the possession of the British, more than three thousand armed inhabitants assembled in the town, ready to undertake any enterprize for the further reduction of the colony. Unfortunately, no use was made of the present advantages, but what they afforded in profit; thus an opportunity was lost, which, as is often the case, never occurred again.

The capture of Port-au-Prince, so much desired, seems to have formed the height of British power in St. Domingo. "From that period the affairs of its possessions," says an old English officer employed on the spot, " "began to decline in proportion, as it were, to the vast accumulation of expence; and all was languor, disease, or peculation!" ${ }^{241}$ As soon as the general satisfaction gave way to the necessary considerations for defence, the soldiery were compelled to assist in raising intrenchments on the side of the town next the mountains by day, and to perform military duty at night, thereby suffering the effects, alternately, of the sun and the dew. Many of these men had been six months on ship-board, and the season was unfavorable to them. At this unfortunate juncture, arrived the Experiment frigate, with the remainder of the troops ordered from the Windward Islands, under the command of the Honourable Lieutenant-Colonel Lennox, ${ }^{\dagger}$ consisting of eight flank companies belonging to the $22 \mathrm{~d}, 23 \mathrm{~d}, 25 \mathrm{th}$, and $41 \mathrm{st}$ regiments. Now commenced in St. Domingo the ravages of that contagion, which, with a power more terrible than ordinary death itself, has bereft so many families of their hopes, and cut off the flower of a promising army, without the gratification of an honorable conflict. $^{242}$

It has been a melancholy object of dispute, whether or not the yellow fever

*Colonel Chambers, inspector-general of colonial troops in St. Domingo. "Remarks," p. 41.

${ }^{\dagger}$ Now General Lennox. [Charles Lennox, fourth Duke of Richmond and fourth Duke of Lennox (1764-1819) was an army officer who later became an MP and lord lieutenant of Ireland. He and his wife hosted the famous ball the night before Quatre Bras, and he was present at Waterloo.] 
had been generated, or even made its appearance in St. Domingo, previous to the arrival of the Experiment at Port-au-Prince. That sickness, and perhaps fevers incidental to all the colonies, had before been experienced by our troops, is certain, none of whom had gone directly from Europe, and might have been expected to be accustomed to the climate; yet it is to be remembered, that many of them had occasionally been kept long in the transports, that they had been sometimes posted on the burning sands of the Mole, and at others seated in marshes, which the colonists themselves could not long endure; and what was little better than either of these, they had opportunities of indulgence, which required more prudence to withstand, than could be expected from soldiers under their circumstances. They had been already harassed by new modes of warfare with the blacks, who, particularly those under Toussaint, a negro general of uncommon ability in the interior, had been trained with singular care. From the sickness arising from the former causes, the colonial troops were entirely free, in consequence of their different habits.

This pestilence is described as having been brought first to Grenada by the Hankey, from Bulam in Africa, where she had staid so long, crowded with passengers who could not be accommodated on shore for some time, as to contract a disease sui generis, similar to the jail distemper. The greater part died, and two only of the ship's company arrived at Grenada. ${ }^{243}$ The circumstances that follow, are scarcely to be conceived by those who do not know the numerous instances that occur, to prove the necessity of an establishment of a Board of Health in all the British colonies. The clothes and bedding of the deceased victims, were sold by auction, distributed among a variety of persons, and the contagion with which they were infected, consequently spread, not only throughout that island, but the other Antilles, and a considerable part of the continent.

It is unnecessary to enter into a description of this distressing malady in a medical view, as sufficient accounts of its nature and treatment may be found in the works of several medical writers of the present day. ${ }^{244}$ - Forty officers, and six hundred rank and file, fell victims to the fever within two months after the surrender of Port-au-Prince.

It is impossible for the best of generals to distinguish, and to avail themselves of every opportunity; but it is unfortunate, that so many troops should have been suffered to collect in the capital, thus increasing the means of disease, when they might have served with utility elsewhere. The same omission can now be perceived on the part of the navy, which suffered the southern coast to be open to communication with Curaçoa $^{245}$ and the continent, from whence supplies of stores of all kinds were constantly received by the enemy, unregarded by a single ship. With common precaution even of this kind, the 
commissioners could not have escaped with the immense wealth with which they loaded themselves from the colony, nor could innumerable privateers have been equipped, which, for, a time, intercepted every vessel in our trade that passed through the Windward passage.

At this period the indefatigable De Charmilly, who was the soul of the British enterprize at St. Domingo, was again commissioned by his drooping countrymen to return to Europe, for the purpose of soliciting additional aid, to complete the business thus far advanced.

General Whyte resigned the command in St. Domingo, on account of ill health, and was succeeded by Brigadier-General Horneck, ${ }^{246}$ a man qualified to ensure success in a situation of difficulty. Only fifty men followed General Horneck from Jamaica, and no reinforcement was received to enable them to make any movement for several months after; he had, therefore, to remain on the defensive for that time, and to preserve the territory already gained, from the defection which was beginning to appear.

The first success which encouraged the revolters, who were chiefly mulattoes, under Rigaud, to farther exertions and attainments, was the seizure of Leogane, where they put to death all the French planters who fell in their way. This was followed in the beginning of September, by a perfidious violation of the neutrality which had been entered into by the men of colour in the town of St. Marc. Lieutenant-Colonel Brisbane, ${ }^{247}$ a valuable young officer, who held that rank from the French legion of St. Marc, being a captain in the 49th regiment, had been pursuing, with only eighty British in addition to the colonial troops under his command, the most rapid successes in the neighbourhood, and had induced a large number of the rebels to submit unconditionally. In the pursuit of these successes, the town was left without troops, which afforded an irresistible temptation; they accordingly seized upon it, putting to death, as before, all who fell in their way. The garrison took refuge in a fort on the seashore, from whence they were relieved by the arrival of a frigate from the Mole of Cape St. Nicholas. Colonel Brisbane returned, and, at the expence of all the advantages he had obtained on the plain, regained the town, making upwards of three hundred of the insurgents prisoners. It had the effect, however, of inspiriting the whole of the people of colour, and of exciting them to greater excesses. Rigaud, who commanded in the south, made apparent arrangements for an attack upon the capital, by investing Fort Bizotton with three columns of his troops, consisting of two thousand men. They began their attack at 3 o'clock in the morning of the $5^{\text {th }}$ of December, and were defeated with great slaughter. Captain Grant, who commanded, and Lieutenants Clunes* and Hamilton, though wounded severely in the

\footnotetext{
*Now Lieutenant-Colonel Clunes.
} 
commencement of the attack, continued at their posts, and earned an honorable fame, of which General Williamson bore a handsome testimony.

Not discouraged by this repulse, Rigaud immediately prepared for a more formidable attack in another quarter, the recapture of Tiburon. His intentions were known, but, as in the escape of the commissioners, it again happened, that not a ship could be spared to intercept his armament, then lying off Aux Cayes. It sailed on the 23d of December, consisting of a brig of sixteen guns, and three schooners of fourteen guns each. His military force was composed of three thousand men, of different colours and descriptions, and the attack commenced on Christmas day. The garrison contained only four hundred and eighty men, the majority of whom were colonists, and the rest British convalescents; it held out four days, till three hundred of that number had fallen. The survivors, with Lieutenant Bradford of the 23d regiment, who commanded under the Chevalier de Sevré, commandant of the district, fought their way, with astonishing bravery, for five miles through the enemy, till they reached Irois. An unfortunate officer, Lieutenant Baskerville, who was from some circumstance left behind, perished by his own hands, as is supposed, to prevent a dishonourable death, or falling into those of the enemy. It is unpleasing to withhold approbation from an act which evinces the most determined bravery, yet it is to be lamented, that he did not find some other means more compatible with the institutes of society, and on which history could dwell with more pleasure.

Tiburon, Leogane, Jean Rabell, La Petite Rivière, and L'Artibonite, were in possession of the people of colour and the negroes; and the latter retaining the whole of the northern province, except the Mole and Fort Dauphin, were increasing in power and independence throughout the colony. The British army, on the contrary, was weakened every day, and the colonists viewed with anxiety and distrust, the delay which took place in the furnishing additional forces. They required them in a body capable of some grand operation, which might complete the conquest of the colony, and suppress the designs of the people of colour; a hope which nothing but the lingering fondness of these unhappy proprietors for their delightful possessions, could have retained to this period. The entire power having been confided to the British commander, the whole of the French colonists submitted themselves to him, as passive agents; but, from the neglect which they experienced, owing to the ample employment of the British government at home, they were still desirous of resuming some share of authority. There will always be found dissatisfied persons under all circumstances, and dissolute characters ever ready to fall in with their designs, for the sake of the treachery itself. Thus, while Colonel Brisbane, who was admired for his bravery, ability, and per- 
sonal qualities, was quelling the disturbance of the mulattoes, whom he had particularly favored, and restoring tranquillity to the whites under his protection, a party of the latter were conspiring against his valuable life, which even war and disease had spared. They were, however, detected and their purpose defeated. But a more extensive conspiracy was soon after discovered at Portau-Prince, where it was intended, by a similar party, to seize the garrison, and put the English to death. Twenty of the conspirators were seized, and tried by a council of war, composed of the principal commanders, among whom were five French field officers; they were found guilty, and adjudged to death. Fifteen of the number were accordingly shot on the 18th of February.

Shortly after this narrow escape, however, the amiable Colonel Brisbane fell, while out on a reconnoitring party. By his death the British affairs in St. Domingo lost one of the most able, indefatigable, and generous of their advocates. He acquired the affections of every one, and of those who were anxious to deprive him of life he was the decided friend, insomuch, that his constant intercourse with the mulattoes excited a degree of disapprobation in the whites: they, nevertheless, confided in his courage, and were never disappointed. He died universally lamented.

The commencement of this eventful year was clouded by the death of Lieutenant-Colonel Markham, who, to use the language of the orders issued by General Horneck, "lived universally respected and beloved, and died, leaving a bright example of military, social, and private virtue." ${ }^{248} \mathrm{He}$ fell in the attack of an out-post, the enemy having again determined on besieging Fort Bizotton. Victory, however, crowned his fall, and his life was revenged upon six hundred of the enemy, who were slain on the spot. Their colours, and five pieces of cannon, were also taken.

About the latter end of April a reinforcement arrived, consisting of the 81st and 96 th, and a few of the $82 \mathrm{~d}$ regiments, which, upon landing, met the fate of so many of their predecessors, and could not but consider their destination as so many graves open for their reception.

In the month of May, 1795, when the colony had become, in the estimation of the British government, a splendid object of enterprize, General Williamson, the governor of Jamaica, to whom it had been ostensibly confided, arrived at Port-au-Prince, having been appointed commander-in-chief of all the British possessions with the honour of the Order of the Bath. ${ }^{249}$

The first exertions of the new commandant were directed to strengthen his position at Port-au-Prince, and to establish and strengthen a cordon from a village called Thomaseau, and from Grand Bois, at the extremity of the $\mathrm{Cul}$ de Sac, to Saint Marc, across a ridge of mountains, which divide the plain of L'Arcahaye from that of Artibonite, besides a chain of posts extending from 
thence to the Cape of Tiburon. For this purpose it became necessary to enlarge the plan, which had already taken place, of embodying corps of negroes; and many slaves were purchased for the purpose from the French planters and others, and placed under the command of officers who had been in the service of the old government, or of planters most likely to ensure their utility by proper attention. Of these, the corps of De Source, De Pyster, De Grasse, La Serre, D’Alsun, and Cocherel were the most respectable; but they were, with many other of the arrangements that now took place, extremely expensive, and not always efficient.

In the month of August arrived the 82d regiment, completing the quantum of the reinforcement, (a small part of which was received in April). It was nine hundred and eighty men strong on landing, of which number three hundred and fifty only remained alive in six weeks.

With troops thus arriving in divisions, and distressed with disease, where a combined body was required to form a decisive power, little could be done; and General Williamson, already embarrassed by the most difficult circumstances, was but ill prepared for those circumstances so dispiriting as the present; neither did his beneficence and complacency, qualities so amiable in private life, contribute to his assistance on the occasion. He was open to imposition from designing persons, and was led to countenance a system of expence fatal to the British interest; he was shortly succeeded in command by Major-General Forbes. ${ }^{250}$

This spirited and active officer commenced his career by an attentive review of the different posts, and an augmentation of the forces by every means that presented; he strengthened the cordons already established, and secured the frontiers of Mirebalais and Banica, to preserve a communication with Spanish Saint Domingo, for procuring cattle, and other purposes. The garrison of Banica, consisting, as usual, of a few British troops, colonials, and some Spaniards in British pay, he placed under the command of an officer of considerable merit, Sir William Cockburn, ${ }^{251}$ who was directed to keep in view the free access to the plain of Cape François, which it commanded.

Towards the close of this year, in consequence of the intrigues of a negrogeneral, ${ }^{252}$ whose character will form a prominent feature in this history, the Spanish government ceded its interest in a colony, it could no longer hold, to the representatives of the French republic.

In May, 1796, after a disastrous passage, about 7,000 troops, under the command of Brigadier-General Howe, who had sailed from Cork ${ }^{253}$ near seven months before, arrived at the Mole of Saint Nicholas, where, as if to complete the destruction the elements had left unfinished, they were obliged to remain some weeks on board the transports. The same number of men, at 
any former period, would have changed the whole affairs of the colony; but they were too far gone; they, with the troops already at the disposal of General Forbes, (to use the language of an old experienced officer,) "were not such as those commanded by General Wolfe."* Among the effects of this insufficiency may be remembered the following disastrous circumstances.

The town of Leogane having been left in an unprotected state by the British troops, the republicans immediately enclosed it with a palisaded ditch, ${ }^{254}$ and began to strengthen the harbour, which General Forbes conceiving necessary to prevent, determined on attacking the enemy with a considerable force. Admiral Parker, after disembarking the troops, attacked the fort at the entrance of the creek, but was obliged to abandon it with loss. General Forbes carried no artillery with him, intending, by the advice of his engineer, Major $\mathrm{M}^{\mathrm{c} K e r r a s,}$ to take it without regular approaches. A few light pieces of cannon were placed to cover those who filled up the ditch, by which means the besiegers were to cross to the assault. The impolicy, however, of despising an enemy, was soon, as it is always, evinced. The besieged perceiving the contemptible consideration in which they were held, from the church-tower directed a twenty-four pounder against the assailants, with such effect, as enabled them to cross the ditch, and take their cannon, while they were glad in the opportunity afforded, by the weakness of their opponents, to re-embark without further injury.

Bombarde, which had been so unsuccessfully attempted to be surprized before, becoming particularly necessary to the garrison and fleet, at the Mole, for the supply of vegetables, \&c. A strong body of troops were sent to attack it, but many of them died on the road from the difficulties of the march, undertaken in the middle of the day. The fort was, however, immediately surrendered by capitulation; and soon after evacuated by the conquerors.

Encouraged by these circumstances, Rigaud became confident of his prowess, and attacked Major-General Bowyer ${ }^{255}$ at Irois. He was repelled, at the expence of near an hundred men killed and wounded; among the latter of whom was the general himself.

In short, so languid became the progress of the British arms, that the republicans commenced operations in every quarter round the capital; besides, compelling General Forbes to fortify the mountain called Grenier, and to occupy all the surrounding heights, they employed some months in the erection of batteries, and on the fortification of two posts at St. Laurent and Le

*Col. Chalmers's Remarks, p. 44. [James Wolfe (1727-59) was known for developing volley and bayonet techniques that revolutionized military training. He died during the Battle of Quebec and is regarded as one of the heroes of the Seven Years War.] 
Boutilliere, within four miles of Port-au-Prince, without the smallest molestation from the English.

Affairs becoming desperate, with misfortune and expence incurring daily, the British government determined on sending General Simcoe ${ }^{256}$ to endeavour to recover the British character; and, if experience and skill were all that were wanting, little doubt could have been entertained of success. He arrived at St. Nicholas Mole in the beginning of March 1797, and immediately proceeded through the British possessions to discover the evil, before the application of remedies with which he was well acquainted. But, alas! no ordinary remedies were applicable to the desperate circumstances with which he had to encounter; for, instructed in the science of government, and the relations of empires, by the inconsistency of one power, and improved in the art of war by the impolicy of others, the Blacks had arrived at a degree of perfection in both, that, notwithstanding the inveteracy of prejudice, compelled itself to be accredited by its effects. An acknowledgment of this fact, incontestibly took place the same month, in which the command of the English army was confided to the wisdom and activity of General Simcoe, by the appointment of Toussaint L'Ouverture, the celebrated negro officer, by the French government, to be general in chief of the armies in St. Domingo. ${ }^{257}$

General Simcoe felt the effect of the powerful situation of his opponent, to whom this nomination was but an honorary sanction of the command he had long possessed. He commenced several economical arrangements, which, even if his cause was hopeless, could not fail to render it a desirable service. He compelled a surrender of all private leases obtained of the vacated property of French absentees, to the public use; and he reformed the colonial corps, from the number 42 to 14, placing on a temporary half-pay, the officers necessarily withdrawn, and rendering more eligible the situation of those, who were the fittest for service: yet, with any other person than General Simcoe, these arrangements must have been of short duration, for Toussaint adopted every mode to harass him, and turn the war in his own favor, by every stratagem that could be devised. He menaced the important frontier post of Mirebalais, which had been erected with stone at considerable expence: the commandant immediately evacuated it, and retired to Port-au-Prince, leaving the rich plain of the Cul de Sac open to the enemy, thereby impeding the communication of the English with Banica ${ }^{258}$ and Spanish St. Domingo.

With somewhat of spirit, and better success, the batteries which had insulted the capital were carried; they required, however, a body of two thousand blacks, besides a reserve of British troops, and some artillery, and cost the life of a brave officer of colour, as he was leading the charge at St. Laurent, Major Pouchet. An attempt to cut off the retreat of Toussaint to Gonave, failed, from a variety of incidents. 
While these operations employed the vicinity of the capital, Rigaud was as active in his quarter. With one thousand two hundred men he attacked the post at Irois, and gave the first notice of his approach, by his fire on the fort. The post was composed of a battalion of black troops under Colonel de Grasse, a company of British under Lieutenant Talbot, and twenty black artillery under M. de Brueil. Fortunately, the artillery of Rigaud was interrupted by Captain Rickets of the Magicienne frigate, which caused him to retire precipitately. To increase the eclat of this repulse, another immediately followed, of Toussaint, from the town of St. Marc: it was a repulse, nevertheless, dearly bought.

Wearied with the kind of warfare in which he was thus unavailingly engaged, General Simcoe returned to England in August, to procure a force, sufficient to pursue a career of glory, or to abandon a scene, furnishing at best but negative honors. The same causes which had before operated with respect to this ill-fated colony, yet continued. - The ministry of Great Britain were employed in the complicated affairs of Europe too much, to give more attention to St. Domingo, and General Whyte supplied the place of General Simcoe, ${ }^{*}$ with no additional means of success. Before the end of the same year, this gentleman was superseded by Major General Nesbit, ${ }^{259}$ who did not live to arrive at a command of which, he would have had no occasion to boast. ${ }^{\dagger}$ His place was supplied by his second in command, the Honourable Brigadier-General Maitland, ${ }^{260}$ to whom little remained, but to perform the humiliations of his country, with the grace which that country demanded, and which no one could have better executed, in all that appertained to the gentleman. He arrived in April, 1798, at Port-au-Prince, and commenced strenuously an attention to circumstances, with which he was well acquainted, from his service under General Simcoe, by whom he had been appointed to several difficult commands.

By the orders of General Nesbit, the British property in St. Domingo ceased to be valued at more than the annual sum of 300,000 l., which General Maitland soon found inadequate to the purpose of their maintenance, as the colonial revenues had decreased to 100,00o $l$. The evacuation of the capital and

*The writer cannot omit in this place paying his tribute of respect to this excellent and gallant officer. If all the abilities of the general, the suavity of the gentleman, and the vigorous powers of a manly understanding may be expected to unite in one person, it is in Lieutenant-General Simcoe. When commanding the Queen's Rangers, in the American war, he distinguished himself on every occasion, and in a variety of important battles crowned himself and his corps with the highest military glory.

${ }^{\dagger}$ By the death of General Nesbit, (whose memory deserves his grateful recollection) the writer lost a very sincere friend in many respects, though he cannot regret the appointment of his Brigade Major, with which he was to have been honoured by him on this expedition. 
its dependencies, was therefore the first step that occupied his attention, and his arrangements were as honorable to his sensibility, as the proudest victory could have been to his courage. - After every consideration for their peculiar circumstances, he effected a truce for a month, and stipulated for the protection in person and property of all the adherents of Great Britain. He then withdrew with the remainder of his force to Jeremie, which he had formerly commanded.

With his concentrated force at this point, he acquiesced in the wishes of Admiral Parker, ${ }^{261}$ to reduce Tiburon, for the purpose of its retention, with the Mole, the object so much desired for the security of the Windward passage: but the tide was now turned, the troops could not disembark for tempestuous weather, and other causes; and even the brave De Source, ${ }^{262}$ who marched across the peninsula to meet him, lingered on his way.

The Mole at length only remained, to which General Maitland retired, for the purpose of his last negotiation with the triumphant black General, Toussaint. The possessions of the English were here given up, as well as their colonial black troops, and some commercial stipulations being entered into, which recognized the island as a neutral power, England resigned all her pretensions to St. Domingo for ever!

Such was the end of this disastrous enterprize, which had for five years fed the hopes and vanity of the British empire, to which had been latterly sacrificed many valuable lives, and an extravagant portion of the public money. That it was undertaken with too little consideration, must be always acknowledged: for, if the British ministry only meant, by finding employment for the French commissioners in St. Domingo, to prevent the seat of war from being carried to Jamaica, they might have effected this purpose, without entering upon so large a field, or sacrificing the lives and interests of a number of brave and unfortunate colonists; and if the conquest of the island was sincerely intended, the means furnished were contemptible, in comparison even with the exertions of the inhabitants. It is, however, probable, that no force which could have been furnished, would have been sufficient to cope with the power of the revolted negroes, and if the British colonies in the Antilles have been saved by these means, it is only to be lamented that their salvation cost so dear, in proportion to their advantages to the country.

Having recounted the progress and termination of the British affairs, it is necessary to recur to the circumstances of those who were left in sole and uninterrupted power in St. Domingo. It will be recollected, that the first consequence of the appearance of the English, was the entire abolition of negro slavery by the French commissioners, who therefore recognized all who enlisted under their standard, as free citizens, and perfected them in 
the knowledge of arms: likewise, that immediately after the first onset of the insurrection in the plain of the Cape, the negro, Jean François, who was then principal in command, had evinced a foresight which exhibited the determined intentions of his followers, in employing the time of those who were unoccupied, with the women and children, in the cares of agriculture, for their future preservation. To this general was soon added several others, not inferior in ability, of whom the most conspicuous were Biassou, ${ }^{263}$ Boukman, ${ }^{264}$ and Toussaint; but, although the last of those who declared himself, the latter soon eclipsed all the others by his conduct in a regular warfare. While Spain yet ranked among the coalesced powers who avowed the restoration of royalty in France, the first and last of the black chiefs had arrived at such consideration from their acknowledged merit, as to be presented (perhaps as an inducement to declare on the side of royalty, to which they appeared to lean, as the enemies of the commissioners, whose invitation they had not accepted) with the rank of general in the Spanish army, and the ancient military order of that country. ${ }^{265}$

The departure of the French commissioners in 1794, and the conclusion of peace between France and Spain, which ceded its territory to the republic, a year after, ${ }^{266}$ had placed Toussaint in almost absolute power: (for his colleague $^{267}$ preferred retiring on his rank to Cadiz); the brave, but cruel Rigaud, afterwards fled from the island; and every occurrence had contributed to his aggrandizement; till the whole was sanctioned, in 1797, by the executive power of the French government in their commission as the general in chief of the armies, and of the whole island of St. Domingo. This consequence was now enlarged in his acknowledgment as a neutral power by the most important of all his enemies.

Such was briefly the progress of Toussaint, which was marked by many circumstances that reflected the highest credit on his character, and gave dignity to his dominion. He had throughout been the moderator of all the different factions in the island, and was every way fitted for its legislator, as well as its chief. He was, indeed, one of those characters who invite the principle of an elective monarchy, but which are too rarely found to advise its universal adoption. His character will be more fully given in the ensuing part of this work; it is at present sufficient to say, that, although he detested the conduct of the French commissioners, he protected their office from indignity, and shielded them from vengeance; he relieved the planters from the intolerable tyranny of the commissioners; he saved the French army from punishment too often not greater than their guilt; and would not permit the increased cruelty of retaliation on the British forces, for the conduct of allies, which even the colonists regretted to adopt. He saved the life of General Laveaux, 
who acknowledged the fact with gratitude; and his intercourse with general Maitland was of the noblest kind. Notwithstanding these exertions, in which he had to combat with the natural prejudices of many of his followers, he preserved their confidence in his integrity, and their obedience to his wishes, and was hailed, with great justice, by common consent, as the perfector of the independence of St. Domingo. ${ }^{268}$

CHAP. IV.

State of Manners on the Establishment of Independence, \&c. in St. Domingo, with a Memoir of the Circumstances of the Author's Visit to the Island.

THE white population of St. Domingo, now still farther decreased by the emigrations which followed the evacuation of the English, presented but a dismal semblance of the flourishing French colony; added to which, many of the whites who were encouraged to remain, now spread through the eastern districts with a spirit of wild speculation, and became more solitary, when they might have been expected to associate with stronger ties than ever. Of the Spaniards, widely scattered, in their most tranquil state, many had emigrated, but more had been sent from the island, on the surrender of the Spanish territory to Toussaint. Although the defection of the whites was striking in the towns where they had been most numerous, that of the blacks was increased in a proportion so large, as to astonish those who had witnessed their losses, and the decrease which was remarked after the first insurrections of the negroes. This is accounted for in a satisfactory manner, by the greater degree of comforts experienced by the females, and the decrease of general labor.* Although, for some time, the change of government appeared to tinge with a melancholy hue, the parts of the island formerly in the possession of the English, yet the rude happiness of those who had now become its possessors, soon suppressed every other effect; and, notwithstanding the despotic rule of martial law, circumstances in general began to wear a promising appearance.

At this period the narrator of their history became possessed of an opportu-

\footnotetext{
*Malouet, Mémoires sur les Colonies. [Pierre Victor, Baron Malouet (1740-1814), Collection de mémoires et correspondences officielles sur l'administration des colonies (1802). A former planter, Malouet eventually became Minister of the Navy under Louis XVIII. He played an important part in the kingdom's unsuccessful schemes to recover the island for France.]
} 
nity of judging of the state and power of the people, who form the subject of his present disquisition; and his personal observations during his detention among them, will supply the information submitted in the present chapter. ${ }^{269}$

A violent hurricane having dismasted the little bark, ${ }^{*}$ in which he was proceeding from Jamaica to join his regiment at Martinique, (having been before accommodated in the cabin of his friend, Admiral Smith, ${ }^{\dagger}$ as far as the Mole St. Nicholas, ) it was driven under the walls of Cape François, and in that state compelled to wait the relief of the brigands, ${ }^{270}$ an appellation which the superior policy that already appeared in this extraordinary republic, had not yet obliterated from its members. To avoid the suspicion in which, notwithstanding the recent treaty, the English yet continued to be viewed, and to prevent the probability of injury to his companions, the writer was induced to assume the character of an American, which was easy to be effected, as the vessel was ultimately bound to that continent. The crew were permitted to land after certain ceremonies, and the first object which excited their attention, was no less than the hero of this novel empire. Toussaint was conversing with two privates of his forces on the batteries, and when he saw the Europeans approaching, immediately walked towards them, and, addressing them in French, inquired the news, from whence they came, and their destination. One served as respondent for the whole, who spoke in such terms as his character demanded, and the General civilly took his leave.

The number of Americans at this port could not fail to attract particular notice, and every attention seemed to be paid to the accommodation of their commerce, and a striking degree of interest in every occurrence that concerned them. Even the women seemed to renew a fondness long repressed for the whites, in favor of the meanest of the American sailors. The present writer, however, requiring some rest after his recent voyage, hastened, on receiving his directions to the purpose, to the Hotel de la Republique, the principal house, usually resorted to by Americans, an edifice of rather elegant appearance; and on his way, except the preponderancy of the black complexion, perceived but little difference from an European city. On entering the house, however, he immediately perceived that the usual subordinations of society were entirely disregarded, and that he was to witness, for the first time, a real system of equality.

Here were officers and privates, the colonel and the drummer, at the same table indiscriminately; and the writer had been scarcely seated at a repast

\footnotetext{
*The Maria, Danish schooner, commanded by James Frazer.

†The liberal reception which the military always met with on board the Hannibal is too well known to require any compliment on the present occasion.
} 
in the first room to which he was conducted, when a fat negro, to initiate him in the general system, helped himself frequently from his dish, and took occasion to season his character by large draughts of the wine, accompanied with the address of "Mon Americain." The appearance of the house, and its accommodations, were not much inferior to a London coffee-house, and on particular occasions exhibited a superior degree of elegance. Toussaint not unfrequently dined here himself, but he did not sit at the head of the table, from the idea, (as was asserted,) that the hours of refection and relaxation should not be damped by the affected forms of the old regimen, and that no man should assume a real superiority in any other place than the field. He was in the evenings at the billiard-table, where the writer conversed and played with him several times; and he could not help, on some occasions, when a want of etiquette disturbed him for a moment, congratulating himself, that if he experienced not the refinement of European intercourse, he saw no room for insincerity: and that if delicate converse did not always present itself, he was free from the affectation of sentiment.

In traversing the once superb city of the Cape, though presenting a tolerable appearance from the shore, desolation every where presented itself. On the site where elegant luxury had exhausted its powers to delight the voluptuary, all was magnificent ruin! and to mark the contrast stronger, of the wrecks were composed temporary houses for the American merchants, and petty shops inhabited by the natives. Several spacious streets towards the centre, displayed the walls of superb edifices of five and six stories, with gilded balconies, of which the beautiful structure exhibited the devastation that had occurred, with additional horror. Nor was this all, for in different parts of these ruins the sad remains of the former possessors were visibly mingled with the crumbling walls:

"There- heedless of the dead,

The shelter-seeking peasant rears his shed,

And wonders man could want the larger pile." ${ }^{271}$

Having been informed of a review which was to take place on the plain of the Cape, the writer availed himself of the opportunity, accompanied by some Americans, and a few of his own countrymen who resided there under that denomination. Of the grandeur of the scene he had not the smallest conception. Two thousand officers were in the field, carrying arms, from the general to the ensign, yet with the utmost attention to rank; without the smallest symptom of the insubordination that existed in the leisure of the hotel. Each general officer had a demi-brigade, ${ }^{272}$ which went through the manual exercise with a degree of expertness seldom witnessed, and performed equally 
well several manoeuvres applicable to their method of fighting. At a whistle a whole brigade ran three or four hundred yards, then separating, threw themselves flat on the ground, changing to their backs or sides, keeping up a strong fire the whole of the time, till they were recalled; they then formed again, in an instant, into their wonted regularity. This single manoeuvre was executed with such facility and precision, as totally to prevent cavalry from charging them in bushy and hilly countries. Such complete subordination, such promptitude and dexterity, prevailed the whole time, as would have astonished any European soldier who had the smallest idea of their previous situation.

The pleasing sensations inspired by the ability manifested in this review, were checked by the additional monuments of human ferocity which presented themselves on his return to the city; the conflagration of which, and of the surrounding plantations, was still in the memory of several Americans, who described the effect, as awfully grand beyond conception.

In one of the squares in the north-west quarter was placed an edifice that made some amends for the desolation appearing in its vicinity, from the elegance of its execution. It was an ascent to a canopy, or dome, of which the architecture was not perfectly regular, beneath which were two seats, and above them an inscription, that eminently exhibited the tolerance of Toussaint. There were two sentinels to guard it, who, being asked if any one might ascend the steps, answered in the affirmative, but with a strict prohibition against touching the cap of liberty, which crowned it. It was a tribute of respect to the memory of Sonthonax and Polverel, the French commissioners, and had been erected by some of their advocates at a time when their largesses obtained for them what they would not otherwise have enjoyed, a transitory popularity. An extract from a speech of one of them formed part of the inscription, in French, and which countenanced the opinion, that the abolition of slavery was a primary object of their mission. It was to the following effect:

My Friends,

We came to make you free.

Frenchmen give Liberty to the World.

You are free.

Guard your Freedom.

Vive la Liberté.

Vive la Republique.

Vive Robespierre. ${ }^{273}$

The remainder of the inscription consisted of a selection from the proclamation for abolishing slavery. The prevailing opinion of these men, notwith- 


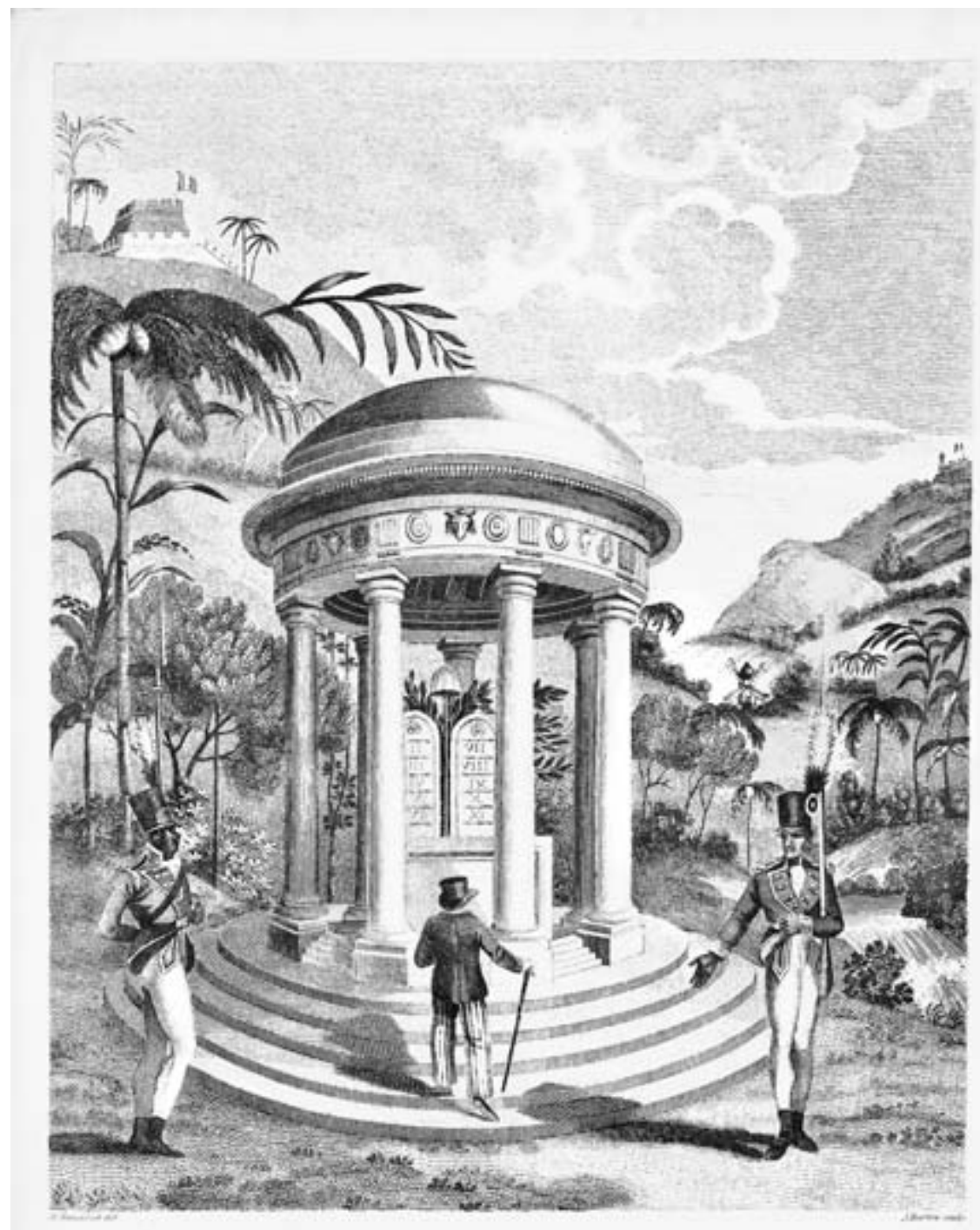

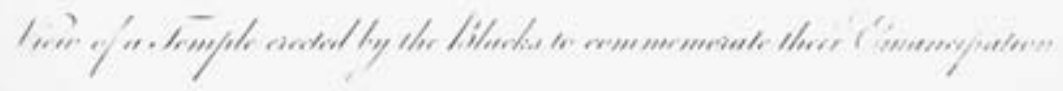

View of a Temple erected by the Blacks to commemorate their Emancipation. Reproduced with the permission of Rare Books and Manuscripts, Special Collections Library, the Pennsylvania State University Libraries. 
standing they had been execrated for their conduct, was favorable to their talents, and to their spirit.

Though impressed with the necessity of caution, it would have required much more sang-froid than was possessed by the observer, to resist the numerous impulses of mingling with a people whose conduct presented the most generous hospitality, and objects of the most interesting contemplation. He obtained access to the houses of most whose intercourse could furnish either information or pleasure; nor did he reject the negro hut at other times, though certainly of less attraction.

As in all states of human society, particularly in the vortex of a revolution, which effected so complete a change, the able and the cunning had elevated themselves above those who were of the same rank of life. Negroes, recollected in the lowest state of slavery, including Africans, filled situations of trust and responsibility; they were, likewise, in many instances, occupied by those who had been in superior circumstances under the old regimen, free negroes, and mulattoes.

The superior order had attained a sumptuousness of life, with all the enjoyments which dignity could obtain, or rank confer. - The interior of their houses was, in many instances, furnished with a luxe beyond that of the most voluptuous European, while no want of trans-atlantic elegance appeared; nor, amidst a general fondness for shew, was the chasteness of true taste always neglected. Their etiquette extended to a degree of refinement scarcely to be conceived; and the service of their domestics, among whom were, from what cause was not ascertained, some mulattoes, was performed with more celerity than in many instances in Europe. A conscious ease, and certain gaieté du coeur, presided over every repast. Conversation had free scope, except as related to their own former circumstances, but when the defence of their country was the subject, every eye filled with fire, and every tongue shoutedVictory! The names of some, who had seceded from the black army were, the only objects that seemed to excite detestation. In many instances the writer has heard reasoning, and witnessed manners of acuteness and elegance, the relation of which would appear incredible, from those who were remembered in a state of servitude, or whose parents were in situations of abject penury; while sallies of wit, not frequently surpassed, have enlivened many an hour. It would ill become him, notwithstanding the tide of prejudice, which has always pervaded his assertions, to suppose his readers capable of gratification from the chit-chat of a St. Domingo table; and it would be equally unjust to employ the opportunities afforded him by unguarded kindness, in the accumulation of fleeting anecdotes, arising from domestic privacy; he therefore contents himself with stating, that the enjoyments of life were to be found in 
a high degree in the capital of St. Domingo, and that their alloy did not exceed, nor perhaps always equal, that of ancient European cities.

The men were in general sensible and polite, often dignified and impressive; the women frequently elegant and engaging. The intercourse of the sexes was on the most rational footing, and the different degrees of colour which remained, had lost most of that natural hostility which formerly existed. Several Americans had intermarried with ladies of colour very advantageously, and to appearance happily. They were, generally, very agreeable women, and felt no inequality in their difference of complexion or nation. Like Sappho, they could plead, (in many instances, in point of wit, sprightliness, and pathos, little inferior to the Lesbian muse, though without her powers of song)

\section{"Brown though I am, an Ethiopian dame \\ Inspir'd young Perseus with a generous flame; \\ Turtles and doves of different hues unite, \\ And glossy black is pair'd with shining white." ${ }^{274}$}

The drama, that source of rational delight, always so prevalent in St. Domingo, existed, in more strength and propriety than it had done before; and that licentiousness which appears inseparable to it in a higher state, was actually restrained. The representations were chiefly comedies en vaudeville, and a sort of pantomime; - sometimes serious representations, allusive to local circumstances, and sometimes merely humourous burlesques. - The conduct of the whole was highly creditable to the talents of the performers, some of whom yet remained from the French school, who, although driven to seek a livelihood under such doubtful auspices, might have shone with equal lustre to their more fortunate contemporaries on an European stage. The black performers, who preponderated in number, were not behind in talents; the writer saw a play of Moliere's performed with an accuracy that would not have disgraced the first theatre in Europe. ${ }^{275}$ - Even painting, from some recent specimens, appeared to be encouraged, and cultivated as an accomplishment, in a slight degree. A young lady of colour, of the name of La Roche, presented a large company, of which the writer was one, in the course of a few minutes, with their likenesses, very accurately cut in profile.-Music, also, though it must be confessed, not such as to vie with the harmony of the spheres, was every where prevalent to an excess, and the practice of most kinds in use, though stringed instruments were preferred.Yet, with an ardent sensibility that appeared in many instances, and which could not fail to be cultivated under present circumstances, the rich blacks suffered the greater part of the capital to lie in ruins; they appeared to shrink 
from reinstating it, as if in rebuilding their former residences, they should create new masters.

The situation of those who still remained in humble privacy, and who formed the great bulk of the people, was indeed very greatly changed. Their condition, agreeably to their capacities of enjoyment, approached nearer happiness than many others which are considered its ultimatum. Crimes were by no means frequent, and those rather attributable to accident than vice. They were perfectly at liberty as regarded themselves, and were more ready to perform their social duties, than the state was urgent in requiring them. Those qualities conspicuous in the negroes under their worst circumstances, their regard for all the relations of life, and tendernesses to each other, seemed expanded with their freedom, and many of the little prejudices that had existed wore away. Those amusements, which were formerly suppressed, had now free scope, but they restrained themselves from public annoyance with more regularity than could have been effected by the strictest police.

The menage of the labourer in the town and its vicinity, was improved in a proportion equal to his condition. A rough, yet neat couch, supplied the place of the wretched bedding of a former period, and the visitor was not unprovided for, though it is lamentable to state, that in several instances the furniture of the cottage was beholden to the public commotions, and in one instance, painfully risible, a beautiful fire-screen, the dextrous workmanship of some fair sufferer, concealed a dog then roasting from some of their fellows, who considered it opprobrious to be mangeurs des chiens. ${ }^{*}$

In one instance, the writer was introduced by a brigand ${ }^{\dagger}$ of peculiar intelligence, (with whom he had frequent conferences on the military tactics of the black army) to the cottage of a black laborer, of whom an account may not be uninteresting. He had a family of thirteen children; eight of them by one woman, and the remainder by two others; the former only lived with him in the same cottage, with his mother, who was aged and infirm; the other two, separately, at a small distance. This man was an epitome of legislature, and his family a well regulated kingdom in miniature. His cottage consisted of three irregular apartments, the first of which was his refectory, where, as often as

* Let it not excite wonder that the blacks, deriving their origin from some peculiar parts of Africa, are remarkably fond of the flesh of this animal, (of which an account may be seen at large, I believe, in Du Tertre, ) for it has been often found an excellent substitute for other food at sea, and has been used with success by convalescents. See Cook's Voyages. I quote the incident from memory. [James Cook (1728-79), A Voyage to the Pacific Ocean (1784).]

†In the recollection of my stay at Cape François, I use the term negro and brigand, (both derogatory of the ruling power of St. Domingo,) not as by any means appropriate to the people they describe at present, but as the means of distinguishing them to the European, who cannot so easily assimilate himself with their present condition. 
possible, and always on jours de fêtes, his subjects assembled, including on those occasions his three wives. The furniture of this apartment was entirely of his own making, even to the smallest utensil, and with an ingenuity beyond what might be expected from perfect leisure; notwithstanding the artificer, during the process, had been obliged to attend his labor in the fields, and was a considerable time in arms. On a neat shelf, appropriated peculiarly to their use, lay a mass book, and a mutilated volume of Volney's Travels, ${ }^{276}$ some parts of which he understood more than his visitor. Every thing convenience required was to be found on a small scale, and the whole so compact, and clean, with such an air of properté throughout as was absolutely attractive. His own bed-room was furnished with an improved bedstead, supported by trussels, with a mattress and bedding of equal quality with the other furniture, but that of his children and mother surpassed the whole. One bedstead contained them, yet separated the male from the female, the young from the aged, and was separated or combined in an instant. ${ }^{*}$ - The third was his kitchen and store-house, and might also be called his laboratory, for conveniences were found for chemical experiments, though not of the most scientific kind; but every utensil for culinary purposes were provided in the best manner. The wife of this laborer (for he had submitted to the ceremony of marriage with the female who had borne him the most children, as is the general custom with them) was nearly as ingenious as himself, and equally intelligent. The mode he pursued in the regulation of his domestic economy was excellent; as continence is not a virtue of the blacks, the increase of his family was not confined to his own house; yet, even in his amours he was just; and as the two mothers before-mentioned were less protected than his ostensible wife, the primary object of his consideration was to have the whole of his children under his own care. This was reconciled to all parties from the first, in so mild a way, that no distinction was perceivable but in age, while the mothers held a relationship to their domiciliated offspring similar to that of an aunt or cousin, each exerting herself for the purpose of adding to the comforts of her own child. - On festive occasions, the two mothers sat alternately on the right or left of the mistress of the house, with as much etiquette as might be perceived in a more elevated station, and with the utmost harmony. The master of the family was absolute, but with him it was in theory, not in practice, for all seemed to vie in forbearance. As soon as the children could contribute their little powers to labor, they were employed; the younger (except as regarded their strength) being subject to the inferior offices; and, sin-

\footnotetext{
*It is a matter of regret to the author, that the plan of this singular bedstead, which might have been adapted to the European cottage with many advantages, was lost.
} 
gular as it may appear, on the festive occasions alluded to, they waited upon their seniors, though but by a few years, and seemed delighted in the office. Agreeable to this rule, in accordance with that reverence for age so remarkable among blacks of every condition, the grandmother received the affection and attention of all; and though often crabbed, infirm, and discontented, no one seemed to consider her failings as such, but as a duty prescribed them to bear.

In fact, the writer considered this numerous family, as he beheld them at their frugal meal a model for domestic life, with a proof that those jarring interests, which, in the smallest connection, as well as in the largest states, creating more embarrassment than the most adverse circumstances, or the greatest crimes, may be avoided by a generous conduct, and reciprocal kindness. He need scarcely add, happy was his humble friend, or that each individual of his family, in their separate capacities, laid up a store of happiness for themselves, and those around them.

From what could be perceived (quitting the confines of the town,) the productive system of the earth seemed to be founded on original principles. Every individual employed a portion of his time in labour, and received an allotted part of the produce for his reward, while all took the field, from a sense of duty to themselves. A perfect combination appeared in their conduct, and every action came directly from the heart. More than sixty thousand men were frequently exercised together on the plain of the Cape, in excellent discipline, whose united determination against an invading enemy, would be victory or death. Little coercion was necessary, and punishment was chiefly inflicted by a sense of shame produced by slight confinement, or the like. Labour was so much abridged, that no want of leisure was felt; it would be a great gratification to the feeling heart, to see the peasant in other countries with a regulated toil similar to that of the labourer in St. Domingo.

Such is a general sketch of the state of society, as it appeared in the capital of St. Domingo, which spread internally as far as its effects could be expected to reach. - There was no possibility of acquiring correct accounts of the plans of government, which had been submitted to Toussaint, much less of the forms he was disposed to adopt. A regular municipal establishment existed, and martial government, dispensed every where in all its vigour, rendered civil jurisdiction of little avail.

The writer observed, with pleasure, the delay in repairing the vessel, which afforded him an opportunity of examining objects which might never return. For several weeks he continued to amuse himself with observations on the manners of the people, which he had no idea at that time of preserving beyond the information and amusement of his own friends, and by sketching 
draughts of the principal posts that were accessible. He enjoyed the habits of a metropolis, and, except the anxiety which would obtrude on account of the delay from his duty, participated in the general happiness.

When the time arrived for the departure of the vessel, at an unexpected moment; such is the human heart, he lingered on a spot which he would have before avoided at the hazard of his life. The ship had been repaired - all was ready - and bidding farewel to new connections which had just began to engage him, he returned on board with the agreeable hopes of a speedy arrival at St. Thomas's: ${ }^{277}$ but-

\section{"Heaven from all creatures hides the book of fate!" 278}

After beating about upon the coast for three days, in the most perilous circumstances, the unfortunate vessel sprung a leak, when they were compelled to put into Fort Dauphin, or, according to the revolutionary nomenclature, Fort Egalité.

In this situation the master of the vessel and the writer apprehended no danger or impropriety in going on shore. Hoisting therefore Danish colours, they came to anchor under a small fort, when in less than half an hour the latter was arrested after landing by four blacks, and a mulatto officer of great ferocity. They returned with him on board, and placed him under the care of two black sentinels. These informed him, in answer to his anxious inquiries, that he was suspected of being a spy, that he would be tried on the morrow, and of course be condemned. Such was the complacent idea attached to the trial of a stranger, who was afterwards to defend the character of their chief.

Apprehensions of different kinds now crowded his imagination: he did not know whether suspicions might not have occurred at Cape François; and the commandant of the district have been prepared for his arrival. He was aware, that, in a few instances, he had ventured farther than he should have done. He had also been allowed access to many of the principal people, and he knew not what might have taken place after his departure. He was, however, left unmolested, and, except his freedom, without any other deprivation; a circumstance of the most fortunate kind, as it afforded him an opportunity of destroying his baggage and papers, including a variety of documents, which must have been dangerous in the highest degree.* These he disposed of, by putting them out of the cabin-window in the middle of the night, with

\footnotetext{
*Besides his military appointments, they included correct views of Fort Picolet and other works, and several plans, which he hoped to have had the honour of presenting to the Duke of York; his Royal Highness having condescended to regard, with attention, other attempts which he had the honour of presenting to him. [Rainsford addressed a Memorial to the Duke of York in 1795 before leaving for the West Indies, but its contents remain a mystery.]
} 
a weight attached sufficient to sink them. Having succeeded in this affair, and the proceedings of the ensuing day continuing to occupy his attention, his situation became most unpleasant. The silence of the night, interrupted by the murmurs of the ocean, the clamours of the guard, and the distant sounds from the shore, produced the strongest melancholy; while confused surmises of the determination of the morrow, and a contemplation of the shame, rather than the terror of an ignominious death, revolving in his mind, deprived him of the possibility of rest, and totally unfitted him for the slightest preparation.

Early in the morning he was taken on shore, and examined by a black general, named Muro, ${ }^{279}$ the commanding officer of the district. He could not help thinking that his appearance augured well, for he bore the principal mythological characteristic of Justice. He was totally blind of one eye, and appeared to see but little through the other. He, however, relieved the prisoner from the apprehension of any charge existing previous to the moment; for he began his examination by insisting, that he was not an American, but an English spy, reconnoitering the coast; and closed it by acquainting him, that a court-martial, already summoned, would assemble on the morrow, and his trial would be prompt and decisive. He was then conducted to a dark prison, (which wanted none of the usual concomitants of such a place,) and treated with the utmost indignity. There was no bed; nor had he any other provision than some coarse, dry fish, which he could not eat - a treatment he was afterwards informed was used to prisoners during the space between apprehension and trial, to prevent any opportunity for the contrivance of evasion. At the hour of ten he was brought before a regular military court, composed of twelve black general officers, the etiquette of which astonished him. General Christophe, ${ }^{280}$ a relative of Toussaint, being in a neighbouring district, presided, and Muro sat on his right-hand. They interrogated him with the utmost discrimination and acuteness, appearing perfectly conversant with the nature of the business. But, for the commandant already named, not a look nor an attitude escaped him - and he darted his eye, in which both seemed to have centered an uncommon degree of fire, over every part of the prisoner, the form of whose very head-dress, he insisted, was not en Americain!

He was put on his defence in equal form, but all he could urge had not the smallest effect, as he had no passports nor any American papers to exhibit. Notwithstanding every appearance to the contrary, they had had some decisive testimony of imprudent liberty on the island; and, after several hours deliberation, he was condemned to suffer death as quick as possible. The master of the vessel behaved with dignity of character, and the utmost solicitude. He protested against the judgment, but without effect; and the prisoner was remanded till the sentence should be transmitted to the General-en-Chef ${ }^{281}$ for his approval. 


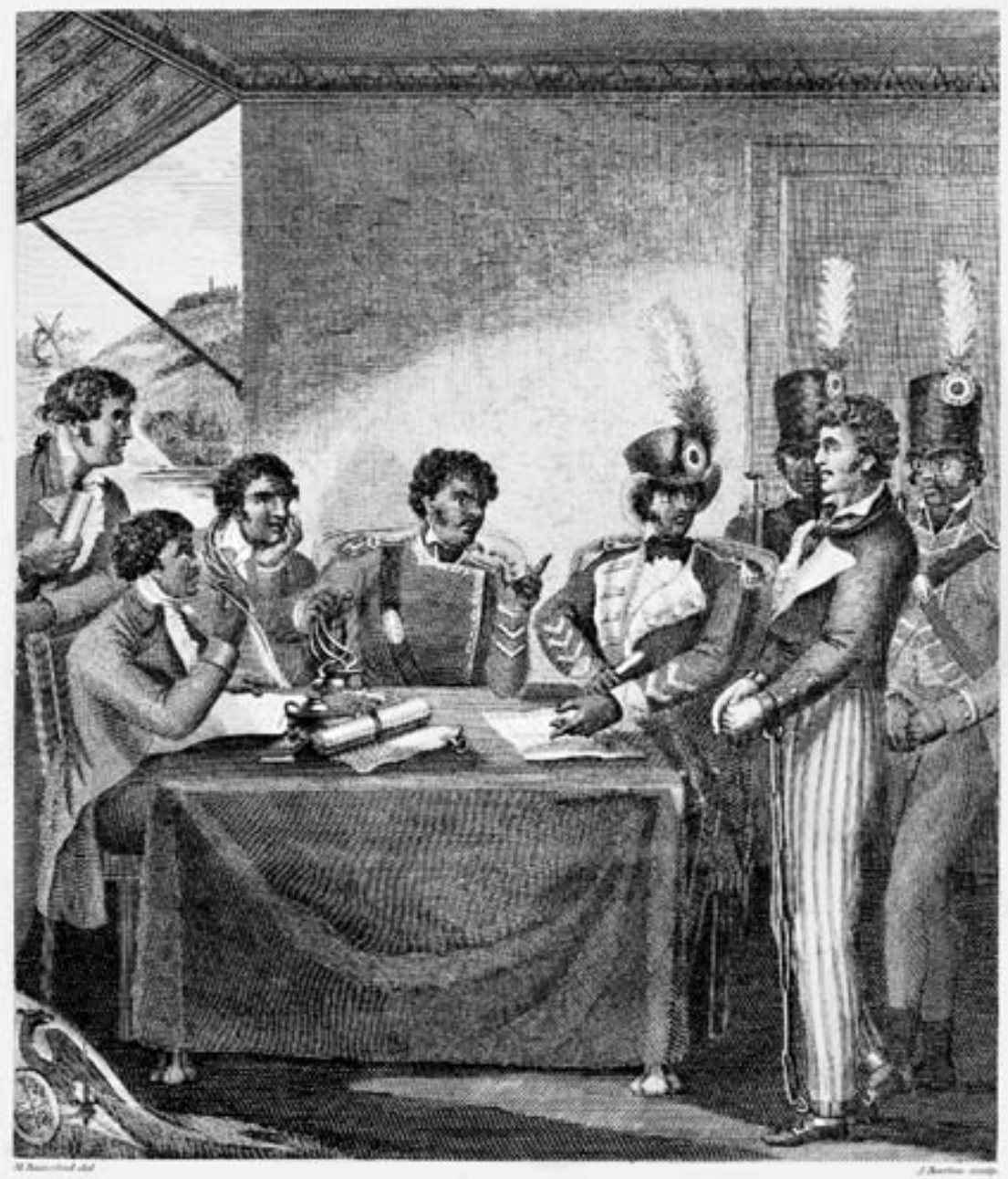

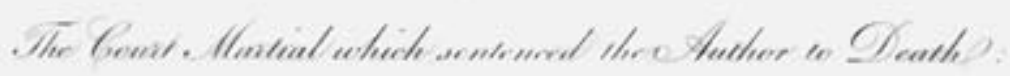

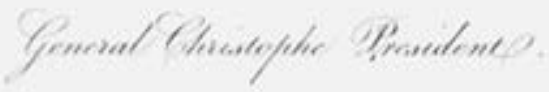

The Court Martial which sentenced the Author to Death: General Christophe President. Reproduced with the permission of Rare Books and Manuscripts, Special Collections Library, the Pennsylvania State University Libraries. 
He was then remanded to a different kind of prison, which, though little superior in point of accommodation, had the advantage of air, and the communication of the human species, though only by stealth. It was the remains of a dilapidated building, the part of which appropriated to the prisoner, was secured with strong iron-bars, in a fashion then very prevalent: he had also the incumbrance of a chain from the right arm to the left foot. For fourteen days he lay in the agony of suspense between life and death, with every evening the cruel intimation, that he would certainly be hanged on the next morning.

Even in this situation he could not resist the opportunity which his prison, or rather cage, afforded him, of observing the surrounding scene, which was more delightful than even fancy could picture. It was situated in the midst of a rich valley, through which a stream from the neighbouring hill meandered in romantic form. A church was nearly hid in the vale, and the rising ground was fortified in every direction. Over the whole the most exquisite foliage exhibited its charming fruits, with all the richness of a tropic region. Beneath the spreading cocoa, and the taller yam, he was nightly amused with the cheerful dance, the negroes assembling when they quitted labour, without any seeming appointment, but as a natural habit; sometimes they had, on jours de fêtes, or holidays, a particular entertainment of activity, the principal part of which was the Calenda, ${ }^{282}$ or "dance of love." On these occasions they were dressed with peculiar care: those who had been recently employed in arms retaining some part of their uniform, and the females bedecked with various jewels: they had also a refection. The animation displayed by both sexes in the dance was astonishing, which consisting entirely of amatory history, was equal to many ballets which are performed on the French or Italian stage, while the dancers might have been called, without any dereliction from the Cytherean goddess, ${ }^{283}$ though not exactly comporting with her in complexion,

_ “fair Venus' train." ${ }^{284}$

The hauteur with which they passed the prison of "the white man taken" was astonishing; yet some seemed willing to pity and relieve, but it arose rather from ostentation than mercy. One circumstance, however, occurred that remains deeply impressed in his bosom, and relieves his mind while recording it, which would have done honor to the most dignified of a different complexion.

After lying two nights on a couch, formed of dried sugar-canes, with a very slender supply of food, the prisoner had resigned himself to the vacuity of despair; he was stretched out in silent agony, when, as the night closed in, and the mirthful troops had progressively retired, a gentle female voice, with 
the tenderest accents, aroused his attention. How long the benign object had been there, he could not ascertain; but, when he looked up, and beheld her, his feelings were indescribable: she was a fine figure, rather tall, and slender, with a face most beautiful, and a form of the finest symmetry, improved by the melancholy air which the scene had given her.

She was dressed in a superior style, and possessed all the elegance of European manners, improved by the most expressive carriage. She held a basket, containing the most delicate food, with the finest fruits: she entreated him to receive them silently, and to destroy any remnants, as a discovery would be fatal to her, and prejudicial to himself. He was about to reply with the ardour of gratitude, when, in an instant, she was gone! On the following evening, she returned, and endeavoured to comfort him with the most obliging expressions; and, by evincing extreme anxiety on his behalf, once more light up the illusion of hope in his breast, which he had abandoned, with all human prospects, for ever. The next evening she repeated her visit, and condescended to favor him with more extensive communication. Still not a word occurred to disclose her name, or situation: once, indeed, she made some distant allusions to the English, which led him to imagine, she had been impressed with gratitude towards the country by some obligation. Whatever her name, or whatever her circumstances, if this slight memorial should live to reach that delightful isle, in which, as an angelic representation of mercy, she may yet stay the hand of the destroyer, it will bear to her the sincere effusions of a grateful heart, which, though bruised by those of a fairer skin, can never discharge its sense of duty.*

The faithful commander of the vessel, from whose mishap this dreadful

*I have ever conceived this adventure as highly illustrative of the character of the sex conveyed in the eulogium of Lediard, which contains sentiments I have always delighted to repeat. - "I have," says he, "always remarked, that women, in all countries, are civil, obliging, tender, and humane; that they are ever inclined to be gay and cheerful, timorous and modest; and, that they do not hesitate, like men, to perform a kind, or generous action. Not haughty nor arrogant, not supercilious, they are full of courtesy, and fond of society-more liable in general to err than man, but in general, also, more virtuous, and performing more good actions than he. To a woman, whether civilized or savage, I never addressed myself in the language of decency and friendship, without receiving a decent and friendly answer. With man it has often been otherwise."

With many opportunities of judging in various countries, and in various situations, I warmly subscribe to this just encomium. [John Ledyard (1751-89) was a famed American traveler, author of A Journal of Captain Cook's Last Voyage to the Pacific Ocean (1783). The "Eulogium" was part of personal papers first published posthumously in Proceedings of the Association for Promoting the Discovery of the Interior Parts of Africa, 1788-179o (1791), 65-67. It became very popular and was often quoted and republished in a variety of journals and newspapers.] 


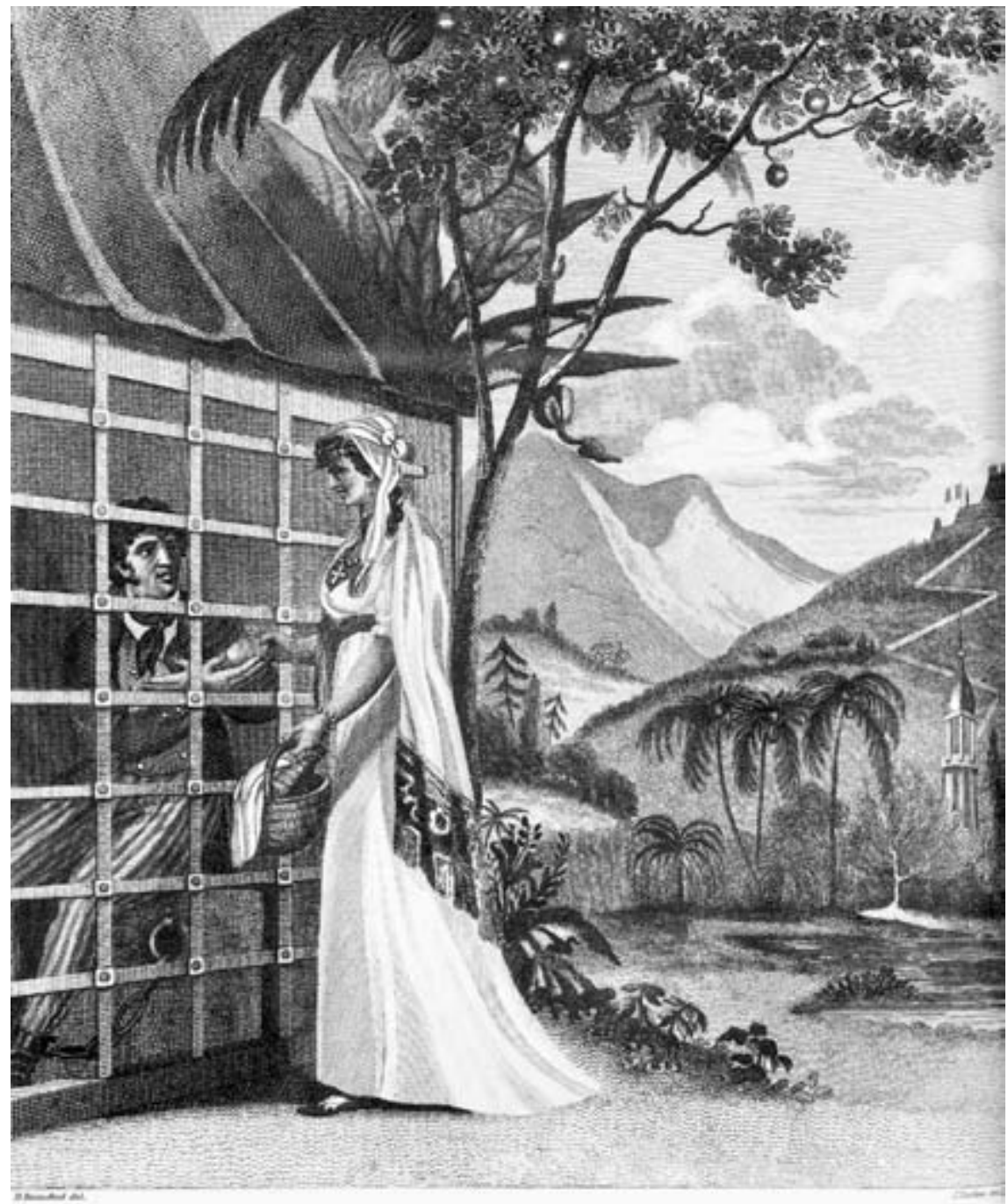

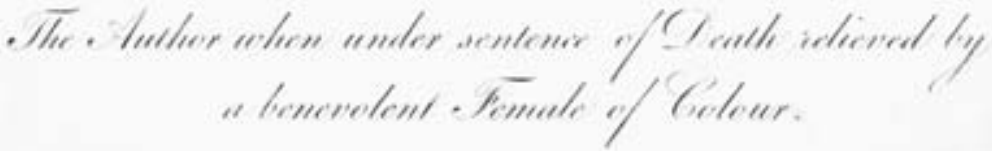

The Author when under sentence of Death relieved by a benevolent Female of Colour. Reproduced with the permission of Rare Books and Manuscripts, Special Collections Library, the Pennsylvania State University Libraries. 
circumstance arose, never long quitted the spot, and frequently ventured to whisper consolation, though with the greatest danger to himself; for it appeared a political method to expose the victims of justice, none being knowingly permitted to approach them. Whatever he heard, however, to relieve the dreadful suspense of his friend, the taciturnity of the jailor tended to contradict, as little could be obtained of information from him, except his assuring him every night, that he would be certainly hanged on the morrow.

However, on the morn of the fifteenth day, when he had ventured to disengage himself of a part of his dress, for the purpose of a temporary relief from the weight of his chains, the answer of Toussaint arrived, bringing, instead of (as was fully expected) the confirmation of the sentence, an order from that truly great man for his release, and to be suffered to proceed on his voyage, with this prohibition, conveyed with much shrewdness, but the greatest magnanimity, "That he must never return to this island without proper passports!"

To describe his feelings on such an unexpected reverse would be difficult and useless. Restored to himself once more, he did not long remain on a part of the island where his sufferings would have tended to efface the agreeable impressions received at Cape François. Once he tried to trace the haunts of his benevolent incognita, but in vain. She was impervious. He again bade adieu to this interesting soil, and at length reached his long-desired destination, the island of Martinique.*

CHAP. V.

View of the Black Army, and the War between the French Republic and the Independent Blacks of St. Domingo.

THE close of the eighteenth century, a period marked by the grandest operations and the most gigantic projects, presented to the world, a new and organised empire, where it was not only supposed to be impossible to exist, but,

\footnotetext{
*It is necessary to add, that on his arrival he met with the usual kindness and urbanity of the commander in chief, General Cuyler, who ordered him a remuneration for the loss of his baggage, and to whom he is indebted for many polite attentions since. He has been also informed, that he was honored with a congratulatory letter from his Royal Highness the Duke of York, which, from some unaccountable accident, he did not receive. [Rainsford's mention of Cuyler indicates that he could only have arrived in Martinique prior to May 1798, when Cuyler was replaced and sailed back to Great Britain. See the Introduction.]
} 
where even its existence was denied, although it was known by those connected with that quarter of the globe to have taken place, and under the most flourishing auspices. The beneficent and able black, Toussaint L'Ouverture, devoid of the extraneous policy of the governors of ancient states, no sooner found himself at ease from the complicated warfare with which, from the first moment of his government he had been surrounded, than he evinced equal talents for the arts of peace, with those which he had invariably displayed in the field; and that mercy which had ever accompanied him in victory, now transfused itself in a mild and humane policy in the legislature. His first care was to establish, on a firm foundation, the ordinances of religion, according to the existing constitutions of society, to watch over the morals, and excite the industry of those who had committed themselves to his charge. ${ }^{285}$

The effects of these exertions were quickly evident throughout his dominion. Such was the progress of agriculture from this period, that the succeeding crop produced (notwithstanding the various impediments, in addition to the ravages of near a ten years war) full one third of the quantity of sugar and coffee, which had ever been produced at its most prosperous period. The increase of population was such, as to astonish the planters resident in the mother country, who could not conceive the possibility of preventing that falling off, in the numbers of the negroes, which formed their absolute necessity for supplying them by the slave-trade. Health, became prevalent throughout the country, with its attendant, cheerfulness, that exhilarator of labour.

Having introduced in a prominent light the surprising character, to whose talents and energies, the inhabitants of this regenerated island were indebted for their then existing advantages, it becomes necessary to present the reader with a view of the circumstances which accompanied a life so important in the history of St. Domingo.

TOUSSAINT L'OUVERTURE was born a slave in the year 1745, on the estate of the Count de Noé, ${ }^{286}$ at a small distance from Cape François, in the northern province of St. Domingo, a spot since remarkable as the very source of revolution, ${ }^{*}$ and site of a camp, (that of Breda,) from whence its native general has issued mandates more powerful than those of any monarch on the earth.

While tending his master's flocks, the genius of Toussaint began to expand itself, by an attention towards objects beyond the reach of his comprehension; and without any other opportunity than was equally possessed by those around him, who remained nearly in impenetrable ignorance, he learnt to read, write, and use figures. Encouraged by the progress he rapidly made in these arts, and fired with the prospect of higher attainments, he employed

\footnotetext{
${ }^{*}$ See Chapter III. of this work.
} 


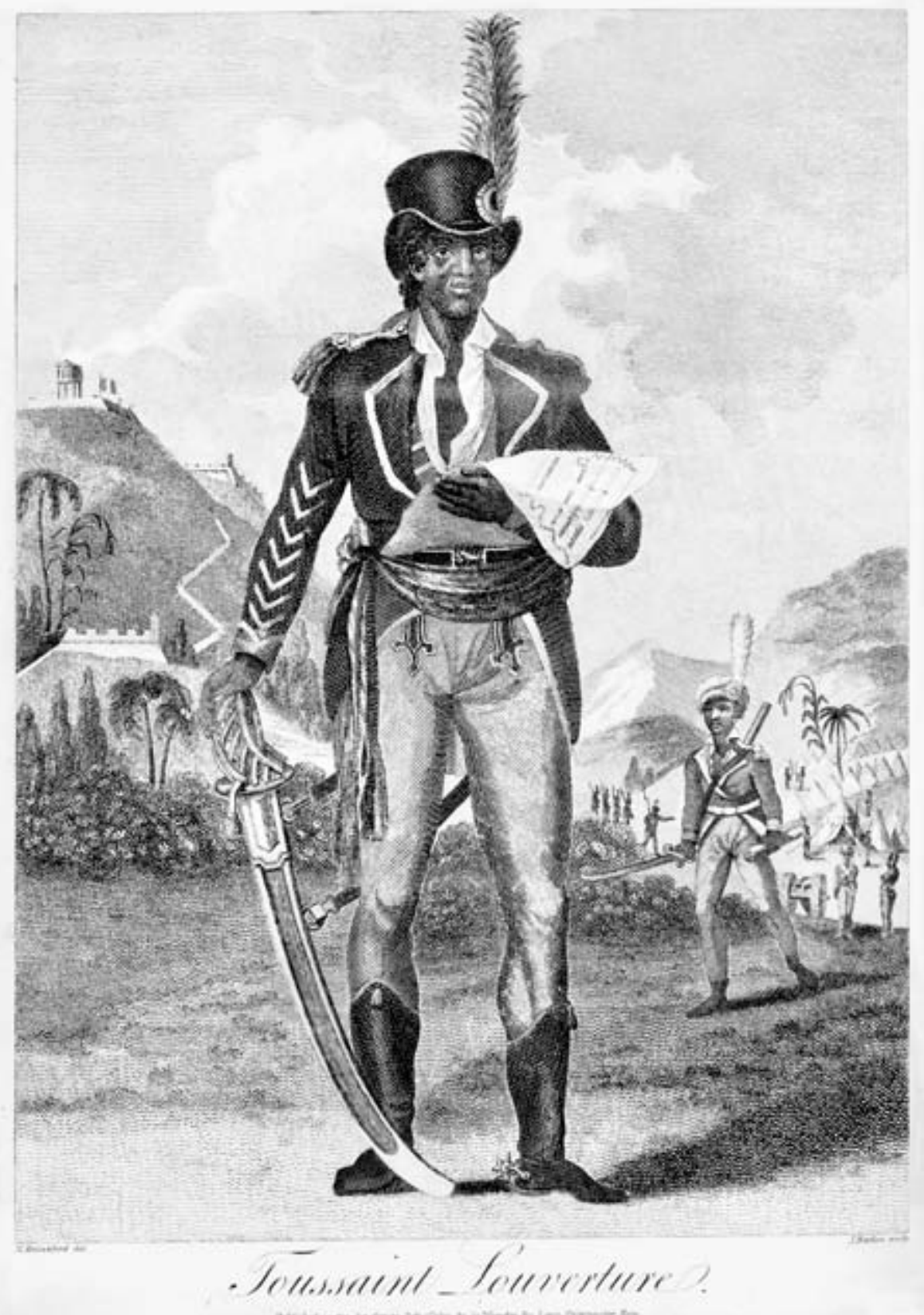

Toussaint Louverture. Reproduced with the permission of Rare Books and Manuscripts, Special Collections Library, the Pennsylvania State University Libraries. 
himself assiduously in the further cultivation of his talents. His acquirements, as is oftentimes the case, under such circumstances, excited the admiration of his fellow slaves, and fortunately attracted the attention of the attorney, or manager of the estate, M. Bayou de Libertas. ${ }^{287}$ This gentleman, with a discrimination honorable to his judgment, withdrew Toussaint from the labour of the fields, to his own house, and began the amelioration of his fortune, by appointing him his postilion, ${ }^{288}$ an enviable situation among slaves, for its profit, and comparative respectability.

This instance of patronage by $\mathrm{M}$. Bayou, impressed itself strongly on the susceptible mind of Toussaint. True genius and elevated sentiments are inseparable; the recollection of the most trivial action, kindly bestowed in obscurity, or under the pressure of adverse circumstances, warms the heart of sensibility, even in the hour of popular favor, more than the proudest honors. This truth was exemplified by the subsequent gratitude of Toussaint towards his master. He continued to deserve and receive promotion, progressively, to offices of considerable confidence.

Among other traits fondly preserved in St. Domingo of the conduct of Toussaint during the early period of his life, are his remarkable benevolence towards the brute creation, and an unconquerable patience. Of the former, many instances are related which evince a mind endued with every good quality. He knew how to avail himself so well of the sagacity of the horse, as to perform wonders with that animal, without those cruel methods used to extort from them the docility exhibited in Europe; he was frequently seen musing amongst the different cattle, seeming to hold a species of dumb converse, which they evidently understood, and produced in them undoubted marks of attention. They knew and manifested their acquaintance, whenever he appeared; and he has been frequently seen attending with the anxiety of a nurse any accident which had befallen them; the only instance in which he could be roused to irritation, was when a slave had revenged the punishment he received from his owner upon his harmless and unoffending cattle. Proverbial became his patience, insomuch that it was a favorite amusement of the young and inconsiderate upon the same estate, to endeavour to provoke him by wanton tricks and affected malignity. But so perfectly he had regulated his temper, that he constantly answered with a meek smile, and accounted for their conduct by such means, as would render it strictly pardonable. To the law of self-preservation, or the misfortune of not knowing the delight of philanthropy, he would attribute an act of brutal selfishness; while he imputed to a momentary misapprehension, an inclination to rude and malicious controversy. Thus was his passive disposition never in the smallest degree affected, being ready on all occasions to conciliate and to bear, in circumstances whether frivolous or of the highest importance. 
At the age of twenty-five Toussaint attached himself to a female of similar character to his own, and their union cemented by marriage, which does not appear to have been violated, conferred respectability on their offspring. ${ }^{289}$ Still he continued a slave; nor did the goodness of M. Bayou, although it extended to render him as happy as the state of servitude would admit, ever contemplate the manumission of one who was to become a benefactor to him and his family. Such is the effect of ancient prejudice, in obscuring, the highest excellence of our nature; he who would perform godlike actions without hesitation, from any other cause, shrinks from a breach of etiquette, or a violation of custom!

In the comforts of a situation possessing a degree of opulence, Toussaint found leisure to extend the advantages of his early acquisitions, and by the acquaintance of some priests, who possessed little more of the character than the name, acquired the knowledge of new sources of information, and a relish for books of a superior order than first attracted his attention; the author of whom he became the most speedily enamoured, was the Abbé Raynal, on whose history and speculations in philosophy and politics he was intent for weeks together, and never quitted, but with an intention to return, with renewed and additional pleasure. A French translation of Epictetus ${ }^{290}$ for a time confined him to its doctrines, which he often quoted; but he soon sought higher food for his capacious mind, and found in a portion of the ancient historians, the summit of his wishes. He was there seen studiously consulting the opinion of those who teach the conduct of empires, or the management of war; yet, he neglected not those who aim to harmonize the mind, and teach man himself; the only difference in his habits imbibing these treasures created, was, an external polish, which imparted an uncommon grace to his manners.*

*The following books were conspicuous in the library of Toussaint, a list of which was handed to the author in consequence of his inquiries respecting the progress of his mind: Scriptores de re Militari. [Vegetius, De Re Militari.]

Caesar's Commentaries, French translation, by DeCrisse. [Lancelot Turpin de Crissé, Commentaires de César, avec notes historiques, critiques et militaires (3 vols., 1785).]

Des Claison's History of Alexander and Caesar. [M. Desclaisons, Précis des histoires d'Alexandre le Grand et de Jules César, et de leurs faits militaires, soit comparés soit opposés entre eux; suivi de différents points de comparaison ou opposition entre ces deux généraux (2 vols, 1784).]

D’Orleans's History of Revolutions in England and Spain. [Pierre Joseph d'Orléans, Histoire des révolutions d'Angleterre depuis le commencement de la monarchie (1689) and Histoire des révolutions d'Espagne, depuis la destruction de l'empire des Goths, jusqu'à l'entière et parfaite réunion des royaumes de Castille et d'Aragon en une seule monarchie (3 vols, 1734).]

Marshal Saxe's Military Reveries. [Maurice de Saxe, Mes Rêveries (1757).] 
Thus proceeded this illustrious man: like the simple acorn, first promiscuously scattered by the winds, in its slow but beauteous progress to the gigantic oak, spreading its foliage with august grandeur, above the minor growth of the forest, defending the humble shrub, and braving the fury of contending elements.

Continuing on the estate on which he was born, when the deliberations preceding the actual rebellion of the slaves, were taking place upon the plantation of Noé, the opinion of him who was always regarded with esteem and admiration was solicited. His sanction was of importance, as he had a number of slaves under his command, and a general influence over his fellow negroes. ${ }^{291}$ Among the leaders of this terrible revolt were several of his friends, who he had deemed worthy to make his associates for mutual intelligence; yet, from whatever cause is not ascertained, he forbore in the first instance to join in the contest of liberty. It is probable that his manly heart revolted from cruelties attendant on the first burst of revenge in slaves about to retaliate their wrongs and sufferings on their owners. He saw that the innocent would suffer with the guilty; and that the effects of revolution regarded future, more than present justice. When the cloud charged with electric fluid becomes too ponderous, it selects not the brooding murderer on the barren heath, but bursts, perhaps indiscriminately, in wasteful vengeance, o'er innocent flocks reposing in verdant fields.

There were ties which connected Toussaint more strongly than the consideration of temporary circumstances. These were, gratitude for the benefits received from his master, and generosity to those who were about to fall, not merely beneath the stroke of the assassin, for that relief from their sufferings was not to be allowed to all, but likewise the change of situations of luxury and splendour, to an exile of danger, contempt, and poverty, with all the miseries such a reverse can accumulate.

Toussaint prepared for the emigration of M. Bayou de Libertas, as if he had only removed for his pleasure, to the American continent. He found means to embark produce that should form a useful provision for the future; procured

Guischard's Military Memoirs of the Greeks and Romans. [Karl Gottlieb Guichard, Mémoires militaires sur les Grecs et les Romains (1757).]

Herodotus, History of the Wars of the Persians against the Greeks. [Herodotus, The Histories.]

Le Beau's Memoirs of the Academy of Inscriptions and Belles Lettres. [Charles Le Beau, Histoire de l'Académie royale des inscriptions et belles-lettres, avec les mémoires de littérature (1759-77).]

Lloyd's Military and Political Memoirs; the Works of the English Socrates, Plutarch, Cornelius Nepos, \&c. \&c. \&c. [Henry Lloyd, The History of the Late War in Germany (1766).] 
his escape with his family, and contrived every plan for his convenience: nor did his care end here, for after M. Bayou's establishment in safety at Baltimore, in Maryland, he availed himself of every opportunity to supply any conceived deficiency, and, as he rose in circumstances, to render those of his protégé more qualified to his situation, and equal to that warm remembrance of the services he owed him, which would never expire.

Having provided for the safety of his master in the first instance, Toussaint no longer resisted the temptations to join the army of his country, which had (at this period) assumed a regular form. ${ }^{*}$ He attached himself to the corps under the command of a courageous black chief, named Biassou, and was appointed next in command to him. Though possessed of striking abilities, the disposition of this general rendered him unfit for the situation which he held; his cruelty caused him to be deprived of a power which he abused..$^{292}$ No one was found equally calculated, to supply his place, with the new officer, Toussaint; therefore, quitting for ever a subordinate situation, he was appointed to the command of a division.

If during this early period of his life, the black general had shone conspicuously, through every disadvantage, with the brightest talents and the milder virtues, he now rose superior to all around him, with the qualities and rank of an exalted chief. Every part of his conduct was marked by judgment and benevolence. By the blacks, who had raised him to the dignity he enjoyed, he was beloved with enthusiasm; and, by the public characters of other nations, with whom he had occasion to communicate, he was regarded with every mark of respect and esteem. General Laveaux called him "the negro, the Spartacus, foretold by Raynal, whose destiny it was to avenge the wrongs committed on his race:" ${ }^{293}$ and the Spanish Marquis d'Hermona ${ }^{294}$ declared, in the hyperbole of admiration, that "if the Supreme had descended on earth, he could not inhabit a heart more apparently good, than that of Toussaint L'Ouverture." ${ }^{295}$

His powers of invention in the art of war, and domestic government, the wonder of those who surrounded, or opposed him, had not previously an opportunity for exhibition as at the period to which we have arrived in this history. Embarrassed by a variety of contending factions among the blacks, and by enemies of different nations and characters, he was too much occupied in evading the blows constantly meditated in different quarters, to find leisure for the display of that wisdom and magnanimity which he so eminently exercised. Nevertheless, a variety of incidents are recorded in the fleeting memo-

\footnotetext{
*It is pleasing to reflect, that Toussaint was not the only instance of a similar conduct to the present. It occurred, with many variations, in numerous cases; an eminent instance of which will be found in the third chapter of this work.
} 
rials of the day to corroborate the excellence of his character, and still more are impressed on the memory of all who have visited the scene of his government. Notwithstanding the absoluteness of military jurisdiction, which existed with extra power, no punishment ever took place without the anxious endeavours of the General in Chief to avoid it, exerted in every way that could be devised. No object was too mean for his remonstrance, or advice; nor any crime too great to be subjected to the rules he had prescribed to himself. The punishment of the idle or immoral labourer was, being withdrawn from agriculture, and condemned to a military service dangerous or severe. In cases of treason he was peculiarly singular in his ideas, and the following incident will afford a specimen:-

Shortly after General Maitland arrived upon the island, four Frenchmen were retaken who had deserted the black chief with aggravated treachery. Every one expected a vindictive punishment, and of course a cruel death. Leaving them, however, in suspence as to their fate, he ordered them to be produced in church on the following Sabbath, and, while that part of the service was pronouncing which respects mutual forgiveness, he went with them to the front of the altar, where, impressing them with the flagitiousness of their conduct, he ordered them to be discharged without farther punishment.

It probably may be expected that something should be mentioned of the general character of Toussaint; and, if there was any object predominant in the wishes of the writer during his sojourn at the Cape, it was - to ascertain the traits of peculiarity in that individual, - to judge of the views, and of the motives that actuated him. The result of his observations was in every respect favorable to this truly great man. Casual acts of justice and benignity may mark the reign of anarchy itself, and complacency sometimes smooth the brow of the most brutal tyrant; but when the man, possessed for a considerable period, of unlimited power, (of whose good actions no venal journalist was the herald, but, to transcribe his errors a thousand competitors were ready) has never been charged with its abuse; but, on the contrary, has preserved one line of conduct, founded by sound sense and acute discernment on the most honorable basis, leaning only to actions of magnanimity and goodness; he has passed the strongest test to which he can be submitted; who, with the frailties of human nature, and without the adventitious aids of those born to rule, held one of the highest situations in society.

His government does not appear to have been sullied by the influence of any ruling passion; if a thirst of power had prompted him alone, he would have soon ceased to be a leader of insurgents; had avarice swayed him, he, like many others, could have retired early in the contest, with immense riches, to the neighbouring continent; or had a sanguinary revenge occupied his mind, he would not so often have offered those pathetic appeals to 
the understanding, which were the sport of his colleagues, on crimes which the governors of nations long civilized would have sentenced to torture! His principles, when becoming an actor in the revolution of his country, were as pure and legitimate, as those which actuated the great founders of liberty in any former age or clime.

Such was the character of Toussaint L'Ouverture, as regarded his office of Commander in Chief, and Governor of the island of St. Domingo. In his relations towards other countries, he appears to have excited admiration for his justice, and the courtesy of every enlightened state: the charges of his most inveterate enemies never extended to a fact that can diminish the wellearned eulogies he has obtained. His rules of conduct were the emanations of a mind capacious and well informed; and but for the exertions of his talents, or those of some chief equally able, indefatigable, and sincere, the country, now blooming with culture, and advancing in true civilization, might have been a ruined state, sacrificed to the conflicts of disappointed ambition, revenge, and the whole train of evils which a multiplicity of factions could create. That there should be found partizans of each of these factions in the then divided state of France, to complain of every arrangement formed by this astonishing individual, is to be expected, rather than wondered at; and to these motives alone, there is no reason to doubt, may be ascribed all the calumnies which have been vented against him.

In his private life, Toussaint lost none of the excellence of that character which is conspicuous in his public actions. With much sensibility, he supported an even temper in domestic privacy; and in contra-distinction to the general custom of other great men, might be considered equally an hero in the closet as the field. To his wife, a sensible and affectionate woman, he behaved with the most endearing tenderness and consideration, and to his children imparted all the warmth of paternal affection; yet he had no overweening fondness to conceal their faults from his notice, even the smallest want of proper attention to an inferior, was censured with severity proportionate to the difference of their condition. If they obtained not knowledge from the transitory nature of human circumstances, so necessary to check the pride of birth or situation, almost always manifest in children reared in affluence, it was not the fault of a father whose life was conspicuous for humility of disposition, and a diffidence of his powers, proportionable to the elevation of his rank, or the accumulation of his honors. As his children grew to an age capable of that education which his individual acquirements instructed him as necessary to the sphere of life in which they were to move, Toussaint procured for them the best tutors he could obtain, and afterwards sent them to France under their care, for the advantages of higher instruction. ${ }^{296}$ - His leisure, which was not great, was occupied in relieving those 
who suffered in any way undeservedly; nor did he, as is often the case in the world, weigh guilt by incapacity or distinction. The weak of every description were his peculiar care; the strong in intellect, the mighty in war, or the amiable in domestic life, shared alike his esteem.

In person, Toussaint was of a manly form, above the middle stature, with a countenance bold and striking, yet full of the most prepossessing suavityterrible to an enemy, but inviting to the objects of his friendship or his love. ${ }^{297}$ His manners and his deportment were elegant when occasion required, but easy and familiar in common; - when an inferior addressed him, he bent with the most obliging assiduity, and adapted himself precisely, without seeming condescension, to their peculiar circumstances. He received in public a general and voluntary respect, which he was anxious to return, or rather to prevent, by the most pleasing civilities. His uniform was a kind of blue jacket, with a large red cape falling over the shoulders; red cuffs, with eight rows of lace on the arms, and a pair of large gold epaulettes thrown back; scarlet waistcoat and pantaloons, with half boots; round hat, with a red feather, and a national cockade; these, with an extreme large sword, formed his equipment. - He was an astonishing horseman, and travelled with inconceivable rapidity.

Thus are given the rough outlines of the character of Toussaint; for the shades it will be necessary to consider what foibles could have existence with the virtues described. It is not intended to sully the present account by the absurdity of attempting to hold him up as a perfect character; but thus much is certain, that if he had any peculiar vices, he had the address to conceal them from the most scrutinous and industrious observer.

Toussaint, surrounded by men of letters and science, whom various circumstances had brought from the mother country found little difficulty in the formation of a temporary constitution, of which justice and equality (of right only, not of property) should be the basis. Among those from whom he received important assistance was the Citizen Pascal, a descendant of the celebrated writer of that name, who inherited the talents of his ancestor. He had been sent to Cape François by the Executive Directory, in the fourth year of the revolution, as secretary to the agents of the republic; when he married the daughter of a mulatto in office, named Raymond, ${ }^{298}$ and acquired by the connection a considerable property. He attached himself early to Toussaint, with the Abbé Moliere, and an Italian ecclesiastic, of considerable talents, named Martini, who were always about his person.*

*Filling every public office with men of talents and letters in France, (as they confessedly do, ) it was scarcely possible to appoint any but persons of ability to the foreign departments; which accounts for the easy acquisition of such persons, to the liberal Toussaint. 
Having settled the grand object of his care, particularly as regarded the safety of the white inhabitants, he next devoted himself to the regulation and increase of his army, on a scale fitting the importance of the country under his care. At the time of his treaty with General Maitland, his force in the northern province amounted to something less than 40,000 men, but they were soon increased to nearly double that number, and at this time exceeded all conception. * As they were necessarily divided in the different provinces, he prepared for a journey round the island for the purpose of reviewing them, and appointing the districts, as well as settling the officers to command them, with greater success and accuracy than could be done at a distance. Vast quantities of ordnance and stores of different kinds were accumulated at different posts, which would be more useful when distributed. $\mathrm{He}$ was desirous of becoming known to a great number of brave men who were attached to his army, many of whom had received a military education in the mother country, and could be placed in situations of responsibility; others, too, required local appointments, for the purpose of residing in situations with which they were acquainted; and it was the wish and policy of Toussaint, to know and gratify them all. - The animation of his presence was also necessary to troops, (in some few instances, perhaps, languid,) who were ambitious of being seen by their General in Chief, whose very name acted with electric force on all. In the capital of the Spanish part of the island, another reason proved the necessity of a visit from the General in Chief. Notwithstanding the cession of the Spanish colony to France in 1795 , and that it had been taken possession of by the generals Paul L'Ouverture, ${ }^{299}$ (the brother of Toussaint,) and D'Hebecour, ${ }^{300}$ who had garrisoned the different posts, a force still remained in the city of St. Domingo, under Don Joachim Garcia, insubordinate to the present government; Toussaint, therefore, with that promptitude for which he was remarkable, though not without due consideration, set out upon this important tour.

*Colonel Chalmers, in his "Remarks on the late War in St. Domingo," supposes certain muster-rolls, which he describes to have been in the possession of Toussaint's adjutantgeneral at the Mole, stating the force (in that quarter) at 35,00o men, to contain the whole effective force of the island, and even then ridicules the idea of its being so strong! It causes an involuntary smile to see such opinions seriously delivered, or to observe the mutual censures of General Maitland and Toussaint, for not continuing a war of annihilation, by Colonel Chalmers on one side, and Stephen Mentor, the black seceder, on the other. [Etienne Mentor (1771-1806) was born to a free black family in Martinique. He gained recognition fighting the British in Guadeloupe. Sent to St. Domingo, he found himself at odds with Toussaint's policies and opposed negotiating with the English. He also opposed independence and was an elected French representative in Paris until Napoleon came to power. He returned to St. Domingo and sided with Dessalines. He was himself assassinated a few days after Dessalines.] 
The reception the General met with in every town and village through which he passed, and at every port he visited, was such as to have gratified the vanity of the proudest potentate. All orders, civil or military, vied with each other in their modes of respect, while the women and children lined the road sides, to bless the pacificator of their country. On every face was depicted content and health, and in every place appeared universal satisfaction. Every means were used to declare the general pleasure with which he was viewed. Garlands, and fantastic wreaths, were woven by those who could do no more. Superb decorations covered the houses of proprietors, and triumphal arches graced his entry to every town. The military, in their proudest array, were anxious to obtain approbation by a soldier-like appearance, and a variety of plans were formed by the maritime people to testify their accordance with the public respect. Innumerable instances might be mentioned which would assume the air of romance, of the singular testimonies which occurred to honor him, and do justice to his character.

In one place, a respectable negro, of the age of ninety-nine, seated on a wicker chair, presented to him ten sons, the children of one wife, employed in agriculture, but ready to devote themselves to the service of their country whenever it should be necessary. Three sisters hung over their father, as if fearing to lose the protection of their brothers. All produced certificates of propriety and industry from their employers, and their neighbours, a part of whom surrounded them. Toussaint leaped from his horse, and knelt at the feet of the old man. "Respectable age," said he, "it is to such members as you, that your country is this day indebted for peace and freedom!" As he arose, an aid-de-camp directed his attention to a solitary youth, who stood at a short distance, unnoticed. "Who is that," exclaimed the General, "apparently miserable on such a day?" He was informed it was one who had disgraced the family now presented to him, in many instances, and had lately encouraged his sister in vice. At this moment an interesting female rushed from the crowd, holding an infant in her arms, with the appearance of extreme anguish, exclaiming, "It is for me, General, that the poor Antony is calumniated." - Her tears interrupted her. - "I could not part with my child, though rejected by his father, and denied even permission to labour in the same plantation with my family, because I quitted it, and nearly starving, engaged myself to another less desirable. - My affectionate brother lent me all the aid his own labours could spare, and when I was to remove, solicited an addition from my other brothers and sisters. He was refused, and he" - "He robbed them, perhaps, to supply you," interrupted the General; "thereby violating his duty to his family, his country, and himself; - this is wrong; - there was something, likewise, erroneous in withholding your child from the pro- 
tection it would have received; yet," turning to the old man who had claimed his approbation, "we must not, father, reject the unfortunate; it is not sufficient to be just, we must also be merciful, recollecting how much need we all have for mercy. Sully, not, therefore, the happiness you enjoy, with the recollection of one individual less happy by your means, much more your son, (leading him towards the old man,) or your daughter, (doing the same)." The impressive manner of the General (though the transaction lasted but a few minutes) drew tears from the whole; the family instantly caressed their brother and sister, and Toussaint, re-mounting his horse, was quickly out of sight.

He never stooped to court the attention of the multitude, but having returned the civilities which every where crowded upon him, galloped on, leaving his aides, or whoever accompanied him, frequently out of sight. Innumerable acts of discriminative goodness are related of him during this route, and the day, where-ever he was, was a day of peace and pleasure.

The effects of this tour were very evident, by the uniform reformation in every part of the island. The municipal governments were brought into one general system, and a chain of communication established. The different brigades were rendered more effective by the better arrangement of the troops composing them, and armed posts were established throughout the island, well supplied with the ordnance his enemies had left behind. In fact, every part was put in a situation to withstand the utmost force of an enemy, however powerful, and to dispute with them every inch of ground. Nor, during an attention to the internal safety of the country in a military view, were its maritime interests forgotten, every commercial encouragement was offered to the neighbouring islands and the continent; the safety of the whites was established, and their power of injuring the state curtailed.

Toussaint returned to the Cape, accompanied by a numerous suite, in which was a selection of the principal talents of the island. He was received with redoubled pleasure to what he had previously experienced on returning to the capital, from the length of his absence, and the reports of his conduct, which had preceded him from every quarter. Neither was this fame confined to the boundaries of St. Domingo; it ran through Europe, and in France his name was frequently pronounced in the Senate with the eulogy of polished eloquence.

It being necessary that the constitution, which in effect now existed, should be published, for the assurance of its permanent execution, and the proper understanding of the different inhabitants and relations of the island, it was proclaimed on the 1st of July 1801. At the head of the ceremony appeared the General in Chief, and the code was promulgated in the name "of the people." 
The intercourse between France and St. Domingo, which had been decreasing for some time previous to the proclamation, now ceased altogether, except by private correspondence, which was considerably checked. Still the late proprietors resident in or near the French metropolis, languished for the recovery of their former importance, and every account of the flourishing state of their beloved colony, awakened each lingering wish to new, but vain hopes of a restoration. They even imagined, in every amelioration of the island, an additional chance of succeeding to their desires, till they had schemed plans of operation, and imagined means of execution, which themselves only could have devised or understood. These were constantly obtruded on the French government, who were too much employed in the complicated politics of Europe to admit them into their views, and all that they obtained was the promises with which they were bribed, as the price of forbearance from anti-revolutionary projects at home.

But a time was approaching when accident produced in a moment what the labour of years could not effect, and obtained for these misguided persons, the interference their restless spirits desired. The government of France, having assumed a novel and original form under the influence of a victorious dictator, ${ }^{301}$ for whose firm establishment it required an interval of peace; and the politics of that country, which was the remaining enemy of the republic, and the only nation in Europe capable of contending with her, suggesting a similar measure, the two countries, after communicating with political sincerity, came to the determination of a cessation of hostilities, and the preliminaries were accordingly executed. ${ }^{302}$ Thus the naval power of France, which for nine years had not sailed from her ports with impunity from the terror of the British flag throughout the globe, was at liberty to perform all its crippled state would permit, and to improve that state with every possible advantage.*

This was but a part of the circumstances arising from the peace of Europe favorable to the expatriated colonists of St. Domingo. The labours of Bonaparte, First Consul of the Republic, hitherto limited in exertions of military prowess, whose rapidity and effect gave no opportunity for objection or scrutiny, were now to be submitted to the test of cool examination. That personal courage which had conquered a great part of the continent of Europe, subverted foreign states, and removed a divided senate at home, would not avail in the convictions of philosophy, or the conciliation of jarring interests

\footnotetext{
*It is painful (and dangerous) to hear the prevalence of an opinion, even from those who should be better informed, that the creation of a French navy is impossible, and that it is not an object of contemplation in the present ruler of France. That it is both the one and the other is most certain, and the writer will be less prophetic than he has been, if a very few years do not exhibit a confirmation.
} 
in a state of peace. It became, therefore, necessary to obtain a powerful influence in the cabinet as well as in the field, and to assure to himself other interests than those of humanity.

At this period the party who had constantly beset the existing ministry, did not neglect a single opportunity of redoubling their appeals to the present government, or of availing themselves of every circumstance, to attach to their cause a more powerful weight than it then possessed. They held out, in temptations of the most florid description, the advantages daily lost to commerce; and those who had till now been occupied in fitting out numbers of privateers, began to think of an advantageous employment of their capital; others, whom the war had confined to France, contemplated with pleasure trans-atlantic views, and the enterprizing regarded the troubles in St. Domingo, as an inviting opportunity of distinguishing themselves. In fact, every description of people became interested in the recovery of the colony, forgetting what had passed in regard to the abolition of slavery in the same metropolis; it became a popular cause, was introduced into the assemblies, and the ladies became partizans, headed by the favorite sister of the First Consul, the lady of General Le Clerc. ${ }^{303}$ The mania spread into England with the beauties of the Consular court, and that nation, where the ministry and people had blindly desired the abolition, at the expence of a portion of their empire of commerce, and the ruin of a large body of colonists, still more blindly joined in the popular wish of returning to slavery, those who were completely emancipated.

Bonaparte viewed the growing spirit with silence, and, it may be, not without some regard to the character the victorious Black had obtained in the mother country. A variety of circumstances contributed to convince him of the necessity of some attention (in the first instance) to the powerful requests which poured in from every quarter; the instance, also, of a power bidding him defiance in a country which had not, by any regular process, become separated from that government over which he was called to preside, was repugnant to his feelings in the rank in which he was elevated. Madame Le Clerc, partaking in the ambition ascribed to her brother, urged the measure of reducing the island, to procure for her husband and herself something more than was to be derived from basking in the beams of the First Consul; and the appointment of General Le Clerc ${ }^{304}$ to a splendid conquest, was confining the dignity of it to the family. When the inclination of Bonaparte was understood to be favorable to the prospects of the colonists, means were found to interest the most powerful merchants in their behalf and urged by those, on whose aid (in the present stage of his government) he was aware much was to depend, this penetrating man, without any other information 
than that derived through so partial a medium, consented to an expedition that was to become an eternal blot upon a career, if not often just or humane, at least always able, and frequently magnificent.

As, to devise and execute were the same thing with the First Consul, this baneful expedition was no sooner determined on, than after forming a plan for the government of the colonies, and submitting to the British government the circumstances of its destination, to prevent the alarm which it must naturally create, its preparation was commenced, to add another shade to the darkened side of human nature.

At the head of the expedition was placed General Le Clerc, and such was the confidence of its success, that he was accompanied by his lady, and her younger brother, Jerome Bonaparte. ${ }^{305}$ General Rochambeau, ${ }^{306}$ who had been a proprietor, assisted with his advice the commander in chief, and also commanded a division. To them were added Generals Kerversan ${ }^{307}$ and Boudet, ${ }^{308}$ with a force of twenty thousand men. The two sons of Toussaint L'Ouverture who had been educated in France, were sent as hostages for the reception of the French army by their father, under the care of the tutors who had accompanied them. Admiral Villaret ${ }^{309}$ (who was in the service of the regal government of France) commanded the fleet, under whom were Rear-Admiral Latouche, ${ }^{310}$ and Captain Magon. ${ }^{311}$ The fleet consisted of some of the best ships of the line, and a proportionable number of frigates, transports, \&c. The prevalent sentiment seemed to be, that after the first attack, a compromise would be effected with Toussaint and the different chiefs, which would enable the French force to establish itself throughout the island, and complete the subjugation of the armed blacks.*

In the month of December the expedition sailed, amidst the acclamations of all, who were either interested in its success, or imagined themselves so;

*The absurdity of this idea, when the state of St. Domingo at the time is considered, and the accumulated strength which the General in Chief had acquired from the defeat of every enemy, as well as the experience which the different contentions had afforded him, is a sufficient proof of the inconsideration with which Bonaparte was hurried into this illcontrived and ruinous measure. The writer did not omit any means, both with those in power and otherwise, to convince them of the futility of the scheme, and to caution the British government against the temptation afforded to Admiral Villaret, to turn his course to a more accessible destination. But such was the pre-determined state of the public mind, that his opinions and his cautions were alike disregarded. Both have, however, been fully corroborated; and if the "feeble and divided" blacks had not given a better account of the French expedition, worse effects of such an inattention might have been experienced. As a curiosity, when compared with the French General's dispatches, the anticipation of his fate, as published at the Military Library in London in the beginning of 1802 , will be found in the Appendix to this work. 
and arrived in the bay of Samana, on the eastern coast of the island, on the 28th of January, when General Kerversan was dispatched with a division to the city of St. Domingo; Rear-Admiral Latouche was ordered to carry the troops under the command of General Boudet to Port-au-Prince; and Captain Magon to land a division under General Rochambeau in Mancenillo Bay, on the northern coast. These divisions were directed so as to surprize different points of the island at the same period; General Le Clerc proceeded, with the remainder of the troops, to the attack of the Black capital, the city of Cape François, where he arrived on the 5 th day. Two frigates and a cutter being sent to reconnoitre the entrance of the road and adjacent posts, were fired on from Fort Picolet.

In the mean time, the secret operations of the Consular cabinet ${ }^{312}$ had not been neglected; a few civic officers among the blacks, and several whites in that part of the country, intended to be first attacked, were prepared, as far as they could, to assist the designs of the invading army. The vigilance, however, of Toussaint had been exerted, and to every part of the island where invasion was expected, or the smallest signs of defection appeared, he had applied every means in his power to prevent their approach towards the interior. He had many faithful adherents distributed through the posts of danger and honor, whose confidence in him nothing could alter. Although cautious of admitting any sanguinary law in his government, he had proved to every officer under his command the impartiality by which he was guided, in the sacrifice of his own nephew, General Moyse, ${ }^{313}$ when a charge of injustice had been proved against him. By attending to the prosecution of the necessary measures for the internal defence of the island, General Toussaint was away from Cape François at the time the expedition arrived.

General Christophe, who was left in command, on perceiving the approach of the French fleet, sent the port captain, an experienced black officer, named Sangos, to acquaint the commander of the expedition with the absence of the General in Chief; and "that it was necessary to wait the return of a courier he had dispatched to him, previous to any steps for the disembarkation of a military force; on a refusal of which he should consider the white people in his district as hostages for the conduct of the French; and that the consequence of attack upon any place would be its immediate conflagration." ${ }^{314}$

Upon this intimation, General Le Clerc conceived it expedient to dissemble awhile, till the effects of his interest, strength, and success (in which was included the mayor of the city) should be known, and accordingly began to administer the palliatives with which he had been furnished from France. He wrote a mild letter to General Christophe, stating the benign intentions of the First Consul and himself towards the island, and inviting him to return to 
his duty as a French citizen, with the most specious promises. He enclosed copies of the proclamations brought with him, and a private letter from General Bonaparte to the General in Chief, Toussaint. In this letter the Black General receives ample indemnity for all that is passed, and the most encouraging promises for the future. "We have conceived for you esteem," says the ruler of France, "and we wish to recognize and proclaim the great services you have rendered to the French people: if their colours fly on St. Domingo, it is to you, and your brave blacks, that we owe it. Called by your talents and the force of circumstances to the chief command, you have closed the civil war, put a stop to the persecutions of ferocious men, and restored to honor the religion and worship of God, from whom all things come." Also, "The situation in which you were placed, surrounded by enemies, and without the mother country being able to succour or sustain you, has rendered legitimate the articles of that constitution, which otherwise would not be so."* This dispatch was borne by a naval officer, named Le Brun, who received in return a repetition in effect, but more strongly expressed of the intimation received by Sangos.

A deputation from the town, headed by the mayor, went on board the fleet, who represented, with visible terror, that, "on the first signal of a debarkation, the city and adjoining estates would be set on fire, and the white people put to the sword; and entreated General Le Clerc to take their unhappy circumstances into consideration." 315 He received this deputation with the greatest complacency, and sent them back with a commission to read the proclamation of the First Consul in the town, and to declare his good intentions towards the inhabitants; Caesar Telemache, ${ }^{316}$ the mayor, fulfilled their wishes in the most open manner. The result was the same as before; notwithstanding the daring conduct of the chief municipal officer and others, and the satisfaction of some whites, (who had been protected and encouraged by the blacks,) at the prospect of the recapture of the colony.

General Le Clerc, conceiving his friends to be sufficiently ripe and numerous for his reception, and impatient to open his splendid career, arranged his plan for landing the troops at a point of land called Du Limbé, a few miles to the westward, from whence he conceived he might be able to gain the height of the Cape before the negroes executed their threatened purpose, or at least, land with less injury than he should be able to do, in the face of a well fortified capital. Admiral Villaret was ordered to attack the town by sea at the same

*See Moniteur, (the official journal of France,) March 21, 1802. - Dispatch of Le Clerc. [The dispatch was actually published in Le Moniteur, 24 Ventose, year X (March 15, 1802), 696.] 
time, which, with the descent of Rochambeau at Fort Dauphin, would form a powerful diversion in their favor. The whole was executed with the utmost difficulty, the blacks acting up to their orders, which were, "To defend themselves against the French to the last extremity; if possible, to sink their vessels; and when a position could not be maintained, to set fire to every thing in their retreat."* In the evening, when Le Clerc came within sight of Cape François, the city was entirely in flames. The troops halted with dismay to behold a scene so dreadful, the effects of which they could not arrest, and the squadron beheld it in awful horror from the water. The next morning they approached the ruins, when every remaining habitation was deserted, and the fields lying in waste. The emissaries of the French rallied around their Chief, among whom was Caesar Telemaque, who was immediately reinstated in the mayoralty. General Humbert, ${ }^{317}$ who had landed a body of twelve hundred men, and reduced a fort to facilitate the entry of Le Clerc, had employed his men in extinguishing the fire, and saving the city from total destruction.

Two detachments were immediately dispatched to occupy Port Paix and the Mole, who contrived, from the means which had been used before the landing of the troops, to enlist (according to their own account) upwards of a thousand black soldiers. They, and several of the municipal officers, were attracted by the proclamations plenteously dispersed, which were as follows:

Paris, Nov. 8, 1801

"Inhabitants of St. Domingo,

"Whatever your origin or your color, you are all French; you are all equal, and all free, before God, and before the Republic.

"France, like St. Domingo, has been a prey to factions, torn by intestine commotions, and foreign wars. But all has changed; all nations have embraced the French, and have sworn to them peace and amity; the French people have embraced each other, and have sworn to be all friends and brothers. Come also, embrace the French, and rejoice to see again your European friends and brothers.

"The government sends you the Captain-General Le Clerc: he has brought sufficient force for protecting you against your enemies; and against the enemies of the Republic. If it be said to you their forces are destined to ravish from you your liberty; answer, the Republic will not suffer it to be taken from us.

"Rally round the Captain-General; he brings you abundance and peace. Rally all of you around him. Whoever shall dare to separate himself from the

\footnotetext{
${ }^{*}$ Moniteur, March 22.
} 
Captain-General, will be a traitor to his country, and the indignation of the country will devour him as the fire devours your dried canes.

"Done at Paris, \&c.

(Signed) "The First Consul, Bonaparte. "The Secretary of State, H. B. MARET." 318

In the mean time, Toussaint, who had been long preparing for the event, had carefully examined the interior, and was approaching the scene of devastation. Notwithstanding the hostile form in which the French armament had approached his seat of government, he was anxious to find, from their conduct, if he had to expect an amicable proposition, or any intention to support with integrity the relation in which he stood to his countrymen. Well acquainted with the political state of Europe, he could not conceive that the man, who had confessedly (however advantageous to his country) usurped a dictatorial power in France, could contemplate the reduction of one who had been called to equal power by the most legitimate of all authority, the voice of the people. He knew, that presenting a vast extent of coast, it would be impossible to prevent a debarkation at one point or the other, therefore had pre-determined to suffer the French to land, if they insisted upon it, after a slight annoyance from the forts, or adjacent posts; but, that previous to their landing, every preparation should be made for securing the property of the inhabitants of the metropolis, or any other town, which should then be set on fire, thus preventing them from taking that rest which, after the voyage, they would naturally require, and impede their penetration into the interior. These operations had been carefully performed, and with so much attention to the whites in particular, that many of them returned to their houses, in full possession of their property after the capital was in possession of the French. Toussaint, satisfied with the state in which he found every preparation for defence in the interior, determined to wait the event of the future motions of the French commander in chief.

The letter which the First Consul had written to Toussaint remaining undelivered, the scheme, which a reliance on the feelings of Toussaint had dictated, was not yet executed. Advices had been received from the other divisions, that they had with difficulty made good their landing, but all remained, as well as Le Clerc, upon the coast, without any attempt to penetrate into the interior. It was determined, as Toussaint's approach was announced, to try the effect of the artifice which had been prepared.

Accordingly Coisnon, ${ }^{319}$ the tutor of the sons of Toussaint, a confidential agent in this expedition, was commissioned to conduct an interview between the General and his children, who had been prepared by the caresses of the 
First Consul, and the enjoyment of every indulgence, to seduce their parent to an acquiescence with the measures of the Captain-General Le Clerc. Toussaint possessed a plantation called Ennery, about ten leagues from the Cape, where he was returning, which was fixed upon as the scene of the intended interview. Thither they repaired, but Toussaint had not returned; they, however, met such a reception as might be expected from a tender and affectionate mother to her darling children, so long absent, and to him who appeared in the character of their restorer. Coisnon availed himself of the pressing invitation of this good and hospitable woman to wait the return of her husband, that he might ingratiate himself upon the softness of her nature sufficiently to win her over as an advocate to his cause. In the mean time, a courier was dispatched to Toussaint, who was to bear the pleasing invitation of his children, and the letter of the First Consul. This was as follows:

“To Citizen Toussaint L'Ouverture, General in Chief of the Army of St. Domingo.

"Citizen-General,

"Peace with England and all the powers of Europe, which places the Republic in the first degree of greatness and power, enables at the same time the government to direct its attention to St. Domingo. We send thither Citizen Le Clerc, our brother-in-law, in quality of Captain-General, as first magistrate of the colony. He is accompanied with the necessary forces, to make the sovereignty of the French people respected. It is under these circumstances that we are disposed to hope that you will prove to us, and to all France, the sincerity of the sentiments you have constantly expressed in the different letters you have written to us. We have conceived for you esteem, and we wish to recognize and proclaim the great services you have rendered to the French people. If their colours fly on St. Domingo, it is to you, and your brave blacks, that we owe it. Called by your talents, and the force of circumstances, to the chief command, you have concluded the civil war, put a stop to the persecutions of some ferocious men, and restored the honor the religion and the worship of God, from whom all things come.

"The situation in which you were placed, surrounded on all sides by enemies, and without the mother country being able to succour or sustain you, has rendered legitimate the articles of that constitution which otherwise could not be so. But, now that circumstances are so happily changed, you will be the first to render homage to the sovereignty of the nation, which reckons you among the number of its most illustrious citizens, by the services you have rendered to it, and by the talents and the force of character with which nature has endowed you. A contrary conduct would be irreconcileable with the idea we have conceived of you. It would deprive you of your numerous claims to the gratitude and the good offices of the Republic, and would dig 
under your feet a precipice which, while it swallowed you up, would contribute to the misery of those brave blacks, whose courage we love, and whom we should be sorry to punish for rebellion.

"We have made known to your children, and to their preceptor, the sentiments by which we are animated. We send them back to you. Assist with your counsel, your influence, and your talents, the Captain-General. What can you desire? - the freedom of the blacks? You know that in all the countries we have been in; we have given it to the people who had it not. Do you desire consideration, honor, fortune? It is not after the services you have rendered, the services you can still render, and with the personal estimation we have for you, that you ought to be doubtful with respect to your consideration, your fortune, and the honors that await you.

"Make known to the people of St. Domingo, that the solicitude which France has always evinced for their happiness, has often been rendered impotent by the imperious circumstances of war; that if men came from the Continent to nourish factions, they were the produce of those factions which destroyed the country; that in future peace, and the power of government, ensure their prosperity and freedom. Tell them, that if liberty be to them the first of wants, they cannot enjoy it but with the title of French citizens, and that every act contrary to the interests of the country, the obedience they owe to the government, and the Captain-General, who is the delegate of it, would be a crime against the national sovereignty which would eclipse their services, and render St. Domingo the theatre of a cruel war, in which fathers and children would massacre each other.

"And you, General, recollect, that if you are the first of your colour that attained such great power, and distinguished himself by his bravery and his military talents, you are also before God and us the principal person responsible for their conduct.

"If there be disaffected persons, who say to the individuals that have borne a principal part in the troubles of St. Domingo, that we are coming to ascertain what they have done during the times of anarchy, assure them that we shall take cognizance of their conduct only in this last circumstance, and that we shall not recur to the past, but to find out the traits that may have distinguished them in the war carried on against the Spanish and English, who have been our enemies.

"Rely without reserve on our esteem, and conduct yourself as one of the principal citizens of the greatest nation in the world ought to do.

"The First Consul, Bonaparte." 320

On the receipt of these dispatches, Toussaint set out on his return home, which he reached the next night. In the intervening day, Coisnon applied 
his powers of elocution on the wife of Toussaint with ardour equal to the baseness of his design. Like the serpent at the ear of the general mother, he whispered every delusion that crafty knowledge could devise, to tempt the unsuspecting woman, whose caution was enveloped in the delight of enfolding her children, (who were much improved by the advantages of European habits and manners,) to use her soft influence with her husband. Inspired by the news that his children were at their paternal home, Toussaint arrived with more than common rapidity. The mother shrieked, and became insensible when he approached; his sons dressed in the uniform of his enemies ran to meet him; and (with eyes glistening with the emotions of the father) he clasped them without utterance to his arms.

Of a scene equal to the highest effort of the drama, narration can give no semblance, without using the language of passion so dangerous to truth. Enough, however, is learned from the self-condemning account of the tutor, to prove, that it was of the most affecting nature. This wretch, with a heart cold as the cell in which he was bred, viewed the emotions of this interesting family, only to take advantage of their situation. When the first burst of joy and affection were over, and the hero turned to caress him, to whom he immediately owed the delight he had experienced, Coisnon began his attack. "I saw them shed tears," says he, "and, wishing to take advantage of a period which I conceived to be favorable, I stopped him at the moment when he stretched out his arms to me;" then recapitulated the letters of Bonaparte and Le Clerc, and invited him to accede to them. He painted the intentions of France towards the island in the most fascinating language; described the advantages of resuming its relation with the mother country, and declared, with the utmost solemnity, that it was not the intention to interfere with the liberty of the blacks; concluding with a wound that struck to the heart of Toussaint, - his orders to return with his charge to the Cape immediately, if he did not consent. The wife of Toussaint, recovered from the convulsive joy with which she was seized, commenced solicitations of a milder kind, and, notwithstanding the check, by a frown, from that face which had always beamed with tenderness upon her, continued to urge the advantages with which she was impressed. The unconscious children described the happiness in which they had been nurtured, and the hero seemed to hesitate in opposing solicitations so tender, when the well practised tutor again assailed him, but becoming less cautious, hinted at his immediate junction with the Captain-General. ${ }^{321}$ Toussaint, now confirmed in his suspicions, instantly retired from the view of his wife and children, and when Coisnon expected,

\footnotetext{
${ }^{*}$ Report of Coisnon to the French ministry.
} 
with infernal pleasure, his fraudulent victory, gave him this dignified determination. "Take back my children, if it must be so, I will be faithful to my brethren and my God!" 322 The characters of father and hero could not agree in this trying situation. Toussaint did not risk another sight of his children, but in less than two hours from the moment of his arrival, departed again for the camp, from whence he returned a formal answer to the letter of General Le Clerc. This circumstance appears to have developed in a clearer view the intentions of the invaders, and is an explanation of the marked hostility in the onset, although professed to be only intended, to re-establish the colonial relation of the island to France. The answer was conveyed by Granville, the tutor of the younger sons of Toussaint, a Frenchman; and a correspondence was continued with the same demands on the one part, and an evasion of satisfactory explanation on the other.

At length, finding the surrender of Toussaint not to be accomplished by artifice, and wearied with the situation to which he was confined, instead of the pleasures of a court, General Le Clerc became impatient, and on the arrival of Admiral Gantheaume ${ }^{323}$ with a supply of two thousand three hundred men, with the prospect of an additional reinforcement under Admiral Linois, ${ }^{324}$ in a moment of irritation, on the 17 th of February, issued a proclamation which seemed designed to hold the French army to contempt, and to resign all claim to that ability or design which at least marks their compositions of this kind.

"I come," says he, "to restore prosperity and abundance! Every one must see what an insensible monster he is!" (Toussaint.) "I promise liberty to the people of this island. I shall make them rejoice! and I shall respect their persons and property. I order as follows:

"Art. I. The General Toussaint and the General Christophe, are put out of the protection of the law. All citizens are ordered to pursue them, and to treat them as the enemies of the French Republic.

"II. From the day on which the French army shall occupy a position, all officers, whether civil or military, who shall obey other orders than those of the generals of the army which I command, shall be treated as rebels.

"III. The cultivators, who, seduced into error, and deceived by the perfidious insinuations of the rebel general, may have taken arms, shall be regarded as children who have strayed, and shall be sent to their plantations, provided they do not seek to excite insurrection.

"IV. The soldiers of the demi-brigade who shall abandon the army of Toussaint, shall be received into the French army.

(Signed, \&C.) Le CLERC.

Dugua." 325 
The proclamation was followed by a commencement of the war at all quarters, and the exercise of every artifice that could be practised to procure defection in the black camp. The clergy were successfully employed to communicate with those of their own order to that effect; thus, those who should have mediated in the cause of peace, by undermining the very power which protected them, promoted a civil war of accumulated horrors.

The war was prosecuted by the Captain-General with all the vigor such haughty and hyperbolical expressions would imply, but the pride which dictates high-sounding proclamations, does not always furnish the means of executing them, and in the present instance they arose more from the disappointed ambition of Le Clerc, than from the power he possessed in the island.

If Toussaint had hitherto suspended his opinion respecting the intention of the French government, he now had no room for doubt. It is not, however, to be wondered at, that he should so long have forborne to view them in the glaring light in which they presented themselves. That any experienced general, or minister, should be found so weak as to depend solely on the opinion and accounts of those who were so deeply interested in the event of a successful expedition against St. Domingo, at once vague, partial, and insufficient, was scarcely to be credited; and Le Clerc's conduct, since his arrival, had been paradoxical throughout. He brought a force professedly to support the existing constitution of the island, and renew the relation between it and the mother country, which had been resigned by the incapacity of the latter; yet, presenting a hostile force, insists on every post being surrendered to him, and desires the immediate submission of the General in Chief, whose conduct had never been questioned. He brings with him the beloved sons of the General, as an earnest of the good intentions of the French government towards him, but scarcely allows him time to embrace them, when they are torn from him and their distracted mother with the most torpid apathy. He says, he comes to restore "peace and abundance" in a country already peaceful and abundant, by putting its inhabitants to the sword, and destroying its territory! The force he brought with him, when divided into the different detachments around the vast extent of coast, was insufficient, and the reinforcements too trifling to effect any enterprize of importance, and without any provision being made till they had obtained it from the invaded country, inasmuch that the admiral was compelled to dispatch a frigate to Jamaica, to solicit aid of every description by the most artful finesse.*

\footnotetext{
*In a letter to the English admiral commanding there, dated February 15. "The disposition," he says, "of the cabinet of St. James's, and the known loyalty of your nation, Sir, permit me to hope that the ports of Jamaica will furnish us (should circumstances demand
} 
Toussaint soon saw that, notwithstanding every deficiency, the mask which had been loosely worn, was entirely thrown aside, and that he had to confide in the pre-dispositions of his own forces, more than the sincerity or benevolence of the French. He therefore made preparation for a conflict, more terrible in proportion to its extent, than any he had yet sustained from the numerous enemies with whom he had had to cope. Considering the distant points as sufficiently provided, and expecting the great blow to be struck in the northern province, in which the French head-quarters were situated, he repaired thither with a select camp, to oppose himself to the CaptainGeneral. His attention was still directed to every quarter, and his capacious mind revolved every object connected with his command. Expert as the whole of the black troops were, those surrounding the person of Toussaint were uncommonly so, being disciplined with inconceivable correctness.

Though formed into regular divisions, the soldiers of the one were trained to the duties of the other, and all understood the management of artillery with the greatest accuracy. Their chief dexterity, however, was in the use of the bayonet. With that dreadful weapon, fixed on musquets of extraordinary length in their hands, neither cavalry nor artillery could subdue infantry, although of unequal proportion; but when they were attacked in their defiles, no power could overcome them. Infinitely more skilful than the Maroons of Jamaica in their cock-pits, ${ }^{*}$ though not more favored by nature, they found means to place whole lines in ambush, continuing sometimes from one post to another, and sometimes stretching from their camps, in the form of a horse-shoe. With these lines artillery was not used, to prevent their being burthened, or the chance of loss; but the surrounding heights of every camp were well fortified, according to the experience and judgment of different European engineers, with ordnance of the best kind, in proper directions. The protection afforded by these out-works, encouraged the blacks to every

it, and should you be abundantly supplied) with provision and ammunition. One of the ministers of his Britannic Majesty has said, that the peace just concluded was not an ordinary peace, but a sincere reconciliation of two of the greatest nations in the world. If it depends on me, Sir, this happy prognostic will certainly be verified, at least I am pleased to imagine, that our pacific communications will be worthy of two nations, to whom war has only multiplied the reciprocal reasons which they had to esteem each other; and to give you authentic proofs of our confidence, I lay before you a faithful statement of our forces in the ports of St. Domingo." - Villaret's Letter to Admiral Duckworth. [Le Moniteur, 2 Germinal year X (March 23, 1802), 729. Sir John Thomas Duckworth (1747-1817) was one of the most successful British admirals during the Napoleonic Wars. He was commanderin-chief of the Jamaica station from 1801 to 1805 . Duckworth captured Rochambeau at sea after the French general evacuated his forces from St. Domingo in 1803.]

*See Dallas's Hist. vol. ii. 
exertion of skill or courage; while the alertness constantly displayed embarrassed the enemy, who, frequently irritated, or worn out with fatigue, flew in disorder to the attack, or retreated with difficulty. Sometimes a regular battle or skirmish ensued, to seduce the enemy to a confidence in their own superiority, when in a moment reinforcements arose from an ambush in the vicinity, and turned the fortune of the day. If black troops, in the pay of the enemy, were dispatched to reconnoitre when an ambush was probable, and were discovered, not a man returned, from the hatred which their perfidy had inspired; nor could an officer venture without the lines with impunity.

With a body of tried grenadiers, and such troops as have been described, Toussaint waited the approach of the French with patient calmness at the camp of Breda; from whence he occasionally made rapid excursions to those points about which he was most anxious, on the north and north-west parts of the island.

On the 17th of February, General Le Clerc commenced his campaign, by forcing a few villages, and forming some posts; and soon after removed his head-quarters to the village of Gros Morne, on the bank of the Three Rivers, about twenty miles south-west from the Cape. From the success he had experienced in the compromises already made with the minor black generals, he had given his whole army directions to negotiate, wherever it could be done with safety, for the surrender of the different commands, and his success was greater than could possibly have been expected; it is, nevertheless, to be recollected, that every one viewed the present period as the commencement of a long war; and with those of inferior discrimination, the proclamations and verbal declarations of the French army presented the most grateful prospects; among which the officers regarded the confirmation of their power, independent of their black superiors, in the first degree.

The whole of the troops landed in this province, having received orders to form a junction, the division under General Desfourneaux ${ }^{326}$ advanced to the Limbé; another under General Hardy ${ }^{327}$ marched to the Grand Boucamp and the Mornets; and that commanded by General Rochambeau proceeded against La Tannerie, and the wood of L'Ance. A small corps, composed of the garrisons of the Cape and Fort Dauphin, advanced against St. Luzanne, Le Fren, and Volliere. These divisions had, according to their own account, "to sustain several actions, rendered very painful by the situation of the ground, and by the movements of the blacks, who concealed themselves in the impenetrable forests which bordered the valleys, and who had a secure retreat in the fastnesses." ${ }^{28}$ They, however, obtained a transitory possession of the position which they had been ordered to occupy.

On the 18th, the divisions of Desfourneaux, Hardy, and Rochambeau, en- 
camped near Plaisance, at Dondon, and St. Raphael, where, after having halted some time, they advanced on the blacks with impetuosity. "It is," observed Le Clerc in his dispatches, "absolutely necessary to see the country, in order to be enabled to form a competent idea of the difficulties which it presented at every step. I have never seen in the Alps any obstacles equal to those with which it abounds."

On the 19th, Desfourneaux's division took possession of Plaisance without resistance. That canton was commanded by a mulatto called Jean Pierre Dumesnel, with whom the career of compromise commenced. He joined the French general, Desfourneaux, with two hundred cavalry, and three hundred infantry, and of course reversed the orders of Toussaint, and preserved the place.

General Hardy's division, before it arrived at Marmelade, made itself master of the Morne at Borspen by similar means, with the party which surrounded it. General Christophe being betrayed, evacuated the place with twelve hundred regular troops in good order. General Rochambeau took up his position at St. Michael, where he found little resistance, his right column carrying an entrenched post, Mare-a-la-Roche, defended by four hundred men and artillery, with the bayonet.

The French General perceiving Toussaint's design was to defend the canton of Ennery and the Gonaives, mustered as much force as he could towards that point. He detached General Debelle ${ }^{329}$ with a division to Port Paix, and he had orders to attack General Maurepas ${ }^{330}$ near the Gonaives, who had two thousand regular troops, and two thousand cultivators under his command, in an entrenched post, within two leagues of Port Paix, and in the defiles of Les Trois Rivières. He was very desirous to disperse that corps which had repulsed General Humbert, and ordered General Boudet to advance towards La Petite Rivière, for the purpose of cutting off the retreat off the enemy's corps, on whose defeat near the Gonaives he placed great reliance. Toussaint, however, prevented the execution of this movement by a skillful separation of one part of the force from the other.

On the 2oth of February, General Debelle marched to attack General Maurepas, but a torrent of rain falling, prevented the columns arriving in time to flank the black division, and thereby turn their position. The columns which attacked them in front were so much exhausted by fatigue, that they were unable to carry it; and those destined to turn them being attacked in

\footnotetext{
*Moniteur, - Dispatch of Le Clerc to the Minister of Marine, dated February 26. [Although it is likely that Rainsford obtained this quote from Le Moniteur, the particular issue could not be located. A translation of the dispatch appeared in Cobbett's Weekly Political Register (April 24, 1802), 462-66.]
} 
every point by the black forces, were compelled to retreat with difficulty and considerable loss.

General Boudet's division, in setting out from Port-au-Prince, marched against La Croix des Bouquets, which was set fire to by the blacks on his approach; and General Dessalines, ${ }^{331}$ who commanded in that quarter, instead of retreating, made a feint by marching over the mountains, and there taking a rapid turn to Leogane, which he fired in the face of a frigate dispatched by the French admiral for its protection. These difficulties increased the offers and the deception of the French, and in consequence, a powerful black general, La Plume, ${ }^{332}$ submitted to General Boudet, with the whole of his district.

On the 22d, the division of Desfourneaux advanced within two miles of Plaisance, then deserted by La Plume, notwithstanding the attempt of Christophe, with the force which remained, to resist it, in which they had a severe skirmish; he, however, cut off a part of their force, and retreated to Bayannai. The brigade of General Salm, ${ }^{333}$ after performing a very fatiguing march on the $22 \mathrm{~d}$, continued during the whole of the night, and at day-break on the $23 \mathrm{~d}$, arrived at the position Christophe had left to join the grand black army, where they were rewarded by the remains of a considerable booty, it having been a depôt of the blacks.

On the 23d, Rochambeau's division took a position at the head of the Ravine-a-Couleuvre, having the Coupe-au-Linde on his left, and the fastnesses where Christophe was entrenched on the right. The divisions of Desfourneaux and Hardy took a position before Ennery.

On the 24th, Desfourneaux advancing, at the Coupe-a-Pintade met the enemy. It was supported by Desplanque's division, and that of General Hardy. General Desfourneaux attacked a black out-post, which he pursued to Gonaives, and from thence to the River Ester. Salm's brigade, belonging to Hardy's division, took a position at Pateau, before La Coupe-a-Pintade.

On the same day, Rochambeau's division entered the Ravine-a-Couleuvre, where General Toussaint, with his guard, forming a corps of fifteen hundred grenadiers drawn from different demi-brigades, and about twelve hundred other chosen troops, with the addition of four hundred dragoons, waited to receive them in person. The Ravine-a-Couleuvre is extremely well protected, being flanked by lofty mountains covered with wood; in advantageous places were posted more than two thousand cultivators. They formed a considerable number of abattis, ${ }^{334}$ which obstructed the passage, and occupied the entrenched positions which commanded the Ravines. From the advantages of the defection, and a knowledge of the country, General Rochambeau executed his movement with a rapidity similar to that of the enemy he was encountering, and attacked their entrenchments. A battle ensued, in which, Le 
Clerc acknowledges, "man was opposed to man, and the troops of Toussaint fought well." ${ }^{335}$ It was an affair deserving an accurate description in the military annals of the time. The ability and bravery of the French troops were called forth, and every manoeuvre of the black tactics was displayed. On a bloody field, at the close of the day, victory remained doubtful, and each party were more anxious with regard to their future movements, than the honor of superiority so dearly bought. Toussaint retired to the banks of La Petite Rivière, and Le Clerc to Gonaives. General Maurepas continued in considerable power in the western province, and repelled the attacks of Generals Debelle and Boudet, until they were reinforced by two divisions, those of Desfourneaux and Rochambeau, dispatched by the French General to support and collect their scattered forces.

On the 27th, General Boudet was master of St. Marc, but Maurepas, by his positions, still retaining the command of the province, Le Clerc summoned all the force he could collect, and putting himself at their head, prepared to march against that general. He ordered General Hardy to advance to Gros Morne with five companies of grenadiers, and eight hundred men belonging to his division. To this corps he added a company of his own guards, consisting of two hundred men, and on the night of the 27th took a position at two miles distance. The divisions of Desfourneaux and Debelle were in motion to join, when the experiment of compromise presenting a more pleasing aspect than the doubtful issue of a battle, Maurepas submitted to General Debelle, on the conditions of the promise of General Le Clerc, to continue their rank to such officers as surrendered.

These important points effected, leisure was obtained to consider the best means of attacking the Black General in Chief, against whom the great body of the French army could now be directed, with the addition of the black officers who had been induced to join it with their troops. General Le Clerc, in consequence of these acquisitions, with the advantages which they gave him, and the consternation with which the inhabitants beheld the defection of their countrymen, began to view his situation with ease, and to indulge more extensive prospects. In this mood, for the first time during the campaign, he sat down to communicate with the Minister of Marine, ${ }^{336}$ and to beg the confirmation of the First Consul of what he had done. It was a campaign which had already cost a profusion of blood and money, and which, nothing but the treachery of La Plume, Dumesnils, and Maurepas, with the powerful forces under their command, and in the favorable positions they occupied, could have been prolonged for an hour. General Le Clerc viewing affairs in another light, more congenial to his own wishes, considered himself at this moment, (though occupying but a few leagues of country with his whole army, and 
constantly in sight of the coast,) "master of the colony!" "The army of St. Domingo," says he, "in the course of five days have routed the chief of their enemies, obtained possession of a considerable quantity of their baggage, and a portion of their artillery. Desertion is frequent in the rebel camp. Clervaux, La Plume, Maurepas, and many other black chiefs, and men of color, have submitted. The plantations of the south are entirely preserved, the whole of the Spanish part of the island has surrendered;" 337 when his army had not visited the French plantations of the south, his troops still remained inactive on the Spanish coast of the island, and Clervaux had only agreed, through the bishop of Yago, to surrender.

Such was the progress of the French arms in St. Domingo, and such the opinion entertained by their general of the successes that had been obtained. The preceding account will be found corroborated by the dispatches of the Captain-General, in which he mentions the whole of the territory he had obtained, which was on the sea-coast, viz. Mancinello Bay, Le Limbé, Port Paix, Gonaives, St. Marc, Port-au-Prince, and Leogane. Notwithstanding the debarkations at nearly the same time at St. Domingo, Port-au-Prince, Cape François, and Fort Dauphin, and that the interior had never been attempted, they had not been able to form a junction till it was accomplished by the acquisition of the defectors from the black army, or to force Toussaint from their very centre. It has already been observed, that the maxim of the Black General in Chief, was to suffer them to harass themselves by forced marches, and to obtain positions untenable, or unavailing. More than this, it appears from their own accounts, they had not effected; while Toussaint and his forces changed their situation or position as often as they chose, never being overtaken in their retreat, or surprized on a march, but frequently falling on the enemy by an unexpected road, and routing them with the utmost dismay. A variety of these manoeuvres were continually practised, but the blacks not fighting for the panegyric of Europeans, they are unnoticed and forgotten, except by their countrymen, and those who suffered from them.

The circumstance of three Generals high in esteem, with a considerable force, going over to the enemy, and joining their local knowledge and peculiar tactics against their own cause, within a few days from each other, and at a distance, is unprecedented, and must have operated with the Commander in Chief more than the shock of an unexpected and powerful army. In fact, such was the effect of gold and promises, of extension of command in the French army, that for a time Toussaint was uncertain, when he ordered a division to march, whether it was not about to join the enemy; while he was preparing against those with whom treaties had been formed previous to the invasion; others, on whom he most depended for the attack or repelling of 
the enemy, and to whom their country looked with confidence, were turning their swords against him. General La Plume, among the first to set the example of abetting the French, was one of whom Toussaint entertained the highest opinion, and entrusted with an extensive district. He seemed at a loss how to render his injuries sufficiently striking, and in consequence receives the eulogium of Le Clerc. One of the first acts of this ungrateful man, was the exposure of a letter, in which himself is mentioned with favour, and which was a principal cause, with his disobedience of Toussaint's orders, of the violence of his praise. It was addressed to the commandant of the district of Jeremie, General Domage, ${ }^{338}$ and dated from the black head-quarters, at that time at St. Marc, for Toussaint's communication was constantly kept up with every part of the island to which the French had obtained access.

Feb. 9, 1802.

"My Dear General,

"I send to you my aid-de-camp Chaney, who is the bearer of the present dispatch, and who will communicate to you my sentiments.

"The whites have resolved to destroy our liberty, and have therefore brought a force commensurate to their intentions. The Cape, after a proper resistance, has fallen into their hands, but the enemy found only a town and plain in ashes; the forts were blown up, and all was burnt.

"The town of Port Republicain (Port-au-Prince) has been given up to them by the traitor, General of Brigade, Agé, ${ }^{339}$ as well as Fort Bizotton, which surrendered without an effort, in consequence of the cowardice and treachery of the Chief of Battalion, Bardet, an old officer of the south; but the General of Division, Dessalines, maintains at this moment a line at La Croix des Bouquets, and all our other places are on the defensive.

"As Jeremie is rendered very strong by its natural advantages, you will maintain yourself in it, and defend yourself with the courage which I know you possess. Distrust the whites, - they will betray you if they can; their desire, evidently manifested, is the restoration of slavery.

"I therefore give you a carte-blanche for your conduct. All which you shall do will be well done. Raise the cultivators in mass, and convince them of this truth, - that they must place no confidence in those artful agents who may have secretly received the proclamations of the white men from France, and would circulate them clandestinely, in order to seduce the friends of liberty.

"I have ordered the General of Brigade, La Plume, to burn the town of Cayes, and every other town and plain in the district, should they be unable to resist the enemy's force; thus all the troops in the different garrisons, and all the cultivators, will be enabled to reinforce you at Jeremie. You will entertain a perfect good understanding with General La Plume, in order to execute 
with ease what may be necessary. You will employ in the planting of provisions all the women occupied in cultivation.

"Endeavour as much as possible to acquaint us with your situation.

"I rely entirely upon you, and leave you completely at liberty, to perform every thing which may be requisite to free us from the horrid yoke with which we are threatened.

"I wish you good health,

(Signed) “Toussaint L’Ouverture.

"A true copy,

(Signed) "The General of Brigade commanding the Department of the South,

"LA Plume." 340

Toussaint, confident in his resources, expected the completion of his wishes, by seeing his enemies, notwithstanding the aid they had received, exhaust themselves. He knew also that the recreant heart which sold its honor, and every sentiment that should be cherished, for the fleeting promise of a sanguine enemy, would be easily regained when time should change the hands in which the power that tempted it was placed; and he had some reason to doubt, whether the defection of those who had abandoned him did not arise from other motives than those which were apparent.

The public feeling in France, on receiving the distorted intelligence which the dispatches of Le Clerc conveyed, grew more and more against the blacks: - those who had been their most strenuous friends became their most active enemies; and, exclusive of the common prostitutions of the press, to which party gives birth on all occasions, ${ }^{*}$ books were published at Paris, avowedly for the purpose of exposing the errors of Negrophilism, or the love of the blacks. In England it was similar, and the voice of discretion, or discrimination, was drowned by the general clamour.

Admiral Duckworth, after receiving the frigate La Cornelie, which was expressly dispatched to him by Le Clerc, with every mark of respect, and loading her captain, Villemandrin, and his lieutenant with honors, wrote home for instructions relative to supplying the French troops with stores and provisions, as without he could not comply with the request of the French commander. The Spanish governor at the Havannah exerted himself in every way for their

\footnotetext{
*The meanness of traducing characters, and, indeed, all vitiations of truth, which are permitted, and considered expedient in the policy of states, is one of the most prominent errors in British legislation, and one which, for the honor of the country, and the credit of its consistency, it is wished were remedied. Its effects are of the worst kind, as relates to the government and the governed, the relations between both, and every other country with whom they hold a correspondence.
} 
accommodation, by furnishing both money and clothing, of which the army was in great want. The following sentiments respecting the black army, as they form a correct delineation of the public opinion, are quoted from Admiral Duckworth's letter, in answer to the French Commander in Chief:

"It is with a painful sentiment I have learned the hostile reception of your excellency, and that direct violation of all the duties of colonies towards their mother country. I perfectly agree with you on the consequences of such conduct, and I really think it interests all the powers of Europe. But, with a force so considerable as you have, the revolt cannot be of long duration; and the devastation committed by the rebels can only produce a temporary evil." 341

Having conveyed Madame Le Clerc by sea to Port-au-Prince, and established his head-quarters there, after making every arrangement in his power of his newly acquired force, the Captain-General re-commenced the campaign with fresh energy. Port-au-Prince was the most desirable residence they had yet obtained, not having been injured in the least, from the ease with which it was taken possession of by Boudet; but the next town in the south, Leogane, was destroyed by Dessalines, and every place that was likely to aid a passage to that quarter. Desfourneaux was left at Plaisance to protect the north, while Hardy, Rochambeau, Boudet, and Debelle, proceeded to the Spanish border of the western district. La Crete a Pierrot, a post rather advantageously situated, between St. Marc and Port-au-Prince, which had been a depôt of the blacks, and lately their apparent head-quarters, was the first object of the French; whereby they committed an error frequent in military tactics, where a necessary position is lost through the desire of booty. The Black General perceived this error, for, after appearing to guard anxiously a celebrated point, and finding means, first to convey away every thing desirable, he then evacuated it, leaving to the self-nominated victorious army, an empty arsenal, empty coffers, and frequently unsheltered quarters. ${ }^{*}$ - Such was the case with La Crete a Pierrot, and in the defence of which, and the operations that immediately followed, the blacks covered themselves with glory, and their enemies with infamy.

The main body of the French army was put in motion against this fortress; and its defence, planned by the General in Chief, was committed to General Dessalines. Whether it was from the weakness of General Le Clerc, or the enthusiasm of his troops at the expectation of booty at this siege, is unknown;

*A General cannot be too much on his guard how he gratifies the best soldiers under his command in this way. To brave and exhausted troops, rest and comfort, when they can be afforded with safety, is a due consideration; but a desire of booty in a dangerous and doubtful warfare, is like sleep in the frigid zone, always tempting, yet frequently destructive. 
but, if the vengeance of disappointed personal ambition, and an accumulation of every bad passion, had been infused in the breasts of the soldiers, it could not have been more cruelly displayed than in the affair of Crete a Pierrot. The scythed car of the ancient Briton, or the poisoned javelin of the savage Indian, are instruments of humanity, compared with the fatal bayonet as used by the French on this day; nor, could the desperation of the blacks in their first struggle for emancipation, exceed their bitter vengeance, of which the very recital stains the page of history. ${ }^{342}$

In the beginning of March, the divisions of Hardy, Rochambeau, Boudet, and Debelle, marched against different posts in the vicinity of their grand object, with the hope of preventing the retreat of an enemy of whose reduction they considered themselves certain. Rochambeau first attacked a village called Cahows, from whose few inoffensive inhabitants he met no opposition; but General Hardy, with a considerable force, surrounded six hundred blacks in the Coupe de L'Inde, who bravely attempted to cut their way to Trianon, they were all taken, and murdered on the spot; and a Chief of Battalion, Henin, with a part of the same force, attacked the position Trianon, and carried it with the bayonet. Enraged by such unexampled warfare, Dessalines made a sortie from the fort, and advancing as far as La Petite Rivière, met General Debelle on his march to Verettes, whom, supposing a part of the cruel perpetrators, he drove before him to La Crete a Pierrot; but, so far from attempting a retaliation, he left them to the mercy of war, and retiring into the fort, discharged a volley of grape shot among them, by which Debelle and a considerable number were wounded. The commandant of artillery, Pambour, took the command of the division, and Debelle fell back into the rear.

General Boudet now passed the Artibonite, for the purpose of blockading Crete a Pierrot, but had scarcely come within sight of the glacis, when he received a wound which compelled him to return, and his men were thrown into disorder. General Dugua advancing with a battalion of the 19th light troops, and the 74th regiment of the line, to form the blockade, was also dangerously wounded, and his party completely routed. To revenge this, Le Clerc, who had a narrow escape, a shot having hit the center of his sash, and carried part of it away, hastened a part of his artillery from Port-au-Prince, and Rochambeau spread fire and sword through every village in his way. General Salines, likewise, with a large body, contrived to surround a small camp of the blacks, and put every man to the sword.

On the 22d of March, Rochambeau attempted to erect a battery of seven pieces of heavy artillery on a rising ground, but in vain, the fire of a redoubt bearing upon him, swept away the whole of his men. He therefore marched to attack the redoubt, but found it so secured by a projection of logwood, that it was impossible to be carried. In the mean time, every thing being prepared 
for evacuating the fort, Dessalines, with a part of his force, sallied forth in the night, and falling in with Desplanques, who commanded General Hardy's advanced guard, a skirmish ensued, which, nevertheless, did not prevent his departure. The absence of Dessalines inspired the besiegers with new hopes, and for the three successive days they bombarded the fort with great activity, frequently setting fire to it. On the evening of the last day, the commander of the black forces remaining at La Crete, made a vigorous sally, and forced the French lines; a small part only accomplished this measure, and passed the Artibonité; the remainder were surrounded, and immediately put to the sword.

Thus ended the siege and blockade, which had cost the French army much, by the loss of some of her best generals and finest troops, but in nothing so much as in the exercise of a ferocious spirit unknown among civilized people. Besides the cruelties in cold blood which have been recited, and which were exultingly acknowledged in the dispatches of General Le Clerc, were numerous acts of private barbarity, the recital of which could answer no good purpose, while the blacks, in this instance, are not charged, even by their enemies, with the commission of any of these enormities. Nor did they avail themselves on the present occasion of those advantages which remain to be found in the fastnesses of the mountains. The fortress which they occupied had been regularly built by the English during their possession of this part of the island, and the defence of it was truly English. The remembrance of this affair will long be found on the banks of the Artibonite, to the disgrace of the one party, and the praise of the other.

Buoyed by what he conceived success, the Captain-General of the French extended his views, and prepared for the dominion to which he had always looked. He published an order in direct violation of his own proclamations, directing proprietors, or their attornies, to resume their ancient authority over the negroes. ${ }^{*}$ He treated with rigor and insolence, on the smallest difference of opinion, the inhabitants who surrounded him, and with indignity the Americans who constantly traded to the coast, compelling them to sell their cargoes of flour, and other provisions, for bills on France, which was but the prelude to farther enormities. To prevent the circulation of facts, he established an official gazette at Port-au-Prince, ${ }^{343}$ whose bulletins solely were to be regarded.

Toussaint L'Ouverture was employed in a care superior to that of contem-

*Journal de Peltier, 1802, p. 531. [L’Ambigu, ou Variétés littéraires et politiques was edited by Jean-Gabriel Peltier. Peltier (176o-1825) was an émigré journalist living in London. He gained some notoriety when Napoleon sued him for libel in English courts during the Peace of Amiens. He later became an agent in London for King Henry I of Haiti before they had a falling out. Chateaubriand discusses him in his Mémoires d'Outre-Tombe (1850).] 
plating his self-sufficiency. He had noticed the neglected situation in which the northern province was left, by withdrawing the whole of the French force to the recent siege, and he resolved to avail himself of it. Therefore, while General Le Clerc was revelling in the reputation of the French arms in the west, and dispatching General Rochambeau to sack Les Gonaives, which at one time had been the black head-quarters, Toussaint effected a junction with Christophe in the mountains, and poured down an accumulated force on the plain of the Cape. Reaching Plaisance by a mountain-road, he routed the forces of General Desfourneaux; passed on without molestation through Dondon and Marmelade, raising the cultivators in his way, and halted within a mile and a half of the city of Cape François. An universal consternation followed. Dispatches were sent, requiring the aid of the victorious generals, and Le Clerc himself left his infant honors, taking a hasty passage by sea to the Cape. From the concourse of people in and about the city, a dreadful contagion began to shew itself. General Boyer, ${ }^{344}$ endeavoured to oppose this astonishing chief, with his whole force, including the marines and sailors from the fleet, and was quickly driven back, under the very hospital; when the blacks laid the whole plain of the Cape in ruins, in defiance of the Captain-General, commanding in the town, and of Generals Hardy and Rochambeau, who arrived by forced marches, they then retired to the mountains of Hincha.*

While these untoward circumstances were interrupting the felicity which General Le Clerc promised himself in his new quarters, another difficulty occurred where it was least expected. Among other objects destined for political use in the invasion of St. Domingo, was Rigaud, the mulatto-general, the ancient opponent of Toussaint, whose presence, it was suggested by some of his friends, might attach his former party to the French arms, but which Le Clerc considered an expedient too dangerous to risque. Rigaud, who expected an immediate restoration of his property and command, finding himself continued in concealment, at a distance from his native province, began to contemplate means of re-instating himself. No sooner, therefore, was the Captain-General called to the Cape, than he attempted a correspondence with General La Plume, on the subject of a visit to his friends, who immedi-

\footnotetext{
*At the time these transactions were taking place, Bonaparte addressed the French people in a message to the Legislative Body, thus: "At St. Domingo great calamities have taken place, and great calamities are to be repaired; but the revolt is daily confined to narrower bounds. Toussaint, without fortresses, without money, without an army, is now no more than a robber wandering from desert to desert, with a few vagabonds like himself, whom our intrepid clearers are in pursuit of, and who will be soon overtaken and destroyed." Moniteur, May 7.-Such was the blindness with which this wonderful man had been influenced, and such is political consistency. - [Le Moniteur, 17 Floréal year X (May 7, 1802), 922.]
} 
ately communicated his letter to Le Clerc. Enraged at what he conceived perfidy at so critical a moment, he immediately ordered the unfortunate chief, with his family, to be sent on board a frigate, and conveyed to France, as one whose principles could not "contribute to the re-establishment of the colony of St. Domingo." This was a circumstance, however, disagreeable to many powerful persons, and Le Clerc, with a facility which has marked the political transactions of Europe in the beginning of the nineteenth century, adds, that Rigaud had "sent emissaries into the south to stop cultivation, and alarm the peaceable citizens with terrors."* The officer whose duty it was to perform the present order, (Dugua,) had the sensibility to solicit Admiral Villaret to escort the wrecks of fallen greatness.

The only means which remained to withstand the shock the French had sustained, were, an extension of the number and powers of the emissaries, who had been constantly kept in employment, to seduce the unconscious cultivators, and had proved successful in the districts to which they had access. Le Clerc saw his error in the premature attempt to re-establish the ancient regimen by his order at Port-au-Prince, which had evidently inclined even the defective to return to the confidence of their brethren, and strengthened in their determination those who held out, being at least three-fourths

*Gazette du Port-au-Prince, - Letter of the Captain-General to General Dugua, Chief of the Staff at Port-au-Prince. The letter of Rigaud, also given in this journal, contains some pathetic appeals, which are interesting, as coming from the hand of fallen power:-

"Persecuted" says he, "these ten years; driven away from my property for the last two years; taken prisoner by the English and other allies of my enemies, I have persevered in the same principles I had before. The French government doing justice to my conduct and fidelity, gave me an employment in the French army, and my first steps were bent towards the incendiary and murdering rebels of the northern part, whose example you were wise enough not to imitate. You are not ignorant of the deep wounds made on humanity, and destruction of my unhappy countrymen; I can only mourn their lot; the evil is irremediable; but for the sake of those who are yet living, for one who would not sink under the weight of misfortune, would you not think it conformable to justice, and even your duty, to give orders, without having recourse to superior authority, that every thing of which we have been deprived should be given up to us. I confine myself at present, to request you to cause my sister, or M. Deronseray, my attorney, to be put again into the possession of my cattle, and that of my brothers; our lands and houses, and their produce, from the time we have been deprived of it.

"When the banditti are destroyed in the northern part, I will bend my course towards the south, where I was born, where I have lived, and commanded with glory! I hope to find there none but brothers and friends, \&c.

"A. Rigaud."

* The nature of this request is explained by the order of Le Clerc (in the amplitude of his power) at Port- au-Prince, - that the ancient proprietors, or their attornies, should resume their estates. 
of the population of the island. To remedy this ill-judged action he adopted another, which, although too often countenanced in the complicated politics of magnificent states, was an instance of the most degrading meanness. This was a proclamation in which the freedom of the blacks is ASSURED, but that assurance is rendered a perfect nullity, by the arrangement of the sentence in which it is conveyed. As an example of the manner in which the French expedition against the blacks was conducted, the instrument is given in its formal state:-

"LIBERTY.

Equality.

"In the Name of the French Government,

“A PROCLAMATION.

"The General in Chief to the Inhabitants of St. Domingo:

\section{"Citizens,}

"The time is arrived when order will succeed that chaos which has been the natural consequence of the opposition made by the rebellious to the landing of the army at St. Domingo.

"The rapid operations and progress of the army, and the necessity of providing for its subsistence and establishment, have, hitherto, prevented my attending to the definitive organization of the colony. I could not have any fixed or certain ideas of a country with which I was totally unacquainted, and consequently could not, without mature deliberation, form an opinion of a people who have been, for ten years, a prey to revolutions.

"The basis of the provisionary organization which I shall give to the colony, BUt WHICH SHALL NOT BE DEFINITIVE TILL APPROVED OF BY THE FRENCH GOVERNMENT, is Liberty and Equality to all the inhabitants of St. Domingo, without regard to colour. This organization comprises:

"1st. The administration of justice.

"2nd. The interior administration of the colony, combined with those measures which its interior and exterior defence require.

" $3 \mathrm{~d}$. The imposition of duties, the means of raising them, and their application.

" 4 th. The regulations and ordinances relative to agriculture.

" 5 th. The regulations and ordinances relative to commerce.

" 6 th. The administration of the national domains, the means of making them most beneficial to the state, so as to be less burthensome to agriculture and commerce.

"As it is of infinite interest to you, Citizens, that every institution should, in an equal degree, protect agriculture and commerce, I have not determined upon this important work, without having first recourse to, and consulted with, the most distinguished and enlightened citizens of the colony. 
"In consequence, I have given orders to the generals of the south and west divisions, to select for each of these departments seven citizens, proprietors and merchants, (without regard to colour,) who, with eight more, which I shall myself choose for the department of the North, are to assemble at the Cape in the course of the present month, to impart their observations to me on the plans I shall then submit to their consideration.

"It is not a deliberative assembly I establish. I am sufficiently acquainted with the evils which meetings of this nature have brought upon the colony to have that idea. The citizens who are thus chosen being honest and enlightened men, to them will I communicate my views; they will make their observations upon them, and will be able to impress on the minds of their fellow citizens the liberal ideas with which the government is animated.

"Let those, then, who are thus to be called together, consider this appointment as a flattering proof of my consideration for them. Let them consider that for want of their counsels and advice, I might pursue measures disastrous to the colony, which would ultimately fall upon themselves. Let them consider this, and they will find no difficulty in leaving, for some time, their private avocations.

"Done at the Head-quarters of the Cape, 5th Floreal, year 10 of the French Republic.

(Signed) “The General in Chief, LE CLERC.

A true copy,

(Signed) “The Deputy Adjutant-General, D’Aoust." ${ }^{445}$

Never was so much art and weakness displayed at one time in any public officer as in this instance of Le Clerc, whose mind must have been capable of the most abject baseness, and reduced to the most contemptible alternatives. ${ }^{*}$ The proclamation, however, had its desired effect, and vast defections from the followers of Toussaint, even those in his last expedition, was the immediate consequence.

In the beginning of April arrived the two squadrons long expected, from Havre and Flushing, and increased the puny advantages on which General

\footnotetext{
*What a noble contrast is afforded to this effort of dirty chicane, by the conduct of General Walpole in Jamaica, who, scorning an act that might appear to inveigle men who had held British troops at defiance, and entered into regular treaties, refused the honorary reward of his gallantry and benevolence from the country he had served, because he did not conceive his engagements with them perfectly fulfilled. See his Letter in the Appendix to Dallas's History. [George Walpole (1758-1835) arrived in Jamaica in 1795 and commanded forces charged with suppressing an uprising among the Trelawney Town Maroons. He negotiated a treaty containing a secret clause guaranteeing that they could remain on the island if they would surrender. The governor ratified the treaty, but decided to have them transported to Nova Scotia because many did not surrender immediately. Walpole was furious with this decision, which he saw as a breach of faith with the Maroons.]
} 
Le Clerc prided himself. If his conduct assumed the air of determination before his late alarm, it had now no bounds, and with all the spirit of jacobinism which his brother-in-law had boasted to abolish, considered every measure expedient that would destroy his opponents, or confirm his power. If a body of suspicious negroes were discovered, an open grave awaited them, to the brink of which they were led unconscious, and either slaughtered, or precipitated alive into the dreadful chasm, as suited the convenience of those to whom the charge was intrusted. If a person connected with the expedition, whose advice had been originally courted, began to discover un-philosophic views in the Captain-General, and to venture opinions upon the state of affairs, a vessel was ready in an adjacent port to convey away the disapproving object. The terror of the present regimen seemed to produce for the time a more powerful effect, than all the successes of the French arms, or the defections of the black chiefs.

Several bold pushes had been made by Toussaint, considering the dangers to which he was exposed, by the loss of his bravest commanders, and consequently their different plans of operation. Notwithstanding the success of his last expedition, his followers began to view forced marches with less patience than they were wont, and the situation of their opponents with proportionate envy. Toussaint continued resolute, with innumerable advantages, contemplating nothing but the prosecution of the war; though arguments more prevailing had been introduced to the ear of Christophe, his relation, and Toussaint was condemned to experience the pangs of Caesar, and exclaim,

"Are you too turned against me?" 346

Christophe perceived the consequences of the disaffection excited among the black troops, although its effects had been confined to, comparatively, a small part of the island. He observed the mental weakness of Le Clerc, and was thereby led to think his present proclamation sincere; it is not in the nature of a brave man to suspect the quibbling arts of inferior authority. He had been frequently tempted, as well as the other black generals, and at length corresponded on the subject of making peace, the terms of his compromise being, a general amnesty for his troops, and the preservation of his own rank, and that of all the other officers; and extending the same terms to his colleague Dessalines, and the General in Chief. Thus the situation of the blacks became no worse by the truce, should it extend no farther, while the artifices of the French would cease to have their effect. To such terms it was hard for the proud commandant to submit, and, it might have been perceived, they could not be permanent. But Le Clerc, who considered only his own aggrandizement, thought a peace on any terms enabled him to claim the praise of restoring the colony to France; and with regard to the means, as he had prac- 
tised a fraud in his proclamation in St. Domingo, so he could deceive the mother country, by his statement of the surrender. Thus, wading on through the same weakness, meanness, and infamy, the preliminaries were arranged with General Christophe, which afforded a temporary peace to this unhappy country. Public hostilities ceased about the 1st of May.

The arrangement completed with Christophe, the General in Chief was induced to commence a correspondence, which ended in a pacific invitation, and acceptance thereof, to Cape François. At his former capital he behaved with a dignity, and at the same time a gentleness, that won all hearts towards him, and obtained a general respect. With Le Clerc it was otherwise; - if the difficulties with Christophe were great, they were much more so with him who had governed the island through a long and arduous period, and Toussaint returned to his camp without concluding a treaty; though he desired no more than what Christophe had obtained, with a dignified retirement - the wish of the greatest men of all countries and ages.

The brave Dessalines alone remained without joining in the treaty of peace. He saw an unnatural amity projected, and he knew there were yet armies ready for the field, when called in defence of their freedom; yet he would not thwart the wish of his brethren, and therefore coincided in the acts of the General in Chief; as such he must be acquitted of suffering any imposition by the professions of the French general, for he believed none of them, and is not responsible for any sincerity, by his accordance with the peace, when he knew the blacks would not regard the dereliction of their leaders.

Le Clerc did not long contend the matter with Toussaint, - a few skirmishes took place, of slight importance, when the Captain-General, impatient for sovereignty, granted his wishes. "You, General, and your troops," says he, "will be employed and treated like the rest of my army. With regard to yourself, you desire repose, and you deserve it; after a man has sustained for several years the government of St. Domingo, I apprehend he needs repose. I leave you at liberty to retire to which of your estates you please. I rely so much on the attachment you bear the colony of St. Domingo, as to believe you will employ what moments of leisure you may have, during your retreat, in communicating to me your ideas respecting the means proper to be taken, to cause agriculture and commerce again to flourish. As soon as a list and statement of the troops under General Dessalines are transmitted to me, I will communicate my instructions as to the positions they are to take."*

Toussaint, with his family, retired to a plantation of his own name, L'Ouverture, at Gonaives, on the western coast; the brave and faithful Dessalines con-

\footnotetext{
${ }^{*}$ Gazette du Cap. [Said to be Haiti's first newspaper. No copies have been located.]
} 
tinued near them, at the town of St. Marc, with an intelligent and agreeable society. Never was a more interesting retreat, than that of these two great men, resigning honors, command, and the fascinations of absolute power, for the peace of their country. They were reverenced with increased affection by the people, and Europeans could not forbear viewing them with wonder. With the despicable jealousy of the Captain-General such an admiration was dangerous, and it did not escape his attention.

To avoid the dreadful effects of the fever at the Cape, which now spread its ravages with uncommon violence, the Captain-General made an excursion to the little island of Tortuga, having previously dispatched his aid-du-camp to France, with an account of the surrender of the blacks. In this dispatch he describes them as begging their lives, and surrendering at discretion, as being hunted down, and made prisoners in their different residences, notwithstanding that his letter to Toussaint, in direct contradiction, was published in Paris at the same moment. ${ }^{*}$ For the convenience of issuing his numerous contradictory edicts, he at this time established a Gazette, under the title of The Official Gazette of St. Domingo, ${ }^{347}$ after their publication in which, they were to be equally in force, as if promulgated in the most formal manner. To this gazette, every account of military or government transactions was confined, those at Port Republicain and other places being restricted to commercial purposes.

At Tortuga Le Clerc exercised the new power he had acquired with his usual want of discrimination, and what was scarcely credible, even from so weak a governor, he again violated the very proclamation which he had issued with so barefaced a quibble, without waiting for its effect or consequences, by directing the blacks who were on several plantations to be set compulsorily to work, under the dominion of their ancient masters. To Toussaint, (whom no compromise could deprive of the power of attending to the calls of humanity, in those who continued under his care,) several bodies made their appeal, and others respectfully acquainted him with their resolutions, not to suffer a violation of the rights which had cost them so dear. On this subject, therefore, he addressed a letter to an official agent, named Fontaine, ${ }^{348}$ at the Cape, on the $27^{\text {th }}$ of May.

"It is said," he writes, "that General Le Clerc is in an ill state of health at Tortuga, of this you will inform me. If you see the General in Chief, be sure to tell him that the cultivators are no longer disposed to obey me, for the planters wish to set them to work at Hericourt, which they certainly ought not to do.

"I have to ask you whether any one near the person of the General in Chief

\footnotetext{
*See the Appendix.
} 
can be gained to procure the release of $\mathrm{D}-$, who would be very useful to me, from his influence at La Nouvelle, and elsewhere.

"Acquaint Gengembre 349 that he should not quit the Borgne, where the cultivators must not be set to work." 350

Whether Fontaine courted the favor of Le Clerc, by communicating this letter immediately, or that it fell into his hands by means of that system of espionage in which his mean and suspicious mind delighted, is uncertain; or whether he had not predetermined the violation of his personal treaty with Toussaint as well as his guarantee of freedom to the blacks, which is most probable. Be this as it may, within a few days after the departure of this letter, and before the expiration of the first month of his retirement, in the dead of the night, the Creole frigate, escorted by the Hero, a 74 gun ship from Cape François, stood in close to the shore of Gonaives, when suddenly landing several boats with troops, they surrounded the tranquil dwelling of Toussaint, where his innocent family lay wrapped in sleep, unconscious of their awaiting fate. To Brunet, chief of brigade, and Ferrari, an aid-du-camp of Le Clerc, was confided this treacherous task, which they performed so as to deserve the commendations of their master.* They entered the chamber of the hero with a file of grenadiers, and demanded his immediate surrender. Great as he had always been, he was now surprized for the first time, by a band of authorised assassins, whom armies had never been able to perplex, Toussaint declared himself indifferent as to his own fate, but remonstrated with regard to his family. "I shall not resist the power you have obtained over me," said he, "but, my wife is feeble, and my children can do no harm. Suffer them, then, to remain at home." ${ }^{351}$ Reasoning of this kind suited neither their policy nor their minds, the guard was increased, and before the vicinage became alarmed, they were on board the vessel, and under sail. Two brave leaders, who were roused, instantly attacked the banditti, but their bravery was useless, they were soon seized, and afterwards shot. ${ }^{352}$

As soon as Toussaint was sent away, the emissaries of the Captain-General, under the direction of Rochambeau, who commanded at St. Marc, set about discovering the connexions, and even acquaintance of the unfortunate general, as if to root the very remembrance of him from the colony: but that rested on a firmer basis, the justice and gratitude of the country, and was so deeply engraven on the hearts of its inhabitants, that it could only be expelled with their lives. The brave Dessalines was for the present politically spared, but above an hundred of those who contributed to form the enlightened society of Toussaint, or who were distinguished for knowledge or benevolence, 
were seized and sent on board different vessels in the harbour, and were never more heard of; in all probability, as the same mode of execution was afterwards openly had recourse to, they were immediately slaughtered, or thrown into the sea.

The astonishment which this flagrant act of the French government occasioned, was such as to paralyse the minds of the whole people. A dread calm succeeded. The Captain-General again boasted to the deluded Bonaparte of enormities which alone were sufficient to subject his government to the execration of posterity. As if designed to hold up the transactions of this island to ridicule, the dispatches continued to display the most glaring falsehoods, and contradictory accounts; in the one alluded to he declares, that joy had been produced at the Cape by the departure of Toussaint. If that sentiment did obtain public declaration, when the town was a common pest-house, and the French army were hourly dwindling away, it was more probable to arise from the death of the sanguinary General Hardy, the second in command, who died on the $2 \mathrm{~d}$ of June, universally detested for his total want of those qualities in which a true soldier delights.

The dispatch, as relates to the circumstances it describes, is a document too striking and important to be omitted. It is as follows:-

"Head-quarters at the Cape, June 11.

"I informed you in one of my last dispatches of the pardon I had been induced to grant General Toussaint. This ambitious man, from the moment of his pardon, did not cease to plot in secret. Though he surrendered, it was because Generals Christophe and Dessalines intimated to him, that they clearly saw he had deceived them, and that they were determined to continue the war no longer; so finding himself deserted by them, he endeavoured to form an insurrection among the working negroes, and to raise them in a mass. The accounts which I received from all quarters, and from General Dessalines himself, with respect to the line of conduct which he held since his submission, left no room for doubt upon the subject. I intercepted letters which he had written to one Fontaine, who was agent at the Cape. These afforded an unanswerable proof that he was engaged in a conspiracy, and that he was anxious to regain his former influence in the colony. He waited only for the result of disease among the troops.

"Under these circumstances it would be improper to give him time to mature his criminal designs. I ordered him to be apprehended, - a difficult task; but it succeeded from the excellent dispositions made by the General of Division Brunet, who was entrusted with its execution, and the zeal and ardour of Citizen Ferrari, a chief of squadron, and my aid-du-camp.

"I have sent to France, with all his family, this so deeply perfidious man, 
who, with so much hypocrisy, has done us so much mischief. The government will determine how it should dispose of him.

"The apprehension of General Toussaint occasioned some disturbances. Two leaders of the insurgents are already in custody, and I have ordered them to be shot. About an hundred of his confidential partizans have been secured, some of whom are sent on board La Muiron frigate, which is under orders for the Mediterranean, and the rest are distributed among the different ships of the squadron.

"I am daily occupied in settling the affairs of the colony, with the least possible inconvenience, but the excessive heat, and the diseases which attack us, render it a task extremely painful. I am impatient for the approach of the month of September, when the season will restore us activity.

"The departure of Toussaint has produced general joy at the Cape.

"The commissary of justice, Mont Peson, ${ }^{353}$ is dead. The colonial prefect, Benezech, is breathing his last. The adjutant-commandant, Dampier, is dead; he was a young officer of great promise. I have the honor to salute you,

(Signed) "Le ClerC." 354

Having rid himself of Toussaint, and assumed the title of General in Chief, in addition to that of Captain-General, with which he came to the island, Le Clerc affected to undertake the organization of a new government for the colony, a labour in which many great men had been unsuccessful. In doing this, however, he did not risque his character, as they had done, by speculative attempts in legislation, for he decreed the continuance of every establishment as he found it in the hands of the exiled General, except as related to the customs, and even in these he admitted the regulations in favor of the English, which occasioned a strong remonstrance from the commercial interest at Paris.

On the $22 \mathrm{~d}$ of June the decree was published, "in the name of the General in Chief Captain-General." Martial law continued in force, with certain modifications. Military commandants had the power over certain districts, with the assistance of the municipality; and each commune provided for the expences of its government, while the whole held a general understanding with each other.*

The object at this time requiring the most ardent and strict attention, was the health of the troops, which had suffered to such a degree, that in many instances where, (in consequence of their necessary dispersion throughout the colony,) small numbers were left at a post, sufficient scarcely remained to attend the sick and bury the dead, instead of performing military duty,

\footnotetext{
*See the Appendix.
} 
while the rigorous service was necessarily obliged to be imposed upon the others, particularly in the south, and towards the Spanish division, where large parties of blacks, never brought into action, continued in arms, and ridiculed the idea of submission. General Le Clerc preserved in his endeavours to infuse terror by the most absolute measures, and to implore the First Consul for reinforcements. Thus, if it could be considered as ended, concluded the first campaign of the army of St. Domingo.

In the mean time, the injured Black General in Chief approached rapidly to the site of exile. During the voyage he was not permitted to see his family, and a guard was placed at the door of his cabin. On the 11th of June the ship arrived at Brest, and on the deck only this great man was permitted to take the last view of his innocent and respectable family. Their agonizing separation will be long remembered by the seamen who witnessed it, notwithstanding the means taken to impress an unfavorable opinion of the blacks, and render them insensible to the emotions of humanity; nature broke through the boundaries which had been thus infernally created, and expressed their sense of the fraudulent delusion so strenuously, that it was conceived necessary to hurry off their august prisoner. He was conveyed in a close carriage, under a strong escort of cavalry, to the Castle of Joux in Normandy, ${ }^{355}$ far from the knowledge of his fame or fate, with a single attendant, who was also confined and prevented from any other communication; and who, afterwards, weary of captivity, procured his own release under the pretence of betraying his master, and disclosing hidden treasures in his native island. From Joux he was removed to Besançon, ${ }^{356}$ and treated as the worst of criminals. - He who had been the benefactor of white people in a country where their enormities had provoked hatred, whose power was never stained by malevolence, and who was greater in his fall, than his enemies in their assumed power, was kept in a damp and cheerless prison, without the comfort of a single friend, without trial or even examination; a proof of his exalted innocence, and a perpetual memorial of the political error of the Conqueror of Italy, which will throw a gloom over his apotheosis, and cast a slur on a government otherwise not destitute of virtues.

The wife and family of Toussaint remained in strict charge at Brest for two months, from whence they were removed to Bayonne, in the same province with their unhappy relative, where they long continued unnoticed, and in ignorance of his fate.*

*After a considerable period, a report gained credit that this hapless family had obtained permission to return to their native country: even miserable as the return under such circumstances must have been, the account is doubtful. [Indeed, Toussaint's family remained in France.] 
This prison may be considered the sepulture of Toussaint. France forgot awhile the habits of a civilized nation, to entomb one she should have graced with a public triumph; and England, instead of making a common cause to annihilate a nation of heroes, and depress the human intellect when rising to its level, should have guarded from violation the rights of humanity in its person. It has been the lot of him whose feeble hand attempts a tribute of gratitude, respect, and justice to his character, to regret the ill-requited life of the discoverer of the new world, and the unpropitious efforts of the enlightened and benignant D'Ogeron, to view the untimely death of many brave and exalted characters in the fluctuation of events in the different attempts to obtain possession of an island whose fate is as conspicuous as the most celebrated ancient state; but in no one instance does the mind linger with such keen sensations as on the unhappy fortune of the great, the good, the pious and benevolent Toussaint L'Ouverture.*

Notwithstanding the disastrous state of the colony, General Le Clerc seemed unwilling to depreciate his government, by admitting that at the end of several months he had not accomplished what he had declared was effected in the first five days. The healthful season so much desired by him had long arrived, and the contagion had not otherwise decreased, than by the number of its victims, which every day grew less. He was himself scarcely convalescent; the best officers of his staff had fallen, and those who arrived being unacquainted with the country, and task to which they were condemned, sunk into despondency, and followed their predecessors to eternity! In the beginning of October, he commissioned an aid-du-camp to the Consular court for instructions and advice, and for once his dispatches wore the semblance of truth; they were in consequence carefully concealed from the public knowledge, but bad news finds its way through a thousand avenues, when the good is most anxiously sought for in vain.

*The death of Toussaint is silently noticed in the Paris journals of April 27, 1803, and briefly alluded to in the London papers of the $2 \mathrm{~d}$ of May following. In one of the most respectable of them is a paragraph nearly in these terms, whose briefness well characterizes an event which could only have been dwelt upon with shame:

“Toussaint L'Ouverture is dead. He died, according to letters from Besançon, in prison, a few days ago. The fate of this man has been singularly unfortunate, and his treatment most cruel. He died, we believe, without a friend to close his eyes. We have never heard that his wife and children, though they were brought over from St. Domingo with him, have ever been permitted to see him during his imprisonment." - Times, May 2, 1803 .

Suspicions have been hinted of this event being accelerated by poison. The author, however, of an eloquent little popular work, states a circumstance from good authority, which would supersede the necessity for this means: "The floor of the dungeon," (in which Toussaint was confined,) he says, "was actually covered with water."-Bonaparte in the West Indies, \&c. [James Stephen, Buonaparte in the West Indies (1803).] 
It was therefore soon known that Christophe had rejoined the black forces with Dessalines, who could never be considered as defected. They began, by affecting in their different characters of commandant of negroes in the northern district, and superintendant-general of negroes, to retreat from those who were hostile, taking care always to leave behind them considerable quantities of ammunition and stores. A number of new generals, likewise, had arisen in arms, from the interior of the island, who began to make excursions from the mountains. Among these was a powerful chief of negroes, of the Congo tribe, called Sans Souci, ${ }^{357}$ who, after committing considerable depredations, could never be discovered. Charles Bellair, ${ }^{358}$ with his Amazonian wife, also made a powerful diversion for a while, till they were both taken, and died under the most inconceivable tortures. Clervaux, whose submission of the eastern part of the island had been formerly boasted without grounds, now declared openly his contumacy; and Maurepas, who had surrendered, was detected in a conspiracy, and put to death. Nor were the defections from the French army confined to the blacks, or to inferior officers among the whites; General Dugua, the chief of the French staff, disgusted with the horrors attendant on the war and more particularly, with the horrid punishment of Bellair and his wife, whom he had tried, was discovered in making arrangements to quit the French army, and took the resolution of destroying himself.

The government at this period (if in the insubordinate state in which every thing appeared, any government could be considered to exist) assumed a complexion more sanguinary and terrible than can be conceived among civilized people, and formed a new aera in martial law. In attempting to disarm the black troops which had been incorporated with the French, the necessity whereof was discovered too late, the most barbarous methods were practised, ship-loads were collected, and suffocated in the holds. In one instance, six hundred being surrounded, and attempting a resistance, were massacred on the spot; and such slaughters daily took place in the vicinity of Cape François, that the air became tainted by the putrefaction of the bodies. At the same time the French troops being driven from the field, and obliged to fortify themselves in the chief towns, contagion spread every where, and the distress became dreadfully general. In their extremity, to aid and fill up the measure of their enormities, the use of blood-hounds was resorted to, that dreadful expedient, the temporary adoption of which in a neighbouring colony, had already excited the disgust of the powers of Europe.*

\footnotetext{
*In this allusion to the circumstance of the introduction of blood-hounds to an English colony, the author has no other aim than to add his testimony (who was an eye witness) to the rectitude of the governor of Jamaica in regard to their use. Though a successful, yet
} 
Fort Dauphin, Port Paix, and several other favourite establishments, were by the middle of October completely lost to the French; and it became known to the seamen who visited the Bight of Leogane, that after a considerable number of blacks had been hunted down in the neighbourhood of Port Republicain, they were hurried on board of the ships at anchor in the bay, and crowded into their holds; that under cover of the night this dishonored navy put to sea, and first either burning brimstone in the hold, or extinguishing sense by suffocation, or neither, the miserable cargoes were discharged into the sea in such quantities, that at length the tide (as if the mighty Arbiter of all, meant to hold their shame before them) brought the corpses into the bay, and rolled them on the very beach. Human nature recoils at the description, yet the scene is not ended, - under the dark concealment of night, the tender wife, the aged parent, and even the rougher comrade in arms, stealing by the watchful suspicion of their masters, were seen wandering on the sea-shore, to identify each victim as the wave produced him.

Towards the end of October, an event occurred which, however expected, produced an extraordinary effect. The General in Chief, whose health had been long impaired, and who had tried every means for its restoration, suddenly became worse, the air of the city had avowedly become mephitic, and Tortuga no longer remained as a retreat for him, being in full possession of the blacks. On the night of the 1st of November, after he had communicated his wishes as to the future government of the colony, died Victor Emanuel Le

it was a dangerous experiment, and one which will, it is hoped, never be again tried by British soldiers; but with the control of such men as Lord Balcarras, and General Walpole, the rights of humanity can no more be violated than the highest point of military honor or discipline. The writer was witness to an anxiety with regard to any employment of the dogs in the noble governor, which must confer eternal honor on his feelings as a gentleman and as a soldier, while the sentiments of General Walpole on the occasion are equally honourable. Strange as it may appear to those who had an opportunity of knowing the fact, the public mind (with a jealousy of national character most laudable and dignified) has never been satisfied that the Maroons were not really hunted down, and destroyed by blood-hounds; it is therefore most solemnly declared in this place, that no farther use was made of them than being marched in the rear of the army to inspire terror in the blacks, as has been mentioned in an account furnished to his respectable historian by Mr. Quarrel, although the writer is not certain that the care taken by Lord Balcarras to prevent it, was perfectly consonant to the inclinations of that gentleman. Some accidents, and perhaps more than those stated by Mr. Dallas, did occur, but they were never let loose, indiscriminately, by a British general, for the inhuman purposes for which they are bred. [Alexander Lindsay, sixth Earl of Balcarres (1752-1825), was an army officer in the American Revolutionary War who served as governor of Jamaica from 1795 to 1801 . He was responsible for the use of dogs during the Second Maroon War and the mass deportation of the Maroons to Nova Scotia.] 
Clerc, having been only eleven months General in Chief and Captain-General of the colony of St. Domingo.

On the morning of November 2, the following proclamation was issued by the principal municipal officer of the colony:

\section{“ARMY OF ST. DOMINGO.}

"The Colonial Prefect, to the Army, and the Inhabitants of St. Domingo:

\section{“Citizens, Soldiers}

"The night which has passed has been a mournful night for us.

"The General in Chief, Le Clerc, your Captain-General, is no more.-He has fallen; an irresistible malady has borne him from you.

"Having scarcely attained the meridian of life, he was already a conqueror in battle and vigorous in council, - at once a hero and a sage.

"Possessing dignity without pride, generosity without ostentation; - his heart was just; - your sorrows and his were perpetually the same.

"Soldiers, although the brother of Bonaparte is no more-he will live in your hearts. The brigands, whose terror he was, will rejoice in his death; you will punish their detested joy.

"The General of Division, Rochambeau, is about to succeed General Le Clerc. He has already delivered the South and West from the brigands who ravaged them. He is the choice of the government, and of the General whom you lament.

"Under his standard you will continue to conquer, and your hearts alone can inform you what loss you have sustained.

"Inhabitants of St. Domingo, rally with confidence around the new Chief who is given to you. - You have long known him, - you have often blessed the success of his arms. You will have to applaud new triumphs. Forget not, Soldiers and Inhabitants, that union constitutes force; and that the only mode of honoring a man whom you loved, and who loved you, is to conduct yourselves as if he were still in the midst of you.

"The French government watches over you: it will never abandon you.

"The Colonial Prefect, D’Aure." 359

This communication, had it been intended to appease the manes ${ }^{360}$ of Le Clerc, could not have been more conformable to his ideas, or more replete with ostentation and falsehood. The body was immediately examined on account of his disease, then embalmed, and placed on board the Swiftsure man of war; Madam Le Clerc, who had no inclination to remain on an island, where, instead of a promised paradise, she had suffered the most painful deprivations, went on board in a few days, Admiral Latouche, chief in command of the naval force in St. Domingo, undertaking to escort her home, accompa- 


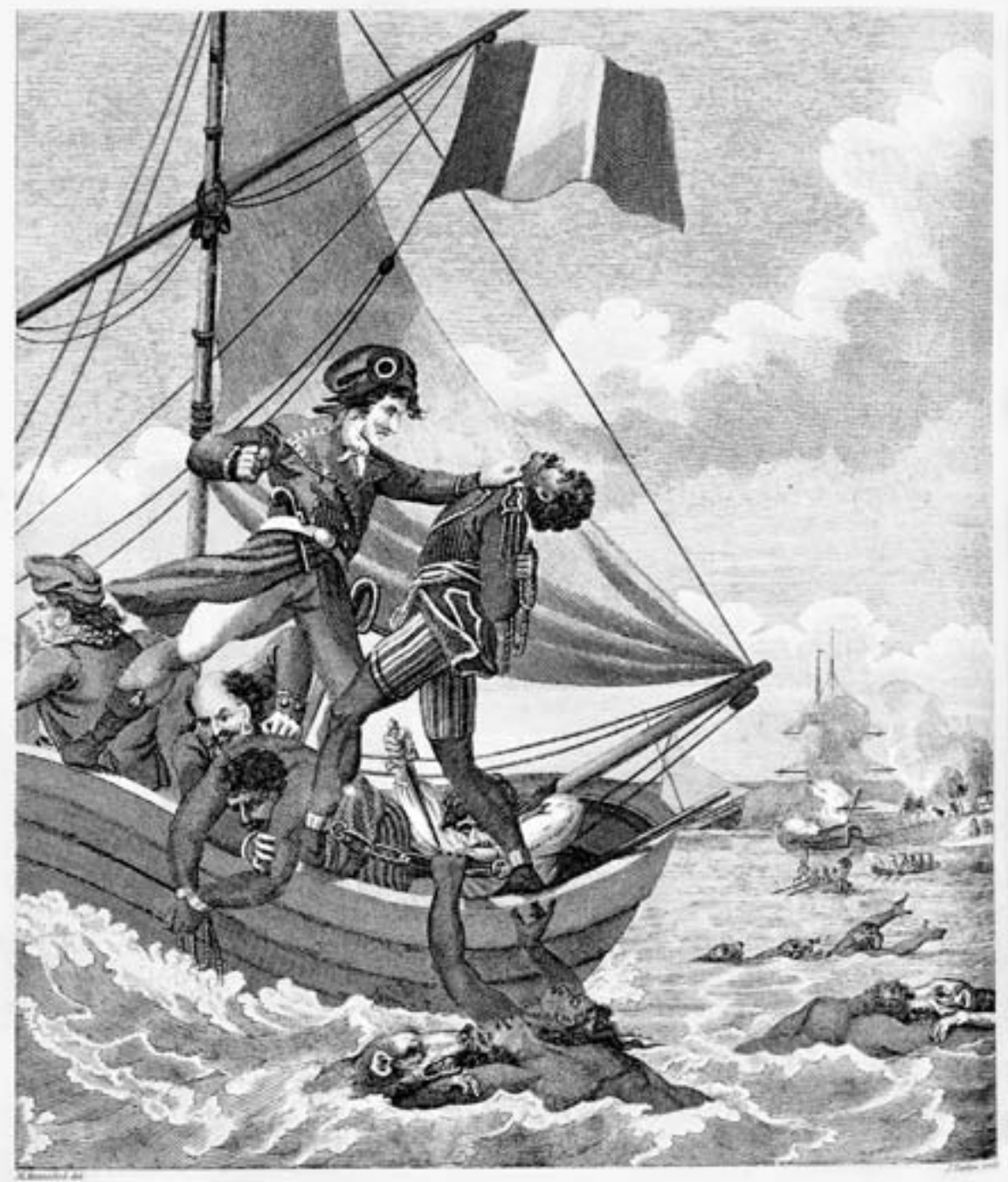

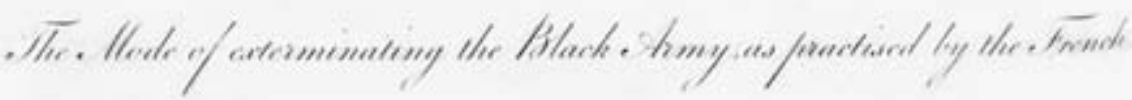

The Mode of exterminating the Black Army as practised by the French. Reproduced with the permission of Rare Books and Manuscripts, Special Collections Library, the Pennsylvania State University Libraries. 
nied by the Chief of Brigade, Netherwood, first aid-du-camp of the departed general. His sabre and hat were placed, with much formality, upon the bier on board, all the officers attending on the occasion.

He appears to have been anxious, that the directions which he thought necessary for the future government of the island, should be put in force, and they were, as far as convenient with some persons, obeyed. As soon as the obsequies of the departed General were performed, it became necessary for some one to prepare for the repelling the blacks, who had advanced with vociferous joy to the very town of Cape François. General Rochambeau, who was appointed Chief in command, was at Port-au-Prince, and could not be expected to arrive in sufficient time, though General Watrin ${ }^{361}$ had set out to succeed him in the west and south; General Clausel, ${ }^{362}$ commanding in the north, therefore, with the remains of a dispirited army, proceeded against them, but to little effect.

A young general, of the name of Boyer, ${ }^{363}$ who had commanded in the Gens d'Armerie, having been appointed Chief of the Staff in the place of Dugua, was entrusted with the execution of every order, and in consequence thought it necessary to address to the French colonial minister some account of the transactions of the French army in St. Domingo from the period of the arrest of Toussaint L'Ouverture. In this dispatch, amidst a variety of matter, such as had been the custom to transmit to France, Boyer confesses the dreadful situation in which the colony then stood. Speaking of the first attempts after the departure of Toussaint, he says, "The heat became excessive, it was impossible to make any movement; - the lowest mornes presented obstacles to us proportionate to the inconvenience of the season. The brigands increased in numbers. Our hospitals were crowded with sick, and disease daily made new ravages." 364 He then mentions insurrections at Marmalade, Dondon, and Moustique, when not only those posts, but the whole plain of the Cape, covered by the black forces, from whom, they might temporarily obtain possession of a small place which they afterwards were obliged to relinquish.

He acknowledges the prosecution of the war against the leaders, which had been begun by Le Clerc, in the course of which Domage, the friend of Toussaint, who had hitherto successfully repelled every attempt upon the south, fell into the hands of General Desbureaux. Loaded with the charge of an intimate connection with his exiled chief, it was not sufficient to send him "on board the squadron,"* as the end of his co-patriots was termed; he was reserved for the extremity of torture that civilized barbarians could inflict.

The arrival of the new Commander in Chief at head-quarters, effected little

${ }^{*}$ Q. d. to be simply drowned. 
change in the situation of affairs, though much was expected, from his superior knowledge of the Island, and character of the blacks; but this knowledge could not effect a change in the elements, or render a power daily weakening equal to that which acquired strength from a continuation of the war. He appeared anxious to direct it to points different from that to which it was ordinarily carried; accordingly an action of considerable violence took place on the parched plains of St. Nicholas Mole, in which the French appear to have made a feeble stand. They continued to fight during the night, and to precipitate each other into the sea. The end, however, was, as it must always be in a like situation, that any advantage the whites obtained was soon relinquished. General Clausel was more successful before Fort Dauphin, which, after withstanding for some time the united attack by sea and land, surrendered to him. Before this capture, Port Republicain and Les Cayes were the only towns, besides the capital, in the possession of the French.

The first public act of Rochambeau, as Captain-General of the Island, was that of calling to account the young Chief of the Staff, who appears to have been an élève $e^{365}$ of Le Clerc, and raised to that dignity more from the General's fondness, than his ability. He was young and spirited, and the faults with which he was charged, appear to have arisen more from errors ascribable to that period of life, than from a decided cupidity. His suspension was announced by an arrêté, thus:

\section{“ARRÊTÉ OF THE GENERAL IN CHIEF.}

December 8.

"The General in Chief orders the deposition of the Chief of Brigade, Boyer, Ex-commander of the first legion of Gens d'Armerie. He shall be detained in prison at the Cape till his accompts are given in, when he shall be sent to France.

(Signed) “Rochambeau."*366

\footnotetext{
*This young General, with more good fortune than was ordinarily met with under the present regimen, was afterwards embarked for France, but war having recommenced, was taken, and brought to England. With the greatest impetuosity he inveighed against his treatment! - But when he found that he was to be deprived of a sum of money, the fruits, probably, of defalcation in his official career, he lost all patience. Notwithstanding every thing of personal property had been returned to him, as well as the other prisoners, he complained with great virulence to his government, "that the English had robbed him!" He was, notwithstanding, granted his liberty on parole at Tiverton, in Devonshire, where his conduct was frequently ludicrous in the extreme; and the letters he wrote to his government occasioned many false constructions in the French papers. Notwithstanding this disagreeable circumstance, his favorable exterior, youth, and vivacity, obtained for him particular notice. On one occasion, the prisoners, having procured musical instruments, and formed a concert on a Sunday, the English peasantry conceiving it derogatory to their
} 
Shortly after, the General in Chief renewed the decree of Le Clerc, so obnoxious in France, permitting foreign importation into the colony, extending it to all descriptions of wares and merchandize, but increasing the duty upon them to twenty per cent; ${ }^{*}$ with this arrêté ended the most eventful year ever experienced in St. Domingo. The French troops appeared to proceed with the season in which they landed, - to rise with the progress of the year, and to fell, with their General, at the approach of winter. Before the month of December, not ten months after their arrival, near forty thousand French troops are supposed to have been sacrificed, and a considerable number, (though by no means proportionate,) of the blacks. Troops still continued to be sent from the ports of Havre and Cherbourg, but each reinforcement was less effective than the preceding, and the conscripts at length consisted only of raw youths, Poles, Piedmontese, and Flemings. Veteran soldiers considered the army of St. Domingo as the by-word of contempt, and the once popular cause of the subjugation of that splendid colony became no more heard of, or if mentioned, it was only with sorrow, or to be treated with derision.

The commencement of the year 1803 was marked by a sullen cessation of arms, more dreadful than active war, as it gave place to secret cruelties, more extensive because less glaring. General Rochambeau was called, by the fortune of war, to a command for which, notwithstanding the local and physical experience which has been allowed to him, he was by no means competent, and to which, no talents, perhaps, would have been adequate. In the outset of the expedition he had borne a subordinate rank, considering his stake as a proprietor, and it was only to the death of his superiors that he owed his present appointment. He evinced no desire to change the system (if so it could be called) on which the war proceeded, nor did he exhibit sufficient ability to produce an amendment. On the 4th of March, without any other communication of importance, the French colonial minister received from the new Captain-General an intimation, that on the arrival of four thousand more troops which were expected, offensive operations might be commenced.

The blacks, on the contrary, during the whole of this awful cessation, were daily strengthened from every quarter, under Dessalines, who was unanimously appointed General in Chief, who resolved vigorously to push the war

religion, insisted on its suppression, and the Magistrates were obliged to interfere. With great gallantry the Frenchmen hoped that, though compelled to relinquish their music, the church of England would not deny them the pleasure of drinking a few bottles of excellent wine, then in their possession, with the Magistrates: the latter declined; but were surprized at hearing nothing of Boyer all the time. - He was busily employed in a corner drawing a caricature of the whole party!

*See the Appendix. 
to a termination. With this view they collected a considerable force upon the plain of the Cape, which being observed by Rochambeau, he found it necessary to withdraw his troops from every other point, and both armies became unawares in a state of preparation for a general battle. This was not what either party designed; Dessalines, therefore, restrained his impetuous blacks, and the French forces were combined to strengthen Cape François. Several skirmishes having taken place in the vicinity of Acul, it was at length determined by Rochambeau to venture an action, for which he had many dispositions in his favor. The troops selected on either side, for the affair were admirably posted on two neighbouring mornes, ${ }^{*}$ the first movement was inauspicious to the French, by the capture of a considerable body marching to strengthen one of the wings who were surrounded and driven into the black camp. Rochambeau began the attack with impetuosity, and the blacks for a short time gave way, but on his endeavouring to push the advantage, they repulsed him with loss, when the day closed. In penetrating the black line the French had secured a number of prisoners, and on them they determined to wreak the vengeance of which they were disappointed in the battle. Whether this determination arose from an idea that the part of the French wing which had been cut off were already absolutely sacrificed, or from the mistaken policy of extermination, cannot here be determined, but the unhappy victims were, without the smallest consideration for their own men who were prisoners in the black camp, immediately put to death. As they were not carefully exterminated, many were left in a mutilated state during the whole of the night, whose moans and shrieks were heard at a distance around the spot sufficiently loud to excite a sensation of horror throughout the country. The black commander, when acquainted with the case although the maxim of the benevolent Toussaint, not to retaliate, had been hitherto followed up, could no longer forbear; he instantly caused a number of gibbets to be formed, selected the officers whom he had taken, and supplying the deficiency with privates, had them tied up in every direction by break of day, in sight of the French camp, who dared not to interfere. The blacks then sallied down with the most astonishing vigor and regularity, raised the very camp, threw the whole line in disorder, and drove the French army close to the walls of Cape François. Such was the retaliation produced by this sanguinary measure; a retaliation, the justice of which, however it is lamented, cannot be called in question.

\footnotetext{
*This French provincial term, which has become a cant phrase in the public conversation on the war in St. Domingo, the writer conceives applies to heights divided by different mounts, separated by delightful vallies, with which the island abounds.
} 
During the latter months, the fluctuating politics of Europe, which had never failed to produce some change to this unhappy island, again took a turn, and the peace, which was not inaptly termed in the British senate a "peace of experiment," had been concluded. In the middle of the ensuing May, war was recommenced between Great Britain and France, when each power directing its attention to those objects of the enemy which were most vulnerable, the former rationally looked towards the force in St. Domingo. ${ }^{367}$

By the time the news arrived with the different commanders on the station, Rochambeau had permanently fixed his head-quarters at the Cape, and Dessalines had so completely lined the country about the city, that the French boundaries were confined to two miles around the Cape. As their power became weaker, an unnatural ferocity was increased, and apparently a desire to render the white complexion detestable throughout the Antilles; for no means, however extraneous, were left unattempted to annoy the enemy. Not content with the use of a considerable number of blood-hounds, (some of which they had procured from the Spanish part of the island, but most from that of Cuba,) which they sent in pursuit of small reconnoitring parties that occasionally ventured within their lines; when they were taken (the pen shrinks from the task of describing it) they were thrown to those animals, less brutal than their barbarous owners, to be devoured alive! All the arts, which invention worse than savage could devise in the people, who continued to inspirit these animals with a ferocity not often known, was employed, to render them more terrific to the blacks, and more effective in the war. Such is the deterioration of the human mind, under a pressure of circumstances.

Dessalines, notwithstanding frequent losses, attended with the most horrid circumstances, sufficient in the relation to freeze the blood of the reader, continued the blockade, and found opportunities to decrease in the French the means of operation, both offensive and defensive. As soon as an English squadron was perceived on the coast in July, he, in conjunction with Christophe, sent a flag of truce with a proposition to act in concert against the French, and, in case of agreement, to request some assistance of stores. - It is probable, that at the same time an account of the atrocities of the French accompanied this request, for shortly after a squadron, under the command of a Commodore, ${ }^{368}$ blockaded Cape François in the ensuing month, when Rochambeau began to sound the Commodore upon terms for a surrender of the French troops. About this time, so unsafe appeared the French interest, that Jerome Bonaparte, the brother of the First Consul, who had remained hitherto, (with what utility is not known,) left the island, and arrived at Baltimore, on the American continent, a young man more fond of fashionable dis- 


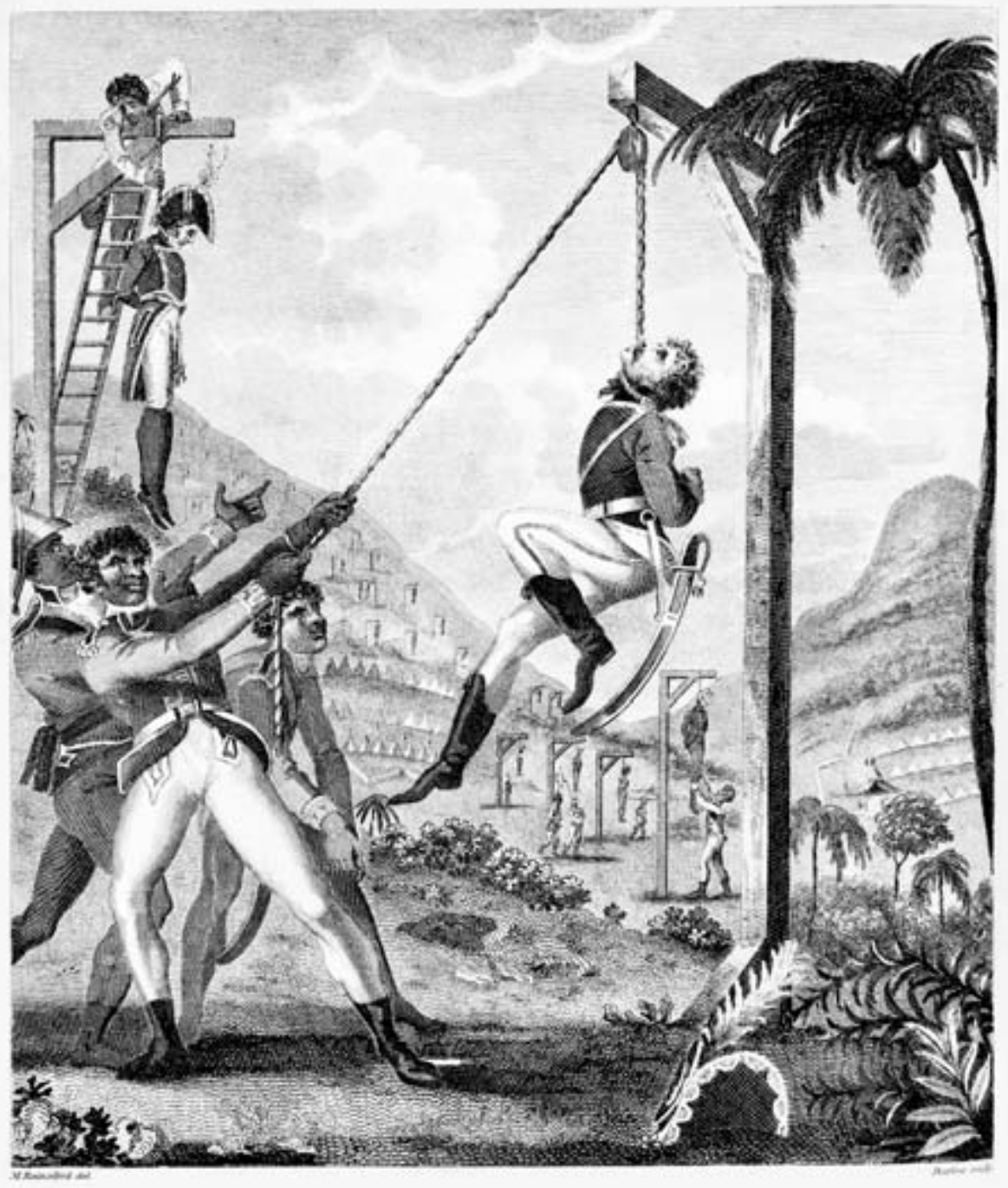

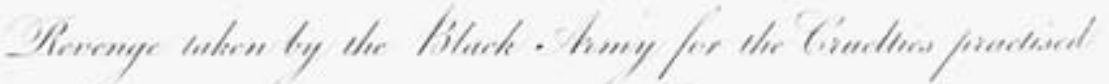

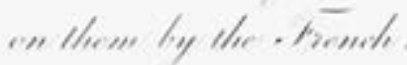

Revenge taken by the Black Army for the Cruelties practised on them by the French. Reproduced with the permission of Rare Books and Manuscripts, Special Collections Library, the Pennsylvania State University Libraries. 
tinction than of war, and more fitting for the agremens ${ }^{369}$ of life than its arduous occupations. ${ }^{*}$

The French affairs continued to depreciate, varying only by the increase of difficulty; attended with the same disgraceful employment of the most cruel actions, till Rochambeau actually relinquished every other merit or aim, than that of keeping possession of the city of the Cape, and fortifying it by every means that human art could devise or effect. In a dispatch on the 29 th of October, he observes, "There is still some merit in defending a ravaged colony against a civil war on one side, and a foreign enemy on the other." ${ }^{370}$

Such was the situation to which were reduced the conductors of an expedition, which had flattered the French people to the highest pitch, - had interested the powers of Europe, - and fed the vanity of every general whom interest could procure to be appointed to its service. - The victorious blacks, however, continuing to pour in reinforcements upon the plain of the Cape, Dessalines resolved to attack the city, and took measures accordingly. A powerful body descended from the Morne du Cap, and having passed the outer lines, and several of the blockhouses, a sharp conflict ensued, and they then prepared to take the city by storm in thirty-six hours. The blacks being irresistible; and before it would be too late, reasonably expecting that every one would be put to the sword, Rochambeau offered articles of capitulation, which, to the honor of the Black General, by foregoing the desire of revenge for the conduct of the French, he accepted, granting them ten days to evacuate the city, (and in so doing the island, leaving every thing in its existing condition,) in their own ships, with the honors of war, all their private property, and leaving their sick to the care of the blacks; ${ }^{\dagger}$ an instance of forbearance and magnanimity, of which there are not many examples in the annals of ancient or modern history.

Though the British squadron under Commodore Loring, which were still stationed off Cape François, did not enter into any definitive alliance in consequence of the application of the blacks, they continued to render their cause an incalculable service, by preventing the arrival of reinforcements or supplies of any kind. Having been informed of the mode by which provisions were obtained from the Spanish part of the island, through the Curacol passage, leading to the eastern entrance of the harbour of Cape François, a frig-

\footnotetext{
*Among other traits of character in this young man was, that he anxiously, and perhaps surreptitiously, obtained the London curricle of an English merchant on the island, which he used with an extravagant peculiarity in the city to which he had removed, while the executors of its owner were instituting legal proceedings to recover its value. [A "curricle" is "a light two-wheeled carriage, usually drawn by two horses abreast" (OED ).]

†See the Appendix.
} 
ate was placed so as to intercept them, by which thirty small vessels, several laden with bullocks, were captured in a short time.* Thus, deprived of supply by sea, and shut from an intercourse with the land, General Rochambeau became reduced to the situation he so forcibly described on a subsequent occasion. "Pressed" said he, "almost to death by absolute famine, and after waiting for a considerable time, wretchedly appeasing the desperate calls of hunger by feeding on our horses, mules, asses, and even dogs, we had no way to escape the poignards of the enraged negroes, but by trusting our fate to the sea." $\dagger$

The same day on which he had treated with General Dessalines, and after he had exchanged hostages, Rochambeau thought proper to send to the English commodore a military and a naval officer, with proposals to treat for the evacuation of the Cape, with a dissimulation disgraceful to the meanest commander. These were General Boyé and Captain Barré. They proposed that General Rochambeau and his guards, comprizing about five hundred men, should be conveyed to France in two vessels, the Surveillant and Cerf, without being considered as prisoners of war. To this proposition, which nothing but the liberality they had so recently experienced could give rise, Commodore Loring returned his refusal, and at the same time sent Captain Moss, of the Desirée, with absolute terms. These were, - a general surrender, - that the French officers and troops in health should go to Jamaica, and the sick to France and America, security being given for the vessels which conveyed them, prohibiting at the same time the white inhabitants of the Cape from going to Jamaica.

To this communication General Rochambeau returned the following answer:-

"The General in Chief of the Army of St. Domingo

to Commodore Loring, \&c. \&c.

"Sir,

"I have received the letter which you have done me the honor to address to me. As your propositions are inadmissible, I must beg of you to consider the preceding letter as not having been received.

"I have the honor to be, \&c.

“D. Rochambeau.” 371

\footnotetext{
*London Gazette, Feb. 7, 1804. [Actually London Gazette, February 4, 1804, 162-63.]

†"On which," he scurrilously adds, "we were taken by the English pirates." See Affidavit of Augustus Stenson, taken at Ashbourne, in Derbyshire, on the 27th of February, 1804, at which time Rochambeau was prisoner there on his parole of honor.
} 


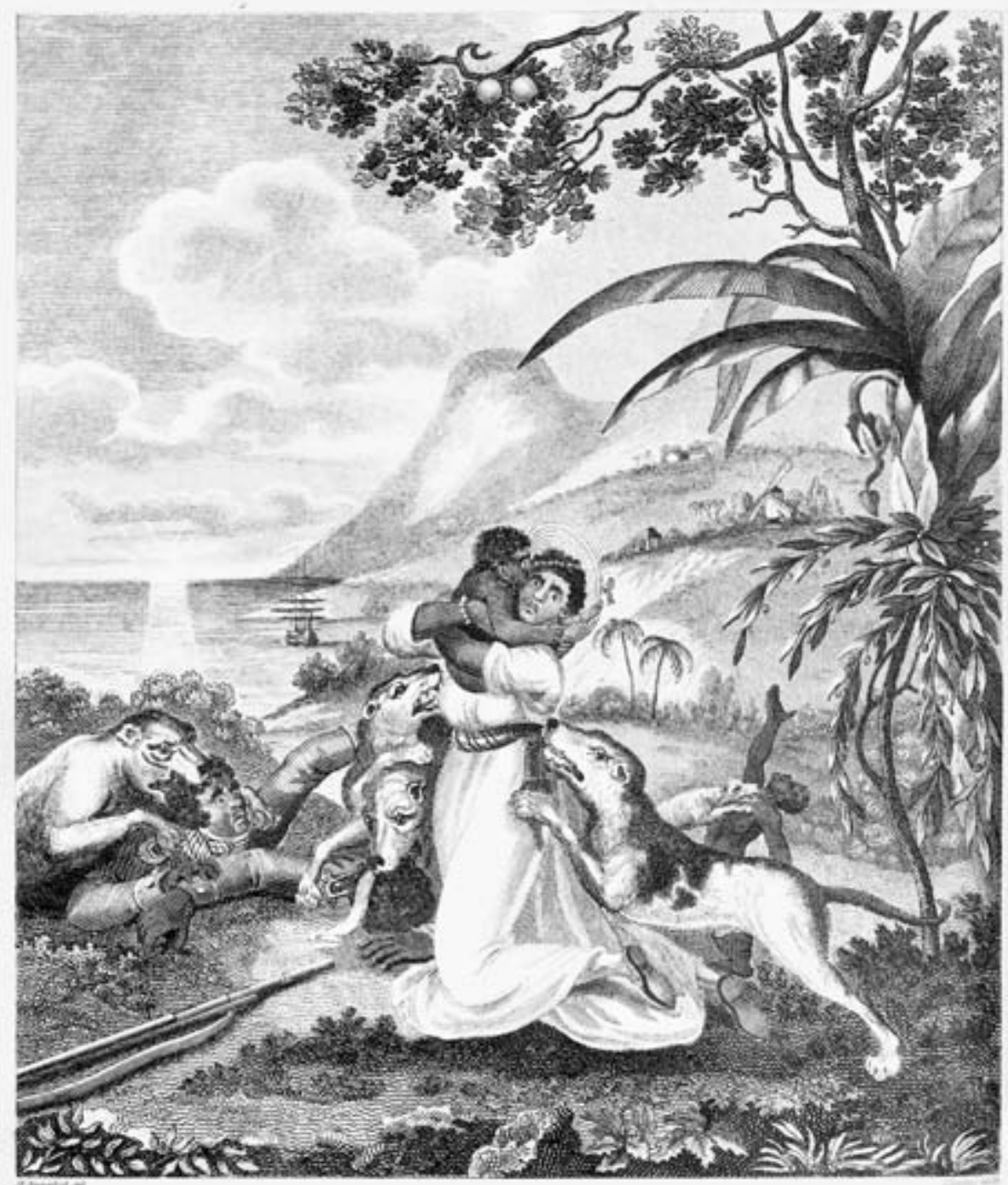

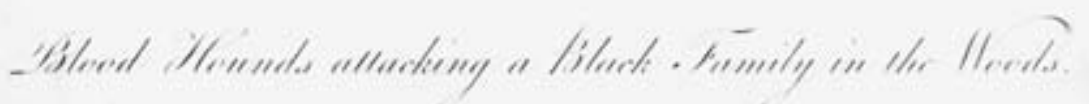

Blood Hounds attacking a Black Family in the Woods. Reproduced with the permission of Rare Books and Manuscripts, Special Collections Library, the Pennsylvania State University Libraries. 
The French general flattered himself with finding an opportunity to make his escape from the Cape, and consequently forbore any farther communication with, and still concealing from the English the capitulation into which he had entered with Dessalines, but they were too vigilant for his purpose.

On the 2nd of December, Captain Loring summoned the General of Brigade, Noailles, ${ }^{372}$ who maintained unmolested a species of solitary command at the Mole, to surrender, who, while equivocating as to the mode of his capitulation, embarked with his garrison in the night on board six vessels, five of which fell into the hands of the commander of the La Pique, the sixth escaping, with General Noailles on board.

Port-au-Prince having been evacuated at different periods, was under the command of the General of Division, Petion, ${ }^{373}$ a black officer of experience and ability, who had been regularly educated at the Military School in France; St. Domingo thus became again in the full possession of the native army. The force which had arrived with the first body of troops, and stationed at the Spanish capital under General Kerversan, had remained without the power of interfering in the war, and contented itself with the parade of communication between the French and Spanish inhabitants, and with the island of Cuba, between whom they found sufficient employment, in those petty political intrigues that are always better avoided, as regard both the character and advantage of the countries using them.

Immediately on the cessation of hostilities, which promised to be more permanent than any former one, the General in Chief, with the two Generals between whom the jurisdiction of the island was become divided, Christophe and Clervaux, began to consider of the proclamation of independence, and those measures which were necessary for the public tranquillity. In a proclamation on November 29 , by the three officers, from headquarters, in the Name of the Black People and Men of Colour, they declared the "General Freedom," and invited the return of those proprietors who fled during the conflict, without having become obnoxious by any cruelty of disposition towards their servants, or inclination to the continuance of slavery; at the same time, avowing, that to those of a contrary temper, no protection would be promised; and that as to soldiery employed in any future expedition, mercy was not to be expected. They declared their disapprobation of, and palliated the cruelties which were the unavoidable consequence of civil dissentions in all countries, and proposed that a new regimen, founded on the basis of justice, should prevail in St. Domingo. ${ }^{*}$ In the execution of these propositions, and in preparations for the pacific state of the Island, to which

\footnotetext{
${ }^{*}$ See the Appendix.
} 
they now looked, closed the year 1803 . It will scarcely be believed, that to this gratifying occupation of restoring order, in the place of distraction, perpetual caution was rendered necessary, by some infatuated people who remained at the Cape, still devoted to the hope of replacing the old constitution, and the principle of slavery.

Hearing no more from General Rochambeau, although acquainted, by Dessalines, with the capitulation, and perceiving no movement, the English commodore addressed that general as the term had nearly expired, expressive of his hopes that no retraction would take place, and requesting pilots, to conduct a part of the squadron into the harbour, to take possession of the shipping. He received the following answer:

\section{“Liberty or DeAth!}

Head-Quarters, Nov. 27.

"The Commander in Chief of the Native Army to Commodore

Loring, \&c. \&c.

"SIR,

"I acknowledge the receipt of your letter, and you may be assured that my dispositions towards you, and against General Rochambeau, are invariable. I shall take possession of the Cape to-morrow morning, at the head of my army. It is a matter of great regret to me, that I cannot send you the pilots which you require. I presume that you will not have occasion for them, as I shall compel the French vessels to quit the road, and you will do with them, what you shall think proper.

"I have the honor to be, \&c. \&c.

"DeSSAlines." 374

On the 3oth, the Colours of the blacks were flying at the different forts, which induced Commodore Loring to send Captain Bligh ${ }^{375}$ to the Black General, to enquire the circumstances which occasioned the change, when, on entering the harbour, he met Captain Barré, who entreated him to go on board the Surveillante, and enter into some capitulation with the French, that they might be placed under the protection of the English, the blacks having threatened to sink the vessels with red-hot shot, in consequence of the terms of the capitulation not being complied with in point of time. This he agreed to, and articles being drawn, in which the English continuing the liberality they had already experienced from the Blacks, agreed to their sailing out under French colours, and firing their broadsides previous to surrender; Captain Bligh went to acquaint the Black General with the capture, and to request his desistance from firing, till a wind should be fair for their departure, which was then directly contrary; his acquiescence was obtained with much difficulty. 
The force being taken possession of by Commodore Loring, comprizing eight thousand men, with the shipping, consisting of three frigates, and seventeen merchantmen, were conveyed to Jamaica, from whence Admiral Duckworth immediately dispatched General Rochambeau, and the officers particularly in his confidence, to England.*

With the new year, a new name and a new constitution was given to St. Domingo. Desirous of obliterating every mark of its recent state, the chiefs who had effected its freedom determined upon resuming, with its pristine simplicity of government, its ancient name. ${ }^{376}$ Aware of the failings of his too credulous countrymen, and knowing that nothing but the firmest consolidation of their whole force, could preserve the advantages they had gained, he appointed the first day of the year for a solemn pledge of hatred to the French government, and an abjuration of all ideas of conquest and aggrandizement. The terms of this declaration of union are dreadful, they were acceded to by the people with the enthusiasm he desired, and proclaimed throughout Hayti.

"It is not enough," says he, "to have expelled from your country the barbarians who have for two ages stained it with blood. It is not enough to have curbed the factions which, succeeding one another by turns, sported with a phantom of liberty which France exposed to their eyes. It is become necessary by a last act of national authority, to ensure for ever the empire of liberty in the country which has given us birth." $\dagger$

The truth of this declaration soon became exemplified by the intrigues of some of the unhappy persons who still retained their property in the Island, and who, notwithstanding the effervescence of the public mind, which was apparent in every occurrence, could not desist from plans of aggrandizement and assumption of power; some, were so imprudent, as to retain the dogs which had created such a fatal hatred. Even experience was not sufficient to cause them to remain quiet, and those whom the strictest caution could hardly be expected to preserve from infuriated revenge, adopted the least. The blacks in their turn, indiscriminately perhaps, viewed in every Frenchman a tyrant; thus, mutually repulsive, amity could not be expected.

One of the first civil acts of the black governor reflects considerable honor upon the consideration by which it must have been actuated. It arose from

\footnotetext{
*The words of that officer are, "I send a vessel of war to England, with General Rochambeau, and those officers who are said to have participated in his cruelties at the Cape." London Gazette, Feb. 7; Letter of Sir J. T. Duckworth. They arrived at Portsmouth on the 3d of February, and were afterwards sent on their parole into the interior. See the Appendix. [London Gazette, February 4, 1804, 164. Loring's ship, the Bellerophon, would eventually carry Napoleon to St. Helena.]

†See the Appendix.
} 
the following circumstances. In the early emigrations, different wealthy proprietors had taken with them for the purposes of pomp, a number of their domestic negroes; afterwards, when they ceased to receive remittances from their estates, and were unable to support a retinue, they abandoned them under various pretexts; others had voluntarily emigrated, during the sway of different factions, and thereby fallen into distress; while both were without the means of returning to their own country. The following proclamation was published, which, as it could have birth in no political view, but was a pure emanation of humanity, is an act worthy the imitation of older states.

\section{"Liberty or Death! \\ “Government Of Hayti}

"Head-Quarters, Jan. 14. "1st Year of the Independence of Hayti.

"The Governor-General considering that a great number of Native Blacks, and Men of Colour, are suffering in the United States of America, for want of the means of returning,

"Decrees,

"That there shall be allowed to the Captains of American Vessels the sum of Forty Dollars for each Individual they may restore to this Country. He orders that this Decree shall be printed, published, and posted up, and that a copy thereof be immediately forwarded to the Congress of the United States.

"By the Governor-General,

"Dessalines." 377

During the period, in which he was occupied in these pleasing cares, his attention was called to others of a troublesome nature. A number of persons yet remaining in the different towns of the island, who had been the tools of every faction, and whose inclinations, and interests had always led them to foment discontent, and sow the seeds of rebellion. To root out these emissaries was necessary to the public peace, and if the expulsion had gone no farther, without sanguinary measures, it would probably have been better for all parties.

The official notice which then presented itself, was the publication of an extract, drawn from the reports of the proceedings of the Government on that subject. It was as follows:

\section{"Extract from the Secret Deliberations of the Government of the Island of Hayti. \\ “Liberty! Independence! or DeAth!}

"The Governor-General considering that there still remains in the Island of Hayti, Individuals who have contributed, either by their guilty writings, 
or by their sanguinary accusations, to the drowning, suffocating, assassinating, hanging, and shooting, of more than sixty thousand of our brethren, under the inhuman government of Le Clerc and Rochambeau, considering that every man who has dishonored human nature, by prostituting himself with enthusiasm to the vile offices of informers and executioners, ought to be classed with assassins, and delivered up without remorse to the sword of justice, decrees as follows:-

"1. Every Commandant of a Division shall cause to be arrested within their respective commands those persons who are, or shall be known to have taken an active part in the different massacres and assassinations ordered by Le Clerc or Rochambeau, \&c.

"2. Before proceeding to the arrest of an individual, (as it often happens that many are innocent, who, nevertheless, may be strongly suspected,) we order each Commander to make all necessary inquiries for, producing proofs, and above all, not to confound with true and faithful reports those denunciations too frequently suggested by hatred or envy.

"3. The names and surnames of persons executed, shall be inscribed and sent to the General in Chief, who will make them public. This measure is adopted in order to inform the Nations of the World, that although we grant an asylum and protection to those who act candidly and friendly towards us, nothing shall ever turn our vengeance from those murderers who have delighted to bathe themselves in the blood of the innocent children of Hayti.

"4. Any Chief, who, in contempt of the orders, and unalterable will of the government, shall sacrifice to his ambition, to his hatred, or to any other passion, any person whose guilt shall not have been previously well ascertained and proved, shall undergo the same punishment which he shall have thus inflicted; and the property of every such unjust officer shall be confiscated, one half to the government, and the other half to the relations of the innocent victim, if any there may be in the island at the time of his death.

(Signed) "Dessalines.

"Done at Head-quarters, Feb. 22."378

"A true copy, B. Aime, Secretary.

To enable the General in Chief to prosecute with that vigor and decision, which the complection of the times required, the different functions of the legislature, it was determined by the deliberative meeting which had assembled throughout the month of April, to invest Dessalines with the Government for life, which was accordingly done in the beginning of May, with the power of making peace and war, and nominating his successor. It is thus, that the advantageous principle of a monarchy, in an extensive population 
arises, self-evident, without the contending interests which afterwards surround it, and the factitious principles by which it is obscured.

During this period, the French Government commissioned the Governor of Guadaloupe ${ }^{379}$ to treat as pirates all neutral vessels going to Hayti, which had been executed with a rigor as ridiculous as unjust. The division stationed in the city of St. Domingo, to whom reinforcements were reported would be sent, having never been called into action, except a few skirmishes on their debarkation, had suffered less than any other division on the island: the Spaniards, also, apparently glad of an opportunity for treachery, had supported and rendered them familiar to the country, nevertheless they were still confined to the Capital, without the power of advancing, or annoying the new Government, any other way than by their continuance in any shape upon the island. Kerversan, who commanded the division on the arrival of the expedition, had long since fallen, and the present commander was Freron, ${ }^{380}$ a man of some talents, but little principle.

Dissatisfied with the Spaniards for their treachery, desirous of removing the French, and impressed with the necessity of preparing for the worst, although nothing hostile was then apparent, Dessalines determined on proceeding round the island, to examine every post or station, and observe the effect of the regulations he had established, many of which required to be enforced. Ever vigilant, Dessalines was never known to make a false movement, or to be surprized* on his post, except by treachery, and of this he had now too much experience to suffer any flagrant imposition.

Previous to his departure, however, it became necessary to address the people, to explain his intended journey, conciliate all parties, and render them firm in the support of his government, in proportion to his exertions in their behalf. The proclamation issued on this occasion (April 28) is a specimen of this kind of composition, and is a positive refutation of those who, in opposition to reason and notoriety, describe the inhabitants of Hayti as being in a "savage state." It burns with all the fire of martial oratory, while breathing that bewitching eloquence which entwines and captivates the heart. ${ }^{\dagger}$

On the 8th of May he dispersed throughout the Spanish part of the island

*The writer cannot resist this opportunity of observing, that it were well if this principle of conduct were always equally acted on in regular armies. It is regretted, that some instances have occurred, in which any infliction under death is too mild a punishment. It should be the maxim of every soldier never to be surprized, and of a general never to admit of such a declaration. Though not sanguinary, he views the effects of such cases in so criminal a light, that he could perform the office of executioner himself to an officer suffering such a circumstance.

†See the Appendix. 
a cautionary proclamation, advising them to desist from countenancing the French soldiery, and the vain hopes of opposing him which they manifested; and on the 14th he set out from Cape François, proceeding by the Mole, to Port Paix and Gonaives, where he halted for a little time at his favorite town and head-quarters. From this time, and during the months of June and July, he employed himself in examining the western and southern provinces, repairing the injuries of war, and settling the distractions of their government. "The Aurora of peace" (to use their own expressions) "now began to afford the glimpse of a less stormy time," 381 and the community to wear a natural appearance; notwithstanding the melancholy scenes of retributive devastation which occasionally unfolded themselves.

An event was brought about during his stay, which, while it savours of aggrandizement in the Chief, who had already been elevated to the highest place in the public confidence, served to combine the people more closely, and to present a more dignified character to their enemies. This was his elevation to the Imperial Dignity in a manner, and on terms not inferior to those which have raised other heroes, in times when heroism was the popular care.

Whether the design originated from the similar event which had taken place in France, or had birth in the magnificent ideas which arise in a state bursting from the clouds of adversity into glory, is not determined; that it had an exalted basis is certain, and it was conducted in a manner comportable with the simplicity of the earliest institutions, and the refined elegance of modern courts.

General Dessalines having formally agreed to accept the dignity of Emperor, a meeting of the constituted authorities took place on the 8th of September at Port-au-Prince, to arrange the time and manner in which the will of the people should be executed; when that day was fixed upon for the coronation, and a Programa* issued, of the different forms and ceremonies with which it should be attended.

A procession was formed representing the different functions of the state, depicted so as to shew how they affected its interest, thereby producing a grand and impressive picture, highly descriptive of the manners and principles of the people. In this procession, Education took the lead, as the first and most prominent local good; the Arts next, as little inferior; and Agriculture the third, as partaking of the first class, and at the head of the second; Foreign and National Commerce succeeded; then Justice and Legislation; followed by the Officers of Health; and last of all the Military.

A superb amphitheatre was erected on a martial plain; when Jean Jaques

\footnotetext{
* See the Appendix.
} 
Dessalines was declared Emperor of Hayti, amid the thunder of cannon, which was re-echoed as an acknowledgement by the Marine of other nations, in the harbour. The Church sanctified the event by a solemn Te Deum, and the day concluded by public rejoicings, apparently the most sincere that ever greeted a similar occasion.

CHAP. VI.

On the Establishment of a Black Empire, and the probable Effects of this Colonial Revolution.

$\mathrm{SUCH}$, then, with the close of the year 1804, was the end of this eventful revolution, in which the Imperial dignity was the reward for the courage and experience of the Chief, who, profiting by the misfortunes of his brave and good predecessor, had more successfully combated his enemies, - those enemies who were weak enough to consider it possible, nay, easy to reduce to slavery a powerful body of men who had for some few years enjoyed a state of the most perfect freedom; nor can it be asserted that his title is in any way inferior to that of the extraordinary man whose laurels have been sullied in the attempt to subdue him.

The recurrence to the earliest state of the new world for the name and character of the government, with the advantage of more than three hundred years experience, is an idea which could not originate in mean or untutored minds; nor is such the character of any of the present rulers of Hayti. With respect to the future policy they may chuse to adopt, time alone can determine. Should they adhere to the basis on which they have founded their proceedings, and remain unmolested by European powers, they may arrive at the most enviable state of grandeur and felicity; but should any evil spirits obtain a footing amongst them, and interrupt the harmony which may otherwise be maintained, by occasioning factions to arise from old contentions, or new divisions, the frequent consequence of overgrown wealth or dominion, they will in all probability fulfil the prediction of Edwards, by becoming "savages in the midst of society, without peace, security, agriculture, or property." 382

But, in either case, their reduction to their former situation is impossible; and though Europe waste her armies, and exhaust her navies in the endeavour, the blacks of St. Domingo will be unsubdued; and if they cannot repel the invasion of a reiterated and extended force, they will cut them off, as hath been already observed, with a scythe more keen and rapid than that of time. 
Every year and every day has been, and will still continue, to be pregnant with experience to them, and no power on earth will be able to reduce them, while their population will continue to increase in a vast proportion. The writer has reiterated these sentiments for several years, and through a period in which their confirmation appeared more than doubtful; his opinions were disinterested, and unmingled with any prejudice, either local, political, or pecuniary, and every event has tended to strengthen them.

Should it ever happen in the course of time, that any of the various means dispensed by providence to check the exuberance of population should fall on Hayti, either in the form of contagion, or by a multiplication of the various diseases, to which the African race are subject, in the degeneration of slavery; and that a white population should by that time be formed, capable of taking advantage of such a calamity; then, but not till then, should the neighbouring continent of America be in a state to colonize, or the policy of European governments desire the attainment of the most splendid colony of the Antilles, an opportunity might possibly be afforded. - Whether it would be rational on the score of justice, or humanity to do so, is a subject not to be argued at present. Those who undertake the project, if ever it should be undertaken, will be capable of defending it with plausibility.

But to this part of the subject the public attention is rarely directed; the danger of a community of manumitted slaves in the American Archipelago, is their chief objection to the new Empire of Hayti. With those who form their opinion on erroneous principles, fears of this kind may arise, as the unreflecting clown startles at his shadow on the moonlight sward. Whether Hayti exist or not, as an independent island, if the black population of the other colonies of the Antilles continue to increase as it has done during the last fifty years, and to overbalance that of the whites, no power but that of the exercise of humanity, can preserve them to their present possessors. The practise of this power, happily, is prevalent at present, and it is hoped, and expected, that profiting by the past, it will be always co-equal with the increased wealth of the proprietors, and their capability of being liberal; but if it does not originate with themselves, that the smallest danger can arise to the colonies, from the Empire of Hayti, may be positively denied. The negroes, though sufficiently warlike and vindictive, when roused by revenge, court quiet, and are ardent in all the relations of life, when kindly treated by superiors. They would then with extreme difficulty, if at all, be persuaded to quit a situation of comparative ease, to join strangers in a bloody conflict. Besides, the inhabitants of Hayti could derive no advantage from such a union. They are not to be compared with the Maroons, or the Charaibs, as they possess a territory with an organised government, and sufficient resources of their 
own, all which they must lose in proportion to the success of any project of ambition. Neither have they, nor do they want the maritime power so absolutely necessary for an attack on the other islands; and many other difficulties occur to prevent such a scheme.

Yet, as many events beyond the utmost stretch of foresight happen in the course of time, it is incumbent upon those in particular, whose local interest is concerned, to take due care to prevent the miseries which they appear prematurely to dread; for extra precaution is not so great an evil, as a deficiency of necessary care; to the Proprietors of the British colonies in particular it is recommended, to think an inducement to some degree of devotion among their slaves an object of importance, with a careful diffusion of morality. In the former, the more peculiar mysteries need not be included, nor in the latter that rigid system, which denies even the innocent gaieties of humble life. The personal care, too, of negroes, should be an object of more attention, than it is on certain occasions, with a view to preserve that health which is of so much value to their proprietors, as well as the comfort, necessary to render them satisfied with their condition. These attentions, including the care of pregnant females, added to those humane and salutary laws ${ }^{383}$ which already preclude excessive punishment, or labour, will always produce the most desirable effects, and be more certain than all the inflictions, that coercive measures can devise to prevent a spirit of deliberation (the first revolutionary system) among slaves.

And finally, if, it should appear from the concessions, which are already granted that the slaves in the colonies may be elevated from the consideration of being a species below, even to the lowest class of human society, the complaints which have formerly arisen, will soon have no grounds for existence; and those philanthropic minds which have been led, from the glorious principle of protecting "him that had none to help him," ${ }^{84}$ to countenance an enthusiasm, which has been of the most fatal tendency, will, no doubt, exert their beneficent offices in increasing the good effects, of what may have been already done. But this principle must always be preserved inviolable, (whether it militate or not against the policy of retaining distant colonies will not be argued,) - that no deliberative body should prescribe for the internal polity of a country at a distance, such as precludes an intimate and constant knowledge of its concerns.

The Enquiry into the Rise of the Black Empire of Hayti, thus concludes for the present. It is hoped a remarkable and correct picture will be found of a Revolution, which ranks among the most remarkable and important transactions of the day. It is, at least, untinctured with prejudice of any kind, unless that spirit can be so called, which inclines towards truth and humanity. 


\section{APPENDIX;}

Comprising

DOCUMENTS

Referred to in Different Parts of the Work:

TOGETHER WITH

AUXILIARY REMARKS. 



\section{APPENDIX.}

NO. I.

(Referred to in p. 89. - “The fascinating eloquence of the Abbé Grégoire," \&c.)

Among the other Public Efforts of the Society of Amis de Noirs, was the following Letter of the Abbé Grégoire, Bishop of the Department of Loire and Cher, Deputy of the National Assembly, to the Citizens of Color in the French West Indies, concerning the Decree of the 15th May, 1791, which produced an immediate and striking Effect.

FRIENDS,

You were Men;-you are now Citizens. Reinstated in the fulness of your rights, you will in future participate of the sovereignty of the people. The decree which the National Assembly has just published respecting you, is not a favour; for a favour is a privilege, and a privilege to one class of people is an injury to all the rest.-They are words which no longer disgrace the laws of the French.

In securing to you the exercise of your political rights, we have acquitted ourselves of $a$ debt: - not to have paid it, would have been a crime on our part, and a disgrace to the constitution. The legislators of a free nation certainly could not do less for you than our ancient despots have done.

It is now above a century that Louis XIVth solemnly acknowledged and proclaimed your rights; but of this sacred inheritance you have been defrauded by pride and avarice, which have gradually increased your burthens, and embittered your existence.

The regeneration of the French empire opened your hearts to hope, whose cheering influence has alleviated the weight of your miseries; miseries of which the people of Europe had no idea. While the white planters resident amongst us were loud in their complaints against ministerial tyranny, they took especial care to be silent as to their own. Not a hint was suggested concerning the complaints of the unhappy people of mixed blood; who, notwithstanding, are their own children. It is we, who, at the distance of two thousand leagues from you, have been constrained to protect these children against the neglect, the contempt, the unnatural cruelty of their fathers!

But it is in vain that they have endeavoured to suppress the justice of your claims. Your groans, notwithstanding the extent of the ocean which separates us, have reached the hearts of the European Frenchmen; for they have hearts.

God Almighty comprehends all men in the circle of his mercies. His love makes no distinction between them, but what arises from the different degrees of their virtues. Can laws then, which ought to be an emanation of eternal justice, encourage so culpable a partiality? Can that government, whose duty it is to protect alike all the mem- 
bers of the same great family, be the mother of one branch, and the step-mother only of the others?

No, Gentlemen:-you could not escape the solicitude of the National Assembly. In unfolding to the eyes of the universe the great charter of nature, your titles were traced. An attempt had indeed been made to expunge them; but, happily, they are written in characters as indelible as the sacred image of the Deity, which is graven on your countenances.

Already had the National Assembly, in the instructions which it prepared for the government of the colonies, on the 28th of March, 1790, comprized both the whites and people of color under one common denomination. Your enemies, in asserting the contrary, have published a forgery. It is incontestibly true, that when I demanded you should be expressly named, a great number of members, among whom were several planters, eagerly exclaimed, that you were already comprehended under general words contained in those instructions. M. Barnave himself, upon my repeated instances to him on that head, has at length acknowledged, before the whole Assembly, that this was the fact. It now appears how much reason I had to apprehend that a false construction would be put upon our decree!

New oppressions on the part of your masters, and new miseries on yours, until at length the cup of affliction is filled even to the brim, have but too well justified my apprehensions. The letters which I have received from you upon this head, have forced tears from my eyes. Posterity will learn, with astonishment and indignation, that a cause like yours, the justice of which is so evident, was made the subject of debate for no less than five days successively. Alas! when humanity is obliged to struggle so long against vanity and prejudice, its triumph is dearly obtained!

It is a long time that the society of Amis des Noirs have employed themselves in finding out the means to soften your lot, as well as that of the slaves. It is difficult, perhaps impossible, to do good with entire impunity. The meritorious zeal of this society has drawn upon them much obloquy. Despicable writers have lanced their poisonous shafts at them, and impudent libels have never ceased to repeat objections and calumnies, which have been an hundred times answered and refuted. How often have we been accused of being sold to the English, and of being paid by them for sending you inflammatory writings and arms? You know, my friends, the weakness and wickedness of these charges. We have incessantly recommended to you attachment to your country, resignation, and patience, while waiting the return of justice. Nothing has been able to cool our zeal, or that of your brethren of mixed blood who are at Paris. M. Raimond, ${ }^{385}$ in particular, has devoted himself most heroically to your defence. With what transport would you have seen this distinguished citizen, at the bar of the National Assembly, of which he ought to be a member, laying before it the affecting picture of your miseries, and strenuously claiming your rights! If that Assembly had sacrificed them, it would have tarnished its glory. It was its duty to decree with justice, to explain itself clearly, and cause its laws to be executed with firmness:-it has done so; and if, (which God forbid!) some event, hidden in the womb of futurity, 
should tear our colonies from us, would it not be better to have a loss to deplore, than an injustice to reproach ourselves with?

Citizens! raise once more your humiliated countenances, and to the dignity of men, associate the courage and nobleness of a free people. The 15th of May, the day in which you recovered your rights, ought to be ever memorable to you and to your children. This epoch will periodically awaken in you sentiments of gratitude towards the Supreme Being; and may your accents ascend to the vault of Heaven! At length you have a country. Hereafter you will see nothing above you but the law; while the opportunity of concurring in the framing of it, will assure to you that indefeasible right of all mankind, - the right of obeying yourselves only.

You have a country: and it will no longer be a land of exile, where you meet none but tyrants on the one hand, and companions in misfortune on the other; the former distributing, and the latter receiving, contempt and outrage. The groans of your afflictions were punished as the clamours of rebellion; and, situated between the uplifted poignard and certain death, those unhappy countries were often moistened with your tears, and sometimes stained with your blood.

You have a country: and happiness will shine on the seat of your nativity. You will now enjoy in peace the fruits of the fields which you have cultivated without compulsion. Then will be filled up that interval, which, placing at an immense distance from each other the children of the same father, has suppressed the voice of nature, and broke the bands of fraternity asunder.

Then will the chaste enjoyments of conjugal union take place of those vile sallies of debauchery, by which the majesty of moral sentiment has been insulted. By what strange perversion of reason can it be deemed disgraceful in a white man to marry a black or mulatto woman, when it is not thought dishonourable in him to be connected with her in the most licentious familiarity!

The less real worth a man possesses, the more he seeks to avail himself of the appearances of virtue. What can be more absurd than to make the merit of a person consist in different shades of the skin, or in a complexion more or less sallow? The man who thinks at all must sometimes blush at being a man, when he sees his fellowcreatures blinded by such ridiculous prejudices; but as, unfortunately, pride is one of those failings we most unwillingly part with, the empire of prejudice is the most difficult to subvert: man appears to be unable to arrive at truth, until he has exhausted his strength in travelling through the different paths of error.

This prejudice against the mulattoes and negroes has, however, no existence in our eastern colonies. Nothing can be more affecting than the eulogium made on the people of color by the inhabitants in that part of the world, in the instructions to those they have appointed their deputies to the National Assembly. The members of the Academy of Sciences pride themselves in reckoning a mulatto of the Isle of France ${ }^{386}$ in the number of their correspondents. Among ourselves, a worthy negro is a superior officer of the district of St. Hypolite, in the department of Gard. We do not conceive that a difference of color can be the foundation of different rights among members 
of the same political society: it is, therefore, we find no such despicable pride among our brave National Guards, who offer themselves to embark for the West Indies, to insure the execution of our decrees. Perfectly concurring in the laudable sentiments manifested by the inhabitants of Bourdeaux, they acknowledge with them, that the decree respecting the people of color, framed under the auspices of prudence and wisdom, is an homage rendered to reason and justice. While the deputies from the colonies have endeavoured to calumniate your intentions, and those of the mercantile part of the nation, the conduct of those deputies is perfectly contradictory. Ardently soliciting their own admission among us at Versailles; ${ }^{387}$ swearing with us in the Tennis Court ${ }^{388}$ not to separate from us until the constitution should be established, and then declaring when the decree of the 15 th of May was passed, that they could no longer continue to sit with us! This desertion is a desertion of their principles, and a breach of their solemn oaths.

All those white inhabitants of the colonies who are worthy the name of Frenchmen, have hastened to abjure such ridiculous prejudices, and have promised to regard you in future as brothers and friends. With what delightful sensations do we cite the words of the citizens of Jacmel. "We swear to obey, without reserve, the decrees of the National Assembly respecting our present and future constitution, and even such of them as may substantially change it." The citizens of Port-au-Prince tell the National Assembly the same thing, in different words:- "Condescend, gentlemen," say they, "to receive the oath which the municipality has taken to you, in the name of the commons of Port-au-Prince, punctually to obey and execute all your decrees, and never to swerve from them in any respect whatever."

Thus has philosophy enlarged its horizon in the new world, and soon will absurd prejudices have no other supporters than a few inferior tyrants, who wish to perpetuate in America the reign of that despotism which has been abolished in France.

What would these men have said, if the people of color had endeavoured to deprive the whites of their political advantages? With what energy would they not have exclaimed at such an oppression! Inflamed into madness at finding that your rights have been pointed out to you, their irritated pride may perhaps lead them to make every effort to render our decrees ineffectual. They will probably endeavour to raise such disturbances, as, by wresting the colonies from the mother-country, will enable them to defraud their creditors of their just debts. They have incessantly alarmed us with the threat that St. Domingo will be lost, if justice be rendered to you. In this assertion we have found nothing but falsehood: we please ourselves in the belief, that our decree will draw the bands still closer which unite you to the mother country. Your patriotism, your interest, and your affections, will concur in inducing you to confine your commercial connections to France only; and the reciprocal tributes of industry will establish between her and her colonies a constant interchange of riches and good offices. If you act unfaithfully towards France, you will be the basest and most abandoned of the human race. But no, generous citizens, you will not become traitors to your country; you shudder at the idea. Rallied, with all other good Frenchmen, 
around the standard of liberty, you will still defend our glorious constitution. The day shall arrive when the representatives of the people of color will cross the ocean to take their seats with us. The day shall arrive among you when the sun will shine on none but freemen; when the rays of light shall no longer fall on the fetters of slavery. It is true, the National Assembly has not yet raised the condition of the enslaved negroes to a level with your situation; because suddenly granting the rights to those who are ignorant of the duties of citizens, might, perhaps, have been a fatal present to them: but forget not, that they, like yourselves, are born to freedom and perfect equality. It is in the irresistible course of things that all nations, whose liberty has been invaded, shall recover that precious portion of their indefeasible inheritance!

You are accused of treating your slaves much worse than the whites: but, alas! so various have been the detractions with which you have been aspersed, that it would be weakness in us to credit the charge. If, however, there be any foundation for what has been advanced on this head, so conduct yourselves in future as to prove it will be a shameful calumny hereafter.

Your oppressors have heretofore endeavoured to hide from their slaves the lights of Christianity; because the religion of mildness, equality, and liberty, suits not with such blood-thirsty men. May your conduct be the reverse of theirs. Universal love is the language of the gospel; your pastors will make it heard among you. Open your hearts to receive this divine system of morality. We have mitigated your misfortunes; alleviate, on your part, those of the unhappy victims of avarice, who moisten your fields with their sweat, and often with their tears. Let the existence of your slaves be no longer their torment; but by your kind treatment of them expiate the crimes of Europe!

By leading them on progressively to liberty, you will fulfil a duty; you will prepare for yourselves the most comfortable reflections; you will do honor to humanity, and ensure the prosperity of the colonies. Such will be your conduct towards your brethren, the negroes; but what ought it to be towards your fathers, the whites? Doubtless you will be permitted to shed tears over the ashes of Ferrand de Baudiere, ${ }^{389}$ and the unfortunate Ogé, assassinated under the forms of law, and dying on the wheel for having wished to be free! But may he among you perish, who shall dare to entertain an idea of revenge against your persecutors! They are already delivered over to the stings of their own consciences, and covered with eternal infamy. The abhorrence in which they are held by the present race of mankind, only precedes the execration of posterity. Bury, then, in eternal oblivion every sentiment of hatred, and taste the delicious pleasure of conferring benefits on your oppressors. Repress even too marked expressions of your joy, which, in causing them to reflect on their own injustice towards you, will make their remorse still more poignant.

Strictly obedient to the laws, teach your children to respect them. By a careful education, instruct them in all the duties of morality; so shall you prepare for the succeeding generation virtuous citizens, honorable men, enlightened patriots, and defenders of their country! 
How will their hearts be affected when, conducting them to your shores, you direct their looks towards France, telling them, "beyond those seas is your parent country; it is from thence we have received justice, protection, happiness, and liberty. There dwell our fellow citizens, our brethren, and our friends; to whom we have sworn an eternal friendship. Heirs of our sentiments and of our affections, may your hearts and your lips repeat our oaths! Live to love them; and, if necessary, die to defend them!"

(Signed) Gregoire.

Paris, 8th June, $1791 .^{390}$

NO. II.

(Referred to, and its Substance explained, pp. 79-8o.)

Principles of the First General Assembly of St. Domingo

A principle from which all the works of the Colony's Assembly stem was generally adopted by all its members, which is that the colonies must be of interest to the metropole, only in proportion to the advantages they bring her. In the minds of all colonists, this consideration gave a character of legality to all means used to ensure the prosperity of the colony, and to increase its relations with the motherland.

One would wish - now more than ever - that a same law may be fit for all climates, all manners of customs, all populations; but sadly men are not the same everywhere; such a law that fits one place would be harmful in another.

The General Assembly therefore designed the constitution of St. Domingo along three angles oriented according to the colony's interest in remaining connected to the metropole, and according to the empire's revolution.

1. As being an integral part of the French empire.

2. As obligated to participate by its products in the prosperity of the state.

3. As subjected to particular needs different from those of the metropole by the dissemblance of its climate, its customs and its population.

DIVISION OF THE CONSTITUTION OF ST. DOMINGO

These various reports divide the constitution adequate for St. Domingo,

Into general laws;

Into common laws;

And into exceptional laws.

\section{General Laws}

The general laws of the empire, those that concern all of the French, whichever corner of the Earth they happen to be in, were judged compulsory for the colonies without any discussion or restriction.

These laws regard; the form of government, the fate of the crown, the recognition of our monarch, declarations of war, peace treaties, the general organization of the police, of justice, \&c. \&c. The interest of the colonies being in this regard the same as 
that of the entire nation, the National Assembly alone has the right to decree these laws.

\section{Common Laws}

Common laws are those concerned with the relation of the metropole with the colonies; they form a contract by which France vows to protect and defend the colonies against foreign powers, were they to become the object of the latter's ambition. This protection cannot and should not be free, and therefore the colonies must compensate the state for it by the advantages of commerce. Thence the prohibitive regime, in whose irons fate has condemned them to always remain; and no matter the degree of freedom the nation may enjoy, the colonies will always be slaves to commerce. This political position being absolutely inherent to their physical position, they do not let out a murmur against it; they know full well that their being French does not give them any claim over the state's monies; they therefore consent to receive from France alone all the commodities that its manufactures and its soil can provide; they submit to the obligation of sating their desires in France only. What they ask, that cannot be refused to them, is that by respecting these fundamental conventions, the abuses brought by the prohibitive system may be destroyed.

\section{Exceptional Laws of the Interior Regime}

Exceptional laws only concern the colonies. Great motives pushed the colony of St. Domingo to reserve the right to their formation: 1. It is recognized that the laws of St. Domingo cannot be designed but in the island's heart: this fundamental truth escaped its most cruel enemy. M. La Luzerne, ${ }^{391}$ in the memoir he presented to the National Assembly on October 27, 1789 (No. 2), said that it has never been possible to manage the colonies with the same laws as the kingdom, and that it has always been necessary to confer to two administrators the power to make local laws, because there is an infinity of infinities of conventions that can only be known on location.

Therefore, what the General Assembly has reserved for itself is the portion of the legislative power that rested, against the right of men, in the hands of two satraps, who were only interested in the colony for the wealth they can draw from it during their terms.

2. It is against constitutional principles, that whomever makes the law should not be subject to it.

All men have the right to participate in the making of the law they are subjected to; but no man can participate in the making of the law that does not subject him.

This principle, the only demand of individual freedom, the only guarantee of the benevolence of the law, did not allow the settlers of St. Domingo to doubt that the National Assembly, dispenser of regenerating benefits, would approve this proposition that insures property in St. Domingo.

Indeed, local laws in faraway sections of the Empire, cannot be the same as laws that only concern France.

A law decreed for the entire kingdom is the same in all counties. All of the National 
Assembly representatives have an interest in scrupulously examining all its reports, and in considering all its advantages and inconveniences. So that the interest that all have in making the law, - of whose vice they would themselves be victims - be but the result of a long meditation and of reflections long and carefully discussed, and may guarantee its wisdom.

As St. Domingo's exceptional laws only subject people residing or holding wealth there, they are of interest only to the twelve representatives of the colonies in the National Assembly.

3. One of the conditions essential to the goodness of the law, is that the one who makes it should know perfectly the relations it must have with the constitution. No one can know local particularities but who lives in the locality, because these very particularities change and vary; and the law must be designed according to these variations.

4. It is a constant that the ties that bind a society are the three powers established to enforce its conditions.

The fortune of any constitution depends absolutely on legal action in these different powers: this equality alone maintains its balance. Executive power must necessarily exist in St. Domingo; for the misfortune of societies demands that in politics reason can never go without force. If this power is balanced by no other, it will end up invading everything, and substituting oppression to the benefits of regeneration to which, thanks to the current revolution, all Frenchmen can pretend. It can therefore only be kept within these bounds by a proportionate mass of legislative power, whose vigilance it may fear.

5. The principles of the National Assembly oppose its decreeing the exceptional constitution of St. Domingo. The constitution of France is based on freedom and equality; that of St. Domingo unfortunately rests on servitude and a class distinction from which the conservation of this superb colony depends. All possible reasonings failed against this truth.

These different observations, well analyzed in the General Assembly, reassured it against the fear it had of not finding itself in agreement with the principles of the National Assembly, and to give calumny a pretext to indict its intentions.

The different members of the General Assembly were far from predicting that the happy revolution that brought joy and enthusiasm to the hearts of all Frenchmen would bring death and desolation to St. Domingo. What does it matter to France what our local regime is, as long as it tends to the good of the colony? As long as we are subjected to the general laws of the Empire? As long as we respect commercial agreements? As long as we regard the obligation to only trade with France as a just indemnity for the protection and help it grants us? As long as we enforce the decrees of the National Assembly, in all that is not contrary to the localities.

It matters to France that we be happy, that we consume the commodities and merchandise that it may provide us with, or that we send her in exchange much sugar, coffee, indigo, cotton, cocoa, \&c. \&c. Finally, it matters to her that the constitution 
of St. Domingo be such that it unite forever this colony to the metropole, and that it participates with its resources to the prosperity of the state.

From these simple and true reflections the General Assembly of St. Domingo set its constitutional foundations in its decree of May 28 (No. 3).

NO. III.

(Referred to in pp. 102-3, where also the Substance is translated.)

Dying Testimony of Ogé against the Insurgents

Excerpt from the minutes of the High Council of Cape François, March Ninth of the year 1791. We, Antoine Etienne Ruotte, Councillor of the King, dean of the High Council of Cape François, and Maria François Pourcheresse de Vertieres, also Councillor of the King at the High Council of Cape François, commissaries named by the court in order to enforce the decision of said court taken on the 5 th of this month, bearing the death sentence against Jacques Ogé, also known as Jacquot, free quarteroon; whom, being in the criminal court, and following the reading of the said decision concerning him, said and declared, to unburden his conscience, after having sworn an oath, hand raised before us, to speak the truth.

That at the beginning of this past February, if the rivers had not overflown there should have been a gathering of gens de couleur, who were to raise with them the workshops, and were to fall upon the city of Cape François in considerable numbers; that there were already eleven thousand men gathered; that the overflowing of the rivers was the only obstacle that prevented them from gathering; this troop of gens de couleur was made up of those from Mirebalais, those from Artibonite, from Limbé, Ouanaminthe, Grande Rivière, and generally from the entire colony. That at this time, a hundred gens de couleur had gone out of Cape François to unite with this band. That the accused is assured that the authors of this revolt are the Declains, free Negroes from Grande Rivière, accused in the trial; Dumas, $\mathrm{f}($ ree $) \mathrm{n}$ (egro); Yvon, f.n.; Bitozin, f.n.; Espagnol; Pierre Gedard and Jean Baptiste, his brother, f.n. from Grande Rivière; Legrand Mazeau and Toussaint Mazeau, f.n.; Charles Lamadieu, the Sabourins, Jean Pierre Goudy, Joseph Lucas, free mulattoes; Maurice, f.n.; all accused in the trial.

That the great movers, at the bottom of the coast, are the Daguins, accused at the trial; Rebel, living in Mirebalais; Pinchinat, accused in the trial; and that the accused here present believes he has to declare to be one of the most ardent supporters of the revolt, who directed in great part the revolt that burst in the area of St. Marc, and who is trying to incite a new one; that there are in this moment several gens de couleur in different districts, resolved to achieve their projects, despite the fact that those who will participate in the revolt will lose their lives; that the accused, here present, cannot remember all their names; but that he remembers that the son of Laplace, $f(r e e)$ q(uarteroon), whose sister he, the accused, saw in jail, left Limbé to get recruits and that these uprisings of gens de couleur are supported here by the presence of Fleury and l'Hirondelle Viard, in the district of Grande Rivière. 
That the accused, here present, declares that the insurrection of the revolted takes place in the underground ways between Crête à Marcant and Giromon county, Grande Rivière parish; that in consequence, if he, the accused, could be led to these locations, he could take the leaders of the revolted; that the agitation in which he finds himself, relative his actual position, will not let him to give us more circumstantiated details; that he will do so later, when he is calmer; that now comes to his mind that Castaing, free mulatto of this dependency, is in no way involved in the current affair; but that he, the accused, assures us that if his brother Ogé had followed the impulse of the aforementioned Castaing, he would have proceeded to great extremes; that this is all he could tell us in this moment, which we notified, and he signed with us and the clerk.

Signed in the minutes, J. OGE, RUOTTE, POURCHERESSE DE VERTIERES, et LANDAIS, clerk.

Excerpt from the minutes of the High Council of Cape François's clerk, in the year 1791, March 10, 3 hours of recording, in the criminal chamber, we, Antoine Etienne Ruotte, Councillor of the King, dean of the High Council of Cape François, and Maria François Joseph de Vertieres, also Councillor of the King in the said High Council of Cape François, commissaries named by the court, following the decision of this day, delivered after the conclusions of the king's general attorney in the said court, in order to check on the declaration made by Jacques Ogé, $\mathrm{f}($ ree ) q(uarteroon); who, after swearing an oath, hand raised before us, to speak the truth, and after the clerk read him yesterday's declaration, was asked by us to declare whether the said declaration contained truth, and if he wanted to add or subtract anything to it, and whether he persisted.

He answered that said declaration from yesterday contains truth, that he persists, and that he adds that the two Didier brothers, of whom one is taller than the other, mulattoes or free quarteroons, having only seen them this once; and Jean Pierre Gerard, $\mathrm{f}($ ree $) \mathrm{m}$ (ulatto) from Cape François, and Caton, also from Cape François, are employed in reaching the workshops of Grande Rivière, and are together during the day, and dispersed at night.

Added that during his confrontation with Jacques Lucas it was said by the latter, that he the accused, here present, had threatened to have him hanged; to which he the accused answered to said Jacques Lucas, that he must know why said Jacques Lucas had not insisted, he the accused did not declare the motive for this threat, in order not to lose said Jacques Lucas; that he declares things as they happened; that said Lucas having told him that he had raised the workshops of Mr Bonancy and of other inhabitants of Grande Rivière, in order to go cut the throats of the army at Mr. Cardineau's; that at the first blow of the horn, he was certain that these workshops would gather and join the troops of gens de couleur; then he, the accused, being fond of whites, was upset at such barbarity, and told said Jacques Lucas, that the author of such a project deserved to be hanged; that he instantly had to send home the negroes he had positioned in different corners with horns; that he, the accused, here present, declares that he gave the said Lucas three bottles of rum, three bottles 
of wine and bread; that he ignored to what use the said Lucas put them; that the third time the said Lucas came to get some, he, the accused, here present, asked him what he was doing with these beverages and food; the said Lucas replied that it was for the negroes he had dispersed here and there; which proves that the said Lucas had the project of raising the slave negroes against the whites, and to have the latter's throats cut by the former; this is the proposition he made to Vincent Ogé, brother of he, the accused, to come to the habitation of Jacques Lucas, so as to be able to join the negroes he had debauched; that if he, the accused, did not reveal these facts during his confrontation with Lucas, it is because he did not want to lose him; that he at least has the satisfaction of having thwarted this horrible cannibal crime; that he had reserved the right to reveal in a court of justice during his hearing; that the same Lucas is the one who wanted to cut the heads of two white prisoners, notably Sire Belisle, for having taken a woman away from him; that Pierre Roubert took the saber out of Jacques Lucas's hands, and called Vincent Ogé, brother of the accused, here present, who remonstrated the said Lucas; that however these prisoners declared in court that this had been the accused's design; that even during the confrontation they had asserted this; but that this having happened at night, the said prisoners have taken him, the accused, for the said Lucas, while he the accused never ceased to supply them with honesty; that during the confrontation, he the accused thought it sufficient to say it was not him, and to assert that he had never known this woman; but that today he felt forced to unburden his conscience, to give us the facts as they are, and to insist to swear that he had never known her.

The accused adds that Fleury and Perisse, the former one of the representatives for gens de couleur at the National Assembly, arrived in this colony on a Bordeaux ship with the man named l'Hirondelle Viard; that the captain left the first two in Aquin, at Dupont's, a man of color; and l'Hirondelle Viard, also representative for gens de couleur, at Cape François. The accused adds further that he had declared to us yesterday that Laplace, whose father is here in prison, who was recruiting in Ouanaminthe, is amongst those who marched from Limbé against Cape François; that in order to dispel suspicions, he went to Port Margot, where he hid for a few days, pretending to have the flux; that the said Laplace Sr. said to him, a white man, that he would not testify against him though he knew all of his plans; that he was assured that Girardieu, held in prison, would say nothing, because he was too much his friend to reveal him; and that if he would betray him, he would be forced to betray many others, from Limbé and other neighborhoods.

The accused observed that when he told us about the means employed by Jacques Lucas to raise negro slaves, he omitted to tell us that Pierre Maury had sent about thirty slaves to Lucas's; that the accused, with the agreement of Ogé the younger, his brother, sent them back, which occasioned general complaints, gens de couleur saying they were reinforcements; that he the accused had on the same occasion a fight with the taller Didier, with whom he almost had a pistol fight for insisting that, being free and seeking to be assimilated by whites, he wasn't made to be assimilated to negro slaves; and that anyway raising slaves was destroying the property of whites, and 
that by destroying it, they were destroying their own; that since he and the accused have been in prison, he has seen a small note written by said Pierre Maury to JeanFrançois Tessier, by which he signified that he was still gathering people, and that the negro named Coquin, belonging to the widow Castaing the elder, armed with a pair of silver-plated pistols and a short sword given to him by Maury watches everything that is going on, and reports every night to the said Maury; that is all that the accused, here present, declares to us, begging us to be persuaded that, if he were able to obtain mercy, he would willingly expose himself to danger in order to stop the leaders of these revolts; and that in all circumstances, he will prove his zeal and his respect for whites.

This declaration, which he claims contains the truth, was read to him; we notified it, and he signed with us and the clerk.

Signed in the minutes, J. oge, RUotte, Pourcheresse De Vertieres, et LANDAIs, clerk.

For collated expedition, signed LANDAIs, clerk.

NO. IV.

(Referring to pp. 97-98.)

Terms of Capitulation proposed by the Inhabitants of La Grand Anse (including the Quarter at Jeremie) represented by Mons. de Charmilly, possessed of full Powers by a Commission from the Council of Public Safety of the aforesaid Place, dated the 18th of August, 1793, and presented to His Excellency Major-General Williamson, His Majesty's Lieutenant-Governor of Jamaica, for his Acceptance.

Art. I. That the proprietors of St. Domingo, deprived of all recourse to their lawful sovereign, to deliver them from the tyranny under which they now groan, implore the protection of his Britannic Majesty, and take the oath of fidelity and allegiance to him, and supplicate him to take their colony under his protection, and treat them as good and faithful subjects till a general peace, at which period they shall be finally subjected to the terms then agreed upon between his Britannic Majesty, the Government of France, and the Allied Powers, with respect to the sovereignty of St. Domingo. Answer. Granted.

Art. II. That till order and tranquillity are restored at St. Domingo, the Governor appointed by his Britannic Majesty shall have full power to regulate and direct whatever measures of safety and police he shall judge proper. - Answer. Granted.

Art. III. That no one shall be molested on account of any anterior disturbances, except those who are legally accused in some court of justice, of having committed murder, or of having destroyed property by fire, or of having instigated others to commit those crimes. - Answer. Granted.

Art. IV. That the Mulattoes shall have all the privileges enjoyed by that class of people in the British islands. - Answer. Granted. 
Art. V. That if, at the conclusion of the war, the colony remains under the sovereignty of his Britannic Majesty, and order be established therein; in such case, the laws respecting property, and all civil rights, which were in force in the said colony before the revolution in France, shall be preserved; nevertheless, until a colonial assembly can be formed, his Britannic Majesty shall have the right of determining provisionally upon any measures which the general good and the tranquillity of the colony may require; but that no assembly shall be called, until order is established in every part of the colony; and, till that period, his Britannic Majesty's governor shall be assisted in all the details of administration and police by a committee of six persons, which he shall have the power of choosing from among the proprietors of the three provinces of which the colony consists. - Answer. Granted.

Art. VI. That, in consequence of the devastations which have taken place in the colony by insurrections, fire, and pillage, the governor appointed by his majesty, on taking possession of the colony, to satisfy the demand of the inhabitants in these respects, shall be authorised to grant, for the payment of debts, a suspension of ten years, which shall be computed from the date of the surrender; and the suspension of all interest upon the same shall begin from the period of the 1st of August, 1791, and terminate at the expiration of the ten years granted for the payment of debts; but all sums due to minors by their guardians, or to absent planters by those who have the management of their property, or from one planter to another for the transfer of property, are not to be included in the above suspension. - Answer. Granted.

Art. VII. That the duties of importation and exportation upon all European commodities shall be the same as in the English colonies. - Answer. Granted. In consequence, the tariff shall be made public and affixed, that every one may be acquainted therewith.

Art. VIII. That the manufactures of white sugars shall preserve the right of exporting their clayed sugars, subject to such regulations as it may be necessary to make with respect to them. - Answer. Granted. In consequence, the duties upon white sugars shall be the same as were taken in the colony of St. Domingo, in 1789 .

Art. IX. That the catholic religion shall be preserved and maintained, but that no other mode of evangelic worship shall be excluded. - Answer. Granted. On condition that such priests as have taken the oath prescribed by the persons exercising the powers of Government in France, shall be sent away, and replaced by others.

Art. X. The local taxes to acquit the expences of garrisons, and of the administration of the colony, shall be assessed in the same manner as in 1789, except the alleviations and remittances which shall be granted to the inhabitants whose property has suffered by fire, till their possessions are repaired. An account shall be kept by the colony of all the sums advanced on the part of Great Britain, for supplying the deficiency of the said taxes; which deficiency, as well as all the public expences of the colony (except those of his majesty's naval forces, destined for its protection) shall always be defrayed by the said colony. - Answer. Granted.

Art. XI. His Britannic Majesty's Governor of St. Domingo, shall apply to the Span- 
ish government, to obtain restitution of the negroes and cattle sold by the Spanish territory by the revolted slaves. - Answer. Granted.

Art. XII. The importation in American bottoms, of provision, cattle, grain, and wood, of every kind, from the United States of America, shall be allowed at St. Domingo. - Answer. Granted. On condition that the American ships, which shall be employed in this trade, shall have only one deck; and this importation shall be allowed only as long as it shall appear necessary for the re-establishment or subsistence of the colony, or until measures have been taken for putting it in this respect upon the same footing as other English colonies; and an exact account shall be kept of the said vessels, with the description of their cargoes, and shall be transmitted every three months to the Right Honourable the Lords Commissioners of his Majesty's treasury, as well as to one of the principal Secretaries of State; and on no account whatever shall any of the said vessels be allowed to take in return any production of the colony, except molasses or rum.

Art. XIII. No part of the aforesaid conditions shall be considered as a restriction to the power of the parliament of Great Britain, to regulate and determine the political government of the colony. -Answer. Granted.

NO. V.

(Referred to in p. 117.)

Copy of the Letter of Mr. the Chevalier of Sevré, Commander of Colonial Troops in Tiburon, to Colonel Whitlock, Commander in Chief of His Britannic Majesty's Troops in St. Domingo.

\section{“Governor,}

"The ship Le Capitaine Robert, arrived this morning in our harbor (and meaning to leave tonight), gives me a certain and prompt opportunity to inform you of the details of the attack carried by the brigands against our positions yesterday, two hours before dawn.

"At half past three, my advanced post in la Vigie was surprized by an army of at least 2,ooo brigands, bringing with them two 4 pound field artillery pieces; they surrounded at the same time the fort and the town. I had difficulties retreating with my garrison to the fort, where I sustained fire for a long time before being able to return fire. Everything was in the brigands' favor; they could see the fort, were overlooking it from all sides, and since it was still dark we could not see them. The battle had been going for about two hours when two barrels of powder caught on fire in the big battery, destroying it completely and taking with it the cannons outside the fort. This unfortunate event killed or wounded twenty of my men and discouraged the garrison for a time. It then got over it and violently fired at the enemy: I then ordered a few of Jean Kina's negroes to make a sortie on the path to the river; they beat the brigands, and forced them to retreat to the heights.

"I then made a sortie with about two hundred men, negroes and whites; I walked on the town side, dividing my troops in two columns, giving Mr. Philibert command 
of one and I heading the other; I climbed in order to encircle them from behind and try to take their pieces, but the first column having been unable to climb on time, the brigands managed to take their cannons with them.

"I could only pursue the enemy in fleet up to the Gensac plantation, my men were so weary of fighting for five hours without respite.

"I had about a hundred battle casualties, thirty of them killed on the spot, and a hundred wounded, among which many died; I estimate they have about five hundred men out of commission: a hundred and fifty were found dead on the battlefield; and the paths by which they retreated are so covered with blood, that they must have a considerable amount of wounded.

"The English troops behaved with the courage that characterize them everywhere: Captain Hardiman is worthy of the highest praise; I despair that you may take him from me, his talents and virtues make him difficult to replace.

"Immediately after combat, I wrote all the commanders in the areas of the dependency to send me help; I am waiting for them at every instant, but I am well reinforced by the presence of the frigate Alligator that arrived this morning.

"I am respectfully, \&c.

(Signed) “Chevalier de Sevré

"Tiburon, 7 April, 1794." 392

NO. VI.

(Referring to p. 123, \&c.)

— "the indefatigable De Charmilly."

THE distinguished part this gentleman acted during the troubles in his adopted country, and the familiarity of his name to every description of persons concerned in the arrangement between Great Britain and St. Domingo, render some account of him, if not absolutely necessary, at least highly interesting to the reader. We have the power more readily to gratify this inclination, as $\mathrm{M}$. de Charmilly has himself afforded the principal materials for the purpose, which we have translated from the work before quoted, entitled, "Lettre à M. Edwards" \&c.

"After," says he, "concluding my attendance at the University of Paris, and travelling through a considerable part of Europe, I arrived at St. Domingo in the beginning of the American war. A few months residence in the colony made me acquainted with its importance. Born with an activity hardly to be surpassed, and favoured with a strong constitution, I became desirous to make myself acquainted with the affairs of the island. During a residence at different times of fourteen years, in the full sense of the word I travelled over the whole colony, having been engaged in some important suits, administered to several large estates, and having business of great consequence in every part of the island, which made me acquainted with the principal planters in its various districts. If you join to that the ambition of becoming one of the richest of its inhabitants, you may judge if I was not, more than any other person, in the pos- 
session of opportunities of information respecting the resources of its different provinces, and the advantages of its different manufactures; besides, my knowing personally almost all the officers of its administration, both military and civil; with the generous hospitality of the Creoles, and my independence of every tye. From all these reasons it may be concluded, that scarcely any inhabitant of the colony had a greater opportunity of knowing its affairs than myself.

"Returning to France at the end of the last war, I was grieved to see the baneful effects of those poisonous principles which the French had imbibed in America. I also saw, with deep concern, the establishment of that philanthropic sect, created first in Philadelphia, and afterwards transplanted to Europe. ${ }^{393}$ I then visited England, where I remained a few months; from thence I went to Jamaica, where I also resided some time.

"Since my return to St. Domingo, having re-established several plantations on my own account, I was under the necessity of acquainting myself with every thing that related to the commercial resources of the colony. I also had, in conjunction with Mr. de Marbois, the arrangement of the affairs of one of the most wealthy contractors of St. Domingo. A long residence at Port-au-Prince and the Cape, enabled me also to judge of every material occurrence that passed in the two principal cities.

"On returning to my plantation, at the moment of the revolution, it will not appear surprising that I was nominated a member of the assembly of my parish, afterwards of that of the province where I resided, and, finally, deputy of the general colonial assembly.

"From the publication of the Rights of Man, I foresaw, with the most rational and well-informed inhabitants, the misfortunes that awaited the colony.

"Residing in the south part of the island, which was in a great measure indebted to the English, and particularly the merchants of Jamaica, for its establishment; and being, also, from frequent visits, perfectly acquainted with England, I happily turned my views towards its government, to ensure the safety of St. Domingo. This sentiment never abandoned me an instant from the first moment of the troubles; I constantly manifested it in my parish, in my province, and in the general assembly at St. Marc, where all my thoughts and actions were continually directed to the means of assuring its success.

"The torrent of revolutionary ideas had too much agitated every head, not to force the wisest people to conform to circumstances; and I freely own, that I was one of those who affected to believe in the possibility of an absurd independence; preferring it, for the interests of the island, to the still more absurd idea, of a sugar colony existing with the pretended rights of man. Unfortunately, persons of the greatest influence in St. Domingo, dazzled by the remembrance of the great commercial advantages derived, during the American war, from their increasing trade with neutral nations, hoped, and pretended that it might exist independent, under the general protection of the European powers. My opinion was always, that such an independence could not take place, and that it was necessary for the colony to be under the protection of 
a mother country; and that it would be well if they were under that of a great nation like England. The diversity of opinions frustrated all my plans, and (mine being well known) obliged me to embark, with many of the resident proprietors, on board the Leopard. This was, with the view of flying from two parties; one of whom saw in us opponents to their ambition, and the other, the enemies of that anarchy which they thought of establishing in this delightful climate. Arrived in Europe, I soon discovered that France was lost; but still more, surely, was St. Domingo, if a power, interested to save her own colonies did not afford her relief.

"The melancholy intelligence of the disasters of St. Domingo, were first brought to Europe by the Daphne, an English frigate. I was the first, and only inhabitant, who came to England to confirm that news, of which I found a proof in two hundred letters, delivered to me by Captain Gardner, the commander of the vessel.

"In the year 1790, I had the honour of an interview with the ministers of his Britannic Majesty, and proposed to them the means of retaining their colonies, by saving St. Domingo. The facts which I communicated then, and have often since repeated, are recorded in the memorial which I submitted to government on the occasion. The revolutionary spirit, which had turned the heads of the French people, furnished the most just and wisest reasons for the British ministry to refuse an offer which had been expressed too late, was become by the effervescence of the colony, and the diminution of its revenues and produce, of too little importance to expose them to the event of a war with the French.

"I returned to Paris, but very soon (in 1792) the miseries of France and the king compelled me to seek an asylum in England. From that time I foresaw the certainty of a war; continually occupied for the welfare of my countrymen, and of the first colony in the world, I renewed my solicitations to the British government. In concert with other inhabitants, I never ceased labouring to prove to the ministers of Great Britain, that, if they saved not St. Domingo, the most considerable colony of the Antilles, they would not save any of their own.

"The French declared war against England in February, 1793. Then, the case of those who had exerted themselves to preserve the English and French colonies were heard; others had evinced as much zeal as myself, and I had no advantage over them but that of a better knowledge of the colony of St. Domingo, and being enabled to say- "Behold what must be done: I will accomplish it, or perish!"

"It is for the British ministers to judge, if I was so happy as to fulfil my promises; they were pleased to assure me so, and his Majesty himself deigned to testify to me, his approbation of the zeal and devotion, with which I had placed myself in his service."

The unfortunate end of this gentleman's services has been already sufficiently pourtrayed. After wasting that strength of which he formerly so much boasted, and covering himself with fruitless wounds, he had the mortification to see his great project fail, and to shelter himself under the position, that it had not failed in toto, since it had diverted the revolutionary principle from Jamaica. He had also the humiliation 
with a number of his contemporaries, to see all his arguments in favor of subjugating the blacks, refuted, and to be obliged to pass the decline of an active life, in a species of dull and solitary exile, under the protection of the English government.

Notwithstanding his misconceptions $\mathrm{M}$. de Charmilly has offered some sensible advice with regard to the island with which he was so well acquainted, and, it may be said, merited a more dignified fate. It was his ambition to be the legislator, and to become the saviour of his country; and it were to be wished that he had exerted himself in a cause in which, though unsuccessful, he might have enjoyed the merit of

\section{_ "Bravely falling with a falling state!" ${ }^{394}$}

But, alas! no such honors awaited him, he was doomed, even in obscurity, to be followed by the suspicious censures of his countrymen, for whom he was so proud to act, while he could expect no other sentiment than contempt from those against whom he vainly ventured his life.

NO. VII.

(Referring to p. 163.)

Documents illustrative of the Character and Manners of Toussaint L'Ouverture.

IT is always pleasing to trace the interchanges of civility in war between two great and benevolent minds; the following letter has been selected as a specimen of Toussaint's familiar intercourse from a variety of other papers of a similar description.

\section{LiBERTy. EQUALITY.}

At Cape François, the 5th January, 7th Year of the French

Republic, one and indivisible.

Toussaint L'Ouverture, General in Chief of the Army of St. Domingo, to Edward Tyrrel

Smith, Esq. ${ }^{*}$ Captain of his Britannic Majesty's Ship Hannibal.

SIR,

Lieutenant STOvin ${ }^{395}$ has performed the commission with which you charged him. As I was at the Cape when he arrived, he was conducted to me, and has brought me your letters of the $3 \mathrm{~d}$ and 5 th January, although addressed to the commandant of this place. I perceive that you have on board sixty-four French prisoners, which you propose to me to exchange, and which I would not have hesitated to do instantly if I had had the same number of prisoners here.

As my principles of humanity correspond perfectly with those you manifest, I shall be obliged to you to release the French prisoners. I shall send you eight English prisoners, the whole that are here, with the exception of one, who, having had his thigh broken, remains at the hospital for it to be set. I will give you letters for Port Paix and

\footnotetext{
*Now Admiral Smith.
} 
the Mole, and I shall give the necessary orders that you may be furnished with the prisoners that will be coming to you; if it should happen that they do not complete the number, I promise you on my word of honor, that they shall be at your disposal whenever the fortune of war shall place them at my command.

In case that you should not be satisfied with the letters I give you for the Mole and Port Paix, you then can carry the French prisoners you have made to those places where they may be exchanged. I wait your answer to govern me.

Although the porter, the rum, and the ham which you have had the civility to address to the Chief of this City, ${ }^{396}$ were not particularly addressed to me, I cannot omit to return you my thanks. I wish there may be any thing here agreeable to you, and you shall receive it. I have given your servant permission to make any provision for which you may have occasion.

I have the honor to be, Sir,

Your most humble and

Obedient Servant,

Toussaint L'Ouverture.

Brief Extract from the MS. Journal of Charles Reilly, Esq.

Port Royal, Jamaica.

ON the 16th of November, 1798, being ready for sea, Col. Harcourt and Capt. Reynolds came on board, and we set sail for Port-au-Prince, in St. Domingo.

On the 24 th, being in the Bight of Leogane, saw a strange sail. In the evening came up with her: she proved to be an American bark from Port-au-Prince, bound to Philadelphia, with French passengers and property, which was sent into Port Royal.

On the 25th November came to anchor without gun-shot of the fort at Port-auPrince, and sent in a flag of truce to prepare for a treaty with the Black General, Toussaint, then commanding the chief part of the island; but the boat returned with information that he was not there. We then got under weigh, and stood off towards Leogane. In the night we manned and armed the boats, and sent them along shore. In the morning they returned with a small copper-bottomed schooner, laden with coffee, and bound to St. Jago, in Cuba. They likewise took four open boats, one of which we sold for four hundred dollars back to a Frenchman, and in the others we sent the prisoners on shore.

On the 26th came to anchor off Leogane; sent a flag of truce, and was informed the general was at Aux Cayes. Got under weigh, and at noon came to an anchor there, out of gun-shot of the fort. Sent a boat on shore, and learned that Toussaint was at Gonaives. An officer, however, came on board in a flag of truce, and told the captain we might send our boat ashore, and purchase what stock we wanted. Of this kindness we availed ourselves, from the extreme cheapness at which we were supplied.

On the 27th we got under weigh, and on the 28th chased two strange sail. By noon we brought one of them to, which proved to be a government sloop from Cape François, bound to Port-au-Prince, laden with wines and provisions of all kinds. The 
Liberté.

Egalité.

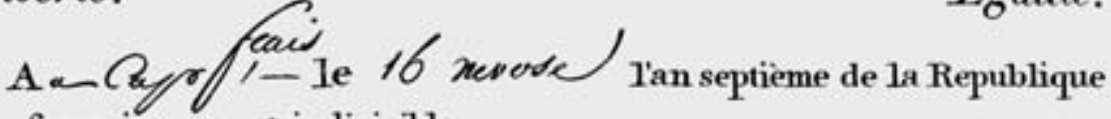
française, une et indivisible.

\section{TOUSSAINT LOUVERTURE,}

Général en chef de 1'Armée de Saint-Domingue, A Nousieur Cesvard bys

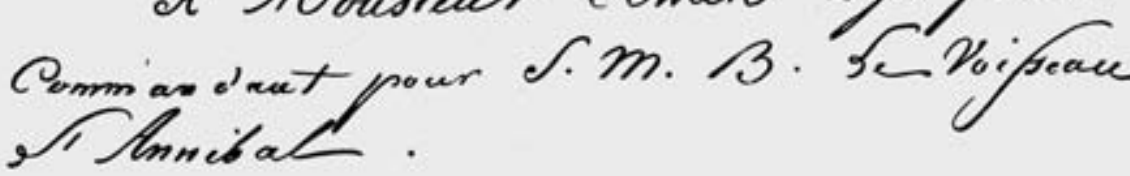
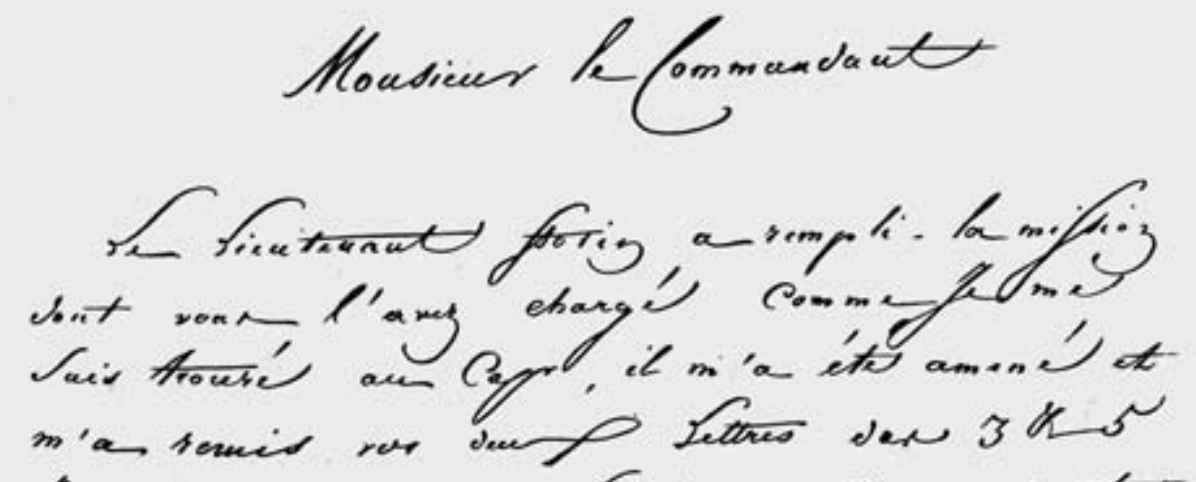

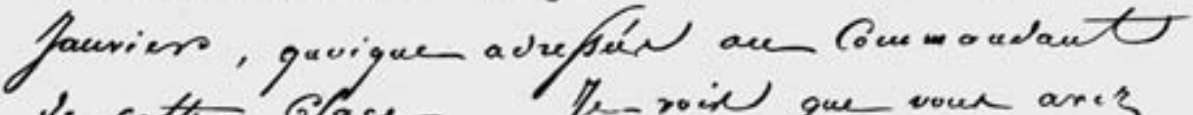

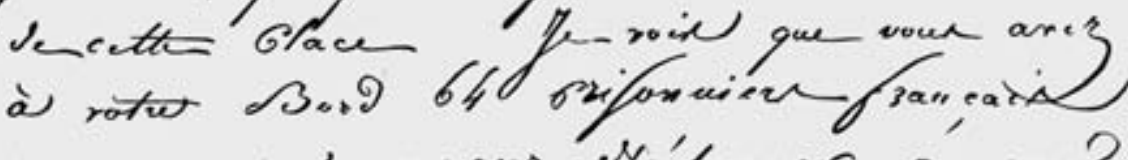
que roun un proporyz, Néchanger, re quel

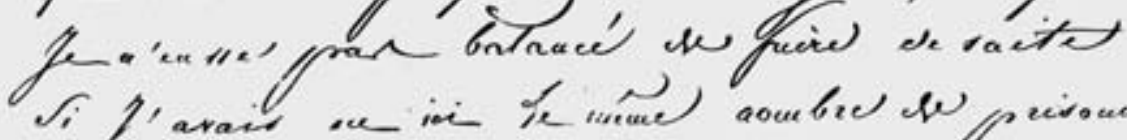

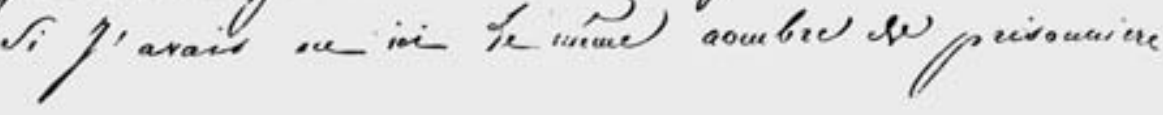

Reproduced with the permission of Rare Books and Manuscripts, Special Collections Library, the Pennsylvania State University Libraries. 


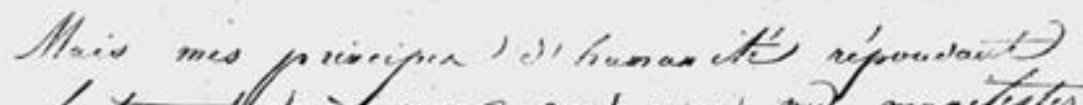

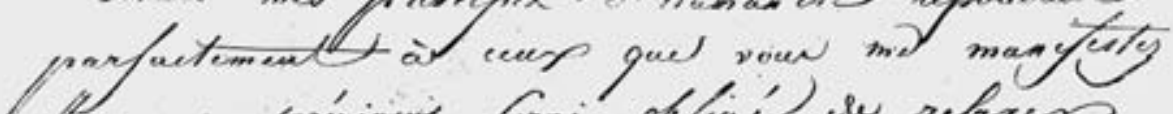

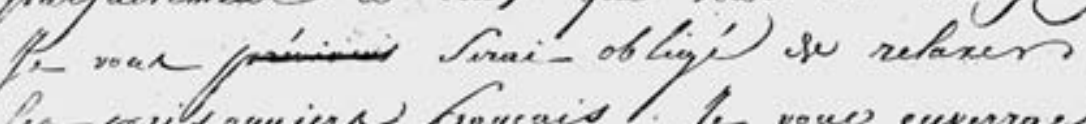

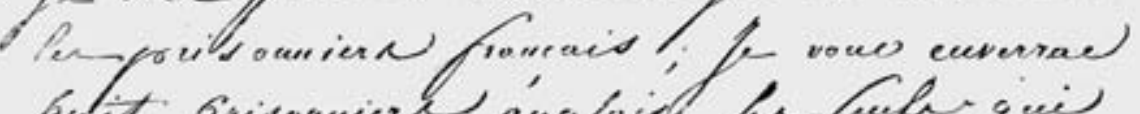

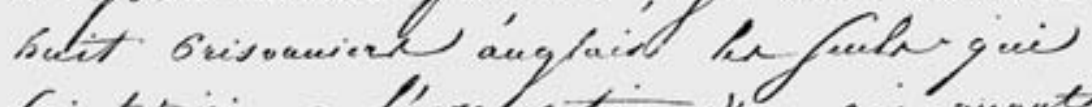

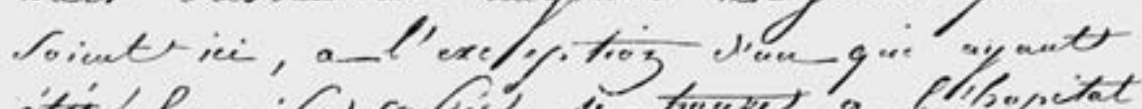

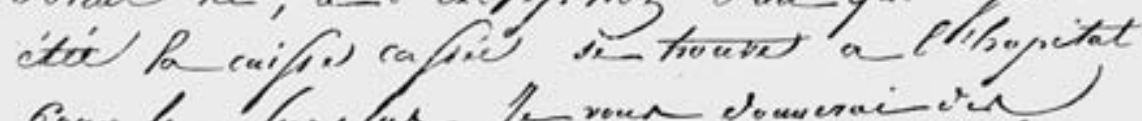

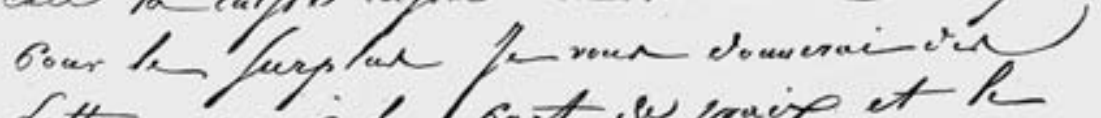
Sethes pour l sost w praif at h

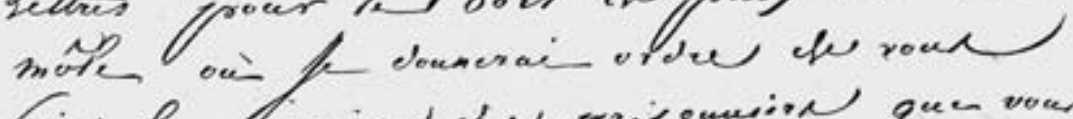

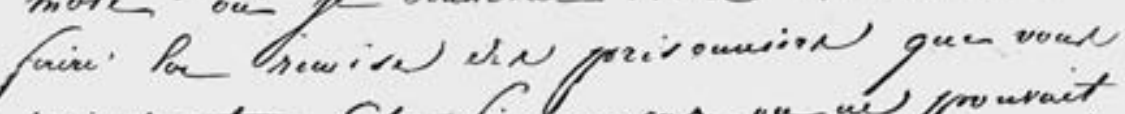

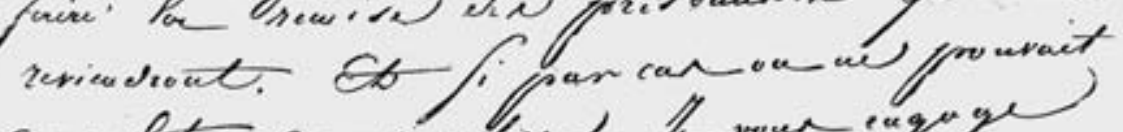
completer ce ar.ubu

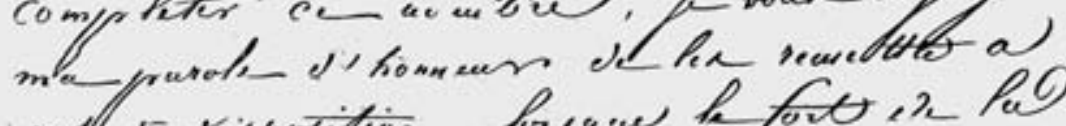

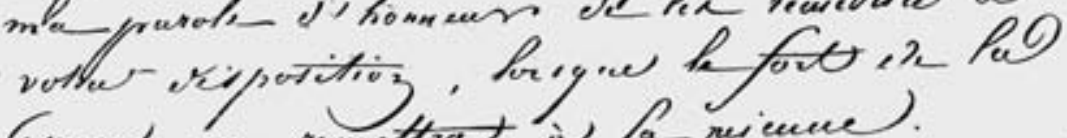

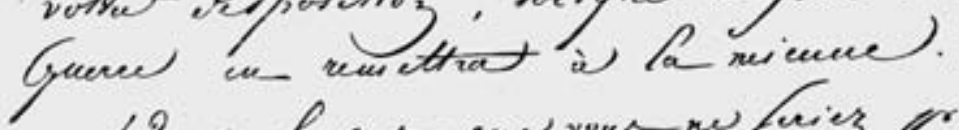
Ware har que vour nufuiez prad

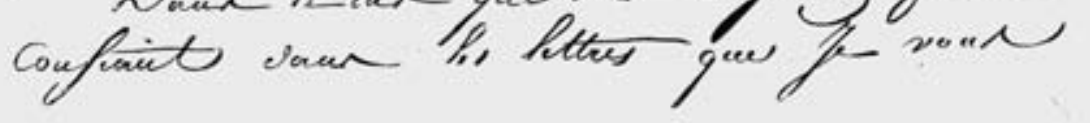




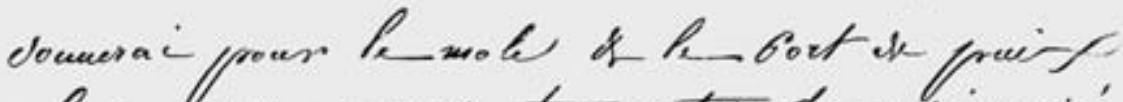

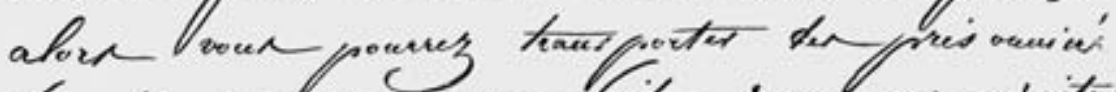

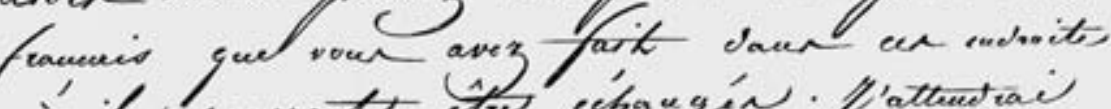

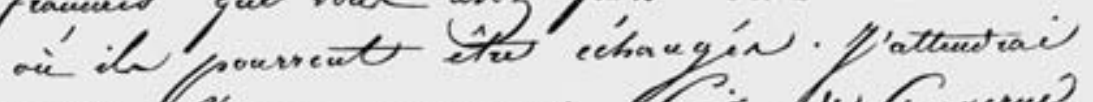

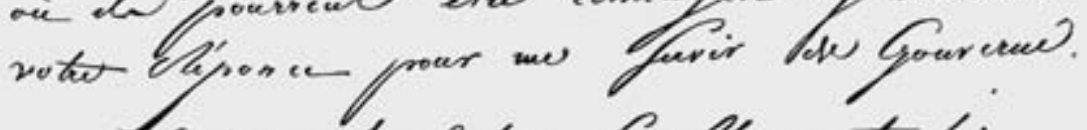

quorigue te boter, iedlowe at he

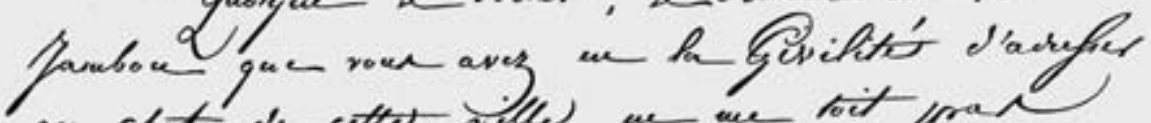
an chef denetter ille we we bit pras

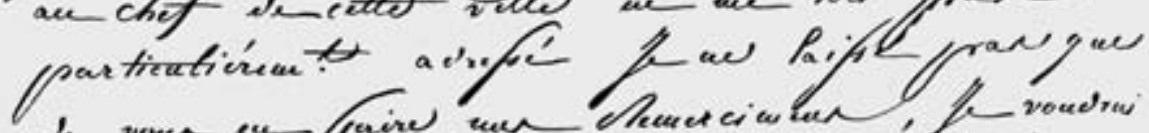

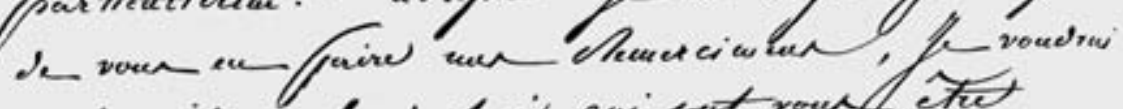

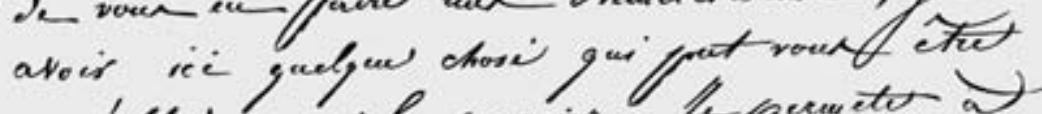

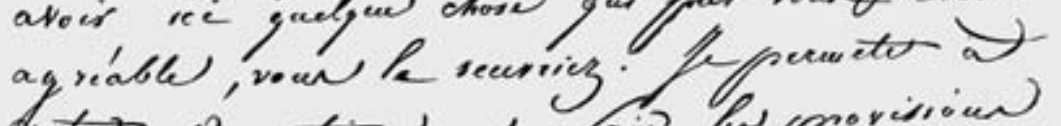

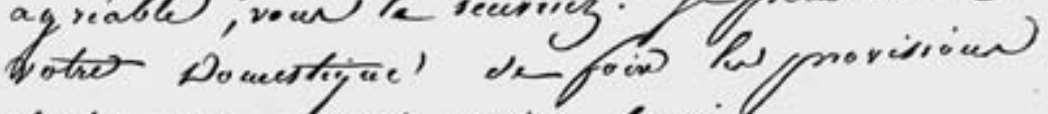
dont roun frourg avoir basois

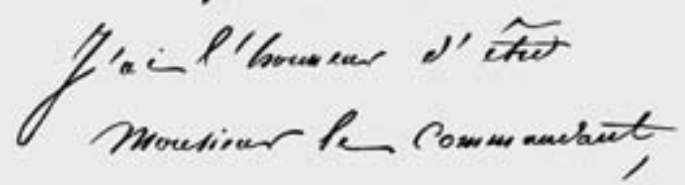

The tis humbli \& obifo feritur Coussaint souventure... 
schooner that had been previously taken, being manned and armed, she was sent one cruize, commanded by the purser, who soon returned with a schooner, laden with provisions, that had sailed with the same sloop. We took every body out of her except some ladies, who were passengers, and the same evening came to anchor in Gonaives Roads.

Sent a flag of truce on shore, and saw General Toussaint, who seemed very well pleased with the proposition of a treaty for trading, to and from Jamaica, and rendering every thing agreeable.

Next day we got under weigh, and stood off and on till evening, as the captain had promised to send all the prisoners on shore when they should send a small vessel for them. In the mean time the person who was sent prize-master, having intoxicated himself in the evening when the ship was running into her anchorage, he bore up for Port Royal, and behaved very unmanly to the poor distressed ladies. He would not allow them to open their trunks for clean clothes, nor would he allow them any of two cases of wine, which the captain had left entirely for them. The vessel came for the prisoners next morning, and they went on shore, but the Black General was exceedingly vexed at the treatment the ladies had received, as they were the wives of officers in whom he had much confidence. This circumstance had nearly been the cause of much mischief, and the dissolution of the treaty, as he would hardly believe it was not intended by the captain, as all the male prisoners were returned with the exception only of one, who had preferred to remain with one of the ladies, who was his sister. In a short time, however, his temper warm, but not irascible, was appeased, and all was well.

On the 14th December a brig, the Mary, arrived from Jamaica, laden with provisions, and on the 6th we put the two gentlemen conducting the treaty on board her, when she hoisted the flag of truce, and we bore up for Port Royal, where we arrived on the 8 th.

NO. VIII.

(Referring to p. 163.)

Extract from the former Publication of the Author of this Work ${ }^{397}$ upon the then projected Expedition of St. Domingo, describing its Progress; and, from a Comparison with the subsequent Dispatches of the French General, demonstrative of the Verity of those

Principles upon which he argued against its Adoption.

UpON what foundation the projectors of the French armament rested their hopes of success (supposing them not totally ignorant of what was to be attempted in the reduction of St. Domingo at present), other than the prowess of the First Consul, it is not easy to conceive - the astonishing difficulties that have been surmounted, and prodigies that have already been achieved by the invincible Bonaparte! But they should have recollected, that the improbable successes of that general were not unfrequently attributed to the CAUSE he supported! - certainly the best calculated to 
inspire young troops with a romantic idea of chivalry, and to carry them, unknowing, through dangers that would appal the most hardy veterans. How different is the object at present: detachments from armies, that held combined Europe at defiance, when resolved to be free, and gave peace to the conquered nations that no longer opposed their freedom, are embarked to expel their own spirit from another land; to suppress every generous emotion they had been accustomed to feel; and to again fill the furrows of a smiling country with blood-the blood of FreEmen, Whom They Had Themselves Created.

"Unused to the sickening suspense of a maritime conveyance, they are painfully wafted to the seat of war in a noxious climate; they debark in a country rendered hostile by a series of inexplicable menaces, and prepared to meet with indignation those it considers as betrayers of the cause in which they had formerly bled! - Vanished is the enthusiastic spirit of bravery, that was wont to lead them to the fight, while other voices sound the Song of Liberty!

\author{
"Allons! enfans de la patrié \\ La jour de gloire est arrivé \\ Contre nous - de la tyrannée \\ Létendart sanglant est elevée! \\ Entendez vous, dans la Campagné, \\ Mugir ces ferocés soldâts, \\ Qui viennent dans nos bras \\ Egorgés vos fils et votre Compagné!
}

$$
\text { Aux armes!" - * }
$$

"The hitherto victorious troops of the republic, land in various directions, beneath the heavy fire of forts well appointed; and mounted chiefly with brass ordnance: they press forward to - what ? - not to enter towns from which the enemy has fled precipitately, leaving behind them every comfort necessary for an army, requiring early rest to recruit; they enter cities, not merely evacuated, but no longer cities! to be mocked by the ruins of repose, and the destruction of necessaries they required.

"Recruited from their own magazines, or the trifling aid to be forced from a few Americans, they proceed into a country, every foot of which, when obtained, is deprived of all that can aid their enterprize. Troops, dispirited by novel tactics, and an enfeebling climate, are to pass their nights in the open air, and exposed to the noc-

\footnotetext{
*"Ye patriot band!
}

The day of glory comes; against us see The bloody standard rais'd of tyranny! Hark! in your fields ferocious soldiers roar, Your children and your country are no more! Close to your breasts they comeTo arms!"-

[La Marseillaise 1l. 1-9. The song, made a national anthem by the Convention on 14 July 1795, was later banned by Napoleon. The French transcription is Rainsford's.] 
turnal vapours, alone fatal to European habits, sustained only by provisions furnished from their own stores, with no more water than they have conveyed with them, and unable to proceed, or to return.

"Occasional aids, with peculiar good fortune, carried them farther into the interior, to experience all those difficulties in a more extensive degree; with a subtraction from their numbers and their comforts, in proportion to the victories they may obtain, and the difficulties they may surmount.

"On the other hand-

"A country is raised, to repel a horde of invaders, to whom are attributed the intentions of despoiling the land, and enslaving its inhabitants; a well-disciplined army in every part, intimately acquainted with every quarter of the island, inured to the climate, and habituated to the soil; trained to a long expectation of the attack, is prepared to meet them. Hardy, and unencumbered with stores, they sport with an harrassed enemy; and, when the day decides against them, leaving the enemy to burning towns, and mined plantations, they recede in safety within the next line of fortifications: were they even deprived of all adventitious aid, ${ }^{*}$ the umbrageous plantain alone affords them repose and food, or they luxuriate in the varieties of the yam and the banana, refreshed by the streams, to which they readily find access; they rise unimpaired, to support the cause next their heart, and revel in proportion as their assailants are dismayed.

"Almost impenetrably fortified up to the very mountains of Cibao, whose inaccessible tops reach the heavens, Toussaint recedes with ease, faster than the wasting enemy can, with pain, pursue him; and in this way is he, in alliance with the very elements to be pursued through a route of this description 500 miles? I speak of the elements, for the period is fast approaching, when, in addition to the horrors already experienced, the rains will commence, whose overwhelming torrents will require portable towns to withstand them, where indifferent camp-equipage only can be conveyed; and, in this situation, if not before, I feel no hesitation in saying, that Le Clerc, lamenting his laurels, which have withered so untimely, will assimilate Macbeth, and exclaim, with heart-felt regret, -

"There is no going hence, nor tarrying here!" 398

"All possible grounds of success, it is easily perceived, are done away-unless Toussaint, during his experience of his government, has acquired the knowledge of "expediency," and on that score is expected to sacrifice his adherents for a snug retirement! - a circumstance hardly to be looked for; or, that three or four millions of men, who have forgotten every other restraint than a voluntary sense of duty imposes, should easily be inclined to return to the dominion of the cowskin!!! ${ }^{\dagger}$

\footnotetext{
*Which is impossible, while every little coasting-bark from America brings a fresh supply; and an ample resource is found in every new situation.

†The instrument of punishment, no doubt, judiciously handled, by those young men, who perform their noviciate in the character of Overseers of the Slaves.
} 
"The English government, in three years, employed above twenty thousand men, and expended thirty millions of money on St. Domingo; ${ }^{399}$ and its army, even then, was never able to penetrate five miles into the country; yet the French government proposes to exterminate the whole race of colour without the least delay.

"Veni vidi, vici! - then - General Le Clerc has completed his career of extermination, and he sits down in the delightful vallies of St. Domingo without a single rebel $^{*}$ to cultivate the soil; it must be supplied by a fresh, a continued importation of negroes, ignorant of labour, and without any to instruct them, at an excessive waste of time and of produce, and an expence of not less than one hundred millions at least!

"Whether France be adequate to colonize at this rate, I presume not to determine. Considering her at the acmé of her present power, I shall not wonder at the attempt, nor at her assuming all the concomitants of colonization, - corporate bodies, chartered companies, and the long train of monopolies, so fatal to the peace and the interest of nations.

"I have now only to add a few observations on those fears, and the promoters of them, which have obtained for the Dictator of France, in his scheme of retrieving to the mongrel government of that country the delightful island of St. Domingo, such an apparently universal patronage with even persons of discernment in this kingdom. To those intimately acquainted with the British colonies in the West Indies, these observations are not necessary; but there are many whose interests in the islands are by no means inconsiderable, who owe their principal information to those eternal babblers, who, without the most distant pretensions to knowledge, experience, or a common portion of common sense, fill every avenue with their alarms, and surprize every new week with a new hypothesis.

"These have affected to view in the establishment of a BLACK REPUBLIC in this extensive territory, the entire annihilation of all our possessions, the elevation of a revolutionary hydra, that breathes another Pandemonium of ills on the afflicted world! till the expedition of Bonaparte has been treated as a common cause, and much has been anticipated that could not be expected, if it could be wished.

"Nothing appears more evident to me, than that the system which, without the intervention of any of those accidents that some time change the face of things, is about to obtain in St. Domingo, is not one that will by any means lead to an extension of territory, or the diffusion of principles. In the possession of a vast island, such as it has been described, much would remain to be done at home, were they henceforward to remain in uninterrupted peace; the cultivation of vast tracts, the renovation of what has been destroyed, and the arrangements of their own interests, will indis-

*To hear this term in France, at this present day, and the diminutive idea entertained of St. Domingo, as well as the contemptible opinion affected of Toussaint, excites risibility. The two former explain themselves; and it is sufficiently known that Toussaint is a more extraordinary character, and at this moment possessed of more real power than the Grand Consul! "Why may not I," says he, "hold absolute power here, as well as the First Consul in France?" 
pensably preclude the interference of Toussaint with the government or opinion of the neighbouring islands.

"Added to this, what person acquainted with the respectable state of defence in which our islands are kept, can ever entertain the least fear respecting them? - Small as they comparatively are, possessed by planters of distinguished talents, ${ }^{*}$ defended by a militia prompt on all occasions; with an army well appointed on their shores, under the superintendance of ability and experience at home; and a navy round their coasts, the wonder of the world; what restless, romantic spirit could induce an attempt so certainly destructive in the effort, and fruitless in the event?"

\section{NO. IX.}

(Referred to in p. 193. - Documents respecting the colonial Administration of Le Clerc.)

First colonial Regulation of the Captain-General, extracted from the Official Gazette of St. Domingo.

\section{ADMINISTRATION OF THE COLONY.}

Head-Quarters, at the Cape, June 22, 1802.

IN the name of the French government,

The General in chief Captain-general, decrees as follows:-

In the French part of St. Domingo, the administration of the quarters and communes is confined to military commandants and councils of notables. The commandants to have the jurisdiction of police in their respective districts, and the chief command of the gens d'armeriè. The councils of notables to be composed of proprietors or merchants, and to consist of five members, in the towns of Port Republicain, the Cape, and Des Cayes, and of three members in other communes. The members to

\footnotetext{
*Notwithstanding it has of late years been the fashion to consider the character of a planter as derogatory to humanity, and incapable of being blended with any of those qualities that ameliorate the condition of the species, every opportunity which I have had of judging has tended to convince me of the contrary. Nothing, indeed, can be more cruel than to single out any description of persons for public reprobation, as may suit the purpose of the fanatic or the partizan; and nothing is more fatal to the cause of truth than an implicit reliance on the vague reports of their enthusiasm, which must inevitably preclude the possibility of acquiring correct information, or adhering to facts if produced to their notice. - If the young and thoughtless squander the accumulations of their ancestors, it is certainly no evidence of general voluptuousness. If there are circumstances exceptionable in the conduct of the slave-trade, does it follow that the planter is a merciless executioner? Certainly not, - it would be hostile to his interest, and inexpedient in his situation. As merchants and as men, many are highly and extensively esteemed and regarded; and instances of affection and regret in the slaves, in whose torture they have been described to exult, are neither unfrequent or unrecorded.
} 
be appointed by the colonial prefect; and every one so appointed to be compelled to accept the office. The military commandants are charged with the delivery (gratis) of passports for travelling in the colony, the suppression of vagrancy, the care of the police, the maintenance of cleanliness and health, the care of citizens newly arrived, the police of the prisons; and the regulation of weights and measures, in concurrence with the council of notables. Except in the case of flagrant crimes, the military commandants cannot arrest any citizen without an order from the Commandant of the quarter. The communes to provide for their own expences; the sums to be regulated by a decree of the general in chief, with the advice of the colonial prefect. No military commandant can put in requisition the labourers or the cattle of any plantation; the general in chief reserves that power to himself. The councils of notables to provide for the expences of the communes and for the imposts adopted by the commander in chief, with the advice of the colonial prefect. Those councils alone to deliberate upon the communal interests; all other assemblies of citizens are prohibited, and shall, if attempted, be considered as seditious, and dispersed by force. The councils to correspond immediately with the sub-prefects, by whom their members may be suspended, and finally dismissed by the colonial prefect. There shall be in each parish a commissary to register the public acts.

(Signed) Le Clerc. 400

COMMERCE OF ST. DOMINGO.

By another decree of the general in chief,

French merchant vessels are to be admitted only in the ports of the Cape, Port Republicain, des Cayes and de Jacmel. Merchandize, or produce of the manufactures, or soil of France, not to be subject to any duty on importation. Colonial produce, exported by French vessels, to be subject to a duty on exportation.

Foreign vessels of the burden of 70 tons, and upwards, are permitted to enter the above four ports. French or foreign merchandize imported in them to be subject to a duty on importation, conformable to tariff. The produce of the colony exported by them to be subject to a duty on exportation.

Every captain of a French or foreign vessel must, on his arrival in port, before any other person on board lands, present himself before the captain general, and the colonial prefect, at the place of their residence, and in other ports to the general commandant, and the chief of administration, for the purpose of giving an account of his voyage. The captain shall transmit on the same day, to the commandant of the place, a declaration, written and signed, containing an account of the passengers he has on board: no passenger to disembark without the authority of the commandant.

The captain must, on the day of his arrival, remit the letters and packets in his charge to the director of the post at the port, and shall receive a discharge.

The captains of French and foreign vessels must, within a day after their arrival, transmit to the directors of the harbours, the bill of lading of their cargoes. All mer- 
chandize found on board which is not included in the bill of lading, will be confiscated.

Every captain of a foreign vessel must consign his cargo to a domiciliated merchant, who shall be personally responsible for the payment of the duties on importation and exportation, and for the frauds which may be committed by the captains of the vessels consigned to him.

No French or foreign vessel shall be suffered to quit the ports, but on producing to the captain of the port the certificate of the director of the customs, stating that all the duties have been paid.

Every French or foreign vessel which shall be found in any of the ports, not designated in the decrees, or sailing within two leagues of the coast, shall be taken possession of by the guard- vessels, and conducted into one of the designated ports, in order that the confiscation of the vessel and cargo may be adjudged by the captain general, on the report of the colonial prefect. The vessel making such capture, to be entitled to one-third of the value of the vessel and cargo confiscated..$^{401}$

\section{TARIFF OF CUSTOMS IN THE FRENCH PART OF ST. DOMINGO. IMPORTATION.}

French merchandize and produce in foreign vessels, 10 per cent. on the valueMeal, biscuits, salt, provisions, wood for carpenters and buildings, cattle and sheep, horses, mules, poultry, \&c. ditto 6 per cent. ditto. - Foreign merchandize, ditto, 20 per cent. ditto.

\section{EXPORTATION.}

The following are the most material articles:

Coffee in foreign vessels, 13 francs 33 cents. per quintal.

-White sugar, ditto, ditto. - Brown ditto, 6 f. 67 c. ditto.

- Cotton, $30 \mathrm{f}$. ditto. - Indigo, $80 \mathrm{c}$. per lb. - Produce not enumerated, 20 per cent. on the value. - French manufactures in foreign vessels exempt from duty. ${ }^{402}$

\section{SUBSEQUENT COMMERCIAL REGULATION.}

(In consequence of a remonstrance of the merchants and shipowners of the city of Havre, \&c. presented to the First Consul, Bonaparte, May 30, 1802, against the admission of British merchandize.*)

Head-Quarters at the Cape, Sept. 8, 1802. ${ }^{403}$

\footnotetext{
*In this remonstrance is the following confession:- "Thanks be to our warriors, thanks be to your genius; - the English have come out of the long contest with much less glory than we have, but they have withdrawn from the struggle rich and astonishingly powerful. All is organised among them, and it will be long, very long, before we can vie with them in trade. We can only be saved from destruction by prohibitory regulation. A convalescent should not enter the lists with a mighty giant."
} 
In the Name of the French Government the Commander in Chief, Captain General, decrees as follows:-

Art. I. After the 1st of Vendemiaire, year 11, (Sept. 23, 1802), no other merchandize or articles of provision, except those specified in the annexed list, can be imported into the colony by foreign ships: - none can be exported by the same ships, but molasses, syrup, spirits, and rum; dye woods and wood for cabinet makers; guiacum, coffee, and provision, or merchandize of every kind imported by the French merchants.

II. After the same period, the duties on the merchandize and provisions specified in the annexed list, imported into the colony by foreign ships, shall pay at the rate of ten per cent. duty ad valorem in the colony, according to a tariff, which the colonial prefect shall settle every three months, from the medium prices of the preceding three months, in the open ports of the colony.

The duties on colonial productions which, according to the permission granted by the first article, shall be exported in foreign vessels, shall pay, over and above, one half more than those exported in French ships, according to the tariff annexed to the decree of the $3 \mathrm{~d}$ of Messidor last (June 22). These productions shall pay, besides the war tax, established by the decree of Messidor 25 (July 14).

Productions and merchandize arising from the French commerce, exported from the colony in foreign ships, shall pay no duties.

III. All merchandize and products not specified in the annexed list, imported by foreign vessels, are prohibited, reckoning from the 1st of Vendemiaire, year 11 (September 23, 1802). The captains of foreign vessels which arrive in the open ports of the colony before that period, shall be allowed to land their merchandize, on lodging a declaration at the custom-house.

Those which arrive in the open ports of the colony after Vendemiaire 1st (September 23) until the 15th Brumaire next (November 6) inclusive, shall be allowed to land the unprohibited goods they have on board. In regard to those prohibited, they shall lodge a declaration of them, and shall be bound to produce them on their departure, under the pain of their vessels being confiscated.

After the 15th Brumaire (November 6) vessels, whose cargoes are not entirely composed of non-prohibited merchandize and productions, shall not be admitted into the ports of the colony. Those not coming within the case of being admitted, which shall procure admission by false declarations, or which, after having been obliged to leave the said ports, shall be found effecting, or trying to effect a fraudulent landing, shall be confiscated, as well as the cargoes.

IV. Nothing in the present decree shall affect that of Messidor $5,{ }^{404}$ which exempts from all duties, till the 3oth of Frimaire, year 11 (December 21, 1802); oxen and mules imported into the ports of the Cape, Port Republicain, Des Cayes, and Jacmel.

All the dispositions of decrees relating to commerce and the customs, not contrary to the present decree, are also maintained.

$\mathrm{V}$. The colonial prefect is charged with carrying the present decree into execution. (Signed) Le Cle RC. ${ }^{405}$ 
List of the merchandize and productions, the importation of which by foreign ships is permitted, on paying a duty of ten per cent. ad valorem:- beer, bricks, coals, cables, and cordage; train oil, spermaceti oil, pitch, tar, resin, \&c.; essence of turpentine, oats, barley, maize, flour, rice, biscuit, salt beef, salt pork, hams, sausages, \&c. are not comprehended under this denomination; salt butter, mantagus, cod-fish, bacaga, \&c.; salt mackarel, dried herrings, pickled herrings, shads, cod sounds, pickled mullets, stock-fish; live cattle, horses, mules, apes, hogs, sheep, ducks, fowls, turkies, geese; timber for building, spars, planks, oars, casks, \&c. \&c.

NO. X.

(Referred to in p. 196, \&c.)

\section{Some Account of the Nature and History of the Blood-Hounds used in the American Colonies.}

on this subject which it is anxiously desired to impress upon the reader, the following particulars may not be unacceptable. - Among the numerous rude inventions of barbarous ages to attain a superiority in war, was that of the use of beasts in a variety of ways, in conjunction with their regular armies. In Virgil the effect of bulls sent in terrible array against an opponent is recorded, and Moses affords a ludicrous employment of foxes, ${ }^{*}$ driven with firebrands towards the enemy's camp. The war-horse and elephant are also represented as taking an active share in the battle at all times. The introduction of dogs, however, is not so generally used, and one which is considered as likely to avail but in a very confined degree. The first particular mention of their use in acting with troops, is by Herrera, the Spanish historian, when describing the first conflict of Columbus with the Indians in $1492 ; \dagger$ the Sleute-hound of the Scots was in much repute as being early applied to discover the haunts of robbers; and Strabo ${ }^{406}$ is said to describe an attack upon the Gauls by dogs of the present description. $¥$ The character of decided enmity to man, however, seems to have been preserved only in Spanish America, and the writer is induced from many circumstances to think that the quadruped which is the subject of this account is, though of a similar species to the Irish wolf-dog breed, a native of the South Seas.

Whether or not the dog in a savage state would devour his master, as is asserted, shall not here be argued; it is certain that on the mode of rearing, and subsequent discipline for use, in war, much has always depended, and that (to the disgrace of

* Or Jackalls. See the curious observations on this subject in Tomlinson's Scriptural Translations, p. 273. [Robert Tomlinson, An Attempt to rescue the Holy Scriptures from the Ridicule they incur (1804).]

†See the former part of this work.

†This incident is on the authority of an obliging writer in the Monthly Magazine, in answer to a query on the subject on account of the present work, Strabo not being at hand for a reference. 


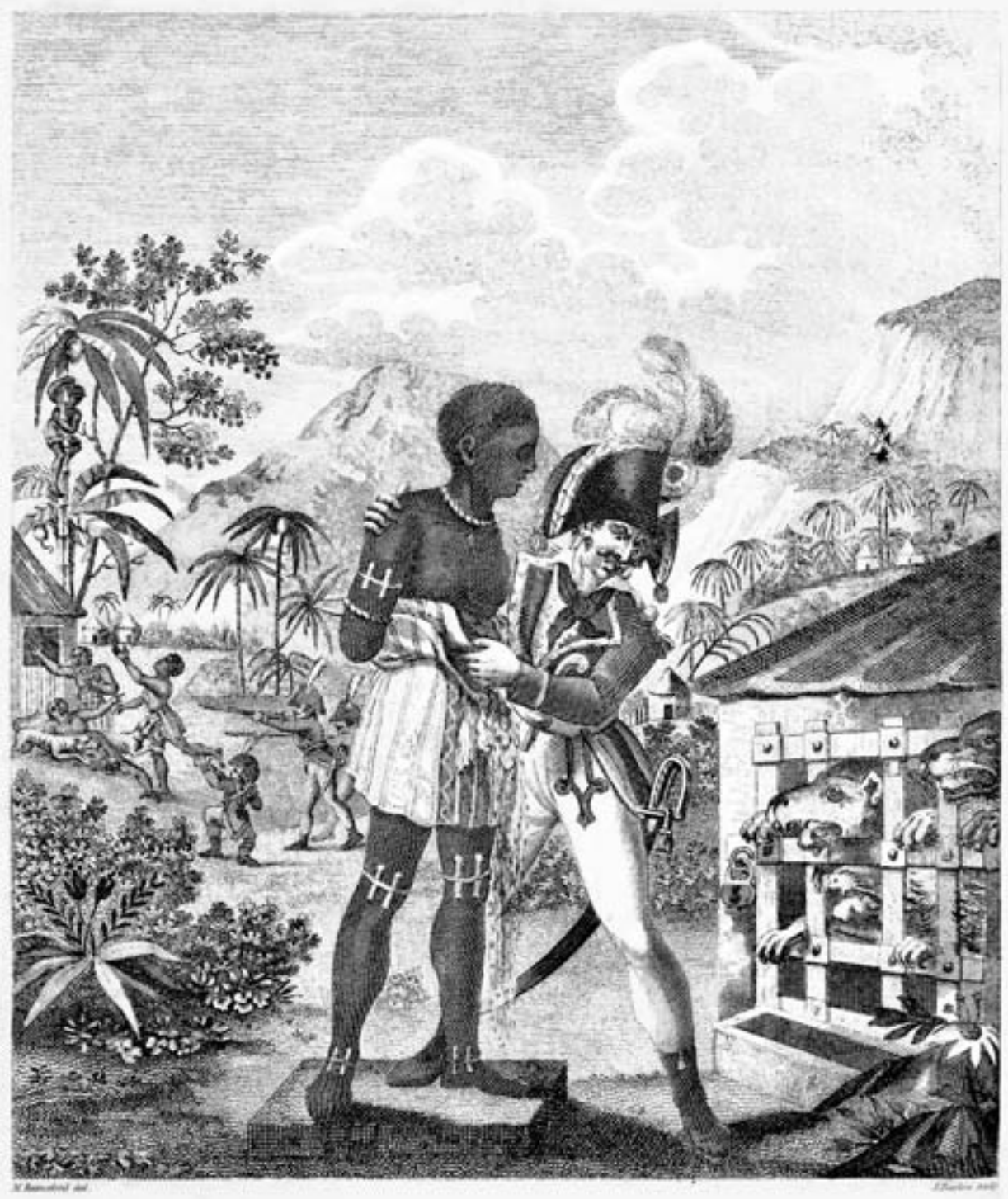

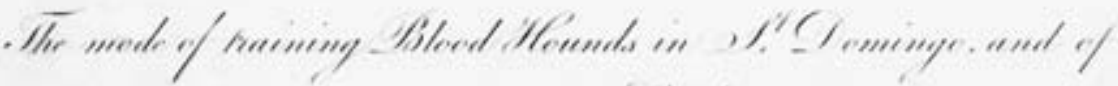

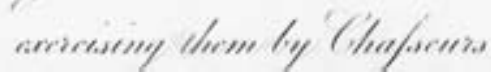

The mode of training Blood Hounds in St. Domingo and of exercising them by Chasseurs. Reproduced with the permission of Rare Books and Manuscripts, Special Collections Library, the Pennsylvania State University Libraries. 
human beings so employed) their education has been reduced to such a system, as to leave little of the natural character remaining.

With the persons who breed and have the care of these animals in Spanish America, the public are already sufficiently acquainted; but there are some facts which are not equally known, both as respect these people, and the mode of rearing the dogs, as particularly practised in St. Domingo, to which attention is at present confined. The first of these subjects will be explained by a comparison easily made; and of the latter the writer is indebted for an accurate knowledge to an intelligent friend, who had the care of those animals and their keepers in their troublesome passage from the Havannah to Jamaica, the same which forms a prominent subject of the history already given to the public on the occasion. ${ }^{*}$

*Dallas's History of the Maroons. Mr. Quarrel (through the medium of a writer always intelligent, and sometimes eloquent) has excited the interest of the public to the whole of his services in relation to the expedition from Jamaica to Cuba, for the purpose of obtaining blood-hounds and their leaders; he has described a long round of difficulties, of

"Moving accidents by flood and field," [Shakespeare, Othello l.3.135]

all of which were overcome by the superior talents, the local, and even maritime skill of the commissioner! According to this account, the minutest object in the arduous business of the expedition was not only managed by him, during sickness or convalescence, but his bark was directed through peculiar courses, and battles fought successfully against a superior power, with a crew somewhat like Falstaff's regiment. But Mr. Quarrel forgot to name the Captain of the vessel which carried him to Cuba, and returned with the bloodhounds to Jamaica, or the wonder would have ceased; and this is the more singular, in a man of letters and enterprize, like Mr. Quarrel, from the exquisite delight and extensive information he must have received from the society of Captain Campbell; a gentleman, with enlarged ideas, high literary talents, the most consummate bravery, and unbounded nautical skill, who almost prefers (under existing circumstances,) the command of a little vessel like that which conveyed Mr. Quarrel and his charge! (and which is generally, or a considerable share, his own property,) peculiarly on account of its being absolutely under his own direction; and with a crew such as the commissioner very justly describes, he has performed more intrepid actions, and visited with success, more parts of the globe than any other officer of his age, which is happily not yet far advanced. The writer had reason to hope from the pen of him who has traced the steps of the injured Bruce in Abyssinia, a valuable paper on this, as well as other subjects relating to the Western Archipelago; but this, as well as other valuable communications intended for the public, in the possession of a mutual friend, was neglected, when

\section{"Old Ocean smil'd,}

"And, dancing on the tide of pleasure wild,

"Brisk Fame high-bounding, blew her echoing horn."

Pursuit of Fame, a Poem.

[Author unknown]

[James Bruce (1730-94) was a Scottish traveler and travel writer who journeyed through Africa to discover the source of the Blue Nile. He later recorded his experiences in Travels to Discover the Source of the Nile (1790).] 
Among the remains of the Buccaniers, (which are every where prevalent in St. Domingo and its vicinity, in the different Trou's ${ }^{407}$ which retain their names, and several local expressions,) are the costume and mode of life, in the Spanish chasseurs who conduct the blood-hounds. The hog-skin trowsers drawn on their limbs warm from the animal when shot wild in the woods, and the mode of preparing their food, (boucaner, a name at present synonymous with cooking in the island,) being common to both; and, in fact, every part of their dress, their migratory life, power of forbearance, and savage habits in the woods, all exhibit the ancient Buccanier in the modern Chasseur; and the portrait of the one when young, robust, and daring, is a very complete resemblance of the other.

The character of these people differed somewhat in the numbers which joined the French army, and were increased by tyros, when their operations became such a favorite relief in the actions between it and that of the blacks.

With respect to the dogs, their general mode of rearing was latterly in the following manner. From the time of their being taken from the dam, they were confined in a sort of kennel, or cage, where they were but sparingly fed upon small quantities of the blood of different animals. As they approached maturity, their keepers procured a figure roughly formed as a negro in wicker work, in the body of which were contained the blood and entrails of beasts. This was exhibited before an upper part of the cage, and the food occasionally exposed as a temptation, which attracted the attention of the dogs to it as a source of the food they wanted. This was repeated often, so that the animals with redoubled ferocity struggled against their confinement while in proportion to their impatience the figure was brought nearer, though yet out of their reach, and their food decreased, till, at the last extremity of desperation, the keeper resigned the figure, well charged with the nauseous food before described, to their wishes. While they gorged themselves with the dreadful meat, he and his colleagues caressed and encouraged them. By these means the whites ingratiated themselves so much with the animals, as to produce an effect directly opposite to that perceivable in them towards the black figure; and, when they were employed in the pursuit for which they were intended, afforded the protection so necessary to their employers. As soon as they were considered initiated into their business, the young dogs were taken out to be exercised in it, and trained with much exactness as possible. In some instances this extended to a great length, but in general their discipline could not permanently retain them under the command of their leaders, the consequence is obvious.

The common use of them in the Spanish islands was in chace of runaway negroes in the mountains. When once they got scent of the object, they immediately hunted him down, unless he could evade the pursuit by climbing up a tree, and instantly devoured him: if he was so fortunate as to get from their reach into a tree, the dogs remained about it yelping in the most dreadful manner, till their keepers arrived. If the victim was to be preserved for a public exhibition of cruelty, the dogs were then muzzled, and the prisoner loaded with chains. On his neck was placed a hoop with in- 
verted spikes; and hooks outward, for the purpose of entangling him in the bushes, or elsewhere. Should the unhappy wretch proceed faster than his wearied pursuers, or attempt to run from them, he was given up to the dogs, who instantly devoured him. With horrid delight the chasseurs sometimes preserved the head to expose at their homes, as monuments of their barbarous prowess. - Frequently on a journey of any length these causes were, it is much feared, feigned for the purpose of relieving the keepers of their prisoners, and the inhuman wretch who perpetrated the act, on his oath of having destroyed his fellow creature, received the reward of ten dollars from the colony!

If the most dreadful accidents among the blacks were ascribed, and it is apprehended justly, to the troops of blood-hounds in the very spots on which they were reared, what was not to be expected on the seat of war, amidst innumerable prejudices, and the powerful motive of self-preservation? when every one conceived himself justified in contributing an act of barbarity to the common cause, while it arose, perhaps, out of his own cruel disposition. The writer shrinks from the task of description in this place, yet the concealment will not excite the detestation he urges against the very idea of ever again introducing these animals under any pretext to the assistance of an army. ${ }^{*}$ But indifferently kept, the dogs frequently broke loose in the vicinity of the Cape, and infants were devoured in an instant from the public way! At other times they proceeded to the neighbouring woods, and surprizing an harmless

*The defence of his friend (certainly a most laudable motive in these degenerate times, notwithstanding the old proverb Amicus Plato, amicus Socrates, sed magis amica veritas) ["Plato is a friend, Socrates is a friend, but truth is a greater friend." This proverb is most often attributed to Aristotle, Nicomachean Ethics.] has led the ingenious writer before alluded to (Mr. Dallas) to some arguments in favor of blood-hounds, however cautiously introduced, not less glaringly false. Such is that, of the use of house-dogs. The writer need not call the attention of this gentleman (with whose sensibility of character he is not unacquainted) to the following obvious facts in behalf of their mutual country. The house-dog commonly used in the united kingdom, is the barking cur, who is not capable of a dangerous attack, and his use is only to create alarm; and even when a more powerful species are used, as the Newfoundland breed, they never kill or wound, except they are aggravated, of which several curious instances have recently occured; two are in the immediate recollection of the writer; one, he believes, at an inn near Hounslow, where a servant being detected by the faithful guard in the act of robbing the house at night, he threw him down on the spot, and placing himself upon him, held him there uninjured till the morning, when he delivered him into other custody. Another was, when an housekeeper remaining in a house alone, where a quantity of plate was deposited, borrowed for one night the dog of a neighbouring butcher to protect her, who, in the following morning presented her with a culprit before the side-board, in the person of a relation of her master: - the rest of the story is too invidious. If at any time an accident occurs, (which is not frequent,) of a dog injuring any one in the smallest degree, the writer never yet knew a master who would not immediately destroy him, and surely none desire to see even the nightly thief lacerated and devoured, instead of his injury prevented; but if even the position of Mr. Dallas were just, the case would by no means apply. 
family of labourers at their simple meal, tore the babe from the breast of its mother, or involved the whole party, and returned with their horrid jaws drenched in the gore of those who were acknowledged, even in the eyes of the French army, as innocent, and therefore permitted to furnish them with the produce of their labour. Huts were broken into by them, and

the picture becomes too dreadful for description even for the best of purposes.

NO. XI.

(Referred to in p. 202.)

The first colonial Regulation issued during the Government of Rochambeau.

\section{ARRETE OF THE GENERAL IN CHIEF.}

I. THE arrêté of the Captain-general of the 15 th Fructidor, 1oth year, ${ }^{408}$ which permits the importation of different articles of produce in this colony in foreign bottoms, paying 10 per cent. duty is received.

II. Foreigners may import into this colony all wares and merchandize not enumerated in the above-mentioned arrêté, subject to a duty of 20 per cent. ad valorem.

III. The colonial-prefect shall make out every six months a tariff of the value of all the wares and merchandize imported under the second article. The duty of 20 per cent. shall be fixed by this tariff.

IV. The importation of goods permitted by the fifth and second article of this arrêté shall only take place at the Cape, Port Republican, and the Port of St. Domingo.

$\mathrm{V}$. The present arrêté shall be in force immediately after its publication.

VI. The colonial-prefect is charged with the execution of the present arrêté, which shall be printed, published, and posted up, and inserted in the Official Gazette.

(Signed) D. F. N. Rochambeau, Capt. Gen.

December $19,1802.409$

NO. XII.

(Referred to in p. 209.)

Documents respecting the Evacuation of St. Domingo, by the French Army under

Rochambeau; from the London Gazette, and other authentic Sources.

\section{ARTICLES OF CAPITULATION BETWEEN THE FRENCH GENERAL ROCHAMBEAU, AND THE BLACK GENERAL IN CHIEF OF SAINT DOMINGO. \\ French and Native Army.}

THIS day, the 27th Brumaire, of the 12th year, according to the French aera, and the 19th of November, $18 \mathrm{O} 2,{ }^{410}$ according to the common aera, the adjutant-commandant, Duveysier, having received full power from General Rochambeau, Commander-in- 
chief of the French army, to treat for the surrender of the Town of the Cape, and Jean Jacques Dessalines, general of the native army, being also authorised to treat on the occasion, have agreed on the following articles, viz.

I. The Town of the Cape, and the forts dependent thereon, shall be given up in ten days, reckoning from to-morrow, the 28 th of Brumaire (Nov. 18), ${ }^{411}$ to the generalin-chief, Dessalines.

II. The military stores which are now in the arsenals, the arms, and the artillery of the town and forts, shall be left in their present condition.

III. All the ships of war, and other vessels which shall be judged necessary by Gen. Rochambeau, for the removal of the troops and inhabitants, and for the evacuation of the place, shall be free to depart on the day appointed.

IV. All the officers, military or civil, and the troops composing the garrison of the Cape, shall leave the place with all the honours of war, carrying with them their arms, and all the private property belonging to their demi-brigades.

$\mathrm{V}$. The sick and wounded who shall not be in a condition to embark, shall be taken care of in the hospitals till their recovery; they are specially recommended to the humanity of Gen. Dessalines, who will cause them to be embarked for France in neutral vessels.

VI. General Dessalines, in giving the assurance of his protection to the inhabitants who shall remain in the country, calls at the same time upon the justice of General Rochambeau to set at liberty all the natives of the country (whatever may be their colour,) as they cannot be constrained, under any pretext of right, to embark with the French army.

VII. The troops of both armies shall remain in their respective positions, until the tenth day after the signature hereof, which is the day fixed on for the evacuation of the Cape.

VIII. The General in Chief Rochambeau will send, as a hostage for the observance of the present stipulation, the Adjutant-General Commandant, Urbain de Vaux, in exchange for whom the General in Chief Dessalines will send an officer of the same rank.

Two copies of this convention are hereby executed in strict faith, at the headquarters on the Heights of the Cape, on the day, month, and year aforesaid.

(Signed) Duveysier.

Dessalines. ${ }^{412}$

Correspondence between the Commander-in-Chief of the French Army of St. Domingo, and Capt. Loring, of his Majesty's Ship the Bellerophon, commanding a blockading force off Cape François.

\section{ARMY OF ST. DOMINGO.}

Head-Quarters at the Cape, 27th Brumaire, An. 12, of the French Republic. ${ }^{413}$ 
The General in Chief to Commodore Loring, commanding the Naval Force of his Britannic Majesty before the Cape.

SIR,

To prevent the effusion of blood, and to save the remains of the army of St. Domingo, I have the honour to send you two officers charged with instructions to enter into an arrangement with you. The General of Brigade Boyé, \&c. and the Commodore Barré, are ordered to transmit this letter to you. I have chosen them to have the honour of treating with you.

I have the honour, \&c. \&c.

D. Rochambeau. 414

Copy of the Propositions made by the General Rochambeau, to evacuate Cape François.

I. THE General Rochambeau proposes to evacuate the Cape; himself and his guards, consisting of about 4 or 500 men, to be conveyed to France without being considered prisoners of war. Not granted.

II. The Surveillant and Cerf to be allowed to carry him and suite to France. Not granted.

(Signed) JoHn Loring. ${ }^{415}$ Bellerophon, off Cape François, Nov. 19, 1803.

SIR,

I HAVE to acquaint you, on the subject communicated to me by General Boyé and Commodore Barré, of your desire to negotiate for the surrender of Cape François to his Britannic Majesty, that I send for the purpose, and to know your final determination, Captain Moss, of his Majesty's ship La Desirée, in order to agree with your wishes in so much as is consistent with the just rights of his Britannic Majesty on that point.

I have also to inform you my instructions confine me to the French officers and troops in health being sent to Jamaica, and the sick to go to France or America. The transports to convey them being first valued, and security given by the commander in chief, for the due payment of the valuation by the French republic. The white inhabitants of the Cape will not be permitted to go to Jamaica.

Such are the parts of my instructions, with which I am bound to comply in any agreement for the surrender of Cape François.

I have the honour to be, \&c.

(Signed) J. LORING. ${ }^{416}$

General Rochambeau, Commander-in-Chief, \&c. \&c. \&c.

[B.]

\section{COLONY OF ST. DOMINGO.}

Head-Quarters at the Cape, 27th Brumaire, 
in the Year $12 .{ }^{417}$

THE GENERAL IN CHIEF OF THE ARMY OF ST. DOMINGO, \&c. \&c. \&c. TO COMMODORE LORING, \&c.

SIR,

I HAVE received the letter which you have done me the honour to write to me. As your propositions are inadmissible, I must beg of you to consider the preceding letter as not having been received.

I have the honour to be, \&c.

D. Rochambeau.

British Account of the Capitulation of the French Army of St. Domingo, in the Letter of Sir John Thomas Duckworth to Sir Evan Nepean.

Port Royal, Dec. 18, 1803.

SIR,

HAVING, in my letter No. 3, by this conveyance stated to you, for the information of my Lords Commissioners of the Admiralty, that General Rochambeau had made proposals for capitulating, which, though inadmissible, I thought soon must lead to others more reasonable; the event has justified my opinion; but I am sorry to say that officer, whose actions are too extraordinary to account for, had, on the 19th ultimo, (previous to his proposal to Captain Loring, through the General of Brigade Boyé, and Commodore Barré) actually entered into a capitulation with the black General Dessalines, to deliver up the Cape to him, with all the ordnance, ammunition, and stores, on the 3oth; I conclude, flattering himself that the tremendous weather, which our squadron was then, and had been, experiencing for three weeks, would offer an opening for escape, but the perseverance and watchfulness thereof precluded him from even attempting it. On the 3oth, the colours of the Blacks were displayed at the forts, which induced Captain Loring to dispatch Captain Bligh, to know General Dessalines' sentiments respecting General Rochambeau and his troops; when, on his entering the harbour he met Commodore Barré, who pressed him in strong terms to go on board the Surveillante, and enter into some capitulation, which would put them under our protection, and prevent the Blacks from sinking them with red hot shot, as they had threatened, and were preparing to do, which Captain Bligh complied with, when, they hastily brought him a few articles they had drawn up; which he (after objecting to some particular parts, that they agreed should be altered, to carry his interpretation to Jamaica) signed, and hastened to acquaint General Dessalines, that all the ships and vessels in port had surrendered to his Majesty's arms, and with great difficulty he obtained the promise to desist from firing, till a wind offered for carrying them out (it then blowing hard directly into the harbour); this promise he at length obtained, and the first instant the land-breeze enabled them to sail out under French colours, which, upon a shot being fired athwart them, the vessels of war fired their broadsides, and hauled down their colours, except the Clorinde, a large frigate 
of thirty-eight guns, who unluckily took the ground abaft, and was forced to throw most of her guns overboard, and knocked her rudder off, when there was great apprehensions for her safety; and I am informed by the captains of the squadron, that we must attribute the saving her (apparently without further damage) to the uncommon exertions and professional abilities of acting Lieutenant Willoughby, with the boats of the Hercule, who, I trust, will be honoured with their lordships' protection.

Captain Loring, after seeing the generality of the prizes taken possession of, left the Theseus and Hercule to fix a temporary rudder to the frigate, and bring the remainder with them, bearing away for the Mole, and on the $2 \mathrm{~d}$ summoned the General of Brigade Noailles, who commanded there, to capitulate; this he declined doing, asserting that he had provisions for five months; and herewith I transmit a copy of his letter. The numerous and crowded state of the prisoners on board all the prizes, and their being without provisions, making it necessary for Captain Loring to proceed to Jamaica, he arrived here the 5 th with the Elephant and Blanche, also the Surveillante and Vertu thirty-eight gun frigates, and various other prizes, leaving the La Pique to blockade the Mole, who anchored in this port the 8th, and acquainted me that General Noailles had evacuated the night he refused to capitulate, bringing in with her five out of the six vessels in which the garrison had embarked, a brig with the general on board only escaping. I send a vessel of war to England, with General Rochambeau and those officers who are said to have participated in his cruelties at the Cape, I am, \&c.

J. T. DUCKWORth.

NO. XIII.

(Referred to in p. 209.)

Declaration of the Independence of the Blacks of St. Domingo.

PROCLAMATION OF DESSALINES, CHRISTOPHE, AND CLERVAUX, CHIEFS OF ST. DOMINGO.

In the Name of the Black People, and Men of Color of St. Domingo:

THE Independence of St. Domingo is proclaimed. Restored to our primitive dignity, we have asserted our rights; we swear never to yield them to any power on earth; the frightful veil of prejudice is torn to pieces, be it so for ever. Woe be to them who would dare, to put together its bloody tatters.

Oh! Landholders of St. Domingo, wandering in foreign countries, by proclaiming our independence, we do not forbid you, indiscriminately, from returning to your property; far be from us this unjust idea. We are not ignorant that there are some among you that have renounced their former errors, abjured the injustice of their exhorbitant pretensions, and acknowledged the lawfulness of the cause for which we have been spilling our blood these twelve years. Toward those men who do us justice, we will act as brothers; let them rely for ever on our esteem and friendship; let them 
return among us. The God who protects us, the God of Freemen, bids us to stretch out towards them our conquering arms. But as for those, who, intoxicated with foolish pride, interested slaves of a guilty pretension, are blinded so much as to believe themselves the essence of human nature, and assert that they are destined by heaven to be our masters and our tyrants, let them never come near the land of St. Domingo: if they come hither, they will only meet with chains or deportation; then let them stay where they are; tormented by their well-deserved misery, and the frowns of the just men whom they have too long mocked, let them still continue to move, unpitied and unnoticed by all.

We have sworn not to listen with clemency towards all those who would dare to speak to us of slavery; we will be inexorable, perhaps even cruel, towards all troops who, themselves forgetting the object for which they have not ceased fighting since $1780,{ }^{418}$ should come from Europe to bring among us death and servitude. Nothing is too dear, and all means are lawful, to men from whom it is wished to tear the first of all blessings. Were they to cause rivers and torrents of blood to run; were they, in order to maintain their liberty, to conflagrate seven eighths of the globe, they are innocent before the tribunal of Providence, that never created men, to see them groaning under so harsh and shameful a servitude.

In the various commotions that took place, some inhabitants against whom we had not to complain, have been victims by the cruelty of a few soldiers or cultivators, too much blinded by the remembrance of their past sufferings to be able to distinguish the good and humane land-owners from those that were unfeeling and cruel, we lament with all feeling souls so deplorable an end, and declare to the world, whatever may be said to the contrary by wicked people, that the murders were committed contrary to the wishes of our hearts. It was impossible, especially in the crisis in which the colony was, to be able to prevent or stop those horrors. They who are in the least acquainted with history, know that a people, when assailed by civil dissentions, though they may be the most polished on earth, give themselves up to every species of excess, and the authority of the chiefs, at that time not firmly supported, in a time of revolution cannot punish all that are guilty, without meeting with new difficulties. But now a-days the Aurora of peace hails us, with the glimpse of a less stormy time; now that the calm of victory has succeeded to the trouble of a dreadful war, every thing in St. Domingo ought to assume a new face, and its government henceforward be that of justice.

Done at the Head-Quarters, Fort Dauphin, November 29, 1803.

(Signed) Dessalines.

Christophe.

Clerveaux.

True Copy, B. Aime, Secretary. ${ }^{419}$ 
NO. XIV.

(Referred to in p. 211.)

Proclamation for a solemn Abjuration of the French Nation.

\section{LIBERTY OR DEATH! — NATIVE ARMY. THE GENERAL IN CHIEF TO THE PEOPLE OF HAYTI.}

\section{Citizens,}

IT is not enough to have expelled from your country the barbarians who have for ages stained it with blood - it is not enough to have curbed the factions which, succeeding each other by turns, sported with a phantom of liberty which France exposed to their eyes. It is become necessary, by a last act of national authority, to ensure for ever the empire of liberty in the country which has given us birth. It is necessary to deprive an inhuman government, which has hitherto held our minds in a state of the most humiliating torpitude, of every hope of being enabled again to enslave us. Finally, it is necessary to live independent, or die. Independence or Death! Let these sacred words serve to rally us - let them be signals of battle, and of our re-union.

Citizens - Countrymen - I have assembled on this solemn day, those courageous chiefs, who, on the eve of receiving the last breath of expiring liberty, have lavished their blood to preserve it. These generals, who have conducted your struggles against tyranny, have not yet done. The French name still darkens our plains: every thing recals the remembrance of the cruelties of that barbarous people. Our laws, our customs, our cities, every thing bears the characteristic of the French. - Hearken to what I say! - the French still have a footing in our island! and you believe yourselves free and independent of that republic, which has fought all nations, it is true, but never conquered those who would be free! What! victims for fourteen years by credulity and forbearance! conquered not by French armies, but by the canting eloquence of the proclamations of their agents! When shall we be wearied with breathing the same air with them? What have we in common with that bloody-minded people? Their cruelties compared to our moderation - their colour to ours - the extension of seas which separate us - our avenging climate - all plainly tell us they are not our brethren; that they never will become such; and, if they find an asylum among us, they will still be the instigators of our troubles and of our divisions. Citizens, men, women, young and old, cast round your eyes on every part of this island; seek there your wives, your husbands, your brothers, your sisters - what did I say? seek your children - your children at the breast, what is become of them? I shudder to tell it - the prey of vultures. Instead of these interesting victims, the affrighted eye sees only their assassins - tigers still covered with their blood, and whose terrifying presence reproaches you for your insensibility, and your guilty tardiness to avenge them - what do you wait for, to appease their manes? Remember that you have wished your remains to be laid by the side of your fathers - When you have driven out tyranny - will you descend into their tombs, without having avenged them? No: their bones would repulse yours. And ye, 
invaluable men, intrepid Generals, who, insensible to private sufferings, have given new life to liberty, by lavishing your blood; know, that you have done nothing if you do not give to the nations a terrible, though just example, of the vengeance that ought to be exercised by a people proud of having recovered its liberty, and zealous of maintaining it. Let us intimidate those, who might dare to attempt depriving us of it again: let us begin with the French; let them shudder at approaching our shores, if not on account of the cruelties they have committed, at least at the terrible resolution we are going to make - To devote to death whatsoever native of France should soil with his sacrilegious footstep, this territory of liberty.

We have dared to be free-let us continue free by ourselves, and for ourselves; let us imitate the growing child; his own strength breaks his leading-strings, which become useless and troublesome to him in his walk. What are the people who have fought us? what people would reap the fruits of our labours? and what a dishonourable absurdity, to conquer to be slaves!

Slaves-leave to the French nation this odious epithet; they have conquered to be no longer free-let us walk in other footsteps; let us imitate other nations, who, carrying their solicitude into futurity, and dreading to leave posterity an example of cowardice, have preferred to be exterminated, rather than be erased from the list of free people. Let us, at the same time, take care, lest a spirit of proselytism should destroy the work - let our neighbours breathe in peace - let them live peaceably under the shield of those laws which they have framed for themselves; let us beware of becoming revolutionary fire-brands - of creating ourselves the legislators of the Antilles - of considering as a glory the disturbing the tranquillity of the neighbouring islands; they have not been, like the one we inhabit, drenched with the innocent blood of the inhabitants - they have no vengeance to exercise against the authority that protects them; happy, never to have experienced the pestilence that has destroyed us, they must wish well to our posterity.

Peace with our neighbours, but accursed be the French name-eternal hatred to France: such are our principles.

Natives of Hayti-my happy destiny reserves me to be one day the centinel who is to guard the idol we now sacrifice to. I have grown old fighting for you, sometimes almost alone; and if I have been happy enough to deliver to you the sacred charge confided to me, recollect it is for you, at present, to preserve it. In fighting for your liberty, I have laboured for my own happiness: before it shall be consolidated by laws which shall ensure individual liberty, your chiefs whom I have assembled here, and myself, owe you this last proof of our devotedness.

Generals, and other chiefs, unite with me for the happiness of our country: the day is arrived - the day which will ever perpetuate our glory and our independence.

If there exist among you a lukewarm heart, let him retire, and shudder to pronounce the oath which is to unite us. Let us swear to the whole world, to posterity, to ourselves, to renounce France for ever, and to die, rather than live under its dominion - to fight till the last breath for the independence of our country. 
And ye, people, too long unfortunate, witness the oath we now pronounce: recollect that it is upon your constancy and courage I depended when I first entered the career of liberty to fight despotism and tyranny, against which you have been struggling these last fourteen years; remember that I have sacrificed every thing to fly to your defence - parents, children, fortune, and am now only rich, in your libertythat my name has become a horror to all friends of slavery, or despots; and tyrants only pronounce it, cursing the day that gave me birth; if ever you refuse or receive with murmuring the laws, which the protecting angel that watches over your destinies, shall dictate to me for your happiness, you will merit the fate of an ungrateful people. But away from me this frightful idea: You will be the guardians of the liberty you cherish, the support of the Chief who commands you.

Swear then to live free and independent, and to prefer death to every thing that would lead to replace you under the yoke; swear then to pursue for everlasting, the traitors, and enemies of your independence.

J. J. DESSALINES.

Head-quarters, Gonaives, 1st Jan. 1804, 1st Year of Independence. ${ }^{420}$

NO. XV.

(Referred to in p. 214.)

Communication of the Intentions of the Black Government on the Appointment of a Governor-General for Life.

\section{Liberty or Death!}

A Proclamation.

Jean Jacques Dessalines, Governor-General, to the Inhabitants of Hayti:

CRIMES, the most atrocious, such as were hitherto unheard of, and would cause nature to shudder, have been perpetrated. The measure of their cruelty overflowed. At length the hour of vengeance has arrived, and the implacable enemies of the rights of man have suffered the punishment due to their crimes.

My arm, raised above their heads, has too long delayed to strike. At that signal, which the justice of God has urged, your hands, righteously armed, has brought the axe to bear upon the decrepit tree of slavery and prejudice. In vain had time, and more especially the infernal politics of Europeans, defended it with triple brass; you have stripped it of its armour; and have placed it upon your heart, that you may become (like your natural enemies,) cruel and merciless. Like an overflowing and mighty torrent, that bears down all opposition, your vengeful fury has swept away, every obstacle to its impetuous course. Perish thus! all tyrants over innocence, all oppressors of mankind!

What then? Bent for many ages under an iron yoke, the sport of the passions, or the injustice of men, and of the caprices of fortune; mutilated victims of the cupidity 
of white Frenchmen; after having fattened by our toils, these insatiate blood-suckers, with a patience and resignation unexampled, we should again have seen that sacrilegious horde attempt our destruction, without any distinction of sex or age; and we, whom they call, men without energy, of no virtue, of no delicate sensibility, should not we have plunged in their breast the dagger of desperation? Where is that Haytian so vile, Haytian so unworthy of his regeneration, who thinks he has not fulfilled the decrees of the Eternal, by exterminating these blood-thirsty tigers? If there be one, let him fly; indignant nature discards him from our bosom; let him hide his infamy far from hence; the air we breathe, is not suited to his gross organs; it is the air of liberty, pure, august, and triumphant.

Yes, we have rendered to these true cannibals, war for war, crime for crime, outrage for outrage; yes, I have saved my country; I have avenged America. ${ }^{421}$ The avowal I make in the face of earth and heaven, constitutes my pride and my glory. Of what consequence to me is the opinion which contemporary and future generations will pronounce upon my conduct? I have performed my duty; I enjoy my own approbation; for me that is sufficient. But, what am I saying? The preservation of my unfortunate brothers, and the testimony of my own conscience, are not my only recompence: I have seen two classes of men, born to cherish, assist, and succour one anothermixed in a world, and blended together-crying for vengeance, and disputing the honor of the first blow.

Blacks and Yellows, whom the refined duplicity of Europe for a long time endeavoured to divide; you, who are now consolidated, and make but one family; without doubt it was necessary that our perfect reconciliation should be sealed with the blood of your butchers. Similar calamities have hung over your proscribed heads; a similar ardor to strike your enemies has signalized you: the like fate is reserved for you, and the like interests must therefore render you for ever one, indivisible, and inseparable. Maintain that precious concord, that happy harmony, amongst yourselves; it is the pledge of your happiness, your salvation, and your success; it is the secret of being invincible.

It is necessary, in order to strengthen these ties, to recal to your remembrance the catalogue of atrocities committed against our species; the intended massacre of the entire population of this island, meditated in the silence and sang-froid of the cabinet; the execution of that abominable project to me was unblushingly proposed, when already begun by the French, with the calmness and serenity of a countenance accustomed to similar crimes. Guadaloupe pillaged and destroyed; ${ }^{422}$ its ruins still reeking with the blood of the children, women, and old men put to the sword; Pelage ${ }^{423}$ (himself the victim of their craftiness), after having basely betrayed his country and his brothers; the brave and immortal Delgresse ${ }^{424}$ blown into the air with the fort he defended, rather than accept their offered chains. Magnanimous warrior! that noble death, far from enfeebling our courage, serves only to rouse within us the determination of avenging or of following thee. Shall I again recal to your memory the plots lately framed at Jeremie? ${ }^{425}$ the terrible explosion that was to be the result, notwith- 
standing the generous pardon granted to these incorrigible beings at the expulsion of the French army? The deplorable fate of our departed brothers in Europe? and (dread harbinger of death) the frightful despotism exercised at Martinique? ${ }^{426}$ Unfortunate people of Martinique, could I but fly to your assistance, and break your fetters! Alas! an insurmountable barrier separates us; yet, perhaps a spark from the same fire which enflames us, will alight on your bosoms: perhaps, at the sound of this emotion, suddenly awakened from your lethargy, with arms in your hands, you will reclaim your sacred and indelible rights.

After the terrible example I have just given, sooner or later Divine Justice will unchain on earth some mighty minds, above the weakness of the vulgar, for the destruction and terror of the wicked. Tremble! tyrants, usurpers, scourges of the new world! Our daggers are sharpened, your punishment is ready! Sixty thousand men, equipped, inured to war, obedient to my orders, burn to offer a new sacrifice to the manes of their assassinated brothers. Let that nation come who may be mad or daring enough to attack me. Already at its approach, the irritated Genius of Hayti, arising from the bosom of the ocean, appears; his menacing aspect throws the waves into commotion, excites tempests, and with his mighty hand disperses, or dashes fleets in pieces; to his formidable voice the laws of nature pay obedience; disease, plague, famine, conflagration, poison, are his constant attendants. But why calculate on the assistance of the climate and of the elements? Have I forgot that I command a people of no common cast, brought up in adversity, whose haughty daring, frowns at obstacles, and increases by dangers? Let them come, these homicidal cohorts? I wait for them with a firm, and steady eye. I abandon to them freely the shore, and the places where cities have existed, but woe to those who may approach too near the mountains! It were better for them that the sea received them into its profound abyss, than to be devoured by the anger of the children of Hayti.

"War, even to Death, to Tyrants!" this is my motto; "Liberty! Independence!" this is our rallying cry.

Generals, Officers, Soldiers, somewhat unlike him who has preceded me, the ExGeneral Toussaint L'Ouverture, I have been faithful to the promise I made to you, when I took up arms against tyranny, and whilst the last spark of life remains in me I will keep my oath. "Never again shall a colonist, or an European, set his foot upon this territory with the title of master or proprietor." This resolution shall henceforward form the fundamental basis of our constitution.

Should other chiefs, after me, by pursuing a conduct diametrically opposite to mine, dig their own graves, and those of their own species, you will have to accuse only the law of destiny, which shall have taken me away from the happiness and welfare of my fellow-citizens. May my successors follow the path I shall have traced for them! It is the system best adapted for consolidating their power; it is the highest homage they can render to my memory.

As it is derogatory to my character, and my dignity, to punish the innocent for the crimes of the guilty, a handful of whites, commendable by the religion they have 
always professed, and who have besides taken the oath to live with us in the woods, have experienced my clemency. I order that the sword respect them, and that they be unmolested. ${ }^{427}$

I recommend anew, and order all the Generals of Departments, \&c. to grant succours, encouragement, and protection, to all neutral and friendly nations, who may wish to establish commercial relations in this island.

Head-Quarters at the Cape, 28th April, 1804, first year of independence, The Governor-General, (Signed) Dessalines. A true Copy,

The Secretary-General, Juste Chanlatte." ${ }^{228}$

NO. XVI.

(Referred to in p. 214.)

Caution to the Spaniards.

\section{Liberty Or Death!}

A PROCLAMATION.

Jean Jacques Dessalines, Governor-General, to the Inhabitants of the Spanish Part of the Island:

SCARCE had the French army been expelled, when you hastened to acknowledge my authority; by a free and spontaneous movement of your heart, you ranged yourselves under my subjection. More careful of the prosperity than desirous of the ruin of that part which you inhabit, I gave to this homage a favourable reception. From that moment I have considered you as my children, and my fidelity to you remains undiminished. As a proof of my paternal solicitude, within the places which have submitted to my power, I have proposed for Chiefs, none but men chosen from amongst yourselves. Jealous of counting you in the rank of my friends, that I might give you all the time necessary for recollection, and that I might assure myself of your fidelity, I have hitherto restrained the burning ardor of my soldiers. Already I congratulate myself on the success of my solicitude, which had for its object, to prevent the effusion of blood; but at this time a fanatic priest had not kindled in your breasts the rage which predominates therein; the incensed Frerand ${ }^{429}$ had not yet instilled into you the poison of falsehood and calumny. - Writings, originating in despair and weakness, have been circulated; and immediately some amongst you, seduced by perfidious insinuations, solicited the friendship and protection of the French; they dared to outrage my kindness, by coalescing with my cruel enemies. Spaniards, reflect! On the brink of the precipice which is dug under your feet, will that diabolical minister save you, when with fire and sword I shall have pursued you to your last entrenchments?

Ah! without doubt, his prayers, his grimaces, his relics, would be no impediment to my career. Vain as defenceless, can he preserve you from my just anger, after I shall 
have buried him, and the collection of brigands he commands, under the ruins of your capital! Let them both recollect that it is before my intrepid phalanx that all the resources and the skill of Europeans have proved ineffectual; and that into my victorious bonds the destiny of the Captain-General, Rochambeau, has been surrendered. To lure the Spaniards to their party, they propagate the report, that vessels laden with troops have arrived at St. Domingo. Why is it not the truth? They little imagine that, in delaying to attack them until this time, my principal object has been to suffer them to increase the mass of our resources, and the number of our victims. To spread distrust and terror, they incessantly dwell upon the fate which the French have just experienced; but have I not had reason to treat them so? The wrongs of the French, do they appertain to Spaniards; and must I visit on the latter the crimes which the former have conceived, ordered, and executed on our species! They have the effrontery to say, that, reduced to seek safety in flight, I am gone to conceal my defeat in the southern part of the island. Well, then! now let them learn that I am ready; that the thunderbolt is about to fall on their heads. Let them know, that my soldiers are impatiently waiting for the signal to go and reconquer the boundaries which nature and the elements have assigned to us. A few moments more, and I shall crush the remnant of the French under the weight of my mighty power.

Spaniards! you, to whom I address myself, solely because I wish to save you; you who, for having been guilty of evasion; shall soon preserve your existence only so far as my clemency may deign to spare you; it is yet time; abjure an error which may be fatal to you, and break off all connection with my enemy, if you wish your blood may not be confounded with his. Name to me, without delay, that part of your territory on which my first blow is to be struck, or inform me whether I must strike on all points without discrimination. I give you fifteen days, from the date of this notification, to forward your last intentions, and to rally under my banners. You are not ignorant, that all the roads of St. Domingo in every direction, are familiar to us; that more than once we have seen your dispersed bands fly before us. In a word, you know what I can do, and what I dare; think of your preservation.

Receive here the sacred promise which I make - not to do any thing against your personal safety or your interest, if you seize upon this occasion to shew yourselves worthy of being admitted amongst the children of Hayti.

Head-Quarters at the Cape, May 8th, 1804, first year of independence,

The Governor-General,

(Signed) Dessalines.

A true Copy,

The Secretary-General,

Juste Chanlatte. ${ }^{430}$

NO. XVII.

(Referred to in p. 215.)

Programa issued to direct the Order of the Ceremonies on the Coronation

of Jean Jacques, the First Emperor of Hayti, 
on the 8th of October all the troops of the garrison, in the best order possible, will march under arms to the Champ de Mars at two o'clock, A. M. precisely, and form in square battalions.

A detachment of grenadiers immediately to form a line to the house of the Commandant-General of Division.

At three o'clock the Members of all the Civil and Military Authorities, having assembled at the Government House, will proceed from thence to the Champ de Mars in the following procession:

A Platoon of Grenadiers.

The Public Teachers,

Conducting a great Number of their Pupils.

The Deputation of the Body of Artisans,

Preceded by a Chief Artisan.

A Deputation of Agriculturists,

Preceded by one of their principal Members.

A Deputation of Foreign Commerce,

Preceded by one of its Members.

A Deputation of National Commerce,

Preceded by one of its Members.

The Members of Justice, and the Ministerial Officers.

The Health Officers of the Army, attached to the Division.

The Officers of the Military Marine.

The Etat-Major of the place, connected with that of the Circuit.

The Administrators, and those in their employ.

The General commanding the Divisions,

Accompanied by his Etat-Major.

A Platoon of Grenadiers.

Arrived at the Champ de Mars, all the drums shall beat a march, and the procession shall advance to an Amphitheatre which shall be prepared for its use.

The Act announcing the nomination of the "Emperor," (DEsSALINES) shall be read in a loud and intelligible voice!

A discharge of musketry and of cannon, which shall be repeated by all the forts of the city, and vessels in the harbour, shall follow the reading of the act.

The ceremony of the Coronation shall next take place on a throne, elevated in the midst of the Amphitheatre, and surrounded by all the great Officers of the Empire.

The ceremony shall be announced by a triple discharge of cannon and musketry.

After the ceremony, the troops shall file off to the church, and form in order of battle.

The Procession, in the order abovementioned, shall also advance to the Church, where a Te Deum, in thanksgiving for this memorable day, shall be sung. 
During the Te Deum, a third discharge of cannon and musketry shall take place.

After the Te Deum, the Procession shall return, in the same order, to the house of the General of Division.

The Fete shall terminate by a grand illumination in all parts of the city.

Done at Port-au-Prince, the 6th September, 1804, the first year of independence,

The General of Division,

(Signed) A. Petion. ${ }^{431}$

NO. XVIII.

(Referred to in p. 68, \&c.)

A View of the Distribution of the Black Force in the French Colonies at the Revolution of St. Domingo, from the Official Returns.

\begin{tabular}{|c|c|c|c|}
\hline \multicolumn{2}{|c|}{ Chief Places, or Jurisdictions. } & \multirow{2}{*}{$\begin{array}{l}\text { Quarters, or Parishes. } \\
\text { The Cape and its dependencies }\end{array}$} & \multirow{2}{*}{$\begin{array}{r}\text { No. of } \\
\text { negroes. } \\
21,613\end{array}$} \\
\hline & & & \\
\hline & & The Petite Anse and Plain of the Cape & 11,122 \\
\hline & & L'Acul, Limonade, and St. Susan & 19,876 \\
\hline & THE CAPE & Morin and the Great River & 18,554 \\
\hline & & Dondon and Marmelade & 17,376 \\
\hline & & Limbé and Port Margot & 15,978 \\
\hline & & Plaisance and Le Borgne & 15,018 \\
\hline \multirow[t]{9}{*}{ Northern Part } & & Fort Dauphin & 10,004 \\
\hline & FORT DAUPHIN & Ouanaminthe and Valliere & 9,987 \\
\hline & & The Ferrier, Rouge, and the Trou & 15,476 \\
\hline & PORT DE PAIX & $\begin{array}{l}\text { Port de Paix, Little St. Louis, Jean } \\
\text { Rabel, \&c. }\end{array}$ & 29,540 \\
\hline & MOLE ST. NICHOLAS & The Mole and Bombarde & 3,183 \\
\hline & & Port au Prince, \&c. & 42,848 \\
\hline & PORT AU PRINCE & Arcahaye & 18,553 \\
\hline & & Mirebalais & 10,902 \\
\hline & LEOGANE & Leogane & 14,896 \\
\hline \multirow[t]{4}{*}{ Western Part } & ST. MARK & $\begin{array}{l}\text { St. Mark, the Little River, Verettes, and } \\
\text { Gonaïves }\end{array}$ & 57,216 \\
\hline & LITTLE GOAVE & $\begin{array}{l}\text { Little Goäve, Great Goäve, and Le Fond } \\
\text { des Nègres }\end{array}$ & 18,829 \\
\hline & & L’Anse à Vaux, Le Petit Trou & 13,229 \\
\hline & JEREMIE & Jeremie and Cape Dame Maria & 20,774 \\
\hline
\end{tabular}




\begin{tabular}{|c|c|c|c|}
\hline \multicolumn{2}{|c|}{ Chief Places, or Jurisdictions. } & \multirow{2}{*}{$\begin{array}{l}\text { Quarters, or Parishes. } \\
\text { The Cayes and Torbuk }\end{array}$} & \multirow{2}{*}{$\begin{array}{r}\begin{array}{r}\text { No. of } \\
\text { negroes. }\end{array} \\
30,937\end{array}$} \\
\hline & THE CAYES & & \\
\hline \multirow{4}{*}{ Southern Part } & TIBURON & Cape Tiburon and Les Coteaux & 8,153 \\
\hline & ST. LOUIS & St. Louis, Cavaillon, and Aquin & 18,785 \\
\hline & JACMEL & Jacmel, Les Cayes, and Baynet & 21,151 \\
\hline & & 51 Parishes & 464,000 \\
\hline
\end{tabular}

Eastern Part, not yet ceded to the French.

The difference between the above total and that furnished in page 68 , is to be accounted for by the erroneous statements of the planters to lessen the amount of the taxes, and other causes.

NO. XIX.

ADDITIONAL REMARKS, \& .

IT was intended to insert in this place a number of papers with which the author has been furnished, as collateral evidence of the sentiments which occur in his work in favor of the people of color; but, on re-considering the accumulation of matter on this subject produced by the discussion of the slave trade, and the accessibility of the works of Barbot, ${ }^{*}$ Bosman ${ }^{\dagger}$ Smith, $¥$ \&c. which all tend to shew the capacity of the African, and the eligibility of his native state, he has been led to think it less necessary; and shall, therefore, merely add the communication of an ingenious friend ${ }^{432}$ on the subject of substituting European labourers for African cultivators; and a quotation from an intelligent and respectable writer, ${ }^{\S}$ which as perfectly accords with his own sentiments, as it surpasses his powers of describing them.

"It is significantly enquired by Postlethwaite, II 'Whether Africa will not admit of a far more extensive and profitable trade with Great Britain than it ever yet has done? and whether the latter might not supply their colonies and plantations with whites instead of blacks?'

"The first of these enquiries may be readily answered in the affirmative; and the

*Account of Africa. [Jean Barbot (1655-1712), A Description of the Coasts of North and South Guinea (1732).]

${ }^{\dagger}$ Description of Guinea. [William Bosman, A New and Accurate Description of the Coast of Guinea (1705).]

†Voyage to Guinea. [William Smith, A New Voyage to Guinea (1744).]

\$The Reverend Joshua Larwood, R. N. [Joshua Larwood was chaplain on board the Britannia and rector of Swanton Morely.]

IDictionary of Trade and Commerce. [Malachy Postlethwayt (c. 1701-76), The Universal Dictionary of Trade and Commerce (1757).] 
latter demonstrated without difficulty. The condition of Africa is now, only what Britain was once; and the slavery of its inhabitants, that which has existed in every age. The one can be remedied by the means which have constituted the rise of all states; and the existence of the latter is inconsistent with the present refinement of the other three quarters of the world.*

"Without, however, referring to humane, or even refined considerations, the proposition about to be made takes its stand solely on the ground of expedience. Among the numerous reasons assigned for a rigorous treatment of negroes, are, besides their constant inclination to revolt, a decided inefficiency, and incredible expence. The high price of their first purchase, the risk of desertion, or of death, by a variety of peculiar maladies; and if neither occur, that their labour is not, by many degrees, equal to that of an European. That many Europeans support the climate with great ease, and particularly those who are abstemious, is certain; it becomes then an obvious fact, that if a sufficient number of labourers could be obtained from Europe for the cultivation of the colonies, no objection could arise to their adoption. The purchase of the negro would be saved, and the colonies relieved from his maladies, while the acquisition of property, and the evitation ${ }^{433}$ of the invidious distinction of complexion, would suppress that inclination to rebellion which the very character of slavery inspires; while the steady toil of the European labourer, even under every disadvantage, could not fail to equal the lax exertion ascribed to the negro.

"With regard to obtaining cultivators for her colonies from the population of Britain, little doubt can exist when the advanced state of this country is considered, and

*The author desires not to be considered as adopting this writer's sentiments. He is, however, of opinion with M. de Charmilly, (so often quoted in this work, and never unprofitably,) who has the following judicious ideas of negro amelioration, which have been, he is happy to be informed, partly acted on. "If I require (says he) the continuation of the trade, I also require that it should be conducted under more vigilant laws than exist at present, for the advantage of the negroes, the planter, and the merchant, in short, that well digested laws be established for regulating the tonnage of the trading ships. They should not exceed three hundred tons, nor be less than two hundred; for if the ship be large, it continues trading too long, and the scurvy and other diseases breed among the negroes first acquired; and if too small, they are too ill at ease. It ought to be settled how many negroes should be carried in each ship, according to the size, without a possibility of evading the law. It should be prohibited to export from Africa any negro more than twenty years old. Man at this age is yet capable of attaching himself to a new country, climate has but little influence upon him, and he leaves in his native land few objects of attachment, compared with the older negro, who leaves a wife and children.

"No negro should be embarked without first being inoculated; several surgeons should be attached to a ship, who should all make oath, before the sale of negroes commences in the colony to which they may be brought, that they have not by any means driven in, or repelled the maladies of negroes, which kill so great a number. These measures I admit would be more expensive, and the fitting out a trading ship would at first cost the person equipping it a still greater sum, which would finally be borne by the planter, who would be well indemnified; for, instead of purchasing two or three negroes, he would only purchase one, whom he would more easily preserve, and who would work more readily, \&c." 
the various means, which, under the appearance of inflictions, are ordered for checking the exuberance of that population that would otherwise tend to its own destruction; ${ }^{*}$ and surely moderate toil, even under a vertical sun, with sufficient provision of every kind, would not be a greater evil than that of vagrancy, or an heart-rending despondency, under the pressure of numerous evils; nor, even where the climate overcame the constitution, would the infliction be more terrible than that of war, contagion, or suicide.

"It is not intended here to recommend the introduction of felons, a resource always insufficient, but to project the prevention rather than the punishment of crimes. It is well known, and has been partially confirmed by a writer, whose declaration, as an intelligent magistrate ${ }^{\dagger}$ has had much weight, that in the metropolis alone there constantly exists an incredible number of persons, who, at a period of life when they may be considered capable of any exertion, and many of them are prepared for that of an important nature, are without the possibility of obtaining any employment of their talents, and often without the means of procuring sustenance; accessible, therefore, to the insidious approaches of vice, and the contemplated victims of a refined police, for they are soon necessarily within the knowledge of its accurate officers, and are at liberty only to exert their claim to its notice. Would it not be a happy salvation from guilt to induce by some liberal system these starving beings from the threshold of sin, to an honest exertion of their faculties, and a suitable provision? and surely if the obnoxious trade be asserted to exist principally "to save the lives of such negroes as are taken captives in African warfare, and who would otherwise have been sacrificed;" 434 the humane sentiment may at least be expected to extend to the unhappy subjects of Britain, whose lives, yet equally innocent, are becoming less secure, and who, without some interposition of Providence will be sacrificed to offended justice.

"The number of those who come under this description throughout Britain is amply sufficient to supply the colonies. Even in London they are estimated by the writer just quoted at, it is believed, 50,00o, and may be easily conceived to extend every where to a considerable number. A timely encouragement on a liberal and rational plan, would select from every quarter the objects calculated for the end, and no fear could be entertained in regard to qualifications for the business, - a subjection to the whip only excepted; and those who had felt the scourge of fate with severity, might if necessary sufficiently submit to a servile obedience by gentle gradations.

"Such a class of cultivators would increase the prosperity of a colony by a variety of means, and insure its affection to the mother country; while by obtaining establishments, each fresh importation, instead of rebellious views, would be inspired with the most pleasing prospects, and most cheering energies for labour.

"It may be safely determined, that by a liberal communication with its extensive

*See Malthus on Population. [Thomas Malthus (1766-1834), An Essay on the Principle of Population (1798).]

${ }^{\dagger}$ Colquhoun, Police of the Metropolis. [Patrick Colquhoun (1745-1820), Treatise on the Police of the Metropolis (1796).] 
coast, the continent of Africa would furnish an advantageous intercourse to Britain, and that a white population of labourers in the colonies is not only possible, but would produce the most desirable benefits to the colonies, and also to the mother country."

In a miscellaneous work entitled Erratics, ${ }^{435}$ by the gentleman before alluded to, forming a mélange of the most exquisite composition, illustrative of human nature, and general history, are the following traits of negro excellence; communicated with perfect freedom from bias to either side, which leaves us in doubt, whether most to admire the subjects or the relator.

In the church-yard of Walton, the Erratic is attracted by an elegant Latin memorial over the grave of two Africans, husband and wife, whose faithful services obtained for them this honorable distinction from Sir Patrick Blake, Bart. their master; this we will not injure by quotation, but proceed to its consequent reflections.

"Martha," (says the sensible writer,) "plucked a few sprigs of clover from the grave, placed one in her own bosom, distributed the others to her companions, and with an eye ready to gush, took me by the arm, \&c. ${ }^{* * * *}$ On our way, however, we could not refrain from pouring forth our ardent and merited eulogium upon the dignified virtue and grateful affection of the worthy Baronet who thus generously recorded the exalted qualities of his exemplary adherents. Indeed, I could even now dwell with delight upon the great credit reciprocally reflected by these parties, so fortuitously and so fortunately cast within the sphere of each other's benevolence; a mutual connexion, cemented by such exalted humanity on one side, and on the other by such cordial and consummate fidelity, that nothing less decisive and fatal than the febris vitce filum abrupens ${ }^{436}$ could have caused to decrease or decay.

- "So captivating a memorial of candid, gentlemanly, family, and liberal attachment, ought to reckon against a few West India delinquencies, and to discourage indiscriminate crimination and prejudice.

"Well, alas! too well do you and I know (for often, too often, have we seen) that there have been (I will not say are) the most flagrant violations of all human feelings, and the most atrocious wantonness of an accursed barbarity; but, amongst the noxious weeds which have disgraced the soil of the different colonies, and contaminated the atmosphere of the Antilles, let us contemplate this attractive and fragrant flower, which sheds around its balmy perfume, and counteracts the poisonous influence of such deleterious productions.

"The quem in deliciis labuit ${ }^{437}$ of our epitaph is a very just expression of the domestic and affectionate Cotto. Nor are the Cottos of sable hue more rare, or less estimable, than their fairer sisters of European celebrity. The most animated and attractive examples of pure and ardent love to the husbands of their hearts, and the fathers of their offspring, are as strikingly exhibited under the roofs of various negro huts, as are any where displayed in the families of the old world. In the laudable duties of wedded life, and the maternal offices to the precious pledges of connubial intercourse, the transported and enslaved matrons of Africa are not to be surpassed by the enlightened and free females of the freest land. 
"That they possess the finer feelings of the soul in a very eminent degree, and are delicately prompt to the most fascinating propensities of humanity, is not only apparent in their domestic and laborious stations on shore; but what incontrovertible proofs have we not seen of their steady and useful courage on board our ships of war!

"Well then might the classical and Sallustian conciseness of the Shepperton Epitaph address the candor of its readers with the generous admonition of-

"Disce ab Æthiope virtutem, et ne crede colori." ${ }^{438}$

"To virtuous Afric, lib'ral reader turn

There, from her sable sons, this maxim learn:

To no complexion is the charm confin'd,

In every climate grows the virtuous mind." 439

Epitaph on Benjamin and Cotto Blake, Erratics, vol. ii. p. 209.

THE END. 



\title{
EDITORIAL NOTES
}

\author{
Introduction
}

1. Hannibal muster, ADM 36/13670, The National Archives, Kew, United Kingdom. "St. Domingo" is the name the British used for the French colony of Saint-Domingue. "Hispaniola" refers to the island as a whole, and "Santo Domingo" to the eastern Spanish colony (ceded to France in 1795).

2. Rainsford, St. Domingo, 2d ed., 25-26.

3. Modern accounts of the British occupation of St. Domingo vary in depth and nuance. The most complete remains Geggus, Slavery, War, and Revolution, but see also Duffy, Soldiers, Sugar, and Seapower; James, The Black Jacobins, 199-223; Fick, The Making of Haiti, 183-203; Dubois, Avengers of the New World, 184-93, 215-19; and Geggus, "British Opinion and the Emergence of Haiti, 1791-1805," 123-49. For contemporary views, see Rainsford's various narratives as well as the anonymous A Particular Account of the Insurrection of the Negroes in St. Domingo, which began in 1791; An Inquiry into the Causes of the Insurrection of the Negroes in the Island of St. Domingo; Edwards, An Historical Survey of the French Colony in the Island of St. Domingo; Stephen, The Crisis in the Sugar Colonies and The Opportunity; Or, Reasons for an Immediate Alliance with St. Domingo; Chalmers, Remarks on the Late War in St. Domingo; and de Coulon, Rapport sur les Troubles de Saint-Domingue.

4. See Geggus, "The Great Powers and the Haitian Revolution," 171-78. For the general history of the Haitian Revolution see especially Dubois, Avengers of the New World, and James, Black Jacobins. Three factions were involved in the fighting: white planters, enslaved Africans, and propertied men of color. Alliances among them were complex and shifting, particularly when class and ideological interests are taken into account.

5. See Brown, Moral Capital.

6. Brathwaite, The Development of Creole Society in Jamaica, 1770-1820, 151-52.

7. See Mintz, Sweetness and Power; Dunn, Sugar and Slaves.

8. Dubois, Avengers of the New World, 166. See Edwards, An Historical Survey of the French Colony in the Island of St. Domingo, for an eyewitness account of the initial rebellion's smoldering aftermath near Cape François.

9. Fortescue, A History of the British Army, vol. 4, pt. 1, 336.

10. Geggus, Slavery, War, and Revolution, 118, 192. As Geggus notes, 1796 saw the arrival of over 10,00o additional troops in St. Domingo.

11. Quoted in James, The Black Jacobins, 141. The great black General Toussaint Louverture famously changed allegiances from the Spanish crown to the French Republic after this declaration, although the extent to which it motivated his decision to do so remains unclear. See Geggus, “The 'Volte-Face’ of Toussaint Louverture,” 119-36. 
12. Geggus, Slavery, War, and, Revolution, 397. To appreciate the racial complexity of the revolution in St. Domingo, see Fick, The Making of Haiti, 15-45; Geggus, Slavery, War, and Revolution, 1-32; James, The Black Jacobins, 27-45; Paquin, The Haitians, $12-27$.

13. The Third, Fourth, Fifth, and eventually the Seventh West India Regiments were to be raised from among French blacks in St. Domingo. See Buckley, Slaves in Red Coats, 164 n19.

14. Ibid., 4. See also Brown and Morgan, eds., Arming Slaves, and Voelz, Slave and Soldier.

15. Buckley, Slaves in Red Coats, 24.

16. Dundas to Abercrombie, January 18, 1798, co 153/31, f.234.

17. Most would come from the ranks of the enslaved, but it is important to remember that mustering in the king's service held a deep appeal for some among them who took pride in the soldier's status and regalia. See Geggus, "The Arming of Slaves in the Haitian Revolution."

18. Geggus, Slavery, War, and Revolution, 362.

19. Howard, The Haitian Journal of Lieutenant Howard, York Hussars, 1796-1798, 49-50.

2o. Ibid., 177 n134.

21. Burke, Two Letters Addressed to a Member of the Present Parliament, 155.

22. The favorite defense of not only contemporary commentators on the British occupation of St. Domingo (Edwards, Stephen, and Chalmers), but modern historians, too, including Fortescue and Geggus. Buckley resists this questionable trend.

23. Geggus, Slavery, War, and Revolution, 142.

24. Ibid., 172.

25. Ibid., 174 .

26. Ibid., 212, 206.

27. Ibid., 382 .

28. Duffy, Soldiers, Sugar, and Seapower, 184 .

29. Quoted in Dubois, Avengers of the New World, 176.

3o. Buckley, "postscript," in Howard, The Haitian Journal of Lieutenant Howard, York Hussars, 1796-1798, 138.

31. Rainsford, St. Domingo, 2d ed., 25.

32. Edward Rainsford's will of 1795 states his son Marcus's birth as "about 1755." See Buckland, The Rainsford Family, 228. The parish register from St. Giles in the Fields, Middlesex, lists the date of his burial as November 4, 1817, and gives his age as fiftynine. Rainsford was thus born in 1758 or possibly late 1757 . See London Metropolitan Archives. The name of Rainsford's mother remains unknown.

33. See Buckland, The Rainsford Family, 219-44.

34. Alumni Dublinenses, "Rainsford (Ransford) Mark," 691.

35. Rainsford, St. Domingo, 3 d ed., 28.

36. In his will, W. E. Doyle declares that "the present Mr Rainsford has withheld everything left to his brother and sister by which me and Mrs Doyle had been forced to support them." Will of Welbore Ellis Doyle, Major General of His Majesty's Forces of Ceylon, East Indies, 11 September 1798, Р вов 11/1312. Buckland's information about Marcus Rainsford is at points counterfactual. The Rainsford family tradition of 
naming sons Edward and Marcus in several consecutive generations contributes to the confusion.

37. National Archives of Canada, RG 8, c Series, v. 1886, 9.

38. On black loyalist soldiers, see Clark, Loyalists in the Southern Campaign of the Revolutionary War; Walker, The Black Loyalists, 18-39; Piecuch, Loyalists, Indians, and Slaves in the Revolutionary South, 1775-1782; Brown, Moral Capital; and Buckley, Slaves in Red Coats.

39. Almanack and Register for the Island of Jamaica, 1782.

40. Muster Books and Pay Lists, Duke of Cumberland's Regiment, 1783, ff.21, 48. wo 12/10684. Rainsford is noted "absent with leave" in the muster rolls for August 1783 .

41. See Pulis, "Bridging Troubled Waters," 183-221.

42. See Morning Chronicle, January 5, 1791, for an account of a lavish dinner party. The same month Rainsford was indicted for "giving a challenge" to a "Capt. Smith" (London Chronicle, January 22, 1791) or "General Smith" (Lloyd's Evening Post, 21 January 1791). Both articles state that Rainsford asked for the case to be moved to the Court of King's Bench.

43. [Marcus Rainsford,] The Revolution; Or, Britain Delivered, a Poem in Twelve Cantos, with Notes Historical and Explanatory. The poem was published simultaneously in Edinburgh and London.

44. As described in the London Chronicle, November 30, 1793.

45. Correspondence of William Pitt the Younger, ff.76-77, PRO 30/8/170. The National Archives dates the undated letter to 1793. Testifying to his eagerness to serve, Rainsford declares, "I have therefore the honor to acquain [sic] you, Sir, that on the late Spanish business We the Officers on half Pay of his Majesty American Forces petition his Majesty to be employed, hoping his Majesty would be pleased to allow some arrangement of Rank in his Majesty Army" (f.76). Rainsford is probably referring to the Nootka Crisis of 179o. The diplomatic incident over trade claims in the Nootka Sound in British Columbia brought Spain and England to the brink of war. Conflict was avoided only when France, in the throes of revolution, withdrew its support for Spain.

46. See Doyle, A Hundred Years of Conflict, 49-79. Doyle led the charge at the victory of Famars in May 1793 and behaved gallantly at the siege of Valenciennes in July of the same year. He contributed to protecting the retreat of the Duke of York and was later involved in the attack on Quiberon in 1795.

47. Rainsford describes these two heroic achievements in detail in his early pamphlets. The latter has him forcing the authorities of the Dutch city of Zwoll to accept ailing British soldiers within their walls, saving them from certain death. Rainsford, St. Domingo, 2d ed., 28-29. For an account of the Netherlands campaign's harrowing end, see Fortescue, A History of the British Army, vol. 4, pt. 1, 320-24.

48. Doyle, A Hundred Years of Conflict, 57.

49. wo $4 / 160$, f.264 is a letter from William Windham of the War Office, dated August 25, 1795, in which Windham presents his compliments to Captain Rainsford, most likely on his new appointment to the Third West India Regiment. Windham confirms having received Rainsford's earlier letter and "acquaints [Rainsford] that the Memorial which accompanied it, has been transmitted to Colonel Brownrigg, to be 
laid before H. R. H. the Duke of York." Rainsford's address - Oswestry, Shropshiresuggests he was staying with his brother-in-law. Doyle's descendant, Colonel Arthur Doyle, lived in Oswestry in 1911. See Doyle, A Hundred Years of Conflict, vi.

50. Rainsford appears in the Army Lists as a captain in Colonel William Keppel's Regiment (later the Third West India Regiment) on July 1, 1795. Muster Rolls, Third West India Regiment, wo 12/11449.

51. Buckley, Slaves in Red Coats, 12.

52. See letters from Henry Dundas to Major-General Adam Williamson, April 17, 1795, and June 4, 1795, wo 1/62. Illustrating the difficulty in recruiting soldiers in St. Domingo is a letter from General Whyte to Williamson: "the Legion L'Egalité wishes to join the cause of the British if I would Guarantee their freedom, and that they were willing to serve White Men for their Officers, \& promis'd either taking the other Blacks to their Habitations, or exterminate them. - I have it much to regret from the Orders I have receiv'd from General Williamson, it is not now in my Power to act in this case, as I wish." MS 1164, National Library of Jamaica.

53. Rainsford claims to have arrived in Jamaica on August 17, 1795, which sits uneasily with available evidence: In the letter of August 25, 1795, addressed to Rainsford at Oswestry, Windham mentions he "had recd. his Letter of the 23d Instt.," wo 4/16o. The dates Rainsford offers in his accounts are often erroneous, as we will see. Musters for the British garrison in Jamaica are spotty, but monthly returns for 1796 list "Officers of the 3 West India" for May through October. Returns for the following six months are missing, wo 17/1988.

54. Lord Balcarres informed Dundas he was requisitioning these troops in a letter dated August 31, 1795, Balcarres to Dundas, wo 1/92, ff.96-97. Dundas in turn in a secret letter informed Major-General Gordon Forbes, then commander in chief in the West Indies, that these troops were to remain in the island, Dundas to Forbes, November 24, 1795, wo 1/62, f.465. Maroons were blacks freed by treaty in 1739, who lived independently on their own territory with the stipulation that they would return runaways to plantations. For the Maroon War, see Dallas, History of the Maroons, from their Origin to their Chief Tribe at Sierra Leone. For a discussion of the role Maroons played in the uprising in St. Domingo, see Fick, The Making of Haiti, 51-88. For a discussion of Maroon history and culture in Jamaica, see Bilby, True Born Maroons.

55. Rainsford's absence from his regiment was typical for recruiters: "Grounds justifying an officer's absence were attendance in Parliament, if he were a Member; recruiting; urgent private business which demanded the officer's immediate personal attendance; and, of course, ill health duly certified by a qualified physician," Buckley, ed., The Napoleonic War Journal of Captain Thomas Henry Browne, 1807-1816, 317 n28.

56. Geggus, "The Arming of Slaves in the Haitian Revolution," 225.

57. Williamson to Dundas, August 5, 1795, wo 1/62. See also Buckley, Slaves in Red Coats, 43-62.

58. Jamaica Monthly Returns 1796-97, wo 17/1988-1989; Muster Rolls, Third West India Regiment, 1795-1800, wo 12/11449-11450.

59. The reason for Rainsford's need to convalesce is unclear. Newspapers give two explanations: an injury to the left arm or yellow fever. That Rainsford suffered an arm injury is corroborated by several accounts. British Parliamentary Papers for 1818 records under "pensions for loss of limbs, etc." an amount of $£ 100$ awarded to "Rains- 
ford, Marcus," rank captain, for an "injury sustained while a prisoner of war [in] St. Domingo, 1796." The date suggests that Rainsford participated in British military operations in St. Domingo. See Estimates and Accounts: Army; Navy; Ordnance; Civil List; Miscellaneous Services, vol. 13, 216-217.

6o. ADM 36/11447.

61. Lewis to Rainsford, 22 February 1797, wo 4/338, f.384.

62. Doyle would die in Ceylon in January 1798. In his will he bequeathed all of his property to his dear friend, the Earl of Moira, whom he trusted to ensure the comfort of his wife and two sons. It is likely that Moira, who had once been rumored to have had an affair with Frances, Doyle's wife, played a part in her marriage a few years later to his former aide de camp and Doyle's comrade in arms, Joseph Grimaldi of Monaco, whose first wife was guillotined in 1794 .

63. Buckley, ed., The Napoleonic War Journal of Captain Thomas Henry Browne, 18071816,24 .

64. In Rainsford's words, "it not being understood by General Keppel that his corps was to be levied there, he ordered me back to Jamaica," St. Domingo, 3d ed., 29.

65. Rainsford was paid "by agent" in July 1798 . He appears "absent by leave from 1 May last" on the musters for July to October 1798 , which suggests his leave was renewed at that date. wo $12 / 1145$.

66. HM S Hannibal Musters, May-October 1797, ADM 36/13670. Rainsford is entered as "Major Rainsford" in this document. In the Lloyd's Evening Post article announcing his arrival in England on January 13, 1797, Rainsford appears as a major, although we found no official record of such a promotion. Rainsford alludes to the possibility in a footnote when he mentions "the appointment of [. . . B Brigade Major, with which he would have been honoured” by General Colebrooke Nesbitt (1755-98), sent in February 1798 to succeed General Whyte as the governor of St. Domingo. Nesbitt died on his way to the West Indies and was replaced by Thomas Maitland. Navy musters often list Army captains as majors to avoid confusion of rank.

67. Account Book of the Deputy Paymaster General, Hispaniola, 1796-97, MS 237, National Library of Jamaica. The payment was made at Port-au-Prince by John Wigglesworth, distributed to Edward Robinson "for amount of return for 122 days pay to Capt. Rainsford of the 3rd West India Regt. from 25 Aug to 24 Dec 1797."

68. For a discussion of theater at Cape François during the revolution, see Fouchard, Le Théâtre à Saint-Domingue.

69. Haitian historian Beaubrun Ardouin describes such a review at Cape François in August 1797, whereby Toussaint Louverture meant to demonstrate his power to the Republican commissioner Sonthonax. See Etudes sur l'Histoire d'Haïti, vol. 3, 358-64.

70. Rainsford identifies a one-eyed, black general named "Muro" as commander of Fort Liberté. It is very likely that this Muro was actually Moïse, who was commander at Fort Liberté at the time. Moïse was also blind in one eye, having apparently lost it in battle: Pamphile de Lacroix has Moïse mentioning "the eye that [whites] made me lose in battle" in Mémoires, vol. 2, 48. A marginal pencil notation in the copy of Rainsford, St. Domingo, 2d ed., in the National Library of Jamaica identifies Muro as Moïse.

71. Rainsford is noted "absent without leave" from October 1798 to April 1799, when he is noted as "joined from Europe on 18th April." wo 12/11450.

72. Lewis to Rainsford, November 1, 1798; Lewis to Rainsford, December 29, 1798; 
Lewis to Rainsford, January 1, 1799: wo 4/339, ff. 355, 399, 403. Lewis explained on these three occasions that, ironically, such appeals for compensation "cannot be taken into consideration by this office, unless they are certified and recommended by the General Officer commanding the station."

73. An anonymous captain offered to exchange his commission in a West India Regiment for one in a "Regiment at home" in the Oracle and Public Advertiser of February 24, 1798; a major did the same in in the Sun of July 2, 1798.

74. Third West India Regimental Musters, 25th February 1800-18 March 180o, wo $12 / 11450$.

75. London Gazette, June 17, 18oo: “3d West India Regiment, Lieutenant Peter Webster, from the $3 \mathrm{~d}$ Foot, to be Captain of a Company, by purchase, vice Rainsford, who retires."

76. See the Monthly Review; or Literary Journal, 34 (1801), 96, and the Critical Review, or, Annals of Literature, 31 (1801), 472-74. Undaunted by the poem's tepid reception, Rainsford's publisher issued a second edition in 1801, differing from the first only in its title page, which finally revealed the identity of the anonymous poet: "Marcus Rainsford, Esq., Author of An Historical, Military, and Political Sketch of St. Domingo." Scott believed Rainsford's epic would benefit from its association with his West Indian adventures. See Rainsford, The Revolution, $2 \mathrm{~d}$ ed.

77. He appears as "a gallant officer, unimpaired by 24 years service, and alert in the service of the fair, at Buxton, and other places of fashionable resort" in Friday's Post Ipswich Journal, January 23, 1802.

78. Events in St. Domingo were a regular feature in newspapers and journals throughout the long war: among newspapers, the Times of London and the London Gazette; among journals the Annual Register and Cobbett's Weekly Political Register.

79. Chalmers, Remarks on the Late War in St. Domingo, 80.

8o. Stephen, The Crisis in the Sugar Colonies, 161, 84 .

81. Ibid., 28.

82. Stephen had an answer: "From this counter-revolution, we are taught as Englishmen to expect none but happy consequences. 'It is to put an end, to the dangerous situation of our own Islands!'” Ibid., 93.

83. The only extended account of Toussaint then available in English was a translation of Jean-Louis Dubroca's mean-spirited sketch. See The Life of Toussaint Louverture, Chief of the French Rebels in St. Domingo. For a recent biography, see Bell, Toussaint Louverture.

84. See the Monthly Mirror, vol. 13, 250, and the British Critic, vol. 20, 212. Among continental journals, see Göttlingische gelehrte Anzeigen, vol. 1, 407, and Der Bote aus Thüringen, 157. Rainsford himself mentions the Merchant, published in Rotterdam.

85. Confident that his memoir "formed the only correct document on the subject in this country," Rainsford expanded it into a "general though cursory view of everything that has relation to the present state of this extraordinary republic," St. Domingo, $2 \mathrm{~d}$ ed., 7-8.

86. The portrait was allegedly engraved after "a correct outline of the author taken on the spot," and meant to counteract the "many grotesque figures of Toussaint" previously published. Rainsford, St. Domingo, 3d ed., 3. This edition was reviewed in the Annual Review; and History of Literature, vol. 1, 333-36. 
87. Rainsford, St. Domingo, 3d ed., 6o. For a detailed British account of the French invasion of St. Domingo and Toussaint's grudging surrender, see the Annual Register, vol. 44, 209-20.

88. An Hymeneal on the Marriage of the Right Hon. Francis, Earl of Moira. The only known copy is held at the Bodleian Library, Oxford University. It is signed "Marcus Rainsford, author of the Revolution, St. Domingo, etc. etc."

89. "LiNES, on the Death of the late and truly benevolent great Doctor Darwin, of Derby," The Gentleman's Magazine, vol. 72, pt. 2, 653:

Darwent, no more thy winding stream I trace, With pensive step, and mute inclining ear; To this high-polished song, whose easy grace Nature herself was emulous to hear.

She bade the Muse her sweetest lesson tell, To him whose tuneful aid could bid it swell, In strains more pure than Maro's softest lines; DARWIN, the fairest wreath that Flora twines, To deck the year's full bounty, should be thine. Enough for me, that in one artless line, While my full heart with tender friendship beats, And mem'ry calls me back to thy retreats, I say, thou wert all that the good should be, Darwent, thy banks no more have charms for me.

90. France's influence in the Caribbean was considerably diminished with the loss of St. Domingo. Napoleon would cut his losses in the Americas by selling the Louisiana Territory to the United States in 1803 for 15 million dollars.

91. Rainsford corresponded with Robert Sutherland regarding a History of St. Domingo written by one of Dessalines's secretaries. See Sutherland to Rainsford, ff. 41-44, wo 1/75. Sutherland was a prominent British merchant who settled in Haiti. He was personally acquainted with Dessalines, Christophe, and Pétion, and would lobby Pétion to fund Simon Bolivar's revolution in South America. See Slatta and de Grummond, Simon Bolivar's Quest for Glory, and Paul Verna, Robert Sutherland: un amigo de Bolívar en Haíti. Though Sutherland does not name him, the secretary in question may have been Louis-Félix Boisrond Tonnerre, who published in 1804 Mémoires pour servir à l'Histoire d'Hayti, or Pompée Valentin de Vastey, who became Christophe's secretary after Dessalines's assassination. Rainsford would translate some of Vastey's pamphlets.

92. Under the titles St. Domingo, of het land der Zwarten in Hayti en deszelfs Omwenteling (Dutch) and Geschichte der Insel Hayti: Oder, St. Domingo besonders des aufderselben errichteten Negerreichs (German).

93. See note 59 above.

94. See the London Gazette, November 6, 1813.

95. For King Henry I's political relationship with Britain, see Trouillot, Le gouvernement du roi Henri Christophe.

96. Louis XVIII's Minister of Marine and the Colonies, Baron Pierre-Victor de Malouet, had once owned plantations on the island and served in administrative roles 
there. Malouet sent agents to the two Haitian rulers, hoping at best to convince them (mulatto President Pétion in particular) to submit to French rule, or at least to find out enough about present forces to make possible a French return. The mission led by adjutant-general Dauxion-Lavaysse was a miserable failure: Pétion did not bite, and Christophe arrested Franco de Medina, the agent sent to speak to him. Secret instructions from Malouet were found on his person revealing a plan to reestablish slavery and arrest and execute all Haitian officers likely to fight French rule. For more detail, see Jean-François Brière, Haïti et la France, 1804-1848, 57-72.

97. For more on Vastey's pamphlets, see Chris Bongie, Friends and Enemies, 112-18, 227-50. Bongie considers Vastey "the first Haitian writer of any note" and argues for the "pioneering nature of Vastey's work," 235, 114.

98. Times of London, November 24, 1814.

99. Another article published in the Times on January 24, 1815, and translated from the Royal Gazette of Hayti of November 20, 1814, describes a banquet at the Haitian court in which the Count St. Louis toasted "the brave and virtuous Major Rainsford; he has only one arm, and he offers it for the cause of the defence of the Haytians; animated with a sentiment so noble, that arm is worth a thousand!" The question of how and when Rainsford injured his arm remains unanswered.

100. Morning Chronicle, February 18, 1815. The appointment is corroborated by an account in the Italian Gazzetta di Milano of June 28, 1816, 706. Like the German Erlanger Real-Zeitung of the same date (217-18), the newspaper describes a banquet held by Rainsford in honor of Haiti and King Henry, at which the French émigré journalist and agent for King Henry I in London Jean-Gabriel Peltier delivered a speech in which he declared that "The promotion of Major Rainsford to the grade of lieutenant-general of the Haitian army, is a bright proof of the excellent criterion adopted by His Majesty the King of Haiti, and of the great-heartedness with which he compensates his servants." Rainsford's speech on the same occasion is worth quoting at length: "I love Haitians. I fought with them in the glorious struggle for their freedom and their independence: if they need again my services in the future, they would find in me a faithful soldier (enthusiastic applause). I joined their rank in my early youth and their bountiful generosity has largely compensated me for the services rendered. [...] By supporting the cause of this favored island, I fought for the cause of freedom and justice, always dear to the heart of an Englishman (thrilled applause). Republican France had emancipated the island, Bonaparte wanted to tie it down again in chains, but the lightning of the Omnipotent freed them from this new disgrace. I had the honor to lead them in their fight, and of 70,000 men that their oppressors sent against them, a very few returned home. Haitians now form a nation that wishes to live in the most intimate harmony with Great Britain and I am flattered that our government will not delay in recognizing the independence of this generous people" (translation Sara Marzioli).

101. Marcus Rainsford, Translation of an Official Communication from the Government of Hayti. The only surviving copy is in the Library of Congress and is signed by Rainsford and dedicated by him to His Royal Highness the Duke of Sussex. On the very last page, a note above Rainsford's signature indicates that this "original Haitian publication" was reprinted in England. In it Vastey made public secret letters from Louis XVIII's agent Pierre-Marie Sébastien Catineau Laroche meant to influence Pétion. In Vastey's version of events, he fallaciously becomes "agent of Pétion." 
102. "Marcus Rainsford, Nov. 4 1817, age 59." London Metropolitan Archives, Transcript of Burials, January 1817 to December 1817. It is likely that Rainsford was buried in what is now St Pancras Gardens in London. Our thanks to Joanne Youngquist.

103. Will of Marcus Rainsford, December 12, 1818, Р RO в 11/1611.

104. Following a list of errors contained in Rainsford's book, the reviewer from the Edinburgh Review states: "from these observations, our readers will be enabled to estimate the credit due to Mr Rainsford's statements, both by attending to his opportunities of information, and considering the bent of his prejudices," Edinburgh Review 8: 58. The reviewer also suggests that "some of Mr Rainsford's account of manners, and of the comforts of the lower orders in this singular commonwealth, we have occasionally suspected of exaggeration" (6o).

105. Rainsford, An Historical Account of the Black Empire of Hayti, 5.

106. [Rainsford], The Revolution, 1791, iii.

107. Hayley later published The Life of Milton, in three parts, a laudatory biography of Milton, expanded from an earlier biographical sketch.

108. Hayley, An Essay on Epic Poetry, 137.

109. Ibid., 105, 1l. 183-84.

110. Ibid., 5, 1l. 43-48.

111. Ibid., 103, ll. 131-32.

112. Ibid., 110, 1l. 287-88.

113. Ibid., 114, 11. 373-76.

114. The phrase is Stuart Curran's. He notes: "It is hard to imagine such thumping couplets inflaming anyone's imagination, and yet Hayley's enthusiasm, his learning, and his humane principles were taken to heart by his culture. [...] By the turn into the new century the British reader had a number of candidates for the great national poem the country lacked." See Poetic Form and British Romanticism, 161. Curran cites James Ogden's 1790 poem The Revolution: An Epic Poem, in Twelve Books as "the first note in harmony" with Hayley's call. Although Curran also mentions The Revolution; Or, Britain Delivered, he remains unaware that Rainsford was the author. Curran mentions only these two texts, but there are others that support his argument about the cultural influence of Hayley's essay. William Blake published the first and only extant book of The French Revolution in 1791.

115. [Rainsford], The Revolution, 1791, iii.

116. For instance d'Orléans, Histoire des révolutions d'Angleterre (translated into English in 1709); Echard, The History of the Revolution and the Establishment of England in the Year 1688; or Hume, A History of England from the Invasion of Julius Caesar to the Revolution in 1688.

117. [Rainsford], The Revolution, 1791, 5-6.

118. "Thus the principal actor in this Poem, is capable of sustaining the character of an Hero, without the aid of fiction, in which respect historical facts are strictly attended to, and the Machinery arising out of them, is only introduced upon the allowed privilege of Poesy, to simplify, and decorate the narrative. Subordinate characters in this Poem, have likewise a foundation in historical facts [...]." Ogden, "Introduction," The Revolution, xvi.

119. [Rainsford], The Revolution, 180o, vii.

120. Monthly Review 34: 96. The Critical Review complained similarly in even 
harsher terms: "from the errors which continually occur throughout the poem, in the position of accent, we are sometimes inclined to think [the author] is one of his majesty's German, French or, peradventure, Corsican subjects," "Review of The Revolution; Or, Britain Delivered. A Poem, in Ten Cantos," Critical Review 33:473.

121. Critical Review 33:472.

122. Monthly Review 34: 96.

123. For a recent reassessment of the Glorious Revolution, see Pincus, 1688.

124. [Rainsford], The Revolution, 1800, 123.

125. Ibid., 46.

126. [Rainsford], The Revolution, 1791, 20.

127. Rainsford, A Memoir, advertisement.

128. Rainsford mentions a host of sources in his introduction, including Columbus, Journal; Peter Martyr, De Orbe Novo; de Las Casas, A Short Account of the Destruction of the Indies; Le Pers, Histoire de I'Isle Espagnole ou de Saint-Domingue; Du Tertre, Histoire générale des Antilles habitées par les Français; Labat, Nouveaux voyages aux iles de l'Amérique; G. Raynal, Philosophical and Political History of the Settlements and Trade of the Europeans in the East and West Indies; Robertson, The History of America; Edwards, History, Civil and Commercial, of the British Colonies in the West Indies, and Historical Survey of the French Colony in the Island of St Domingo; de Charmilly, Lettre à M. Bryan Edwards, en Réfutation de son Ouvrage; Long, The History of Jamaica; Dubroca, The Life of Toussaint Louverture, Chief of the French Rebels in St. Domingo; and Chalmers, Remarks on the Late War in St. Domingo.

129. Rainsford, An Historical Account of the Black Empire of Hayti, 146.

130. Edinburgh Review 8:52-64, 54 .

131. See Anti-Jacobin Review 22:235-43; Monthly Review 52:287-98; La Belle Assemblée: Or, Bell's Court and Fashionable Magazine 2:20-25; British Critic 26:405-9; New Annual Register, 316; Eclectic Review 2, pt. 1, 405-14; Gentleman's Magazine 76, pt. 2, 6o9-13; Critical Review 9:1-9.

132. Anti-Jacobin Review 22:239.

133. Monthly Review 42:292.

134. For Rainsford's possible influence on Hegel, see Buck-Morss, Hegel, Haiti, and Universal History.

135. Edwards, An Historical Survey of the French Colony in the Island of St. Domingo, iv. 136. Ibid., xiv.

137. Ibid., 117 .

138. Clarkson gave money for guns to Vincent Ogé, the failed mulatto rebel who was broken on the wheel. See James, The Black Jacobins, 73-75.

139. An Inquiry into the Causes of Insurrection, 5.

140. See Wood, Slavery, Empathy, and Pornography, 181-99.

141. For the Haitian Revolution as "unthinkable history," see Trouillot, Silencing the Past, 70-107, and Fischer, Modernity Disavowed.

142. The cartoon is signed "M. Rainsford, inv." and was published buy T. Williamson, an engraver who also sold prints and music, best known for publishing the work of Isaac Cruikshank.

143. In St. Domingo, 2d ed., Rainsford first describes the papers he threw overboard when arrested: "views of forts [... ] (besides views of Fort Piccolet, \&c.) several Plans, 
which I hoped to have had the honor of presenting to the Duke of York" (43). This edition also includes a crude outline of the monument to Sonthonax later depicted as a temple, a seating chart of the tribunal in which Rainsford was condemned to death, as well as a map of the island engraved by John Luffmann, mapmaker and author of A Brief Account of the Island of Antigua, an epistolary account of his travels on that island in the late 1780 os. He is also known for maps of the United States and of the West Indies designed after his personal surveys of those territories.

144. In the second edition, this monument sits in the centre of a city square and is described as "a structure of wood, forming a regular ascent of steps to a kind of canopy, beneath which were two seats" (St. Domingo, 2d ed., 34).

145. Rainsford, An Historical Account of the Black Empire of Hayti, 135.

146. Ibid., 135, 137.

147. Buck-Morss argues that this engraving contains references to Masonic imagery, the structure evoking representations of Solomon's temple sometimes found on Masonic aprons. See Hegel, Haiti, and Universal History, 64-67. Representations of Solomon's temple in Masonic iconography generally include two freestanding columns in front of the structure. The closest such element in the engraving would be the two sentinels. While Rainsford was certainly surrounded by Freemasons, no evidence points to his initiation into the order. Freemasonry was a vital presence in the British army, and Irish Masons played an important part in the development of black Freemasonry in North America: Prince Hall, head of the first African American lodge, was initiated by Irish soldiers who were members of Lodge No. 441, garrisoned in Boston in 1775. Rainsford's influential acquaintance, the Earl of Moira, was among the foremost Freemasons of his day, rising to become Grand Master of the Regular Grand Lodge, a position he occupied from 1790 until 1813. See William Alexander Laurie, The History of Free Masonry and the Grand Lodge of Scotland, 167-69. Rainsford included transparent references to Freemasonry in his An Hymeneal on the Marriage of the Right Hon. Francis, Earl of Moira.

148. As noted by René Chartrand regarding this image, "the black accoutrements with oval belt plates are possibly materiel captured from the unhappy British intervention of 1793-8," Chartrand and Back, Napoleon's Overseas Army, 19. The historical accuracy of this detail remains difficult to judge, but the inclusion of English items reinforces identification, as we will see with Rainsford's portrait of Toussaint Louverture.

149. See Daguillard, Enigmatic in his Glory, 6-15. Half a dozen portraits of Toussaint were published in France in $18 \mathrm{O} 2$.

150. See advertisement for the book in the Times of London, May 18, 1802. No such claim is made in the book itself. Bonneville's youthful Toussaint is "recognizable" primarily for the French general's uniform he wears, including golden oak leaves signaling his rank embroidered on the lapels and a plumed and cockaded bicorn hat. The chapter entitled "Portrait of Toussaint Louverture" in turn offers next to nothing in way of physical description. The English translation of Dubroca's book was published in May 1802. Rainsford's portrait of Toussaint engraved by Blanchard was published by S. W. Fores on June 18, 1802.

151. Schoelcher, quoted in Tyson, Toussaint L'Ouverture, 132.

152. Quoted in Daguillard, Enigmatic in His Glory, 11. As Toussaint himself testifies: 
"I received a violent blow on the head from a cannon-ball, which knocked out the greater part of my teeth, and loosened the rest." Quoted in John Relly Beard, Toussaint L'Ouverture, 324-25.

153. In Rainsford's words, "as many grotesque figures of Toussaint have appeared, a portrait of the Black General in the field (from a correct outline of the author taken on the spot) has been done by an ingenious youth, and added to the work" (St. Domingo, 3 d ed., advertisement). The illustration is signed "H. Blanchard, sculp." - who was an engraver about whom nothing further is known. Scottish engraver and caricaturist John Kay produced and published a better known version of this engraving that same year, also included in A Series of Original Portraits and Caricature Etchings.

154. Rainsford, An Historical Account of the Black Empire of Hayti, 157.

155. Black characters were present in medieval European theatre, and became more common on the English theatre stage starting in the late sixteenth century, generally as villains. A perhaps more direct precedent ancestor of Rainsford's Toussaint is Aphra Behns's 1688 "royal slave," Oroonoko, who was infamously described as follows: "He was pretty tall, but of a shape the most exact that can be fancy'd. [...] His face was [. . ] a perfect ebony or polished jet. [. . ] His nose was rising and Roman instead of African and flat. His mouth, the finest shaped that could be seen, far from those great turn'd lips which are so natural to the rest of the Negroes. The whole proportion and air of his face was so noble and exactly form'd that, bating his colour, there could be nothing in nature more beautiful, agreeable and handsome," Oroonoko, 33. On representation of Africans in England, see Anthony Gerard Barthelemy, Black Face, Maligned Race; Derek Hughes, Versions of Blackness; Nussbaum, The Limits of the Human (more specifically the last two chapters); and Hazel Waters, Racism on the Victorian Stage.

156. Rainsford, An Historical Account of the Black Empire of Hayti, 157.

157. See Chartrand and Chappell, British Forces, in the West Indies, 1793-1815, 8.

158. Chevrons in the British and French armies appeared in the late eighteenth century as a way to indicate years of service among lower ranks, but not among commanding officers. See Emerson, Chevrons, 39.

159. Antoine Métral and Isaac Louverture, Histoire de l'expédition des français, 337 (translation Pierrot).

16o. Consider this description of the uniform worn by British black colonial troops during their campaign in St. Domingo: "This consisted of a round hat with a cockade and a plume, a red jacket with collar and cuffs of a facing color chosen by the colonel, a shirt and coarse trousers," in Chartrand and Chappell British Forces in the West Indies, $1793-1815,16$.

161. Rainsford, An Historical Account of the Black Empire of Hayti, 255-56.

162. The earliest official French-language accounts of Leclerc's and Rochambeau's use of bloodhounds appear to have been produced in Haiti. Boisrond Tonnerre mentions in passing dogs in his Mémoires pour servir à l'histoire d'Hayti (1804). Juste Chanlatte, one of King Henry I's publicists, published Le Cri de la Nature (1810), in which he discusses at length Rochambeau's use of bloodhounds. His pamphlet was later republished in France by Auguste Jean-Baptiste Bouvet de Cressé as Histoire de la catastrophe de Saint-Domingue (1824). Henry Christophe's Manifeste du Roi (1814) also mentions Rochambeau ordering the count de Noailles to import dogs from Cuba. 
Rochambeau's dogs are described succinctly in works by the former St. Domingo planters Colonel Malenfant, Des colonies, et particulièrement de celle de Saint-Domingue (1814) and Drouin de Bercy, De Saint-Domingue: de ses guerres, de ses révolutions, de ses ressources (1814).

163. Rainsford's friend was one Captain Campbell, "who had the care of those animals and their keepers in their troublesome passage from the Havannah to Jamaica" (253). Rainsford follows the official line according to which the dogs were only used to scare, rather than actually hunt, the Maroons, only to contrast British restraint with French extremity. Following the Maroon War, there had been heated debates in the English Parliament on the use of bloodhounds.

164. The images tread a thin line between exposition and exploitation. Their sensationalism proved a winning commercial strategy, pandering to a perennial taste for the Gothic. For a discussion of the influence of the Gothic on representations of the Haitian revolution, see Clavin, "Race, Rebellion, and the Gothic," and Wood, Slavery, Empathy, and Pornography.

165. British Critic 26:409.

166. Edinburgh Review 8:64. It bears noting that the engravings in the German and Dutch editions of Rainsford's book significantly alter the facial features of black and French characters. In Toussaint Louverture and the American Civil War, Clavin tracks reproductions of Rainsford's image of Toussaint in U.S. abolitionist literature in the mid-nineteenth century. Some - such as the one used on the 1838 cover of the Penny Magazine - were actually copied from the Dutch version of the engraving.

167. Its style notably inspired a portrait of the early black nationalist figure Martin R. Delany. See Clavin, Toussaint Louverture and the American Civil War, 131-34.

168. It is generally understood that Maurin sketched the portrait and Delpech engraved it, yet according to the collector François Châtillon, Delpech sketched the portrait as early as 1825 , before he died, and Maurin painted it only years later in 1838 . See de Cauna, Toussaint Louverture et l'indépendance d'Haïti, 41.

169. In Vie de Toussaint Louverture, the portrait is preceded by these words: "The portrait of L'Ouverture is authentic. - It was given by L'Ouverture himself to the agent Roume. The original for the portrait is preserved religiously in Roume's family, in the home of Count Roume de Saint-Laurent, who resides in Paris" (n.p., translation Pierrot). See Daguillard, Enigmatic in His Glory, 26-28. Historian Jacques de Cauna has voiced doubts as to the veracity of Saint-Rémy's story. See de Cauna, Mémoires du Général Toussaint Louverture, 32.

170. The portrait of Louverture was first published in 1829 with three others as the thirty-fourth delivery of the Iconographie des Contemporains, a collection of portraits that would be published in a full volume in 1832 (see Bibliographie de la France 40 [October 3, 1829], 671). Daguillard shows an early variation on this profile, engraved by Dulompré after a sketch by Alphone Louis Duc published in 1834 (Daguillard, Enigmatic in his Glory, 28). The profile published in Joseph Saint-Rémy's Vie de Toussaint-Louverture (1850) was drawn by Alphonse de Farcy and engraved by Fourquemin, and the medallion version engraved in Saint-Rémy's Mémoires du Général Toussaint-L'Ouverture (Paris: 1853) by Choubard. Because both de Farcy and Maurin's portraits are obviously derived from the same image, many commentators have freely - though erroneously - applied Saint-Rémy's story to the Maurin portrait, and 
suggested that the different artists may have copied the same original in the possession of the Count Roume de Saint-Laurent. This mysterious character, whose exact relation to Philippe-Rose Roume de Saint-Laurent remains unclear, was active for a time in independent Haiti. Joachim Roume de Saint-Laurent's life remains obscure. Historian Michel Roussier quotes documents showing that Philippe-Rose Roume sent a fifteen-year-old son named Joachim to school in France in 1799 along with Toussaint Louverture's sons. See Michel Roussier, "L'éducation des enfants de Toussaint Louverture et l'Institution nationale des colonies," 214, 244. Yet Roume does not name this son in the papers for his second marriage (contracted in St. Domingo in 1799 with Louverture as a witness), in which he does mention his daughter Rosette; see Pocock, Out of the Shadows of the Past. According to the Trinidadian historian and publisher Gerard Besson, descendents of the Roume de Saint-Laurent family living in Trinidad have no knowledge of Roume ever having had a son. Joachim Roume is best known for the part he played in the spread of the Scottish Rite Freemasonry. On this topic, see Bernheim, “Le 'Bicentenaire' des Grandes Constitutions de 1786." Joachim Roume de Saint-Laurent also played a tumultuous part in the political life of the early unified Republic of Haiti under President Boyer. He is mentioned in Ardouin, Etudes sur l'histoire d'Haïti 9:170-200; and 10:122.

171. The miniature was owned by Mrs. Edward Felder and exhibited in 1936 at the Gibbes Museum in Charleston, S.C. The exhibition catalog attributes the miniature as follows: "Marcus Rainsford, b.1750. Captain in the 3rd West India Regiment; wrote and illustrated 'An Historical Account of the Black Empire of Hayti' London 1805. He was a friend of the Pinckney family and it is thought that he painted this miniature and presented it to Miss Sarah Rutledge, Gen. Pinckney's niece, who was staying with his family at that time." Entry 133, An Exhibition of Miniatures Owned in South Carolina. Sarah Rutledge lived in England with Major Thomas Pinckney when he was U.S. ambassador to England between 1792 and 1796. It seems unlikely that Rainsford or anybody else could have given her a portrait of Louverture at that time.

172. The provenance of this miniature is vexed but fascinating. According to one account, Mrs. Felder's grandson sold the miniature to an anonymous art agent in 1962, who in turn allegedly sold it "to an agent who said he was acquiring it for Haiti" (Hellen G. McCormack to Mrs. John de Menil, June 5, 1967). In 1936 the Frick Gallery in New York purchased a copy of the Gibbes photograph of the miniature. Checking provenance of the original in 1985, the Frick Gallery concluded that "the government of Haiti" possessed it "by 1985" (Provenance, Class \#275-10a). This claim is deeply compromised, however, by the existence of what appears to be the same miniature in the collection of the New-York Historical Society. Mounted in a precisely similar frame, the ivory wafer that bears Toussaint's image is also attached to a sheet of paper bearing beneath it the inscription, "Toussaint was born November $5^{\text {th }} 1744$ according to the authority of Mr. Roume." Accompanying documentation indicates that the art dealer Gerald C. Paget offered it to the New-York Historical Society in 1956 for $\$ 500$. In a letter to its director, R.W. G. Vail, Paget mentions that "this miniature has already been shown at an exhibition of miniatures in a museum in this country [the Gibbes in 1936], at which time it was published and reproduced in the press" (NYHs Object 195.123, Gerald C. Paget to R. W. G. Vail, August 10, 1956). In another letter he provides the following unsubstantiated attribution: "The portrait was painted c. 1797 by 
Augustin Brunias (Brunyas), and is said to have been presented by Toussaint himself to Captain Reid, who was probably carrying supplies and arms to Haiti" (NYHs Object 1956.123, Gerald C. Paget to R. W. G. Vail, September 20, 1956). Although Paget asserts that the miniature "descended in the family of Captain Reid until recent times," he offers neither indication of Reid's identity nor corroboration of the attribution to Brunias, almost certainly false. Mrs. Felder seemed certain of the provenance dating back two generations, but less certain of how it originated in the Rutledge family through Rainsford. This account cannot be ignored. We take the Rutledge family's attribution of the miniature to Rainsford seriously enough to advance the possibility that he had a hand in producing it.

173. The paper to which the miniature is affixed as well as the ink and script beneath it are acceptable as late eighteenth century, as is the painting technique. The transparency of the watercolor could indicate an artist with an English or military background (continental artists tended to prefer using gouache, an opaque watercolor, for miniatures). The date "c. 1797" therefore seems reasonable.

174. Pierre Pluchon argues that the Maurin portrait is an accurate representation of Louverture, basing his judgment on such eyewitness descriptions of Louverture as that of General Caffarelli cited above. See Pluchon, Tousssaint Louverture. Many see in the transparent bias of the earlier descriptions - and by extension in the Roume portrait-examples of French prejudice against a man who by then was considered the enemy. See Bell, Toussaint Louverture, 292-94. For a more measured consideration of both possibilities, see Carlo Avierl Célius, "Les enjeux de la représentation," 342-50.

175. Rainsford, An Historical Account of the Black Empire of Hayti, 148-49.

176. England extended diplomatic recognition to Haiti in 1833. France's conditional recognition agreement of 1825 was finally granted in 1838 , and the United States did not recognize Haiti until 1862.

177. He would do so for the rest of his life, as his toast at the banquet reported in Gazzetta di Milano indicates: "To the independence of Haiti, that it be recognized as soon as possible by all the world powers!," 706 (translation Sara Marzioli).

178. James, The Black Jacobins, 388.

179. David Scott, in his book-length study of James's representation of Toussaint, argues that "if for James, that melancholic and obsessively self-regarded Prince of Denmark symbolized the emergence of a new kind of individual, the modern intellectual, I suggest that similarly, for James, Toussaint inaugurates a new kind of individual, the modern colonial intellectual." See Conscripts of Modernity, 20.

180. Rainsford, An Historical Account of the Black Empire of Hayti, 154.

181. Ibid., 155-56.

182. Rainsford's Toussaint also draws upon British theatrical tradition. The famous illustration of Toussaint included in Rainsford's book is a pictorial nod to other black heroes in British drama, most obviously Othello and Oroonoko, but more subtly to even simpler ancestors such as the many Moors of revenge tragedy. These black heroes go through the motions of tragic suffering without experiencing its inner pangs. Like them but on an epic scale, Rainsford's Toussaint is all action, no interior. James prefers the complexities of the Greek or Shakespearean tragic hero.

183. Rainsford, An Historical Account of the Black Empire of Hayti, 191.

184. Ibid., 195. 
185. See Brown, Moral Capital, especially 155-206, 333-89, 451-62. After the evacuation of St. Domingo and even more keenly after Haiti's independence, freedom for its black population became a matter of sound economic policy.

186. Rainsford, An Historical Account of the Black Empire of Hayti, 77.

187. Ibid., 218.

188. Ibid.

189. Ibid., 214 .

19o. Ibid., 56.

191. Ibid., 133.

192. Ibid., 133-34.

193. Ibid., 137.

194. Ibid., 140.

195. Ibid.

196. Ibid.

197. Ibid., 141.

198. Ibid.

199. Ibid.

200. Ibid., 130.

201. Ibid., 218.

\section{An Historical Account of the Black Empire of Hayti}

1. "Trojans, Tyrians: they will be all the same to me." Virgil, The Aeneid, bk. 1, 689.

2. "We can say with truth that there are few features of barbarism that they (the blacks) can be charged with." Venault de Charmilly, Lettre à M. Bryan Edwards. PierreFrançois Venault de Charmilly (d. 1815) was born in Paris and moved to St. Domingo in 1776 , where he became a planter and a captain in the dragoons. He was elected representative to the Colonial Assembly and early declared himself in favor of the colony's annexation by Britain. He fought for the British during the occupation and remained an officer in the English army, serving notably in the Peninsular War.

3. Philip Dormer Stanhope, Lord Chesterfield, "Preface" to James Hammond's Love Elegies (1742). The original quotation reads, "He sat down to write what he thought, not to think what he should write."

4. Edward Tyrrell Smith (1752-1824) was born in Barbados and joined the British navy at an early age, rising eventually to the rank of admiral. He took part in the British occupation of St. Domingo and was stationed primarily in Léogane.

5. Probably John Campbell, Esq., secretary to Lord Nelson. He died in 1798 during the Battle of the Nile.

6. William Curtis (1752-1829) was a banker and politician. He was MP for the city of London and director of the West and East India Dock Companies.

7. Edmund Burke, Speech on Conciliation with America (1775).

8. France. Rainsford is referring to the Terror.

9. Hispaniola refers to the island shared by present-day Haiti and the Dominican Republic. Santo Domingo was the name of the original Spanish colony established on Hispaniola. The French referred to their colony on the island as Saint-Domingue, and 
the British referred to either the French side or the entire island indiscriminately as St. Domingo.

10. Sir Hans Sloane (1660-1753) was the author of A Voyage to the Islands Madera, Barbados, Nieves, S. Christophers and Jamaica, with the Natural History of the Herbs and Trees, Four-footed Beasts, Fishes, Birds, Insects, Reptiles, \&c. Of the last of those ISLANDS; referred to in short as The Natural History (1707; 1725).

11. Christopher Columbus (1451-1506) established the first European colony in the New World on Hispaniola in 1492.

12. Peter Martyr d'Anghiera (1457-1526) wrote an early account of Hispaniola in his famous history of the New World, De Orbe Novo (1530).

13. Bartolomé de las Casas (1484-1566) lived in Hispaniola and harshly criticized Spanish treatment of the natives in A Short Account of the Destruction of the Indies (1552).

14. Antonio de Herrera y Tordesillas (1559-1625) was a Spanish historian whose Historia general de los hechos de los Castellanos en las islas y tierra firme del Mar Oceano (1601-15) relates the history of the Spanish American colonies from 1492 to 1554.

15. Amerigo Vespucci (1454-1512) refers to Hispaniola in his Letters. The "injury" mentioned by Rainsford may refer to the fact that Vespucci's suspect voyages and letters resulted in the New World bearing his name rather than Columbus's.

16. Spain ceded the western part of Hispaniola to France in 1697.

17. Pierre François Xavier de Charlevoix (1682-1761) published Histoire de I'Isle Espagnole ou de Saint-Domingue (1730), based on notes by Jean-Baptiste Le Pers. Jean-Baptiste Du Tertre (1610-87) wrote Histoire générale des Antilles habitées par les François (1667-71). Jean-Baptiste Labat (1663-1738) wrote Nouveau voyage aux isles de l’Amérique (1722).

18. Around the middle of the sixteenth century French pirates had taken control of Tortuga, a small island just north of Port-de-Paix.

19. Guillaume Thomas François Raynal (1711-96), an abbot and Enlightenment philosopher, was best known for the four-volume L'Histoire philosophique et politique des établissements et du commerce des Européens dans les deux Indes (1770), published in English translation as A philosophical and political history of the settlements and trade of the Europeans in the East and West Indies (1776).

20. William Robertson (1721-93) was a British historian who wrote The History of America (1777-96).

21. Bryan Edwards (1743-1800) was a leading English planter in Jamaica. He was a staunch supporter of the slave trade and wrote The History, Civil and Commercial, of the British Colonies in the West Indies (1793) and Historical Survey of the French Colony in the Island of St Domingo (1797).

22. François Alexandre-Stanislas, baron de Wimpffen, wrote A Voyage to Saint Domingo in the Years 1788, 1789, 1790 (1797).

23. Jean-Louis Dubroca was a French biographer in the pay of Consul Napoleon Bonaparte. He wrote The Life of Toussaint Louverture, Chief of the French Rebels in St. Domingo (1802) as well as propagandistic biographies of Jean-Jacques Dessalines and Napoleon Bonaparte.

24. Colonel James (also Charles) Chalmers (1727-1806) was born in Scotland. He made his fortune in the West Indies before settling in Maryland. A staunch Loyal- 
ist, he published pamphlets against Thomas Paine and fought in the American War of Independence as Lieutenant-Colonel of the Maryland Loyalists. After the war he relocated to Jamaica in 1785 . He participated in the expedition against Domingo as Inspector-General of the Colonial Contingent. He also published Remarks on the Late War in St. Domingo (1803).

25. Johann Wilhelm von Archenholz (1741-1812) was a famous German historian who wrote a history of pirates in the Americas entitled Geschichte der Flibustier (1803). He also edited the journal Minerva, which published translations of Rainsford's history.

26. Robert Charles Dallas (1754-1824) was born in Jamaica and wrote A History of the Maroons (1803).

27. Maroons were blacks freed by treaty inhabiting Jamaica's mountainous interior. Maroon communities still exist in the Caribbean and Central and South America.

28. William Quarrell (1750-1807) was a wealthy planter and member of the legislative assembly in Jamaica. He was instrumental in securing bloodhounds from Cuba for use in the Second Maroon War (1795-96) and afterward assisted with the transportation of a large number of Maroons from Jamaica to Halifax, Nova Scotia.

29. The Peace of Amiens (March 25, 1802-May 18, 1803) produced a temporary cessation of hostilities between Britain and France.

30. These exact coordinates are located in today's Del Este National Park on the southeast coast of the Dominican Republic. More accurate coordinates would be $19^{\circ}$ oo' $\mathrm{N}$ and $70^{\circ} 4 \mathrm{O}^{\prime} \mathrm{W}$.

31. The actual length is closer to four hundred miles from east to west.

32. The Spanish gave the name Arawak to the peaceful and docile natives they encountered in the West Indies and eastern South America. The term derives from their common language, called Arawakan. The Amerindian group indigenous to Jamaica is today known as the Taíno.

33. Slightly misquoted from Robertson's The History of America. The original reads, "In those delightful countries Nature seemed to assume another form; every tree and plant and animal was different from those of the ancient hemisphere" (vol. 1, bk. 3, 282).

34. Cibao translates "place where rocks abound." During the Spanish conquest, Cibao referred to the fertile valley located between the Central and Septentrional mountain ranges of Hispaniola.

35. Diego de Arana (1468-93).

36. Caonabo.

37. La Isabela was located in the Puerto Plata province of today's Dominican Republic. It was eventually abandoned in favor of Santo Domingo in 1496.

38. Giacomo (Diego) Columbus (1468-1515?) was Columbus's brother. Rainsford may be mistaking his name for that of Columbus's first son.

39. Don Pedro Margarita avenged the massacre at La Navidad by killing large numbers of natives during Columbus's absence.

40. Bartholomew Columbus (c. 146o-1515) was Columbus's younger brother. He was a skilled mapmaker and helped to chart his brother's famous journey to the New World. He founded the settlement of Santo Domingo in 1496.

41. Juan de Aguado accompanied Columbus on his first voyage to the New World. 
They do not appear to have had the adversarial relationship depicted by Rainsford. Nevertheless Isabella sent Aguado to Hispaniola after she received word of Columbus's harsh treatment of the natives.

42. Columbus reached South America in August 1498.

43. Santo Domingo was settled after La Isabela proved susceptible to hurricanes. It is the site of the present-day capital of the Dominican Republic and the oldest continuously occupied European settlement in the New World. Most sources suggest that it was Bartholomew rather than Diego who founded the city.

44. Francisco de Bobadilla (d. 1502).

45. Nicolás de Ovando y Cáceres (1460-1518) served as the governor of the Indies from 1502 until 1509.

46. Among those who arrived with Ovando were the conquistador Francisco Pizarro and the natives' greatest advocate, Bartolomé de las Casas.

47. Columbus arrived at Jamaica on May 4, 1494, during his second voyage. Spain began occupying the island in 1509, naming it Santiago.

48. Sugar cane was first introduced to Hispaniola by Columbus at the time of his second voyage. It thrived in the temperate Caribbean climate and spread rapidly to the other islands in the region as well as Brazil. By 1680 sugar cane had become the dominant West Indian crop. Cultivating it was an extremely laborious process requiring a large labor force. As sugar production proliferated, so too did the enslavement of native populations and increased importation of African slaves.

49. The Lucayans were the original inhabitants of the Bahamas. They had all been removed from the area by 1520 .

50. Juan Ponce de León y Figueroa (1474-1521) was an explorer and the first governor of Puerto Rico. He led the first European expedition to Florida in 1513.

51. Sebastián de Ocampo circumnavigated Cuba in 1508 and is sometimes credited with discovering the Gulf of Mexico.

52. Diego Colón Moniz (1479/80-1526) was the firstborn son of Columbus and Filipa Moniz. He was the second viceroy of the Indies, second admiral of the Indies, and fourth governor of the Indies.

53. Cubagua was discovered by Columbus in 1498. The short-lived settlement of Nueva Cádiz was established there in 1528. Today Cubagua is part of Nueva Esparta, Venezuela.

54. Located between Panama and Colombia, the Gulf of Darién is the southernmost area of the Caribbean.

55. Vasco Núñez de Balboa (1474-1519) was a Spanish conquistador and the first European to see the Pacific Ocean (then called the South Sea) from the New World.

56. Diego Velázquez de Cuéllar (1465-1524) was a Spanish conquistador who conquered and later governed Cuba. He succeeded Diego Colón as governor of the Indies.

57. Hatuey (d. 1512) was a Taíno cacique who is still celebrated as a national hero in Cuba for his bold resistance to the Spaniards.

58. These "perverted fortunes" most likely refer to Balboa's conflicts with his fatherin-law, the powerful governor of Castilla de Oro, Pedro Arias de Ávila (c. 1440-1531). Balboa's insistence on further exploring the South Sea against Pedrarias's wishes led to his arrest for treason, a hasty and unjust trial, and eventual execution. 
59. The term refers to "distributions." Worthy Spanish settlers would be apportioned a certain amount of land, which included the natives living there as well. The indigenous inhabitants were not technically slaves, although they frequently were forced to labor as tribute for instruction in the Catholic faith and Spanish language. The practice was also called encomienda during this period.

6o. By 1531 only 600 Taíno remained on Hispaniola. The native population had seen an 80-9o percent decline since the arrival of Europeans roughly four decades earlier. While heavy labor was largely to blame, their "extinction" was accelerated by smallpox and intermarriage with the Spaniards.

61. The Dominicans are a Catholic monastic order founded in 1216 by Saint Dominic to preach the Gospel and challenge heresies. They are regarded as formidable intellectuals in theology and philosophy.

62. Franciscans are a Catholic monastic order founded in 1209 by Saint Francis of Assisi. The order embraces asceticism and poverty. They were distinguished by their obedience and loyalty to the Pope and clergy.

63. Francisco Jiménez de Cisneros (1436-1517) rose from modest origins to become the regent of Spain $(1506,1516-17)$ and grand inquisitor.

64. Alonso de Zuazo (1466-1539) was a colonial administrator in Santo Domingo.

65. The Hieronymites were a Catholic monastic order founded in Spain in 1374. Although distinguished for their devotion to a hermetic existence of solitude and prayer, they were extremely active in bringing Christianity to the New World.

66. Charles V (1500-58) was Holy Roman Emperor and king of Spain. He is perhaps best known for combating the spread of Protestantism.

67. Despite the fact that slaves were brought to labor in Hispaniola as early as 1502, Las Casas has regularly been credited with introducing African slaves to the New World. James, for example, writes, "Las Casas, haunted at the prospect of seeing before his eyes the total destruction of a population within one generation, hit on the expedient of importing the more robust Negroes from a populous Africa; in 1517, Charles V. authorised the export of 15,00o slaves to San Domingo, and thus priest and King launched on the world the American slave-trade and slavery" (Black Jacobins, 4). Las Casas later repented this decision.

68. Between 1502 and 1518 hundreds of Spanish-born Africans called "Ladinos" were sent to the New World.

69. Juan Rodríguez de Fonseca (1451-1524) was Spain’s leading minister for colonial affairs from 1493 to 1523. He opposed Columbus's governorship of the colonies and also made enemies with Hernan Cortés.

70. Privateers were privately owned ships converted into warships with official sanction to disrupt commerce and capture enemy ships and their lucrative cargoes.

71. St. Saturninus (d. 257) was the bishop of Toulouse and a martyr.

72. Francisco de Garay (d. 1523) was the second Spanish governor of Jamaica, serving from 1514 to 1523 .

73. Garay sailed from Jamaica on June 14, 1523, with a royal patent to reestablish a failed settlement on the Río Pánuco in Mexico. On his arrival, he discovered that Cortés's forces had beaten him there, having already set up the town of Santiesteban del Puerto, present-day Pánuco, Vera Cruz.

74. From Oviedo, Historia general. 
75. Peltry are "undressed skins, esp. of animals valuable for their furs; furs and skins prepared for sale; pelts collectively" (OED).

76. Sir Francis Drake (1540-96) was a famous English sea captain and politician. The Spanish viewed Drake as a fearsome pirate. He was second in command for the famous battle against the Spanish Armada in 1588 and led the first English circumnavigation of the world.

77. The Windward Islands are the southern islands of the West Indies. In the late eighteenth century they included Barbados, Saint Lucia, Saint Vincent, the Grenadines, and Grenada.

78. Sir Thomas Warner (c. 158o-1649) first arrived at St. Kitts in 1622 and immediately recognized its potential as an English settlement and tobacco plantation.

79. Pierre Bélain, sieur d'Esnambuc (1585-1635) actually arrived at St. Kitts in 1625 when Warner was absent from the island, having returned to England in order to secure additional colonists and slaves for the new settlement. While it was true that the English and French peaceably divided the island between them on May 13, 1627, this agreement was only reached after they had cooperated in a preemptive strike against the island's natives. In 1635 Esnambuc would become the first European to settle Martinique.

8o. St. Christopher is more commonly referred to as St. Kitts.

81. Don Fadrique Álvarez de Toledo y Mendoza (1580-1634).

82. Although Tortuga was discovered by Columbus on his first voyage to the New World, it was not settled until 1625 . Tortuga was a major center of piracy in the seventeenth century.

83. Columbus landed at Port-de-Paix on December 6, 1492. The first settlement there, however, was not built until 1665 by French pirates from Tortuga. In 1679 Portde-Paix witnessed the first black slave revolt in the New World.

84. Sir William Penn (c. 1621-70) was a Parliamentarian admiral who distinguished himself first in Ireland and then later in the Dutch Wars. He was made commander of the naval forces for Cromwell's Western Design.

85. Robert Venables (1612-87) was a Parliamentarian army officer who made his reputation by waging a long and difficult but ultimately successful campaign against the Royalists in Ireland. Cromwell appointed him commander of the ground forces for a surprise attack on the Spanish West Indies.

86. Oliver Cromwell (1599-1658) was the first Lord Protector of England, Scotland, and Ireland. Cromwell's Western Design aimed to disrupt Spanish supremacy in the New World. The assault on Hispaniola turned out to be a complete disaster owing to strong Spanish fortifications, bad weather, poor planning, poorly trained volunteer soldiers, and heated quarrels between Cromwell's hand-picked commanders, Robert Venables and William Penn. Venables salvaged the mission when he conquered Jamaica on May 17, 1655 .

87. A buccaneer is "One who dries and smokes flesh on a boucan after the manner of the Indians. The name was 'first given to the French hunters of St. Domingo, who prepared the flesh of the wild oxen and boars in this way" (OED). A "buccan/bucan/ boucan" is defined as "a native South American name for a wooden framework or hurdle on which meat was roasted or smoked over a hurdle" (OED).

88. Around 1630 some French buccaneers were driven from the Hispaniola main- 


\section{8}

EDITORIAL NOTES

land to the island of Tortuga. They settled there along with many other French, Dutch, and English outcasts. Soon they began raiding Spanish ships and cities, and the area developed a reputation as a haven for pirates. English settlers in Jamaica first made the term "buccaneer" synonymous with "pirate."

89. A fusilier is "a soldier armed with a fusil," a "light musket or firelock" (OED ).

90. Daniel Montbars (1645-1707?) earned the nickname "the Exterminator" on account of the terrors and casualties he inflicted on the Spanish.

91. Nicholas van Hoorn (c. 1635-83) was a Dutch merchant who became a notorious pirate.

92. Languedoc is a region in the south of France. Its capital city is Toulouse.

93. Ostend is a Belgian city and municipality located in the Flemish province of West Flanders.

94. Glamorganshire or Glamorgan in south Wales is one of the thirteen historic counties of Wales.

95. Bristol is a large city in southwest England. It has long been an extremely important port and was a major player in the transatlantic slave trade.

96. Porto Bello is a port city located on the northern part of the Isthmus of Panama. At the time of Morgan's assault it was an important silver-exporting port.

97. Edward Vernon (1684-1757) was an English admiral who captured Porto Bello in 1739 during the War of Jenkins' Ear.

98. Morgan took possession of the fortress of San Lorenzo on the Caribbean coast of Panama in 1670. He led a successful assault on Panama City in 1671 but was ordered to return to England in 1672 because his campaign had violated the existing peace treaty between England and Spain.

99. Santa Catalina island is located just north of the Isla de Providencia, and is now part of the present-day Colombian department Archipelago of San Andrés, Providencia, and Santa Catalina. Morgan's buccaneers controlled the islands from 1670 to 1689 .

100. Morgan served as the lieutenant-governor of Jamaica from 1675 to 1682 . He established Port Royal as a haven for privateers and greatly profited from the 10 percent commission he received from their activities. He made Port-Royal the most fortified English city in the West Indies.

101. The Tower of London is a castle on the River Thames in central London, primarily used as a prison for political and religious criminals during the sixteenth and seventeenth centuries.

102. Morgan was imprisoned in the Tower from 1672 to 1674 but was eventually released without being charged with any crime. He died in Jamaica in 1688 and received the equivalent of a state funeral.

103. Bertrand Denis d'Ogeron de la Bouëre (1615-75) was a former French colonist and buccaneer. He was appointed the governor of Tortuga in 1665 and gained the respect of the unruly buccaneers. He successfully grew tobacco on Hispaniola, and his fortune as a planter prompted many other pirates to become farmers.

104. Anjou is a former province centered on the city of Angers in the lower Loire Valley of western France.

105. The French West India Company (Compagnie des Indes Occidentales) was founded in 1664 . 
106. A typo; this date should read 1669.

107. Ogeron died in 1675.

108. Gobin settled Cape François on the north coast of St. Domingo in 1670. The city is now known as Cap-Haïtien.

109. Louvilliers de Poincy was the nephew of Ogeron. He became the governor of Tortuga in 1676 following his uncle's death.

110. Martinique is an island in the eastern Caribbean discovered by Columbus in 1502. Pierre Bélain d'Esnambuc established a French settlement there in 1635. Control of the island alternated between France and Britain for much of the eighteenth century and early nineteenth. Martinique is now a French Département d'OutreMer.

111. Petit-Goâve is one of the oldest cities in Haiti. It is located southwest of Portau-Prince on the coast.

112. This expedition actually took place in 1687 .

113. Christopher Monck, second Duke of Albemarle (1653-88), was a former English army officer who was the governor of Jamaica from 1687 until his death.

114. Sir William Phips (1651-95) was an army officer and governor of the Massachusetts colony during the Salem witch trials.

115. Jean-Baptiste Du Cassé (1646-1715) acquired prominence and wealth through the slave trade. He became the first French governor of St. Domingo in 1691. He is credited with restoring prosperity to the colony.

116. Du Cassé led the invasion of Jamaica in 1694. It is estimated that he took three thousand slaves with him.

117. The Treaty of Ryswick was signed on September 20, 1697. It brought an end to the hostilities between France and the Grand Alliance-Spain, England, the Holy Roman Empire, and the United Provinces. As Rainsford notes, France gained official possession of St. Domingo through this treaty.

118. The Treaty of Aix-la-Chapelle or Treaty of Aachen was signed on May 2, 1668, ending the War of Devolution between France and Spain.

119. The Treaty of Nijmegen brought an end to the Franco-Dutch War.

120. The Compagnie de Saint-Louis was given the south of the island to administer in return for colonizing it in 1698. It went bankrupt in 1726, and its assets were given to the French West India Company.

121. John Law (c. 1671-1729) was a Scottish economist who was appointed the controller general of finances of France by Louis XIV. He is infamously known as the architect of the Mississippi Company bubble and subsequent collapse. Law greatly exaggerated the value of French holdings in Louisiana in order to increase investment. By creating the first central bank, the Banque Générale Privée, he could print paper money to repay investors in the company. When it became clear that the value of the notes issued by the company greatly surpassed the amount of specie it held, the value of the paper currency fell by half.

122. Castilians are historically held to be the architects of the Spanish state because of their leading role in the Reconquista. The name Castille refers to a large region in central Spain whose exact boundaries are disputed. Herrera was writing in the early seventeenth century.

123. The governor of a French colony represented the king. The intendant over- 
saw internal administration. These two branches of government, the military and the civil, were often at odds.

124. Real Compañia de Comercio de Barcelona a Indias, Barcelona Royal Company of Commerce to the Indies.

125. Charles III (1716-88) was the king of Spain and the Spanish Indies from 1759 to 1788 .

126. Raynal lists the number of mulattoes at 4,114.

127. The demarcation was agreed upon at the Treaty of Aranjuez, signed on June 3 , 1777.

128. The American Revolutionary War ended in 1783 with the Treaty of Paris.

129. The defining principles of the French Revolution are encompassed in the "Declaration of the Rights of Man and of the Citizen" and the Republican motto "Liberté, égalité, fraternité."

130. The independent state of Haiti was proclaimed on January 1, 1804.

131. A suffragan is "a bishop considered in regard to his relation to the archbishop or metropolitan, by whom he may be summoned to attend synods and give his suffrage" (OED).

132. Ferdinand and Isabella established the Spanish Inquisition in 1478 , primarily targeting converts from Judaism and Islam who were suspected of retaining some aspects of their former faiths. It was formally abolished in 1834 .

133. In fact, the former is called mestizo and the latter mulatto.

134. This discussion of color is an oversimplification by Rainsford and probably reflects his British bias. After the fourth generation a person of mixed race was legally considered white in Jamaica. See Brathwaite, The Development of Creole Society in Jamaica, 1770-1820, 167 .

135. Cassava is "a plant, called also by its Brazilian name Manioc. It is cultivated in Africa, in the West Indies and in tropical America for its fleshy tuberous roots" (OED ).

136. In 1790 the population of the colony of Santo Domingo was approximately 125,00o. Roughly 40,000 were white landowners; 60,000 were enslaved; and 25,000 were free people "of color" or mixed race.

137. In French, the town name Les Cayes varies if preceded by a location preposition, in which case it becomes Aux Cayes, like Le Havre, for example. Rainsford indiscriminately calls the town Cayes, Les Cayes, or Aux Cayes throughout the text.

138. Raynal writes, "Notwithstanding the confusion into which the houses of Providence, $[\ldots]$ there are fallen, there are still proportionally a less number of people who die at the Cape than in any other of the maritime towns of the colony" (A Philosophical and Political History [1788], vol. 6, bk. 13, 170).

139. A free port is "a port which is open to all traders, or which enjoys exemption from particular customs duties, regulations, etc." (OED ).

140. Established in 1607, Acadia was the first permanent French settlement in North America. Its territory encompassed Quebec, Maine, Nova Scotia, New Brunswick, and Prince Edward Island.

141. Raynal, A Philosophical and Political History, vol. 4, bk. 13, 219.

142. The French used the phrase gens de couleur libres (and its shortened variation, gens de couleur) to refer to free mulattoes. The term could also be applied to free blacks, but was never used with reference to slaves. 
143. In 1789 there were approximately 25,00o gens de couleur in St. Domingo. By comparison, there were only around 10,00o in Jamaica in 1800.

144. The maréchaussée was a police force primarily composed of mulattoes.

145. The petits blancs or "small whites" were the middle- and lower-class whites in St. Domingo. This group's members included artisans, merchants, and laborers as well as debtors and fugitives. See Fick, The Making of Haiti, 17-20.

146. Corvée is "A day's work of unpaid labour due by a vassal to his feudal lord; the whole forced labour thus exacted; in France, extended to the statute labour upon the public roads which was exacted of the French peasants before 1776" (OED).

147. François Barbé-Marbois (1745-1837) was a French politician, and the intendant of St. Domingo from 1785 until 1789. He negotiated the Louisiana Purchase and later wrote a history of Louisiana.

148. The number of whites was closer to 32,000.

149. Jamaica. Among these histories are Browne, The Civil and Natural History of Jamaica (1756); Leslie, A New History of Jamaica (1740); Long, The History of Jamaica (1774).

150. Indian wheat is maize or Indian corn.

151. Also known as dasheen.

152. An ortolan is a small bird regarded as a delicacy in French cuisine.

153. Pulse refers to "the edible seeds of leguminous plants cultivated for food (peas, beans, lentils, etc.)” (OED).

154. Feculence is "Feculent matter; dregs, lees, dross, scum. Also (now chiefly) in stronger sense, filth" (OED).

155. The Quakers presented the first petition against the slave trade to Parliament in 1783. Four years later they joined with evangelical English Protestants in order to found the Society for Effecting the Abolition of the Slave trade. Two of this organization's most important members were Thomas Clarkson, who had written a famous essay attacking the slave trade, and William Wilberforce, an MP who introduced the first parliamentary bill to abolish the slave trade in 1791. Although the measure was defeated then and again in 1793 and 1805, it finally passed as the Act for the Abolition of the Slave Trade in 1807.

156. Marooned is "of a slave: to run away, esp. to join other escaped slaves living in mountains or woods" (OED).

157. Louis XIV's 1685 Code Noir regulated the behavior of slaves, slave traders, slaveowners, and free blacks. Although this document required the slaveowner to provide food, clothing, and Catholicism to his slaves, it also gave him a great deal of autonomy in determining how he would treat them.

158. Several slave rebellions occurred in Barbados during the seventeenth century. Revolts were even more common in Jamaica. Among these the most notable was Tacky's War in 176o.

159. Louis XVI (1754-93) ruled as the king of France from 1774 until he was arrested and deposed during the Insurrection of August 10, 1792. He was later found guilty of high treason by the National Convention, and guillotined on January 21, 1793.

16o. Among these prophetic poets were François-Marie Arouet [Voltaire] (16941778) and Jean-Jacques Rousseau (1712-78). These Enlightenment writers favored 
equality and advocated progressive principles such as civil liberties, the general will, and the social contract.

161. Thomas Gray, "Elegy Written in a Country Church-Yard," 1. 76.

162. Louis XVI called on the Estates-General to meet on May 5, 1789, to help solve France's financial crisis. The assembly comprised representatives from the nobility, the Church, and the "Third Estate" - the common people. They had last been summoned in 1614 .

163. Being considered the king's property rather than full-fledged regions of France, colonies were not formally represented in the Estates-General. Planters insisted on being represented, even though Louis XVI refused to recognize their delegation. It was accepted when the delegates of the Third Estate proclaimed themselves a National Constitutive Assembly on June 20, 1789. Mirabeau famously denied the planters' delegation, arguing that it spoke neither for slaves nor for free people of color. The Assembly allowed only six delegates to represent the white population of St. Domingo.

164. Gens de couleur living in Paris organized themselves into a club, the Société des Citoyens de Couleur (Society of Citizens of Color). For a time it was led by St. Domingo mulattoes Vincent Ogé and Julien Raimond. They gained some support among French representatives and sent a delegation to the Assembly in October 1789.

165. The Société des Amis des Noirs was a French abolitionist society formed in Paris in 1788 by Jacques-Pierre Brissot. It was organized on the English model but went beyond its English counterpart by seeking to abolish slavery rather than merely the slave trade. Notable members included Maximilien Robespierre, Michel Guillaume Jean de Crèvecœur, and Honoré Mirabeau. The society was disbanded in 1793 and shortly revived between 1797 and 1799. Its overall contribution to the cause of abolitionism is widely contested.

166. The Society for Effecting the Abolition of the Slave Trade.

167. Shakespeare, Measure for Measure 2.2.125. Slightly misquoted by Rainsford. The line reads as "makes the angels weep."

168. Marie-Charles, marquis du Chilleau (1734-94), was a French military officer who made his reputation fighting in the American Revolutionary War. He was the governor-general of St. Domingo from 1788 to 1789 .

169. The "Declaration of the Rights of Man and of the Citizen" was one of the first steps toward a French constitution. Its emphasis on popular sovereignty rather than divine right of kings moved the country closer to Republicanism. Founded on the natural law principle of universal rights for all men, the document does not address the status of women or slaves.

170. Article Premier. The original French reads, "Les hommes naissent et demeurent libres et égaux en droits."

171. The National Assembly allowed internal self-government to the colonies under metropolitan supervision. Unlike the Estates-General this assembly was constituted by "the people." Louis XVI failed in his attempt to break up the new body, which was gaining a great deal of power and public support. The National Assembly refashioned itself into the National Constituent Assembly on July 9, 1789.

172. Rainsford is referring to the fact that gens de couleur attempting to join the Colonial Assemblies were excluded from them, often violently. 
173. Joseph Alexandre Ferrand de Beaudière (ca. 1707-89) fought in the American War of Independence as an officer in the Volunteer Grenadiers of St. Domingo. A lawyer at the Paris Parliament, he also held high offices in St. Domingo as king's counsel, civil and criminal judge, and lieutenant-general of the admiralty for Petit Goâve. In 1789 he wrote a petition to the new Provincial Assembly in favor of local gens de couleur, some of whom had fought by his side in America. He was arrested, but a mob dragged him away and decapitated him.

174. Dubois was jailed for a time in Fort Dauphin for declaring slavery contrary to the principles of individual freedom. The case was discussed in the National Assembly on March 2, 1790.

175. Decree of March 10, 1790.

176. Antoine de Thomassin, count de Peynier (1731-1809), was the governorgeneral of St. Domingo from 1789 to 1790.

177. Thomas Antoine, chevalier Mauduit du Plessis (1752-91), became commander of the French regiment stationed at Port-au-Prince in 1788. A loyal supporter of the ancien régime, he was strongly opposed to the revolutionary designs of the Colonial Assembly. His policy toward them was notable for its brutality.

178. The count d'Artois (1757-1836) was the younger brother of Louis XVI and Louis XVIII. He fled to Italy at the outbreak of the French Revolution. He became King Charles X in 1824 and ruled France until the July Revolution of 1830.

179. Décret de l'Assemblée Générale de Saint-Domingue, rendu le 28 mai 1790, à l'unanimité; et développement de ce décret par l'assemblée aux observations sur ce décret par l'assemblée provinciale du Nord, en date de 1er juin (1790). This appears to be Rainsford's own summary of the various articles in this document.

18o. De Charmilly led the planter party that advocated the capitulation of St. Domingo to England in 1793.

181. Athanase-Scipion Barrin, marquis de la Galissonière (1739-1805), joined the French navy while he was very young. He fought the British in India and later in the American War of Independence, where in 1786 he was made head of the Leeward Islands district defense. As commander of the Leopard, he was barred by his own crew from boarding when it sailed to France with eighty-five colonial representatives.

182. Vincent Ogé (c. 1755-91) was born in St. Domingo and educated in Bordeaux. Rainsford may be confusing Vincent's name with his older brother, Jacques, who also participated in Ogé's rebellion.

183. Maximilien Robespierre (1758-94) was a central figure of the French Revolution. He was a leading member of the Committee of Public Safety and one of the chief architects of the Terror. There is no concrete evidence he had any influence on Ogés rebellion.

184. Jean-Baptiste Chavannes (1748-91) was a mulatto who had fought on the American side of the Revolutionary War. Whereas Ogé sought voting rights for mulattoes, Chavannes advocated for abolition of slavery in St. Domingo.

185. Benoit Joseph André Rigaud (1761-1811) was a mulatto goldsmith with an impressive military career, having also fought in the American Revolutionary War. He was one of the leading figures of the Haitian Revolution.

186. Decree of May 15, 1791.

187. Antoine Pierre Joseph Marie Barnave (1761-93) was an influential orator and a 
leading figure of the Feuillants, a more moderate faction of the Jacobins who favored a constitutional monarchy rather than a republic.

188. Philippe (or Philibert) François Rouxel, viscount de Blanchelande (173593), was the governor-general of St. Domingo from 1790 until 1792. A committed supporter of the ancien régime, he was executed in Paris for treason and counterrevolutionary activities.

189. The cities of Ruotte and Vertières contained many wealthy mulattoes.

19o. The national cockade was colored red, blue, and white. A cockade is "a ribbon, knot of ribbons, rosette, or the like, worn in the hat as a badge of office or party, or as part of a livery dress" (OED).

191. Henri Grégoire (1750-1834) was a Roman Catholic priest, abolitionist, and revolutionary leader who wrote De la littérature des nègres, ou Recherches sur leurs facultés intellectuelles, leurs qualités morales et leur littérature (1808). Gilbert du Motier, marquis de La Fayette (1757-1834) was a French military officer who had distinguished himself in the American Revolutionary War and played an important role in French politics for nearly fifty years. Jacques-Pierre Brissot (1754-93) was one of the leaders of the Girondins during the French Revolution.

192. Again, the decree of May 15, 1791.

193. These words, usually attributed to Robespierre, were originally uttered by Pierre Samuel Dupont de Nemours, and echoed by Robespierre at the National Assembly session of May 12-13, 1791.

194. Nicolas de Caritat, marquis de Condorcet (1743-94), was a philosopher and early political scientist who favored free public education and equal rights for women and blacks.

195. This passage likely comes from the Rewbell Amendment of May 15, 1791. It granted civil rights to people of color born to a free mother and father, thus modifying the decree of May 13, which denied such rights in the absence of a prior appeal by the Colonial Assembly.

196. Ignace-Frédéric de Mirbeck, Philippe-Rose Roume, and Edmond de SaintLéger.

197. Rainsford is most likely referring to Blanchelande's letter to M. de Bertrand, the minister of the navy, dated September 2, 1791.

198. The marquis de Gallifet, a wealthy planter with land in the northern region of the island. Rainsford is referring to a local saying mentioned in Edwards: "The largest sugar plantation on the plain was that of Mons. Gallifet [...], the negroes belonging to which had always been treated with such kindness and liberality, and possessed of so many advantages, that it became a proverbial expression among the lower white people, in speaking of any man's good fortune, to say il est heureux comme un nègre de Gallifet (he is as happy as one of Gallifet's negroes)" (History, Civil and Commercial, of the British Colonies in the West Indies, 74). Edwards failed to note that this saying was eminently ironic, as the overseers of the Gallifet plantation were renowned for their cruelty.

199. De Touzard was a royalist military commander who supported mulatto rights.

200. A cheval de frise is "a defensive appliance of war, employed chiefly to check cavalry charges, and stop breaches; a line of spikes or nails similarly fixed along the top of a railing, paling, or wall" (OED). 
201. Laurent François Lenoir, marquis de Rouvrai, was a military officer and planter who urged the Northern Provincial Assembly to grant mulatto rights.

202. Edwards, Historical Survey of the French Colony in the Island of St. Domingo, 78.

203. Phillip Affleck (c. 1725-99) was a naval officer who distinguished himself in the East Indies. He served as commander-in-chief of the Jamaica station from 1790 to 1792.

204. Charles Arnold Ignace Hanus de Jumécourt (1749-98) was captain in a regiment of artillery sent to the West Indies in 1786. He married a local woman whose father owned a sugar factory. As a representative in the colonial assembly, he engineered the September 7, 1791, settlement between the whites of Croix-des-Bouquets and Mirebalais and the gens de couleur, which legitimized rights granted the latter in the National Assembly's Decree of May 15, 1791. He fought on the English side during the occupation, left with them for Jamaica in 1798 , and apparently died there the same year.

205. Modeled on Jumécourt's peace agreement, another concordat was actually signed by representatives of Port-au-Prince and the gens de couleur on September 11, 1791.

206. They would be further placated by the April 4, 1792, decree, which gave equal rights to all gens de couleur.

207. Mirbeck (1732-1818), Roume (1743-1805), and Saint-Léger comprised the First Civil Commission. They arrived at Cape François on November 29, 1791. Although these three were first charged with enforcing the Decree of May 15, 1791, they were sent to announce the Decree of September 24, 1791, which would grant amnesty to gens $d u$ couleur rebels willing to disarm and take a loyalty oath.

208. The French Constitution of 1791 established France as a constitutional monarchy, gave legal existence to the National Assembly, and limited the powers of the sovereign. It was adopted on September 3, 1791, and was effectively terminated with the insurrection of August 10, 1792, against the monarchy and the subsequent foundation of the National Convention.

209. The law granted citizenship and suffrage to landed or taxpaying free men of color.

210. Léger-Félicité Sonthonax (1763-1813), Étienne Polverel (1740-95), and JeanAntoine Ailhaud actually arrived at Cape François on September 17, 1792. The three commissioners divided the island into thirds: Sonthonax took responsibility for the northern region, Polverel the western, and Ailhaud the southern.

211. Jean-Jacques d'Esparbès de Lussan (1720-1810) served as the governor-general of St. Domingo from June 1792 until October 1792.

212. Edwards, Historical Survey of the French Colony in the Island of St. Domingo, 11213 .

213. When Ailhaud returned to France Polverel assumed control over the south as well.

214. François-Thomas Galbaud du Fort (1743-1802) was the governor-general from June 1793 until October 1793. He was an absentee plantation owner and quickly aligned himself with the big whites and the small whites against the mulattoes, Sonthonax, and Polverel. 
215. Adrien-Nicolas Piédefer, marquis de La Salle, count d'Offrémont (1735-1818), was a cavalry officer who had fought in the Seven Years War.

216. Edwards writes "The governor [Galbaud] sent a flag proposing to exchange the commissioner's son for his brother; but Polverel rejected the proposal with indignation; declaring in answer, that his son knew his duty, and was prepared to die in the service of the republick," Historical Survey of the French Colony in the Island of St. Domingo, 116.

217. Born in the African kingdom of Kongo, Macaya was the spiritual and military leader of a group of Maroons living independently in St. Domingo's mountains. He first fought on the side of the Spanish, then joined Sonthonax, and finally sided with Toussaint. He resisted Toussaint's agrarian reforms but fought at his side against Leclerc.

218. Sir Adam Williamson (1733-98), an experienced army officer, was sent to Jamaica in anticipation of a possible conflict with Spain in late 179o. He took over as the governor of the colony in 1791 and was well liked by the plantation owners. He ordered British forces to occupy St. Domingo in 1793 and served as governor of the occupied territory from 1795 to 1796.

219. Joaquín García y Moreno (1732-?) was the Spanish governor of Santo Domingo from 1788 until 1801.

220. Most likely Sir Josias Rowley, Baronet (1765-1842). Known as "the Sweeper of the Seas," he later commanded the fleet responsible for capturing the French islands of La Réunion and Mauritius in 1810.

221. Henry Shirley (1745-1812) was a wealthy British colonist and assemblyman in Jamaica.

222. Pope, "Elegy to the Memory of an Unfortunate Lady," 1. 14.

223. John Ford commanded the British naval presence at Port-au-Prince during the occupation.

224. Louis Morin Duval was commander of the army of Grand Anse. Jean Kina was among his troops.

225. Colonial troops were made up of local inhabitants recruited to serve with the metropole's army. One of the most famous examples of colonial troops was the Sepoys in India.

226. Rainsford is referring to Jean Kina. See note 233.

227. Étienne Maynard Bizefranc, count de Laveaux (1751-1828), served as the governor-general of St. Domingo from 1793 to 1796 . He became close friends with Toussaint Louverture.

228. Jean Charles, baron de Montalembert (1747-1810), was a cavalry officer in the royal French army. Coming to St. Domingo in 1792, he formed a legion of émigrés in the service of the British. He became the first Catholic promoted to brigadier general in the British Army. He died in Trinidad.

229. William McKerras of the Royal Engineers. He was promoted to brevet major in 1797 for service in St. Domingo. He was killed in Egypt in 1801.

230. Lieutenant-colonel David Markham (1766-96) of the Twentieth Regiment of Foot was the town commandant of Port-au-Prince. He died while attacking the fort of Bombarde. 
231. Lambert Marie Deneux (1761-?) was commandant of the Mole St. Nicholas and surrendered the town to the British. He fled with them to Jamaica.

232. A redoubt is a "fortification; a small work projecting from or within a bastion or ravelin. An entrenched stronghold or refuge" (OED).

233. Jean Kina was a slave from the southern part of St. Domingo who fought for the planters and was later integrated into the British auxiliairies. He became a colonel in British pay and left the island with the British in 1798. He lived for a time in London before being sent to Martinique where he led an aborted rebellion in 1800. He went to France in 1802 and was for a time imprisoned in Fort de Joux with Toussaint. His trail disappears in the south of France in 1804. See Geggus, "Slave, Soldier, Rebel."

234. The chevalier de Sevré (d. 1796), a Creole, was commander at Tiburon at the time of the British expedition to St. Domingo. He surrendered the city to the British and joined their forces, becoming the commander of the Chasseurs des Irois.

235. Jean-Rabel is a city located west of Port-de-Paix and east of Mole St. Nicholas in the northern province of Haiti.

236. John Whyte replaced Whitelocke as commandant of the British forces in St. Domingo. On June 8, 1794, he issued a proclamation declaring British sovereignty over the colony.

237. Charles Grey, first Earl Grey (1729-1807), a controversial British general during the American Revolutionary War, was appointed commander of the first West Indian expedition in November 1793. With Admiral Sir John Jervis he captured Martinique in 1794 .

238. A glacis is "the parapet of the covered way extended in a long slope to meet the natural surface of the ground, so that every part of it shall be swept by the fire of the ramparts' (Voyle Mil. Dict.)" (OED ).

239. Loosely quoted from de Charmilly, Lettre à M. Bryan Edwards, 153 .

240. François-Dominique Toussaint Louverture (1743-1803) was a leader of the Haitian Revolution. He was born on a plantation in Bréda and freed in 1776. He fought long and brilliantly to end slavery on St. Domingo. He initially sided with the Spanish but joined the French in 1794 following the National Convention's formal abolition of slavery. He expelled the British from the colony, then the Spanish, acting as the de facto governor of St. Domingo until Napoleon sent an expedition against him under the command of Charles Leclerc in 1802. Toussaint battled Leclerc's French troops fiercely and was only captured through a ruse. He was sent to prison in Fort de Joux in the Jura mountains of France, where he died of pneumonia.

241. Peculation is "the appropriation of money or property held in trust for another by a servant, employee, or official; esp. the embezzlement of public funds belonging to a ruler, state, or government" (OED).

242. Yellow fever is a virus transmitted by mosquitoes. It is believed to have originated in Africa and spread to the Americas through the slave trade. The disease saw several epidemic outbreaks in the eighteenth and nineteenth centuries. Yellow fever gets its name from the jaundice that occurs in its toxic phase.

243. The Hankey sailed from England in 1792. Rainsford appears to be drawing on Tytler, A Treatise on the Plague and Yellow Fever, 400-402. 
244. Some of these medical writers include Anderson, A Few Facts and Observations on the Yellow Fever of the West Indies (1798); Clark, A Treatise on the Yellow Fever (1797); and Moseley, Medical Tracts (1800).

245. Curaçao is one of the Lesser Antilles islands. Located near the Venezuelan coast, it was first seen by the Spaniards in 1499. It was settled by the Dutch in 1634 and became a center of the Atlantic slave trade. The French, British, and Dutch alternated control over the island in the eighteenth and early nineteenth centuries.

246. Horneck replaced Whyte on September 18, 1794.

247. Thomas Stewart Brisbane (d. 1795) led British troops into Saint Marc. He was a charismatic and gifted British officer whose early death in the field dealt a blow to British military hopes.

248. Edwards, An Historical Survey of the French Colony in the Island of St. Domingo, notes to chap. 11, 246-47. Edwards reprints Horneck's letter in full.

249. The Order of the Bath is the fourth oldest of the British orders of chivalry. It was founded in 1725 by George I, and its name is derived from the medieval purification ceremony for knighthood.

250. Gordon Forbes (1738-1828) was a career soldier who eventually became a general. He stood in for Williamson as commander of the colony when the latter was recalled to England.

251. Lieutenant-general Sir William Cockburn (1769-1835).

252. Toussaint Louverture.

253. Cork is a populous coastal town located in County Cork, in southern Ireland. It served as an important British military port.

254. A palisade is "a strong, pointed, wooden stake fixed deeply in the ground with others in a close row, either vertical or inclined, as a defence" (OED).

255. Henry Bowyer replaced de Sevré as the commander of the Chasseurs des Irois. 256. John Graves Simcoe (1752-1806) made his reputation as leader of the Queen's Rangers, a corps of loyalist troops during the American Revolutionary War. After a successful stint as the lieutenant-governor of Upper Canada, he was made the governor of St. Domingo and immediately set about improving British defenses.

257. May 3, 1797.

258. Banica was a Spanish outpost in St. Domingo. It sat on the present-day boundary between Haiti and the Dominican Republic.

259. Colebrooke Nesbitt (1755/56-98) distinguished himself in the Third AngloMysore War against Tipu Sultan. During the war with France he served as the inspector-general of all foreign corps.

26o. Sir Thomas Maitland (176o-1824) served in St. Domingo from 1795 to August 1797. He believed that the British occupation of the colony was doomed because of vast troop losses to tropical diseases. Sent back to the island as General Nesbitt's second in command, he eventually led secret negotiations with Toussaint to formalize the evacuation of the British in 1798.

261. Sir Hyde Parker (1739-1807) was given chief command of the Jamaican station in 1796. He had earlier helped establish a base for the British fleet at Mole St. Nicholas.

262. Dessources, a St. Domingo-born Creole, commanded a troop of black soldiers. 
263. Georges Biassou (d. 1801) was one of the leaders of the 1791 slave revolt. He was present at the meeting of August 21, 1791, at Bois Caïman, which initiated a general slave revolt and is often seen as marking the beginning of the Haitian Revolution. Biassou is credited with launching Toussaint's military career.

264. Dutty "Zamba" Boukman (d. 1791) was a Jamaican maroon who led the vodou ceremony at Bois Caïman.

265. It seems Toussaint was given a gold medal for his services rather than a military order.

266. The Peace of Basel was signed on May 22, 1795. With this agreement Spain ceded the eastern part of Hispaniola to France.

267. Rainsford is most likely referring to Biassou, who remained with the Spanish army and was defeated by Toussaint. Biassou left St. Domingo in 1795 for Spanish Florida, where he was put in charge of a black militia.

268. Rainsford implies Toussaint Louverture's goal was independence, which remains debatable. This position was adopted and circulated early in the British press.

269. Although Rainsford suggests these adventures happened in 1799 after the British withdrawal, they most likely took place in late 1797 and early 1798 , when British troops still occupied parts of St. Domingo. See the introduction to this book.

270. "Brigand" was a term used by both the British and the French to refer to insurgent blacks.

271. Goldsmith, "The Traveler," 1l. 158-61. Slightly misquoted by Rainsford. The original reads, "Amidst the ruin, heedless of the dead, / The shelter-seeking peasant builds his shed, / And, wond'ring man could want the larger pile, / Exults, and owns his cottage with a smile."

272. A demi-brigade is "the name given, under the first French Republic, to a regiment of infantry and artillery" (OED).

273. This is one of several instances where the illustration does not completely match its attendant description. The monument as engraved by J. Barlow displays a Decalogue-like, numbered list, visually suggesting the format of the Declaration of Human Rights.

274. Pope, "Sappho to Phaon: From the Fifteenth of Ovid's Epistles," 1l. 41-44. Slightly misquoted.

275. Theatre thrived at Cape François between 1797 and 1802. See Fouchard, Le Théâtre à Saint-Domingue, 36-38.

276. Constantin-François Chassebœuf, count de Volney (1757-1820), Voyage en Egypte et en Syrie (1787).

277. St. Thomas is one of the Virgin Islands. It was controlled by Denmark until the twentieth century. The island had one of the largest slave auctions in the region.

278. Pope, An Essay on Man, Epistle I, 1. 73.

279. The commander at Fort Liberté (or Fort Egalité, formerly Fort Dauphin) was Hyacinthe Moïse (1769-1801), Toussaint Louverture's adopted nephew. In his Mémoires, Pamphile de Lacroix mentions that Moïse lost an eye in battle.

280. Henry Christophe (1767-1820) was a leading figure in the Haitian Revolution. Christophe was a former slave, born in St. Kitts. He fought in the American War of Independence with d'Estaing's Free Coloreds of St. Domingo on the side of the colonists. He became a general under Toussaint and contributed to defeating the Leclerc 
expedition. After Dessalines's death in 1806 he was elected president, but soon parted ways with his rival, Alexandre Pétion, who became head of the southern Republic of Haiti. Christophe would proclaim himself King Henry of the northern Kingdom of Haiti in 1811 . He committed suicide in 1820 as his government was being overthrown. Christophe was no relative of Toussaint.

281. Toussaint.

282. The Calenda is "An American Negro dance, found in Latin America and the southern United States" (OED). The dance was considered indecent by many Europeans.

283. Aphrodite or Venus.

284. Gray, "Ode on the Spring," 1.2.

285. In decisions made in October 1800 and later as part of his 1801 Constitution, Toussaint established a system of so-called "agrarian militarism" that returned workers to plantations, denied them freedom of movement, and restored the property rights of French émigré planters. These harsh rules triggered revolts in the north, then controlled by Toussaint's adopted nephew, Moïse, in October 1801. Moïse refused to quash them, and Toussaint had him arrested and executed for rebellion on November 9, 1801.

286. Louis Panteléon, count de Noé (b. 1728), was a Creole from an old St. Domingo family. He inherited several other major plantations in the colony in addition to the Bréda Plantation.

287. Bayon de Libertat managed Bréda and other estates for the absentee count de Noé. While overseeing these larger holdings he also managed to buy and sell smaller properties to make a fortune of his own.

288. A postilion is "a person who rides a post-horse, a post-boy; (more generally) a courier, a swift messenger" (OED).

289. Toussaint's wife was Suzanne Simon Baptiste. She was born about 1749 and listed on the last surviving inventory of Bréda's slaves, dated 1785. They married in 1782 and had two sons together, Isaac and Saint-Jean. A third, Placide, fathered by another, was ten months old at the time of the marriage. Toussaint acknowledged paternity. He produced eight other children.

290. Epictetus (AD 55-135) was a Greek stoic philosopher. He was born a slave. His teachings, recorded in The Discourses, aim to distinguish what is from what is not within one's power to control.

291. Bayon de Libertat set Toussaint free in 1776. As a free black, Toussaint leased a small coffee plantation (about sixty-four acres) at Petit Cormier, overseeing the labor of thirteen slaves. He would acquire properties of his own near Grande Rivière and Ennery, amassing what he described as a considerable fortune. At the time of the revolution Toussaint was a long-standing member of the class called affranchis or freedmen, manumitted Africans or people of color, a rank he preferred to understate as the leader of black revolutionary forces. See Bell, Toussaint Louverture, 69-75.

292. Rainsford may be mistaking Biassou for another revolutionary leader, Jeannot, whom Jean-François and Biassou executed for excessive cruelty.

293. In a passage since attributed to Denis Diderot, Raynal asks, "Where is this great man to be found, whom nature, perhaps, owes to the honour of the human species? Who is this new Spartacus, who will not find a Crassus? Then will the black 
code be no more; and the white code will be a dreadful one, if the conqueror only regards the right of reprisals"; Raynal, A Philosophical and Political History, vol. 3, 466. Laveaux is said to have pronounced these words on the main square of Cape François on April 1, 1796, after Toussaint freed him from jail following an attempted coup by Villate on March 20, 1796.

294. The marquis d'Hermona was Toussaint's immediate superior in the Spanish military.

295. Dubroca, The Life of Toussaint Louverture, 63.

296. Isaac and Placide were educated in France, first at l'École de Liancourt, then at Collège de la Marche.

297. Compare Dubroca's description: "Toussaint Louverture is of the middle stature. He has a fine eye, and his glances are rapid and penetrating. Extremely sober by habit, his activity in the prosecution of his entreprizes is incessant [...]. He is an excellent horseman, and travels on occasion with inconceivable rapidity, arriving frequently at the end of his journey alone, or almost unattended" (Dubroca, The Life of Toussaint Louverture, 62).

298. Julien Raimond (1744-1801) was one of the wealthiest mulatto planters in St. Domingo. A fervent advocate and pamphleteer for equal rights for the gens de couleur, he brought the issue before the French National Constituent Assembly in 1790 and 1791, the result of which was the Decree of May 15, 1791. Raimond eventually aligned himself with Toussaint and helped to draft the Constitution, which was completed shortly before his death.

299. Paul Louverture (c. 1761-c. 1803) was Toussaint's younger brother. He was an officer under Toussaint's command and served as the brigade commander of the Eastern Division.

30o. Two brothers d'Hébécourt served in high positions under Toussaint. The youngest was named Louis-Armand.

301. Napoleon Bonaparte (1769-1821) rose to prominence after leading the forces of the French Republic to victory against the First and Second Coalitions. In 1799 he became First Consul of the French Republic through a coup d'état and elevated himself to Emperor of the French in 1804. He met his final defeat at the battle of Waterloo in 1815. He was sent in exile to the British island of St. Helena, where he died in 1821. Of St. Domingo Bonaparte declared, "I have to reproach myself with the attempt made upon the colony during the consulship. The design of reducing it by force was a great error. I ought to have been satisfied with governing it through the medium of Toussaint." Las Cases, The Life, Exile, and Conversations of the Emperor Napoleon, vol. 2, 170.

302. The Treaty of Amiens was signed on March 25, 1802, bringing hostilities between Great Britain and France to a temporary end. War resumed just over a year later. The peace allowed Napoleon to invade St. Domingo in the attempt to retake it and restore slavery while Britain observed a studious neutrality.

303. Pauline Bonaparte (1780-1825) was Napoleon's younger sister and the wife of the leader of the expedition against St. Domingo. She arrived there with her husband and son in early 1802 during the height of hostilities between France and its rebellious colony.

304. Charles Victor Emmanuel Leclerc (1772-1802) was the commander of the 
French military expedition to regain control over St. Domingo in 1802. He first allied himself with Napoleon in 1793 and quickly rose through the ranks of the French army. He married Napoleon's sister in 1797. His campaign was initially successful, resulting in the surrender of Toussaint. This victory was short-lived, however, as yellow fever and fierce resistance obliterated his troops. He waged an extremely brutal campaign against the insurgents before dying of yellow fever himself.

305. Jérôme Bonaparte (1784-1860) was Napoleon's youngest brother and the king of Westphalia from 1807 to 1813 . He served in the French navy and was sent to St. Domingo in 1802 .

306. Donatien-Marie-Joseph de Vimeur, viscount de Rochambeau (1755-1813), became the commander of the French forces in St. Domingo following Leclerc's death. He continued his predecessor's brutal tactics against the insurgents, which only helped to unite the mulattoes and the blacks against the French. Rochambeau was ultimately defeated by Jean-Jacques Dessalines's forces at the Battle of Vertières in 1803.

307. François Kerverseau was a French military officer who had previously served in St. Domingo. His troops landed at Santo Domingo during the 1802 French expedition.

308. Jean Boudet (1769-1809) commanded the French forces in Guadeloupe that reclaimed the island from the occupying British. He was assigned to the 1802 expedition to St. Domingo on account of his previous successes in colonial warfare. He landed at Port-au-Prince and later captured Léogane, but was wounded shortly thereafter.

309. Louis Thomas Villaret de Joyeuse (1750-1812) had a tumultuous relationship with France throughout the revolutionary period. He remained loyal during the Revolution and distinguished himself as commander of the Brest fleet. He was elected to the Council of Five Hundred, then arrested in the radical coup of 18 Fructidor year V (September 4, 1797) and exiled. Napoleon restored Villaret's position as commander of the Brest fleet and enlisted him to transport the majority of the French forces to St. Domingo. Villaret would later serve as the capitaine-general of Martinique and St. Lucie.

310. Louis-René-Madeleine, count de Latouche-Tréville (1745-1804), distinguished himself in the American Revolutionary War. He was later promoted by Napoleon and assisted Boudet in the capture of Port-au-Prince and Léogane. He was continually drawing up plans for a naval invasion of England but died before they could be realized.

311. Charles René Magon de Médine (1763-1805) served primarily in the Indian Ocean before being sent to St. Domingo, where he successfully captured Fort Dauphin (also known as Fort Liberté) and was promoted by Leclerc. He was killed in the Battle of Trafalgar.

312. The Consular Cabinet was the government led by Napoleon Bonaparte, elected First Consul in November 1799, and later made Consul for life.

313. Moïse was actually Toussaint's adopted nephew. He was the general of the division of the northern province. Moïse was executed on November 9, 1801, ostensibly for supporting a workers revolt among free blacks.

314. Rainsford draws this quote from Leclerc's dispatch of 20 Pluviose (February 9) 
to the minister of the navy, published in La Gazette Nationale, ou Le Moniteur Universel, 24 Ventose, year X (March 15, 1802), 696.

315. Rainsford most likely drew this information from the same issue of Le Moniteur, though this is more a paraphrase than a direct quote from Leclerc's dispatch.

316. César Télémaque, a free black, was the mayor of Cape François at the time of the French expedition's arrival.

317. Jean Joseph Amable Humbert (1755-1823) was an officer in the Army of the Rhine who led the failed French invasion of Ireland in 1798.

318. Le Moniteur, 24 Ventose, year X (March 15, 1802), 696.

319. Jean-Baptiste Coisnon (1731-1810) was an abbot and educator who took part in the French Revolution. He was principal of the collège de la Marche, a Parisian institution where French West Indian children were sent to be educated. Coisnon became a tutor to Toussaint Louverture's sons, whom he would accompany on their return to St. Domingo in 1802.

320. Le Moniteur, 24 Ventose year X (March 15, 1802), 696-97.

321. Rainsford is referring to Coisnon's letter of 1 Ventose year X (February 2O, 1802) to General Decrès, minister of the navy, published in Le Moniteur, 1 Floréal year X (April 21, 1802), 856-57.

322. The source of this quote has not been located.

323. Honoré Joseph Antoine Ganteaume (1755-1818) distinguished himself as a naval officer during Napoleon's Egyptian campaign. He had previously served under Villaret in 1793-94.

324. Charles-Alexandre Léon Durand, count de Linois (1761-1848), served under both Villaret and Ganteaume before becoming commander of the French fleet in the Indian Ocean in 1803.

325. Le Moniteur, 2 Germinal year X (March 23, 1802), 728. Charles Francis Joseph Dugua (1740-1802) was Leclerc's chief of staff. He distinguished himself during Napoleon's Egyptian campaign. He brought printed copies of the contents of the Rosetta Stone back to France.

326. Edme Étienne Borne Desfourneaux (1767-1849) fought in St. Domingo against the Spanish forces in 1793-94 and later served there under Laveaux. He returned to the colony with Leclerc and played a leading role in the victory at Gonaïves.

327. Hardy was among Leclerc's leading officers. He was tasked with battling Christophe's forces and recapturing Gonaïves.

328. The source of this quote has not been located.

329. Jean-François Joseph Debelle (1767-1802) was sent to Port-de-Paix in order to reinforce Humbert's troops. Debelle later died of yellow fever.

330. Jacques Maurepas (d. 1802), an old free black, was a brigade commander of the Northern Division, charged with defending Port-de-Paix from the French invaders. He successively defeated Humbert's troops and Debelle's reinforcements before finally capitulating to the French.

331. Jean-Jacques Dessalines (1758-1806) was one of the leading figures of the Haitian Revolution. Born a slave, he began his military career fighting for the Spanish against the French during the 1791 rebellion. It was during this time that he first attached himself to Toussaint. He replaced Toussaint as the general in chief following the latter's capture. Dessalines was responsible for two major victories against the 
French: Crête-à-Pierrot and the Battle of Vertières. He declared independence on January 1, 1804, and renamed the country Haiti. Dessalines proclaimed himself Emperor Jacques I of Haiti in September 1804, a post he held until his assassination in 1806 .

332. Laplume was appointed the commander of Léogane by Toussaint. Loyal to France, he defected and joined Leclerc's troops. In 1803 he was deported to the Spanish port of Cadiz, where he died later that year.

333. Jean-Baptiste Salme (1766-1811). He was sent back to France by Leclerc, apparently for protesting the resstablishment of slavery.

334. An abattis is "a defense constructed by placing felled trees lengthwise one over the other with their branches towards the enemy's line, and piling them up until a shelter for workmen is obtained" (OED).

335. Le Moniteur, 2 Germinal year X (March 23, 1802), 728.

336. Denis Decrès (1761-1820) was a French naval officer who served as Napoleon's minister of the navy from 1801 until 1814 .

337. Le Moniteur, 2 Germinal year X (March 23, 1802), 728. Augustin Clervaux (?-1805) was the free mulatto son of Augustin-Anne de Clervaux, a landed aristocrat captain in the colonial militia. Clervaux was educated in France. He led troops in formerly Spanish Santo Domingo when Leclerc landed, eventually surrendering to him. In 1802 he joined Dessalines in ousting the French. He died in 1805, possibly poisoned by Christophe.

338. Dommage, a black general, was the military district commander of Jérémie. He and Laplume had been charged with defending the south. After Laplume's defection he was unable to stop the French forces from controlling the region.

339. Pierre Agé, a Frenchman (d. circa 1820), was the chief of staff of the Republican Army under Sonthonax. He was made the commander of Port-au-Prince, but he disobeyed Toussaint's orders and allowed the French troops to take the city with ease, whereupon he joined Leclerc's forces.

340. Le Moniteur, 2 Prairial year X (May 22, 1802), 998.

341. Likely from Le Moniteur; issue unidentified.

342. The siege of the fort of Crête-à-Pierrot took place from March 4 to March 24, 1802. Although Dessalines's forces eventually yielded the fort, they suffered far fewer casualties than the French.

343. La Gazette Officielle de Saint-Domingue.

344. Jean Pierre Boyer (c. 1776-1850) was one of the leading mulattoes of the Haitian Revolution. Initially aligned with Leclerc and the French against Toussaint, Boyer eventually joined the rebellion and served under Pétion and Dessalines. He was the president of Haiti from 1818 until 1843 .

345. Act of 5 Floréal year X (April 25, 1802).

346. A variation on Shakespeare's "Et tu, Brute?" in Julius Caesar, 3.1.77.

347. La Gazette Officielle de Saint-Domingue.

348. Fontaine was Toussaint's adjutant general. Toussaint claimed that these letters were fakes.

349. Gingembre-Trop-Fort, one of Toussaint's loyal officers.

350. Toussaint's supposed letter was published in Le Moniteur, 9 Thermidor year X (July 28, 1802), 1267. 
351. The source of this quote has not been located.

352. Toussaint was placed under house arrest at Ennery following the treaty. By maintaining contact with his leaders he raised Leclerc's suspicions that another rebellion might be brewing. Leclerc summoned Toussaint to an interview where he formally arrested him and then spirited him away to France.

353. Montperon.

354. Letter published in Le Moniteur, 24 Messidor year X (July 13, 1802), 1208.

355. The Fort de Joux is actually located in the eastern region of Franche-Comté, in the Jura mountains. The eleventh-century castle served as a prison from the seventeenth century to the nineteenth. Beside Toussaint, other famous prisoners held there include Mirabeau, Heinrich von Kleist, and Toussaint's adversary Jean Kina.

356. Besançon is a heavily fortified city located in eastern France near the border with Switzerland.

357. Jean-Baptiste Sans-Souci, an African-born slave, was one of the leaders of the black insurgents in the 1791 uprising. He later became one of Toussaint's most trusted officers, serving directly under Christophe. Sans Souci was one of the first officers to rekindle the war against the French after the surrender in 1802 . He fell victim to Henry Christophe. For a discussion of Sans Souci, see Trouillot, "The Three Faces of Sans Souci" in Silencing the Past, 31-69.

358. Charles Belair (b. 1778), a nephew of Toussaint's, was widely believed to be his appointed successor. He distinguished himself against the British and was one of his uncle's most loyal commanders. His wife, Sanite, fought alongside him in an insurrection against the French in August 1802. Dessalines had Belair and his wife arrested and sent to Leclerc. Both were subsequently executed.

359. Published in Le Moniteur, 17 Nivose year XI (January 7, 1803), 429. Hector Daure, known also as count d'Aure (1774-1846), participated in the Egyptian campaign in the 179os. He served as commissary in the Leclerc expedition before becoming colonial prefect. He remained active in the military throughout Napoleon's reign.

36o. Manes are "the deified souls of dead ancestors; the spirit or shade of a dead person, considered as an object of homage or reverence or as demanding to be propitiated" (OED).

361. François Watrin (1772-1802) was a French army officer who distinguished himself in the French Revolutionary Wars.

362. Bertrand, count Clausel (1772-1842), distinguished himself in the French Revolutionary Wars prior to serving in St. Domingo. He became a marshal of France in 1831 .

363. Pierre François Joseph Boyer (1772-1851) took part in the French expedition in Egypt before joining Leclerc's forces. Captured by the British in 1803 and later freed, he participated in all major Napoleonic campaigns, earning the nickname "Pierre the Cruel" for his brutality. He would also be involved in the colonization of Algeria.

364. Le Moniteur, 18 Nivose year XI (January 8, 1803), 433.

365. Pupil.

366. Le Moniteur, 14 Pluviose year XI (February 3, 1803), 540.

367. The Peace of Amiens lasted only until May 18, 1803, when Britain again declared war on France. 
368. Sir John Wentworth Loring (1775-1852) served under Hyde Parker, the commander-in-chief of the Jamaica station. He remained in the West Indies from 1797 to 1805 .

369. Agréments are "grace-notes; embellishments" (OED ).

370. This remark likely comes from Le Moniteur, though the exact issue remains unidentified.

371. London Gazette, February 4, 1804, 162-63.

372. Louis-Marie, viscount de Noailles (1756-1804) made his reputation serving under Lafayette in the American Revolutionary War. After defending Mole St. Nicholas he attempted to flee St. Domingo for Cuba but was attacked and seriously wounded by the British navy during the voyage. He died in Cuba shortly thereafter.

373. Alexandre Sabès Pétion (1770-1818) was actually a wealthy mulatto. Although he returned to his native St. Domingo with Leclerc's 1802 expedition, he joined Dessalines's forces following the capture and deportation of Toussaint. Pétion became the president of the southern Republic of Haiti, a position he held from 1806 until his death.

374. London Gazette, February 4, 1804, 165.

375. John Bligh (1770-1831) became the captain of the Surveillante after the French surrendered the ship to the British. He was promoted to rear-admiral after a distinguished career.

376. Ayti was the indigenous Arawak name for Hispaniola. Dessaline renamed St. Domingo accordingly on January 1,1804 .

377. Dessalines's decree was sent to American newspapers. It was reprinted in the Times of London on May 4, 1804.

378. Times of London, July 3, 1804.

379. Jean Augustin Ernouf (1753-1827) was a decorated French military officer who served as the captain-general of Guadeloupe from 1803 to 1810.

380. Louis-Marie Stanislas Fréron (1764-1802) was a journalist and politician. He held a civilian position, the underprefect at Les Cayes, and died there of yellow fever.

381. See the Declaration of the Independence of the Blacks of St. Domingo in section XIII of the appendix.

382. Edwards, An Historical Survey of the French Colony in the Island of St. Domingo, 191.

383. Between 1801 and 1826 Jamaican authorities voted a series of "Consolidated Slave Laws" meant to better the treatment and living conditions of slaves.

384. Job 29:12.

385. Regarding discrimination against color, Raimond wrote in a pamphlet, "What earthly power can give itself the right to create unjust laws, when the Eternal itself has abstained from doing so?" (quoted in Dubois, Avengers of the New World, 6o). Although he was a mulatto and opposed to racial discrimination, Raimond had slaves of his own.

386. Jean-Baptiste Lislet Geoffroy (1755-1836) was born in Mauritius. His mother was a freed black slave and his father a white French colonist. Geoffroy was a skilled geographer and mapmaker.

387. Located just a few miles outside of Paris, Versailles contains France's most 
splendid palace and was the unofficial capital of France from 1682 to 1789 . The Estates-General were convened in Versailles on May 5, 1789.

388. The Tennis Court Oath was one of the most significant events of the French Revolution. It took place on June 20, 1789, and resulted in the members of the National Assembly swearing not to disband until they had formulated a constitution for France. The National Assembly was forced to meet on a tennis court because Louis XVI had ordered that the doors of their former chambers be locked and guarded by soldiers.

389. Ferrand de Baudière was lynched in St. Domingo for defending rights for mulattoes.

39o. Grégoire's Lettre aux citoyens de couleur et nègres libres de Saint-Domingue (1791) was published and circulated in Paris.

391. César Henri Guillaume, count de La Luzerne (1737-99) was a French naval minister who served as the governor-general of St. Domingo from 1785 to 1787 .

392. It is unclear how Rainsford obtained this document. He may have received it from Whitelocke himself.

393. It appears that de Charmilly is talking about abolitionism at large. "That philanthropic sect" must be the Quakers who according to him spread abolitionism to Europe.

394. Slightly misquoted from Pope, "Prologue to Mr. Addison's Cato," 1. 22. The line actually reads, "greatly falling with a falling state!"

395. Richard Stovin (d. 1825) distinguished himself in the British campaigns in the West Indies. He was involved in the Battle of Martinique and the invasion of Guadeloupe before being sent to St. Domingo.

396. This was probably Christophe, whose headquarters were in la Petite-Anse.

397. Excerpted from Rainsford, St. Domingo, 2d ed., 51-62.

398. Shakespeare, Macbeth 5.5.46. Slightly misquoted by Rainsford. The line reads, "There is nor flying hence nor tarrying here."

399. According to Geggus's calculations, while Rainsford's financial estimate was "hugely erroneous," his body count was not too far from the truth; Geggus estimates that losses (i.e., dead, discharged, and deserted) of British and auxiliary troops sent to St. Domingo between 1793 and 1798 amounted to just over 20,0oo, of whom about 12,500 died. See Geggus, Slavery, War, and Revolution, 362.

40o. Published in Le Moniteur, 5 Fructidor year X (August 23, 1802), 1367; in English in Cobbett's Weekly Political Register 2.10 (September 11, 1802), 299-300.

401. Le Moniteur, 5 Fructidor year X (August 23, 1802), 1368.

402. Ibid., 1368-1369.

403. Actually September 2, 1802 (15 Fructidor year X).

404. June 24, 1802 .

405. Le Moniteur, 11 Frimaire year XI (December 2, 1802), 285.

406. Strabo (c. 63 BC-C. 24 AD) was a Greek historian whose most famous work was Geographica.

407. A hole or a pit. It can also designate a lake or pond.

408. September 2, 1802.

409. Published in English in Cobbett's Annual Register, February 19 to February 26, 1803, 274 . 
410. Actually 1803 .

411. Actually November 20.

412. London Gazette, February 4, 1804, 166.

413. November 19, 1803.

414. London Gazette, February 4, 1804, 163.

415. Ibid.

416. Ibid.

417. November 19, 1803.

418. All British translations of this text mention this date, although its reference remains unclear. See note 419 regarding the authenticity of this proclamation.

419. This text was republished widely in British newspapers, but the Haitian historian Thomas Madiou asserts he never found a local version and considers it apocryphal (Histoire d'Haiti, vol. 3, 99).

420. Rainsford's source for this proclamation has not been located. It was likely published in British newspapers.

421. Dessalines is indirectly referencing Raynal's famous quote.

422. In 1802 Napoleon sent a military expedition to Guadeloupe to put down the rebellion and reinstitute slavery in the colony.

423. Magloire Pélage (d. 1810) was a black officer of the French army born in Martinique. He fought in the American War for Independence and against the British in the West Indian campaigns. In Guadelouple he took the lead in resisting Admiral Lacrosse, sent by Napoleon to reestablish slavery in 1801 . He was the acting governor of Guadeloupe when an expedition commanded by Antoine Richepanse arrived in 1802. Pélage put his lot in with Richepanse and helped him quash rebels and reestablish slavery on the island. He was still an officer in the French army when he died in France.

424. Louis Delgrès (1766-1802) was a Martinican-born mulatto. He had long been a comrade-in-arms of Pélage but became leader of the resistance in Guadeloupe following Pélage's treason. He and his followers ultimately chose suicide over slavery, detonating their gunpowder store when it became clear that they were surrounded.

425. Dessalines may be justifying the massacre of the whites in Jérémie on March 9, 1804 , by alleged plots against his rule.

426. Napoleon maintained slavery in Martinique in 1802 when France reacquired control of the island colony from the British through the Treaty of Amiens. Slavery was not abolished there until 1848 .

427. Dessalines delivered "letters of naturality" to whites he wanted to be spared. Some French, German, and Polish citizens were thus allowed to remain in Haiti and even become citizens. See Ardouin, Etudes sur l'histoire d'Haiti, vol. 6, 59-61.

428. A translation of the proclamation was published in the Times of London on July 23, 1804. Juste Chanlatte (1766-1828), born in Port-au-Prince, St. Domingo, was a journalist and playwright. He studied in France and, after returning, became secretary first to Dessalines and then to Christophe. He wrote for Gazette du Cap and later edited the official government publication under President Boyer, the Télégraphe.

429. Fréron.

430. Times of London, July 23, 1804.

431. It is unclear how Rainsford obtained a copy of this program. He corresponded 
with Robert Sutherland, a British merchant who resided awhile in Haiti and may have shared such documents with him.

432. We could not ascertain the identity of Rainsford's "ingenious" friend.

433. Evitation is "the action of avoiding or shunning; avoidance, shirking" (OED ).

434. This sentence is a slight misquotation of Benezet: "that argument, so commonly advanced in vindication of that trade, viz. 'That the slavery of the Negroes took its rise from a desire, in the purchasers, to save the lives of such of them as were taken captivesin war, who would otherwise have been sacrificed to the implacable revenge of their conquerors'" (Some historical account of Guinea, iii).

435. Larwood, Erratics.

436. The "fever that cut the thread of her life." Rainsford is quoting from the poem in Latin that adorns the graves of Benjamin Blake - the African servant of Sir Patrick Blake - and his wife Cotto. They are buried in the cemetery of Shepperton, near Walton-on-Thames, Middlesex, England. The entire epitaph is quoted in the Gentleman's Magazine 58: 65 .

437. The poem mentions that Cotto is buried near her husband, "whom [she] tenderly loved."

438. "Learn virtue from an Ethiop, and do not trust too much to color." This is the final line of Benjamin Blake's epitaph, and a pun on the Latin locution "Nimium ne crede colori," in which "colori" is usually translated as "good looks" or "appearances." 439. Larwood's translation of the last lines of Benjamin Blake's epitaph. 



\section{B IBLIOG RAPHY}

Account Book of the Deputy Paymaster General, Hispaniola, 1796-77. National Library of Jamaica, Kingston.

Adanson, Michel. Histoire naturelle du Sénégal. Coquillages. Avec la relation abrégée d'un voyage fait en ce pays pendant les années 1749, 50, 51, 52 et 53. Paris: Bauche, 1757.

Almanack and Register for the Island of Jamaica. Kingston, 1782.

Alumni Dublinesis: A Register of the Students, Graduates, Professors, and Provosts of Trinity College in the University of Dublin. Dublin: A. Thom, 1935.

Anderson, Adam. An historical and chronological deduction of the origin of commerce from the earliest accounts to the present time, containing an history of the great commercial interests of the British empire. London: Millar, 1764 .

Anderson, James. A Few Facts and Observations on the Yellow Fever of the West Indies. Manchester: Harrop, 1799.

The Annual Register. London, 1791-1804.

The Annual Review; and History of Literature. London: Longman and Rees, 1803.

The Anti-Jacobin Review and Political Magazine. London, 1806.

Archenholz, Johann Wilhelm von. Geschichte der Flibustier. Tübingen, 1803. , ed. Minerva. Jena, 1802, 1806.

Ardouin, Beaubrun. Etudes sur l'histoire d'Haïti. 11 vols. Paris: Dézobry et Magdeleine, 1853-6o.

Barbot, Jean. A Description of the Coasts of North and South Guinea and of Ethiopia Inferior, vulgarly Angola. In Collection of Voyages and Travels, ed. Thomas Astley and J. Churchill. 5 vols. London, 1732.

Barthelemy, Anthony Gerard. Black Face, Maligned Race: The Representation of Blacks in English Drama from Shakespeare to Southerne. Baton Rouge: Louisiana State University Press, 1987.

Beard, John Relly. Toussaint L’Ouverture: A Biography and Autobiography. Boston: James Redpath, 1863 .

Bell, Madison Smartt. Toussaint Louverture: A Biography. New York: Pantheon, 2007.

Benezet, Anthony. Some historical account of Guinea, its situation, produce, and the general disposition of its inhabitants. 1771. London: Owen, 1772.

Benzoni, Girolamo. Historia del Mondo Nuovo. Venice, 1565.

Bercy, Drouin de. De Saint-Domingue: de ses guerres, de ses révolutions, de ses ressources, et des moyens à prendre pour y rétablir la paix et l'industrie. Paris: Hocquet, 1814.

Bernheim, Alain. “Le 'Bicentenaire' des Grandes Constitutions de 1786: Essai sur les cinq textes de référence historique du Rite Écossais Ancien et Accepté," part I, Renaissance Traditionnelle 68 (1986): 241-63; part II, Renaissance Traditionnelle 69 (1987): 29-80; part III, Renaissance Traditionnelle 70 (1987): 99-138.

Bibliographie de la France: ou Journal général de l'imprimerie et de la librairie. Paris, 1829. 
Bilby, Kenneth E. True Born Maroons. Gainesville: University of Florida Press, 2008.

Boisrond-Tonnerre [Louis-Félix]. Mémoires pour servir à l'histoire d'Hayti. Dessalines: De l'imprimerie centrale du gouvernement, 1804.

Bongie, Chris. Friends and Enemies: The Scribal Politics of Post/Colonial Literature. Liverpool: Liverpool University Press, 2008.

Bosman, William. A New and Accurate Description of the Coast of Guinea. London: J. Knapton, 1705 .

Der Bote aus Thüringen. Schnepfenthal, 1802.

Bouvet de Cressé, Auguste Jean-Baptiste. Histoire de la catastrophe de Saint-Domingue. Paris: Peytieux, 1824 .

Brathwaite, Edward. The Development of Creole Society in Jamaica, 1770-1820. Oxford: Clarendon, 1971.

Brière, Jean-François. Haïti et la France, 1804-1848. Paris: Editions Karthala, 2008.

The British Critic. London: F. C. and J. Rivington, 1802, 1805.

Brown, Christopher Leslie. Moral Capital: Foundations of British Abolitionism. Chapel Hill: University of North Carolina Press, 2006.

Brown, Christopher Leslie, and Philip D. Morgan, eds. Arming Slaves: From Classical Times to the Modern Age. New Haven: Yale University Press, 2006.

Browne, Patrick. The Civil and Natural History of Jamaica: in Three Parts. London, 1756. Bruce, James. Travels to Discover the Source of the Nile, In the Years 1768, 1769, 1770, 1771, 1772 and 1773. 5 vols. Edinburgh, 1790.

Buckland, Emily A. The Rainsford Family, with Sidelights on Shakespeare, Southampton, Hall and Hart, Embracing 1000 years of the Rainsford family and their successive partakings in the main lines of national life. Worcester: Caxton Press, 1932.

Buckley, Roger Norman. Slaves in Red Coats: The British West India Regiments, 17951815. New Haven: Yale University Press, 1979.

Buckley, Roger Norman, ed. The Napoleonic War Journal of Captain Thomas Henry Browne, 1807-1816. London: Army Records Society, 1987.

Buck-Morss, Susan. Hegel, Haiti, and Universal History. Pittsburgh: University of Pittsburgh Press, 2009.

Burke, Edmund. Speech on Conciliation with America. London, 1775.

- Two Letters Addressed to a Member of the Present Parliament on the Proposal of Peace with the Regicide Directory of France. London: F. and C. Rivington, 1796.

Cauna, Jacques de, ed. Mémoires du Général Toussaint Louverture, commentées par Saint-Rémy. Guitalens-l'Albarède: La Girandole, 2009.

— tenaire. Paris: Karthala, 2004.

Célius, Carlo Avierl. "Les enjeux de la représentation. Portraits de noirs et de mulâtres pendant la révolution à Saint-Domingue (1789-1804)." In Negros, mulatos, zambaigos: Derroteros africanos en los mundos ibéricos, ed. Berta Ares Queija and Alessandro Steall. Seville: EEHA, 2000. 313-6o.

Chalmers, Col. [James]. Remarks on the Late War in St. Domingo. London: Nichols and Son, 1803 .

Charlevoix, Pierre-François-Xavier de. Histoire de I’Isle Espagnole ou de Saint-Domingue, écrite particulièrement sur des mémoires manuscrits du Jean-Baptiste Le Pers. 4 vols. Paris: François Barois, 1730-31. 
Charmilly, P. F. Venault de. Lettre à M. Bryan Edwards, en Réfutation de son Ouvrage intitulé Vues Historiques sur La Colonie Française de St. Domingue, \&c. London, 1797.

Chartrand, René, and Francis Back. Napoleon’s Overseas Army. London: Osprey, 1989.

Chartrand, René, and Paul Chappell. British Forces in the West Indies, 1793-1815. London: Osprey, 1996.

Chateaubriand, François-René de. Mémoires d'Outre-Tombe 42 vols. Paris, 1849-50.

[Chesterfield, Philip Dormer Stanhope, Lord]. Preface. Love Elegies by James Hammond. Dublin: J. Potts and S. Watson, 1742. iii-iv.

Clark, James. A Treatise on the Yellow Fever as it Appeared in the Island of Dominica in the Years 1793-4-5-6. London: J. Murray and S. Highley, 1797.

Clark, Murtie June. Loyalists in the Southern Campaign of the Revolutionary War. Baltimore: Genealogical Publishing, 1981.

Clavin, Matthew. "Race, Rebellion, and the Gothic: Inventing the Haitian Revolution." Early American Studies 5.1 (2007): 1-29.

. Toussaint Louverture and the American Civil War: The Promise and Peril of a Second Haitian Revolution. Philadelphia: University of Pennsylvania Press, 2009.

Cobbett's Weekly Political Register. London, 1802-4.

Colquhoun, Patrick. Treatise on the Police of the Metropolis. London: H. Fry, 1796.

Cook, James. A Voyage to the Pacific Ocean. 3 vols. London: Strahan, 1784.

Coulon, Jean Philippe Garran de. Rapport sur les Troubles de Saint-Domingue. 4 vols. Paris: 1797-99.

Crissé, Lancelot Turpin de. Commentaires de César, avec notes historiques, critiques et militaires. 3 vols. Paris, 1785 .

The Critical Review; Or, Annals of Literature. London: J. Mawman, 1801, 1806.

Curran, Stuart. Poetic Form and British Romanticism. Oxford: Oxford University Press, 1986.

Daguillard, Fritz. Enigmatic in His Glory: Toussaint Louverture (1743-1803). Port-auPrince: Musée du Panthéon Nationale Haïtien, 2003.

Dallas, R. C. The History of the Maroons, from their Origin to the Establishment of their Chief Tribe at Sierra Leone. 2 vols. London: Longman and Rees, 1803.

Décret de l'Assemblée Générale de Saint-Domingue, rendu le 28 mai 179o, à l'unanimité; et développement de ce décret par l'assemblée aux observations sur ce décret par l'assemblée provinciale du Nord, en date de 1er juin. Paris, 1790.

Desclaisons, M. Précis des histoires d'Alexandre le Grand et de Jules César, et de leurs faits militaires, soit comparés soit opposés entre eux; suivi de différents points de comparaison ou opposition entre ces deux généraux. 2 vols. Paris, 1784 .

Doyle, Arthur. A Hundred Years of Conflict: Being some Records of the Services of Six Generals of the Doyle Family, 1756-1856. London: Longmans, Green, 1911.

Dubois, Laurent. Avengers of the New World: The Story of the Haitian Revolution. Cambridge: Harvard University Press, 2004.

Dubroca, [Jean-Louis]. The Life of Toussaint Louverture, Chief of the French Rebels in St. Domingo. Translated from the French. London: H. D. Symonds, 1802.

Duffy, Michael. Soldiers, Sugar, and Seapower: The British Expeditions to the West Indies and the War against Revolutionary France. Oxford: Clarendon, 1987.

Dunn, Richard S. Sugar and Slaves: the Rise of the Planter Class in the British West Indies, 
1624-1713. 2d ed. Chapel Hill: Omohundro Institute of Early American History and Culture and University of North Carolina Press, 2000.

Du Tertre [Jean-Baptiste]. Histoire générale des Antilles habitées par les François. 4 vols. Paris: Thomas Iolly, 1667-71.

Echard, Laurence. The History of the Revolution and the Establishment of England in the Year 1688. London: Hyde and Dobson, 1725.

The Eclectic Review. London: C. Taylor, 1806.

The Edinburgh Review. Edinburgh, 1806.

Edwards, Bryan. An Historical Survey of the French Colony in the Island of St. Domingo. London: Stockdale, 1797.

- The History, Civil and Commercial, of the British Colonies in the West Indies. 3d ed. 3 vols. London: Stockdale, 1801.

Emerson, William K. Chevrons: Catalog of U.S. Army Insignia. Washington: Smithsonian Institution Press, 1983.

Estimates and Accounts: Army; Navy; Ordnance; Civil List; Miscellaneous Services. Vol. 13. London, 1818.

An Exhibition of miniatures owned in South Carolina and miniatures of South Carolinians owned elsewhere painted before the year 186o. Charleston: Carolina Art Association, Gibbes Memorial Art Gallery, 1936.

Fick, Carolyn E. The Making of Haiti: The Saint Domingue Revolution from Below. Knoxville: University of Tennessee Press, 1990.

Fischer, Sibylle. Modernity Disavowed: Haiti and the Cultures of Slavery in the Age of Revolution. Durham: Duke University Press, 2004.

Fortescue, J. W. A History of the British Army. 4 vols. London: Macmillan, 1910-30.

Fouchard, Jean. Le Théâtre à Saint-Domingue. Port au Prince: Editions Henri Deschamps, 1988.

Friday's Post Ipswich Journal. London, 1802.

Gazette Nationale, ou Le Moniteur Universel. Paris, 1791-1805.

Gazette Officielle de Saint-Domingue. Port-au-Prince.

Gazzetta di Milano. Milan, June 26, 1816.

Geggus, David Patrick. "The Arming of Slaves in the Haitian Revolution.” In Arming Slaves: From Classical Times to the Modern Age, ed. Christopher Leslie Brown and Philip D. Morgan. New Haven: Yale University Press. 209-32.

_. "British Opinion and the Emergence of Haiti, 1791-1805." In Slavery and British Society 1776-1846, ed. James Walvin. Baton Rouge: Louisiana State University Press. 123-49.

—. "The Cost of Pitt's Caribbean Campaigns, 1793-1798." Historical Journal 26.3 (1983): 699-706.

—. "The Great Powers and the Haitian Revolution." In Haitian Revolutionary Studies, $171-78$.

- Haitian Revolutionary Studies. Bloomington: Indiana University Press, 2002. . Slavery, War, and Revolution: The British Occupation of Saint Domingue, 17931798. Oxford: Clarendon, 1982.

_. "Slave, Soldier, Rebel: The Strange Career of Jean Kina." In Haitian Revolutionary Studies, 137-51. 

$119-36$.

The Gentleman's Magazine. London: Nichols and Son, 1806.

Goldsmith, Oliver. "The Traveler." In The Poetical Works of Dr. Goldsmith. London: Osborne and Griffin, 1785 .

Gómara, Francisco López de. La Historia general de las Indias. Saragossa, 1552.

Göttlingische gelehrte Anzeigen. Göttingen, 1802.

Gray, Thomas. "Ode on the Spring." In The Poetical Works of Thomas Gray, LL. B. London: Scatcherd, 1799.

Grégoire [Henri]. Lettre aux citoyens de couleur et nègres libres de Saint-Domingue, et autres isles françoises de l'Amérique. Paris: imprimerie du patriote français, 1791.

—. De la littérature des nègres, ou Recherches sur leurs facultés intellectuelles, leurs qualités morales et leur littérature. Paris, 1808.

Guichard, Karl Gottlieb. Mémoires militaires sur les Grecs et les Romains. The Hague, 1757.

Hakluyt, Richard. Diverse Voyages Touching the Discoverie of America. London, 1582.

Hayley, William. An Essay on Epic Poetry: in five Epistles to the Revd. Mr. Mason. London: J. Dodsley, 1782.

- The Life of Milton, in three parts. 2d ed. London: Cadell and Davies, 1796.

[Henry I of Haiti]. Manifeste du Roi. Cap Henry: P. Roux, 1814.

Herodotus. The Landmark Herodotus. Robert B. Strassler, ed. Andrea L. Purvis, trans. New York: Pantheon, 2007.

Herrera y Tordesillas, Antonio de. Historia general de los hechos de los Castellanos en las islas y tierra firme del Mar Oceano. 1601-15.

Histoire Générale des Voyages. 15 vols. Paris: Didot, 1697-1763.

Howard, Thomas Phipps. The Haitian Journal of Lieutenant Howard, York Hussars, 17961798. Roger Norman Buckley, ed. Knoxville: University of Tennessee Press, 1985.

Hughes, Derek, ed. Versions of Blackness: Key Texts on Blackness from the Seventeenth Century. Cambridge: Cambridge University Press, 2007.

Hume, David. A History of England from the Invasion of Julius Caesar to the Revolution in 1688. 6 vols. London: T. Cadell, 1762.

An Inquiry into the Causes of the Insurrection of the Negroes in St. Domingo, to which are added Observations of M. Garran-Coulon on the Same Subject. London: J. Johnson, 1792.

James, C. L. R. The Black Jacobins. 2d ed. New York: Vintage, 1989.

Kay, John. A Series of Original Portraits and Caricature Etchings. With Biographical Sketches and Illustrative Anecdotes. Edinburgh: A \& C Black, 1877.

Labat, Jean-Baptiste. Nouveau voyage aux isles de l'Amérique. 6 vols. Paris, 1722.

Lacroix, Pamphile de. Mémoires pour servir à l'histoire de la révolution de SaintDomingue. 2 vols. Paris: Pillet Aîné, 1819.

Larwood, Joshua. Erratics: by a sailor; containing rambles in Norfolk, and elsewhere. 2 vols. London, 1800.

Las Casas, Bartolomé de. A Short Account of the Destruction of the Indies, 1552.

Las Cases, Emmanuel-Auguste-Dieudonné de. The Life, Exile, and Conversations of the Emperor Napoleon. 2 vols. London: Henry Colburn, 1835. 
Laurie, William Alexander. The History of Free Masonry and the Grand Lodge of Scotland. Edinburgh: Seton and Mackenzie, 1859.

Le Beau, Charles. Histoire de l'Académie royale des inscriptions et belles-lettres, avec les mémoires de littérature. Vols. 25-39. Paris, 1759-77.

Ledyard, John. "Eulogium." Proceedings of the Association for Promoting the Discovery of the Interior Parts of Africa, 1788-179o. London: T. Cadell, 1791.

- A Journal of Captain Cook's Last Voyage to the Pacific Ocean. London, 1783.

Leslie, Charles. A New History of Jamaica. London: J. Hodges, 1740.

[Lloyd, Henry]. The History of the Late War in Germany; Between the King of Prussia, and the Empress of Germany and her Allies. London, 1766.

The London Gazette. London, 1813.

London Metropolitan Archives. Saint Giles in the Fields: Saint Giles High Street, Holborn, Camden. Transcript of Burials, January-December 1817. DL/t Item 036/o29, DL/T/036/029.

Long, Edward. The History of Jamaica; Or, General Survey of the Antient and Modern State of that Island. 3 vols. London: T. Lowndes, 1774.

Madiou, Thomas, fils. Histoire d'Haïti, 8 vols. Port-au-Prince: Courtois, 1848.

Malenfant, Colonel. Des colonies, et particulièrement de celle de Saint-Domingue: Mémoire historique et politique. Paris: Audibert, 1814.

Malouet, Victor Pierre. Collection de mémoires et correspondances officielles sur l'administration des colonies et notamment sur la Guiane française et hollandaise. 5 vols. Paris, 1802.

[Malthus, Thomas]. An Essay on the Principle of Population. London: J. Johnson, 1798.

Martyr, Peter (Martire d'Anghiera, Pietro). De Orbe Novo, 1530.

Métral, Antoine, and Isaac Louverture. Histoire de l'expédition des français à SaintDomingue sous le consulat de Napoléon Bonaparte; suivie des Mémoires et Notes d'Isaac Louverture. Paris: Fanjat Aîné, 1825.

Mintz, Sidney Wilfred. Sweetness and Power: The Place of Sugar in Modern History. New York: Viking, 1985.

The Monthly Mirror: Reflecting Men and Manners. London, 1802.

The Monthly Review; Or, Literary Journal. London, 1801.

Moseley, Benjamin. Medical Tracts. 2d ed. London: T. Cadell, Jr., and W. Davies, 1800. - A Treatise on Sugar. London: C. G. and J. Robinson, 1800.

The New Annual Register; Or, General Repository of History, Politics, and Literature. London: Stockdale, 1806.

Nussbaum, Felicity. The Limits of the Human: Fictions of Anomaly, Race, and Gender in the Long Eighteenth Century. Cambridge: Cambridge University Press, 2003.

[Ogden, James]. The Revolution: An Epic Poem, in Twelve Books. London: J. Johnson, 1790.

Orléans, Pierre Joseph d'. Histoire des révolutions d'Angleterre depuis le commencement de la monarchie. Paris, 1689.

- Histoire des révolutions d'Espagne, depuis la destruction de l'empire des Goths, jusqu'à l'entière et parfaite réunion des royaumes de Castille et d'Aragon en une seule monarchie. 3 vols. Paris, 1734 .

Oviedo [Gonzalo Fernández de Oviedo y Valdés]. La historia general y natural de las Indias. Toledo, 1526-35. 
Pachonski, Jan, and Reuel K. Wilson. Poland's Caribbean Tragedy: A Study of Polish Legions in the Haitian War of Independence 1802-1803. Boulder: East European Monographs, 1986.

Paquin, Lyonel. The Haitians: Class and Color Politics. Brooklyn, NY: Multi-Type, 1983.

A Particular Account of the Commencement and Progress of the Insurrection of the Negroes in St. Domingo, which began in August 1791. 2d ed. London: J. Sewell, 1792.

Piecuch, Jim. Loyalists, Indians, and Slaves in the Revolutionary South, 1775-1782. Columbia: University of South Carolina Press, 2008.

Pierrot, Grégory. "'Our Hero': Toussaint Louverture in British Representations." Criticism 50.4 (2008): 581-607.

Pincus, Steve. 1688: The First Modern Revolution. New Haven: Yale University Press, 2009.

Pluchon, Pierre. Toussaint Louverture: un révolutionnaire noir de l'Ancien Régime. Paris: Fayard, 1989.

Pocock, Michael Rogers. Out of the Shadows of the Past: The Story of the Great House of Champs Elysées, Maraval, and an Account of the Families who lived in it, 1780-1932. Port of Spain: Paria Publishing, 1993.

Pope, Alexander. An Essay on Man. In Epistles to a Friend. Epistle I. London: 1733.

- . "Prologue." In Cato, by Joseph Addison. 1713. London: Longman, Lowndes, Bladon, Cadell et al. 1795 .

— . "Sappho to Phaon: From the Fifteenth of Ovid's Epistles." In The Major Works, by Alexander Pope. Oxford: Oxford University Press, 2009.

Postlethwayt, Malachy. The Universal Dictionary of Trade and Commerce. London: J. Knapton, 1757 .

Pulis, John W. "Bridging Troubled Waters: Moses Baker, George Liele, and the African American Diaspora to Jamaica." In Moving On: Black Loyalists in the Afro-Atlantic World, ed. John W. Pulis. New York: Garland, 1999. 183-222.

Rainsford, Captain [Marcus]. A Memoir of Transactions That Took Place in St. Domingo in the Spring of 1799. London: R. B. Scott, 1802.

Rainsford, Marcus. Geschichte der Insel Hayti: Oder, St. Domingo besonders des auf derselben errichteten Negerreichs. Trans. Doctor Levi and Posstefretär Roch. Hamburg: A. Schmidt, 1806.

- An Historical Account of the Black Empire of Hayti: Comprehending a View of the Principal Transactions in the Revolution of Saint Domingo; with its Antient and Modern State. London: Cundee, 1805 .

- St. Domingo, of het land der Zwarten in Hayti en deszelfs Omwenteling. 2 vols. Amsterdam: Johannes Allart, 1806.

- St. Domingo; Or, an Historical, Political and Military Sketch of the Black Republic. 2 d ed. London: R. B. Scott, $18 \mathrm{O} 2$.

- St. Domingo; Or, an Historical, Political and Military Sketch of the Projected Black Republic. 3d ed. London: R. B. Scott, 1802.

- Translation of an Official Communication from the Government of Hayti. Bristol: John Evans, 1816.

[Rainsford, Marcus]. An Hymeneal on the Marriage of the Right Hon. Francis, Earl of Moira, etc. etc. etc., to the Right Hon. Flora, Countess of Loudon; on the 12th Day of July, 1804. London: Isaac Bisset, 1804. 
. The Revolution; Or, Britain Delivered: A Poem in Twelve Cantos, with Notes Historical and Explanatory. Edinburgh: Creech; and London: Cadell, 1791.

- The Revolution; Or, Britain Delivered: A Poem in Ten Cantos. 2d ed. London: R. B. Scott, 1800.

Raynal, Guillaume Thomas François. A Philosophical and Political History of the Settlements and Trade of the Europeans in the East and West Indies. Trans. J. Justamond. 5 vols. 2 d ed. London: T. Cadell, 1776.

Robertson, William. The History of America. 3 vols. 6th ed. London: Strahan and Cadell, 1792.

Roussier, Michel. "L'éducation des enfants de Toussaint Louverture et l'Institution nationale des colonies." In Toussaint Louverture et l'indépendance d'Haïti: Témoignages pour un bicentenaire, ed. Jacques de Cauna. Paris: Editions Karthala, 2004.

Saint-Rémy, Joseph. Mémoires du Général Toussaint-L'Ouverture, écrits par lui-même, pouvant servir à l'histoire de sa vie. Paris: Pagnerre, 1853.

- Vie de Toussaint-L'Ouverture. Paris: Moquet, 1850.

Saxe, Maurice de. Mes Rêveries. Paris, 1757.

Scott, David. Conscripts of Modernity: The Tragedy of Colonial Enlightenment. Durham: Duke University Press, 2004.

Shakespeare, William. Complete Works. New York: Modern Library, 2007.

Slatta, Richard W., and Jane Lucas de Grummond. Simon Bolivar's Quest for Glory. College Station: Texas A\&M University Press, 2003.

Sloane, Hans. A Voyage to the Islands Madera, Barbados, Nieves, S. Christophers and Jamaica, with the Natural History of the Herbs and Trees, Four-footed Beasts, Fishes, Birds, Insects, Reptiles, \&c. Of the last of those ISLANDS. 2 vols. London, 1707-25.

Smith, William. A New Voyage to Guinea. London, 1744.

Stephen, James. The Crisis in the Sugar Colonies. London, 1802.

[Stephen, James]. Buonaparte in the West Indies; or, the History of Toussaint Louverture, the African Hero. London: J. Hatchard, 1803.

- The Opportunity; Or, Reasons for an Immediate Alliance with St. Domingo. London: Hatchard, 1804.

The Times of London. London, 1790-1820.

Tomlinson, Robert. An Attempt to rescue the Holy Scriptures from the Ridicule they incur, with the Inconsiderate, occasioned by Incorrect Translation. London: Baynes, 1804.

Trouillot, Hénock. Le gouvernement du roi Henri Christophe. Port-au-Prince: Imprimerie Centrale, 1972.

Trouillot, Michel-Rolph. Silencing the Past: Power and the Production of History. Boston: Beacon, 1997 .

Tyson, George F. Toussaint L'Ouverture. Englewood Cliffs: Prentice Hall, 1973.

Tytler, James. A Treatise on the Plague and Yellow Fever. Salem, Mass.: Joshua Cushing for B. B. Macanulty, 1799.

United Kingdom. The National Archives. Admiralty and Secretariat Papers.

- Records of the Colonial Office.

- Records of the Prerogative Court of Canterbury.

- Records of the War Office.

Vegetius, Flavius. Vegetius: Epitome of Military Science. N. P. Milner, ed. 2d rev. ed. Liverpool: Liverpool University Press, 1996. 
Verna, Paul. Robert Sutherland, un amigo de Bolívar en Haíti: Contribución al estudio de los destierros del libertador en Haíti y sus expediciones de los Cayos y de Jacmel. Caracas: Fundacíon John Boulton, 1966.

Vespucci, Amerigo. Letters from a New World: Amerigo Vespucci's Discovery of America. Luciano Formisano, ed. David Jacobson, trans. New York: Marsilio, 1992.

Virgil, The Aeneid. Trans. Robert Fagles. New York: Penguin, 2006.

Voelz, Peter M. Slave and Soldier: The Military Impact of Blacks in the Colonial Americas. New York: Garland, 1993.

Volney, Constantin-François Chasseboeuf de. Voyage en Egypte et en Syrie. Paris, 1787.

Walker, James W. St. G. The Black Loyalists: The Search for a Promised Land in Nova Scotia. Toronto: University of Toronto Press, 1992.

Walvin, James, ed. Slavery and British Society 1776-1846. Baton Rouge: Louisiana State University Press, 1982.

Waters, Hazel. Racism on the Victorian Stage: Representation of Slavery and the Black Character. Cambridge: Cambridge University Press, 2007.

Wimpffen, François Alexandre-Stanislas de. A Voyage to Saint Domingo in the Years 1788, 1789, 179o. Trans. J. Wright. London: T. Cadell Jr., W. Davies, and J. Wright, 1797.

Wood, Marcus. Slavery, Empathy, and Pornography. Oxford: Oxford University Press, 2002. 



\section{INDEX}

abolitionism: British actions in Haiti contrasted with, xviii; campaign against slave trade, 301n155; Clarkson, xxxiii, xli, lii, 286n138, 301n155; Henry I of Haiti appeals to, xxxiii; Rainsford and, lii; Rainsford's An Historical Account of the Black Empire of Hayti and, xli; Wilberforce, xxxiii, 301n155. See also Société des Amis des Noirs

Acul, 64, 91, 98, 203, 270

L’Acul de Léogane (fortress), 114, 117

Adanson, Michel, 6n

Affleck, Phillip, 96, 98, 305n2O3

Agé, Pierre, 179, 314n339

Aguado, Juan de, 24, 294n41

Ailhaud, Jean-Antoine, 104-5, 305n210, 305n213

Aime, B., 213, 261

Albemarle, Christopher Monck, second Duke of, 47, 299n113

Albuquerque, Roderigo, 31, 32

Amis des Noirs. See Société des Amis des Noirs

Arana, Diego de, 21, 294n35

Arcahaye: British occupy, 112, 118, 119; distribution of black force in the French colonies during the Revolution, from official returns, 270 ; in western province of Haiti, 58, 64

Archenholz, Johann Wilhelm von, xl, 8, 9n, 294n25

Ardouin, Beaubrun, $281 n 69$

Aux Cayes. See Cayes

Azua, 52

Baillen, Monsieur and Madame, 93-94

Balboa, Vasco Núñez de, 30-31, 295n55, $295 n 58$
Balcarres, Alexander Lindsay, sixth Earl of, xxvii, 197n, 28on54

Banica, 53, 126, 128, 308n258

Barbé-Marbois, François, marquis de, 68, 301n147

Barbot, Jean, 271

Barcelona Royal Company of Commerce to the Indies, 50

Barlow, Inigo, xlii-xliii

Barnave, Antoine Pierre Joseph Marie, $85,89,222,303 n 187$

Barré, Captain, 207, 210, 258, 259

Baynette, 64

Bayon de Libertas, Antoine-François, 151, 152, 153-54, 310n287, 310n291

Behn, Aphra, 288n155, 291n181

Belair, Charles, 196, 315n358

Benezet, Anthony, 319n434

Benzoni, Girolamo, 28n

Biassou, Georges, 131, 154, 309n263, 3ogn267, 310n292

Blake, Sir Benjamin, 274, 319n436

Blake, Cotto, 274-75, 319n437

Blake, Sir Patrick, 274, 319n436

Blake, William, xli, xliii

Blanchelande, Philippe (Philibert)

François Rouxel, viscount de, 86, 88, 9o, 96, 105, 304n188

Bligh, John, 210, 259, 316n375

bloodhounds, xxvii, xlvi, 10-11, 196, 208, 251-56, 288n161

Bobadilla, Francisco de, 25, 295n 44

Boisrond Tonnerre, Louis-Félix, 283n91, 288n161

Bombarde, 115-16, 127

Bonaparte, Jérôme, 163, 204, 206n, 312n305 
Bonaparte, Napoleon. See Napoleon Bonaparte

Bonaparte, Pauline, 162, 163, 311n303

Bonneville, François, xliv, 287n150

Bosman, William, 271

Boudet, Jean, 163, 164, 175, 176, 177, 181, 182, 312n3o8

Boukman, Dutty “Zamba," 131, 309n264

Bowyer, Henry, 127, 308n255

Boyé, General, 207, 258, 259

Boyer, Jean Pierre, 184, 314n344

Boyer, Pierre François Joseph, 200, 201, 315n363

Brisbane, Thomas Stewart, 123, 124-25, 308n247

Brissot, Jacques-Pierre, 89, 302n165, 304n191

Brown, Christopher Leslie, lii

Bruce, James, 253n

Brunet, General, 191, 192

Buccaniers, 7, 8, 38-47, 59, 254n, 297n87, 297n88

Buckley, Roger Norman, xx, xxiii

Buck-Morss, Susan, 287n147

Burke, Edmund, xxi, 292n7

Calenda (dance), 145, $310 n 282$

Campbell, John, 3, 292n5

cannibalism, $21 \mathrm{n}$

Cape François, 58-59; in cession of western Hispaniola, 48; Dessalines sets out from, 215; Edwards on aftermath of uprising around, xl; English attack on, 47; establishment of, 46-48; free blacks at, xxxix, liv, lvlvi; French commissioners land in, 105; and French invasion of Haiti, xxxi, 164, 166, 178, 184, 189, 192, 203, 204, 206-7; fugitives from Ogé rebellion jailed in, 86; Leclerc in administration of, 247, 248, 250; new Colonial Assembly meets at, 90; in northern province of Haiti, 58; Northern Provincial Assembly meets in, 78; Ogé's connection to, 84; plan of, xli, 6o-61; Port-au-Prince compared with, 50; Rainsford at, xxviii,
10, 133-41; representatives to General Assembly of St. Domingo from, 80; Rochambeau surrenders, 257, 258, 259; as seat of government, 48, 62, 65; slaughters by French near, 196; slave revolt of 1791 around, 91-101; temple to liberty in, xliii, 135-37, 136, $287 n 147$

Cape St. Nicholas. See Mole St. Nicholas

Castaing (mulatto), 102, 103, 230, 232

Cauna, Jacques de, 289n168

Cayes, 63; and British occupation of Haiti, 112; distribution of black force in the French colonies during the Revolution, from official returns, 271; and French invasion of Haiti, 179, 201; Leclerc in administration of, 247, 248, 250; representatives to General Assembly of St. Domingo from, 80; Rigaud as mulatto leader at, 85 ; in southern province of Haiti, 58; Southern Provincial Assembly meets in, 78; St. Louis in defense of trade of, 64

Chalmers, James (Charles), xxx, 8, 158n, 277n3, 286n128, 293n24

Chanlatte, Juste, 267, 268, 318n428

Chapetones, 56

Charles III (king of Spain), 50, 30on125

Charles V (emperor), 33, 296n66

Charlevoix, Pierre François Xavier de, 7, 293n17

Charmilly, Pierre-François Venault de, 234-38, 292n2; on blacks, 1, 66; British involvement sought by, 82, 108-9, 110-11, 232; in British occupation of Haiti, 115, 116, 119, 120; on capitulating to Britain, 81-82, 303n18o; on Caribs, 21n; letter in reply to Edwards, 7-8, 28n, 286n128, 307n239; on planters in StatesGeneral, 76; on population of St. Domingo, 28n, 57; returns to Europe, 123; on two parts of St. Domingo, 2O; on West India colonists from France, 
Chartrand, René, 287n148

Chavannes, Jean-Baptiste, 84, 86, 303n184

Chesterfield, Philip Dormer Stanhope, Lord, 292n3

children of black laborers, 140-41

Christophe, Henry (King Henry I of Haiti), 309n28o; becomes king, xxxii, 310n28o; Britain favored by, xxxii; corresponds with abolitionists, xxxiii; and French plan to retake Haiti, xxxii, 164, 171, 175, 176, 184, 188, 189, 192, 196, 209, 284n96; Haitian independence proclaimed by, 260-61; Manifest du Roi, 288n161; presides over Rainsford's trial, xxix, xliii-xliv, 143, 144; and Rainsford's appointment as lieutenant-general, xxxiii, 284n10o; and Sutherland, 283ng1

Clarkson, Thomas, xxxiii, xli, lii, 286n138, 301n155

Clausel, Bertrand, Count, 200, 201, $315 n 362$

Clements, M., 91

Clervaux, Augustin, 178, 196, 209, 260$61,314 n 337$

Cobbett, William, $9 n$

Cockburn, Sir William, 126, 308n251 cocoa, 36, 47, 48, 50, 57, 64, 67, 68n

Code Noir, 84, $301 n 157$

Coisnon, Jean-Baptiste, 167-68, 169-70, $313 n 319$

Colonial Assembly, 65, 85-86, 9o, 94, 96, 104, 105

Columbus, Bartholomew, 22, 24, 31, $294 n 40$

Columbus, Christopher, 6, 15-27, 29, 251, 293n11

Columbus, Diego (brother), 22, 24, $294 n 38$

Columbus (Colón Moniz), Diego (son), 29-30, 31, 34-35, 295n52

commission intermediaire, 105-6

Concordat, 99, 100

Condorcet, Nicolas de Caritat, marquis de, 89, 304n194 constitutions: Constitution of 1801, 157, 16o-61, 310n285, 311n298; Constitution of 1804, 211; French Constitution of 1791, 101, 305n208; plan for new constitution of $1790,80-81$

corvées, 67

Council of the Indies, 55

Coupe-a-Pintade, 176

Creoles, 56

Crête-à-Pierrot, 181, 182-83, 314n331, $314 \mathrm{n} 342$

Croix des Bouquets, La, 100, 176, 179, 305n204

Cromwell, Oliver, 38, 297n86

Cuba: French aided by, 18o-81, 209; Maisi, 62; Ocampo explores, 29; Peynier appeals for aid from, 82; Spanish colony established on, 30

$\mathrm{Cul}$ de Sac (plain), 62, 119, 120, 125, 128

Cul de Sac (town), 64, 100

Curran, Stuart, 285n114

Curtis, William, 3, 292n6

Cuyler, Cornelius, xxix, 148n

Dallas, Robert Charles, 8, 253n, 255n, 294n26

Daniel, Captain, 119

Darwin, Erasmus, xxxi, 283n89

Daure, Hector (count d'Aure), 198, 315n359

Debelle, Jean-François Joseph, 175-76, 177, 181, 182, 313n329, 313n330

Declaration of the Rights of Man and of the Citizen, 78, 236, 302n169

Decree of April 4, 1792, 104-5, 305n206

Decree of March 8, 1790, 85, 89, 104

Decree of May 15, 1791: Civil Commission charged with enforcing, 305n207; Abbé Grégoire on, 221-26; Jumécourt and, 305n204; new Colonial Assembly called for, 85, 89, 303n186, 304n192; Raimond and, 311n298; repeal of, 99-100

Decree of September 22, 1791, 101

Decree of September 24, 1791, 104, 305n2O7 
Decrès, Denis, 314n336

Décret de l'Assemblée Générale de SaintDomingue, rendu le 28 mai 1790 , 81-82, 303n179

Delgrès, Louis, 265, 318n424

Delpech, François-Séraphin, xlvii, xlviii, 289n167

Deneux, Lambert Marie, 115, 307n231

Desbureaux, General, 200

Desfourneaux, Edme Étienne Borne, $174-75,176,177,181,184,313 n 326$

Desplanques, General, 176

Dessalines, Jean-Jacques, 313n331; becomes emperor, 215-16, 268-70; in French invasion of Haiti, xxxi, 176, 179, 181-83, 188-92, 196, 202-4, 312n306; as governor-general for life, 213-14, 264-67; Haitian independence proclaimed by, xxxi-xxxii, 209, 26o-61; on massacres by the French, 212-13; proclamation for a solemn abjuration of the French nation, 211, 262-64; proclamation of April 28, 1804, liv; proclamation to the Spanish part of the island, 214-15, 267-68; Rochambeau negotiates with, 207, 209, 210, 256-57; St. Domingo renamed by, 316n376; and Sutherland, 283ng1; tours the island, 214-15

Dessources (commander), 126, 130, 308n262

Didier brothers, 102, 103, 230, 231

Dominicans, 32, 34, 35, 296n61

Dommage, General, 179, 200, 314n338

Dondon, 93, 98, 175, 184, 200, 270

Doyle, Arthur, 28on49

Doyle, Welbore Ellis, xxiv-xxv, xxvi, xxvii, xxxi, 278n36, 279n46, 281n62

Drake, Sir Francis, 36, 297n76

Dubois (deputy procureur-general), 79, 303n174

Dubroca, Jean-Louis, xliv, 8, 286n128, 287n150, 293n23, 311n297

Du Cassé, Jean-Baptiste, 47, 299n115

Du Chilleau, Marie-Charles, marquis, 77-78, 302n168
Duckworth, Sir John Thomas, 173n, 180, 181, 211, 259-6o

Dugua, Charles Francis Joseph, 171, 182, 185, 196, 200, 313n325

Dumesnel, Jean Pierre, 175, 177

Dundas, Henry, xix, xx, xxii, lii, 28on54

Du Tertre, Jean-Baptiste, 7, 293n17

Duval, Louis Morin, 112, 306n224

Edwards, Bryan, 293n21; Charmilly's letter to, 7-8, 28n, 286n128, 307n239; on fertility of Hispaniola, 20; on Galbaud, 306n216; and Gallifet, 304n198; An Historical Survey of the French Colony in the Island of St. Domingo, xl-xli, 7, 286n128, 293n21; History, Civil and Commercial, of the British Colonies in the West Indies, $\mathrm{xl}$, 286n128, 293n21; on imprisoned commissioner, 106; on population of Hispaniola, 28n, 49; prediction about Haiti's future, 216; on proclamation abolishing slavery, 11on; Rainsford on, 7; on slave revolt of 1791, 93-94, 95, 96-98; on Whitelocke, 114n

Ennery, xxxi, 168, 175, 176

Ernouf, Jean Augustin, 214, 316n379

Erratics (Larwood), 274-75

Esnambuc, Pierre Bélain, sieur d', 37-38, 4on, 297n79, 299n110

Esparbès de Lussan, Jean-Jacques d', 105, 305n211

Essay on Epic Poetry, An (Hayley), xxxvxxxvi

family life, 140-41

Farcy, Alphonse de, 289n169

Ferdinand II (king of Aragon), 24, 25, 27, 29-30, 31, 33, 35, 300n132

Ferdinand VI (king of Spain), 54n, 55

Ferrand de Beaudière, Joseph Alexandre, 79, 303n173

Ferrari (aide-de-camp), 191, 192

Figuerra, Roderigo de, 33

First Civil Commission, 89-90, 100101, 305n2O7

Flaville, M., 91 
Fontaine, Adjutant General, 190-91, $314 \mathrm{n} 348$

Forbes, Gordon, 126, 127, 28on54, 308 n250

Ford, John, 111-12, 113, 118, 121, 306n223

Fort Bizotton, 118-19, 123

Fort Dauphin (Fort Liberté), 59; distribution of black force in the French colonies during the Revolution, from official returns, 270; and French invasion of Haiti, 166, 178, 197, 201; in northern province of Haiti, 58; Rainsford at, xxix, 10; slave revolt of 1791 in, 98

Fort de L'Hôpital, 120

Fortescue, J. W., xix

Fort Robin, 120

Franciscans, 32, 35, 296n62

"Fraternal Embrace!, A" (Rainsford), xli-xlii, xlii

Frazer, James, xxviii, xxix, 133n

free people of color: in American War of Independence, xxv; benevolent woman of color aids Rainsford, xliv, 145-46, 147; British recruit, xxvi; in Cape François, xxix, liv, lv-lvi; and Decree of April 4, 1792, 104-5, 305n206; drive British from Haiti, xxiii; in Paris, 302n164; in population of Haiti, 65, 68; in population of St. Domingo, 3oon136; Rainsford's appreciation of, liv; Toussaint Louverture orders them back to the plantations, lv-lvi. See also Decree of May 15, 1791; mulattoes

Fréron, Louis-Marie Stanislas, 214, $316 \mathrm{n} 380$

Friends of the Blacks. See Société des Amis des Noirs

Galbaud du Fort, François-Thomas, 106-7, 305n214, 306n216

Galissonière, Athanase-Scipion Barrin, marquis de la, 82, 303n181

Gallifet, marquis de, 91, 94, 304n198

Ganteaume, Honoré Joseph Antoine, $171,313 n 323$
Garan de Coulon, Jean-Philippe, 7n, 104

Garay, Francis de, 34, 296n73

Garcia, Joachim, 158

Garstin, Lieutenant, 116

Gedard, Jean Baptiste, 101, 229

Gedard, Pierre, 101, 229

Geggus, David Patrick, xxii, 317n399

General Assembly of St. Domingo, 79-85; and colonial committee at Paris, 89; principles of, 226-29; and slave rebellion of 1791, 92, 99

Geoffroy, Jean-Baptiste Lislet, 223, 316n386

Gerard, Jean Pierre (John Peter), 102, 230

Glorious Revolution of 1688, xxv, xxxvi, xxxvii-xxxviii

Gobin (Calvinist), 46, 299n108

Gonaives, 63; Dessalines visits, 215; and French invasion of Haiti, 175, 177, 178, 184, 189, 191; in western province of Haiti, 58

Gonçalves, Antão, 71n

Goudy, Jean Pierre, 102, 229

Grand Rivière, La, 98, 101, 102, 229, 230

Granville (tutor), 171

Grasse, Colonel de, 126, 129

Grégoire, Henri, 89, 221-26, 304n191

Gregory I, Pope, 74n

Grey, Sir Charles, 118, 307n237

Gros Morne, 174, 177

Guacanahari, 19

Haiti (St. Domingo): borders after treaty of 1777, 51-52; British defeat in, xxi-xxiii, xxxiv, 121-30; British forces arrive in, xix, 108-21; British-French rivalry over, xvii-xix; British neocolonial policy toward independent, xxxix; chronology, xi-xv; diet in, 68; diplomatic recognition for, $x l i x-1$, 291n175; economic and social conditions at end of ancien régime, 51-69; European planters in, 66, 74-75; French gain foothold on, 40-50; Glorious Revolution leads to counterrevolutionary intervention in, xxxviii; 
Haiti (St. Domingo) (continued) government of, 65; and Hispaniola, 292n9; historical overview of, 15-69; histories of, 6-8; independence declared, xxxi, xlix, 209, 260-61; location of, 15; map, xvi, 16-17; population of, 50, 68; religion in, 64-65; rivers of, 67; separation into two states, xxxii; social and economic conditions in, 57-69; three provinces of, 58. See also Haitian Revolution; and towns by name

Haitian Revolution, 77-132; abolitionist support for, xli; accounts of atrocities in, xxxi; British interest in, xxx, 282n78; brutalities following French invasion, xlv-xlvi, 196, 199, 205, 213, 26o; Dessalines's proclamation for a solemn abjuration of the French nation, 211, 262-64; distribution of black force in the French colonies during, from official returns, 270-71; Edwards on, xl-xli; factions in, 277n4; French invasion, xxx, xxxi, 161-94, 243-47; as global event, xlix; Hegel's Master-Slave dialectic and, $\mathrm{xl}$; manners on establishment of independence, 132-48; Ogé rebellion, $84-85,86-87,89$; origin of revolutionary spirit, 69-77; probable effects of, 216-18; Rainsford associates with Glorious Revolution, xxxviii, xxxix; Rainsford's An Historical Account of the Black Empire of Hayti as first complete English account of, xvii; Rainsford's An Historical Account of the Black Empire of Hayti portrays as progressive, xl, liii-liv; in Rainsford's ideological agenda, xxxiv; Rainsford's A Memoir of Transactions that Took Place in St. Domingo in the Spring of 1799, xxx; Rainsford's St. Domingo; Or, an Historical, Political and Military Sketch of the Black Republic on, xxxi; revenge taken by the black army for cruelties of the French, 205; slave revolt of 1791, 91-101; sources on, xxxix, 286n128; victory over French, xxxixxxii, 256-6o

Hardy, General, 174-75, 176, 177, 181, $182,183,184,192,313 n 327$

Hardy, Thomas, xxvi

Hatuey, 30, 295n57

Hayley, William, xxxv-xxxvi, xxxvii, xxxviii

Hébécourt, Louis-Armand d', 158, $311 n 300$

Hegel, Georg Wilhelm Friedrich, xl Hermona, Marquis d', 154, $311 n 294$

Herrera y Tordesillas, Antonio de, 6, 28n, 34, 49, 251, 293n14

Hieronymites, 32, 296n65

L'Hirondelle Viard, 102-3, 229, 231

Hispaniola, 292ng; cession of western part to France, 47-48; Columbus's voyages to, 15-27; constitution of Spanish, 55; decline of native population, 28-29, 31, 296n6o; Dessalines's proclamation to the Spanish part of the island, 214-15, 267-68; Drake pillages, 36; ecclesiastical government of Spanish, 54-55; historical overview of, 15-69; histories of, 6-8; location of, 15; map, 16-17; new demarcation line of 1777, 50-52; Ovando as governor, 25-26, 27-30, 295n45; population of Spanish, 57, 30on136; Spanish cede their territory in, 131, 158; Spanish division of, 52-57; sugar introduced to, 27, 295n48. See also Haiti (St. Domingo)

Historical Account of the Black Empire of Hayti, An (Rainsford), xxxviii-xli; abolitionism and, xli; advertisement, 3; authorial persona in, xxxix; on black soldiers, $\mathrm{xx}$; on bloodhounds deployed against blacks, xxvii, xlvi, 10-11, 208, 251-56; contents, 13-14; context of writing of, xvii, xxiii; continues project of The Revolution, xxxviii; as epic, xxxiv-xxxvi, xxxviii, xxxix; errors, xxxiv, 285n104; as first 
complete English account of Haitian Revolution, xvii; on free blacks of St. Domingo, liv-lvi; ideological agenda of, 1; illustrations for, xli-xlix, 2; immediate impact of, xxxii; indebtedness to Rainsford's poetic work, xxxv; introduction, 5-11; James on, 1; on limits of imperial power, lvi; mixed form of, xxxv, xxxix-xl; most lasting contribution of, liv; romantic aura of, 1; temple to liberty depicted in, xliii, 135-37, 136, 287n147; title page, 1; on Toussaint Louverture, xl, xliv-xlv, lilii, 131-32, 155-6o, 238-43, 291n181; on women of color, xliv, 145-46

Historical Survey of the French Colony in the Island of St. Domingo, An

(Edwards), xl-xli, 7, 286n128, 293n21 Hôpital de la Charité, 59

Horneck, Brigadier-General, 123, 125

Howard, Thomas Phipps, xxi

Howe, Brigadier-General, 126

Humbert, Jean Joseph Amable, 166, 175, 313n317, 313n330

Hymeneal on the Marriage of the Right

Hon. Francis, Earl of Moira, An (Rainsford), xxxi

indigo, 47, 49, 50, 57, 64, 67, 68n

Instructions of March 28, 179o, 85, 222

Irois, 113, 127

Isabella (queen of Castile), 22, 24, 27, $300 n 132$

Isabella (town), 22, 48, 52, 294n37, $295 n 43$

Jacmel, 64; distribution of black force in the French colonies during the Revolution, from official returns, 271; Leclerc in administration of, 250; planters and slave-trade, 248; in southern province of Haiti, 58

Jacobins, xix, 104, 105, 108

Jamaica: black military roles in, xx; in British involvement in Haiti, 109, 111, 130; British occupation of, 38; Columbus arrives in, 295n47; Diego
Columbus suppresses revolt in, 34-35; Edwards in, xli; expedition from French colony to, 47; French solicit aid from, 172; Maroon wars, xxvi-xxvii, xlvi, 8-9, 111, 173, 28on54, 289n162, 294n28; Morgan becomes lieutenant-governor, 41, 43; refugees from slave revolt of 1791 to, 98 ; slave revolts in, 301n158; slavery in, xviii; South Carolina Rangers in, xxv; Spain occupies, 295n; threat of rebellion in, xviii, $\mathrm{xxx}$

James, C. L. R., l-li, 291n178, 296n67 Jean François Papillon, 131, $310 n 292$ Jeannot, $310 n 292$

Jean Rabel, 307n235; British occupy, 112, 117; Rainsford's spelling of, lvii; rebels retake from British, 124 Jeremie (La Grand Anse), 63; British occupy, 111, 112, 113, 118, 232-34; distribution of black force in the French colonies during the Revolution, from official returns, 270; and French invasion of Haiti, 179; Maitland withdraws to, 130; massacre of whites of March 1804, 265, 318n425; in western province of Haiti, 58

Jesuits, 58, 64-65

Jiménez (Ximenes) de Cisneros, Francisco, 32, 33, 296n63

Jumécourt, Charles Arnold Ignace Hanus de, 99, 305n204

Keppel, Lieutenant-Colonel, xx, xxviixxviii, 281n64

Kerverseau, François, 163, 164, 209, 214, 312n3O7

Kina, Jean (John Vina), 112, 117, 306n224, 307n233, 315n355

Labat, Jean-Baptiste, 7, 293n17 laborers, living conditions of, 139-40

La Fayette, Gilbert du Motier, marquis de, 89, 304n191

La Luzerne, César Henri Guillaume, count de, 227, 317n391

Lamadieu, Charles, 102, 229 
Lapaire, Ginga, 101

Laplume, General, 176, 177, 178, 179-8o, $184-85,314 \mathrm{n} 332$

Larwood, Joshua, 271n, 274-75

La Salle, Adrien-Nicolas Piédefer, marquis de, count d'Offrémont, 106, 306n215

Las Casas, Bartolomé de, 6, 32-34, 293n13, 295n46, 296n67

Latouche-Tréville, Louis-RenéMadeleine, count de, 163, 164, 198, $312 \mathrm{n} 310$

Latour, M., 92

Laveaux, Étienne Maynard Bizefranc, count de, 113-14, 117, 120, 131, 154, 306n227, 311n293

Law, John, 48, 299n121

Leclerc, Charles Victor Emmanuel, 311n304; bloodhounds used by, 196, 208, 288n161; commands French forces, xxxi, 162, 307n240; death of, 197-200; documents respecting colonial administration of, 247-51; horrors attending invasion by, xliii, 196, 199, 213; in invasion of Haiti, 164-96, 200, 245, 246

Lennox, Charles, 121

Leo Africanus, $5 \mathrm{n}$

Léogane, 63; black soldiers in, xxii; British occupy, xix, 118, 119, 120; distribution of black force in the French colonies during the Revolution, from official returns, 270; in French invasion of Haiti, 178, 181; general Colonial Assembly to meet in, 78; new Colonial Assembly meets at, 90; rebels retake from British, 124, 127; in western province of Haiti, 58

Leopard (ship), 83, 87

Le Pers, Jean-Baptiste, 7, 66, 286n128, 293n17

Les Cayes. See Cayes

Lewis, M., xxvii, xxix, 281n72

Life of Toussaint Louverture (Dubroca), xliv, 287n15o, 293n23

Limonade, Count, xxxiii
Linois, Charles-Alexandre Léon Durand, count de, 171, 313n324

Loring, Sir John Wentworth, 204, 206, 207, 209, 210, 211, 257-6o, 316n368

Los Llanos, 53, 57

Louis XVI (king of France), 75, 301n159, 302n162, 302n163, 302n171

Louis XVIII (king of France), xxxii, 283n96, 284n101

Louverture, Isaac, xlv

Louverture, Paul, 158, 311n299

Louverture, Suzanne Simon Baptiste (wife of Toussaint Louverture), 152, 156, 170-71, 191, 194, 310n289

Louverture, Toussaint. See Toussaint Louverture

Louvilliers de Poincy, Philippe, 46, 299n109

Lucas, James (Jacques), 102, 230-31

Lucas, Joseph, 102, 229

Lucayans, 29

Luffmann, John, 287n143

Macaya, 107, 306n217

Madiou, Thomas, 318n419

Magon de Médine, Charles René, 163, 164, 312n311

Maitland, Sir Thomas, 129-30, 132, 155 , 158, 281n66, 308n26o

Malouet, Pierre-Victor de, 132n, 283n96

Manifest du Roi (Christophe), 288n161

Margarita, Pedro, 22, 23, 294n39

Markham, David, 115, 116, 125, 306n230

Marmelade, 175, 184, 200, 270

marriage among black laborers, 140

Marshalsea (maréchaussée), 66, 301n144

Mauduit du Plessis, Thomas Antoine, chevalier, 8o, 82-83, 85, 86, 87-88, 303n177

Maurepas, Jacques, 175, 177, 178, 196, 313n330

Maurin, Nicolas Eustache, xlvii, xlviii, 289n167, 289n169, 291n173

Maury, Peter (Pierre), 103, 231, 232

Mauzi, Peter, 101

Mazeau, Legrand, 101, 229 
Mazeau, Toussaint, 101, 229

McKerras, William, 115, 119, 127, 306n229

Memoir of Transactions That Took Place in St. Domingo in the Spring of 1799, A (Rainsford), xxx-xxxi, xxxiv, 1, 282n85

Mentor, Étienne, $158 \mathrm{n}$

Mestizos, 56

Milton, John, xxxv

Miragoane, 64

Mirbeck, Ignace-Frédéric de, 89-90, 100-101, 304n196, 305n2O7

Mirebalais, 101, 102, 126, 128, 229, 230, 270, 305n204

Moira, Earl of, xxvi, xxxi, 281n62

Moïse, Hyacinthe, 143, 164, 309n279, 310n285, 312n 313

Mole St. Nicholas, 67; black soldiers in, xxii; British land at, xix, 111, 117, 118, 123, 126, 127, 128, 130; Dessalines visits, 215; distribution of black force in the French colonies during the Revolution, from official returns, 270; and French invasion of Haiti, 166, 201, 209; location of town, 62; in northern province of Haiti, 58; Rainsford lands at, xvii, xxviii, 133

Moliere, Abbé, 157

Moll, Herman, 48n

Montagu, Lord Charles, xxv

Montalembert, Jean Charles, Baron de, 114-15, 117, 119, 120, 306n228

Montbars, Daniel, 41-42, 298ngo

Monte Christi, 53-54

Morgan, Sir Henry, 41, 42-44, 298ng8, 298n100

Moseley, Benjamin, 7on

Moss, Captain, 207, 258

Moustique, 200

mulattoes: attempt to join Colonial Assemblies, 78-79; British opposed by, 123-30; and Decree of April 4, 1792, 104-5, 305n206; emancipation of slaves of, 107-8; in independent Haiti, 137; join party supporting Peynier, 83; look down on slaves, 75, 91;
Ogé rebellion, 84-85, 86-87, 101-3, 230-32; place in Spanish Hispaniola, 56 ; in population of Haiti, 50, 65, 66; and slave revolt of 1791, 92, 99; and States-General, 76. See also Decree of May 15, 1791; free people of color music, 138

Napoleon Bonaparte, 311n301; depicted in Rainsford's “A Fraternal Embrace!," xlii, xlii; on Haitian revolt as declining, 184n; invasion of Haiti organized by, xxx, xxxi, 161-63; letter to Toussaint Louverture, 165, 168-69; maintains slavery in Martinique, 318n426; proclamation to inhabitants of Haiti, 166-67

National Assembly (France): concern with interior regulation in Haiti, 78, 79; Declaration of the Rights of Man and of the Citizen, 78, 236, 302n169; delegates from St. Domingo to, 302n171; General Assembly of St. Domingo censured by, 85-86, 87; General Assembly of St. Domingo on, 227-28; Abbé Grégoire’s letter to citizens of color, 221-26; Leopard's dispatches to, 83; in plan for new constitution, 81; and slave revolt of 1791, 97, 100; and Société des Amis des Noirs, 89

Negroes: characteristics attributed to, 72; Declaration of the Rights of Man rouses, 78; in independent Haiti, 13741; place in Spanish Hispaniola, 56; in population of Haiti, 50, 65, 66-67, 68; possibilities for self-government by, 217-18; Rainsford on, 5-6, 27075; Société des Amis des Noirs (Friends of the Blacks), 76-77. See also slavery

Nepean, Sir Evan, 259-6o

Nesbitt, Colebrooke, 129, 281n66, 308n259

Netherwood, Chief of Brigade, 200

Nipes, 64

Noailles, Louis-Marie, viscount de, 209, 259, 316n372 
Noé, Louis Panteléon, count de, 149, 153, 310n286

Northern Provincial Assembly, 78, $8 \mathrm{o}-81,83,85,86,87,90$

Ocampo, Diego, 34

Ocampo, Sebastián de, 29, 295n51

Ogden, James, xxxvi, 285n114, 285n118

Ogé, Jacques, 303n182

Ogé, Vincent, 303n182; death of, 89; deposition of, 86, 101-3, 230-32; Grégoire on, 225; rebellion of, 84-85, 86-87; in Société des Citoyens de Couleur, 302n164

Ogeron de la Bouëre, Bertrand Denis d', 44-46, 195, 298n103, 299n107

Oroonoko (Behn), 288n155, 291n181

Ovando y Cáceres, Nicolás de, 25-26, 27-30, 295n45

Oviedo y Valdés, Gonzalo Fernández de, 28n, 35

painting, 138

Paradise Lost (Milton), xxxv

Parker, Sir Hyde, 127, 130, 308n261

Pascal, Citizen, 157

Passamont, Michael, 35

peasants, 141

Pélage, Magloire, 265, 318n423

Peltier, Jean-Gabriel, 183n, 284n10o

Penn, Sir William, 38, 297n84

Peter Martyr d'Anghiera, 6, 18, 286n128, 293n12

Pétion, Alexandre Sabès, 316n373; and Catineau Laroche, 284ng6; and French invasion of Haiti, 209; as president of southern republic, xxxii; rivalry with Christophe, xxxiii, 310n280; and Sutherland, 283ng1

Petit Fond, 64

Petit Goäve, 63; in cession of western Hispaniola, 48; distribution of black force in the French colonies during the Revolution, from official returns, 270; Jacmel compared with, 64; superior council at, 46 ; in western province of Haiti, 58
Peynier, Antoine de Thomassin, count de, 8o-81, 82-83, 84, 85, 86, 303n176

Phips, Sir William, 47, 299n114

Pinchinat (rebel), 102, 103, 229

Pitt, William, xviii-xix, xxii, xxvi, lii, 279n 45

Plaisance, 64, 175, 176, 181, 184, 270

Pluchon, Pierre, 291n173

Pointe de Boucassin, 112

Polverel, Étienne, xliii, 104-6, 109, 121, 135, 305n210, 305n213

Ponce de León y Figueroa, Juan, 29, 295n5o

Port-au-Prince (Port Republicain), 62; British evacuate, 129-30; British occupy, xix, 118-21; distribution of black force in the French colonies during the Revolution, from official returns, 270; earthquake of 1770,50 , 62; establishment of, 49; and French invasion of Haiti, 164, 178, 179, 181, 182, 183, 185-86, 197, 201, 209; Leclerc in administration of, 247,248 , 250; regiment shows loyalty to monarchy, 87, 88; representatives to General Assembly of St. Domingo from, 80 ; as seat of government, $48,62,65$; and slave revolt of 1791, 99, 100; in western province of Haiti, 58; Western Provincial Assembly meets in, 78, 83; yellow fever in, xxi

Port-de-Paix (Port Paix), 59, 62; British occupy, 113; Dessalines visits, 215; in French invasion of Haiti, 166, 175, 178, 197; in northern province of Haiti, 58; settlement of, 297n83; and Tortuga, 38

Port Margot, 93-94, 103, 231, 270

Port St. Louis, 100

Postlethwayt, Malachy, 271

Pourcheresse de Vertières, Maria François, 86, 229, 230, 232

Prelude, The (Wordsworth), xxxix

Quarrell, William, 8, 197n, 253n, 294n28 
Raimond, Julien, 157, 222, 302n164, 311n298, 316n385

Rainsford, Marcus: accounts of his adventures in St. Domingo, $\mathrm{xxx}-\mathrm{xxxi}$; in American War for Independence, xxiv-xxv; arrest and condemnation of, xxix, xliii-xliv, 142-48, 144; arrives in Haiti for first time, xxvii; authorial persona of, xxxix; benevolent woman of color aids, xliv, 145-46, 147; biography of, xxiv-xxxiii; black soldiers recruited by, xx, xxiii, liii; on Cape François, xxviii, 10, 133-41; death and burial of, xxxiii; discrepancy over date of his return to Haiti, xxxiv; drawings by, xli-xlii, xlvii-xlix; education of, xxiv, xxxv; Henry I of Haiti's thanks to, xxxiii; ideological agenda of, xxxiv; in images in An Historical Account of the Black Empire of Hayti, xliii-xliv, 2; indictment for offering a challenge, xxv, 279n42; injury to his arm, xxvii, 28on59, 284n99; later years of, xxxii-xxxiii; as lieutenant in Haitian army, xxxiii, 284n1oo; meets Toussaint Louverture, xxiii, xxviii, l; money problems of, xxxii; paternalism, liii; as poet, $\mathrm{xxv}, \mathrm{xxix}-\mathrm{xxx}$, xxxv-xxxviii; retires from military, xxix; returns to Haiti in 1797 , xvii, xxxiv, 133; returns to military service, xxv-xxix; sonnet on death of Erasmus Darwin, xxxi, 283n89; as spy, xxviii, xxix, xxxiv, 1, 143; as Third West India Regiment captain, xx-xxi, xxvi, xxviixxviii, 279n49; Toussaint Louverture releases from prison, xxix, l, 148; writings of, xxxiv-xli

Raleigh, Sir Walter, 19, 44

Ravine-a-Couleuvre, 176-77

Rawdon, Francis Hastings, Lord, xxiv Raynal, Guillaume Thomas François, Abbé de, 293n19; on Aux Cayes, 63; on Buccaniers, 42n; on fertility of Hispaniola, 19; on houses of Providence, 59, 30on138; on new Sparta- cus, 154, 310n293; on population and economy of Hispaniola, 49; Rainsford criticized for depending on, $\mathrm{xl}$; Rainsford on, 7, 286n128; on slavery in Hispaniola, 37; Toussaint Louverture on, 152; on West India colonists from France, 71

refugees, xxii

Reilly, Charles, 239, 243

Revolution, The: An Epic Poem, in Twelve Books (Ogden), xxxvi, 285n114, 285n118

Revolution, The; Or, Britain Delivered (Rainsford), xxxvi-xxxviii; authorial persona in, xxxix; critical response to, $\mathrm{xxv}, \mathrm{xxx}, \mathrm{xxxvii}, 285 \mathrm{n} 12 \mathrm{O}$; first line of, xxxv; Glorious Revolution and Haitian Revolution associated in, xxxix; An Historical Account of the Black Empire of Hayti continues project of, xxxviii; narrator of, xxxviii; publication of, $\mathrm{xxv}, \mathrm{xxix}-\mathrm{xxx}$; second edition of, xxxvii, 282n76; as Whig history, xxxvii-xxxviii

Rewbell Amendment, 304n195

Rigaud, Benoit Joseph André, 303n185; British opposed by, 123-24, 127, 129; flees Haiti, 131; and French invasion of Haiti, 184-85; French opposed by, 117, 118, 120; in Ogé's rebellion, 85

Robertson, William, xl, 7, 18, 19, 28n, 29n, 30, 286n128, 293n2o

Robespierre, Maximilien, 84, 89, 135, 302n165, 303n183, 304n193

Rochambeau, Donatien-Marie-Joseph de Vimeur, viscount de, 312n306; bloodhounds used by, 208, 288n161; Boyer arrested by, 201; correspondence with Loring, 257-6o; cruelties committed by, 213, 260; Dessalines on defeat of, 268; Duckworth dispatches him to England, 211, 26o; foreign importation permitted by, 202, 256; in French invasion of Haiti, 163, $164,166,174-75,176-77,181,182-83$, 184, 191, 200-201, 202-7; negoti- 
Rochambeau, Donatien-Marie-Joseph de Vimeur, viscount de (continued) ates with Dessalines, 207, 209, 210, 256-57; succeeds Leclerc as CaptainGeneral, 198

Rodríguez de Fonseca, Juan (bishop of Burgos), 33, 296n69

Roldan, Francis, 24-26

Roume, Joachim, $290 n 169$

Roume de Saint-Laurent, Philippe-Rose, xlvii, xlix, 89-9o, 100-101, 289n168, 29on169, 304n196, 305n2O7

Rouvrai, Laurent François Lenoir, marquis de, 94, 305n201

Rowley, Sir Josias, 109, 113, 116, 306n220

Ruotte, Antoine Étienne, 86, 229, 230, 232

Rutledge, Sarah, 290n170

Sabourins, 102, 229

St. Christopher (St. Kitts), 37-38

St. Domingo (city), 53; conditions in 1528, 35; Drake seizes, 36; founding of, 24, 295n43; and French invasion of Haiti, 164, 214; garrison of, 55, 158; in Spanish division of Hispaniola, 52

St. Domingo (Haiti). See Haiti (St. Domingo)

St. Domingo; Or, an Historical, Political and Military Sketch of the Black Republic (Rainsford), xxxi, 243-47

St. Jago, 48, 52, 54

Saint-Léger, Edmond de, 89-90, 100101, 304n196, 305n2O7

St. Louis, 64, 271

St. Louis, Company of, 48, 299n12o

St. Marc, 62-63; black soldiers in, xxii; British attempt to strengthen, 125; British occupy, xix, 112, 118; colors taken from national guards in, 87; distribution of black force in the French colonies during the Revolution, from official returns, 270; and French invasion of Haiti, 177, 178, 179, 181, 190, 191; General Assembly of St.
Domingo meets in, 79, 83; general Colonial Assembly meets in, 78; and Ogé rebellion, 102, 299; rebels retake from British, 123; Toussaint Louverture driven by British from, 129; in western province of Haiti, 58; yellow fever in, xxi

Saint-Rémy, Joseph, xlvii, 289n168, 289n169

St. Thomé, 52, 54

Salines, General, 182

Salme, Jean-Baptiste, 176, 314n333

Sans Souci, Jean-Baptiste, 196, 315n357

Schoelcher, Victor, xliv

Scott, David, 291n178

Scott, R. B., xxix, xxx, xxxvii

Second Civil Commission, 104-6, 12021, 131, 135

Sevré, Chevalier de, 117, 124, 234-35, 307n234

Sharpe, Granville, lii

Shirley, Sir Anthony, 36n

Shirley, Henry, 109, 306n221

Simcoe, John Graves, 128, 129, 308n256 slavery: Africans introduced to New World, 33, 296n67; commencement of African slave trade, 71-72; corvées, 67; Dubois opposes, 79, 303n174; French abolish, xix, xxiii, 107-10, 130-31, 135; interbreeding with slaves, 36-37; introduced into Haiti, 47; mulattoes look down on slaves, 75, 91; in origins of Haitian Revolution, 71-74; planters and slavetrade, 247n; possibilities for selfgovernment by manumitted slaves, 217-18; privateers kidnap Indians into, 34, 37; Rainsford's position on, lii-liv, 9-10, 74, 272-74; as raison d'être of British occupation, xix-xx; revolts, 35, 91-101, 153, 301n158; seen as too profitable to stop, xviii; slaves in South Carolina Rangers, xxv; Somerset decision on, xviii, lii; Spaniards reduce Indians to, 24, 26, 30, 31-32; struggle over in West Indies, 
xvii-xviii; Treaty of Paris allows resumption of slave trade, xxxii, xxxiii. See also abolitionism

Sloane, Sir Hans, 6, 293n10

Smith, Edward Tyrrell, xxviii, 3, 133, 238-39, 240-42, 292n 4

Smith, William, 271

Société des Amis des Noirs, 76-77, 302n165; and Decree of April 4, 1792, 104; and Decree of May 15, 1791, 100, 221-26; mulatto attitude toward, 108; new projects of, 89; and Ogé, 84

Société des Citoyens de Couleur, $302 n 164$

Somerset decision, xviii, lii

Sonthonax, Léger-Félicité: decree abolishing slavery issued by, xix, xxiii; and French invasion of Haiti, 109; returns to Haiti, 121; in Second Civil Commission, 104-6, 305n210; temple of liberty quotes speech from, xliii, 135; Toussaint Louverture review intended to impress, 281n69

South Carolina Rangers, xxv

Southern Provincial Assembly, 78, 80 Spencer, Sir Brent, 113, 115, 116, 119 States-General: colonies not represented in, 302n162; declare themselves National Assembly, 78; National Assembly contrasted with, 302n171; summoning of, 76. See also National Assembly (France)

Stephen, James, xxx, 277n3, 282n82

Stovin, Richard, 238, 317n395

sugar: Columbus introduces to Hispaniola, 27, 295n48; in Haiti, 47, 49, 50, 62, 64, 67; in Jamaica, xviii; in Spanish Hispaniola, 36, 57

Sutherland, Robert, 283n91, 318n431

Tapion, 63

Télémaque, César, 165, 166, 313n316 theater, 138

Third West India Regiment, $x x-x x i$, xxvi, xxvii-xxviii, $279 n 49$

Tiburon: black soldiers in, xxii; British occupy, xix, 112, 113, 117, 118, 234-35;

distribution of black force in the French colonies during the Revolution, from official returns, 271; Maitland fails to retake, 130; Rigaud retakes from British, 124

Toledo y Mendoza, Fadrique Álvarez de, $38,297 n 81$

Tortuga, 297n82; Buccaniers on, 38, 39, 40; Jacmel and, 64; Leclerc at, 190, 197; in northern province of Haiti, 58; Ogeron de la Bouëre as governor of, 298n103

Toussaint Louverture, 149-6o, 307n240; agrarian militarism of, 310n285; appointed general in chief, 128, 131; arrest and death of, xxxi, lii, 195n, 307n240, 315n352; British newspapers spread notoriety of, xxx; British opposed by, 128; calls on blacks to take up arms, xxiii; changes allegiance from Spain to France, 277n11; character of, 131-32, 155-56, 238-43; children of, 156, 163, 167-68, 169, 170-71, 172, 191, 194, 310n289, 311n296; descriptions of, xliv; Dessalines criticizes, 266; dines at Hôtel de la Republique, 134; emancipation of, 310n291; free blacks ordered back to plantations by, lv-lvi; French invasion opposed by, 165, 167-8o, 181, $183,184,187-95$; as general of Spanish army, 131, 309n265; James on, 1li, 291n178; joins army, 154; kindness to animals of, 151; letter to Edward Tyrrell Smith, 238-39, 240-42; library of, 152n; Macaya and, 306n217; marriage of, 152, 156, 310n289; Napoleon's letter to, 165, 168-69; patience of, 151; physical characteristics of, xliv, 157, 311n297; portraits of, xliii, xliv-xlv, xlvii-xlix, xlviii, 150; private life of, 156-57; Rainsford meets, xxiii, xxviii, 1; Rainsford released from prison by, xxix, 1, 148; Rainsford's An Historical Account of the Black Empire 
Toussaint Louverture (continued) of Hayti on, xl, xliv-xlv, li-lii, 291n181; Rainsford's A Memoir of Transactions that Took Place in St. Domingo in the Spring of 1799 on, xxx, l; Rainsford's St. Domingo; Or, an Historical, Political and Military Sketch of the Black Republic on, xxxi, 282n86; Spanish cede their territory to, 131, 132; surrender to French, xxxi, 191-95; tour of the island, 158-6o; troop reviews of, 134, 158, 281n69; uniform of, 157

Touzard, M. de, 92, 304n199

Translation of an Official Communication from the Government of Hayti (Rainsford), xxxiii, 284n101

Treaty of Aix-la-Chapelle (1668), 47, $299 n 118$

Treaty of Amiens (1802), 311n302, $315 n 367,318 n 426$

Treaty of Aranjuez (1777), 3oon127

Treaty of Nijmegen (1678), 47, $299 n 119$

Treaty of Paris (1814), xxxii, xxxiii

Treaty of Ryswick (1697), 47, $299 n 117$

Trigg, Thomas, xxix

Vache Island, 63-64

Vala: Or, the Four Zoas (Blake), xli

Van Hoorn, Nicholas, 41, 42, 298ng1

Vastey, Pompée Valentin de, xxxiii, 283n91, 284n1o1

Vaughan, John, xxvi

Vega, La, 52, 54

Vega Real, 54, 57

Velázquez de Cuéllar, Diego, 30, 295n56

Venables, Robert, 38, 297n85

Vernon, Edward, 43, 298n97

Vertières, Battle of (1803), xxxi, 312n306, 314n331

Vespucci, Amerigo, 6, 15n, 293n15

Vie de Toussaint Louverture (Saint-

Rémy), xlvii, 289n168
Villaret de Joyeuse, Louis Thomas, 163 , 165-66, 173n, 185, 312n309

Vina, John (Jean Kina), 112, 117, 3o6n224, 307n233, 315n355

Vincent, Captain, 114, 115

Wallace, Captain, 119

Walpole, George, 187n, 197n

Warner, Sir Thomas, 37-38, 4on, 297n78

Watrin, François, 200, 315n361

Western Provincial Assembly, 78, 8o, $82-83$

West India Regiments, xx, xxv, xlv, 278n13

West Indies: Luffmann's maps of, 287n143; struggle over slavery in, xvii-xviii. See also Cuba; Haiti (St. Domingo); Hispaniola; Jamaica

Whitelocke, John, 111, 112, 113, 114, 115, $117,234-35$

Whyte, John, 118, 120, 123, 129, 281n66, $307 n 236$

Wilberforce, William, xxxiii, 301n155

Williamson, Sir Adam, xxii, 109, 112, 124, 232-34, 28on52, 306n218

Wimpffen, François AlexandreStanislas, baron de, 8, 293n22

Windham, William, 279n49, 28on53 women: benevolent woman of color aids Rainsford, xliv, 145-46, 147; in Columbus's third voyage, 24; family life among laborers, $140-41$; in independent Haiti, 138

Wordsworth, William, xxxix

yellow fever, xxi, xxx, 121-22, 190, $307 n 242$

Zeibo, 52, 54

Zuazo, Alonso de, 32, 33, 296n64 